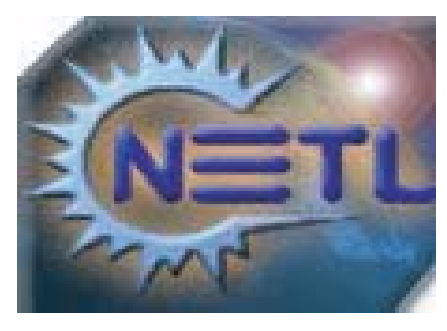

\title{
Final Report: \\ Systematic Technical Innovations Initiative Brine Disposal in the Northeast
}

\author{
Principal Authors: \\ Langhorne Smith, NYSM \\ Courtney Lugert, NYSM \\ Stephen Bauer, SNL \\ Brian Ehgartner, SNL \\ Richard Nyahay, NYSM
}

January 5, 2005

(DE-FC26-01NT41298)

Reservoir Characterization Group

New York State Museum

Cultural Education Center

Albany, New York 12230
Sandia National Laboratories

Eubank Blvd.

Sandia National Labs

Albuquerque, New Mexico 87185
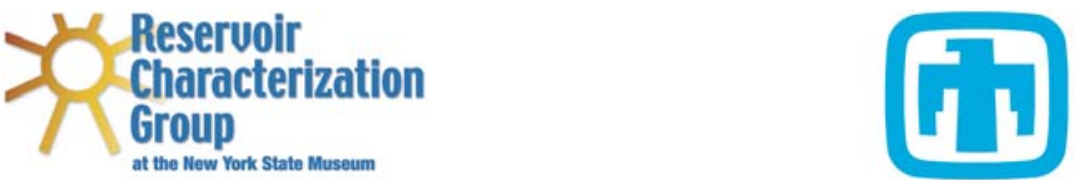

Sandia

National

Laboratories 
"This report was prepared as an account of work sponsored by an agency of the United States Government. Neither the United States Government nor any agency thereof, nor any of their employees, makes any warranty, express or implied, or assumes any legal liability or responsibility for the accuracy, completeness, or usefulness of any information, apparatus, product, or process, disclosed, or otherwise does not necessarily constitute or imply it endorsement, recommendation, or favoring by the United States Government or any agency thereof. The views and opinions of authors expressed herein do not necessarily state or reflect those of the United States Government or any agency thereof." 


\section{Abstract}

The purpose of this study was to develop a systematic methodology to evaluate geologic formations for brine disposal by injection (New York Sate was chosen as a representative example). Currently, brine disposal is the most significant barrier to developing salt cavern storage in areas remote to ocean disposal. Potential injection formations have been identified, with emphasis on defining potential reservoirs that could accept brine, along with delineation of salt bodies that could be developed into cavern storage facilities.

Salt caverns are ideal for natural gas storage because of high deliverability rates and short cycle times. New York has salt in the Silurian Salina Group, which is thick enough and deep enough in the south central portion of the state to make caverns that meet industry standards. Currently within the state there are two operational salt cavern storage facilities and several others in various stages of completion. The greatest obstacle to completion of many of these salt caverns is disposal of the brine created during cavern development. This study was conducted to systematically analyze potential formations for their ability to accept brine within the area where the salt is thick enough and deep enough for cavern development.

Analysis of potential brine disposal reservoirs was first limited to sandstones and carbonates that have acceptable reservoir characteristics. Once potential reservoirs had been identified, more detailed reservoir characterization studies were conducted on each reservoir. The most promising prospects are the Ordovician Queenston Sandstone, the Ordovician Black River Group hydrothermal dolomite reservoirs and dolomites in the Cambro-Ordovician Beekmantown. Cores from collections of the New York State Museum were used to complete geologic studies and material properties testing and the resulting data was then linked to geophysical wire line log data. The identified injection reservoirs are presented in the context of the regional geology. 
Parameters established during the characterization of potential disposal reservoirs were used by our collaborators at Sandia National Laboratories to model and quantify how effective brine disposal into these formations would be in our proposed reservoirs. After initial analyses the Trenton-Black River carbonates stand out as the most promising potential disposal reservoirs. 


\section{Executive Summary}

The natural gas market has experienced greater stability since salt caverns have been utilized as underground vessels to store natural gas. During the non-heating season, gas is pumped into the caverns with the intent of withdrawal during the heating season or to help minimizes the affects of short peaks in demand. This practice allows for more consistent production and pipeline system efficiency and minimizes peaking prices during the high demand heating months. While many regions of the country have benefited greatly from this increased stability the Northeast has yet to fully enter the salt cavern storage market even though the region has the demand and bedded salt necessary for this type of project. The main obstacle to salt cavern storage in the Northeast is disposing of the large volumes of brine that are created during the solution mining of the caverns.

If the Northeast is to benefit from the increased stability offered by salt cavern storage, a reliable brine disposal method needs to be found. The purpose of this research initiative was to provide a systematic approach to overcoming the dominant barrier to developing salt cavern storage; brine disposal. This was achieved in a two-phased manor in which salt bodies suitable for salt caverns were defined and then within these areas potential brine disposal reservoirs were identified and evaluated. Cores from the evaluated intervals were sent to our collaborators at Sandia National Laboratories for rock mechanics testing. The results of this testing in conjunction with our formation evaluations were used by SNL to model the disposal potential of each proposed disposal reservoir. New York has been chosen as the representative model for this study, but application of our approach in other states and possibly regions may have similar outcomes.

In Phase I we delineated the areas of New York where salt cavern development is possible. This is areas where the salt has characteristics that are suitable for cavern development based on regulatory and industry standards. We used these characteristics of suitable salt to develop a set of criteria that allowed us to evaluate the salt interval of New York State for its potential for cavern development. The first criterion establishes salt intervals that lie at the appropriate depth for cavern development. Depths are selected where the geostatic pressure is sufficient to maintain the compression-expansion systems used to inject and withdrawal from the cavern, but shallow enough to avoid cavern closure due to creep. The suggested depths for economic cavern construction are between 2000 and 6000 feet below the surface. The second set of criteria eliminates salt that is not of the appropriate thickness and quality for cavern construction. The salt available in New York State is bedded, which dictates that caverns must be wide and short, sort of peanut shaped. To be economic caverns are typically developed in salt that is between 100 and 300 feet thick, but thicknesses greater than 200 feet are optimal. To account for salt quality, intervals of salt were considered that were at least 100 feet thick and contained no nonsalt intervals thicker than 10 feet. Higher quality salt maximizes solution mining efficiency and minimizes the amount of rubble left at the bottom of the cavern after mining is complete. The area underlain by salt that meets both of these criteria defines our study area, where work in Phase II was focused.

The salt deposits of New York are positioned within the Upper Silurian Vernon and Syracuse Formations, which are further delineated into beds with letter designations A through F. Based on the work of past researchers, the F-unit has been established as having the greatest potential for thicknesses appropriate for cavern development and was therefore the focus of the Phase I in 
the current evaluation. Larger portions of south central New York State are suitable for cavern development. In most of the region, the salt is greater than 2000 feet below the surface (accept in the valleys of the Finger Lakes) and only at the New York-Pennsylvania border does the salt approach the lower limit of 6000 feet. The salt reaches thicknesses sometimes greater than 400 feet in this region. Areas of particular interest for their abundance of thick salt are Stueben, Schuyler, Chemung, Tompkins and Tioga Counties.

In Phase II work was done to first identify potential disposal formations, and then to evaluate the selected formations. This process was accomplished through the use of two sets of criteria, the Disposal Formation Selection Criteria and the Disposal Formation Evaluation Criteria.

The Disposal Formation Selection Criteria were developed after a review of regulatory and industry standards for New York. These criteria are 1) Lithology, sandstones and carbonates were selected, 2) Evidence of good porosity and permeability (in previous studies or industry related data), 3) History of production (either here or in nearby states), 4) not currently used for conventional depleted reservoir storage and 5) Connate Water Salinity greater than 200,00 ppm. Criteria 1-3 allowed potential disposal reservoirs to be selected from the units present in south central New York. Criteria 4 and 5 served to eliminate formations. If a formation is already a good storage reservoir, most operators will not want to risk trying brine disposal. Additionally it is necessary that brine disposal reservoirs have high connate water salinities (greater than 200,000 ppm).

Using the Disposal Formation Selection Criteria, three stratigraphic intervals were selected as potential brine disposal reservoirs. These are the Upper Ordovician Queenston Formation, the Middle Ordovician Trenton-Black River Interval and the Cambro-Ordovician Beekmantown Group.

The Disposal Formation Evaluation Criteria were used to evaluate each of the potential disposal reservoirs to gauge their ability to accept brine at the rates necessary for cavern development. These criteria are 1) sufficient porosity and permeability to maintain an injection rate of 10 BPM, 2) reservoir volume is capable of accepting $11 \mathrm{MMB}$ in 3 years, and 3) hydraulically separated from sources of potable water. These criteria were established based on projects typical of New York and the northeast which propose 5 wells and approximately 77 MMB (15.4 MMB per well) of brine must be disposed of over a 3 year period.

The Queenston formation, which is known regionally as a shale, is sand rich in the producing region of north central New York and also in south central New York where salt cavern development is possible. Though it has proven to have the capacity to accept brine at the Bath Petroleum Inc. facility, elsewhere injection tests into the Queenston formation have not proven that the formation would accept brine at the rates necessary for economic cavern development. The favorable injection achieved at the Bath Facility could be related to the existence of an open fracture system, which serves to elevate the traditionally low porosity and permeability of the formation. Another possible explanation for the success at the Bath Facility is that the formation is not completely water saturates as commonly believe, but rather it is partially gas saturated which improves the injection conditions enough to allow the brine to flow away from the well bore. Both of these options would lead to more favorable injection conditions. Further research is need to identify where these conditions exist in south central New York and how they would 
affect injection potential. After evaluation and modeling the Queenston Formation is not considered to have the proper characteristics of a brine disposal reservoir. Brine is accepted into the Queenston, but not at rates acceptable for cavern development projects typical of this region. Several alternatives are discussed that may improve disposal success.

The fault related hydrothermal dolomites associated with the Trenton-Black River (TBR) play that currently producing at prolific rates in New York, may also prove to be an excellent brine disposal reservoirs. The current production is located within our study area. Once depleted, the fields may prove to be unattractive for traditional depleted reservoir storage due to their heterogeneity and unknown lateral extent. If this is the case, the infrastructure already in place from production could be use at least in part to initiate brine disposal. Also, many of the fields in south central New York are long and narrow and are located in close proximity to one another meaning several fields could potentially be utilized together to develop one cavern facility. Although additional research is needed to determine if the reservoirs will be attractive for traditional storage, the TBR interval has the greatest potential as brine disposal reservoirs. The TBR meets all of the Disposal Formation Evaluation Criteria and after modeling the interval has the greatest potential as a brine disposal reservoir.

Brine disposal potential in the Beekmantown Group lies primarily in the porous sandstones of the Galway Formation. Recent production from these zones in western New York has yielded numbers as high as 0.5 BCF. The Galway Formation was tested at the Avoca Site in Stueben County, with mixed results. The first well drilled had porosity in this interval, but subsequent tests in later wells did not find porosity. This is currently rated as a possible disposal reservoir, but at this time it appears that the porous zones are too patchy and small to make it a dependable brine injection target. Current research was hindered by the lack of wells drilled into the Beekmantown Group in our study area. As new wells are drilled additional research can be conducted to determine its distribution of this Group. Modeling done on existing well cores from the Mohawk Valley indicate that the Group has permeabilities too low to maintain disposal rates necessary for cavern development. 


\section{TABLE OF CONTENTS}

Section

$\underline{\text { Page }}$

Disclaimer i

Abstract

ii

Executive Summary

iv

Table of Contents

vii

List of Figures

ix

List of Tables

xii

List of Plates

xiii

Introduction

General Overview of the Problem

Research Objectives

Background

Salt Cavern Development Practices

Brine Disposal

Government Regulations

General Geology of New York State

Subsurface Geology of Central New York State

Characteristics of a Good Disposal Reservoir

Summary of Avoca and other projects

Phase I - Delineation of Salt Suitable for Cavern Development and the Study Area Boundaries 
$\begin{array}{ll}\text { Criteria Development } & 38\end{array}$

$\begin{array}{ll}\text { Phase I Methods } & 38\end{array}$

Phase I Results - The Occurrence of Salt in New York State 41

Phase I Conclusions $\quad 52$

Phase II - Identification and Evaluation of Potential Disposal Reservoirs $\quad 54$

$\begin{array}{lr}\text { Criteria Development } & 54\end{array}$

$\begin{array}{ll}\text { Queenston Formation } & 61\end{array}$

Trenton-Black River Interval $\quad 92$

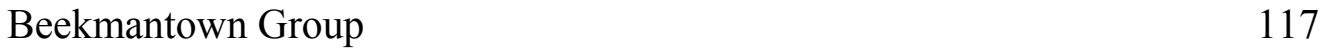

$\begin{array}{lr}\text { Conclusions } & 128\end{array}$

$\begin{array}{ll}\text { References } & 130\end{array}$

$\begin{array}{ll}\text { Appendixes } & 137\end{array}$

$\begin{array}{lll}\text { A } & \text { Silurian Data } & 138\end{array}$

B Queenston Formation Data 153

$\begin{array}{lll}\text { C } & \text { Trenton-Black River Data } & 189\end{array}$ 


\section{LIST OF FIGURES}

Number Title

$\begin{array}{lll}\text { Figure } 1 & \text { Single well leaching system diagram } & 7\end{array}$

$\begin{array}{lll}\text { Figure } 2 & \text { Double well leaching system diagram } & 8\end{array}$

Figure $3 \quad$ Schematic of Avoca Project leaching program 9

Figure $4 \quad$ Generalized Columnar Section of the Salina Group 11

$\begin{array}{lll}\text { Figure } 5 & \text { Stratigraphic section } & 18\end{array}$

Figure $6 \quad$ Generalized Bedrock Geology Map 19

Figure 7a Schematic North-South Cross Section - Legend 25

Figure 7b Schematic North-South Cross Section, through central New York 26

$\begin{array}{lll}\text { Figure } 8 & \text { Regional north-south seismic line }- \text { central New York } & 28\end{array}$

Figure $9 \quad$ Representative log of the Paleozoic section in central New York 29

Figure $10 \quad$ Map of salt storage facilities in New York State 33

Figure $11 \quad$ Avoca project proposed facility site map 34

Figure 12 Correlation of the Salina D-unit at the Avoca project site 35

Figure 13a Cross Section of Silurian Section - Legend and Location Map 43

Figure 13b Cross Section of Silurian Section, Chemung County, New York 44

Figure $14 \quad$ Salina Group outcrop map $\quad 45$

Figure 15 Salina F-unit isopachous map 46

Figure $16 \quad$ Seismic Line - Thicken salt in south central New York 47

$\begin{array}{lll}\text { Figure } 17 & \text { Salina F-unit structure contour map } & 49\end{array}$

Figure $18 \quad$ Salina F-unit measured depth map $\quad 50$

Figure $19 \quad$ Map of salt with suitable thickness for cavern development 51

$\begin{array}{lll}\text { Figure } 20 & \text { Study Area Map } & 53\end{array}$ 
$\begin{array}{lll}\text { Figure } 21 & \text { Disposal Formation selection matrix } & 56\end{array}$

$\begin{array}{lll}\text { Figure } 22 & \text { Stratigraphic section with potential brine disposal reservoirs } & 57\end{array}$

Figure 23 Queenston Formation representative log, Stueben County, New York 62

$\begin{array}{lll}\text { Figure } 24 & \text { Formation density log determination of porosity }\end{array}$

$\begin{array}{lll}\text { Figure } 25 & \text { Relative radioactivity of selected sedimentary rocks }\end{array}$

$\begin{array}{lll}\text { Figure } 26 & \text { Rock Mechanics Testing Configuration }\end{array}$

$\begin{array}{lll}\text { Figure 27 Queenston Surface Exposures } & 70\end{array}$

Figure 28 Sand/Shale Ratio Map of Queenston Lorraine Interval 72

$\begin{array}{lll}\text { Figure } 29 & \text { Queenston Formation structure contour map }\end{array}$

$\begin{array}{lll}\text { Figure } 30 \quad \text { Queenston-Oswego Isopachous Map } & 74\end{array}$

Figure 31 Map of Fields Producing from the Queenston Formation 76

Figure 32 Mechanism for gas entrapment in the Queenston Formation 77

Figure 33 Rock Types in Delaney A-124-5 Core, Cayuga County, New York 80

Figure $34 \quad$ Upper $150 \mathrm{ft}$ of the Delaney A-124-5 core description 81

$\begin{array}{lll}\text { Figure } 35 & \text { Queenston Sandstone Permeabilities } & 82\end{array}$

Figure 36 Comparison of Relationships Developed by Gruy and Associates to Current Research Tests Results for Queenston Formation. 83

$\begin{array}{lll}\text { Figure } 37 & \text { Brine Pressure in Queenston after } 3 \text { years } & 84\end{array}$

Figure 38 Brine Injection Quantity and Rate for Queenston 85

$\begin{array}{lll}\text { Figure } 39 & \text { Illustration of Fracture Conduit }\end{array}$

$\begin{array}{lll}\text { Figure } 40 & \text { Fracture Conduit Flow in Queenston } & 86\end{array}$

$\begin{array}{lll}\text { Figure } 41 & \text { Illustration of Horizontal Well } & 87\end{array}$

$\begin{array}{lll}\text { Figure } 42 & \text { Brine Pressure in Queenston after } 3 \text { years } & 88\end{array}$

Figure 43 Brine Injection Quantity and Rate for Queenston 88 
Figure 44 Pinnate Well Pattern

Figure 45 Trenton-Black River and Beekmantown representative log, Stueben

County, New York

Figure 46 The density-neutron cross plot

Figure 47 Matejka \#1 TBR Core Images

Figure 48 Gray \#624468 TBR Core Images

Figure 49a Whiteman \#1 TBR Core Images

Figure 49b Whiteman \#1 TBR Thin Section Images

Figure $50 \quad$ Black River Isopachous Map

Figure $51 \quad$ Black River Structure Contour Map

Figure 52 Trenton Isopachous Map

Figure 53 Trenton Structure Contour Map

Figure 54 Model for Hydrothermal Leaching and Dolomitization

Figure 55 3D Seismic of the Rochester Field, Ontario, Canada

Figure 56 Seismic Expression of a TBR field in Southern Tier of New York State

Figure 57 Map of Fields producing from the Trenton-Black River Interval

Figure 58 Permeability of Trenton-Black River

Figure 59 Brine Injection Quantity and Rate for Trenton-Black River

Figure 60 Brine Pressure in Trenton-Black River after 3 years

Figure 61 Schematic of Trenton-Black River Fields as a disposal reservoir

Figure 62 Gamma Ray Picks in the Beekmantown from Bass et al., 1996

Figure 63 Stratigraphy of the Cambro-Ordovician strata

Figure 64 Beekmantown Limestone Permeabilities 


\section{LIST OF TABLES}

$\underline{\text { Number }} \underline{\text { Title }} \quad \underline{\text { Page }}$

Table $1 \quad$ Salinity of selected producing formations in New York State 58

$\begin{array}{lll}\text { Table } 2 & \text { Geocolumn shading explanation } & 64\end{array}$

$\begin{array}{lll}\text { Table } 3 & \text { Test Matrix for Queenston } & 79\end{array}$

$\begin{array}{lll}\text { Table } 4 & \text { Test Matrix for Queenston and Beekmantown } & 126\end{array}$ 


\title{
LIST OF PLATES
}

\author{
Number $\quad \underline{\text { Title }}$ \\ Plate $1 \quad$ East-West Cross Section Silurian Section - A-A' \\ Plate 2 North-South Cross Section Silurian Section - B-B' \\ Plate 3 Salina F-unit Isopachous Map \\ Plate 4 Salina F-unit Structure Contour Map - datum sea level \\ Plate 5 Salina F-unit Measured Depth Map - datum surface elevation \\ Plate 6 Map of Salt with Suitable Thickness for Cavern Development \\ Plate $7 \quad$ Study Area Map \\ Plate 8 Disposal Formation Selection Matrix \\ Plate 9 East-West Cross Section Queenston Formation - C- C' \\ Plate 10 North-South Cross Section Queenston Formation - D-D' \\ Plate 11 Queenston Formation Structure Contour Map \\ Plate 12 Queenston-Oswego Formation Isopachous Map \\ Plate 13 Description for the Delaney A-124-5 Well \\ Plate 14 Glodes Corners Road Field Cross Section - E-E' \\ Plate 15 Trenton - Black River Regional Cross Section - F-F' \\ Plate 16 Matejka \# 1 Core Description Poster \\ Plate 17 Gray \# 62448 Core Description Poster \\ Plate 18 Black River Isopachous Map \\ Plate 19 Black River Structure Contour Map \\ Plate $20 \quad$ Trenton Isopachous Map \\ Plate 21 Trenton Structure Contour Map \\ Plate 22 Mohawk Valley Core Correlation - Beekmantown Group
}


Plate 23 East-West Cross Section of Beekmantown Group G-G' 


\section{Section 1 \\ INTRODUCTION}

\section{GENERAL OVERVIEW OF PROBLEM}

Storage is the primary means of managing fluctuations in natural gas supply and demand, and is an essential component of an efficient and reliable interstate natural gas transmission and distribution network. The stored gas is used for two primary purposes: to meet seasonal demands for natural gas (base load storage), and to meet short-term peaks in demand (peaking storage), which can range from a few hours to a few days.

To ensure that adequate natural gas supplies are available to meet seasonal base-load customer requirements in winter, industry injects large amounts of gas into underground storage reservoirs form April through October. During these non-heating season months, gas demand declines as temperatures rise. During the heating season, industry supplements pipeline capacity from the producing regions with supplies from storage to meet demands. Gas withdrawn from working gas storage can supply up to 30 percent of the daily gas demand in winter months.

Storage enables greater system efficiency by allowing more level production and transmission flows throughout the year. End-use customers gain from such system efficiency with reduced overall costs of service. Storage also allows continuous service even when production or pipeline transportation services are interrupted. This can be achieved by using or establishing new storage facilities in market areas where there is a strong seasonal variation to demand.

Industry has recognized the need to expand the existing gas storage system to meet anticipated future demand for natural gas, which is forecasted to increase by as much as 6 Tcf by 2010 and 10 Tcf by 2020. This rising demand raises concerns about the system's ability to meet peak requirements in the future.

Natural gas is distributed to virtually every region of the country through an extensive system made up of more than 1.3 million miles of pipeline, meters, compressor stations, and 
approximately 410 storage reservoirs. The gas industry currently has the capability to deliver approximately $75 \mathrm{Bcf}$ per day during peak periods.

In 2004, total working gas storage capacity from U.S. gas storage sites was 3.1 Tcf (EIA, 2005). These sites are heavily concentrated in and near major eastern and mid continent markets. The significant shift in natural gas supply and consumption patterns expected by 2010 will create a need for new natural gas pipeline transmission and storage facilities. With the anticipated decline in production from the southwest central region, additional transmission and storage capability will be required to move gas from the Rocky Mountains and Canada to neighboring regions and to expanding markets in the northeast, southeast, and California.

Given the significantly large storage volume requirements detailed above for natural gas alone, underground storage facilities that utilize geologic formations are the only realistic alternative. If engineered correctly, underground storage facilities have the potential for larger volumes, are environmentally friendly, and present relatively safe conditions to the public. Following this rationale, utilizing underground space for storage facilities would present lowered risk to permitting, regulatory, and investment interests.

Storage of liquids and gases in solution-mined caverns in salt began approximately 60 years ago (Thoms and Gehle, 2000). Cavern use for storage and disposal is generally considered safe and efficient because salt is relatively impermeable and has proven to be a good containment vessel (when properly engineered). Use of salt caverns for "vessels" has other advantages over other rock types which include: (1) cost for creating similar size caverns in salt (by solutioning) versus hard rock by mining are significantly less for salt and (2) salt material properties are such that fractures in salt tend to heal under ambient conditions.

The question then arises, why not only store in salt? What are problems with salt storage? There are at least three types of problems with underground storage in salt. The problems are related to availability of "usable" salt, locating and engineering safe brine disposal, and development of well-engineered caverns. This research initiative was primarily focused on finding solutions to the first two of these problems. 
In order for cavern development to be economic, it is necessary to dispose of brine at significant rates. This is true because most of the storage and therefore profit making cannot occur until the majority of salt solutioning and brine disposal is complete. Economics of a project, in concert with engineering, will dictate the need for brine generation and disposal rates.

The importance of delineating feasible brine disposal options has been brought to a head in New York State, where significant economic risk has been taken to initiate the highly desirable salt cavern storage facilities. For example, before cavern construction was even started, one hundred million dollars was spent at the Avoca Project in Steuben County (discussed in more detail below). This number could have been considerably less if the operators had found a suitable brine disposal reservoir prior to investing in any other infrastructure.

Much of south central New York State is underlain by salt beds suitable for salt cavern development has sustainable fresh water supplies for leaching and is within economic reach of large markets, but the lesson learned at the Avoca Project is that brine disposal is the limiting factor in siting a project. It is the purpose of this research initiative is to provide developers with disposal reservoir options chosen and supported with high quality research. The results of this study will help to minimize uncertainty and alleviate financial risk by taking steps to overcome the brine disposal barrier that is currently plaguing the industry in this region.

\section{RESEACRCH OBJECTIVES}

The goal of this research has been to develop a systems approach to overcome the dominant barrier to developing salt cavern storage in areas remote to ocean disposal: brine disposal. This system includes a three-dimensional understanding of the geology if the region (NYS was used as a test case) with a view towards identification of potential target horizons that can accept brine at the rates necessary within acceptable levels of environmental impact. The geology of potential injection formations has been determined with a view towards understanding rock properties of target hydrogeologic units on a regional geologic scale. This includes 
determination of rock properties from core, correlating that information to geophysical logs, and then extending that information to a regional scale.

Potential hydrogeological units for brine disposal and salt body locations have been identified. This includes the collection, assimilation and analyses of geologic, hydrologic, environmental, and regulatory information as it applies to brine disposal. This also included examining core and subsequent correlation of those results with geophysical logs, the results of this correlation were used for regional extrapolation.

A key contribution to the brine disposal issue is presentation of a clear understanding of injection mechanics such that a means to balance a desired injection rate with in situ conditions and rock properties is obtained while induced seismicity is minimized and brine volume acceptance is maximized. Potential volumes of brine to create needed cavern space are significantly large. Also, brine generation rates and thus brine injection rates "need" to be relatively high for a cavern to be created in a "profitable" manner. The potential for pore pressure increases to adversely modify the effective stress, exist if the injection mechanics are poorly understood or implemented. Perhaps stimulation methods, directional drilling, etc. could be used in the injection wells in order to enhance the reservoir's ability to accept brine at overall rates that meet injection needs.

This methodology and criteria has ultimately allowed us to systematically delineate potential brine disposal formations. Other items that may impact the site selection process for potential brine disposal locations includes infrastructure availability, distance from population and distance to major gas transmission lines.

The completion of this work has resulted in a regional geologic model that can be used to gain understanding of the potential brine volumes and injection rates that can be expected within specified hydrogeologic units in the New York State region. An important product of this study is a publicly available assessment of the feasibility of brine injection in areas where there is significant salt accumulations in New York State. The ability to assesses the potential for brine disposal will help companies to know when to seek alternative methods for gas storage and brine 
disposal. The same methods used here will likely work in other states with similar subsurface geology, such as Pennsylvania, Ohio and West Virginia.

\section{BACKGROUND}

The successful development of natural gas storage facilities in bedded salt requires the combined occurrence of several factors at the project site. This section contains a review of the background knowledge, industry standards and government regulations that outline these factors and influence site selection of salt cavern storage and related brine disposal. This information was the basis for the criteria developed for Phase I and II of this research initiative. The methods section of this report contains a discussion of the criteria used in both phases.

\section{$\underline{\text { Salt Cavern Development Practices }}$}

Natural gas storage in salt cavern facilities is highly desirable when geologic conditions are present to make such facilities feasible. This desirability is primarily due to the fact that salt cavern facilities can be operated at high deliverability rates and relatively short cycle times. Salt cavern storage facilities are operated by compression-expansion, which leads to the high deliverability with comparably lower amounts of working immobilized gas. Working gas is the total gas storage capacity minus base gas, which is the volume of gas intended as permanent inventory of the storage reservoir used to maintain adequate pressure conditions.

Storage of liquids and gases in solution-mined caverns in salt began approximately 60 years ago (Thoms and Gehle, 2000). Cavern use for storage and disposal is generally considered safe and efficient because salt is relatively impermeable and has proven to be a good containment vessel (if engineered properly). Use of salt caverns for "vessels" has other advantages over other rock types which include: (1) cost for creating similar size caverns in salt (by solutioning) versus hard rock by mining are significantly less for salt and (2) salt material properties are such that fractures in salt tend to heal under ambient conditions. 
Rock salt is exploited for natural gas storage because it is considered impermeable to hydrocarbons (capillary phenomena stemming from its petrophysical characteristics: extremely low permeability and porosity). The leaching of pressure- tight cavities, constituting gigantic gas cylinders with volumes of several hundred thousand cubic meters is possible because of the stability guaranteed by the good mechanical rupture strength of salt, even though its "ductile" or "creep" behavior leads to gradual and regular reduction in cavity volume. A storage site typically consists of one or, more often, several storage caverns.

The solubility of salt in water is utilized in the solution mining of the caverns, which is easier to implement than mechanical mining, requiring less manpower and heavy equipment (Hougout and Roger, 1990). The leaching process entails drilling a well or wells down into the target formation, and cycling large amounts of fresh water through the salt. The fresh water dissolves portions of the salt deposit, and is then cycled back up the well, leaving a large empty space that the salt used to occupy. In a single-well system (Figure 1) a fresh water stream is injected into the inner annulus of a well and the brine solution escapes through the outer annulus and is collected at the surface. In a double-well system (more typical of regions with bedded salt) one well brings fresh water down to the formation and the second well brings the created brine back to the surface (Figure 2). The double well system was proposed for the Avoca site in central New York. Figure 3 is a schematic diagram of how the leaching process would be carried out at the Avoca site from Morrill, 1996.

\section{Industry Standards for Salt Cavern Development}

Several authors have detailed the factors required for choosing a suitable location for potential salt-cavern storage facilities, e.g. Morill, 1996; Bass et al., 1996; Haddenhorst 1989. All have outlined the following standards used by operators who develop caverns in salt for the purpose of storing natural gas: (1) adequate salt thickness, (2) appropriate depth to salt, (3) suitable geographic location, (4) access to fresh water supply, and (5) a method of brine disposal. This section summarizes the findings of previous researchers. 


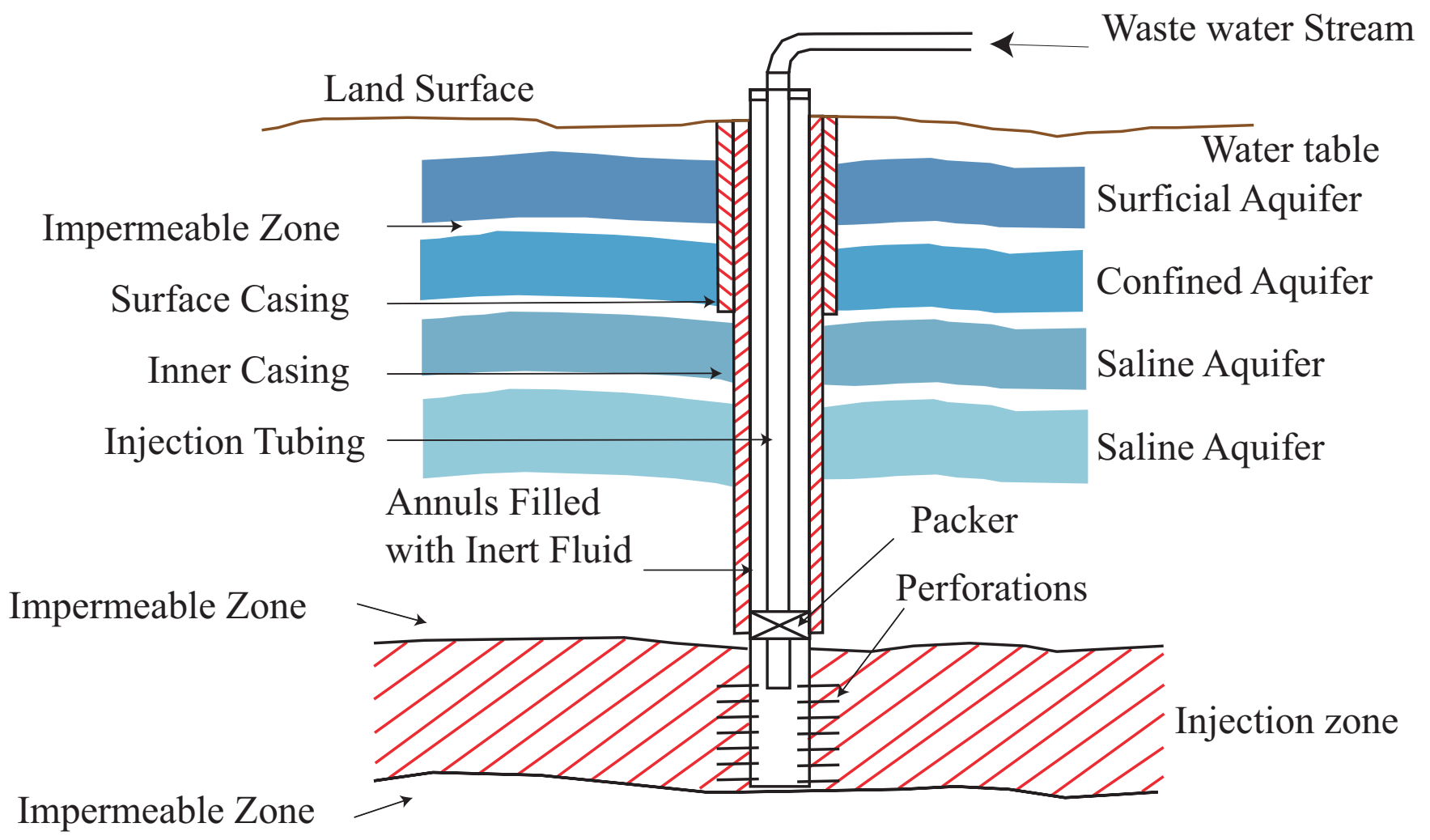

Figure 1 In a single well System (shown above) a fresh-water stream is injected into the inner annuls of a well and the brine solution escapes through the outer annuls and is collected at the surface. In a double well system (more typical of in regions with bedded salt) one well brings fresh water down to the formation and the second well brings the created brine back to the surface. 


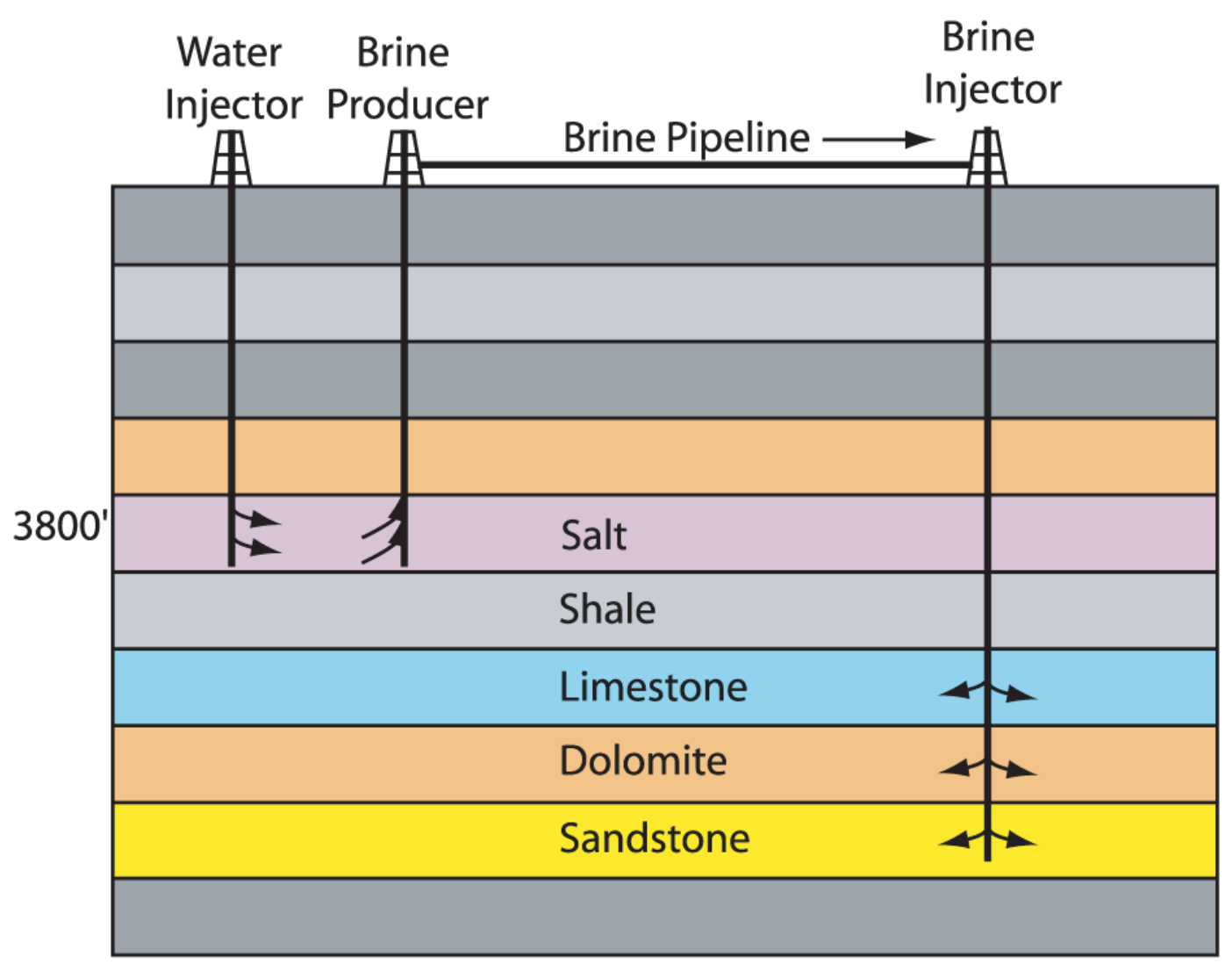

Figure 2 During cavern development a two well system is setup, where freshwater is circulated through a salt layer generating brine, which is then extracted. Ideally, this brine will then be disposed of on or near the cavern site. Limestones, sandstones and dolomite zones offer the best opportunity for finding porosity and permeability levels acceptable for brine disposal. 

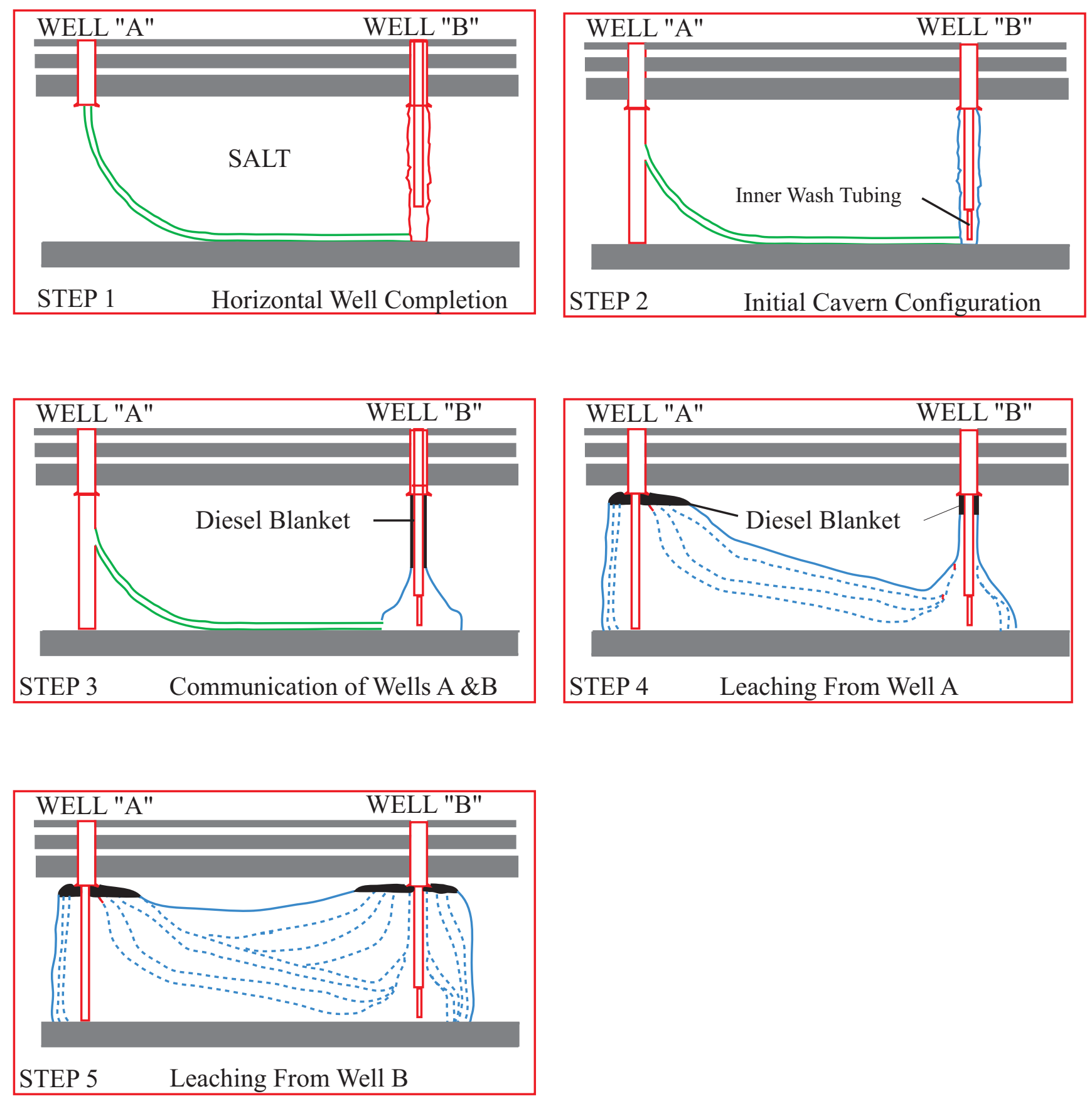

Figure 3 Five basic steps in the construction of the elongated caverns planned for the Avoca facility. Horizontal Drilling is used to connect to widely spaced boreholes.

From Morrill (1996), originally from PB-KBB Inc. 
Salt Thickness. Due to the importance of retaining structural stability, the diameter of caverns developed in bedded salt is limited. To balance the need for a narrow diameter a cavern must be of sufficient thickness to be economic (Morill, 1996). This is based on the idea that several smaller caverns in thinner salt would cost much more than creating fewer larger caverns in thicker salt (Bass et al., 1996). According to Morill (1996), caverns are commonly developed in 200-300 feet of bedded salts and he cites examples from Saskatchewan, Alberta and Michigan. Anything less than 100 feet would be considered uneconomical for cavern development (Bass et al., 1996; Morrill, 1996). The proposed facility at Avoca, New York would be developed in roughly 100 feet of bedded salt.

In addition to the necessity that salt be of the appropriate thickness, salt quality is important. Salt considered for cavern development should be as homogeneous as possible, which for solution mining purposes should be for the most part free of insoluble and poorly soluble components (Haddenhorst, 1989). Interbedded among the salt units of the Salina Group are layers of insoluble or less soluble rock types, such as shale, anhydrite and dolomite (see Figure 4). If insoluble unit is thin enough, thinner than approximately $10 \mathrm{feet}$, the salt is mined away from both sides of the layer and differential pressure is applied to the layer causing it to collapse and fall to the bottom of the cavern (Bass et al., 1996). Insoluble layers thicker than 10 feet become uneconomical, as they are more difficult to break and produce a large volume of rubble at the bottom of the cavern that diminishes the cavern's storage capacity (Bass et al., 1996). In a report conducted for the Electric Power Institute in 1994, the engineering firm PB$\mathrm{KBB}$, made the statement that "The salt formation, over the intended cavern interval should contain a minimum of $60 \%$ salt."

Depth to Salt. While salt deposits are found at varying depths within sedimentary basins, cavern development can only be carried out at depths where overburden is sufficient to maintain rupture strength while remaining in balance with factors that contribute to closure due to creep. The suggested depth for the economic construction of a salt cavern for the storage of natural gas ranges from a minimum of 2,000 feet to a maximum of 6,000 feet (e.g. Morill, 1996; Friedman et al., 2002; Bass et al., 1996). At depths greater than 2,000 feet, the geostatic pressure is sufficient to operate an efficient and economical compression-expansion system necessary for short cycle 


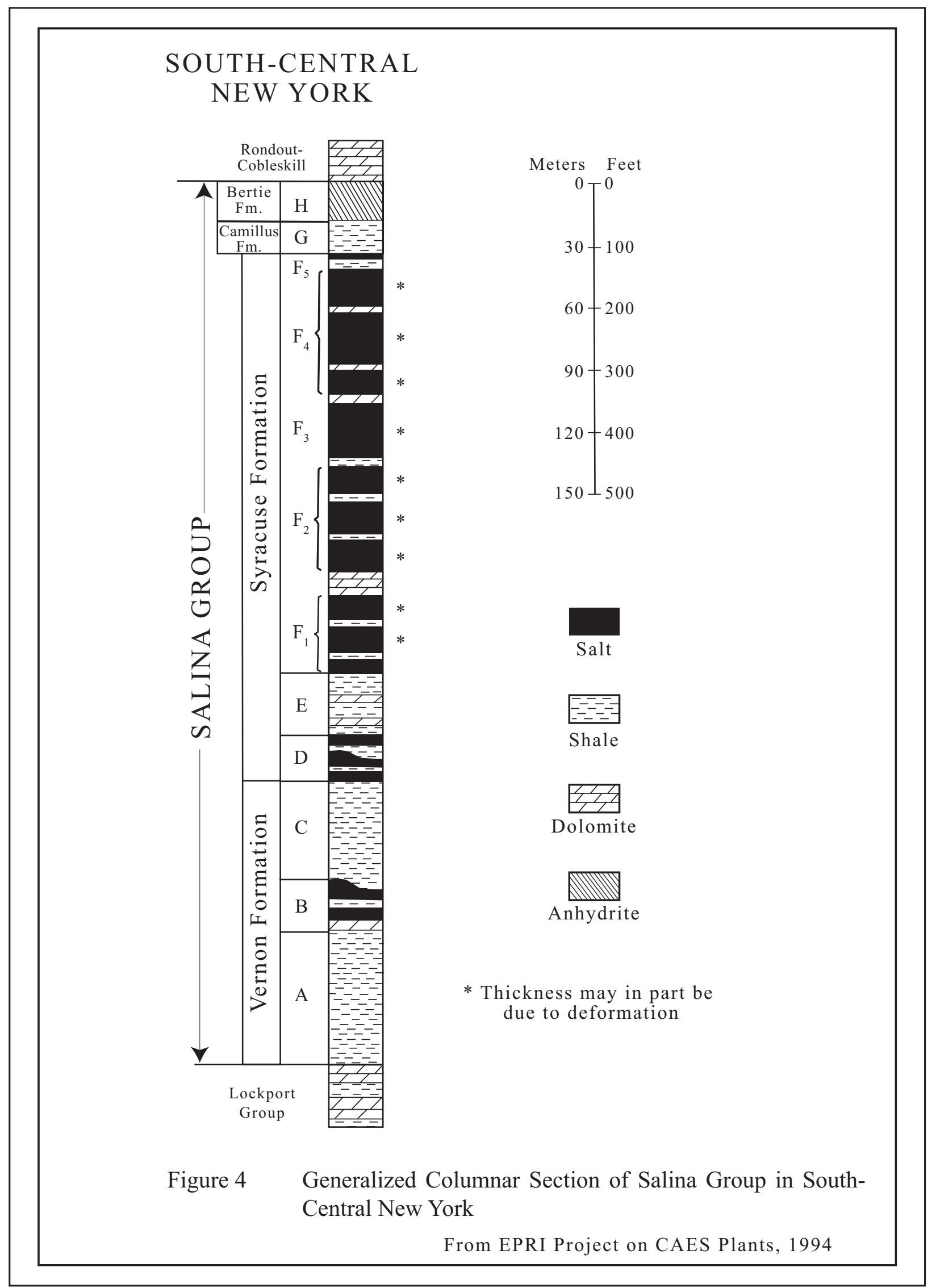


times. At depths greater than 6,000 feet temperatures and pressures are elevated enough significantly change the plasticity of the salt and put the cavern at risk of closure due to salt creep (Bass et al., 1996).

The few proposed or active salt cavern storage facilities in New York State have, or propose varying cavern depths. The depths of these caverns are as follows: 3,440-4,050 feet for the proposed Avoca site, roughly 2,800-3,000 feet for the Bath site (currently a propane storage facility looking to convert to natural gas storage), and the New York State Electric and Gas Corporation (NYSEG) facility located near Seneca Lake has caverns at depths from roughly 2,300-2,850 feet.

Geographic Location. Several elements are required for the economic operation of any facility that stores natural gas (outlined in this section). These elements include, fresh water availability (discussed in the next section), proximity to local populations, and proximity to major electric power transmission lines. In order to avoid costly construction it is advantageous for proposed sites to be chosen where these elements already exist in close proximity.

The ideal location for a high-deliverability storage facility would be close to a market or market hub where it could be used to meet high demands during peak demand situations (Friedman et al., 2002). One option operators have is to build a pipeline to connect their facility to the closest transmission line or market hub. Distance, topography and the ability to access right of way between the facility and the pipeline could make this option costly and estimates in the range of $0.5-1$ million dollars have been given. However, in the northeast there is enough demand for natural gas and storage that this initial cost would soon be offset in profit once that facility came online. Friedman et al. (2002) went as far as to say that for this reason, proximity to market was null as a factor for determining site suitability. For the reasons presented above, distance to market or transmission lines will not be a parameter of this study.

Fresh Water Supply. In order to develop a cavern in salt, a significant amount of fresh water is needed; in volumetric terms, about 7 times the amount of fresh water is needed as the volume of 
cavern to be developed. The amount of fresh water ultimately used depends on the design size and the efficiency of the leaching process.

Using liquid measure, individual caverns on the order of $1-3$ million barrels ( $42 \mathrm{gal} / \mathrm{bbl}$ ) have been considered for gas storage in New York and surrounding areas. This translates to 7 to 21 million barrels of fresh water per cavern. Fresh water injection rates are planned to complete a cavern in as short of a time as possible while in compliance with the leach plan (a fresh water injection schedule including injection rate and injection/withdrawal pipe placement) and ultimately to engineer the desired shape and dimensions for the cavern. Injection rates on the order of 100,000 bbl/day have been typical in large commercial cavern development projects. Rates plus or minus $50 \%$ of this value should be considered on a planning basis. These rates assume that brine disposal is not an issue. For some proposed gas storage projects in the NE their designs have been based on approximately 20,000 bbl/day, in part due to disposal rate restrictions (also realize that approximately 1/7 more volume needs to be disposed of than is injected for leaching). For the above range of cavern size, and an average injection rate of $100,000 \mathrm{bbl} /$ day, sustained supply would be 70 to 210 days. This is the target amount of fresh water availability (volume, rates, and duration) that would be required in a cavern project in the northeast.

Sources for this amount of water would have to be determined for the specific area of interest, but considering the general geohydrologic settings and climatic characteristics of the northeastern U.S., source water is not considered a deterring factor for a cavern development project and therefore will not be assessed in this study. Groundwater availability is well discussed in the literature (Friedman et al., 2002) in terms of aquifer types, seasonal impacts, recharge aquifer permeability and thickness and potential impacts on other uses. These factors would have to be addressed in the permitting process for the water well(s) to supply the cavern development project.

Brine Disposal. During cavern development large amounts of brine are created as salt is removed by leaching. As an example, brine generation was at a rate of 20,000 to 100,000 bbl/day during the development of the U.S. Strategic Petroleum Reserve (caverns ranging in size 
from 5-10 MMB). There are several methods of brine disposal currently used, e.g., deep well injection, ocean discharge, road spreading (for dust control), discharge to surface waters, evaporation, and salt plant feed. The method of brine disposal addressed by this research project is deep well injection, which is the most commonly employed method in areas remote to the ocean disposal.

A typical injection well has several concentric pipes, which extend down from the surface into the injection zone (see Figure 1). The outermost pipe or surface casing extends below the base of any underground sources of drinking water and is cemented back to the surface to prevent contamination. Directly inside the surface casing is a long string casing that extends to and sometimes into the injection zone. The casing is filled in with cement all the way back to the surface in order to seal off the injected material from the formations above. The fluid is injected through the injection tubing inside the long string casing either through perforations in the long string casing or in an open hole below the bottom of the long string. The space between the string casing and the injection tube, called the annulus, is filled with an inert, pressurized fluid, and is sealed at the bottom by a removable packer preventing injected wastewater from backing up into the annulus.

An optimal disposal reservoir should have both good porosity and high permeability to allow for reasonable injection rates. The primary porosity of sandstones, dolostones and limestones makes them potential disposal reservoirs. Especially when fractured these lithologies will provide the best porosity/permeability combinations. Permeability and porosity of reservoirs in the Appalachian Basin of New York State are generally regarded as low in comparison with those of other basins. Porosities and permeabilities on the order of 10 percent and a few millidarcies respectively, are common for the tight rocks of the state (McCann et al., 1968).

\section{Industry Standards for Brine Disposal}

There are four basic standards that determine the suitability of a given formation to act as a reservoir for brine disposal. These are: 
- The disposal formation must exhibit sufficient porosity and permeability to allow reasonable injection rates at acceptable pressures.

- The connate water salinity of the disposal reservoir must be similar to injected brine.

- The disposal reservoir is located well below all fresh water aquifers and separated from the aquifers by impermeable formations.

- The reservoir volume must be capable of accepting the total volume of brine generated over an economically viable duration of time.

(After Swenson and Potashik, 1994)

\section{Government Regulations}

The following section contains brief summaries of the regulations put forth by the federal and state governments pertaining to cavern development through solution mining and brine disposal through deep well injection. Some background to the regulations is included so that the readers can follow up with more research and this is highly suggested. These are summaries, and are not intended to be used as direct statements of the laws or regulations themselves, but rather are to be used as a tool for understanding the criteria presented in this report.

New York State. The New York State Legislature, in Article 17 of the Environmental Conservation Law (ECL), has given the Department of Environmental Conservation (DEC) the authority to regulate the underground injection of industrial wastes, while ECL Article 23 addresses cavern development. With in the DEC the Minerals Resources and Water divisions have jurisdiction over cavern development, underground storage and brine disposal. That authority includes the establishment and enforcement of standards and the issuing of State Pollutant Discharge Elimination System (SPDES) permits for brine disposal.

In 1997, the DEC developed new draft regulations for the solution mining and underground storage industries, until this process is concluded the industries are regulated using the oil, gas and solution mining regulations currently on the books in 6NYCRR Parts 550-559 (Sanford, 1996). The need for new regulations was recognized by a DEC study (Briggs, 1995), which 
found that there was overlap between the federal and state regulatory programs concerning solution mining. Along with the overlap, Division staff also concluded that the federal program's focus was deficient in areas pertaining to reducing subsidence and subsidence related groundwater protection. To correct this, the division took the position the State's role in regulating would be to supplement the federal program in areas where they perceived a gap in regulatory interests (Sanford, 1996). The State's primary focus is to supplement injection related interests of the EPA with requirements that ensure the development of safe caverns. These requirements are not of interest to this study because they deal with engineering of the cavern and not with the initial site selection.

There are several steps that an operator looking to dispose of brine wastewater through deep-well injection must take into consideration. First the operator must file an application with the DEC Division of Mineral Resources for a permit to drill a new well or deepen, plug back or convert an existing well to a disposal well. Additionally, to use the well for disposal the operator would need to apply to the DEC Division of Water for a discharge permit under the State Pollution Elimination System or SPDES (Briggs, 2002). The SPDES program is covered by Article 17, Title 8 of the ECL and 6NYCRR Part 750 (Rules and Regulations).

Federal. The Underground Injection Control (UIC) Program, established by the US Environmental Protection Agency (EPA), regulates injection wells with the goal of preventing them from contaminating drinking water resources. Each State has the option of applying to the EPA for primary responsibility over the UIC program in their state. To do this a state must prove that they have and effective program for preventing underground injection, which would endanger drinking waters. Currently, New York has decided not to accept primary enforcement responsibility over the UIC program in the state.

According to the UIC, underground injection wells are divided in to five classes based on the type of fluid they inject and where the fluid is injected. Solution mining wells used during cavern development fall into Class III- Mining Wells. The deep injection wells used to dispose of brine generated during cavern development are Class II, which covers oil and gas production, brine disposal and other related wells. The are some general requirements for owners and 
operators of both Class II and III injection well that would influence the site selection of salt cavern storage and related brine disposal facilities, these are:

- Site the wells in a location that is free of faults and other adverse geological features;

- Drill to a depth that allows the injection into formations that do not contain water that can potentially be used as a source of drinking water.

- These injection zones are confined from any formation that may contain water that may potentially be used as a source of drinking waster (EPA, 2005)

The Federal UIC permit also requires certain monitoring practices. Monitoring injection pressure, rate of injection, annular pressure and accumulative volumes injected is recorded on a daily basis (Motsumoto et al., 1996). In addition, groundwater-monitoring program must be established to ensure that contaminants are not migrating towards potable aquifers. Along with these, the EPA has other general requirements for Class II and III well operation, but they are do not directly influence the facility site selection process and are therefore beyond the scope of this project. Specific details on UIC regulations can be found in the Code of Federal Regulations, Title 40, Parts 124, 144, 146 and 147.

\section{General Geology of New York State}

Most of central and western New York State is located in the northern portion of the Appalachian Basin. Except for the wide spread of Pleistocene glacial drift ranging in thickness from zero to more than 1,000 feet, all of the sedimentary rocks of New York are of Paleozoic age (Figure 5). Silurian, Ordovician and Cambrian strata rim the Adirondack uplands to the northeast (Figure 6). Devonian strata cover most of the rest of the western part of the State with the exception of a few very small outcrops of Mississippian and Pennsylvanian strata in the western portion of the Southern Tier (McCann et al., 1968, Rogers et al. 1990).

The Paleozoic section ranges in thickness from zero, near the Adirondack uplift in northeastern New York, to more than 13,000 feet $(3,961 \mathrm{~m})$ in Steuben County in the south-central part of the state (McCann, 1968; Saroff, 1987). Together Figure 5 and 6 show the general stratigraphic and 


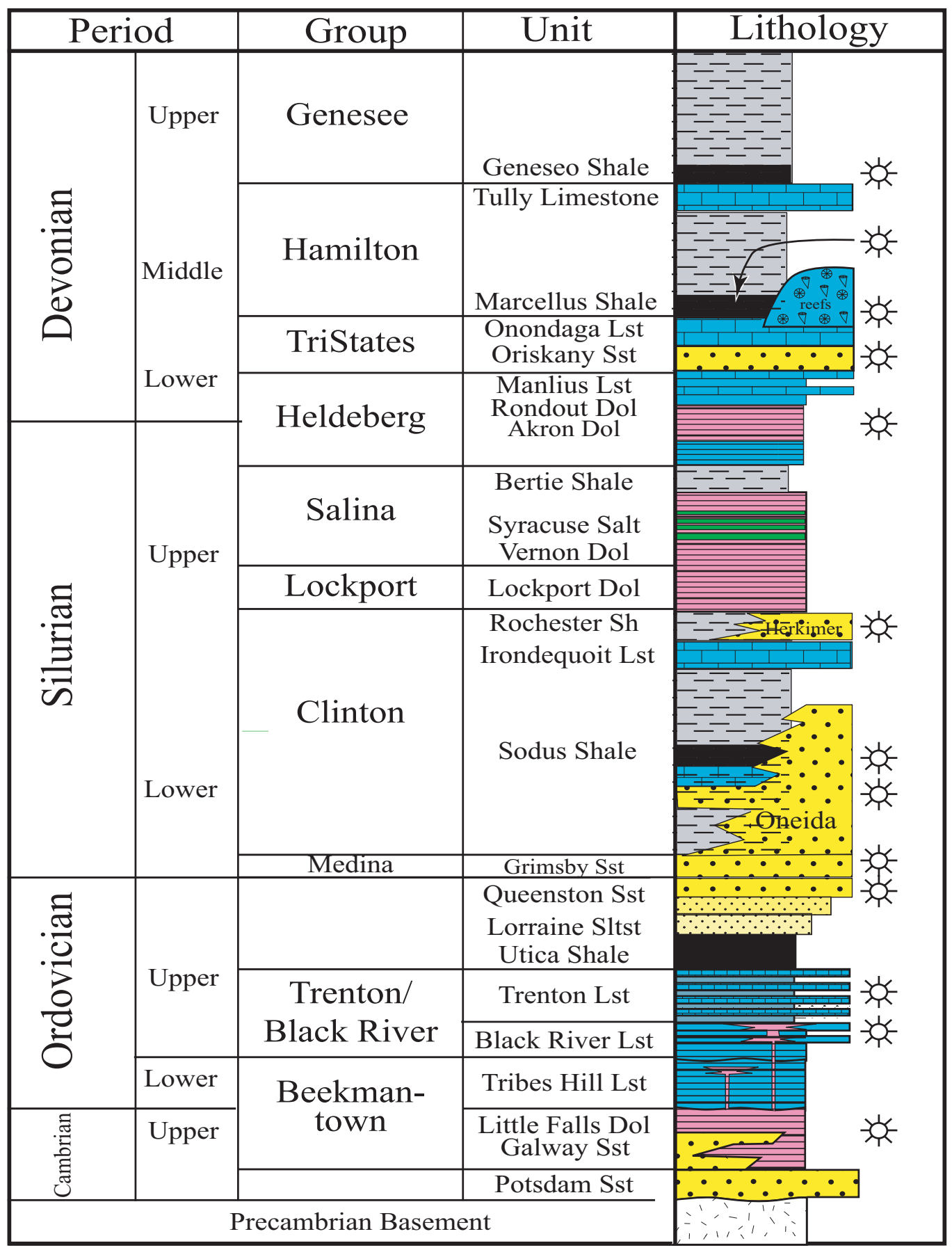

Figure 5 Stratigraphic Section of central New York. (Smith, 2005) 


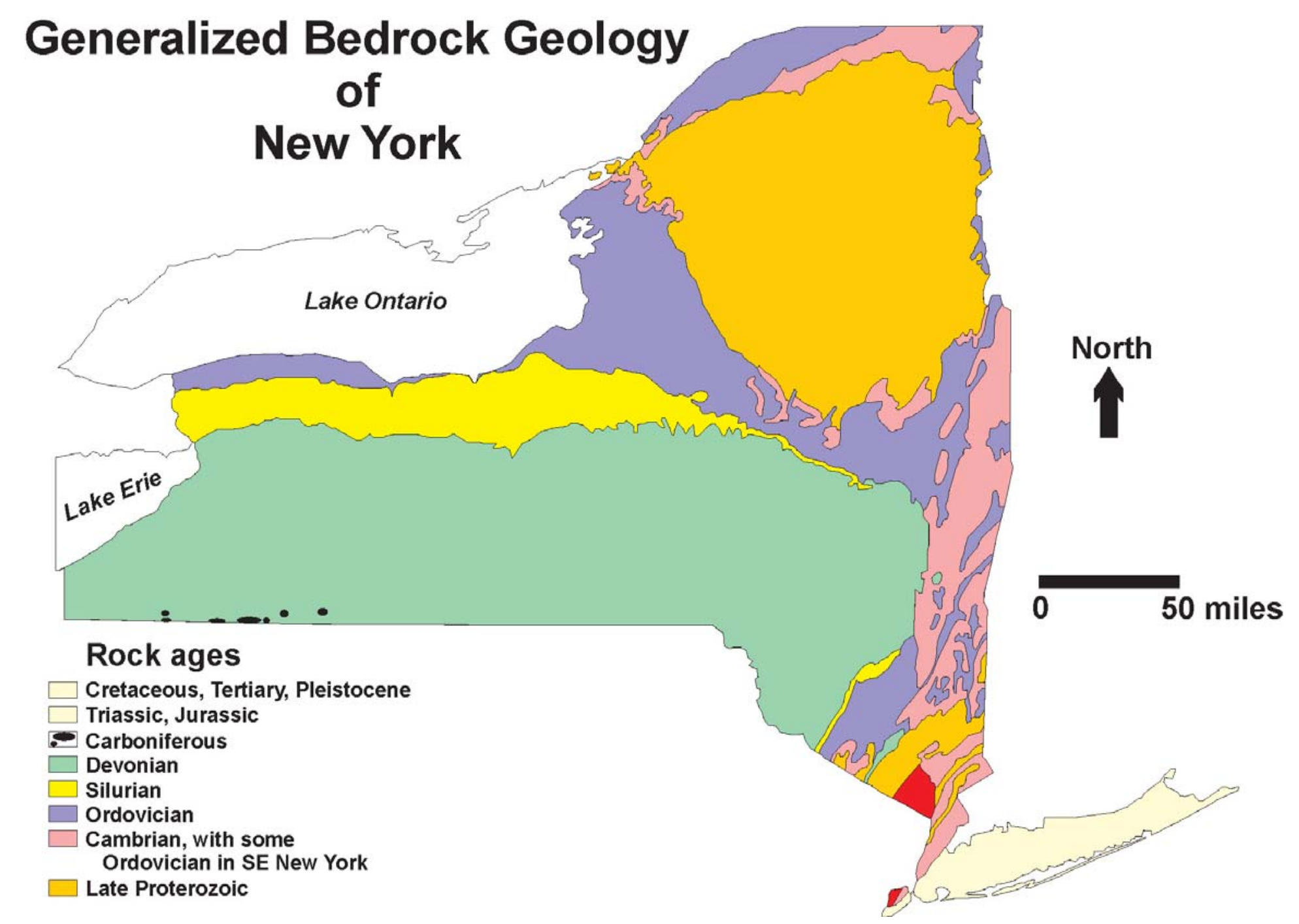

Figure 6 Generalized Bedrock Geology of New York State 
spatial distribution of sedimentary strata in western and central New York State. The descriptions below are more detailed, with specific inclusion of characteristics related to the current research initiative (i.e. porosity, permeability, production, storage, etc.).

\section{Subsurface Geology of Central New York State}

At the base of the sedimentary section is the Cambro-Ordovician Beekmantown Group, which is composed of interbedded dolomite and sandstones of the Potsdam, Galway, Little Falls and Tribes Hill formations. The Upper Cambrian Potsdam Sandstone is predominantly sandstone with minor beds of dark gray and tan, very finely textured dolomite and dark gray shale. The formation crops out on the flanks of the Adirondack uplift and has some porosity and permeability near the outcrop belt. Kreidler (1963) reported shows of oil in Morrisonville well in Clinton County (Kreidler, 1963). Gas produced commercially from this formation in the Memphis Field of Onondaga County in 1897 (Robinson, 1985). Very few wells in the western part of the State have penetrated the Potsdam, but where they have it was not porous or permeable.

Overlying the Potsdam Formation is the Galway Formation (Cambrian), a dolomite with interbedded sandstone. In some places the Formation contains dark gray, laminated slightly dolomitic shale in the upper 20 to 30 feet. In west-central New York the sandy dolomite grades into a distinct sandstone facies at it upper limits. Fields that produce from this formation include Cascade Brook, Northwoods, Bockhahn, and Connoisarauley Creek fields, all of which are located in western New York. Permeability reported in the pay section varies from .75 to 3.67 $\mathrm{mD}$.

The Little Falls Formation (Cambrian) is mainly a light gray, finely crystalline dolomite with a few rounded and frosted quartz grains, which was deposited in a peritidal environment. Commonly pryrite, chert, and oolites are found in this unit. Flagler (1966) delineated an oollitic chert zone present near the base of the Little Falls to define the boundary between it and the Galway. Gas show reported in northeastern part of the basin in Herkimer County. No commercial production known. 
The Tribes Hill Formation (Ordovician) is a light gray, dense to very fine crystalline variably dolomitic limestone. Tribes Hill was deposited on a wave-dominated shelf with a uniform stratigraphy (Landing, 1996). Some operators and geologists argue that some wells reported to be producing from the Little Falls are actually producing from the Tribes Hill, but no documented production has occurred from this formation.

Separated from the underlying Beekmantown by the Knox unconformity, is the Black River Group (Ordovician), which consists of dark-gray to brown cherty limestone and various amounts of shale. The Black River Group is comprised of predominantly peritidal to shallow subtidal fine grained carbonates (Cornell, 2001). Hydrothermally altered dolomites of the Black River located in basement fault controlled sag features currently produce natural gas in much of south central New York State a prolific rates. Fields include, Glodes Corners Road (discovery), Muck Farms, Quacken Bush, Terry Hill South, and Wilson Hollow Fields.

The Trenton Group (Ordovician) is a light to dark gray limestone beds with alternating thin, gray calcareous shale beds. The Trenton is composed almost exclusively of subtidal, shallow shelf calarenites (pack- and grainstones), and deeper ramp calcisiltites, calcilutites (limestone wackestones and mudstones) and shales (Cornell, 2001). Believed to be a fracture limestone play in the northern tier of the state, it produces initially at high volumes and than decreases quickly. Fields include Sandy Creek, Pulaski, and Camden. In Ohio and Ontario, Canada the production from the Trenton occurs in hydrothermally altered carbonates, in New York similar reservoirs are found in the Black River in New York.

Overlying the carbonates of the Beekmantown, Black River and Trenton formations is a thick succession of clastic rocks that comprise the remainder of Ordovician strata in New York State. This includes the Utica, Oswego, and Queenston formations and the Lorraine Group.

The lowermost formation, the Utica (Ordovician) is both younger and equivalent to the Trenton Formation. The formation is a dark gray to black calcareous shale with interbedded gray calcareous siltstone (Baird and Breet, 2002) with many K-bentonite beds. The Utica Formation 
is several hundred feet thick in central New York and up to 1,000 feet thick in the Mohawk Valley region (Saroff, 1987, McCann et al., 1968). Several researchers believe that the Utica Shale in New York has great potential as a gas shale play, but to date, only gas shows have been reported, but no commercial production.

Overlying the Utica in central New York is the Lorraine Group (Ordovician), which is another thick interval of shale. The Lorraine consists of gray, slightly calcareous shale with some interbedded fine grained sandstone and siltstone. The Lorraine group is transitional with both the underlying Utica Formation and the overlying Oswego Formation. In the subsurface of central New York this type of contact makes the break between the two very hard to notice on geophysical well logs (Saroff, 1987). The Oswego Formation (Ordovician) is a greenish-gray, very fine grained sandstone which is argillaceous and slightly calcareous. The sandstone usually has interbedded greenish-gray, brick-red and purplish-gray shales. Shows have been reported in south central New York, but there is currently no production from this formation.

The Queenston Formation (Ordovician) is a red, brown gray, and green shale siltstone and fine to medium grained sandstone. In east and central New York the Queenston is primarily a siltstone and sandstone. In the western part of the state it grades into a slightly calcareous brown to green, gray and red silty shale. It is composed of multiple, stacked, fluvial, sandstones, siltstones and shales. The producing zones are channel lag deposits and vary from braided -fluvial to tidalinlet sandstones.

At the base of the Silurian section is the Medina Group, which is separated from the Ordovician strata by the regional Cherokee Unconformity (Swezey, 2002). It unconformably overlies the Queenston with the Whirlpool pinching out to the east. It is overlain conformably by the Silurian Clinton Formation. Medina Group was the main producing formation in New York until the new Black River play came online in the late nineties. Low volumes and longevity characterize the play. The Lakeshore Field, a Medina Field, is the largest (aerial extent) gas field in New York. Porosity ranges between $6-8 \%$ and average permeability is $0.1 \mathrm{md}$. The Grimsby Formation unconformably overlies the Queenston Formation in central New York where the Whirlpool Formation is absent (pinches out farther west). 
Overlying the Medina Group is the Clinton Group (Silurian), which is predominately a silty and argillaceous dark gray shale with interbedded limestone overlying a gray-white sandstone. Most of the production in Chautauqua and Erie Counties is from the Clinton Group. The Lockport Group consists of dolomites and limestones with a little interbedded shale. The Lockport is used as a marker bed in the subsurface because of its sharp contact with the Vernon shale at the top and the Rochester Shale at the base. In geophysical logs the Lockport has a consistent and easily identifiable signature over a large portion of the state. Gas has been encountered in the lower part of the formation in central New York.

The Silurian Salina Group in central New York consists of five formations in the subsurface: the Vernon Shale, Syracuse salt, the Camillus shale, the Bertie Limestone and the Cobleskill Limestone (detailed discussion below). Significant salt beds are found in the Vernon B unit and the Syracuse D, E and F units. In much of the Appalachian Basin, the evaporites of the Silurian act as a regional hydrocarbon seal. That is, petroleum reserves located below the Salina group evaporites are derived from pre-Salina source rocks, forming two distinct petroleum systems. The salt located in the Vernon and Syracuse formations of the Silina Group are mined for salt at many facilities in central and western New York. There are also two existing solution mined storage caverns in south central New York. One stores natural gas and the other propane. Several other facilities have been proposed within the state and also in Pennsylvania. The Silina Group is the focus of Phase one of this research initiative and there is a much more detailed discussion of the group later in this report. Akron dolomite facies of the Cobleskill limestone in central and eastern New York. (Ciruca and Hamell, 1994) produced oil and gas in the Bass Island field in western New York. The Akron Formation is the youngest Silurian formation in central New York State.

The Helderberg Group is the lowermost Group in the Devonian interval of central and western New York State. In central New York the Group consists of the Manlius and Roundout Limestones, which are shaley and silty limestones. Although the Helderberg Group is originally reported to be the producing formation at the Stagecoach Field in Steuben County, it was later changed to the Oriskany Formation. There is currently no production from the Helderberg. 
The Oriskany Formation (Devonian) is a white to gray, fine to medium grained mature sandstone that was deposited in a shallow marine environment. The Oriskany is notoriously patchy in most of western and central New York, where it is less than 50 feet thick if present at all. No longer a major gas producer, the Oriskany did produce in the 1930's and 1940's and was at that time comparable to the Medina Play. Now most of the fields have been converted into gas storage (9 of the 22 depleted reservoir style storage fields are in the Oriskany). Most of the Oriskany sand production

The carbonates of the Onondaga Formation (Devonian) were deposited in a westwardtransgressing, shallow, northeast-trending epicontinental sea (Lindemann and Feldman, 1987). The Onondaga Formation has produced gas from porous limestone in pinnacle reefs found in Steuben and Cattaraugus counties. The pinnacle reefs were found by seismic surveys in the mid 1960's. It was also the first formation used for traditional depleted reservoir style gas storage in the Zoar Field in 1916.

Though there are several additional groups and formations (Hamilton Group, Tully Formation, Genesee Group, Sonyea, Group, West Falls Group, Canadaway Group, Conneaut Group and Conewango Group) that complete the succession of strata in central New York, none of these formations are being evaluated as part of the current research initiative and therefore are not included in this summary.

Some of the general relationships discussed above can be seen in Figure 5 the Stratigraphic section for Central New York and in Figure 7, a north-south schematic cross-section through central New York.

Glacial debris left behind by the retreating Pleistocene ice sheets created deposits as thick as 180 $\mathrm{m}$ to $300 \mathrm{~m}$ in valleys such as those found in the Finger Lakes (e.g. Isachsen et al., 2000). Elsewhere across the region, glacial deposits on the uplands vary in thickness from 0 to $50 \mathrm{~m}$ (Muller, E. H. and Cadwell, 1986; Cadwell and Nottis, 1998). 


\section{Schematic North-South Cross Section}

Finger Lakes Region of New York State

Prepared by : Courtney Lugert

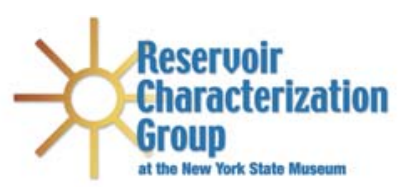

Scale:

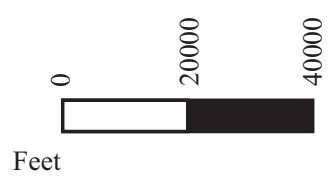

Legend:

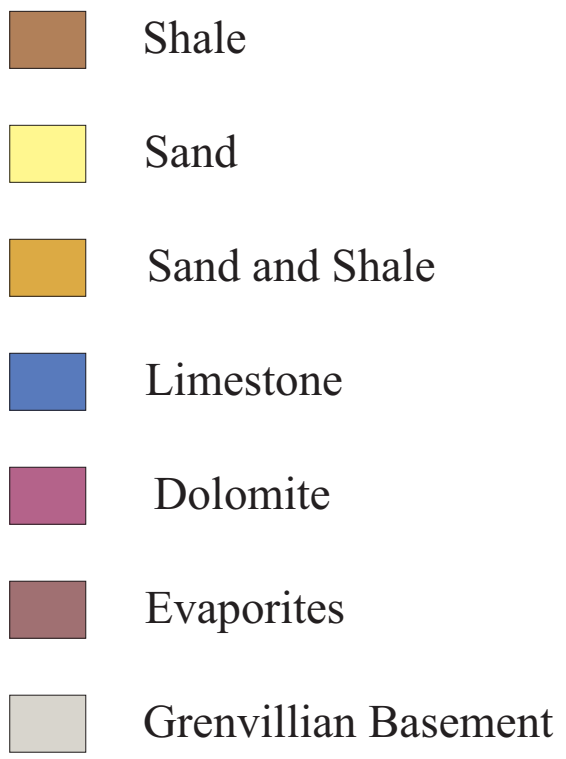

Vertical Exaggeration: 20x

Figure 7a Legend for Schematic North-South Cross Section - Finger Lakes Region of New York State. Actual well logs and formation tops were used to compile the initial layout of the section, this version however has been simplified and is very schematic. The surface topography shown in the cross section was generated from the ground elevations on file for the wells used to generate the section and does not indicate the actual surface topography. 


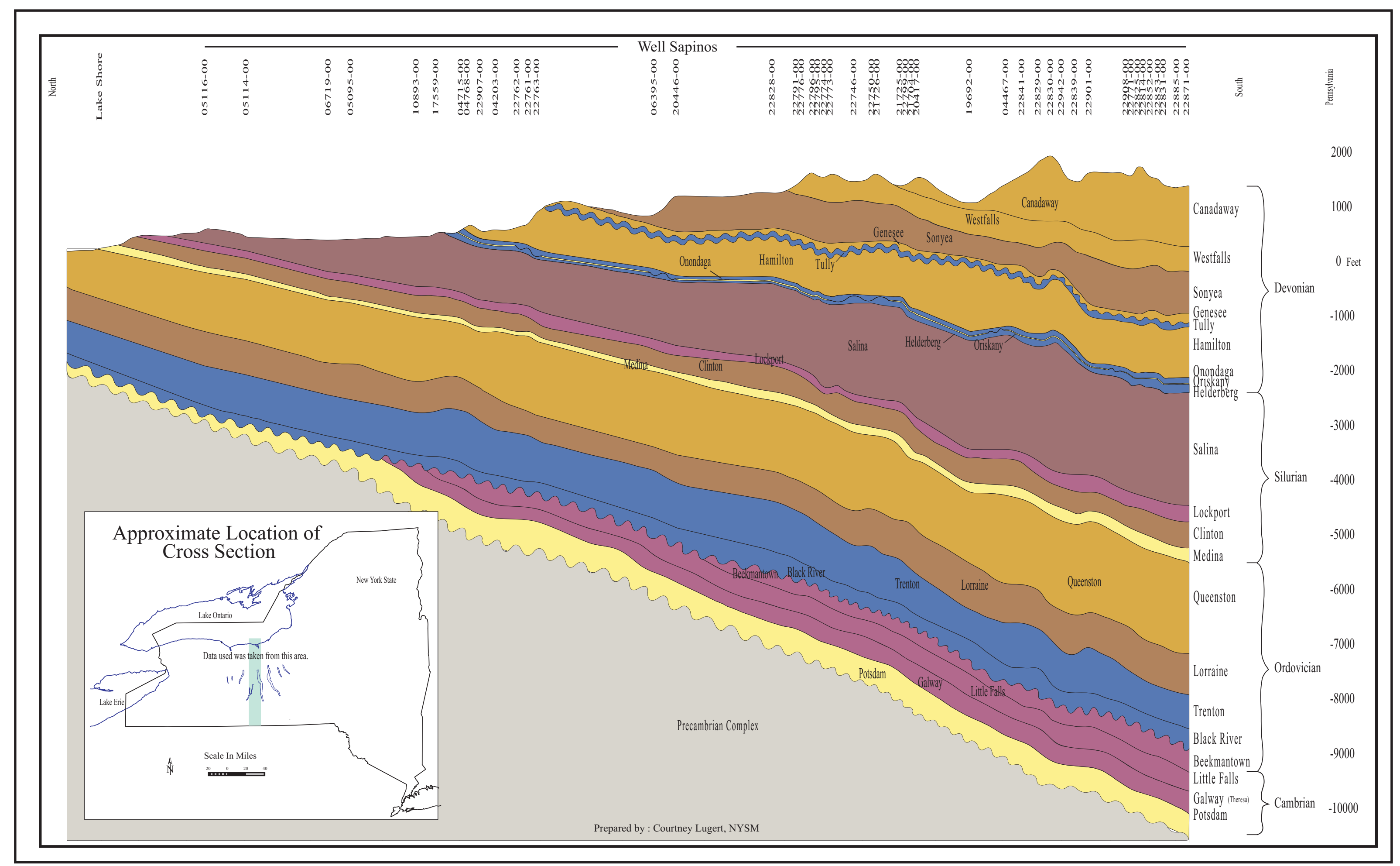

Figure 7b Schematic North-South Cross Section - Finger Lakes Region of New York State. are labeled along the top of the section. The surface topography shown in the cross section was generated from the ground elevations on file for the wells and does not indicate the actual surface topography. 
Except in the vicinity of local faults and other local structure, the regional dip to the south never exceeds more than a few degrees and in both the surface and subsurface it is roughly 50 feet/mile or $9.5 \mathrm{~m} / \mathrm{km}$ (McCann et al., 1968). Figure 8, a regional north-south seismic line through central New York clearly shows the subtle southerly dip as long as other more localized structures.

Figure 9 is a type log for the Paleozoic Section in central New York from the Precambrian crystalline basement to the upper Devonian sand and shales. Tops were obtained from ESOGIS and checked against picks from Rickard (1969), Stone and Webster (1978), Saroff (1988), Bastedo and VanTyne (1990), Kearny (1983) and Bass et al. (1996).

\section{Characteristics of a Good Disposal Reservoir}

For cavern development to be economically feasible, potential disposal reservoirs must be capable of accepting brine at the volumes and rates necessary for cavern development. This capability is a combination of several characteristics of the disposal reservoir, the viscosity of the brine, injection pressure, thickness and aerial extent of the reservoir and porosity and permeability of the formation. Potential brine disposal formations must have sufficient permeability to accept brine at high rates and enough porosity (generally greater than 10\%) to store the total amount of brine generated during the leaching process. These characteristics are best if naturally occurring, but formations that are candidates for hydraulic fracturing should also be considered. Brine disposal wells are usually completed into porous saltwater aquifers (salinity greater than 200, $000 \mathrm{ppm}$ ) with salinity similar to the injected brine. Typically these aquifers are below and isolated from any potable freshwater aquifers (Friedman et al., 2002), to prevent the contamination of such aquifers.

Porosity and Permeability. In its most basic form, porosity is the ratio of the nonsolid portion of a rock to the solid portion or the percentage of a rock unit that consists of void space. When actually testing or defining the porosity of a formation, additional parameters must be considered. 


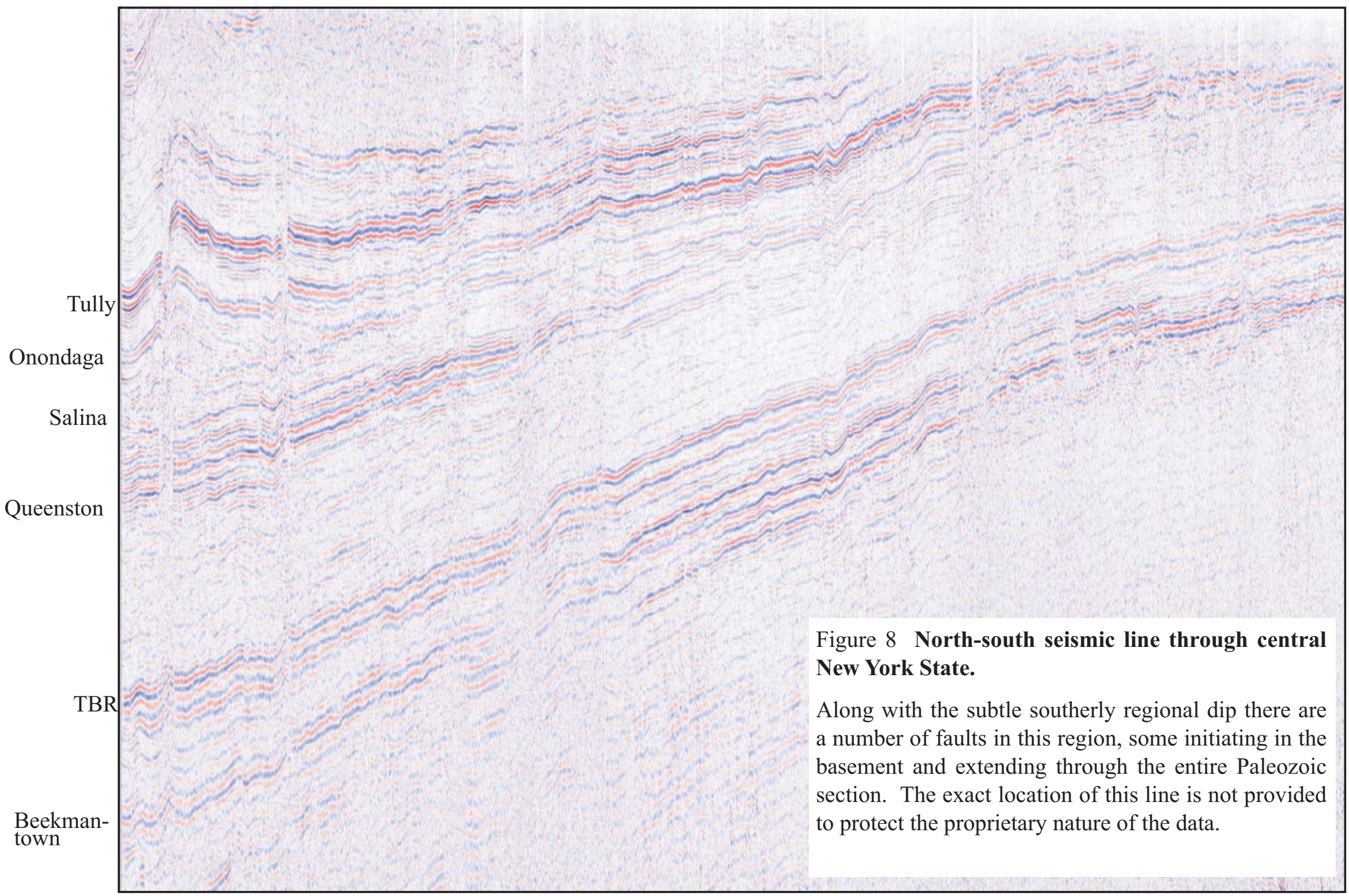



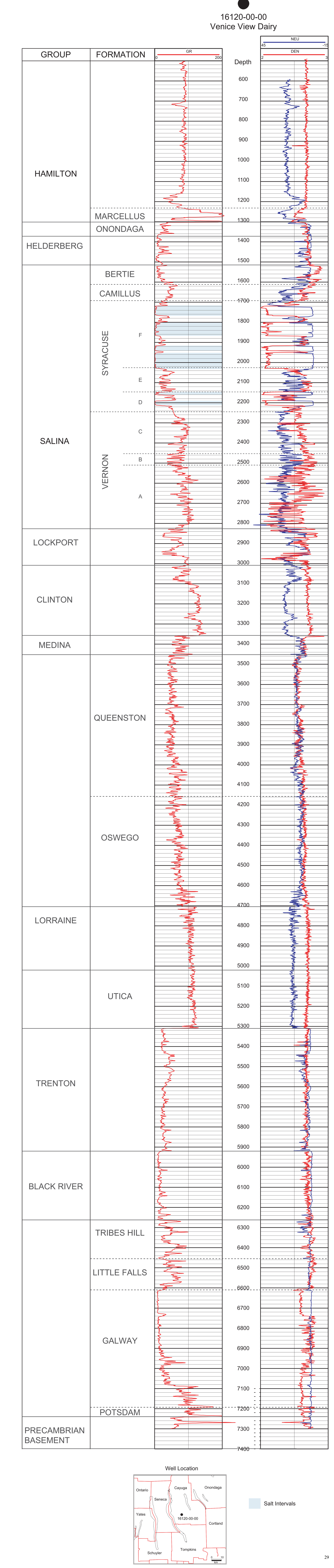
Primary porosity is the porosity developed during the original sedimentation and compaction processes that created the rock. Porosity not attributed to the original sedimentation and compaction, due to processes such as natural fracturing and diagenesis, are considered secondary porosity.

As its name implies, porosity is an estimate of the space between the grains forming the rock, or the pores. If a rock unit has significant porosity, but the passageways between the pores (pore throats) are too small to allow for the transport of the molecules being stored or extracted (brine, gas, oil...) or aren't connected at all, the porosity wont contribute to the overall reservoir volume or performance. Effective porosity is the sum of the primary and secondary porosity that actually contributes to the reservoir volume and performance.

It is not enough to have a reservoir with the pore space to accept the brine; just as important to successful disposal, the brine must be able to flow away from the well bore and into the reservoir. Permeability is a measure of a rock's ability to defuse fluids throughout the reservoir. It is related to porosity, but not always dependent upon it. Several additional parameters determine the permeability of a reservoir. These include grain size, viscosity of the transported fluid and presence of additional fluids in the pores.

The ability of a rock to transmit a single fluid when it is $100 \%$ saturated with that fluid is referred to as absolute permeability. Effective permeability refers to the presence of two fluids in the system and is the ability of the rock to transmit a fluid in the presence of another fluid when the two fluids are immiscible (Asquith, 1982). In the case of a hydrocarbon or disposal reservoir, connate water (pore fluids) in the formation serves to inhibit the flow of hydrocarbons or the disposal fluid. This happens because the pore fluid takes up space within the pores and the pore throats, blocking or otherwise reducing the ability of other fluids to move through the formation (Asquith, 1982). It is possible to overcome this barrier, but there are limits, while injecting brine in to a disposal reservoir an operator must be very careful to work within a range of pressure that will not induce seismicity. This brings about the point that reasonable effective permeability is crucial to successful disposal. 
The symbol $\mathrm{K}_{\mathrm{a}}$ is used to represent (absolute) permeability and the darcy (d) or millidarcy (md) are the units of measure most commonly used in the petroleum industry. Permeabilities normally encountered in reservoir rocks range from less than 1 millidarcy in low porosity sands to about $50 \mathrm{~d}$ in fractured rock (Crain, 1986).

In general, porosity and permeability of reservoirs in New York and much of the Appalachian Basin are low when compared to the same from other regions. With a few notable exceptions, the porosity of rocks in the Appalachian Basin commonly is less than $10 \%$ and the permeability is on the order of a few millidarcies or less. In areas where natural fractures exist and induced fractures occur, permeability can be elevated significantly (McCann et. al, 1968). The low porosities and permeabilities found in New York State have contributed to brine disposal becoming a barrier to salt cavern storage in the State.

\section{Summary of Avoca and other Projects}

According to Sandford (2000), at year-end in 1999, New York had a total underground natural gas storage capacity (working gas capacity) of $90.4 \mathrm{Bcf}$. This was maintained in 21 traditional depleted reservoir storage facilities with a combined working gas capacity of $89.6 \mathrm{Bcf}$ and 1 salt cavern storage facility with a working gas capacity of $0.8 \mathrm{Bcf}$.

The one operational natural gas salt cavern storage facility in New York, NYSEG - Seneca Lake Storage Inc., is located along the shore of Seneca Lake, near the town of Watkins Glen (Figure 10). This facility has a capacity of $0.8 \mathrm{Bcf}$ and a deliverability rate of $80 \mathrm{MMCF} / \mathrm{day}$ and a cycle time of roughly 30 days ( 10 day injection and 20 day withdrawal). This facility was created by converting an existing cavern, which was original solution mined for the salt industry, to a storage cavern. Brine disposal was not a problem at this facility because the caverns were created for the purpose of harvesting the salt. New York State has many solution salt mining operations that if properly engineered have potential to be converted to natural gas storage. The problems with this type of project are related to the depth at which the cavern lie (not appropriate for natural gas storage) and that the caverns were not originally engineered and mined for natural 
gas storage. Also, salt quality was often not considered when mining these caverns, they tend to have an irregular shape and large amounts of non-salt ruble at the base of the cavern, meaning larger amounts of cushion gas would be needed.

In addition to the natural gas facility operated by NYSEG, there is one propane storage facility in Bath, New York (Bath Petroleum Inc.; Figure 10). The facility at Bath consists of several tall cylindrical caverns solution mined in the Salina. Brine is pumped into and removed from the caverns when propane is injected or withdrawn. Onsite there are several brine holding ponds where the brine used to displace the propane is stored while not being used. Recently, one of these brine holding ponds was breeched. The Department of Environmental Conservation (DEC) allowed the facility to temporarily dispose of the brine from that holding pond into an existing disposal well, to alleviate the emergency conditions. The reservoir targeted by this well was the upper portion of the Queenston Formation. Though the disposal was temporary, lasting only a few months, rates of 5 BPM (barrels per minute) were sustained during that time. Bath Petroleum Inc. is currently seeking to convert the facility to store natural gas rather than propane. As part of this conversion they would be expanding their cavern capacity and hope to dispose of the generated brine into the Queenston Formation. This process will need approval and permitting by the DEC.

In addition to the two operational storage facilities (Bath Petroleum Inc. and the NYSEG facility) there are several facilities that have been proposed in New York (Figure 10). We have chosen to include a discussion of the most complete of those proposed facilities, the Avoca Project. A complete discussion of the original plan for the Avoca Project can be found in Morill, 1996.

The proposed Avoca facility is located in Avoca, New York (Figure 10) in the vicinity of the Cohocton River (Figure11). The Avoca facility was originally proposed to include 6 caverns to be leached into the Salina D unit at depth of 3,500-4,000 feet (Figure 12). The salt there was judged to be of sufficient quality and thickness to make caverns. These 6 caverns would have a total capacity of $6.72 \mathrm{Bcf}$ and a deliverability rate of $500 \mathrm{MMCF} /$ day. In the development of the caverns, the project engineers calculated that they would generate roughly 50 million barrels of 


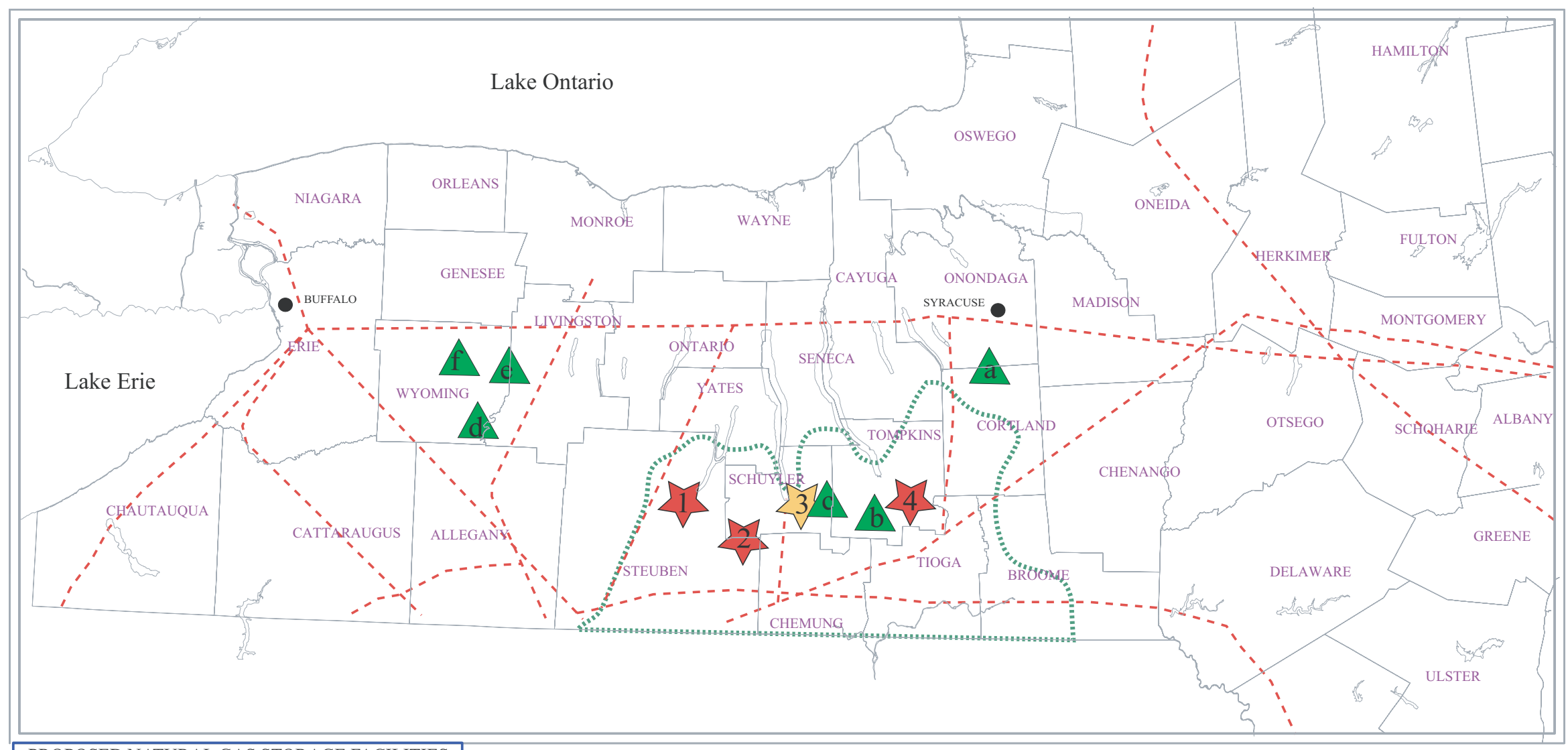

\begin{tabular}{|c|c|c|c|}
\hline \multicolumn{4}{|c|}{$\begin{array}{l}\text { PROPOSED NATURAL GAS STORAGE FACILITIES } \\
\text { IN SOLUTIONED SALT AND MAJOR PIPELINES }\end{array}$} \\
\hline \multicolumn{3}{|c|}{ Scale } & \\
\hline & 25 & 50 & \\
\hline \multicolumn{3}{|c|}{ KILOMETERS } & \\
\hline \multirow{4}{*}{$\begin{array}{c}* \\
\Delta \\
\ldots+\cdots \\
\square \\
\square\end{array}$} & \multirow{4}{*}{\multicolumn{2}{|c|}{ 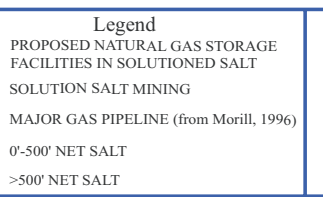 }} & \multirow[t]{4}{*}{$\begin{array}{l}\text { Salina Group } \\
\text { Outcrop }\end{array}$} \\
\hline & & & \\
\hline & & & \\
\hline & & & \\
\hline \multicolumn{2}{|c|}{ Mining Facilities } & \multirow{2}{*}{\multicolumn{2}{|c|}{$\begin{array}{l}\text { Proposed Nat. Gas } \\
\text { Storage Facilities }\end{array}$}} \\
\hline \multirow{6}{*}{$\begin{array}{l}\mathbf{A} \\
\mathbf{A} \\
\mathbf{A} \\
\mathbf{A} \\
\mathbf{A}\end{array}$} & Allied, Tully (inactive) & & \\
\hline & Cargill, Watkins Glen & is & Avoca \\
\hline & Akzo, Watikins Glen & & Bath \\
\hline & Morton, Silver Springs & & \\
\hline & Texas Brine, Wyoming & & NYSEG - Seneca Lake \\
\hline & Texas Brine, Dale & 4 & Cayuta \\
\hline
\end{tabular}

Figure 10 Map of storage and mining facilities operating in the New York's Silurian Salt deposits. The green dashed line indicates the study area defined by this study. 


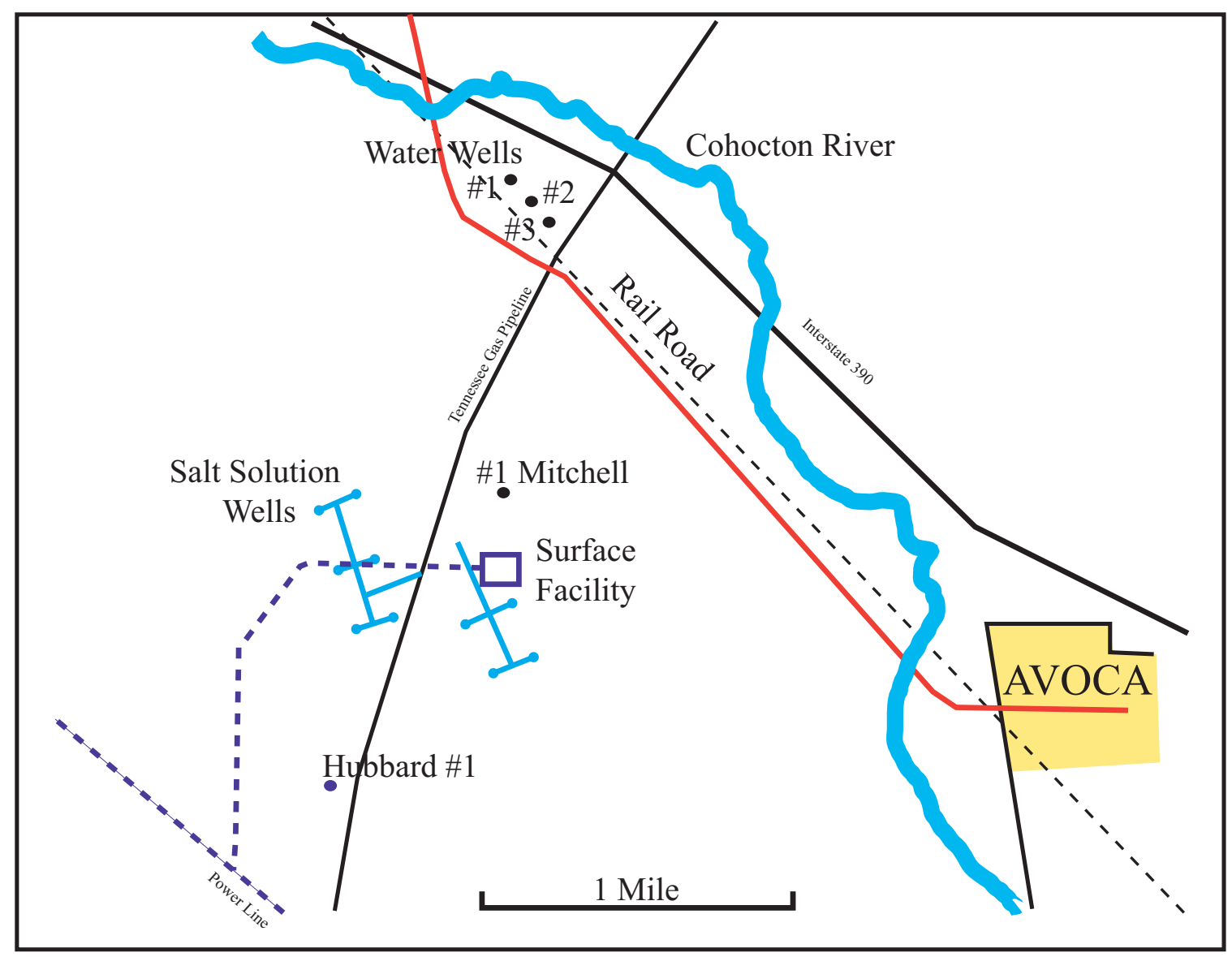

Figure 11 Avoca Project Facility Map. (Modified from Morill, 1996) 


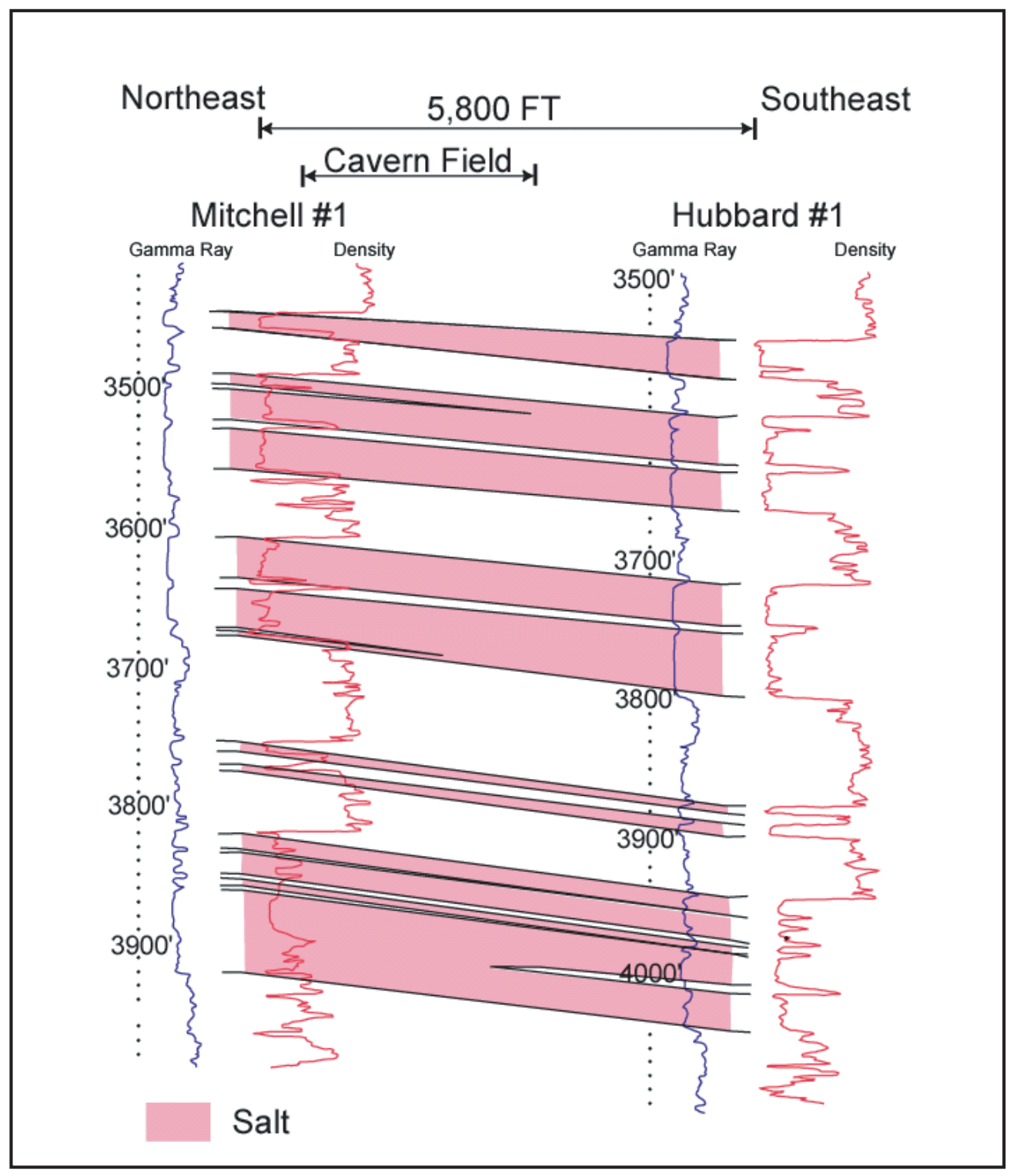

Figure 12 Correlation of the Salina D-unit at the Avoca Salt Cavern Storage Project Site. (Morrill, 1996) 
brine, which were going to be disposed of in six injection wells at a rate of three million gallons per day or each well at 8-10 barrels per minute. The targeted disposal formations were located below the Utica Shale, into Cambrian Potsdam and Theresa Sandstones.

The original operators of the Avoca Site tested disposal into the Cambrian section in the Mitchell No. 1 well (Morill, 1996). Three zones of the Cambrian section were perforated and tested for injection potential. These tests recorded rates up to 8.6 barrels per minute (Morill, 1996). Further testing was conducted on the Mitchell No. 1 Well, which determined that the tested disposal zones were not limited aerially and that 6 disposal wells spaced 4,000 feet apart could adequately dispose of the brine generated during cavern leaching (Morill, 1996). These encouraging results were soon followed by very discouraging results. Subsequent testing of the same zones in a second well, the Hubbard \#1, resulted in significantly poorer results. Four more disposal wells were drilled and they all had similarly poor porosity and permeability in the Cambrian section. Attempts were made to pump brine into the low permeability sandstones at elevated pressures. Small earthquakes occurred in the area at that time and the NYS Department of Environmental Conservation (DEC) shut the project down. Their position was that the injection had caused the earthquakes.

After many years and approximately $\$ 100$ million dollars of expenditures, the Avoca project was abandoned because of the lack of a feasible brine disposal plan. Much of this money was spent on drilling the thirteen wells located on the Avoca site. There are six disposal wells and seven other wells, some of which were intended to be cavern development wells. Drilling wells is an expensive endeavor; it is therefore sensible that in future cavern development attempts a brine disposal method is secured prior to the drilling of the cavern wells. The project has been sold several times and there are still plans to make the caverns, but brine disposal continues to be the major obstacle to success. 


\section{Section 2}

\section{CURRENT INITIATIVE}

Using the findings of previous researchers and inline with current state and federal regulations, this report outlines a set of criteria, which can be used to identify areas suitable for developing salt cavern storage facilities for natural gas. These criteria have been used to evaluate portions of New York State for its potential for salt cavern storage. In general the work was broken into two phases. During Phase I, areas having salt suitable for cavern development were defined. This initial step allowed later research to be focused into areas where cavern development is a possibility. The primary focus of Phase II was to locate formations that offer potential as brine disposal reservoirs.

Depths to formation surfaces or tops were identified and collected for each of the formations evaluated in Phase I and II of this research initiative. Tops were primarily identified using rasterized or digitized wireline (when available) logs from the collections of the New York State Museum (NYSM). The identification of formation boundaries on wireline logs, which are called picks, were based on similar picks completed in previous studies, as obtained directly from such studies or from ESOGIS (Empire State Oil and Gas Information System). The measured depths collected in this manor were entered in to a GeoPlus Petra тм (a well-based GIS software package designed for petroleum exploration) project for each formation being evaluated where they could be used to generate maps and cross sections. GeoPlus Petra automatically creates subsea elevations based on entered surface elevations where logging was initiated (i.e., kelly bushing, drillers floor, etc.). Figure 9 is a type log, which illustrates these picks for central New York. The elevation of these formation tops can be found in the Appendix that relates to the formation being studied under the table labeled Tops Data.

All of the contour maps presented in this report were created in the GeoPlus Petra mapping module from grids generated with the least squares method, which is appropriate for highly connected features. The grid size was computed from the $\mathrm{z}$ data distribution, using an average size estimate. 


\section{PHASE I - DELINEATION OF SALT SUITABLE FOR CAVERN DEVELOPMENT AND DEFINITION OF STUDY AREA BOUNDARIES}

\section{Criteria Development}

After reviewing the industry standards discussed above we determined that there are two basic criteria that determine if salt in a given area is suitable for cavern development: salt thickness and salt depth. Efforts in Phase I were focused on defining areas that have the appropriate depth and thickness. The criteria used to resolve these areas are:

Criterion 1 - Depth to salt $=2,000$ feet to 6,000 feet below the surface elevation

Criterion 2 - Aggregate salt thickness $>100$ feet. (the Salina F salt was chosen because it has the greatest potential to reach a thickness of 100 feet.; after Friedman et al., 2002)

The study area for this research project was defined where the salt meets both of these requirements.

\section{Phase I Methods}

Several studies have been conducted to define the salt extent in New York State, Rickard (1969), Kreidler (1957), Stone and Webster (1978), Beinkafner (1983) and Friedman et al. (2002). After a review of the existing data and literature from previous studies it was determined that there already existed a wealth of data on the Silurian Section in New York State. Thus, a review of the wells, tops and correlations from previous work was begun. Where necessary, formation top data from the original reports were modified before being added to the database. This was done to keep a make sure that the tops used in the current research were consistent and all fit with the methods used in this project. This tops data was then combined and supplemented with additional well data for areas with little control or where new wells have been drill since the completion of the previous studies. The many new wells drilled and logged since these studies were completed have shed a new light on the extent and distribution of the Salina in central New York. A new set of isopachous and structure contour maps for the Salina (discussed below) has 
been generated using the newer data and the data collected by the previous researchers together. The area on these maps that is outlined by the 100 foot isopach and the 2,000 foot contour of the Salina F unit (all of the salt in NYS is shallower than 6,000 feet), defines the study area of this research.

The Museum has a collection of geophysical well logs from over 20,000 wells in New York State. Some of the wells used in this study have geophysical well logs through the Silurian and it is from these wells and logs that tops were picked. Some of the wells used in previous studies did not have associated well logs. In these cases the previous researchers data was assumed to be correct. In some of these cases, mostly in wells from Rickard's (1969) study the tops were originally obtained and verified using Geologs тм. Geologs were created as a log of the lithologies encountered in a well as inferred from well bore cutting samples. The Geologs and some of the well bore cutting samples are also held as a collection of the museum. Most of the Geologs are proprietary and therefore cannot be displayed in this report.

General information for each well was uploaded into a Petra project from the New York State Museum's Reservoir Characterization Group's (RCG) web-based wells database, ESOGIS or Empire State Oil and Gas Information System. Information obtained from ESOGIS for this step includes latitude, longitude, total depth well name, SAPINO (short American Petroleum Institute number), well type, operator, town and county. This process generated a basic project to which, both old and new formation tops was added. Storing all of the data in this manner made mapping, cross section creation and data mining a simpler process. Appendix A contains a list of the wells and basic well information used to complete Phase I.

Using the Petra project described above in combination with the criteria described for Phase I, maps and cross sections that illustrate how each criterion affects the data set spatially were created. This was done in two steps. First a structure contour map was generated to illustrate the top of the F unit, with the surface elevation as the datum (Plate 5). As mentioned above, the F unit will be the focus in Phase I of this research because it offers the best potential for finding salt of the appropriate thickness. From the structure contour map everything was removed that fell outside of the 2000 and 6000 foot contours (highlighted in red on Figure 17 and Plate 5). 
The remaining area contains F unit salt that meets Phase I Criterion 1 - salt that is between 2,000 and 6,000 feet deep.

To meet Phase I - Criterion 2 (salt that is the appropriate thickness and quality) a second map was created. Phase I wells that contained salt of the appropriate thickness ( $>100$ feet) and quality (no intervals of nonsalt greater than 10 feet thick) were identified using well logs. Appendix A - Salina F unit Salt Interval Characteristics is a record of what was observed during this process. The table contains the following fields:

Net thickness of the F unit salt - the total thickness of all salt intervals in the F unit, excludes non salt intervals (feet)

Intervals of Salt Suitable for Cavern Development - many of the wells contained multiple intervals of salt that meet Phase I Criterion 2, all of the depth range of each of these intervals is listed in this field

Interval Thickness - the thickness of each interval of salt suitable for cavern development, only the greatest interval is used to make the corresponding map of salt suitable for cavern development.

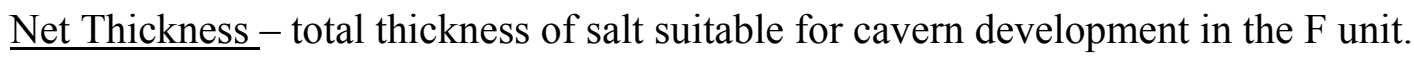

The greatest interval of salt suitable for cavern development found in each well was used to create a corresponding map - Salt with Suitable Thickness for Cavern Development. All of the colored area on this map meets Phase I - Criterion 2 (suitable thickness and quality). This is true because only wells that met the criteria were used to generate the map.

It was necessary that portions of the Salt Suitable for Cavern Development Map be rejected to create a map that illustrated the area where both of the Phase I criteria are met (that is salt that is greater than 2,000 feet below the surface and is over 100 feet. thick with no intervals of nonsalt greater than 10 feet thick). The area that was removed was the small area of salt suitable for cavern development that wasn't deep enough to meet Phase I - Criterion 1 (salt shallower than 2,000 feet). The resulting map shows the area where both criteria for Phase I are met and defines 
the study area for this research. The isopachs were left on the map and the color scheme is altered to highlight areas where cavern development is better suited. Remember, cavern development can be achieved in no less than 100 feet of salt, but a thickness of 200 feet is optimal. The Salt with Suitable Thickness for Cavern Development Map is discussed further below.

\section{Phase I Results - The Occurrence of Salt in New York State}

Rickard (1969) established subsurface correlation of the Salina Group in New York State. Rickard correlated the units found in New York with those established by Landes (1945) and Ells (1967) in the Michigan Basin and by Uteig (1964) for the Appalachian Basin of Ohio.

Figure 13 is a cross section of the Silurian interval in Chemung County, New York, where the salt intervals are highlighted in blue. Figure 13 illustrates that the salt intervals are often punctuated by non-salt intervals consisting of shale, dolomite and anhydrite. Correlation of both the non-salt and salt bearing intervals has allowed for a better geographic definition of where usable salt is available in New York.

The salt deposits of New York State and the Central Appalachian Basin are positioned within the Upper Silurian Vernon and Syracuse formations of the Salina Group (Figure 4). The Salina Group consists of lithologies common to evaporite series (shale, dolostone, anhydrite and halite, as seen in Figure 4) and point to deposition in restricted marine or playa lake conditions. Evaporite conditions, such as these, occurred during the late Silurian, in the Salina depositional basin that extended northeasterly from Pennsylvania into New York and shared a principle axis with the Appalachian Basin (Rickard, 1969; Stone and Webster, 1978). The Salina group is known to have great extent, occurring for hundreds of miles across the Appalachian and Michigan Basins, allowing for regional mapping of units. Figure 14 shows how the Salina Group outcrops in New York State, forming an east-east band from the Buffalo area and Rochester through Syracuse and into Herkimer County. 
In New York the Salina Group is divided into the Vernon, Syracuse, Camillus and Bertie Formations. As shown in Figure 4, the Vernon is divided into A, B and C units, the Syracuse is divided into the D, E and F Units and the Camillus and Bertie Formations are designated the G and $\mathrm{H}$ Units respectively. The variable thickness of these formations are illustrated in Plate 1 and 2, which are east-west and north-south cross sections (respectively) through the Silurian section in western New York. An examination of wells in central New York State conducted for the current research initiative, found that the Salina Group reaches a maximum thickness of 2,207 feet in the NYS GMA 2 well in Steuben County. This thickening in south central New York is primarily due to the introduction of large thicknesses of salt in the Syracuse $F$ unit. Elsewhere in the Appalachian Basin the group is reported (Rickard, 1969) to reach thicknesses exceeding 4,000 feet so there are similar opportunities elsewhere in the region.

Within the current study area, salt occurs in both the Vernon and Syracuse Formations, but the Syracuse D and F are the major salt bearing units (Figure 4). The D unit forms the relatively thin layer at the base of the Syracuse Formation and varies between 7 and 230 feet thick (Plate 1 and 2). According to a study completed by Stone and Webster Engineering Corporation in 1978, salt in the D unit occurs throughout south-central New York, except in Broome and central Cortland Counties. Across the same area, our group observed that up to 7 salt beds occur in this unit (Plate 1 and 2). Rickard (1969) found five major salt beds in the F unit that are separated by thin intervals of dolomite and/or shale. Following Rickard's (1969) designation, the locations of these beds are labeled on Plate 1 and 2. Within the F Unit, individual salt beds are generally less than 50 feet thick, but can reach thicknesses of several hundred feet and are commonly found to be interbedded with thin dolostones, anhydrites and shales.

The F unit (salt and nonsalt) is generally 100-300 feet thick. Though this range is the normal thickness observed in the F unit in much central New York, the F unit thickness is elevated in portions of south-central New York (Plate 3), which can be accounted to the introduction of many thick salt beds (Plates 1, 2 and 3 and Figure 15). Figure 16 is a seismic line shot over a thickened portion of salt in south central New York. In this figure the thickening is related to thrust faulting, which has ramped the Silurian section onto itself several times forming a thick wedge of salt, shale, gypsum and anhydrite. In some cases, overlying these thick salt wedges 


\section{Silurian Section - Chemung County, New York}

\section{LEGEND}

Salt Intervals $\quad \longrightarrow$ Gamma Ray Curve

Neutron Porosity Curve

\section{WELL LOCATION MAP}

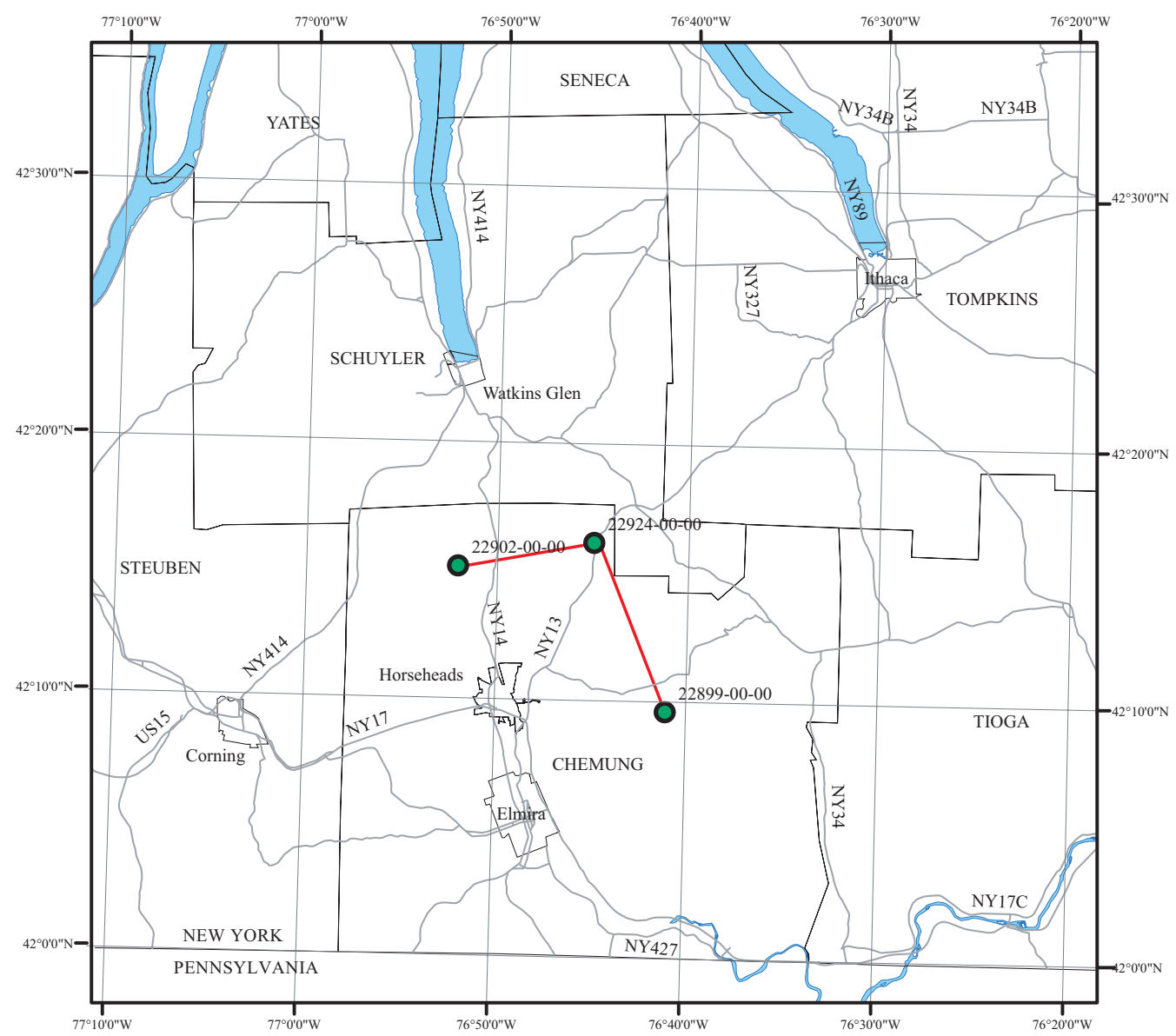

Figure 13a Cross-Section Legend and Well Location Map for Figure 17b

Figure 13b Cross-section through the Silurian Section in Chemung County, New York. Note that, the Bertie Formation was used as the datum in this section and the well spacing is not to scale, actual well spacing is indicated between the well headers. Picks were made by Lugert after Rickard (1969). 


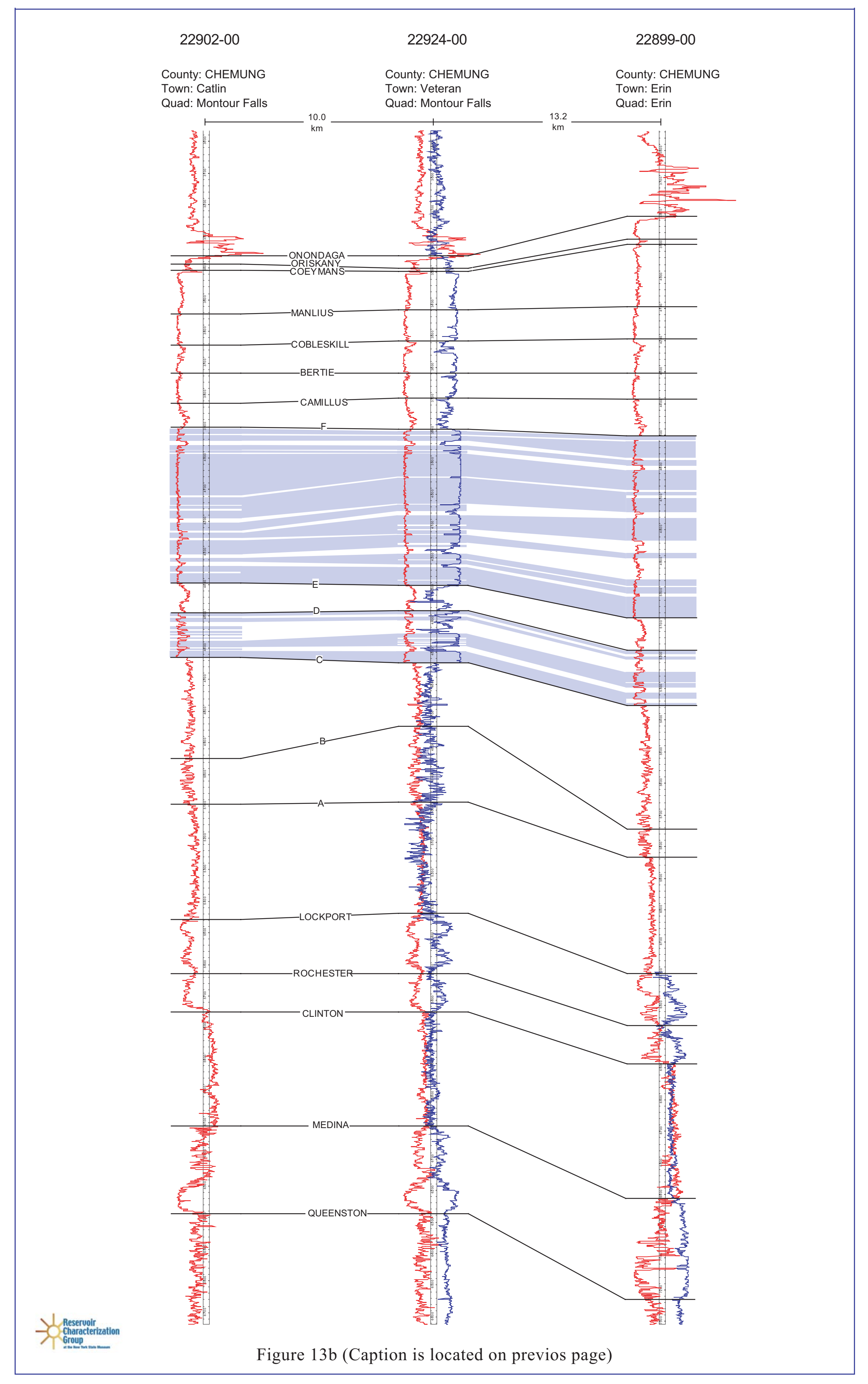




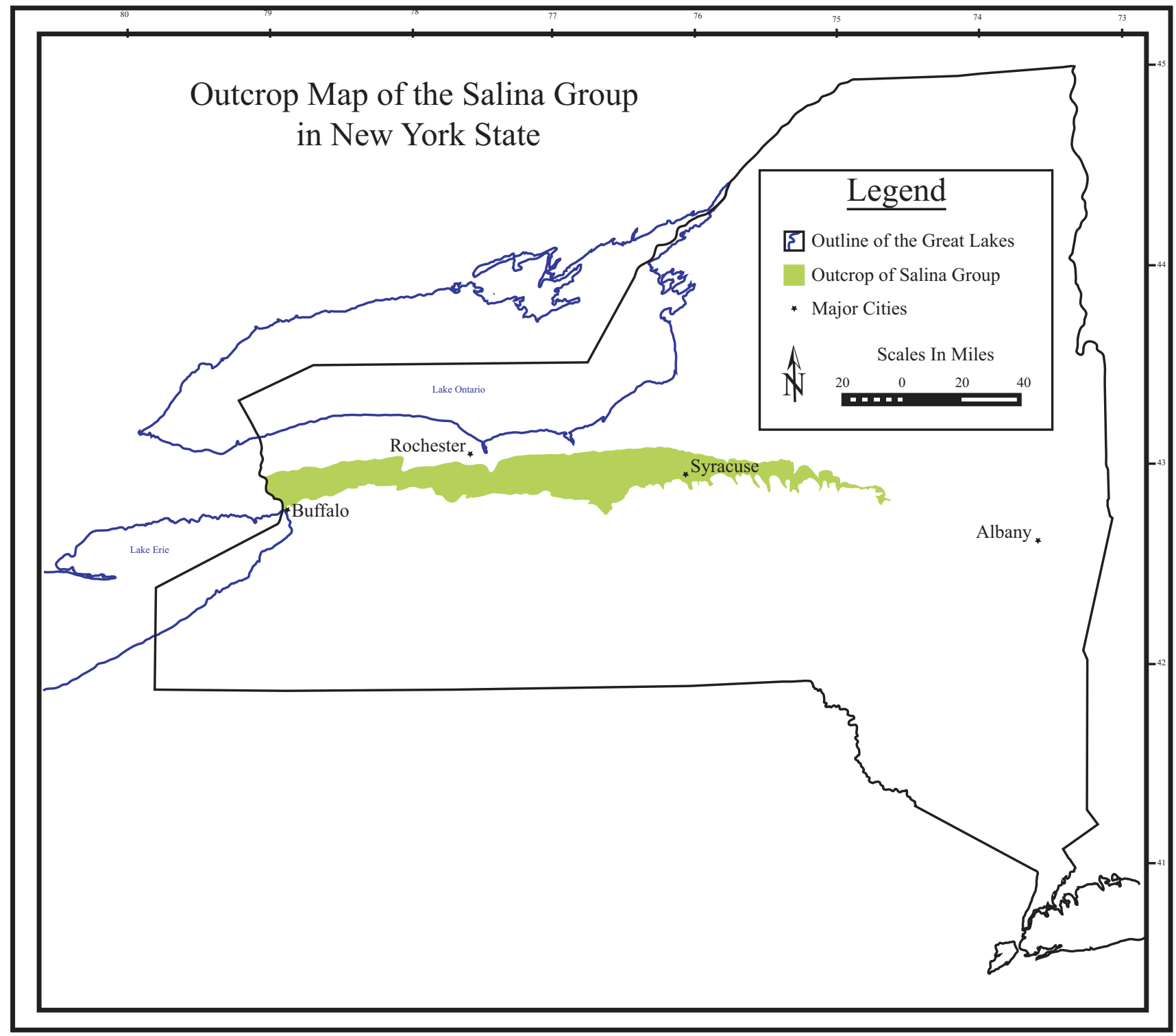

Figure 14 The Salina Group outcrops in an east-west band from near Buffalo and Rochester through Syracuse to Herkimer County. (Modified from Rickard, 1969) 


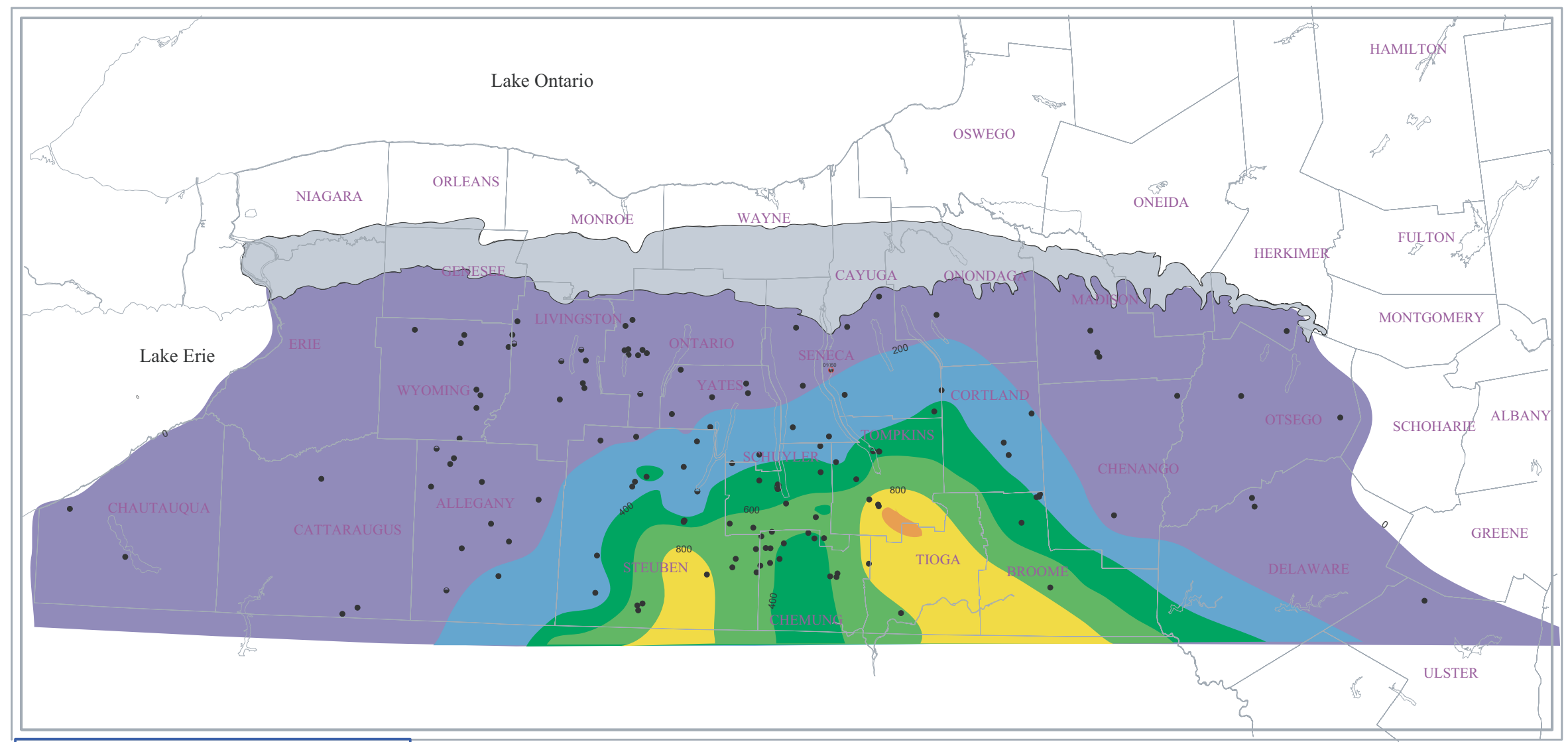

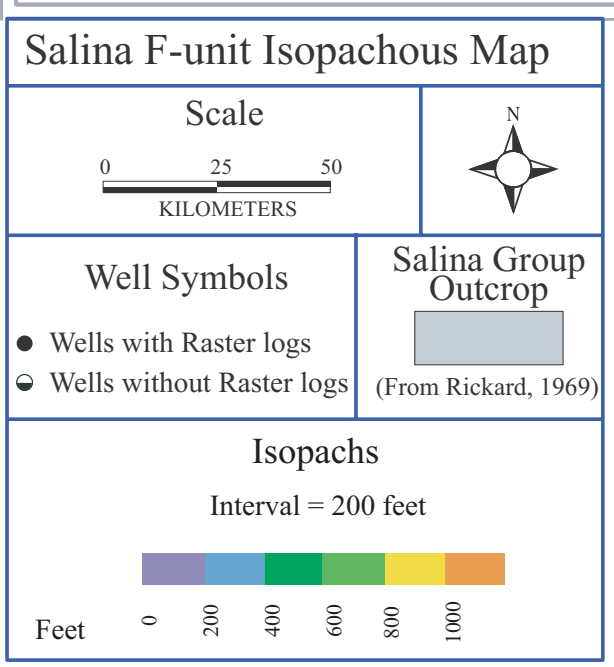

Figure 15 Salina F-Unit Isopachous Map. Areas of thick salt in this unit are located in south central New York State, in the counties of Broome, Tioga, Tompkins, Chemung, Stueben and Schuyler. The well SAPINOs are labeled in Plate 4. 

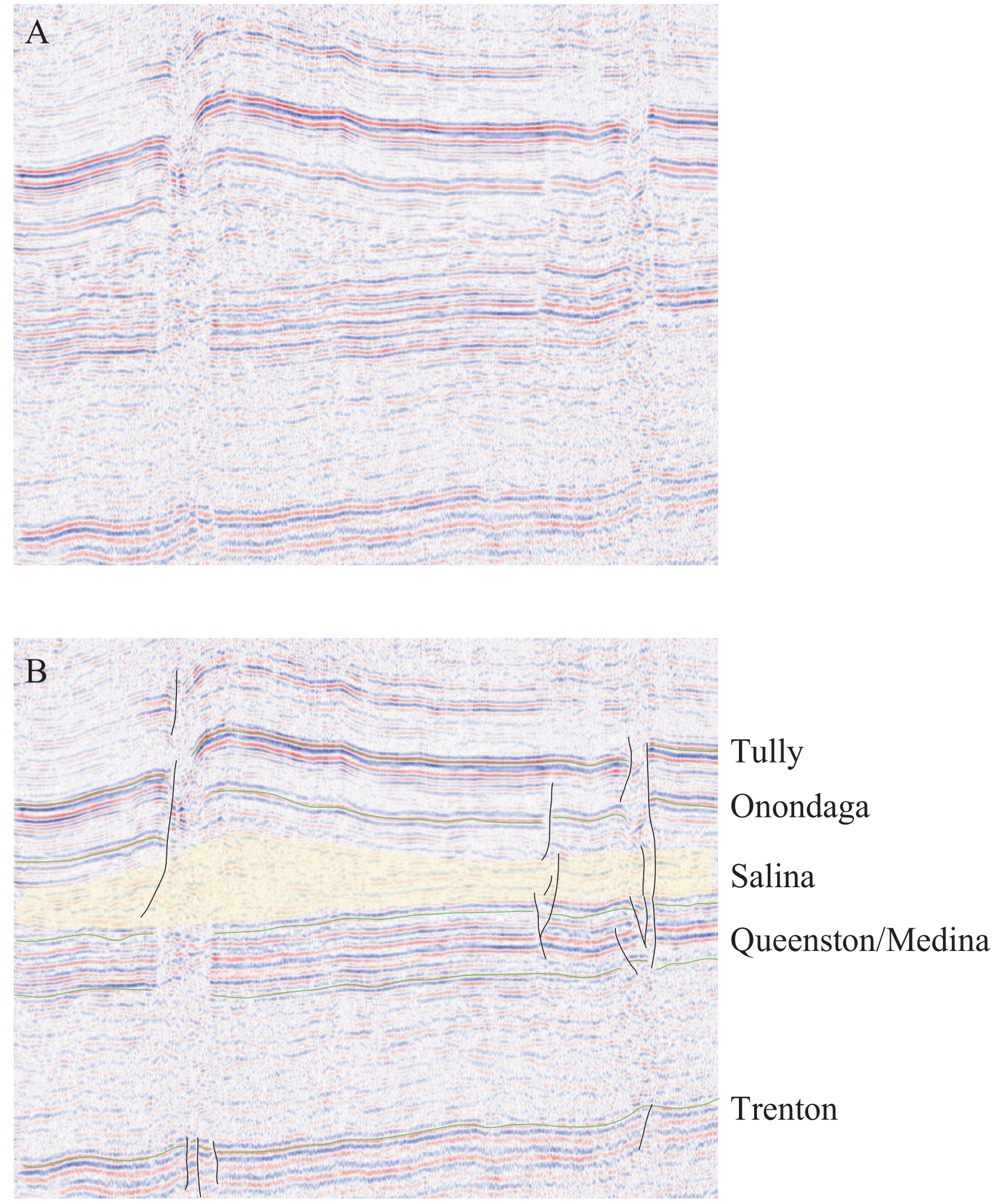

Figure $16 \quad$ Uninterpreted (A) and interpreted (B) seismic line shot over an area of thickened salt. 
there are fields that currently or once produced from the Oriskany Formation, which could prove to provide a brine disposal option. The Oriskany is currently used as a traditional depleted reservoir type storage field and therefore was not evaluated as part of this research. The Oriskany was not evaluated as a potential disposal reservoir in this research because operators may not want to or be able to risk, what has already proven to be a profitable storage method, to attempt brine disposal and cavern development.

Though the Salina F unit Structure Contour Map (Figure 17 and Plate 4) does indicate that there are significant portions of central New York where the F unit is deep enough for salt cavern development, it does not take into account the hilly topography of central New York, which is crucial to Phase I Criterion 1 - appropriate depth for salt cavern development. The top of the F unit, as shown in Figure 17 and Plate 4, ranges in depth from 500 feet above sea level to the north, to more than 4,000 feet below sea level at the New York-Pennsylvania border. Measured depth to the Salina F unit (Figure 18 and Plate 5) is a more appropriate estimate of depth to salt for cavern development, as it considers the entire rock column overlying the unit. In central New York, the surface depicted by the measured depth contours (F igure 18 and Plate 5) reflects the deep valleys surrounding the Finger Lakes rather than undulations in the surface of the F unit. In general, depth to the Salina F unit increases to the south, reaching depths greater than 5,500 feet at the New York-Pennsylvania border. The shaded area indicates where salt within the F unit meets Phase I Criterion 1, salt depths between 2,000 and 6,000 feet below the ground surface.

As stated earlier, in order to be suitable for salt cavern storage, individual packages of salt must be greater than 100 feet thick and contain no individual nonsalt interbeds greater than 10 feet thick. Figure 19 and Plate 6, are a map of the area underlain by F unit salt that meets these criteria. In several wells there was more than one interval of salt in the F unit that met these criteria. The interval with the greatest thickness in each well was used to create the contours on Figure 19 and Plate 6. The entire shaded region in Figure 19 and Plate 6 has at least one interval of salt that based on thickness and quality, could potentially be used to develop salt caverns for the purpose of storing natural gas. The regions highlighted in yellow are better suited for cavern development, because the salt there is thicker than 200 feet and sometimes greater than 400 feet thick. 


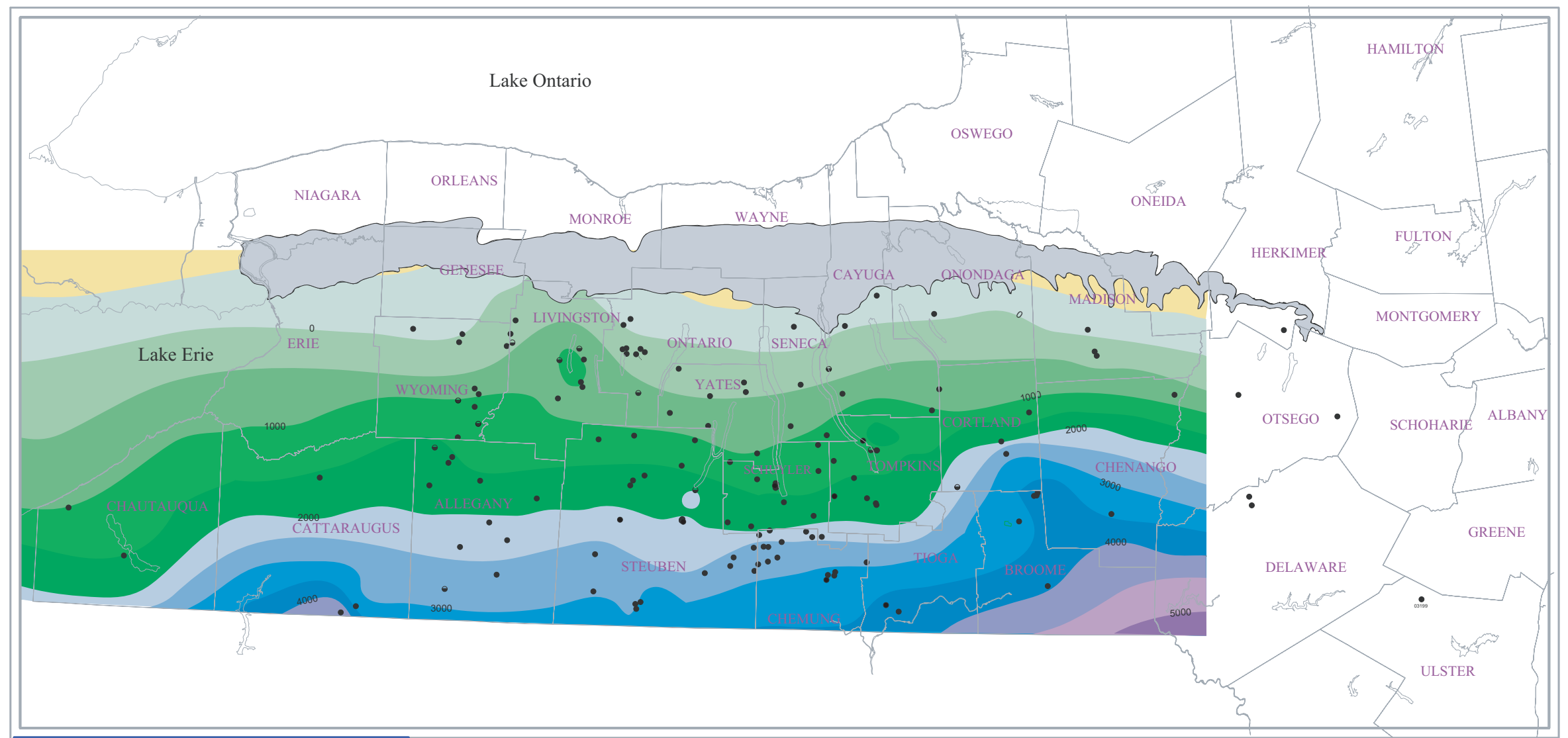

\begin{tabular}{|c|c|}
\hline \multicolumn{2}{|c|}{ Structure Contour Map of Salina F-unit } \\
\hline \multicolumn{2}{|c|}{ Scale } \\
Well Symbols \\
• Wells with Raster logs \\
- Wells without Raster logs
\end{tabular}

Figure 17 Structure Contour Map of the Salina F-unit. The datum is sea level and the undulations are believed to be variations in the surface of the F-unit. In south-central New York the F-unit reaches depths of 1000- 4000 feet below sea level. The well SAPINOs are labeled in Plate 4. 


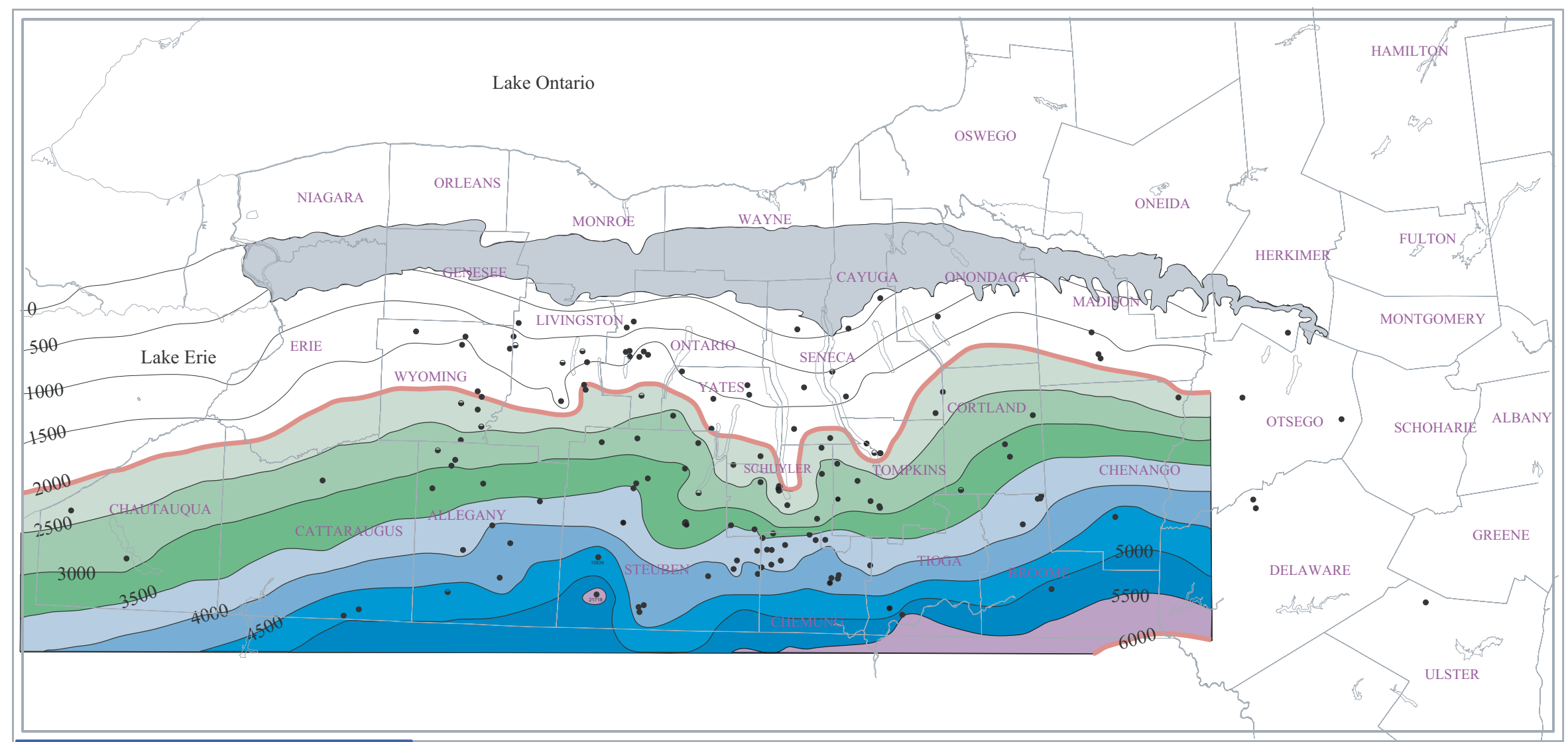

\begin{tabular}{|c|c|}
\hline \multicolumn{2}{|c|}{ Measured Depth to Salina F-unit } \\
\hline Scale & \\
\hline $25 \quad 50$ & \\
\hline \multicolumn{2}{|l|}{$\overline{\text { KILOMETERS }}$} \\
\hline Well Symbols & $\begin{array}{l}\text { Salina Group } \\
\text { Outcrop }\end{array}$ \\
\hline \multirow{2}{*}{$\begin{array}{l}\text { - Wells with Raster logs } \\
\text { - Wells without Raster logs }\end{array}$} & \\
\hline & (From Rickard, 1969) \\
\hline \multicolumn{2}{|c|}{$\begin{array}{l}\text { Measured Depth Contours } \\
\text { Datum }=\text { Surface Elevation } \\
\text { Contour Interval }=500 \text { feet }\end{array}$} \\
\hline 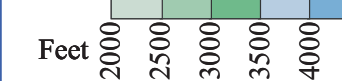 & $8 \%$ \\
\hline
\end{tabular}

Figure 18 Measured depth to the top of the Salina F-unit in western and central New York State. Measured depth was used to take into account the hilly topography of the region covered by this map. The shaded contours highlight the portion of New York State where the Salina F-unit lies at the appropriate depth for cavern development. As stipulated in Phase I Criteria I cavern development is considered in salt at depths between 2000 and 6000 feet (red contours) below the surface. The well SAPINOs are labeled in Plate 5. 


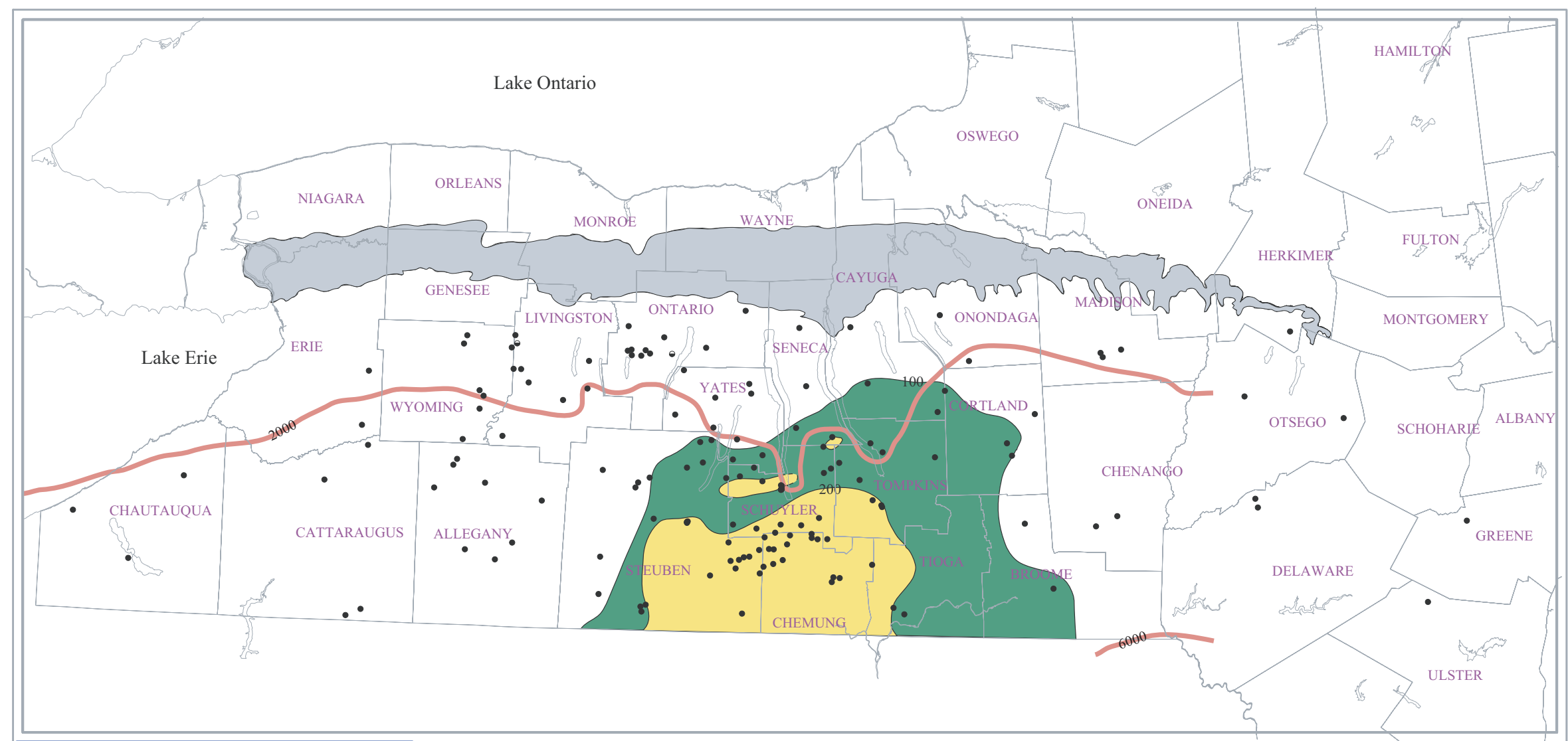

\begin{tabular}{|l|}
\hline Salt Suitable for Cavern Development \\
\hline Scale \\
- Well Symbols \\
- Wells with Raster logs \\
\hline \multicolumn{2}{|c|}{ Isthout Raster logs }
\end{tabular}

Figure 19 Map of salt with suitable thickness for cavern development. Map of the area underlain by salt that meets Phase I Criteria II, aggregate salt thickness of 100 feet or more with less than 10 feet of non salt breaks. In several wells there was more than one interval of salt in the F-unit that met these criteria, only the interval with the greatest thickness was used to generated the contours display in this map. The red contours are the 2000 and 6000 foot contours. The area between these contours is underlain by F-unit salt that also meets Phase I Criterion I (appropriate depth for cavern development), as shown on Figure 21. The well SAPINOs are labeled in Plate 6. 
When the region delineated by salt that occurs at the appropriate depth $(2,000-6,000$ feet below the surface) is overlain on the region delineated by salt of appropriate thickness, it is possible to reject a portion of the F unit salt that are not thick enough or deep enough. The area where both criteria are met, defines the study area. Figure 20 and Plate 7 shows the study area and the area rejected based on Usable Salt Criterion 1 (dashed line). Large portions of Steuben, Chemung, Tioga, Broome Cortland, Tompkins, Allegany and Schuyler Counties are underlain by F unit salt in which a salt cavern storage facility could potentially be created.

\section{Phase I Conclusions}

The delineation of salt bodies that are appropriate for the development of Salt Cavern Natural Gas Storage Facilities has identified a large area of south central New York that could be used to develop this type of project. Areas of particular interest for their abundance of thick salt are Steuben, Schuyler, Chemung, Tompkins and Tioga Counties. The completion of Phase I of this research has also resulted in construction of a large database of information related to the Silurian Section in New York State. This database and other data related to this project will be made available on the New York State Museum's Oils and Gas web-base database, ESOGIS (Empire State Oil and Gas Information System) at www.nysm.gov/esogis. 


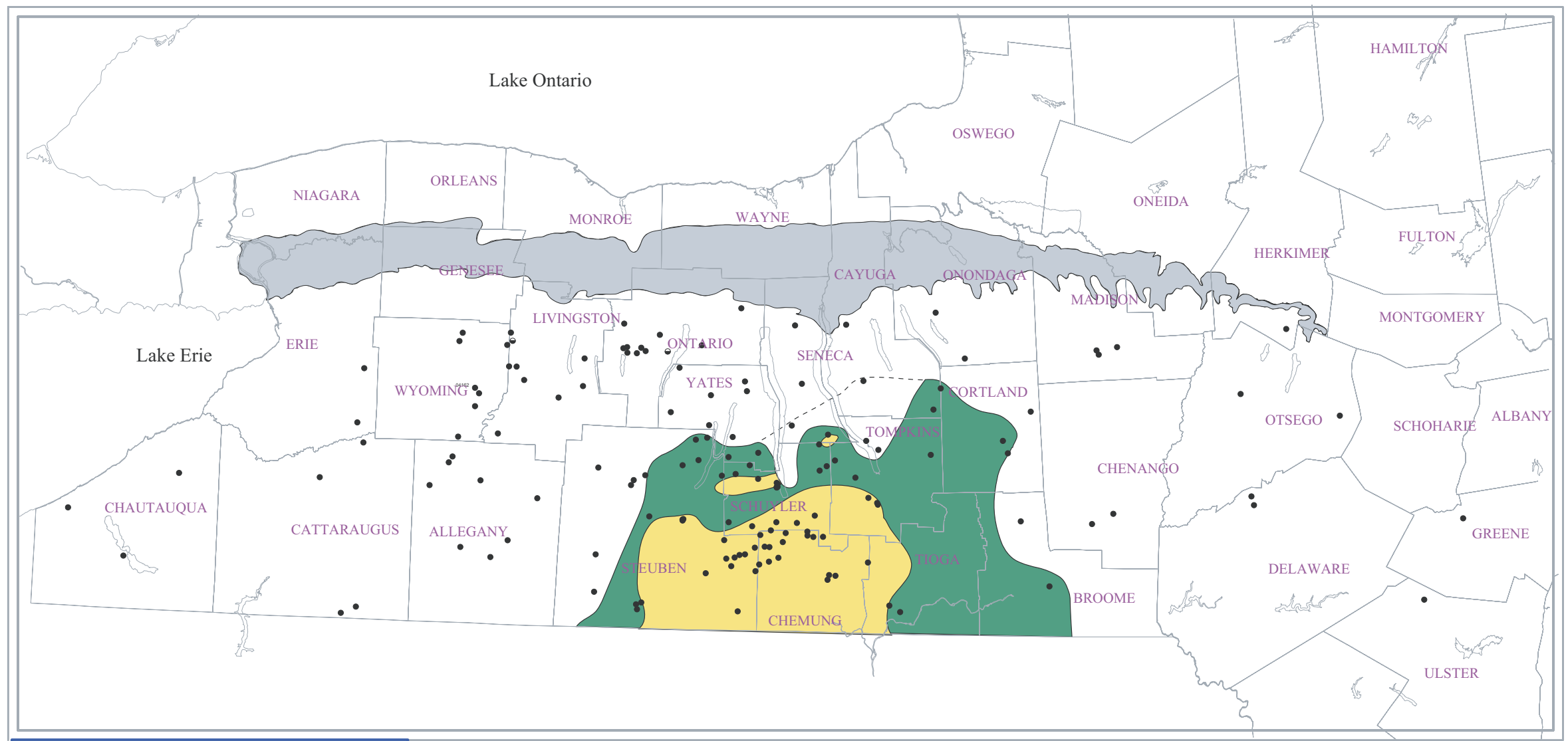

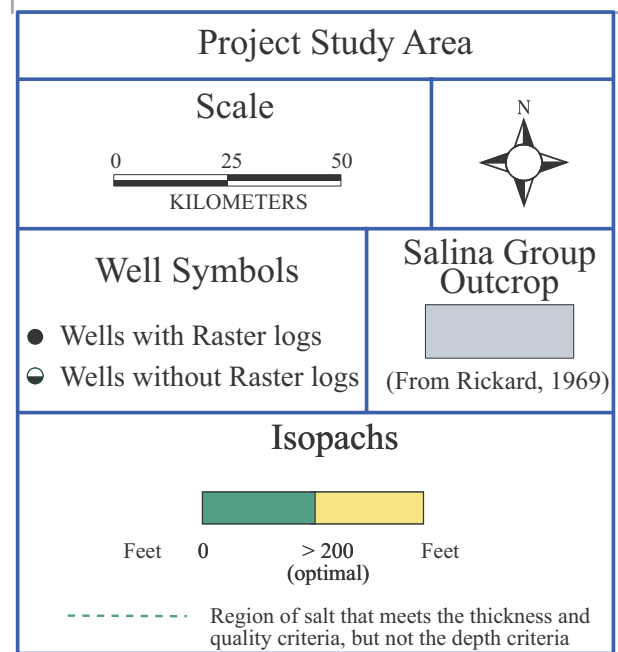

Figure 20 Study area defined in Phase I. The shaded portion of this map represents that area underlain by F-unit salt the meets both criteria for Phase one of this research. The green dashed line represents the area rejected based on Phase I Criteria I. Salt in the rejected portion, while thick enough is not deep enough for cavern development, based on industry standards. A review of the engineering and economics of developing a cavern in the rejected portion may prove that it is viable. Large portions of Stueben, Chemung, Tioga, Broome Cortland, Tompkins, Allegany and Schuyler Counties are underlain by F-unit salt in which a salt cavern storage facility could potentially be created. The well SAPINOs are labeled in Plate 7. 


\section{PHASE II - IDENTIFICATION AND EVALUATION OF POTENTIAL DISPOSAL RESERVOIRS}

The area defined in Phase I could be used to develop salt caverns assuming one had an effective brine disposal solution and a source of fresh water. As stated previously in this report fresh water availability is not considered an obstacle to this type of storage in New York, therefore once salt availability has been determine, the primary factor that will determine site suitability is brine disposal potential. Research efforts in Phase II were focused on delineating and evaluating potential brine disposal reservoirs.

\section{$\underline{\text { Criteria Development }}$}

In the background section of this report the characteristics of a good disposal reservoir were given. Those were:

- The disposal formation must exhibit sufficient porosity and permeability to allow reasonable injection rates at acceptable pressures.

- The connate water salinity of the disposal reservoir must be similar to injected brine.

- The disposal reservoir is located well below all fresh water aquifers and separated from the aquifers by impermeable formations.

- The reservoir volume must be capable of accepting the total volume of brine generated over an economically viable duration of time.

(After Swenson and Potashik, 1994)

From these characteristics two sets of criteria were defined. The first, the Disposal Formation Selection Criteria (or Selection Criteria), allowed us to high-grade potential disposal reservoirs from the geologic units present in central New York. The second set of criteria, the Disposal Formation Evaluation Criteria (or Evaluation Criteria), were used to evaluate the selected formations for their ability to perform as brine disposal reservoirs. 
Disposal Formation Selection Criteria. The Disposal Formation Selection Criteria are the following:

Criterion 1- Lithology (sandstones and carbonates);

Criterion 2 - Evidence of good porosity and permeability (in previous studies);

Criterion 3 - History of production either here or in nearby states; and

Criterion 4 - Not currently used for conventional depleted reservoir storage (if a formation is already a good storage reservoir, most operators will not want to risk trying brine disposal).

Criterion 5 - Connate water salinity greater than 200, $000 \mathrm{ppm}$.

To help organize this process the Disposal Formation Selection Matrix was created (Figure 21 and Plate 8). The matrix contains columns for Selection Criteria 1-4 (Criterion 5 is addressed separately below) and rows representing the geologic units of central New York State. Units not highlighted, are considered to have no brine disposal potential. Units highlighted in green, have potential as brine disposal reservoirs, because they meet all of the Phase II criteria after a literature review and basic evaluation. Units highlighted in yellow meet the first three criteria, but are currently used for conventional, depleted reservoir type storage and therefore may be less desirable for brine disposal.

Geologic units that have potential as brine disposal reservoirs based on Selection Criteria 1-4 are: the Upper Ordovician Queenston Formation, the Middle Ordovician Trenton-Black River Interval and the Cambro-Ordovician Beekmantown Group (Figure 22). In the Phase II Results section, each of these formations is described and then evaluated using the Disposal Formation Evaluation Criteria discussed below.

In addition to the criteria used to build the Disposal Formation Selection Matrix (Figure 21 and Plate 8), it is necessary to assess the connate water salinity (Selection Criterion 5) of the potential disposal reservoirs. Only formations with salinities greater that 200,000 ppm are considered as potential disposal reservoirs. This is true because formations with naturally occurring high 


\begin{tabular}{|c|c|c|c|c|c|c|c|c|c|}
\hline \multicolumn{2}{|c|}{ PERIOD } & GROUP & UNIT & LITHOLOGY & ENVIRONMENT & $\begin{array}{l}\text { POROSITY/ } \\
\text { PERM. }\end{array}$ & $\begin{array}{c}\text { OIL OR GAS } \\
\text { RESERVOIR TYPE }\end{array}$ & $\begin{array}{l}\text { CURRENTLY USED } \\
\text { FOR STORAGE }\end{array}$ & $\begin{array}{l}\text { POTENTIAL AS BRINE } \\
\text { DISPOSAL RESER VOIR }\end{array}$ \\
\hline \multirow{6}{*}{$\begin{array}{l}Z \\
\vdots \\
Z \\
0 \\
0 \\
0\end{array}$} & \multirow[t]{2}{*}{$\begin{array}{l}\text { 傯 } \\
\text { S }\end{array}$} & \multirow[t]{2}{*}{ GENESEE } & \begin{tabular}{|l} 
WEST RIVER \\
ITHACA \\
RENWICK \\
SHERBURNE \\
PENN YANN \\
GENESEO \\
\end{tabular} & $\begin{array}{l}\text { SHALE WITH MINOR } \\
\text { SILTSTONE AND } \\
\text { LIMESTONE }\end{array}$ & DEEP MARINE BASIN & & & & NO \\
\hline & & & TULLY & \begin{tabular}{|c|} 
LIMESTONE WITH MINOR \\
SILTSTONE AND LIMESTONE
\end{tabular} & LOW ENERGY & & & YES, 1, GILBERT & MAYBE \\
\hline & \multirow[t]{2}{*}{ 崖 } & \multirow[t]{2}{*}{ HAMILTON } & $\begin{array}{l}\text { MOSCOW } \\
\text { LUDLOWVILLE } \\
\text { SKANEATELES } \\
\text { MARCELLUS }\end{array}$ & $\begin{array}{l}\text { SHALE WITH MINOR } \\
\text { SANDSTONE } \\
\text { AND CONGLOMERATE }\end{array}$ & $\begin{array}{c}\text { DEEPBASIN, UNDER WATER } \\
\text { DELTA CHANNELS,TIDALFLATS, } \\
\text { OFFSHORE BARS } \\
\text { DEEP BASIN, } \\
\text { POOR CIRCULATION OF OXYGEN }\end{array}$ & & GAS & & MAYBE \\
\hline & & & ONONDAGA & $\begin{array}{c}\text { FOSSILIFEROUS } \\
\text { LIMESTONE \& REEFS }\end{array}$ & $\begin{array}{c}\text { SHALLOW MARINE, } \\
\text { MEDIUM- LOWENERGY }\end{array}$ & & $\begin{array}{l}\text { GAS, REEF AND FAUIT GENERATED } \\
\text { FRACTURES }\end{array}$ & $\begin{array}{l}\text { YES, 2, FRACTURED LS AND } \\
\text { PINNACLE REEF }\end{array}$ & MAYBE \\
\hline & \multirow{2}{*}{ 苗 } & TRISTATES & ORISKANY & QUARTZ SANDSTONE & $\begin{array}{l}\text { NEAR SHORE, SHALLOW } \\
\text { MARINE, HIGH ENERGY } \\
\end{array}$ & $\begin{array}{l}\text {-ave. } \begin{array}{l}9 \% \\
\text {-open fractures, } \\
200-800 \mathrm{md}\end{array} \\
\end{array}$ & $\begin{array}{l}\text { GAS, FORMATION PINCHES OUT } \\
\text { LOCALIY FORMING TRAPS,ANY } \\
\text { CLOSED STRUCTURALL YIGHER POSITION } \\
\end{array}$ & YES, AT LEAST 9 & MAYBE \\
\hline & & HELDERBERG & $\begin{array}{l}\text { MANLIUS } \\
\text { RONDOUT }\end{array}$ & $\begin{array}{c}\text { LIMESTONE } \\
\text { AND DOLOSTONE }\end{array}$ & $\begin{array}{l}\text { TIDAL, SHALLOW MARINE } \\
\text { SHALLOW MARINE, HIGH SALINITY }\end{array}$ & & & & NO \\
\hline \multirow{6}{*}{ 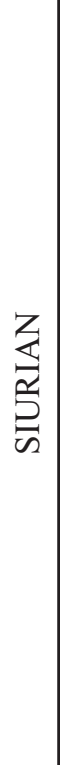 } & \multirow{3}{*}{ 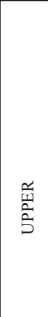 } & & $\begin{array}{l}\text { AKRON- } \\
\text { COBLESKILL }\end{array}$ & $\begin{array}{l}\text { DOLOSTONE } \\
\text { AND LIMESTONE }\end{array}$ & SHALLOW MARINE, NORMAL SALINITY & $\begin{array}{l}<5 \% \\
<1 \mathrm{md}\end{array}$ & $\begin{array}{l}\text { OIL AND GAS, BASS ISLAND TREND, } \\
\text { STRUCTURAL TRAPS, FRACTURES }\end{array}$ & YES & MAYBE \\
\hline & & SALINA & $\begin{array}{l}\text { BERTIE } \\
\text { CAMILLUS } \\
\text { SYRACUSE } \\
\text { VERNON }\end{array}$ & $\begin{array}{l}\text { SHALE, DOLOSTONE, } \\
\text { ANHYDRITE AND HALITE }\end{array}$ & $\begin{array}{l}\text { SHALLOW SHELF, HIGH SALINITY } \\
\text { RESTRICTED MARINE PLAYA OR LAKE } \\
\text { COASTAL PLAIN, SHALLOW SHELF }\end{array}$ & & & $\begin{array}{l}\text { YES, 1-LPG, } 1 \text { OPERATIONAL AND } \\
\text { SEVERAL PROPOSED NAT GAS, } \\
\text { SOUTH-CENTRALNY }\end{array}$ & NO \\
\hline & & LOCKPORT & LOCKPORT & \begin{tabular}{|c|} 
LIMESTONE AND \\
DOLOSTONE \\
STROMATALITE MOUNDS \\
\end{tabular} & SHALLOW SHELF TO CARBONATE FLATS & & $\begin{array}{l}\text { GAS, PINNICALE REEF, NO MAJOR } \\
\text { PRODUCTION }\end{array}$ & & NO \\
\hline & \multirow{3}{*}{$\sum_{0}^{\frac{1}{11}}$} & \multirow[b]{2}{*}{ CLINTON } & $\begin{array}{l}\text { ROCHESTER } \\
\text { IRONDEQUOIT }\end{array}$ & $\begin{array}{c}\text { SHALE } \\
\text { SANDSTONE } \\
\text { LIMESTONE }\end{array}$ & $\begin{array}{c}\text { OPEN MARINE SHELF } \\
\text { WARM, CLEAR, SHALLOWSHELF }\end{array}$ & & GAS, STRATIGRAPHIC & & NO \\
\hline & & & $\begin{array}{l}\text { WILLOWVALE } \\
\text { SAUQUOIT } \\
\text { WOLCOTT } \\
\text { SODUS } \\
\text { BEAR CREEK } \\
\text { FURNACEVILLE } \\
\text { KODAK } \\
\end{array}$ & $\begin{array}{c}\text { SHALE } \\
\text { SANDSTONE AND SHALE } \\
\text { LIMESTONE } \\
\text { SHALE } \\
\text { HEMATITE \& IRON ORE } \\
\text { SANDSTONE }\end{array}$ & $\begin{array}{c}\text { NEAR SHORE, SUBTIDAL QUIET } \\
\text { WATER TO SHALLOW SHELF } \\
\text { SHALLOW MARINE IN DEPRESSIONS } \\
\text { BETWEEN } \\
\text { NEAR SHORE RIDGES OF SAND }\end{array}$ & & & & \\
\hline & & MEDINA & \begin{tabular}{|l|} 
GRIMSBY \\
WHIRLPOOL \\
\end{tabular} & SANDSTONE AND SHALE & DELTAIC - SHALLOW TURBULENT WATER & & $\begin{array}{l}\text { GAS, SAND DOMINATED CHANNEL } \\
\text { DEPOSITS, PRODUCED FROM FRACTURES }\end{array}$ & $\begin{array}{l}10 \text { GAS STORAGE FIELDS IN } \\
\text { WESTERN NEW YORK }\end{array}$ & MAYBE \\
\hline \multirow{4}{*}{ 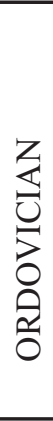 } & \multirow[b]{2}{*}{$\begin{array}{l}\text { 装 } \\
\text { 它 }\end{array}$} & & QUEENSTON & SANDSTONE AND SHALE & DEIIAIC, BRAIDED STREAM & $\begin{array}{l}\text { AS HIGH } \\
\text { AS } 15 \% / 1-.01 \mathrm{md}\end{array}$ & GAS, UP DIP ACIES CHANGE & POTENTIAL GAS STORAGE RESERVOIR & YES \\
\hline & & & $\begin{array}{l}\text { OSWEGO } \\
\text { LORRAINE } \\
\text { UTICA }\end{array}$ & \begin{tabular}{|c|} 
SHALEY SANDSTONE \\
SHALE \\
WITH \\
SANDSTONE ANDSILTSTONE
\end{tabular} & $\begin{array}{c}\text { NEAR SHORE AND BEACH } \\
\text { SHALLOW AND MODERATEIY DEEP MARINE } \\
\text { DEEP BASIN }\end{array}$ & & PORPOSED GAS, GAS SHALE & & NO \\
\hline & 崖 & $\begin{array}{l}\text { TRENTON- } \\
\text { BLACK RIVER }\end{array}$ & $\begin{array}{l}\text { TRENTON } \\
\text { BLACK RIVER }\end{array}$ & $\begin{array}{l}\text { FOSSILIFEROUS LIMESTONE } \\
\text { DOLOSTONE AND } \\
\text { HYDROTHERMALDOLOMITE }\end{array}$ & $\begin{array}{c}\text { SHALLOW MARINE, } \\
\text { TIDALFLATS AND SLOPE } \\
\text { SHALLOW SHELF }\end{array}$ & & $\begin{array}{l}\text { GAS, VUGGY } \\
\text { HYDROTHERMAL DOLOMITE, } \\
\text { FRACTURES-TUG HILLAREA }\end{array}$ & $\begin{array}{l}\text { BECAUSE OF THE HETEROGENEITY OF THE } \\
\text { RESERVOIRS, IT IS UNLIKELY THAT MANY OF } \\
\text { THESE FIIDS WILL BE UTLIIZED FOR } \\
\text { TRADITIONAL UNDERGROUND STORAGE }\end{array}$ & YES \\
\hline & 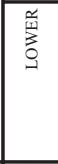 & $\begin{array}{l}\text { BEEKMAN- } \\
\text { TOWN }\end{array}$ & \begin{tabular}{|l} 
TRIBES HILL \\
LITTLE FALLS \\
THERESA \\
(GALWAY)
\end{tabular} & \begin{tabular}{|c|} 
DOLOSTONE, LIMESTONE \\
AND SILSTONE \\
DOLOSTONE \\
SANDSTONE \\
\end{tabular} & $\begin{array}{l}\text { TROPICAL } \\
\text { COASTAL } \\
\text { COMPLEX } \\
\end{array}$ & $\begin{array}{l}\text { Numerous porous } \\
\text { zones in upper } \\
\text { portion of L.F. }\end{array}$ & $\begin{array}{l}\text { GAS, vuggy dolomite, STRUCTURAL } \\
\text { CLOSURE OF FRACTURE SYSTEM }\end{array}$ & $\begin{array}{l}\text { POTENIAL TRADITIONAL STORAGE } \\
\text { RESERVOIR }\end{array}$ & YES \\
\hline 舟z & $\begin{array}{l}\text { 前 } \\
\text { 产 }\end{array}$ & & POTSDAM & $\begin{array}{c}\text { AND SANDY DOLOSTONE } \\
\text { QUARTZ SANDSTONE }\end{array}$ & & $\begin{array}{l}\text { Basal Potsdam } \\
\text { extremely porous } \\
\text { and permeable }\end{array}$ & & & \\
\hline \multicolumn{3}{|c|}{ PRECAMBRIAN } & $\begin{array}{l}\text { MARBLE } \\
\text { QUARTZITE etc> }\end{array}$ & $\begin{array}{c}\text { METAMORPHIC } \\
\text { AND IGNEOUS ROCKS }\end{array}$ & & & & & NO \\
\hline
\end{tabular}

\section{NEW YORK STATE POTENTIAL DISPOSAL RESERVOIR}

Figure 21 The table above is a compilation of information from several sources. By bringing this information together we were able to identify formations with potential as brine disposal reservoirs. Potential brine disposal reservoirs were chosen based on Lithology, coverage in south central NewYork and production and storage potential and history. Formations with potential to act as brine disposal re servoirs were designated as YES or MAYBE. Formations that have produced oil or gas were designated YES based on the similar characteristics necessary for both production and disposal. The MAYBE designation was used when a formation is commonly used for storage. This becomes necessary because economically, an operator would probably profit more form getting online quickly with a storage facility that will continually operate rather than the possible slow, one-time disposal that would occur with the brine disposal use. 


\section{POTENTIAL BRINE RESERVOIR TARGETS}

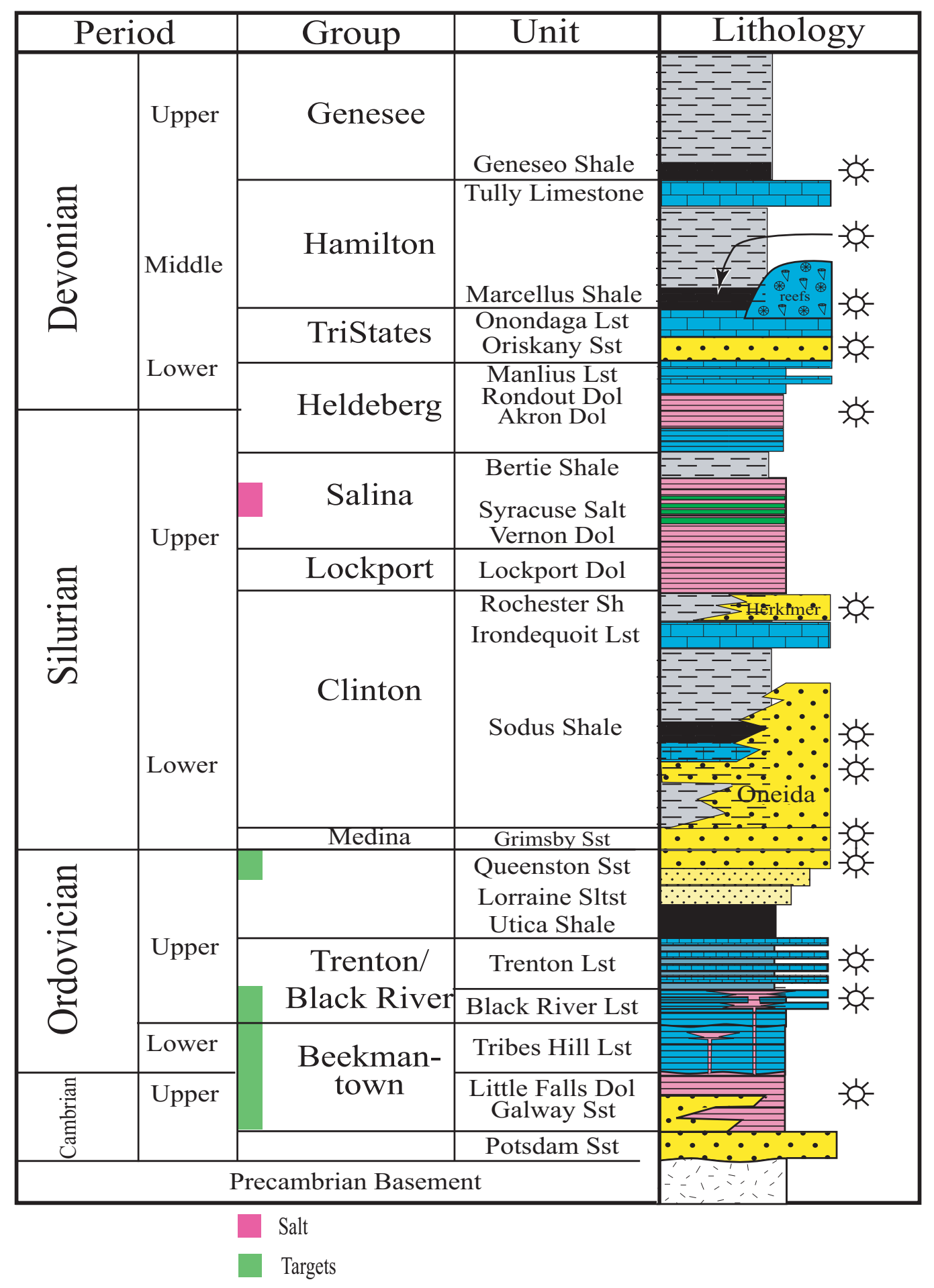

Figure 22 Stratigraphic Section of central New York. Highlighted areas represent sections that are of interest to this study. (Modified from Smith, 2005) 
connate water salinities are unlikely to be considered as potential potable water sources and will be less affected by the introduction of the saturated brines generated during cavern development.

\begin{tabular}{|c|c|c|c|c|c|c|c|}
\hline & \multicolumn{6}{|c|}{$\begin{array}{c}\text { Modified from Matsumoto et al, 1992, All Values are for New } \\
\text { York State }\end{array}$} & \multirow{2}{*}{$\begin{array}{c}\text { From USGS, } 2002 \\
\text { Trenton } \\
*=\text { Ohio, } \\
* *=\text { Michigan } \\
\end{array}$} \\
\hline & $\begin{array}{c}\text { Potsdam/ } \\
\text { Theresa }\end{array}$ & Queenston & Medina & Oriskany & $\begin{array}{l}\text { Bass } \\
\text { Island }\end{array}$ & \begin{tabular}{|c|} 
Upper \\
$\begin{array}{c}\text { Devonian Oil } \\
\text { Zones }\end{array}$ \\
\end{tabular} & \\
\hline $\begin{array}{c}\text { Measured } \\
\text { TDS (mg/L) }\end{array}$ & 300,763 & 298,358 & 292,121 & 231,836 & 232,500 & 156,267 & \\
\hline $\begin{array}{c}\text { Calculated } \\
\text { TDS (mg/L) }\end{array}$ & 299,187 & 302,869 & 292,727 & 232,743 & 232,558 & 149,582 & \\
\hline $\begin{array}{c}\text { Unknown } \\
\text { Method TDS } \\
(\mathrm{mg} / \mathrm{L}) \\
\end{array}$ & & & & & & & $\begin{array}{c}232,432 * \\
195,592 * * \\
* * *\end{array}$ \\
\hline & & & & & & & $\begin{array}{l}* * * \text { New York is } \\
\text { discussed in the text }\end{array}$ \\
\hline $\begin{array}{l}\text { No. of } \\
\text { Analyses }\end{array}$ & 9 & 2 & 8 & 4 & 2 & 3 & 1,7 \\
\hline
\end{tabular}

Table 1 Brine Quality Data From Selected Production Reservoirs in New York State. Reservoirs in the Beekmantown Group (Theresa and Potsdam) and the Queenston Formation have high salinities (greater than 200,000 ppm) that are necessary for brine disposal. Reservoirs in the Trenton-Black River Interval (not shown) also have high salinities. (Modified from Matsumoto et al., 1992, Trenton Salinities from USGS, 2005)

Table 1, Brine Quality Data for Selected Oil and Gas Producing Formations in New York State (modified from Matsumoto et al., 1992 and supplemented from USGS, 2002), demonstrates that there are several deep formations that have salinities (as measured by TDS or Total Dissolved Solids) high enough to be considered suitable brine disposal reservoirs. Three of these formations were selected as potential brine disposal formations using Selection Criteria 1-4. The Potsdam/Theresa (Beekemantown sandstones and dolomites) and the Queenston Formation both have levels of salinity of roughly 300,000 ppm in New York State (Motsumoto et al., 1992), high enough to allow the formations to be considered for brine disposal. Published salinity values for the Trenton Group in New York State were not found. The carbonates of the Trenton and Black River groups are known to have brines that are 30\% (by weight) salts, which is close to 
saturation. We consider the reservoirs within Trenton-Black River interval to be of adequate salinity for brine disposal. This conclusion is supported by the Trenton Group TDS values given in Table 1, which were collected from wells in Michigan and Ohio. In Ohio, the salinity of the Trenton Group (in the sampled well) is high enough to permit brine disposal. The value presented in Table 1 for the salinity of the Trenton Group in Michigan is an average of samples collected from 7 wells. This average is slightly below the 200,000 ppm mark that in necessary for brine disposal, but several of the individual samples were above 200,000 ppm.

Disposal Formation Evaluation Criteria. After the initial selection process, each of the three potential brine disposal reservoirs was evaluated to gauge its ability to accept brine at an economic rate.

The Disposal Formation Evaluation Criteria are the following:

Criterion 1 - Sufficient porosity and permeability to maintain an injection rate of 10 BPM (Ehgartner et al. 2005).

Criterion 2 - Reservoir volume is capable of accepting 11 MMB in 3 years (Ehgartner et al. 2005).

Criterion 3 - Hydraulically separated from sources of potable water.

Porosity and permeability are interrelated and therefore it is not possible to set a definitive number needed for each. Instead, it is necessary that these two factors together are adequate to reach the desired injection rate. The injection formations must have sufficient storage volume to handle the large quantities of brine produced in leaching salt storage caverns as well as sufficient permeability to accept the brine at reasonable cavern development rates. In general, projects are typically based on 5 wells and approximately $77 \mathrm{MMB}$ (15.4 MMB per well) of brine must be disposed of over a 3 year period (Ehgartner et al. 2005). This results in an average injection rate of about 10 BPM and creates an underground cavern volume of 11 MMB (Ehgartner, 2005). Sandia National Laboratories tested and modeled the potential disposal formations to determine if the characteristics of the formations would support safe injection of typical brine volumes at the desired rate if 10 BPM over a 3 year period. 
The sections below contain methods, descriptions and analyses for of each of the three potential disposal reservoirs. The description section for each formation was completed by at the New York State Museum and was used to inform the testing and modeling completed by Sandia National Laboratories. The analysis of each formation contains an evaluation of each formation's fitness to act as a brine disposal reservoir as defined by the Disposal Formation Evaluation Criteria. 


\section{Queenston Formation - Methods}

Top Identification. Tops used in the evaluation of the Queenston and surrounding formations were primarily derived from comparison with the work of Saroff (1988) who worked in the producing region of the Queenston in north central New York, Kearney (1983) and Bastedo and VanTyne (1990) who worked in western New York. Figure 23 is a representative log for the tops picked in the evaluation of the Queenston Formation. Additional visual examples of the Queenston Formation pick used in this report can be seen in Figures 9, 23 and 24.

Delaney Core Description Poster. The core description poster found in Appendix B is of 342 feet (104 m) of 4 in. core taken from the Delaney \#A-124-5 well (API \#31-011-13645), a well located in the West Auburn field in Cayuga County, New York. Of primary interest in this description is the depositional texture and visible porosity identification; also recorded are sedimentary structures, grain size and color. The Queenston is known to vary in color from a gray green to a rich red. A discussion of the origin of these colors is given in Hughes, 1976.

The core description is displayed and correlated with the gamma ray, density and neutron logs from this portion of the well. The density log was used to determine zones within the well where the density drops below that of the accepted matrix density of sandstone, $2.65 \mathrm{~g} / \mathrm{cc}$. Figure 24 , a graph used to convert formation density to porosity, shows that intervals of sandstone with densities of $2.65 \mathrm{~g} / \mathrm{cc}$ are considered to have zero porosity and that porosity increases with decreasing density. At density values of $2.5 \mathrm{~g} / \mathrm{cc}$ the evaluated interval has reached $10 \%$ porosity, which is considered reservoir quality rock. In the Delaney Core description, those portions of the density curve that fall to the left of the green line indicating $2.5 \mathrm{~g} / \mathrm{cc}$ are representative of potential reservoir rock. This method was also used in the east-west and northsouth cross sections to the Queenston Formation presented in Plates 9 and 10.

Cross Sections. Plates 9 and 10 are east-west and north-south cross sections respectively of the Queenston Formation. The cross sections show the interval from the lower Silurian Lockport Group to the Middle Ordovician Trenton Group. The cross sections are stratigraphic and are hung on the Lockport Formation, which is consistent and easily identifiable in the area covered 


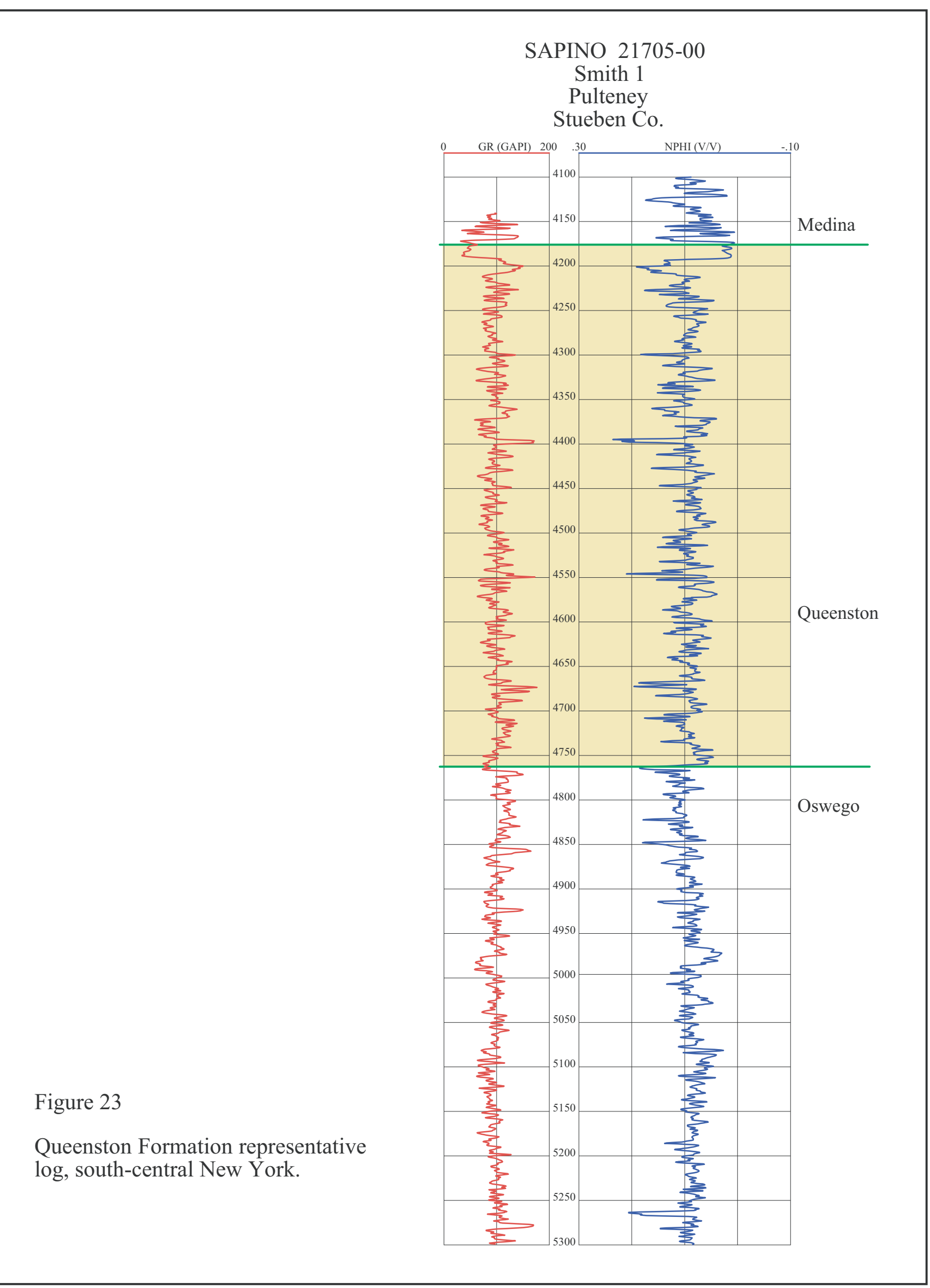




\section{Formation Density Log Determination of Porosity}

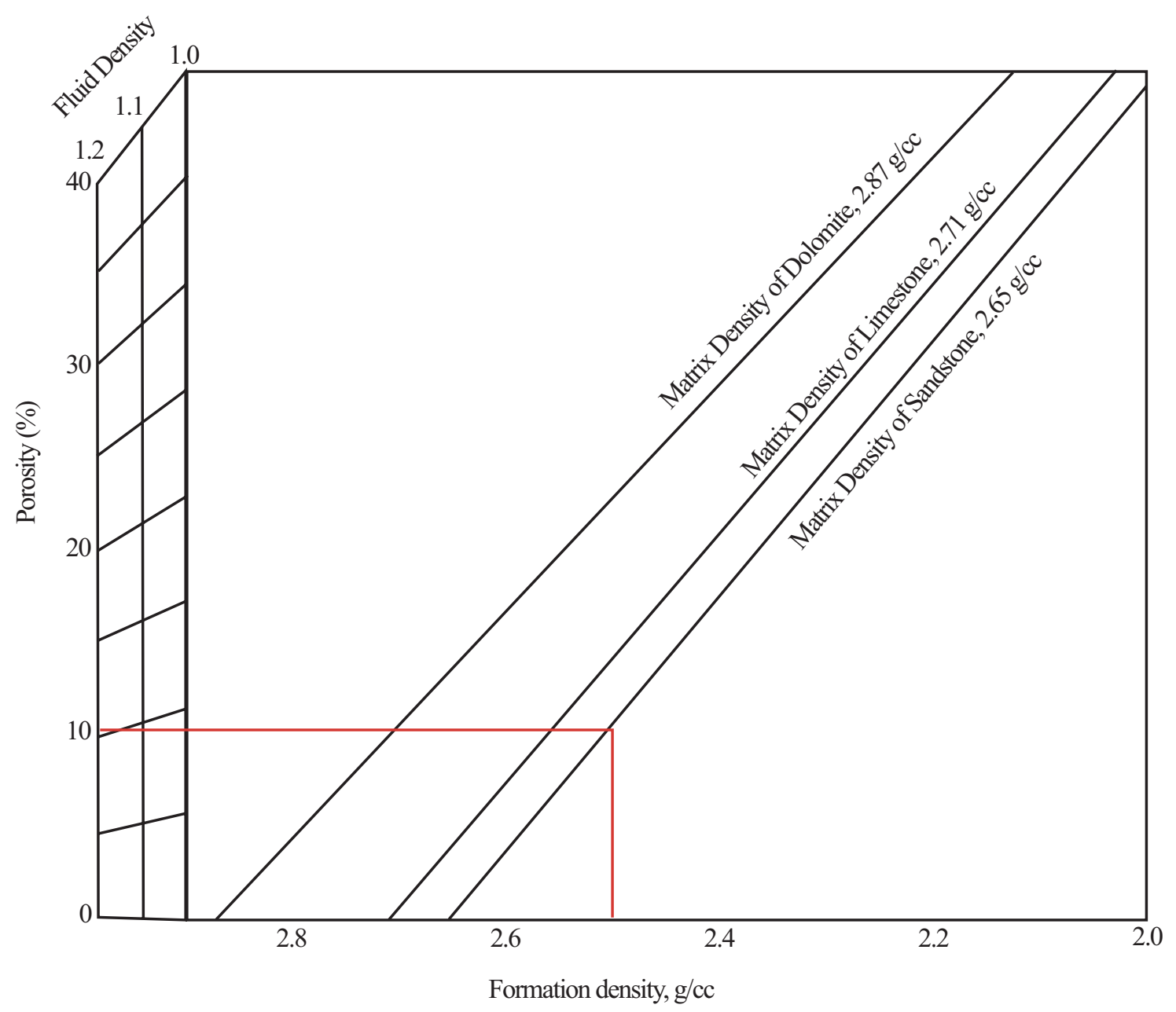

Figure 24 Chart for converting density to porosity using values picked from a density log. The red line shows the correlation between a sandstone density of $2.5 \mathrm{~g} / \mathrm{cc}$ and porosity estimate of $10 \%$. Porosities of $10 \%$ or more are needed in reservoir rocks. (Modified from Asquith, 1982) 
by the sections. Geocolumn shading (described below) is used to highlight variations in lithology from the top of the Queenston Formation to the top of the Lorraine Group.

Gamma Ray logs record the natural gamma ray emissions of rocks that result from the disintegration of radioactive elements that naturally occur in the rock strata (Asquith, 1982). Figure 25 shows the relative radioactivity of selected sedimentary rocks (modified from Lynch, 1962). Clay minerals formed during the decomposition of feldspars and micas from igneous rocks tend to be enriched in radioactive material and also have the ability to absorb radioactive elements released during the decomposition of other minerals. Typically, this results in the enrichment of radioactive elements in clays and shale, compared to clean sandstones and carbonates. Based on this relationship the gamma ray log is often used to determine rock type, wherein shales will have high or "hot" gamma ray values and clean sandstones and carbonates are expected to have low values on the gamma ray curve (Lynch, 1962). The shading of the logs on the east-west and north-south cross section of the Queenston Formation (Plates 9 and 10) take advantage of this relationship to delineate what we interpret to be intervals of sandstone, shale and sandy shale. On these curves the shading is representative of the rock types and gamma ray values listed below in Table 2 .

Table 2 Geocolumn shading explanation.

\begin{tabular}{|c|c|c|}
\hline Rock Type & Color & Gamma Ray Values (API units) \\
\hline Sandstone & Yellow & $0-70$ \\
\hline Sandy Shale & Orange & $71-80$ \\
\hline Shale & Gray & $>80$ \\
\hline
\end{tabular}

Rock Mechanics Testing of Queenston Formation. Permeability tests were conducted on core samples from the Queenston sandstone from New York State. The core samples were selected from intervals of the Delaney \#A-124-5 well (API \#31-011-13645) that were identified as having visible porosity (see Appendix B). The test apparatus is shown in Figure 26. The test matrix 


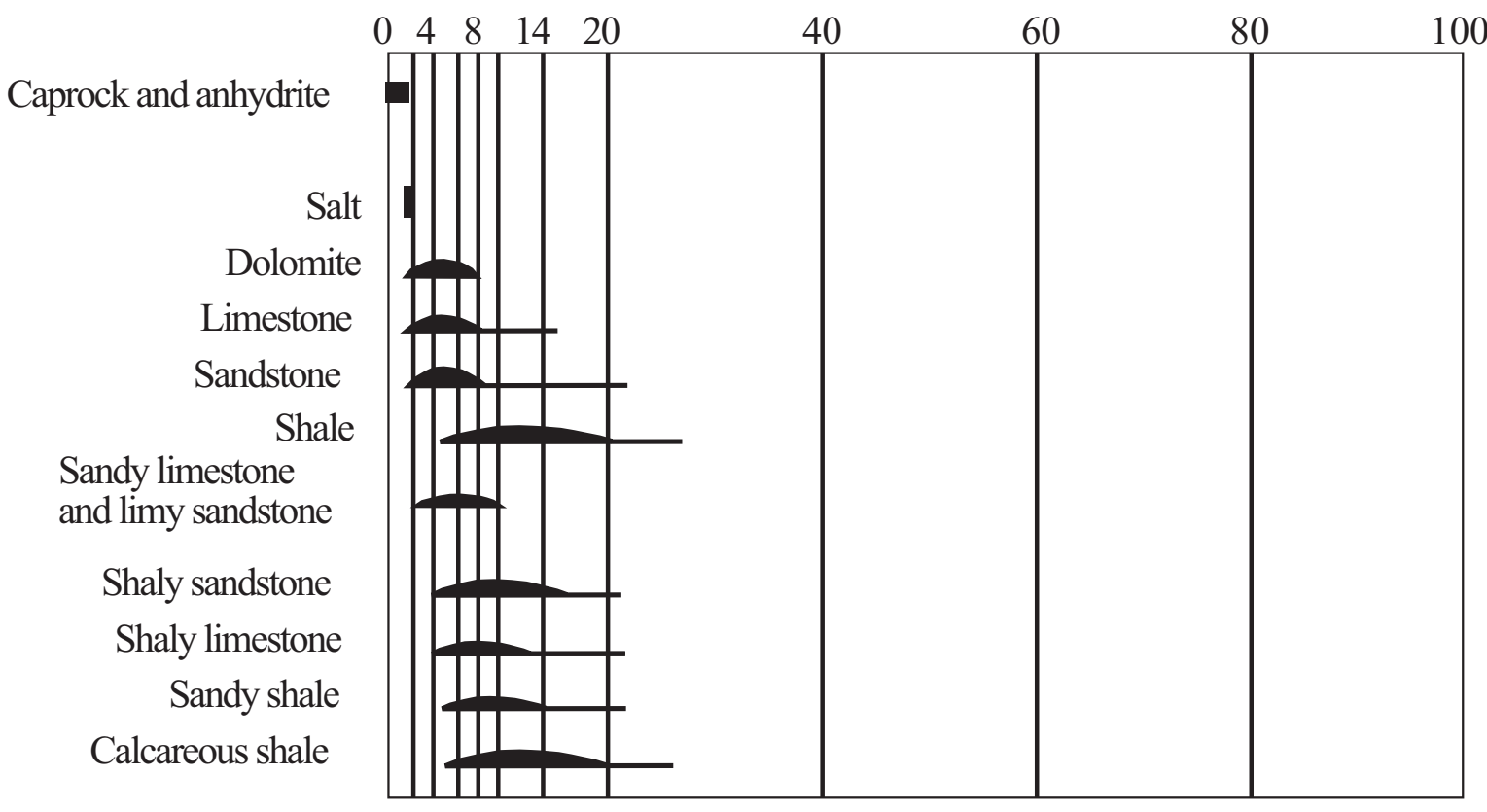

Figure $25 \quad$ Relative radioactivity for selected sedimentary rocks (modified from Lynch, 1962) 

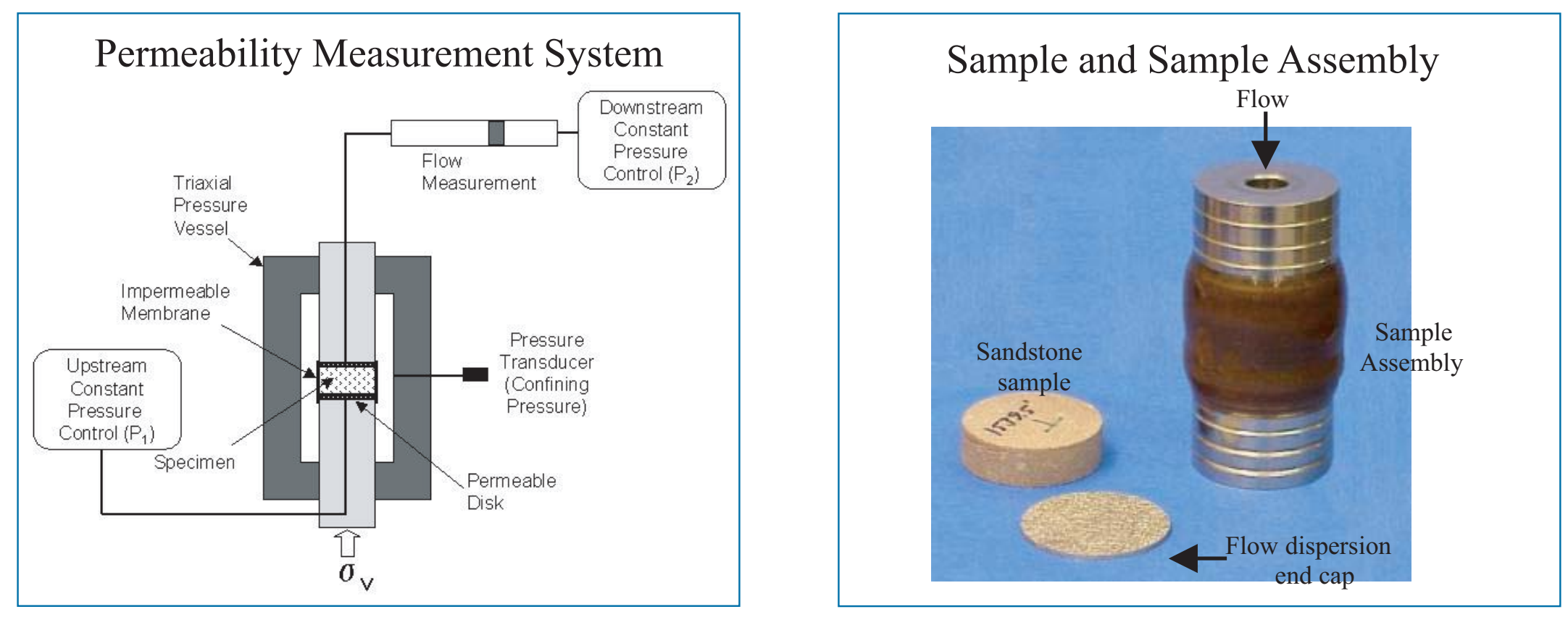

Figure $26 \quad$ Test Configuration and Picture 
consisted of over 80 tests preformed on 5 core samples. The confining pressure and pore pressures were varied over a wide range with the core orientated both parallel and perpendicular to the bedding planes, which were dominantly horizontal. A synthetic non-aqueous fluid (Isopar-H) was used in most of the tests, although brine and water were also used.

Modeling of Queenston Formation. A standard vertical injection well with and without stimulation was modeled. Stimulation or enhanced injection was achieved through modeling the effects of a large fracture extending radially from the well. The amount of stimulation through fracturing was varied in the modeling to determine how much stimulation was necessary to make a formation viable as a disposal reservoir.

Extensive fracturing can be problematic in tight formations, as potential for fractures to propagate out of the disposal zone and perhaps generate induced earthquakes exists. This hazard minimized with proper engineering. The injection pressure must be maintained below the minimum principal stress of the formation. Otherwise the formation could fracture. Although this is beneficial, and the practice is used to stimulate wells, it must be limited to prevent extensive fracture lengths, which could propagate outside the disposal zone and perhaps generate earthquakes. This potential was addressed in the modeling of the Queenston Formation by limiting the injection pressure to 90 percent of the minimum in situ stress.

Both 1-D radial and half-space models were used to simulate transient flow. The hydraulic conductivity of the formation was calculated from the viscosity of brine and the permeability of the rock as determined through the rock mechanic testing.

The pre-existing saturation content of the pore is important to storage. A gas filled pore enables much more brine to be disposed of than a fluid filled pore due to the compressibility of the gas. Water saturation varies from complete saturation to near gas filled pores. For purposes of these analyses the storage coefficient was based on a saturation of 50 percent. Scoping studies showed that some degree of gas saturation is an important to successful storage. In its absence, the compressibility of formation water is insufficient to accommodate the large amount of brine that 
needs to be disposed. The modeling of formations initially saturated with water would require the displacement of formation fluids over a very large area to reach the desired storage volumes.

The flow of brine into a formation is time dependent. At constant injection pressure, the amount of flow rate will decrease with time as the pore pressure in the formation builds up. Initially the pore pressure in the formation is assumed to be hydrostatic. The mathematical formulation for radial flow is presented below. The flow rate $(\mathrm{q})$ from a well of radius $r$ is defined as follows:

$$
\dot{q}=2 \pi r T \frac{\partial h}{\partial r}
$$

where $\mathrm{T}$ is the transmissivity of the formation and $\delta \mathrm{h} / \delta \mathrm{r}$ is the hydraulic gradient near the well bore or the change in head (h) with distance (r) into the formation. The transmissivity is a product of the thickness of the disposal layer times the hydraulic conductivity (K). Although most formations are commonly a hundred or more feet thick, the high permeability layer typically resides in the upper 10 to 150 feet of the formation. Therefore the assumed thickness used in the analyses is 100 feet unless otherwise noted. The injection amount scales directly with the layer thickness. Therefore the results are applicable to any thickness, provided they are scaled to the known thickness of the disposal layer. Hydraulic conductivity is related to permeability (k) and the fluid properties through the relationship:

$$
K=k \frac{\rho g}{\mu}
$$

where $\rho$ is the density of the brine, $g$ the gravitational constant, and $\mu$ the brine viscosity. The above relationships show that the injection rate into a formation is directly proportional to the formation permeability.

The hydraulic pressure gradient is dependent on the injection pressure and time. Over time, the gradient decreases as pore pressures spatially distribute in the formation. This results in less injection assuming the injection pressure in the well remains unchanged. A constant injection 
pressure was used in the analyses to provide the maximum amount of disposal. In practice, both the injection rate and pressure may vary as completion of the multiple injection and cavern wells is phased in over time.

The change in head over time ( $t$ ) can be simulated using numerical solutions (the finite difference technique was used here) according to the following second order partial differential equation

$\frac{\delta^{2} h}{\delta r^{2}}+\frac{1}{r} \frac{\delta h}{\delta r}=\frac{S}{T} \frac{\delta h}{\delta t}$

where: $\mathrm{S}$ is the storage coefficient or storativity of the disposal horizon. Storativity is defined as the volume of fluid that the disposal layer can accept per unit surface area of the layer per change in head.

\section{Queenston Formation - Description}

The Upper Ordovician Queenston Formation was selected as a potential brine disposal reservoir because it is a widespread sandstone that has produced gas in north-central New York for more than 60 years and it has proven to have the capacity to accept brine in current brine disposal operations in Bath, New York. Where it produces gas in north-central New York, the formation has salinity of over 200,000 ppm, which makes it appropriate for brine disposal. Data tables related to the Queenston Formation are located in Appendix B.

The Queenston Formation, which crops out just south of Lake Ontario (Kreidler, 1975) is roughly 700-1,000 feet (244-274m) thick in most of western New York. Figure 27 is a map of the Queenston surface exposures in New York State. Exposures of the Queenston Formation are limited both by the non-resistant nature of the formation and by the thick cover of Pleistocene sediments (Hughes, 1976). Kreidler (1975) reviewed available well data for the Queenston and determined that the formation for the most part is thicker in western New York and thins to the 


\section{Outcrop Map of the Queenston Formation}

in New York State

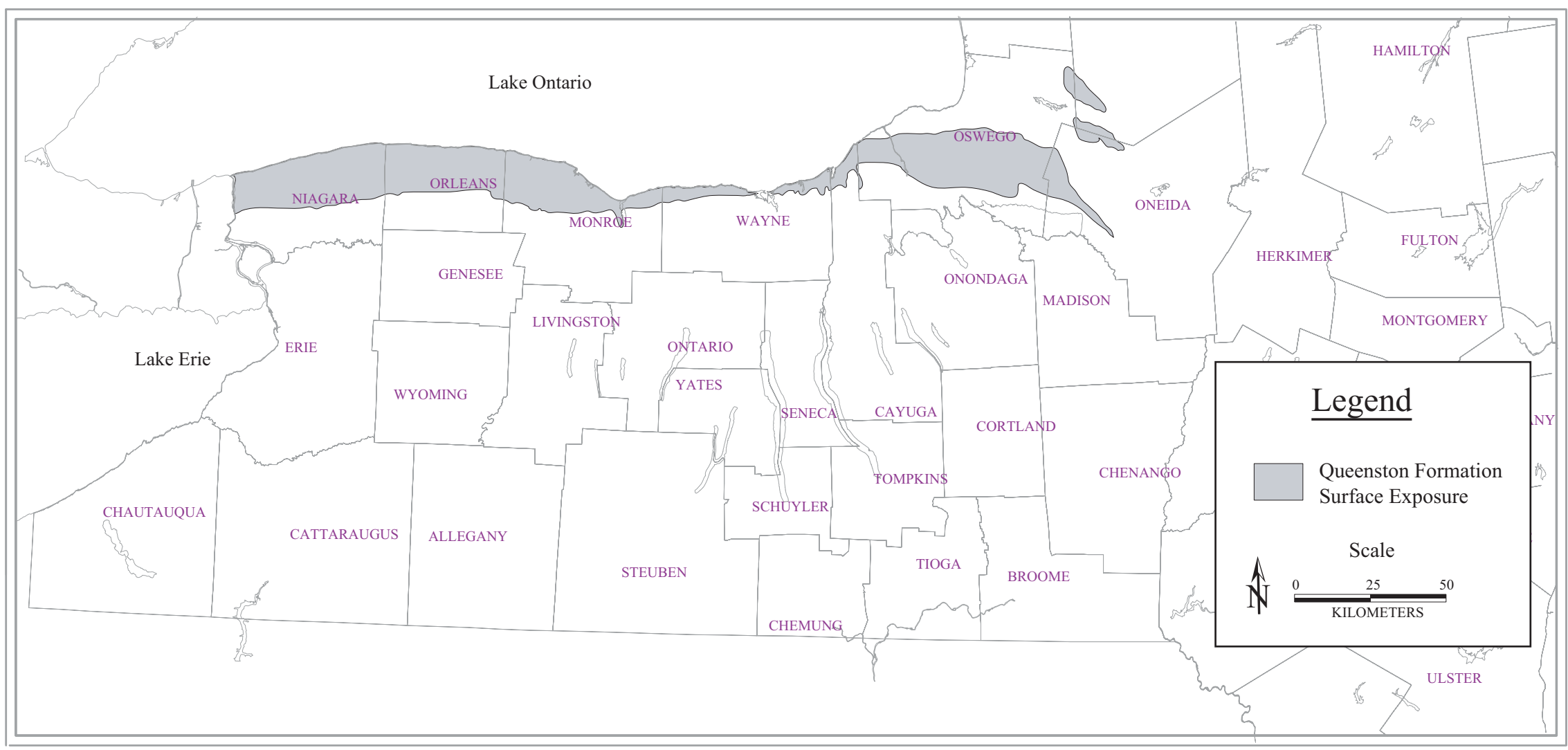

Figure 27 The Queenston Formation outcrops in an east-west band across the northern portion of western and central New York State. 
east. In New York State, the lower units of the Medina Group unconformably overlie the Queenston Formation.

In the subsurface, the Queenston Formation is a thick sequence of shale, siltstone and fine- to medium-grained sandstone ranging in color from reddish brown, gray to green. The Queenston Formation was laid down as part of a sequence of detrital clastic deposits that formed a large deltaic complex. In general the clastic material comprising the Queenston becomes coarser from west to east as you get nearer to its source, the Taconic uplands. The formation is mainly composed of sandstone in the southeastern part of the study area and grades to shale and siltstone to the northwest. The thickening and coarsening of the Queenston is illustrated in Figures 28 (modified from Saroff, 1987) and Plates 9 and 10.

The top of the Queenston Formation is roughly 1,000 to 1,800 feet below sea level in the producing area in north-central New York. Figure 29 and Plate 11 are a structure contour map of the Queenston Formation. From the Producing area the formation dips to the south roughly 50 feet/mile, reaching depths of 6,000 feet or more below sea level at the New York - Pennsylvania Border. Within the study area the Queenston is between 2,500 and 6,500 feet below sea level. The formation has a consistent thickness of roughly 550 feet to 700 feet in Plates 9 and 10, but other researchers have reported thicknesses up to 1,000 feet in portions of western New York (Saroff, 1987). The shading on the regional cross section in Plates 9 and 10 indicates different lithologies as interpreted from the gamma ray log in each of the wells (see methods section). The yellow shading highlights sections with lower gamma ray values, which we interpret to be sandstone. On both the east-west and north-south cross sections, the sand content varies, but over all these sections show that the Queenston is increasingly sandy to the south and east, with the sandiest sections located in the upper portions of the well.

The Queenston Formation and underlying Oswego Formations are often grouped together in studies due to their similar lithology. Figure 30 and Plate 12 are an isopachous map of the Queenston-Oswego interval. Note that this interval is thickest in south-central New York in areas where salt cavern storage facilities could be developed. According to Kreidler (1975) the deeper portion of the basin near Corning and Binghamton, New York offers a better potential for 


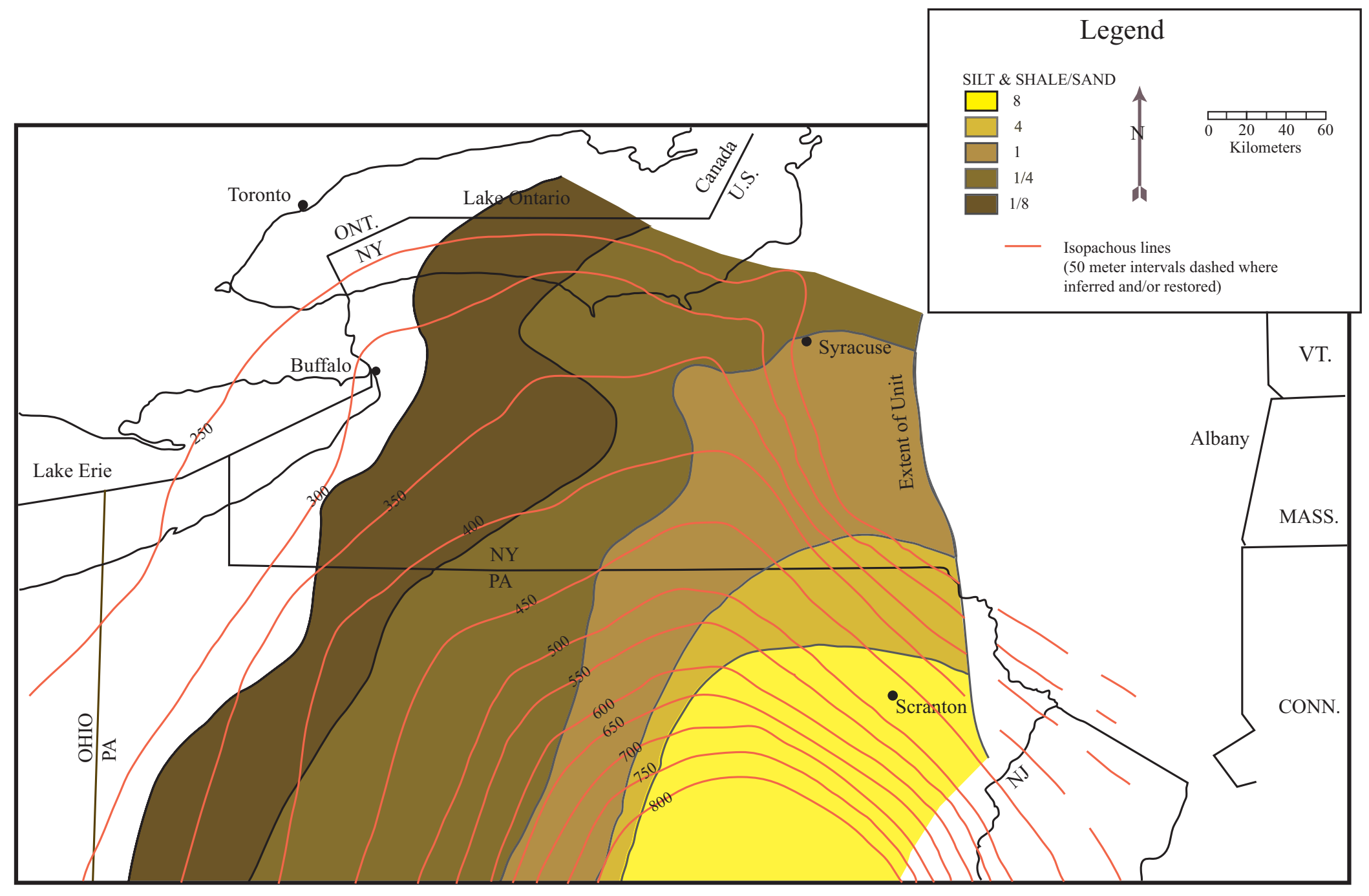

Figure 28 Upper Ordovician Oswego and Queenston Formations Isopachous and Sand/Shale ratio map (modified from Saroff, 1987). 


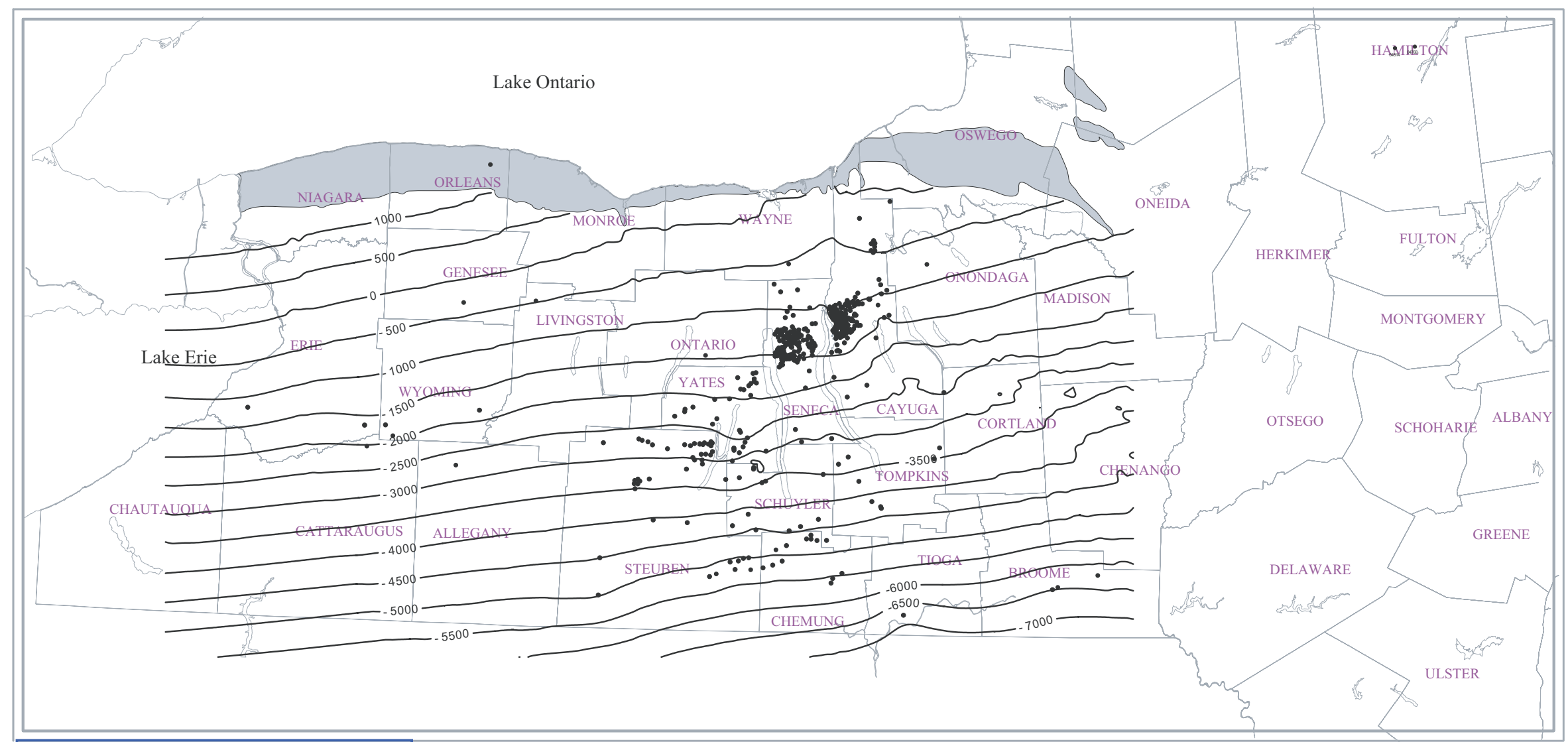

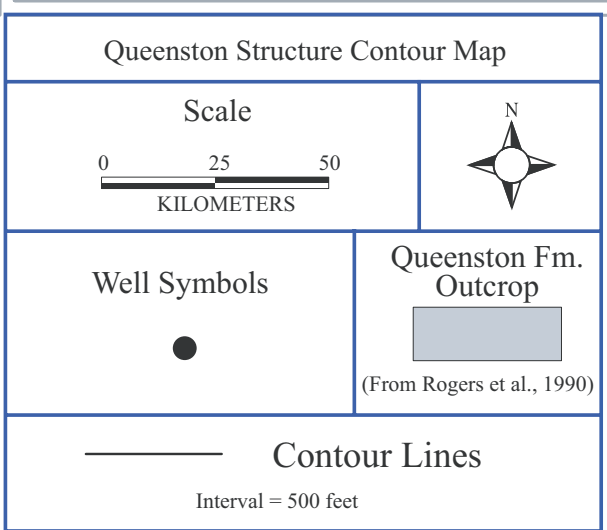

Figure 29 Queenston Formation structure contour map. The top of the Queenston Formation is roughly 1000 to $1800 \mathrm{ft}$ below sea level in the producing area in north-central New York. From the Producing area the formation dips to the south roughly $50 \mathrm{ft} /$ mile, reaching depths of $6000 \mathrm{ft}$ or more below sea level at the New York - Pennsylvania Border. Within the study area the Queenston is between 2500 and $6500 \mathrm{ft}$ below sea level. The well SAPINOs are labeled and greater detail is given in Plate 11. 


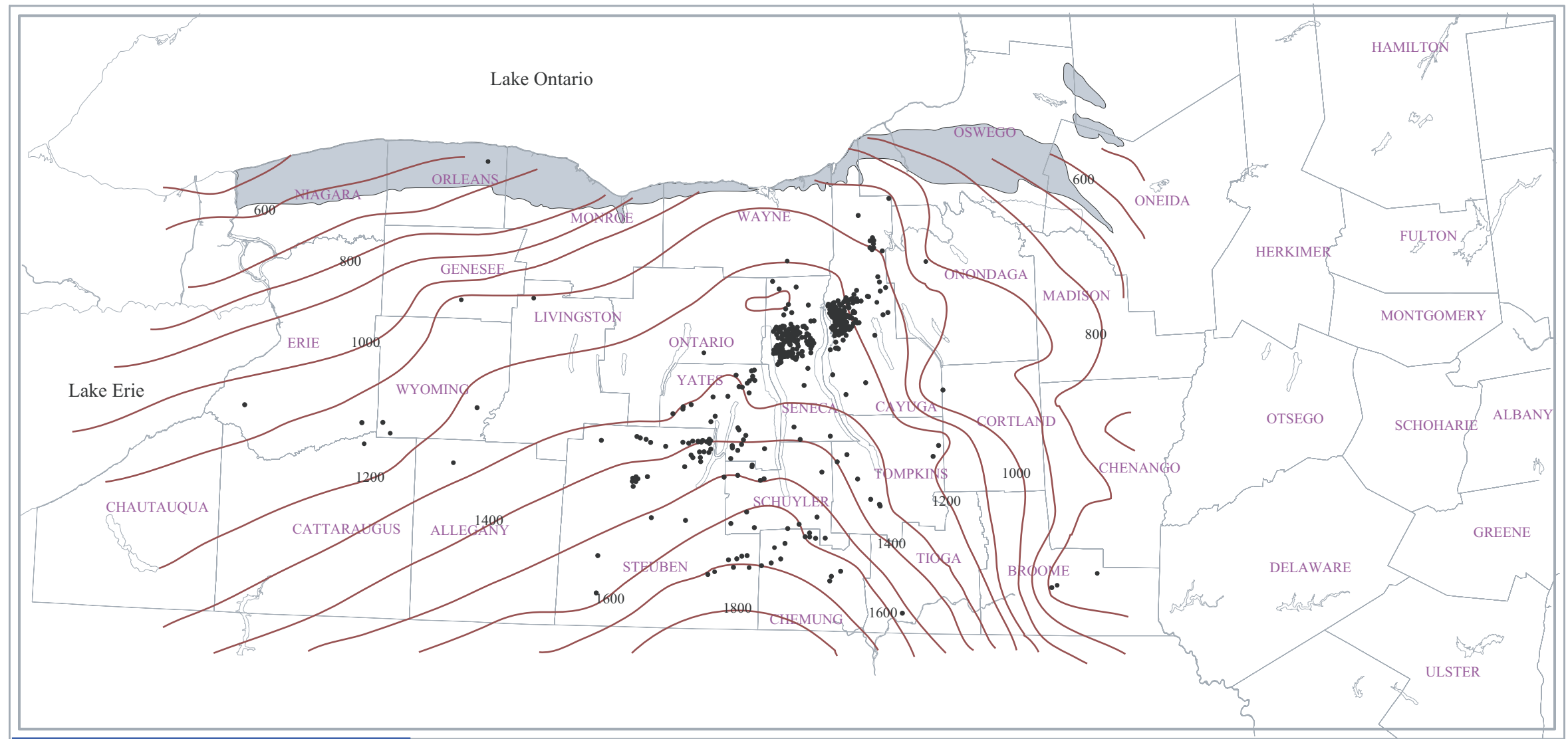

\begin{tabular}{|c|c|}
\hline \multicolumn{2}{|c|}{ Queenston - Oswego Isopachous Map } \\
\hline \multicolumn{2}{|c|}{ Scale } \\
\hline KILOMETERS \\
\hline (Frll Symbols
\end{tabular}

Figure 30 Isopachous map of the Queenston-Oswego interval. This interval is thickest in south-central New York in areas where salt cavern development is a possibility. The well SAPINOs are labeled and greater detail is given in Plate 12. 
disposal of liquid wastes. At the time Kreidler conducted his study, few wells had been drill in this area that were deep enough to reach the Queenston.

Production from the Queenston Formation has occurred at the West Auburn Field in northcentral New York (Figure 31) for over sixty years (since 1940). Figure 32 (modified form Saroff, 1978) illustrates the mechanism that has allowed gas to be trapped and subsequently produced at economic rates in this area. Gas migrates updip within the sandstone facies of the Queenston Formation until it encounters a facies change, which acts as a permeability barrier. The Grimsby Formation overlying the Queenston is a silty shale in the Queenston producing region and therefore acts as a caprock (Saroff, 1978).

Because of the benefit to production, the Queenston Formation's petrophysical and geological attributes have been studied in the vicinity of the West Auburn Field. Ward, 1988 reported that there are 3 primary gas sands in the Queenston in the producing area and that together they have an average porosity of $13 \%$ and a permeability of roughly 0.2 md with extreme examples showing peak porosities approaching 20\% and permeabilities over $5.0 \mathrm{md}$. In 1987 and 1988 Saroff reported on his study of 111 wells from the West Auburn Field. Saroff (1987 and 1988) found that the Queenston Formation contained several intervals of various thickness where the sand content is over $75 \%$ and intervals where the apparent porosity is over $10 \%$. Saroff (1987) also stated that other authors had reported permeabilities of 0.1-1 md for the Queenston in this area.

Both Ward (1988) and Saroff (1987 and 1988) discuss the importance of the regional and local structure on the productivity of wells within the field. Saroff (1987 and 1988) noted that the better producing wells were located in areas with higher sand content, though he felt that it was more important that these wells were completed in zones of increased fracturing. Saroff determined that the zones with increased fracturing were focused "on trend" with Precambrian basement faults as recognized in regional gravity and aeromagnetic survey maps. Ward (1988) also commented that the occurrence of natural fractures are associated with gentle folding within the field and contributed to production from what is generally considered a low permeability reservoir. 

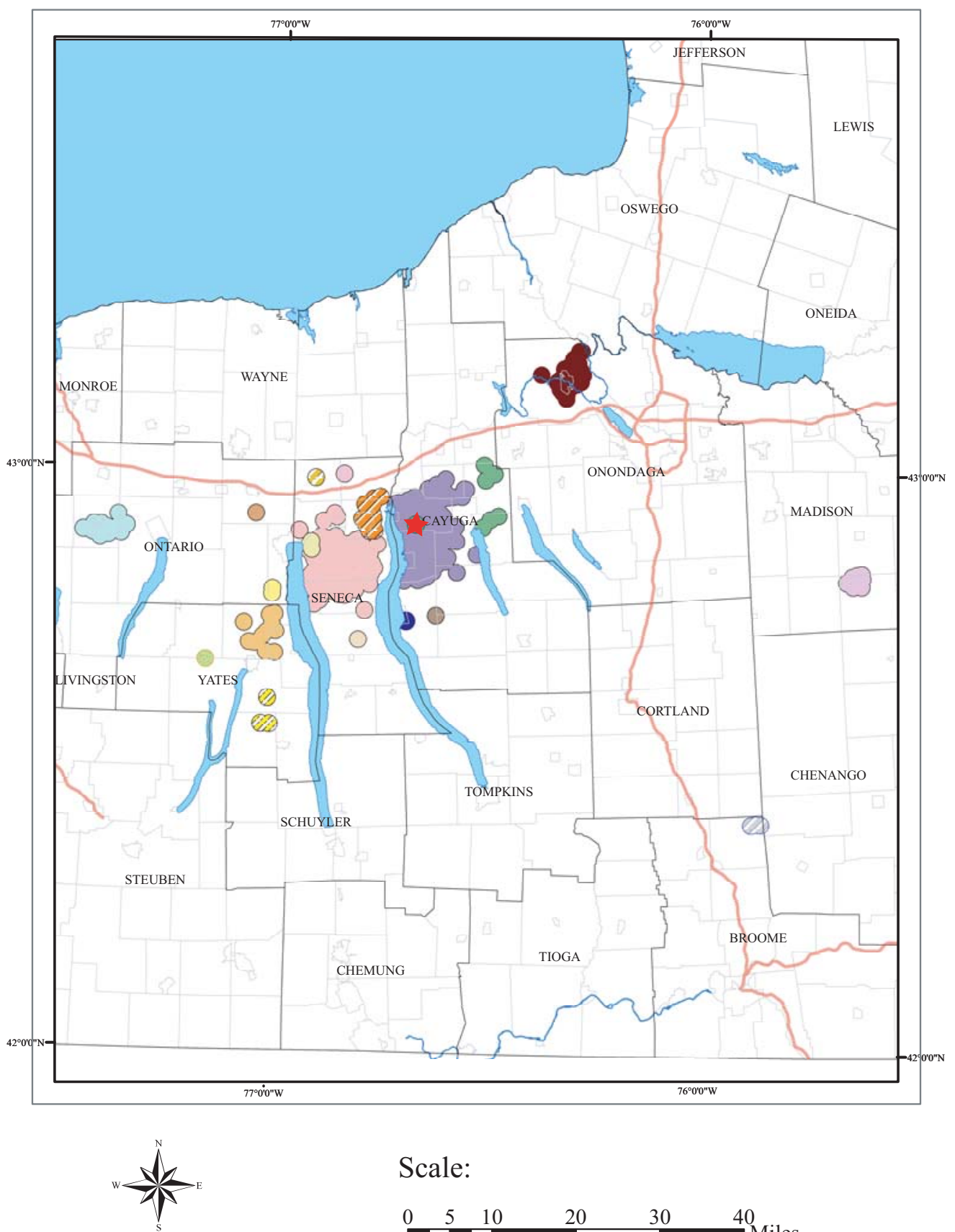

Scale:

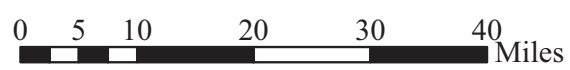

Legend

211 whiskey hill

wells college

WN triangle

sugar creek

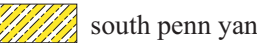

VIIA seneca falls

rose hill

romulus

north penn yan

montezuma marsh

melvin hill

lebanon

fayette-waterloo

east bloomfield

benton run

baldwinsville

auburn

ashland_farm

west auburn

Location of

Delaney A-124-5 well

(SAPINO 13645-00-00)

Figure 31 Map of fields producing from the Queenston Formation in north- central New York 


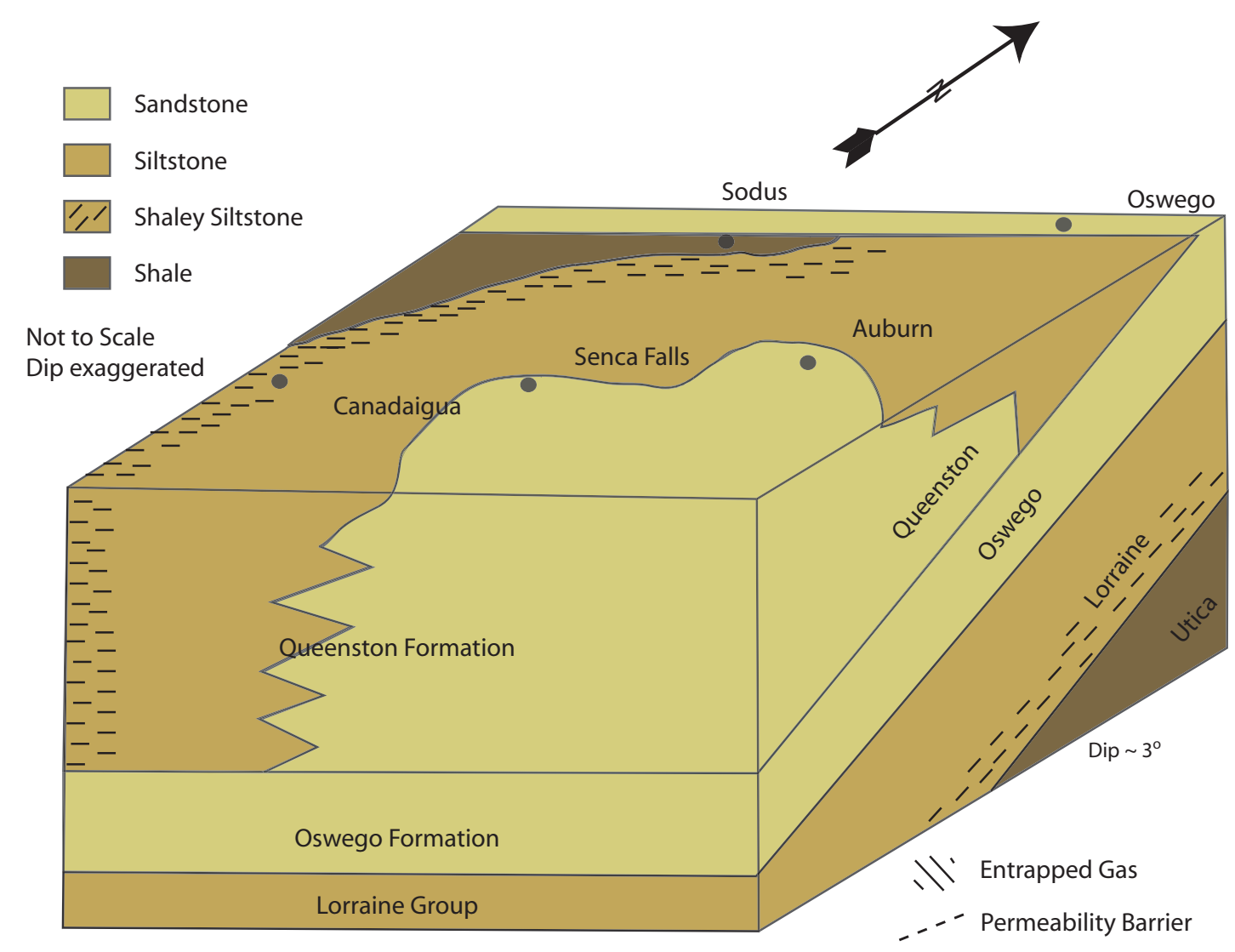

Figure 32 Model of gas entrapment. Gas migrated up dip and was subsequently trapped within the sandstone facies and against a permeability barrier within the the Queenston Formation. The Grimsby Formation, a silty shale, lies directly above the Queenston in this area, and forms a caprock (From Saroff, 1987). 
Bath Petroleum Inc., in Steuben County recently disposed of brine from their holding ponds into the Queenston Formation in a well located at their facility (BPSI 8, 21551-00). This use of the Queenston was allowed by the DEC (New York State Department of Environmental Conservation) only to alleviate emergency conditions and was temporary. Bath Petroleum Inc. disposed into the formation at rates between 3-5 bbls/min for at least two months (see Appendix B). It is not known how long this might continue and whether the formation could accept brine from multiple disposal wells in the same area or if it would work elsewhere in the study area, but these results are encouraging. Bath is currently seeking permits that will allow them to use this well for disposal on a more regular basis.

Delaney A-124-5 Well - Core Description. Our group has observed lithology similar to that described by previous studies of the Queenston Formation in the cored interval from Miller Brewing Company's Delaney A-124-5 well (SAPINO = 13645-00) in the West Auburn Field, Cayuga County, New York (location marked by a star on Figure 31). Plate 13 is the entire core description for the Delaney A-124-5 well and contains many thin section and core images that are correlated to the description and geophysical well logs.

Three general rock types were observed in the core (Figure 33). A medium- to fine- quartz rich sandstone, a thinly bedded siltstone and 0.5 inch to 6 inch thick conglomeratic sections where pebble sized clasts of ripped-up siltstone have been incorporated into the sandstone (both matrix and clast supported conglomerates were observed).

Several sections of sandstone exhibit visible porosity (highlighted in red on and Plate 13). In these sections and others, intergranular porosity was also observed in thin section. Both the visible porosity in the core and the intergranular porosity observed in the thin sections are often found in linear, horizontal bands associated with horizontal fracturing. Figure 34, the upper 150 feet of the Delaney A-124-5 core description, illustrates that there are several zones of visible porosity in this section. These zones of porosity are often associated with mircrofracturing and correlate with drops below $2.5 \mathrm{~g} / \mathrm{cc}$ on the density curve. Porosity was visually estimated from thin sections through out the core and varies from $0 \%$ to as high as $15 \%$, but is more commonly 
less than 5\%. Appendix B contains a list of these porosity estimates by depth. While, the zones of visible porosity described in the core do occasionally align with high estimates of porosity from the thin sections, no correlation can be made.

An X-ray diffraction study completed on the Delany core (H.J Gruy and Associates, 1979), concluded that the upper Queenston sandstones in this well have a high total clay content, reaching as much as 20\% (5.25\% Montmorillonite, 7.50\% Illite, and 8.00\% Kaolinite). The high clay content increases the likelihood for particle plugging between the pores, which would reduce flow of gas into the well bore or flow of water away from the well bore during injection.

Testing and Modeling Results for the Queenston Formation. The permeabilities of the Queenston Formation in the Delaney well were found to correlate to the difference in the confining and pore pressures. By necessity, the confining pressures were larger than the pore pressures. As shown in Figures 35 a smaller difference in the confining pressure resulted in the largest permeabilities. Table 3 shows the range, mean and median permeabilities measured. In some cases, samples located less than a foot a part had two orders of magnitude difference in permeability. Orientation did not seem to be a factor influencing permeability.

Table $3 \quad$ Test Matrix

\begin{tabular}{|l|l|l|l|l|l|l|l|}
\hline Formation & $\begin{array}{l}\text { No. of } \\
\text { Samples }\end{array}$ & $\begin{array}{l}\text { No. } \\
\text { of } \\
\text { Tests }\end{array}$ & $\begin{array}{l}\text { Confining } \\
\text { Pressure }\end{array}$ & $\begin{array}{l}\text { Pore } \\
\text { Pressure }\end{array}$ & $\begin{array}{l}\text { Range in } \\
\text { Permeability } \\
\text { (m-D) }\end{array}$ & $\begin{array}{l}\text { Mean } \\
\text { Permeability } \\
\text { (m-D) }\end{array}$ & $\begin{array}{l}\text { Median } \\
\text { permeability } \\
\text { (m-D) }\end{array}$ \\
\hline Queenston & 5 & 86 & $\begin{array}{l}470 \text { to } \\
7000\end{array}$ & $\begin{array}{l}100 \text { to } \\
6700\end{array}$ & $\begin{array}{l}0.000027 \text { to } \\
0.0979\end{array}$ & 0.0162 & 0.0074 \\
\hline
\end{tabular}

As stated above, Isopar-H was typically used during testing. When water was used to test the Queenston Formation, no measurable permeability resulted. It is thought that the presence of clay (discussed above in the description of the Queenston Formation) was the underlying cause for the flow resistance as clay can cause particle plugging and swelling when wetted. A sample was tested using saturated brine. The results of that test compared favorably to those using Isopar-H. The swelling of clays is limited by brine, in contrast to water. High salinity sodium 
Sandstone
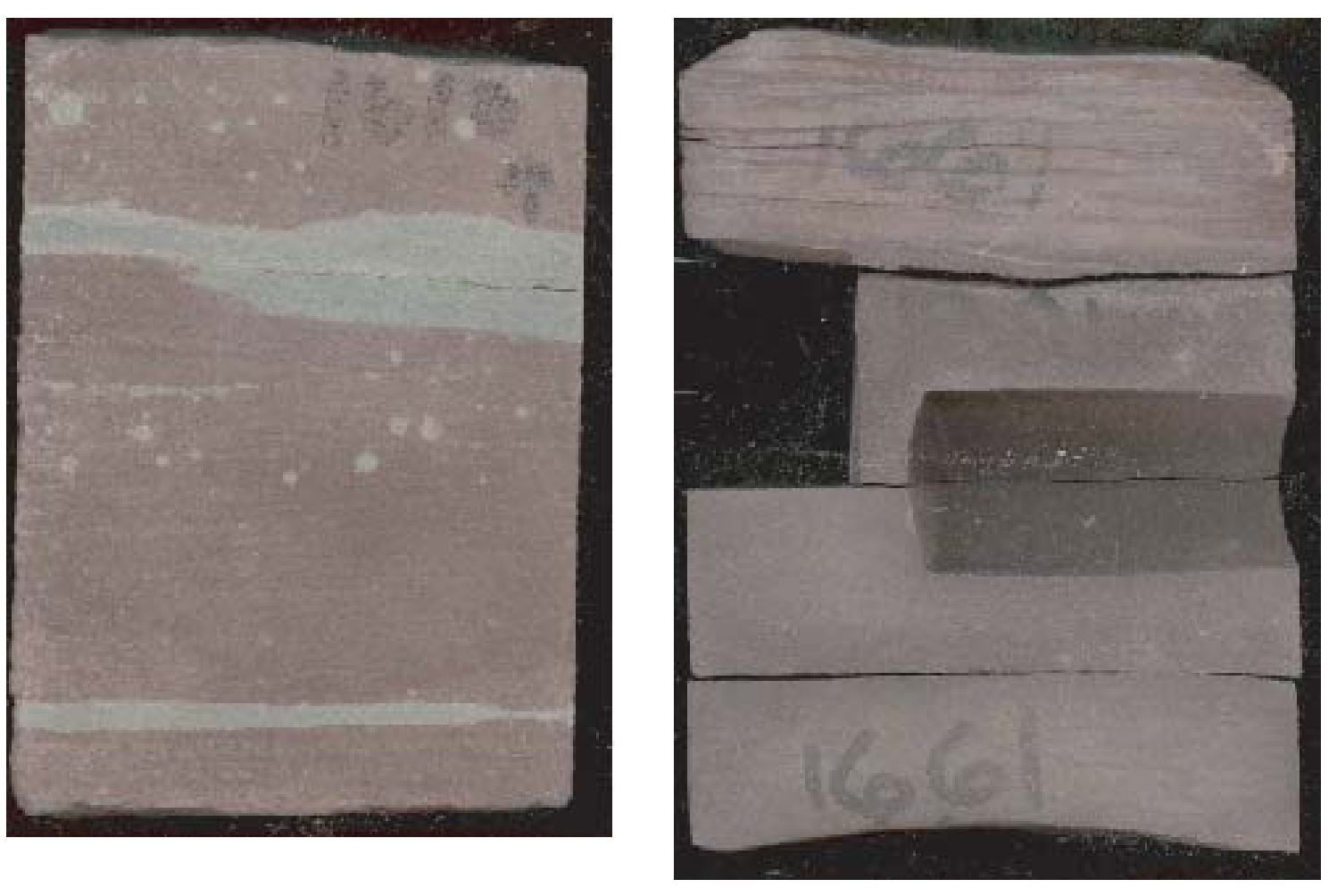

Siltstone

4 in.

\section{Conglomerate}

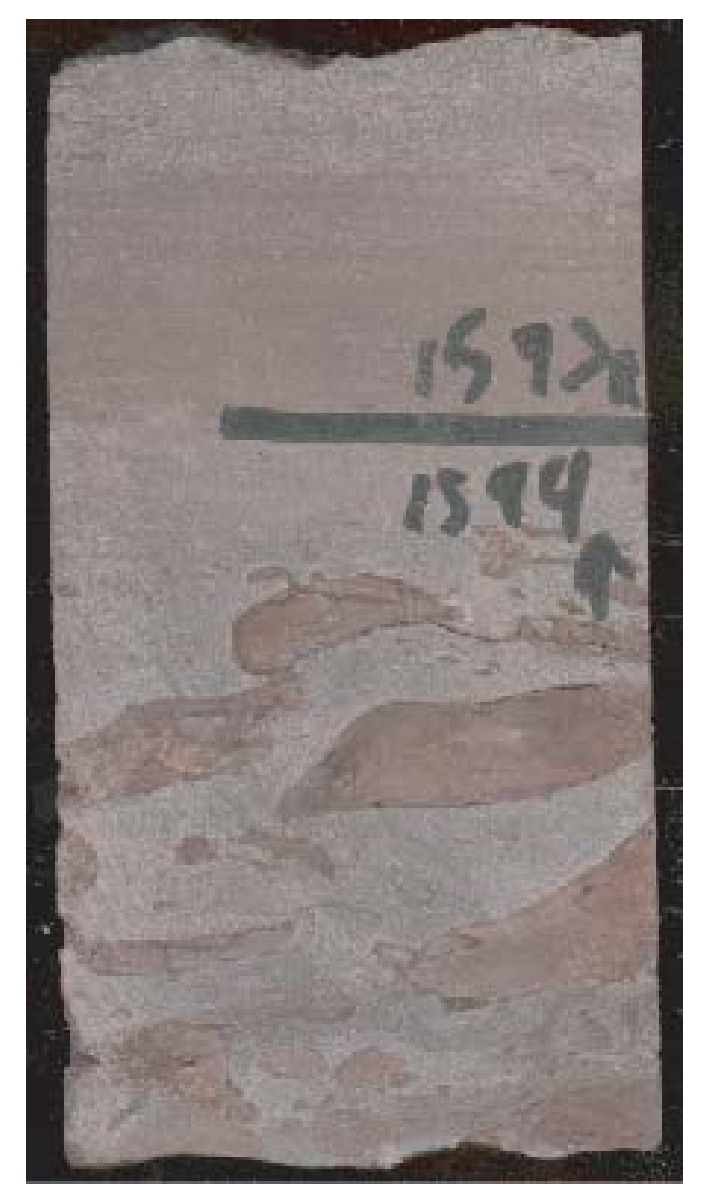

Figure 33 Rock types found in the Delaney A-124-5 core (SAPINO 13645-00-00). 


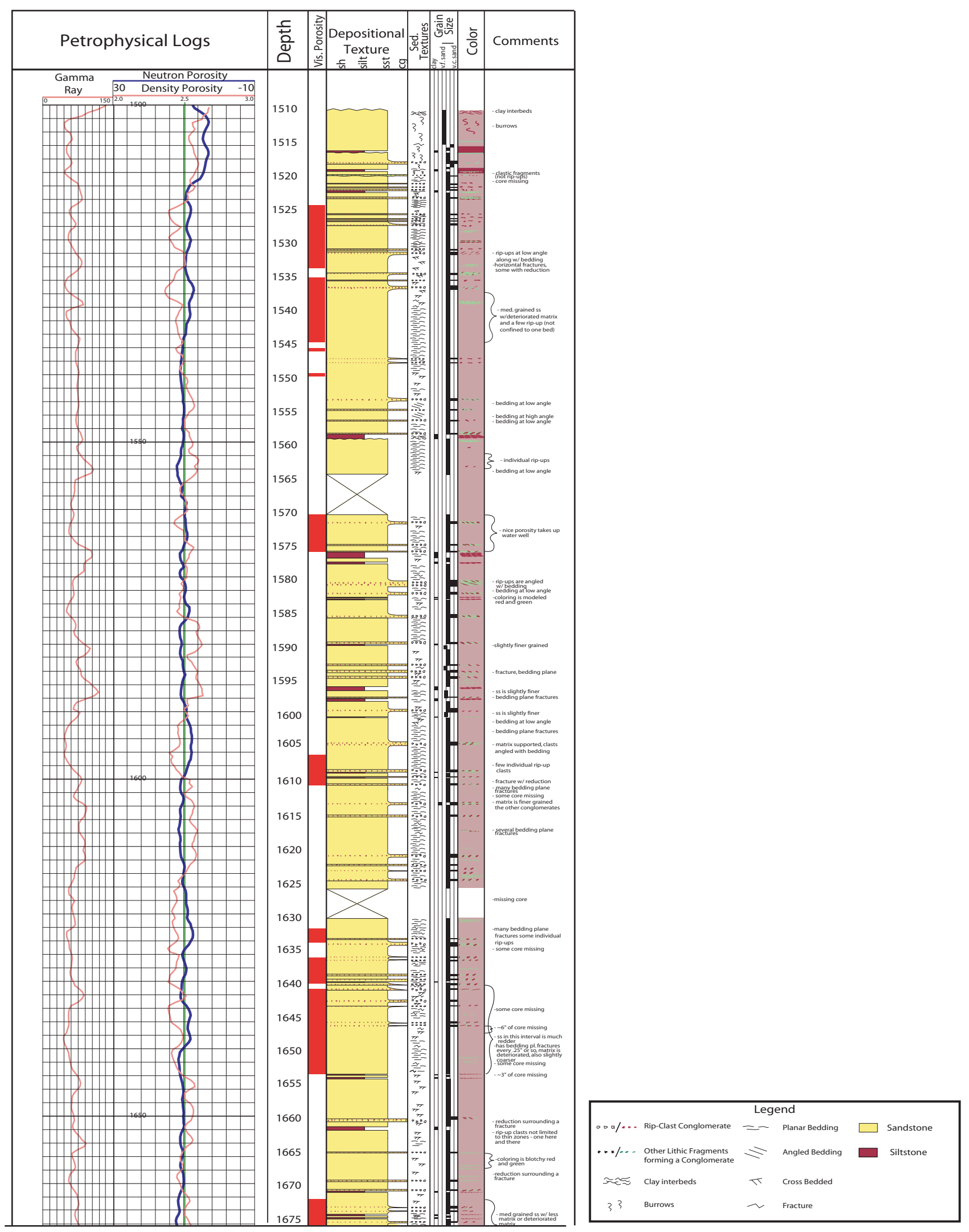

Figure 34 Queenston Formation Core Description from the Delaney A-124-5 well in Cayuga County, New York. The location of this well is shown on Figure 30. 
chloride brines (s.g.>1.1) preclude the swelling of clays and minimizes clay dispersion. Therefore if clays are known to exist in the disposal formation, caution must be taken on the well completion as not to use fresh brine. Once the cavern is being leached, the salinities are high enough as to not impact on brine disposal.

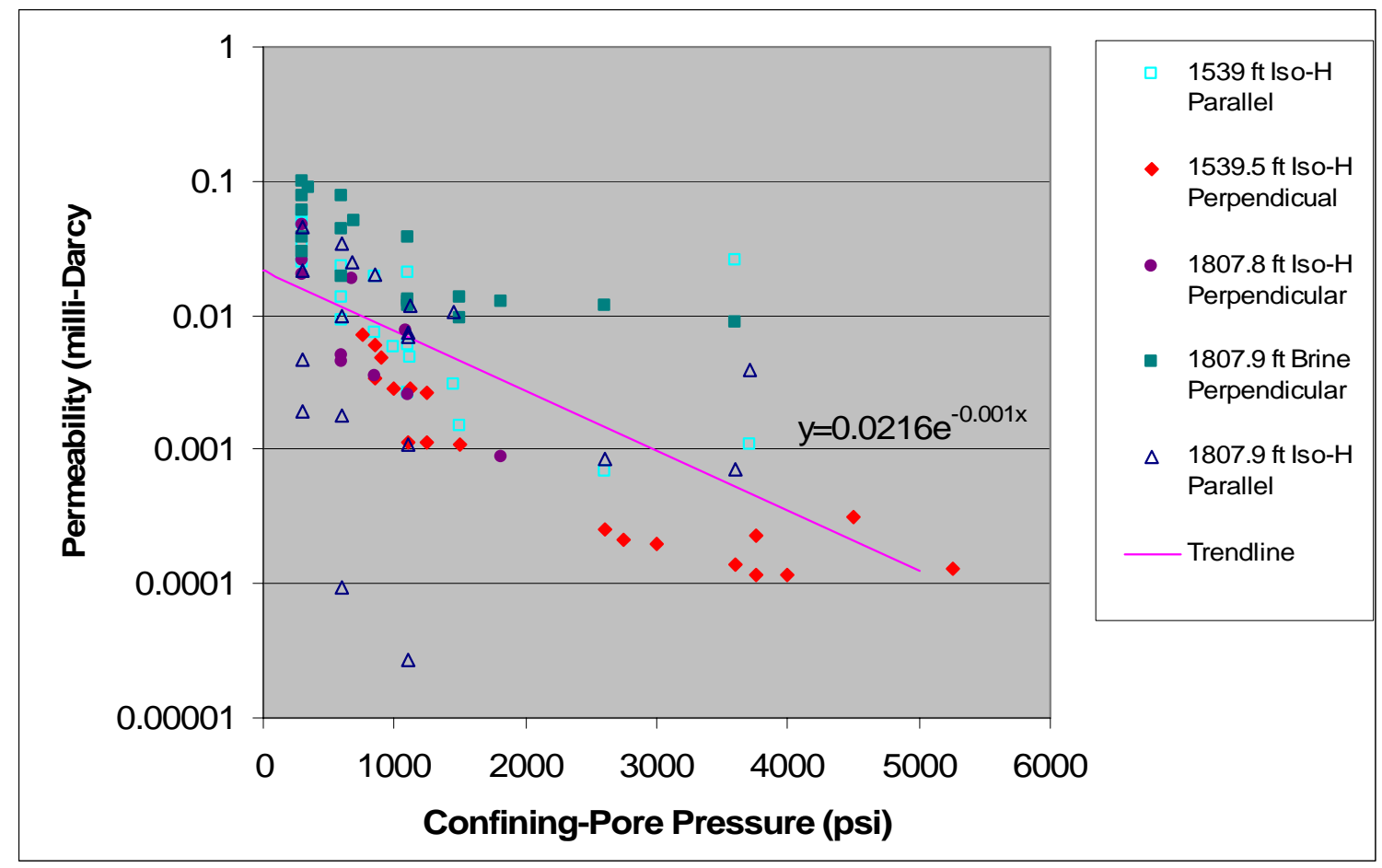

Figure 35 Queenston Sandstone Permeabilities.

The permeability of the Queenston sandstone was found to vary with porosity. A similar trend was noted in previous test conducted by H.J. Gruy and Associates, Inc. (1979) on the Queenston Formation in plugs removed from the Delany core. In that study, the permeability was found to be a strong function of porosity, and relationships were developed from tests conducted on 296 plugs and 83 whole core samples (Figure 36). The small size of the plugs used in the above testing and by Gruy and Associates resulted in a smaller permeability as shown in Figure 37. The average, minimum, and maximum porosity and permeability results are shown for the Lee plugs (current research). For purposes of analyses the relationship developed for the whole core permeability is used.

$\mathrm{K}\left(\right.$ milli-Darcy) $=0.0005 \mathrm{e}^{0.5478 \text { porosity (\%) }}$ 
The average porosity of whole cores tested was 10.8 percent, resulting in a permeability of 0.185 milli-Darcy. The porosity of the formation not only increases the permeability, but increases the storage capacity of the formation, which would enable more brine to be disposed. The excellent agreement of the current test results (current research) with previous work by Gruy and Associates suggests that the permeability of the Queenston is consistent.

When injection was modeled in into upper 100 feet of the Queenston Formation through a vertical well over a 3 year period, the brine migrated approximately 500 feet from the well (Figure 37). The total amount of brine disposed in the single well was less than $150 \mathrm{MB}$ bbl, far short of the $15 \mathrm{MMB}$ needed in each well. Figure 38 shows an injection rate of less than 0.1 BPM, which again is well below that needed for economical disposal (10 BPM).

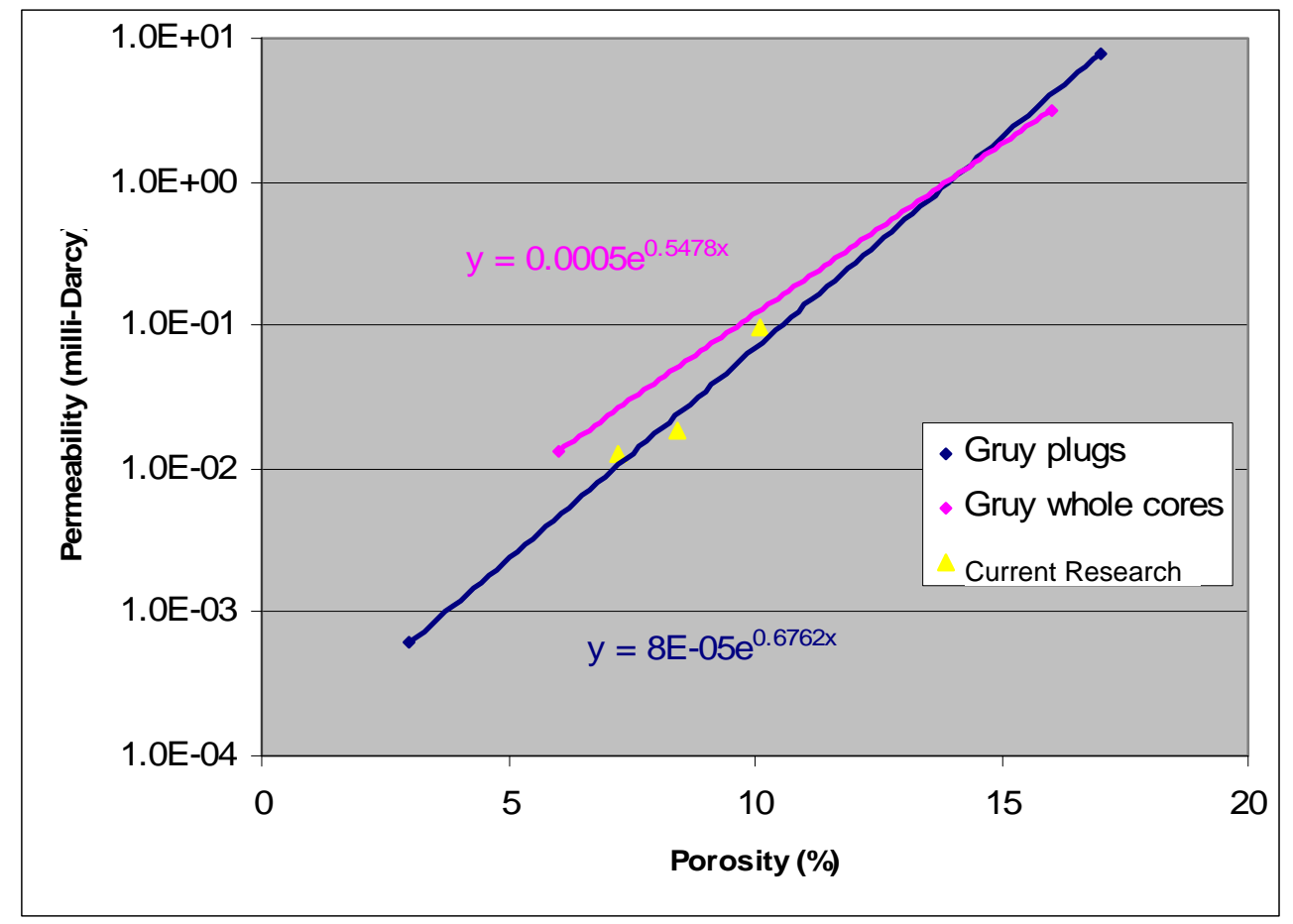

Figure 36 Comparison of Relationships Developed by Gruy and Associates in 1979 to Current Research Tests Results of Lee, 2004 for Queenston Formation.

The facility operated by Bath Petroleum Inc. was visited for this study and later the company produced injection records for the top of the Queenston (discussed above in the background 
section). An injection rate of $5 \mathrm{BPD}$ was sustained over a several month period. These records show that the resistance to flow increases with time. In this case, the injection pressures rose 25 percent over the injection period. If pressures had been maintained as in the modeling, the injection quantities would have decreased a commensurate amount. At the Bath facility, the injection zone was 2,000 feet deep. At greater depths, the rate would increase and the difference between the hydrostatic pressure at startup and the maximum formation pressure would be greater. It has been calculated that at 4,250 feet, the injection rate would be 45 percent greater. This would result in 7.2 BPD. While the injection rate is slightly below the criteria established for disposal (Evaluation Criteria 1 - 10 BPM), it demonstrates that injection potential exists in the Queenston.

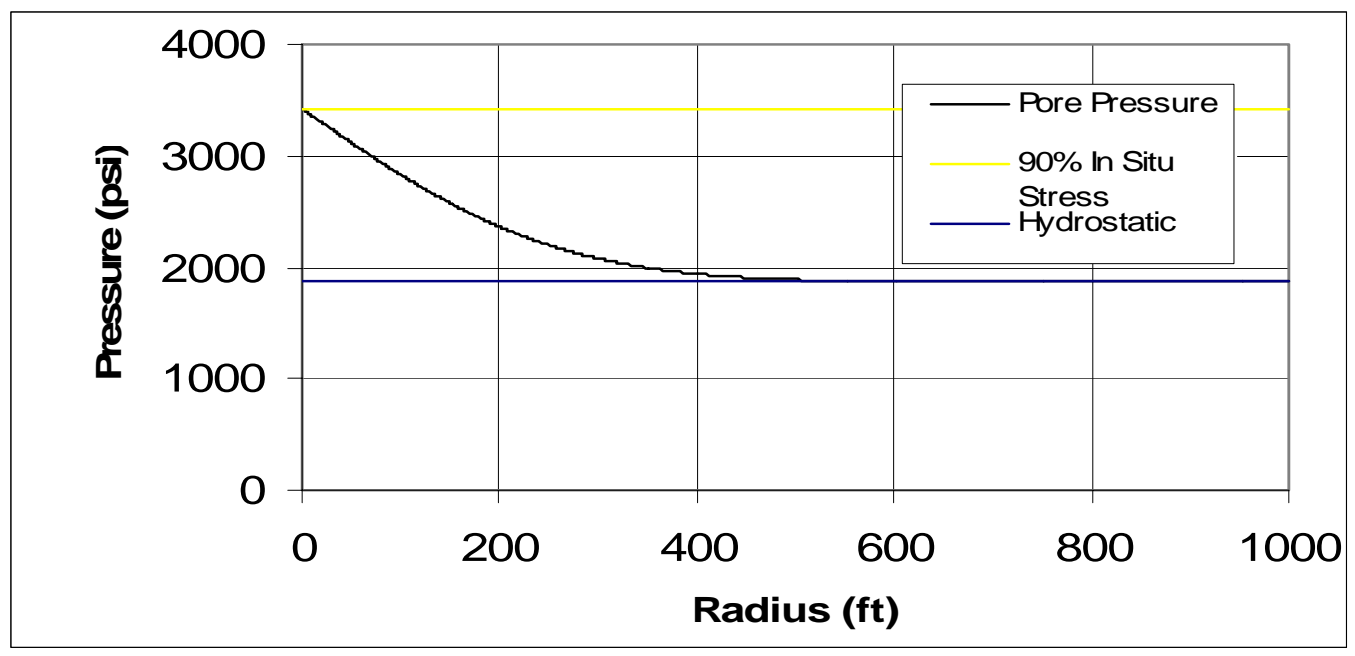

Figure 37 Brine Pressure in Queenston after 3 years (Vertical Well).

The addition of a horizontal fracture extending from the wellbore is considered in the model. The fracture is assumed to have small resistance to flow, and thus acts as a conduit for delivery of brine to the formation. The geometric configuration is illustrated in Figure 39.

Using the same porosity (10.8\%), permeability (0.185 milli-Darcy), and layer thickness (100 feet), the radial distance that the fracture must extend from the wellbore can be computed to meet the criteria established for successful disposal. In this case, a fracture length of 2,950 feet enables a sufficient formation volume to be exposed for storage of the brine and at time frame that is more than adequate to accomplish disposal in 3 years (Figure 40). 


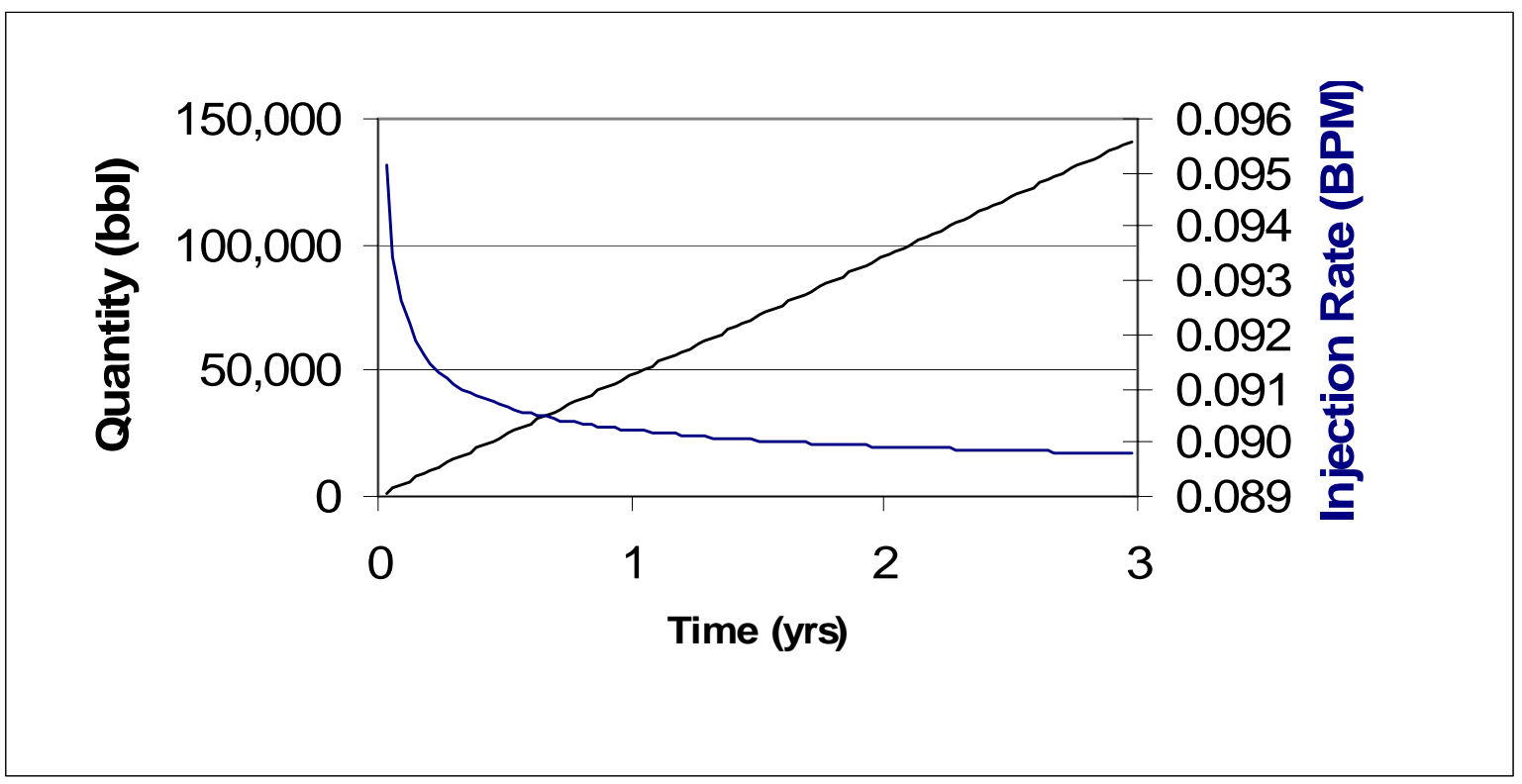

Figure 38 Brine Injection Quantity and Rate for Queenston (Vertical Well).

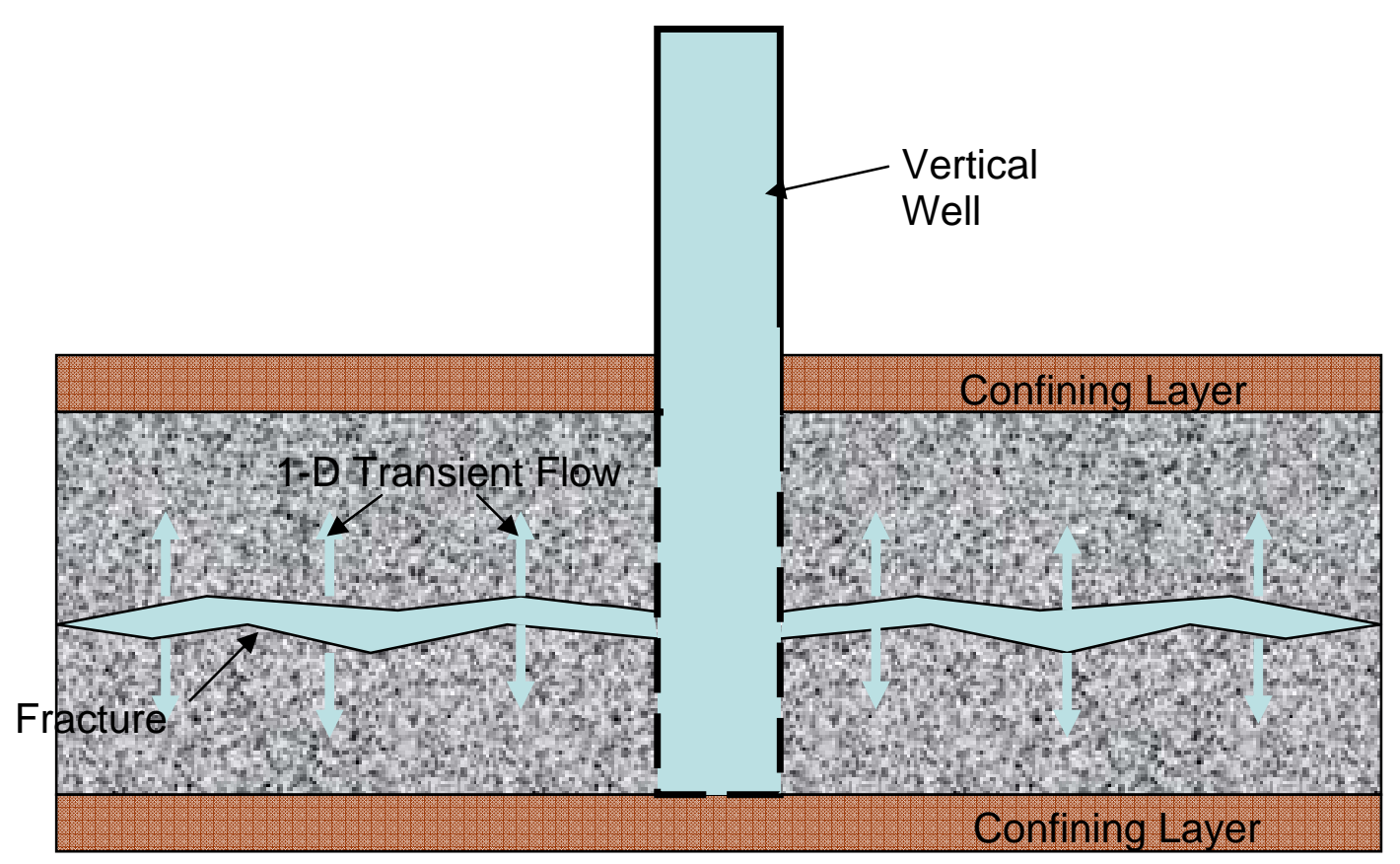

Figure $39 \quad$ Illustration of Fracture Conduit. 
While natural fracture lengths on the order of 3,000 feet may exist underground, they are difficult to discover and characterize prior to drilling. Advances in geophysical techniques may someday enable discovery of the necessary natural fracture system and hence guide successful well locations. In the absence of that, operators can stimulate wells through hydrofracturing. By over-pressurizing the formation, a fracture can be induced. This practice can be performed prior to brine injection whereby a proppant is used to keep the flow path open. A typical fracture length for stimulation is limited to 500 feet. While larger fracture lengths are possible, as is the practice of growing the fracture during brine disposal, the generation of large fractures can result in earthquakes. Nicholson and Wesson (1990) provide an overview of known and suspected underground injections that have resulted in earthquakes in the U.S., including a case study in the Attica-Dale area (western NY). More recently (2001), injection tests performed for a gas storage project near Avoca, NY correlated to magnitude 2.5 and 3.2 earthquakes during the 3 week test duration. Modeling of the tests predicted a fracture length of over 500 feet. It is interesting that geologists believe that some of the fracture systems that exist in NY were indeed the result of natural hydraulic fracturing (Carter et al, 2001).

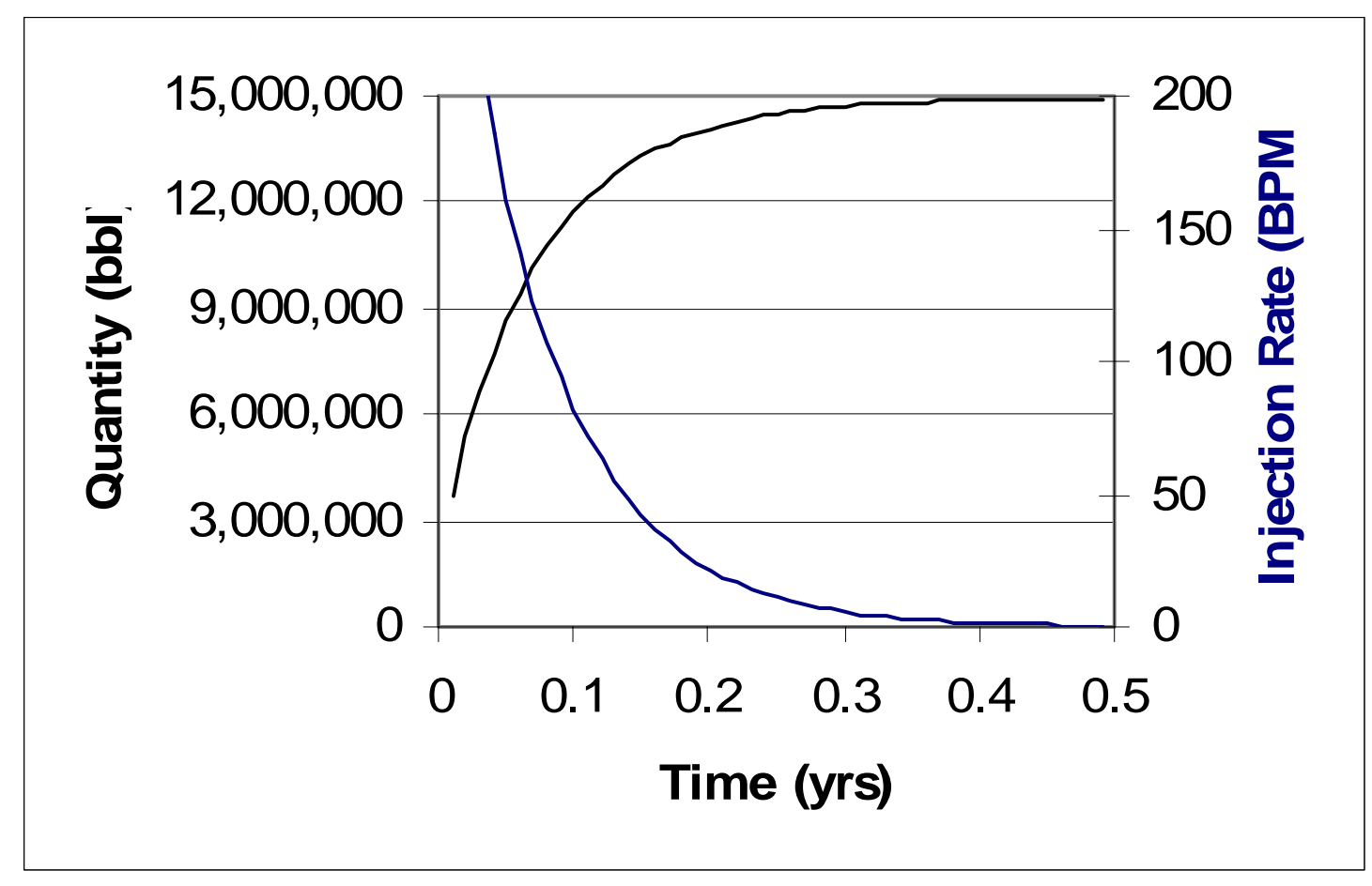

Figure $40 \quad$ Fracture Conduit Flow in Queenston (Vertical Well with Fracture) 
Another way to achieve higher rates of brine disposal is the emplacement of a horizontal well as illustrated in Figure 41. In this model, the height of the formation is assumed to be small compared to its lateral extent.

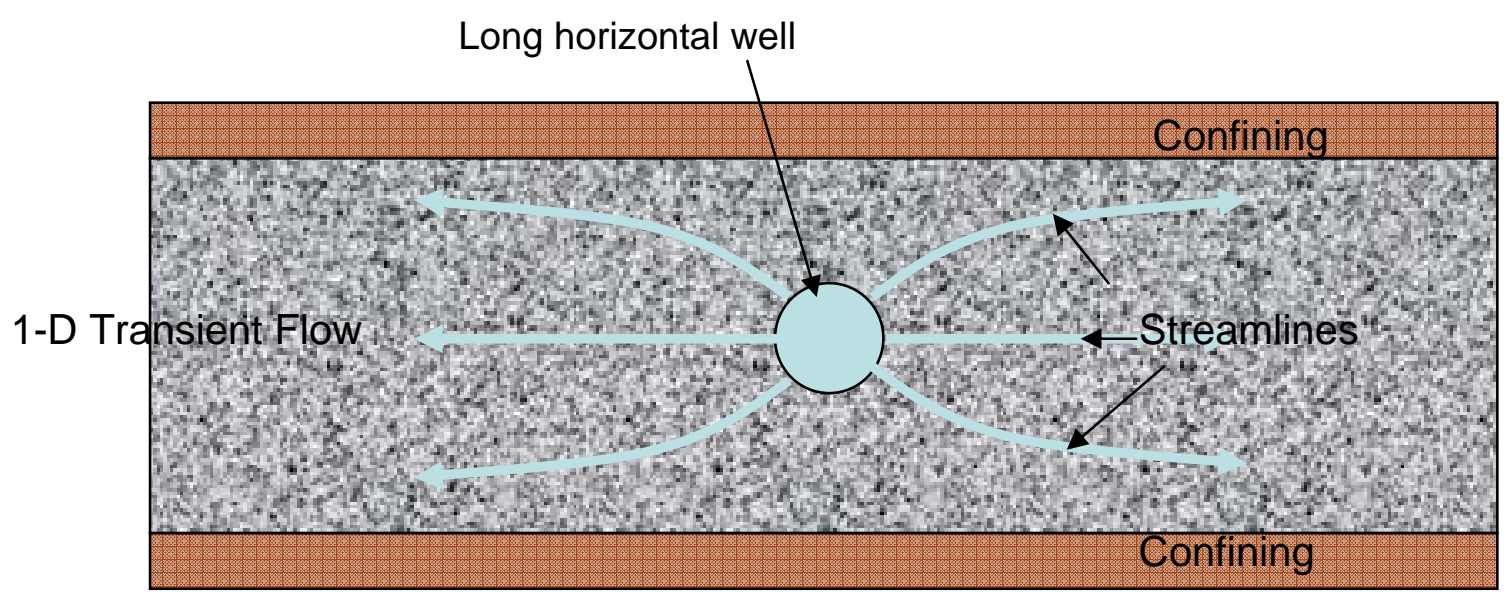

Figure $41 \quad$ Illustration of Horizontal Well

In order to achieve the desired brine production over 3 years, a well with an 11 mile length through the formation is needed. The predicted brine pressures in Figure 42 show brine flow up to 600 feet from the well bore during this time, and the flow criteria is met (Figure 43). The costs of horizontal drilling are typically more expensive than a vertical well, depending upon the stimulation techniques used. An 11 mile well would be considered extensive by today's standards. Horizontal wells typically run 1 to 3 miles. The injection would be reduced in proportion to the well length.

Horizontal drilling is a relatively new technique and the state of art continues to advance. One technique involves the use of side laterals from the main horizontal well. This technique is used to drain coal bed methane in West Virginia. There the side laterals are drilled 45 degrees from the main well and 90 degrees to each other to produce a pinnate drilling and drainage pattern. This results in a square drainage area (over 1000 acres) where the wells resembled the veins in a leaf (Figure 44). This technique is a an option to the drilling of a single long well since the injection area is limited to 600 feet from the well bore. 


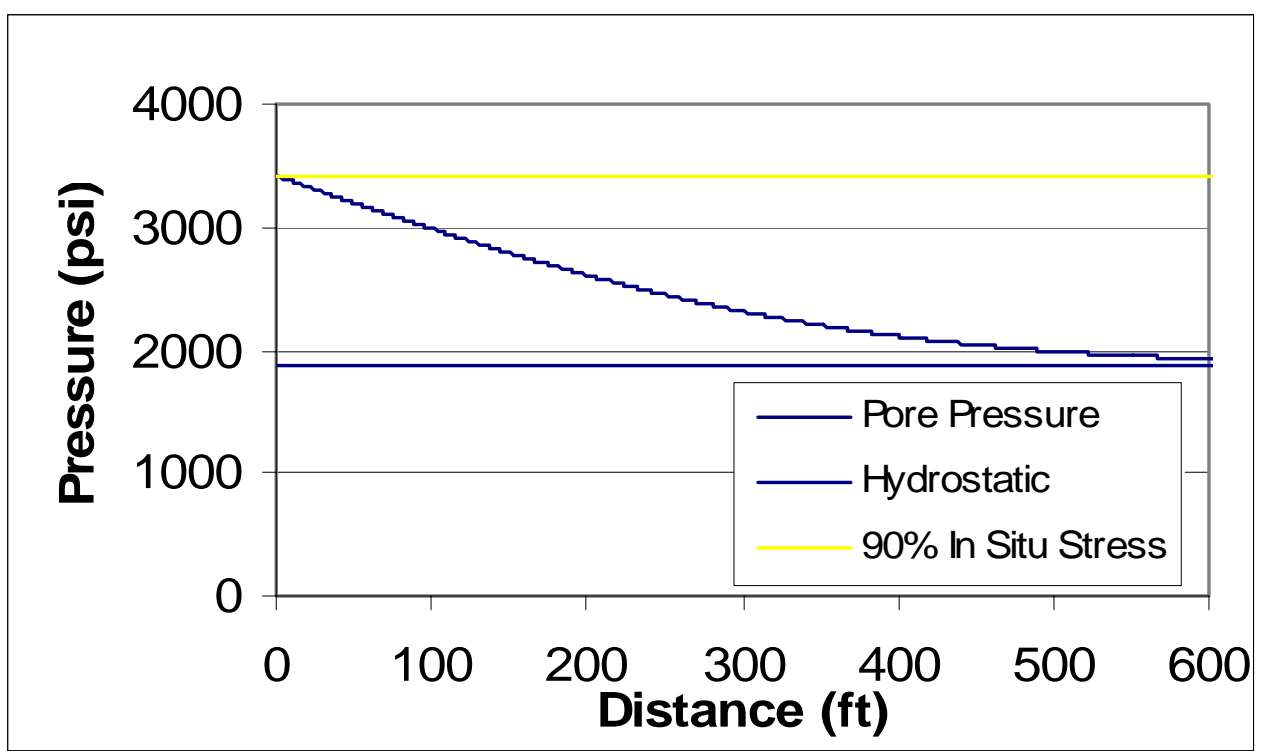

Figure 42 Brine Pressure in Queenston after 3 years (Horizontal well)

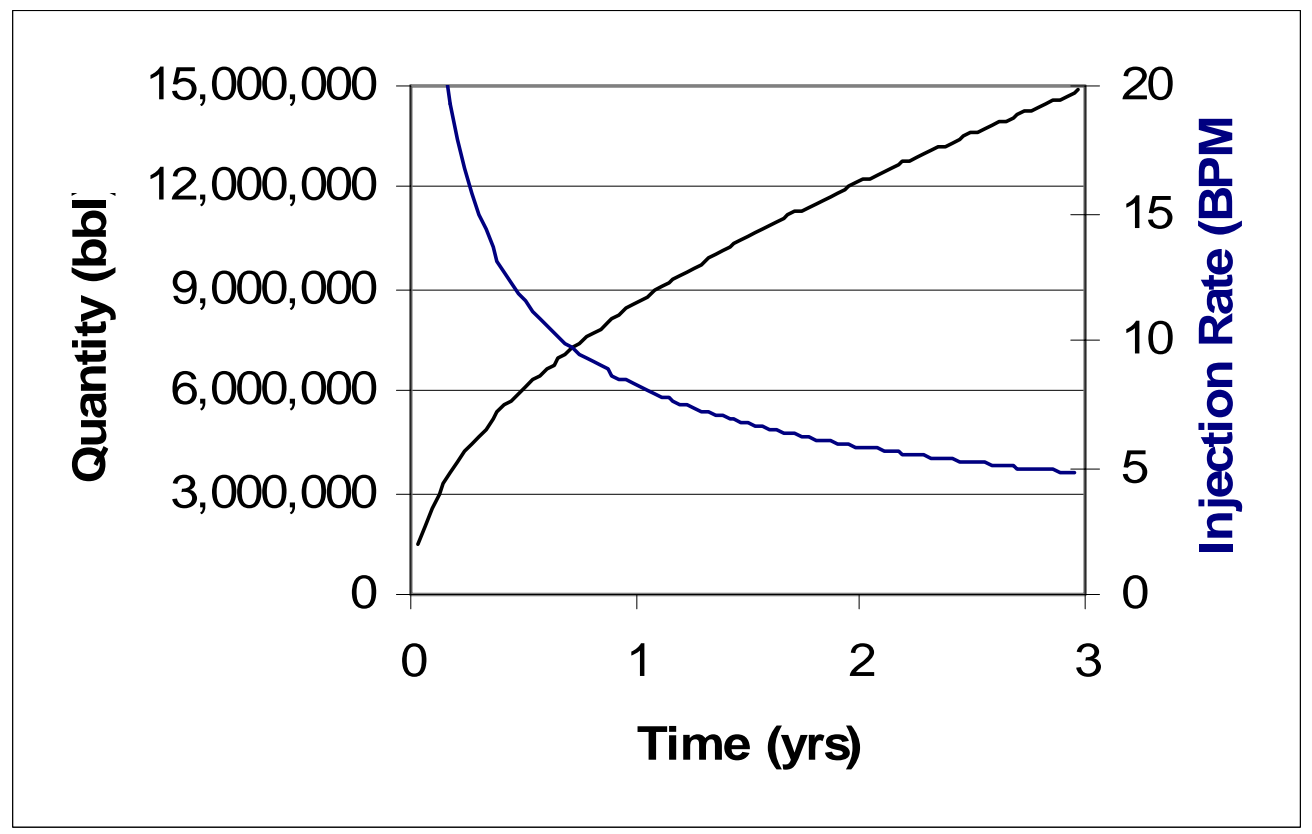

Figure 43 Brine Injection Quantity and Rate for Queenston (Horizontal Well). 


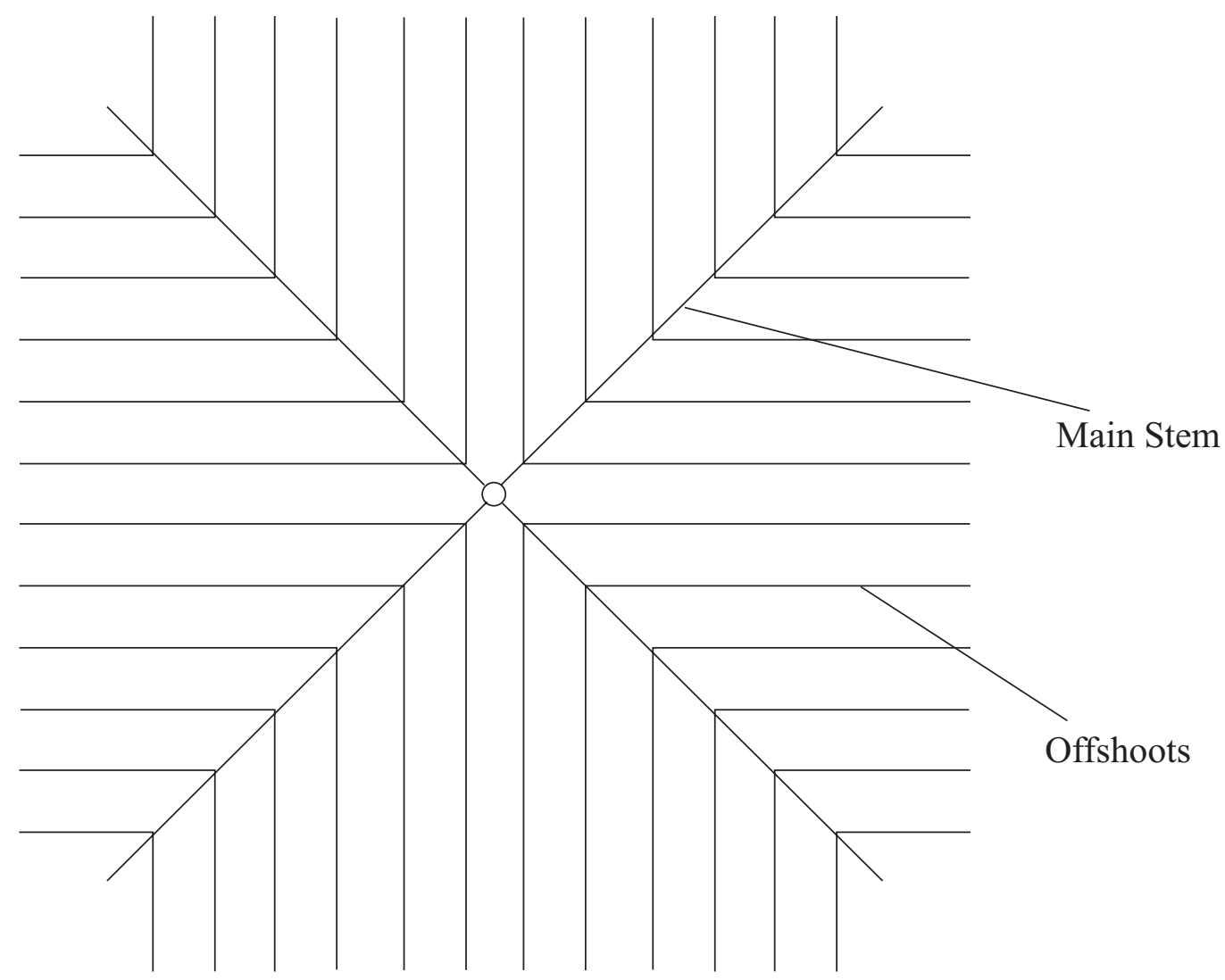

Figure 44 Schematic of a Pinnate Well Network. A pinnate horizontal well network is built from one surface well with multiple lateral completions. The main stem can be up to several thousand feet long with the offshoots offering several miles of well length total. Pinnate wells are currently in use worldwide for primary coal bed methane recovery. There is a possible opportunity to inject brine into a pinnate network for disposal during salt cavern development. 


\section{Analysis of Queenston Formation as a Potential Brine Disposal Reservoir}

Though the Queenston Formation has been proven to have favorable porosity and permeability in the producing region of north central New York, modeling of disposal and actual disposal attempts have had mixed results to the south in the area where salt cavern development is possible. Similar or better lithologic conditions to those in the producing region occur farther south in the state, as the Queenston Formation becomes more sand rich in this area.

The Queenston Formation's ability to accept brine at acceptable rates and volumes is limited by the fact that the formation has low porosity and permeability. This attribute can be overcome by finding ways to expose the brine to more of the formation volume than is accomplished in a standard vertical well. During modeling the disposal rates and volumes accomplished into the Queenston Formation in a standard vertical well were far lower than those necessary to meet the disposal rate of 10 BPM established by Evaluation Criterion 1. The disposal rate of less that 0.1 BPM would not support achieving the 11 MMB in 3 years stipulated by Evaluation Criterion 2.

Techniques suggested to increase formation volume exposure and therefore disposal rates include, well stimulation (induced fracturing), drilling into a natural fracture network, the use of horizontal wells and utilizing a pinnate drilling pattern. Though all of these techniques would increase the formation volume available to the disposed brine, they are not all able to do so within realistic parameters. The use of a pinnate well pattern or multiple horizontal laterals on a vertical well may be the most realistic way to achieve, or come closer to achieving, the disposal rate necessary to meet Formation Evaluation Criteria 1 and 2 in the Queenston Formation.

The key to securing the highest production rates in the producing region has been tied to finding favorable structure (open fractures) along with zones of high permeability and porosity (Saroff, 1987 and Ward, 1988). It is highly likely that this is also the key to finding areas where the Queenston Formation is capable of accepting brine at the rates necessary for economic cavern

solutioning. In addition, the Queenston Formation in south central New York has traditionally been view as completely saturated with brine, an incompressible fluid. Recent gas production 
from the Queenston Formation in south central New York suggests that that this is not always the case, which would also lead to more favorable injection conditions and increase the likelihood of achieving the disposal rate of 10 BPM. Additional research needs to be completed to identify where these conditions exist and how they would affect injection potential.

Evaluation Criterion 3 requires potential disposal formations be hydraulically separated from sources of potable water. The Queenston Formation is located well below any sources of potable water. In addition the Queenston is older than and located below the Clinton Group, which provides many thick shales that inhibit upward movement of the disposed brine. 


\section{Trenton-Black River Interval - Methods}

Top Identification. The middle Ordovician rocks examined in the evaluation of the TrentonBlack River Groups, all produce gamma ray patterns that can be traced for miles without significant change in New York and into portions of Ontario, Ohio and Pennsylvania (Rickard, 1973). Tops used in the evaluation of the Trenton-Black River Groups and surrounding formations in this report were primarily derived from comparison with the work of Rickard (1973), Beinkafner (1983) and Flagler (1966). Figure 45 is a representative log for the tops picked in the evaluation of the Trenton-Black River Interval. Additional visual examples of the Trenton-Black River picks used in this report can be seen in Plate 14 and 15. Data tables related to the Trenton-Black River interval are located in Appendix C.

Cross Sections. Plate 14 is an east-west cross section through the Glodes Corners Road Field. These cross sections are stratigraphic and are hung on the top of the top of the Trenton Group. Intervals of hydrothermal dolomite and bentonite are highlighted and correlated. The method used to identify dolomite from wells logs is described below.

Plate 15 is an east-west cross section of the Trenton-Black River interval through south-central New York. The cross sections show the interval from the lower Utica Formation to the upper Beekmantown Group. These cross sections are stratigraphic and are hung on the top of the Black River Group. Intervals interpreted to have dolomite are highlighted in magenta (see below for an explanation how Dolomite was identified).

Dolomite Identification using Geophysical Logs The bulk density of a clean, tight limestone is roughly $2.71 \mathrm{~g} / \mathrm{cc}$ and drops from there as porosity increases. Knowing this, dolomite (density $2.86 \mathrm{~g} / \mathrm{cc}$ ) is picked in zones where the density curve displays values above $2.75 \mathrm{~g} / \mathrm{cc}$, which is a significant increase beyond a clean limestone. This method is only practical in intervals of dolomite with little or no porosity.

In more porous intervals, the density curve can be used to identify dolomitized intervals when used in conjunction with the neutron curve. If the density curve is plotted on a limestone scale 
(i.e. $0 \%$ porosity $=2.71 \mathrm{~g} / \mathrm{cc}$ ), then there should be significant separation of the density and neutron curves in dolomitized intervals and they should plot on top of each other in limestone intervals. A positive separation of the neutron and density curves, where the density curve reads about $5.5 \%$ less porosity than the neutron $\log$ (density curve will fall to the right of the neutron curve), is indicative of clean dolomite (see Figure 46 modified from Rider, 1986).

Where available, the Photoelectric Factor ( $\mathrm{PEF}$ or $\mathrm{P}_{\mathrm{e}}$ ) curve is an excellent tool for distinguishing dolomite from limestone. In a simplified explanation, the photoelectric factor is a measurement of the amount of gamma ray energy a material can absorb before emitting an $\mathrm{x}$ ray. The amount of energy a material can absorb depends on the average atomic number (or average atomic size) of the constituents of the rocks being evaluated and it thus can be related to mineralogy (i.e. Schlumberger, 2005). Dolomite has $\mathrm{P}_{\mathrm{e}}$ values between 2.5 and 3.2, while limestones (calcite) have $P_{e}$ values between 3.8 and 5.1 (i.e. Schlumberger, 2005).

Black River Core Posters. The Black River interval from two wells is described in detail using slabbed cores and thin sections. The cores were taken from the Matejka \#1 (10335-00) and Gray \# 624468 (22949-00) wells in central New York State. The results of this work are displayed in poster format in Plates 16, and 17. The description includes lithology (dolomite, limestone, shale), Dunham rock texture (grainstone, packstone, wackestone, etc), sedimentary structures, fracture intensity, porosity type and more. The posters also include pictures of the cores and thin sections, which are correlated to the appropriate depth in the core description. The well logs for each well were also correlated to the description to make it possible to evaluate the log response to various features.

These are two of the three Black River cores that are publicly available in New York. The Whiteman \#1 (22839-00) core is the third core available in New York, in this report core images and thin section images are included, but no description. The Matejka \#1 core was from a dry hole drilled in 1975 by Shell Oil Co (Figure 47 and Plate 16). It has common dolomite but little porosity and permeability. The Gray \# 624468 core was from a well that produced some gas but not at economic rates (Figure 48 and Plate 17). This core has large vugs lined with saddle dolomite, but they appear to be isolated within a low permeability matrix. The Whiteman \#1 has 


\section{SAPINO 21636-00-00 \\ Fee 6 \\ Avoca \\ Stueben Co.}

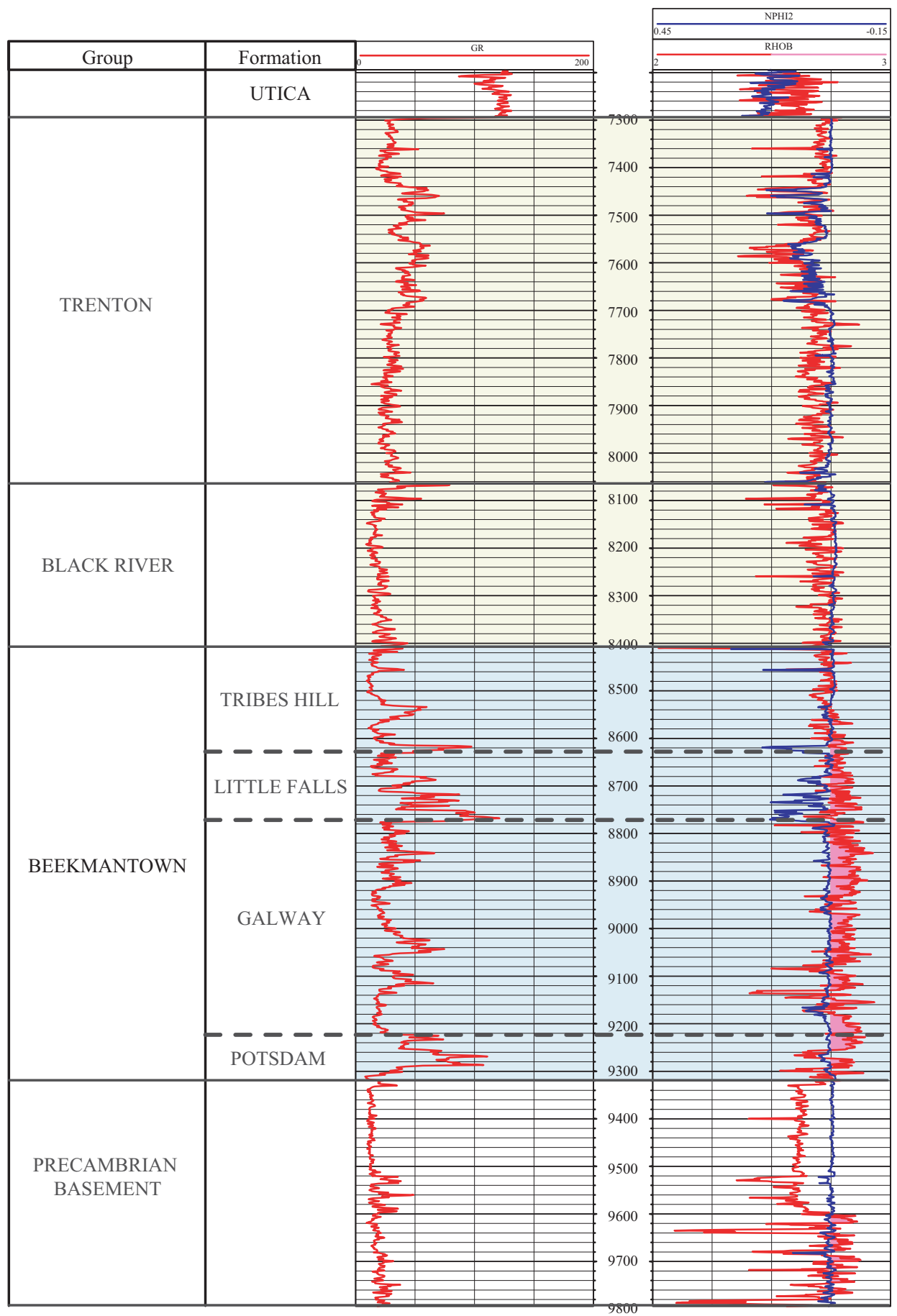

Figure 45 Representative log for the Trenton-Black River Interval and the Beekmantown Group in south central New York State. 


\section{Lithology-Porosity from Density-Neutron Crossplot}

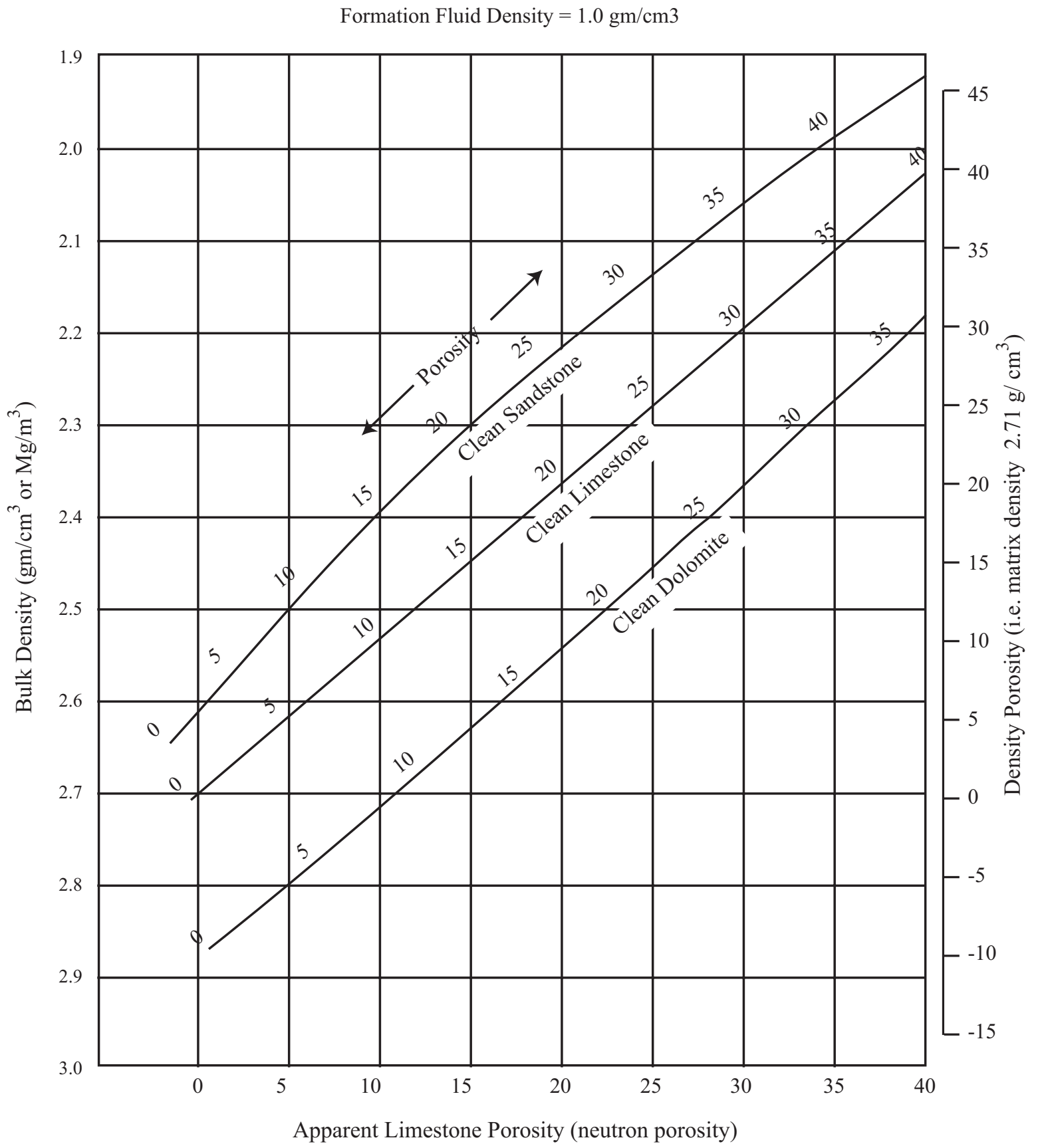

Figure 46 The density-neutron crossplot. This plot is necessary to find real, clean formation porosities because of the differing effects of matrix type on the two log types. (Modified from Rider 1986) 


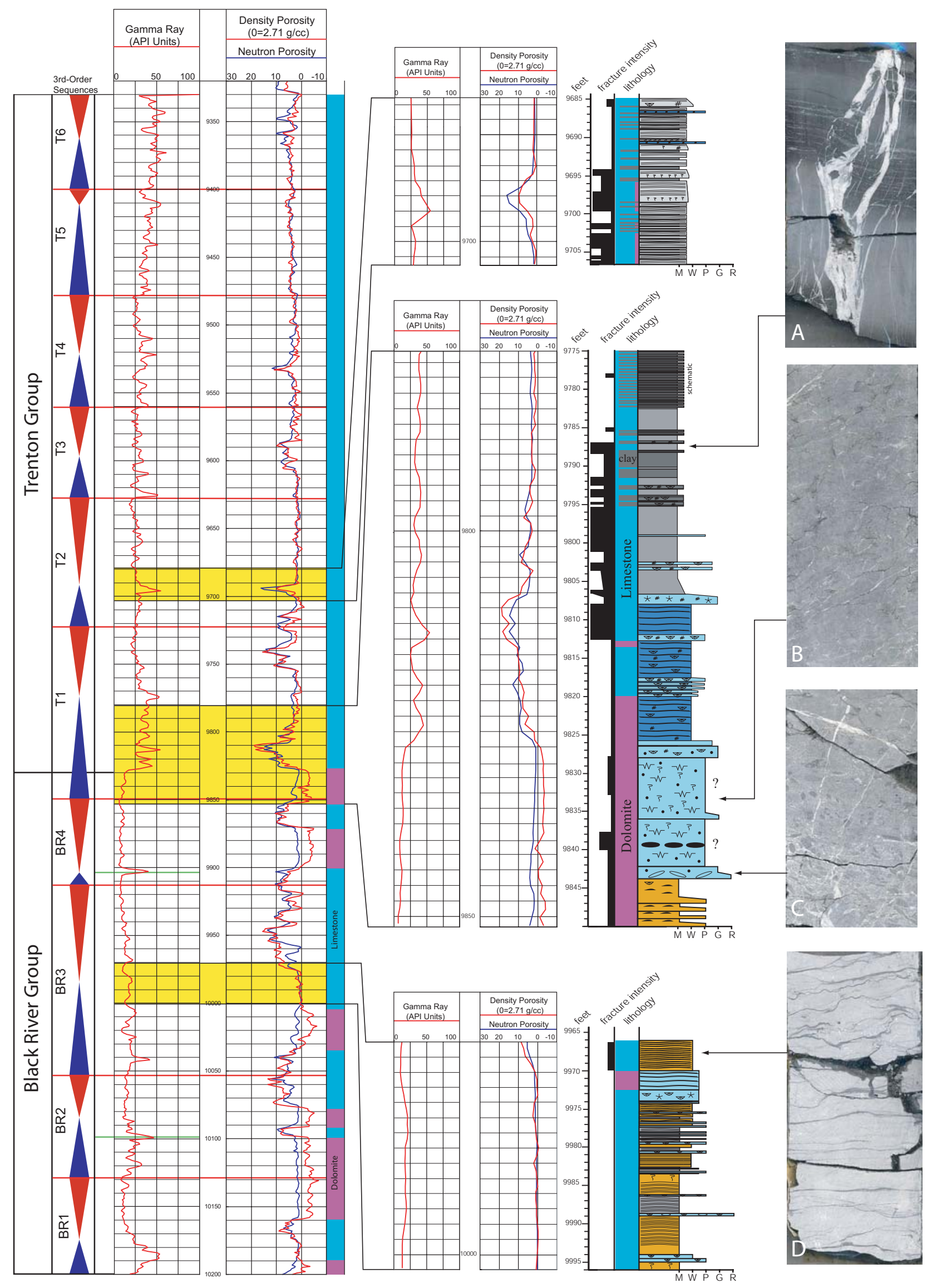

Figure 47 Core Images of the Matejka \#1 well (10335-00), Chemung County, New York State. 

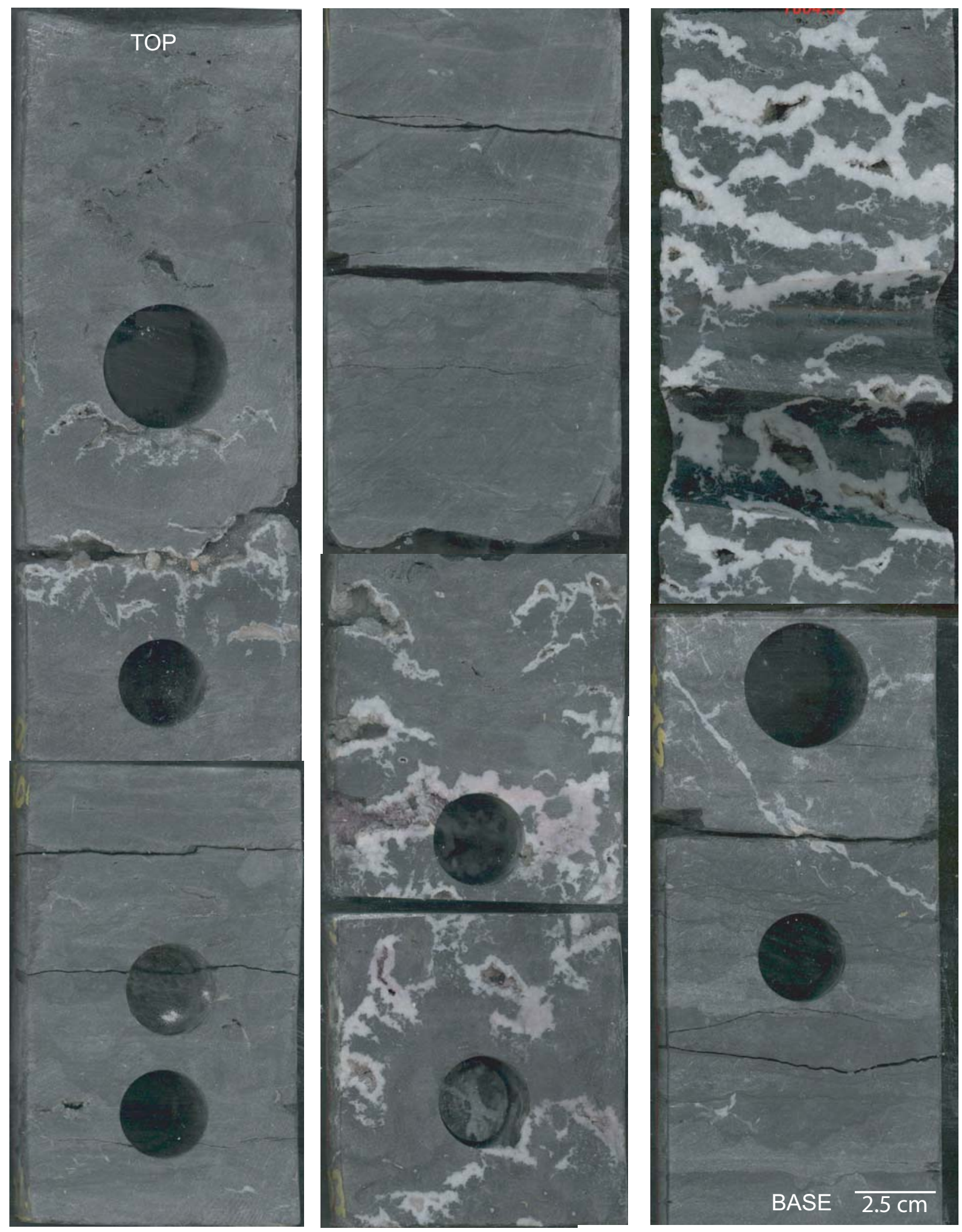

Figure 48 Core images of the Gray \# 624468 well, (22949-00) Stueben County, New York State. 
common fractures, breccias and vugs lined with white saddle dolomite and it has been an economic producer (Figure $49 \mathrm{a}$ and $\mathrm{b}$ ). These cores show the heterogeneity of this reservoir and the difficulty that operators have had finding porous and permeable reservoir facies.

Rock Mechanics Testing of the Trenton Black River Interval. No Trenton-Black River core was available for rock mechanics testing at the time when Sandia National Laboratories tested the Queenston and Beekmantown cores. Fortuna Energy provided porosity and permeability numbers for the Whiteman \#1 well. These numbers were used to model the ability of the Trenton-Black River interval to accept brine at the rates and volumes stipulated by the Evaluation Criteria.

Modeling of the Trenton-Black River Interval. The same model was used for the TrentonBlack River interval as was used for the Queenston Formation. This substitution is acceptable as long the inputted parameters are altered to accommodate the differences in the formations. The parameters that were changed are: permeabilities changed to 60 milli-Darcy (vs. 0.185 milliDarcy), porosities changed to 7 percent (vs. 10.8 percent), saturation changed to 30 percent (vs. 50 percent), depth changed to 9,500 feet (vs. 4,250 feet), and layer thickness changed to 20 feet (vs. 100 feet).

\section{Description}

Fault-related hydrothermal dolomite reservoirs in the Upper Ordovician Black River Group were selected as a potential brine disposal reservoir based on the following observations:

- Current production is located within the study area,

- Most wells are still active and may be converted easily,

- Most prolific producer in the Allegheny Plateau of New York State,

- The fields may prove unattractive for conventional depleted reservoir storage due to the heterogeneity, unknown lateral extent and size

- Salinities of formation water are near halite saturation 


\section{Whiteman \#1 Core, County Line Field}
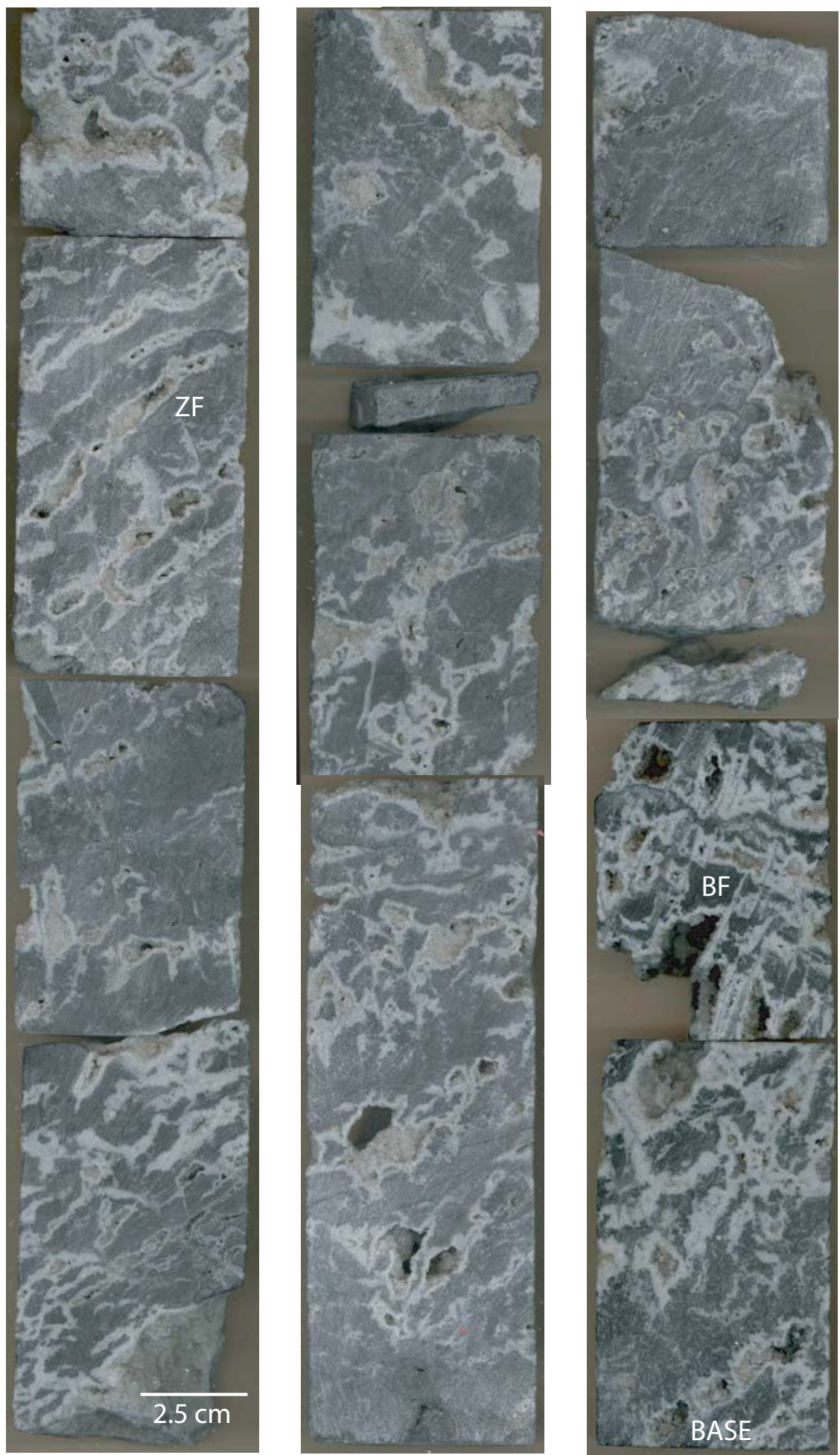

Figure 49a Core from the upper Black River. Most porosity in the cores recovered from the Black River Fields is in vugs, fractures and breccias- there is very little matrix porosity. Some vugs are due to solution enlargement by hydrothermal fluids during early stages of alteration. 

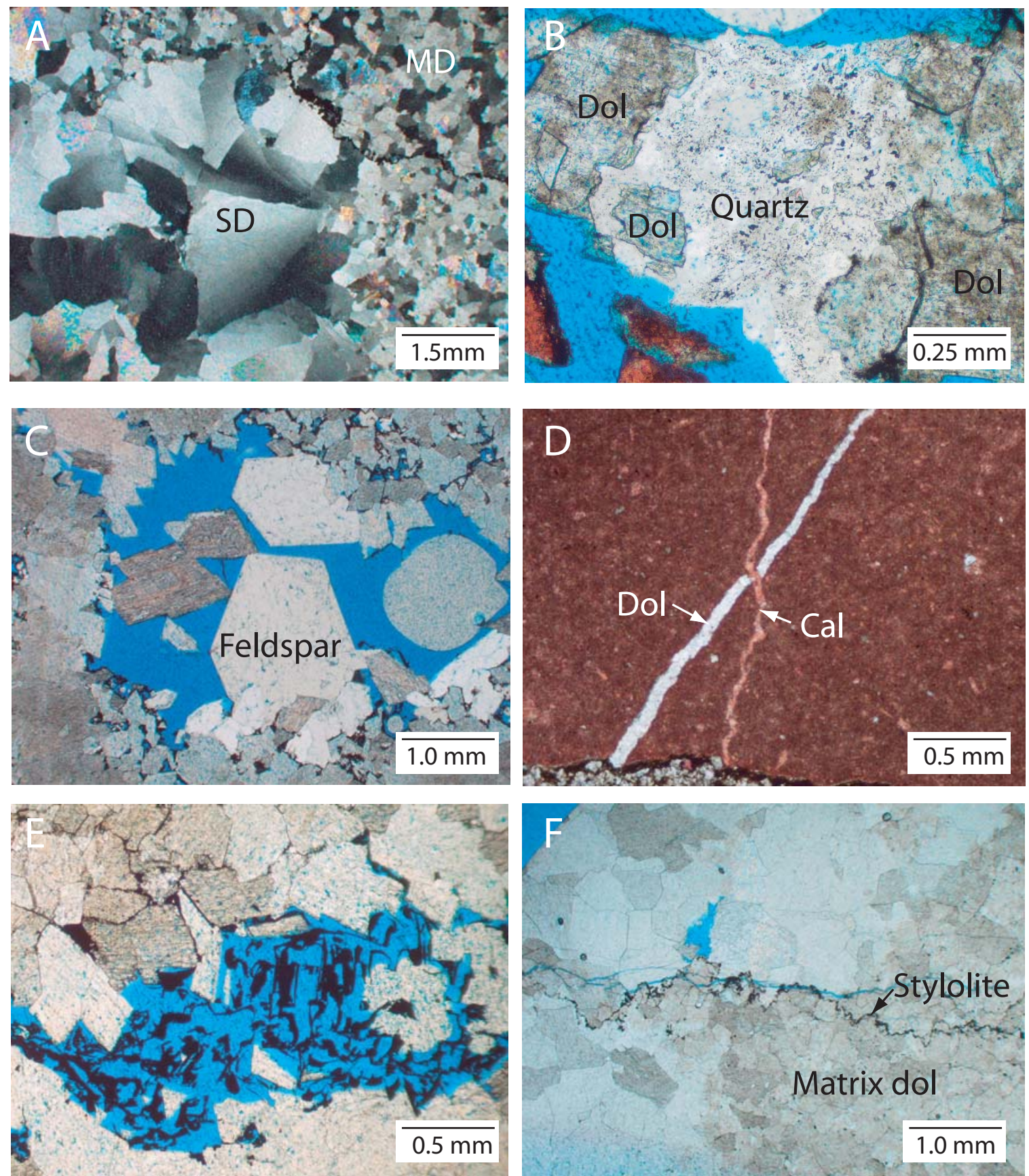

Figure 49b Trenton-Black River thin section images. 
The Black River Group overlies the global Lower Ordovician Knox Unconformity, which separates the group from the Beekmantown Group below. The Black River Group is primarily composed of muddy and fine-grained shallow marine carbonates. The formation thins toward eastern New York, where it is absent in some places, and gradually thickens into the southcentral part of the state where it reaches thicknesses of over 500 feet (Figure 50 and Plate 18). Current production is in these thick areas. Figure 51 and Plate 19, a structure contour map of the Black River Group, shows that the group is between 5,000 and 9,500 feet below sea level within the study area of this research.

The Black River Group is overlain by the Trenton Group, which is composed of low energy deeper water argillaceous limestones and calcareous shales and high-energy shallow marine grainstones and packstones. The Trenton is overlain by the deeper water Utica Shale, which is a black shale that blankets much of the eastern United States. This contact is diachronous as the Trenton Limestone grades laterally into the Utica Shale to the south and east. The upper part of the Trenton Limestone grades laterally into dark shales in the Appalachian Foreland Basin to the east and into the Sebree Trough to the south (Wickstrom et al., 1992). Variations in the thickness of the Trenton (Figure 52 and Plate 20) are partially due to variations in subsidence and partially due to the facies relationship with the Utica Shale. The Utica Shale is generally thick where the Trenton is thin and vice versa. The Trenton Group reaches maximum thicknesses of more than 800 feet in the Finger Lakes Region of central New York State (Figure 52 and Plate 20). From there the Trenton Group thins significantly to the east. Within the study area of this research, the Trenton Group is between 400 and 800 feet thick and is found at depths between 4,000 and 9,000 feet below sea level (Figure 53 and Plate 21).

Most of the gas in New York is produced from dolomitized intervals in the Black River Group (Plate 14). These dolomites formed from hydrothermal fluids flowing up subtle wrench faults soon after the Black River carbonates were deposited (Figure 54; Smith et al., 2003). The fields occur in subtle structural sags that form in dilational or transtensional parts of strike-slip fault zones. Figure 55 shows a 3D seismic image of Rochester Field in Ontario, which is a hydrothermal dolomite reservoir in the Trenton and Black River Groups. This map is a structure map of the top of the Trenton Group. The cooler colors (blue and green) represent lows and the 


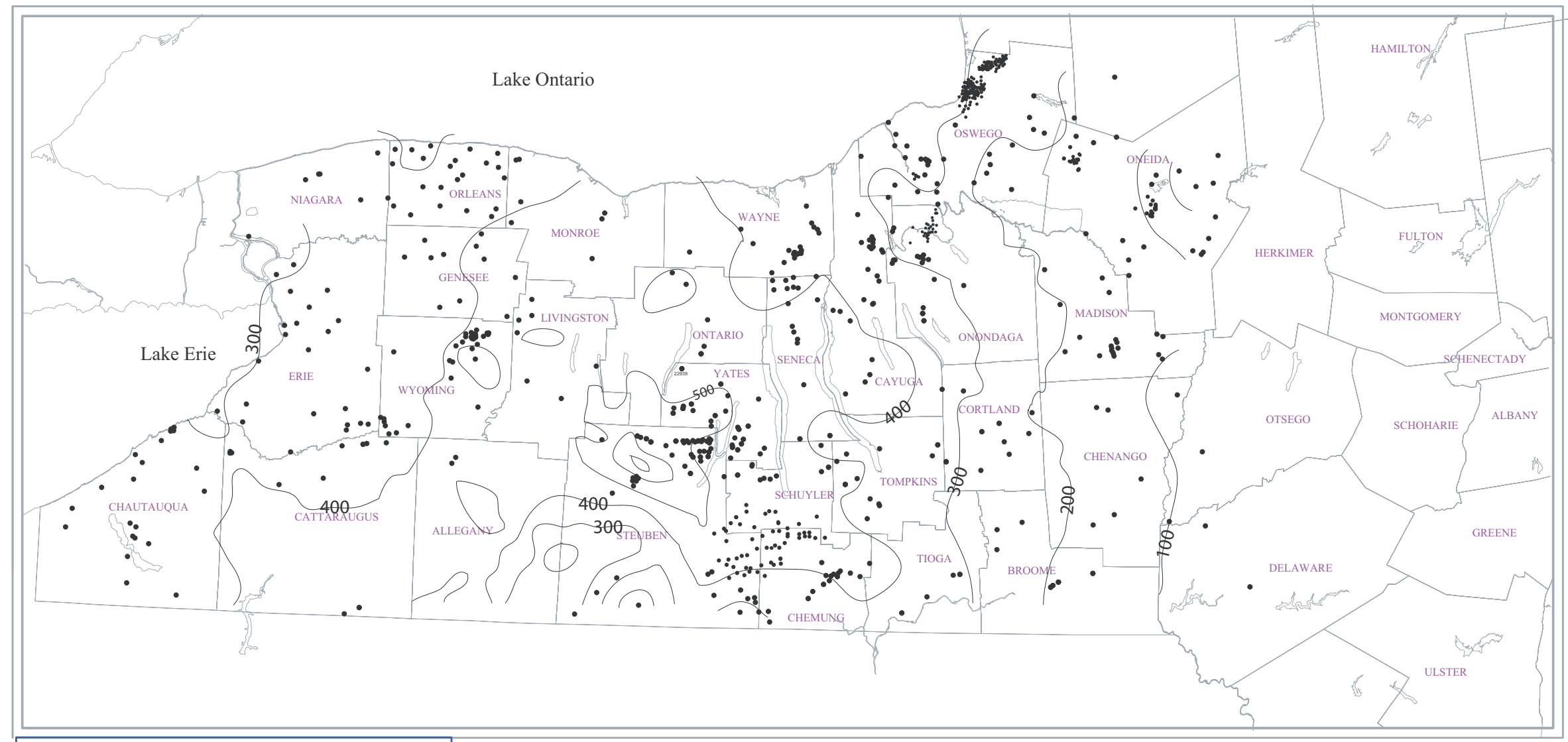

\begin{tabular}{|l|l|}
\hline \multicolumn{2}{|c|}{ Black River Isopachous Map } \\
\hline \multicolumn{2}{|c|}{ Scale } \\
\hline $\begin{array}{l}\text { KILOMETERS } \\
\text { Well Symbols } \\
\text { Wells with TBR }\end{array}$ & $\begin{array}{c}\text { Contours } \\
\text { Black River Isopachs } \\
\text { Interval = 100 feet }\end{array}$ \\
\hline
\end{tabular}

Figure 50 Black River Isopachous Map. The well SAPINOs are labeled in Plate 18. 


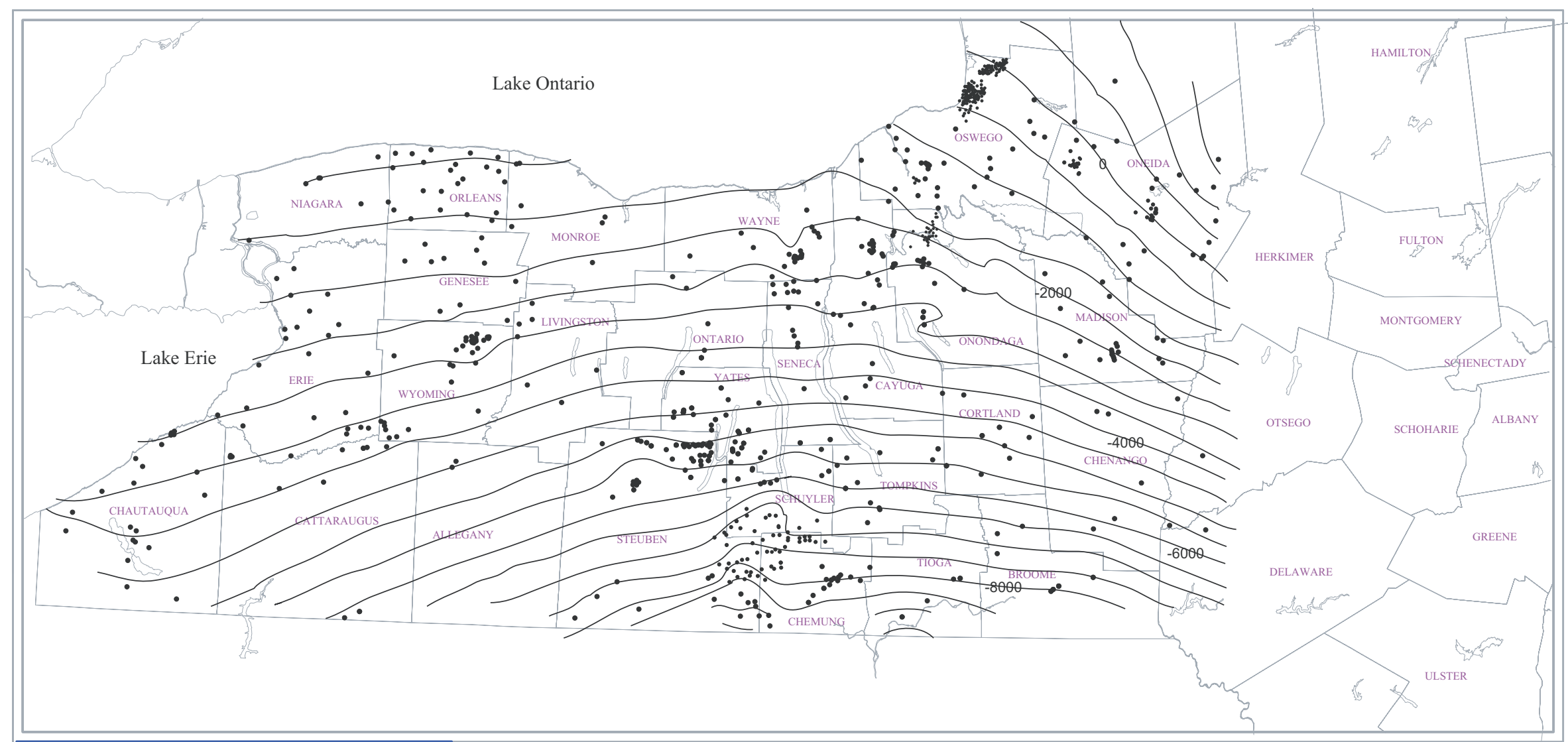

\begin{tabular}{|l|l|}
\hline \multicolumn{2}{|c|}{ Black River Structure Contour Map } \\
\hline \multicolumn{2}{|c|}{ Scale } \\
\hline $\begin{array}{l}\text { WILOMETERS } \\
\text { Well Symbols } \\
\text { Wells with TBR } \\
\text { tops }\end{array}$ & $\begin{array}{c}\text { Contours } \\
\text { Interval = Black River }\end{array}$ \\
\hline
\end{tabular}

Figure 51 Black River Structure Contour Map. The well SAPINOs are labeled in Plate 19. 


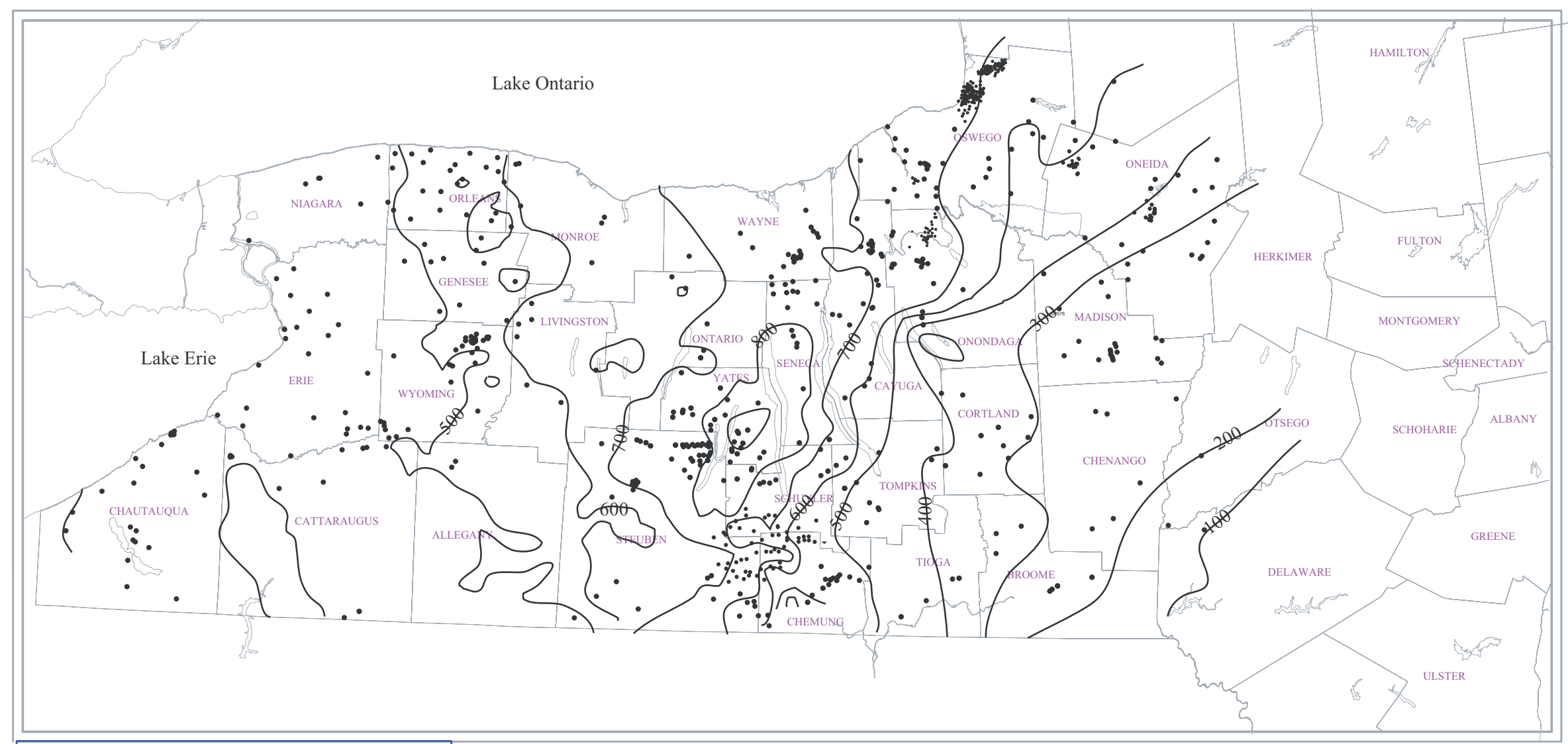

\begin{tabular}{|l|l|}
\hline \multicolumn{2}{|c|}{ Trenton Isopachous Map } \\
\hline \multicolumn{2}{|c|}{ Scale } \\
\hline $\begin{array}{l}\text { Well Symbols } \\
\text { - Wells with TBR } \\
\text { tops }\end{array}$ & Contours \\
Interval = 100 feet \\
\hline
\end{tabular}

Figure 52 Trenton Isopachous Map. The well SAPINOs are labeled in Plate 16. 


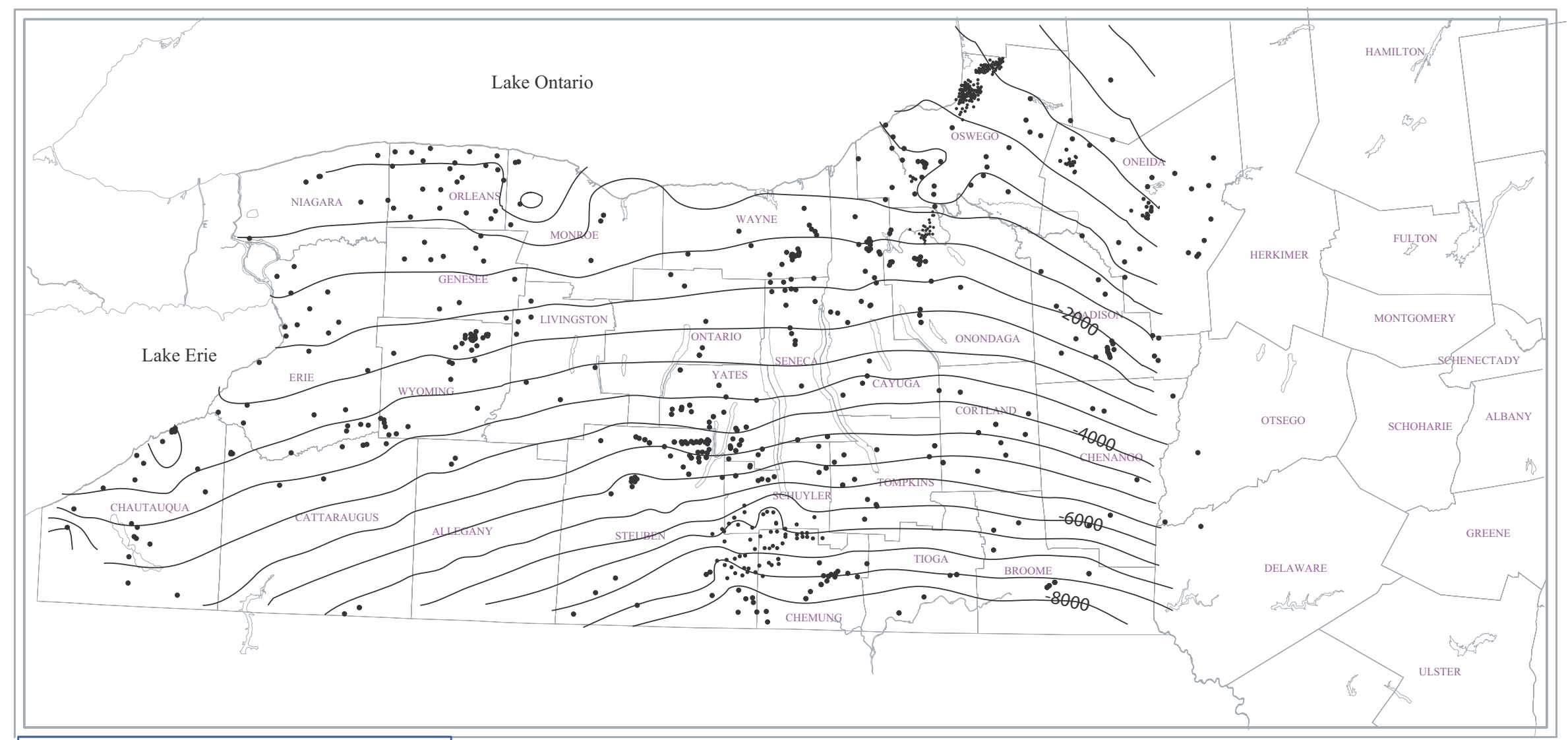

\begin{tabular}{|l|l|}
\hline \multicolumn{2}{|c|}{ Trenton Structure Contour Map } \\
\hline \multicolumn{2}{|c|}{ Scale } \\
\hline $\begin{array}{l}\text { Well Symbols } \\
\text { - Wells with TBR } \\
\text { tops }\end{array}$ & Contours \\
\hline
\end{tabular}

Figure 53 Trenton Structure Contour Map. The well SAPINOs are labeled in Plate 19. 


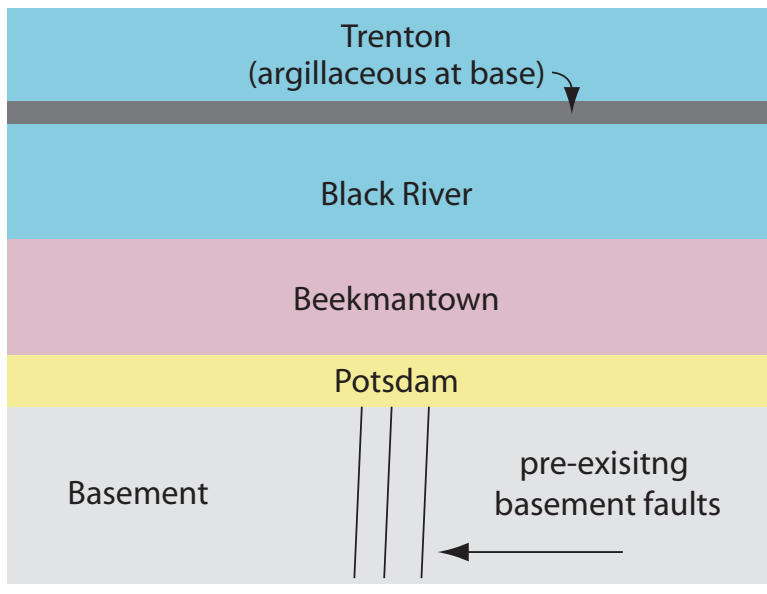

A) Trenton time

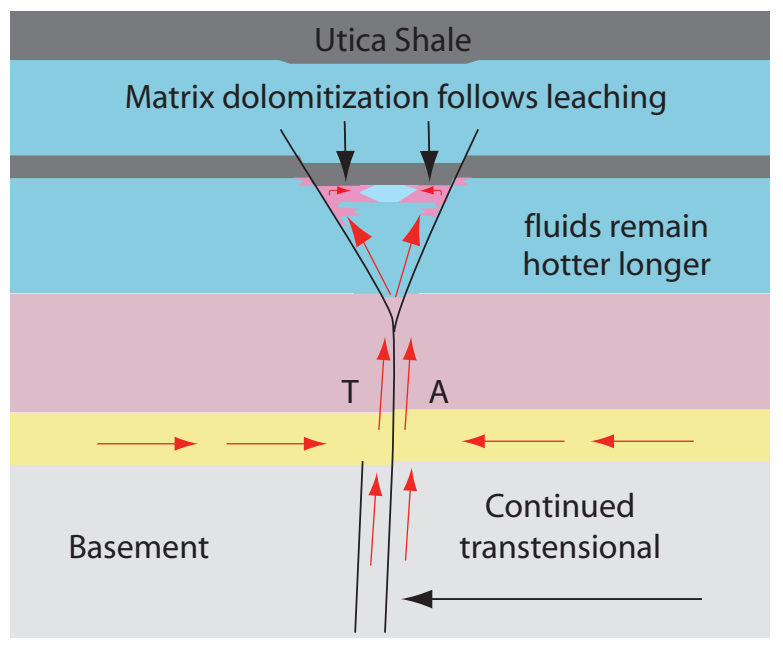

C) Faulting continues (Utica time); hotter fluids dolomitize leached matrix

Shale

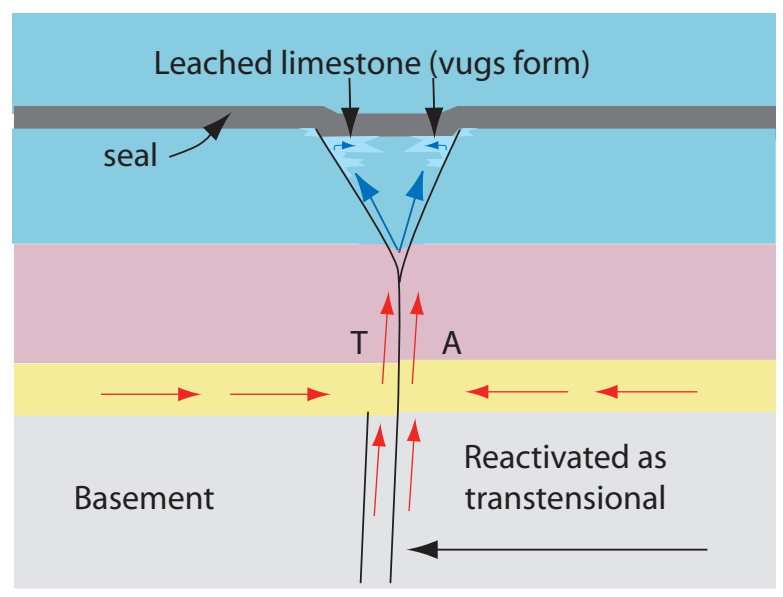

B) Onset of faulting (Trenton time), cooling fluids leach limestone

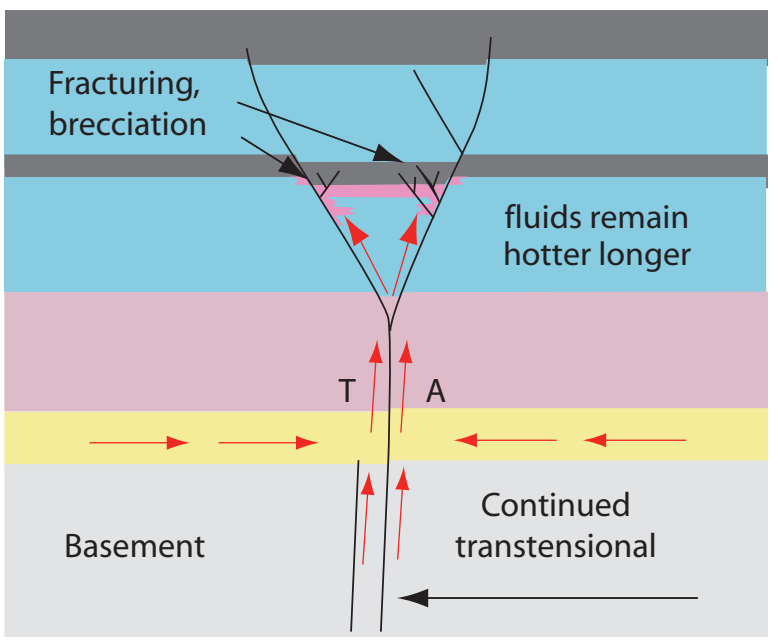

D) Faulting continues (Utica, later?); Matrix fractured, vugs, breccias and fractures filled with saddle, etc.

Sandstone hot $/$ cooling

Figure 54 Model for hydrothermal leaching and dolomization that has lead to the formation of reservoirs in the Black River carbonates of south central New York. 


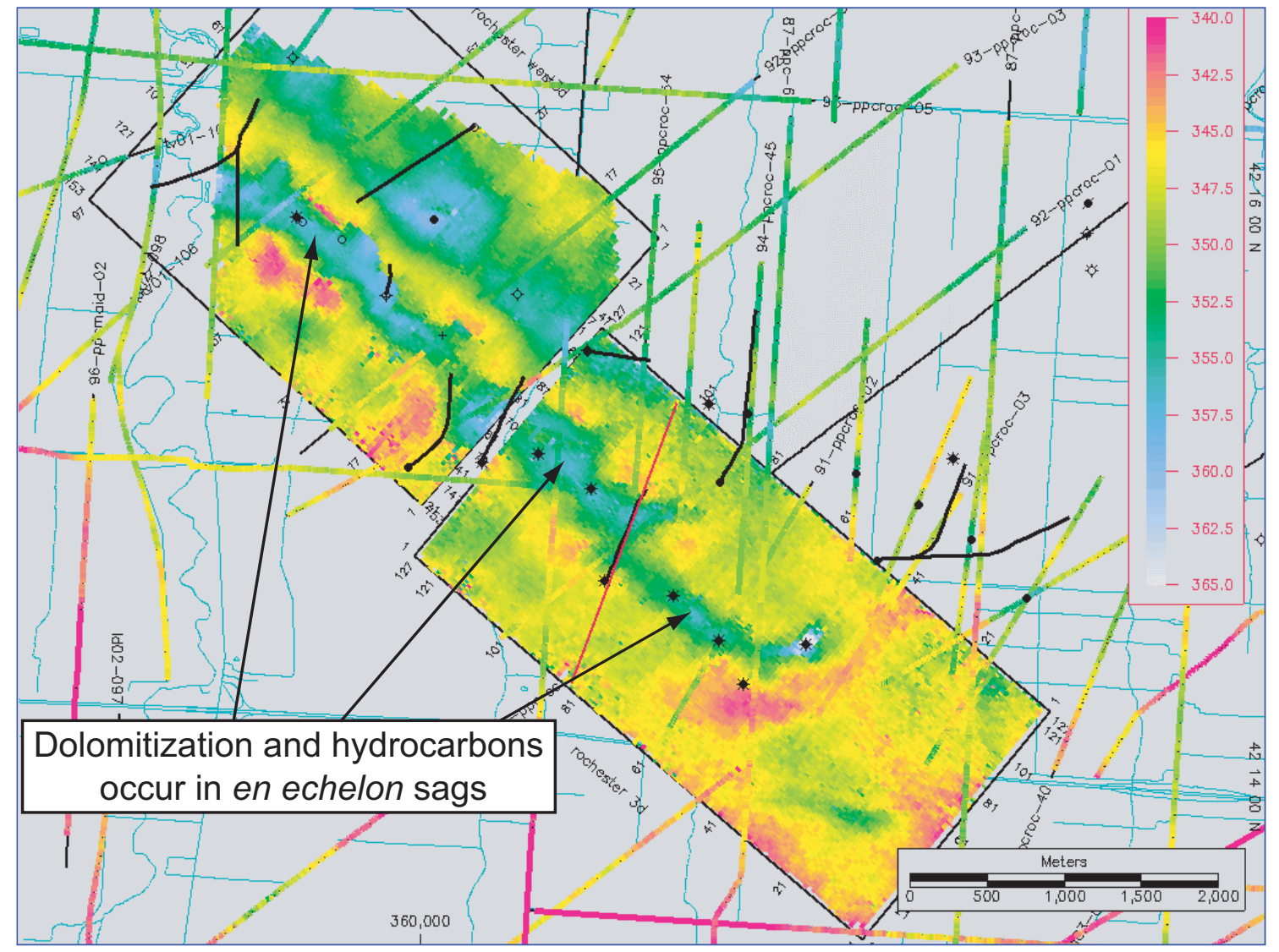

Figure 55 The Trenton and Black River hydrothermal reservoirs occur in faultbounded structural "sags" or "grabens" that are visible on seismic. The 3D map above is a top Trenton time structure map from the Rochester Field in Ontario, Canada (courtesy of Talisman Energy). 
warmer colors (red and yellow) represent structural highs. The dolomite, porosity and hydrocarbons all occur in the structural lows.

Figure 56 shows the seismic expression of two hydrothermal dolomite reservoirs in the Southern Tier of New York. The porosity and gas occur in the subtle structural lows marked as the Glodes Corners Road sag and the Muck Farm Sag. These fields can be very productive but are difficult to discover and develop due to their heterogeneity.

Many wells in New York penetrate dolomitized Black River Group carbonates but do not produce gas. There is very little matrix porosity preserved in the dolomites in New York. It appears that much of the reservoir porosity is in vugs, fractures and between breccia clasts (Figures $49 \mathrm{a}$ and $\mathrm{b}$ ). Some vugs are connected and contribute to production while others are isolated and will not produce gas at economic rates. For instance, the core shown in Figure 49 a and $b$ is from dry hole even though it looks very porous.

The two cores that were described illustrate this heterogeneity (Plates 16 and 17). The Matejka \#1 core and the Gray \# 624468 core described in Plates 16 and 17 are both considered "tight" dolomite wells in that they have significant quantities of dolomite, but very low permeability. Most of the dolomite in these wells is matrix dolomite with little or no porosity. The Matejka well has tens of feet of dolomite but no vugs and few open fractures (Figure 47). The Gray \# 624468 core (Figure 48) does have numerous open vugs, but they are isolated because there are few fractures and the matrix dolomite between them has little or no permeability. In many cases, bitumen, quartz or other minerals occur between the dolomite rhombs and may plug what would otherwise be effective porosity.

The Whiteman \#1 core has high permeability in several beds that have vuggy and fracture porosity (Figure 49a and b) and the well has been a good producer. This suggests that penetration of at least some open fractures may be essential to drilling a productive well in the Black River dolomite play in New York. The abundance of fractures and saddle dolomite suggest that the Whiteman \#1 core may be closer to a fault than the Matejka \#1 and Gray \# 624468 wells. 

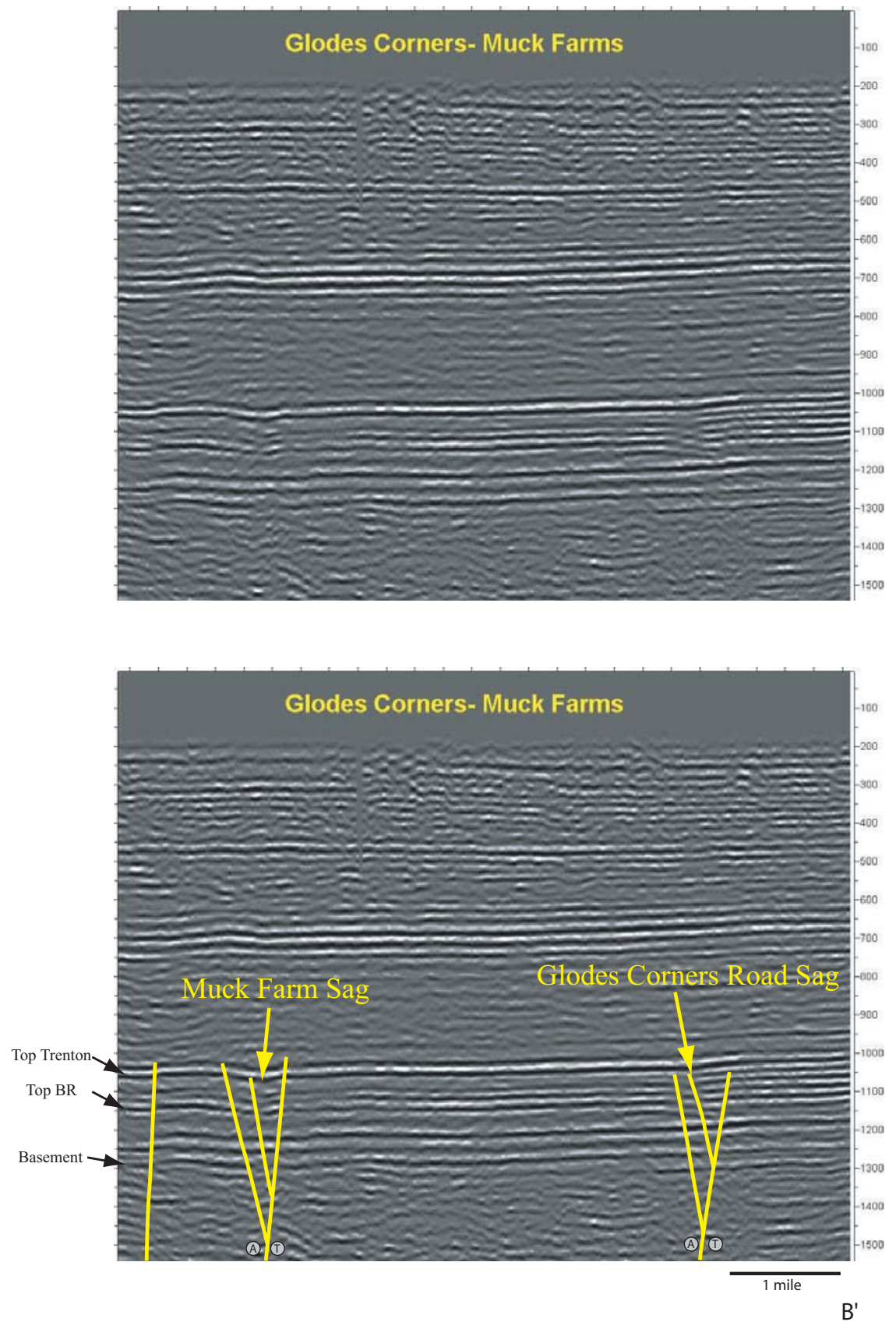

Figure $56 \quad$ Seismic expression of the Glodes Corners Road and Muck Farms Fields in south central New York State. Porosity and therefore production occur in subtle structural lows called sags. 
The cores studied as part of this research suggest that penetrating open faults, fractures and breccias and vugs connected by fractures may be the key to drilling a successful well in this play. Most of the early wells in the trend were vertical wells that were commonly sidetracked once or twice after encountering tight dolomite or limestone. The probability of success on a vertical development well was about 35\% (Bob Bonnar, Talisman Energy, pers. comm). This may be because the wells were less likely to penetrate faults and fractures. More recently, a series of horizontal wells have been drilled that have a more consistent level of success (about 60\%) along with much higher initial production rates and greater cumulative production. Because horizontal wells cut across the fault and fracture zones and penetrate the formation at a range of distances from the faults, they have a much higher probability of success. It may also be the case that some successful producers have good matrix porosity, but that no cores have been acquired from these wells.

Figure 57 shows the distribution of producing Trenton Black River hydrothermal dolomite wells and fields in New York. Note that many of these fields are in the process of being drilled and extended and that this map is likely to look quite different when all drilling is completed. Two of the more mature fields in the play, Muck Farms and Glodes Corners Road, are about 6miles $(10 \mathrm{~km})$ long and .4 miles $(0.7 \mathrm{~km})$ wide. This proportion of length to width appears to be common for Trenton Black River Fields in New York. The linear nature of the fields strongly suggests an underlying fault control.

Note the many features with the classic Trenton-Black River sag style structure on Figure 8, which illustrates the potential that this region of the state holds for production from this already prolific play. We are confident that many if not all of the structures are dolomitized. Though there are many structures to be explored, finding the productive zones within the structures in the difficult part. The Trenton-Black River reservoirs are notoriously heterogeneous on the scale of a single field. This proves to be a high risk factor in exploring for Trenton-Black River reservoirs, but should not serve to deter potential brine disposal considerations. A cavern developer should seek to utilize inactive, depleted fields for brine disposal where the most porous and permeable zones have already been delineated and infrastructure is already in place. 

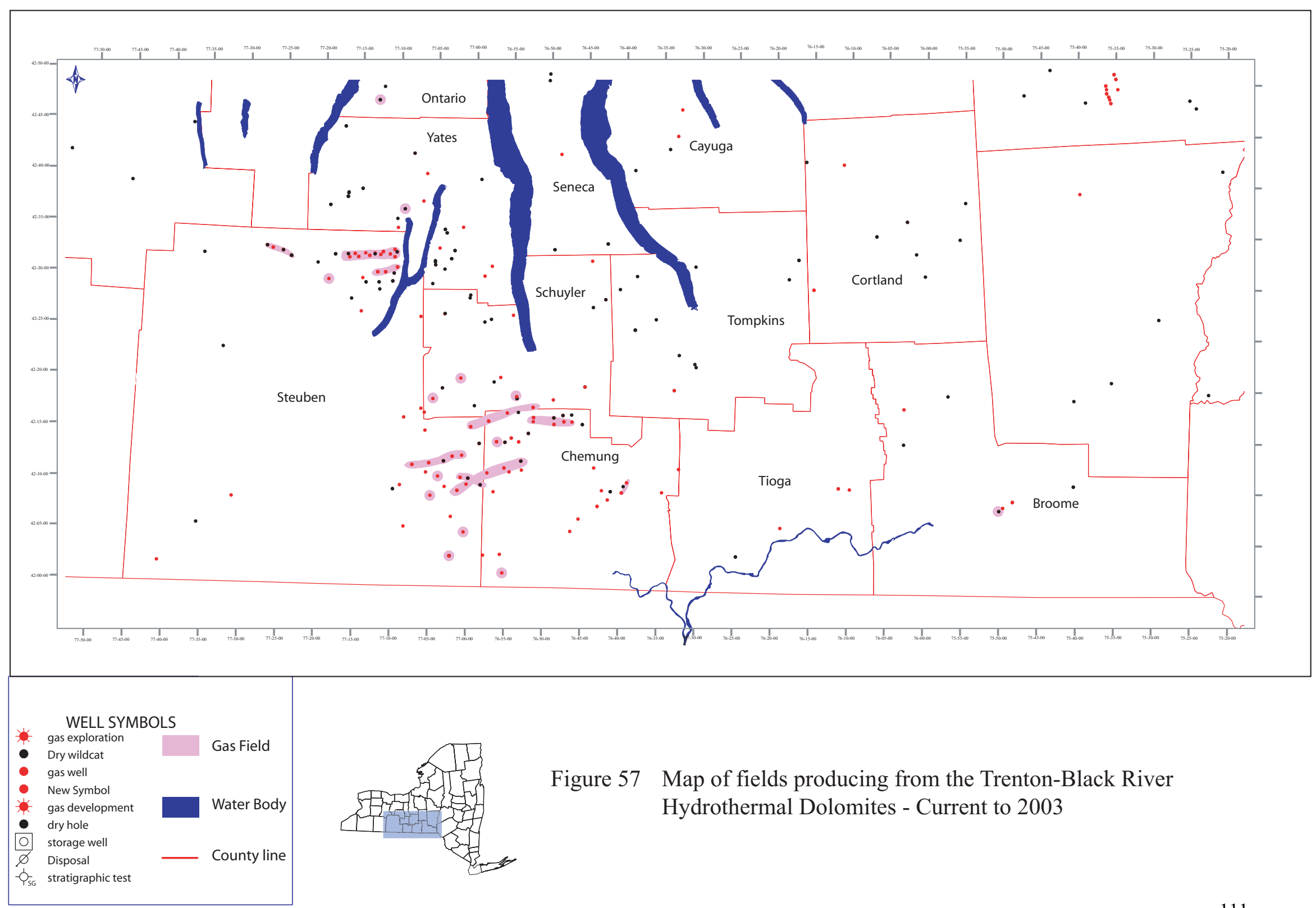

Figure 57 Map of fields producing from the Trenton-Black River Hydrothermal Dolomites - Current to 2003 
Cross section E-E' (Plate 15) includes several producing wells that are dolomitized in the Black River along with wells between fields that are predominantly composed of limestone in the Black River. The laterally discontinuous nature of the dolomite suggests that the dolomitization process was highly localized. When these cross sections are referenced to seismic data it becomes clear that dolomitization is localized around subtle wrench faults.

Testing and Modeling Results for the Trenton-Black River Interval. The permeabilities from the Whiteman \#1well (data courtesy of Fortuna Energy) indicate that the permeabilities of the Trenton-Black River interval are high. Like the Queenston Formation, the permeability of the Trenton-Black River interval is also a function of its porosity, with porosity of 7 percent resulting in a 60 milli-Darcy permeability. The presented permeabilities are horizontal, while those in the vertical direction are much lower. Figure 58 shows the permeability as a function of porosity for the Whiteman \#1 well. The permeabilities are horizontal. The 20 foot thickness mutes the impact of the lower vertical permeabilities on flow. The formation is 30 percent saturated, thus the effective compressibility of the pore is reduced slightly from the analyses presented for the Queenston Formation.

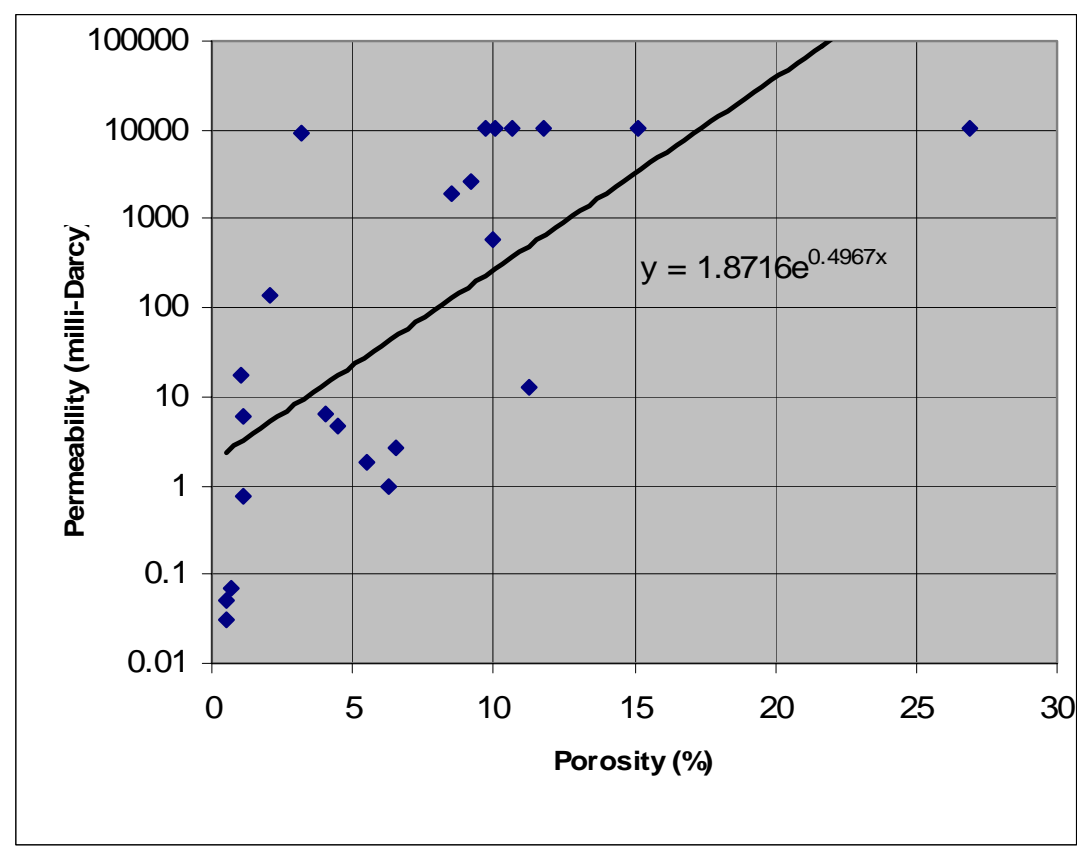

Figure 58 Permeability of Trenton-Black River. 
During modeling of the Trenton-Black River interval, the length of a horizontal well was adjusted until Evaluation Criteria 1 and 2 are reached and exceeded (10 BPM leading to 15 MMB of brine over a 3 year period). This resulted in a well length of 2.8 miles in the TrentonBlack River. The injection rate (Figure 59) was very similar to the results of the 11 mile hole for the Queenston even though there are considerable differences in the inputted formation parameters.

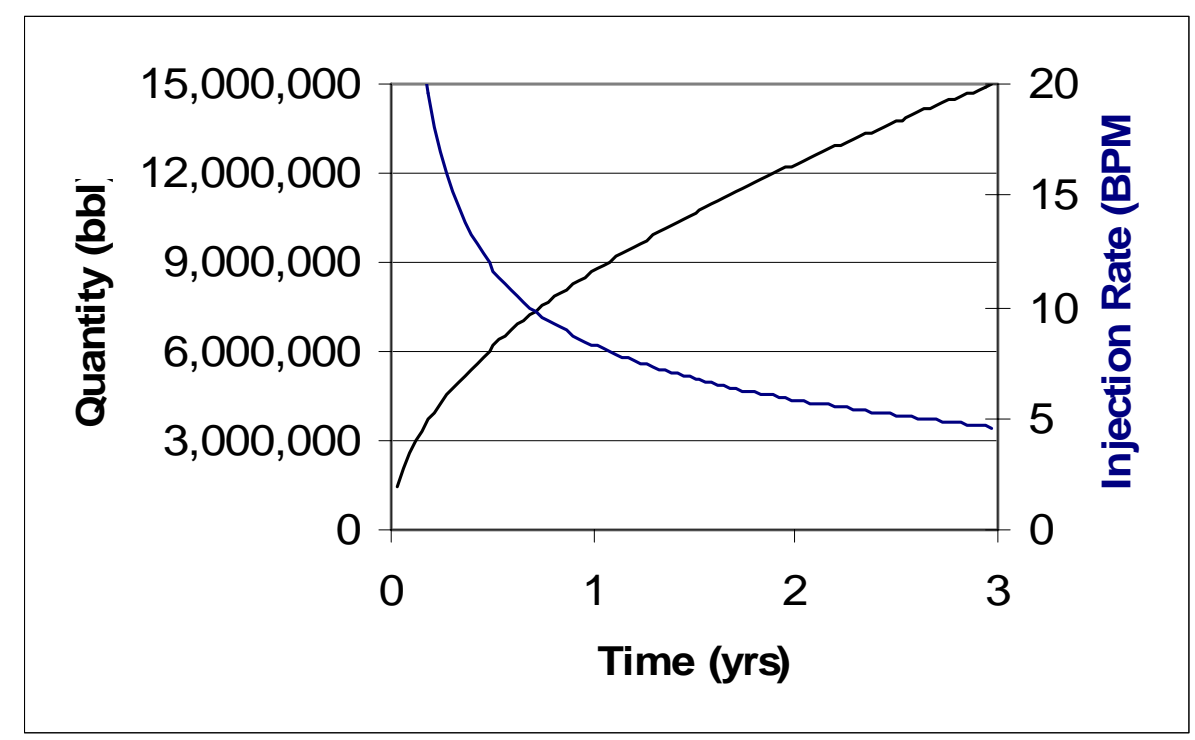

Figure 59 Brine Injection Quantity and Rate for Trenton-Black River (Horizontal Well).

What differs most in the Trenton-Black River vs. Queenston predictions is the lateral extent of flow from the well. The relatively high permeability of the Trenton-Black River in combination with its lower porosity and formation thickness, result in a lateral flow exceeding 2 miles (Figure 60). Thus a single well can distribute brine over a large formation area.

\section{Analysis of the Trenton-Black River Interval as a Potential Brine Disposal Reservoir}

Unlike the Queenston Formation, the Trenton-Black River interval has porosity and permeabilities that support injection at acceptable rates. Evaluation Criterion 1 and 2 would be met in a vertical well, but the horizontal wells typically used to produce from the Trenton-Black River interval would only increase the effectiveness of this formation. Due to production from 
the formation in the area of usable salt many of these horizontal wells already exist into the most favorable portions of the reservoirs.

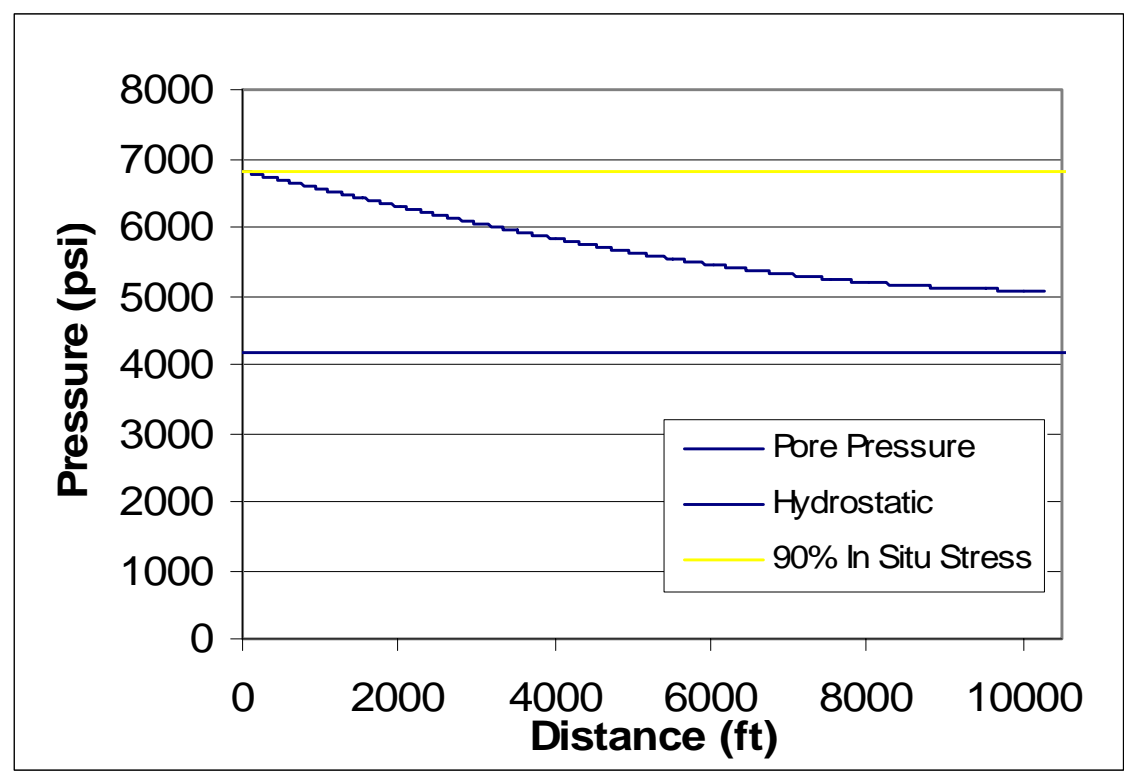

Figure 60 Brine Pressure in Trenton-Black River after 3 years (Horizontal well).

Because these fields are so heterogeneous and their lateral extent is unknown, they may make poor gas storage reservoirs themselves. In this scenario, gas might be injected and flow to an area where it cannot be recovered. Also, some of the bigger fields ( $>100 \mathrm{BCF})$ may be too big make good gas storage fields because too much gas would have to be used as cushion gas.

If they do not make good gas storage reservoirs due to their heterogeneity, unknown extent or size, the newly discovered Trenton Black River Fields could prove to be excellent brine disposal reservoirs. The heterogeneity is not a problem for brine injection, especially with fields that have already been discovered because the well porosity and permeability is already known and these good wells can be reused for disposal.

Using the calculations in Appendix C, a rule of thumb is that the brine produced from creation of 1 BCF of cavern space will fill the space in a Black River reservoir that produced 10 BCF of gas. 
This will vary somewhat based on the depth of the field (shallower fields might accept a bit more brine per BCF of production than deeper fields). The Black River Fields discovered to date have produced between 1-50 BCF. Two of the largest Trenton-Black River fields, the Quackenbush and the Wilson Hollow fields are estimated to have $150 \mathrm{Bcf}$ and $50 \mathrm{Bcf}$ of gas in reserve and many fields are still being delineated and could produce similar quantities of gas. A $50 \mathrm{BCF}$ field should be able to accept enough brine to make a 5 BCF salt cavern storage facility and this is a big enough to make a project economically feasible.

Because the fields are near each other, multiple fields could be used to dispose of brine from a single facility. Another obvious benefit to this approach is that many wells have already been drilled to the Black River and these well bores could be re-used as disposal wells. Any gas storage facility could also use the existing pipelines and other infrastructure, which would improve the economics of any salt cavern project considerably. Caverns could be mined directly above the reservoirs using new sidetracks completed from wells already drilled and brine could be injected into the highest perm wells (Figure 61). This could be an excellent opportunity for operators of these fields.

Like the Queenston Formation the Trenton-Black River interval is located below the salt and well below and sources of potable water. The groups are further separated from any potable water by several shale intervals, including the extremely thin Utica Formation and the Clinton Group. These facts establish that the Trenton-Black River interval meets Evaluation Criteria 3, which stipulates that formations mush be hydraulically separated from sources of potable water. 


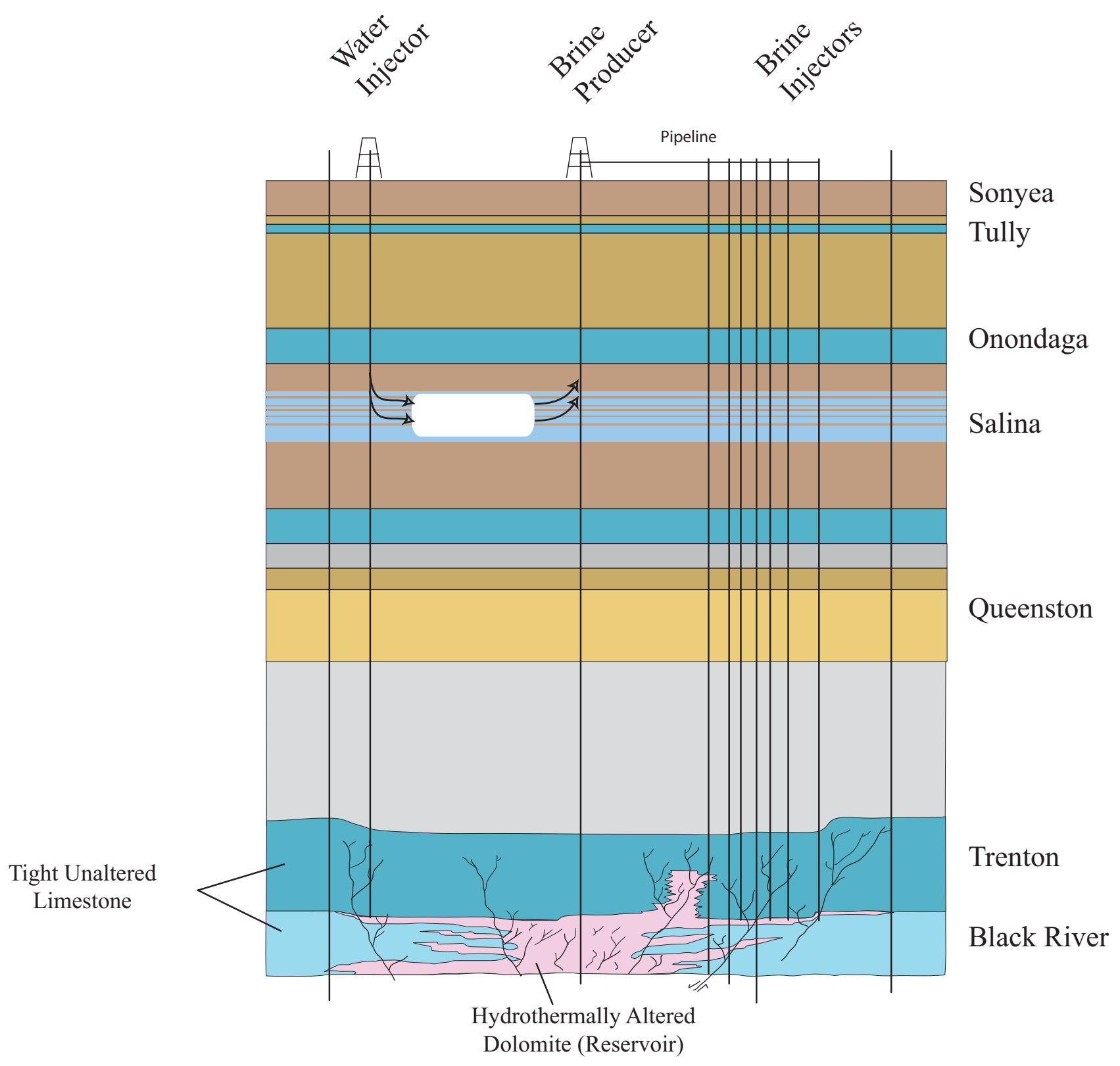

Figure 61 Glodes Corner Road Field used as an example of how existing Trenton field infrastructure could be used to develop salt-cavern storage facilities with brine disposal on or near site. 


\section{Beekmantown Group - Methods}

Top Identification. The Cambro-Ordovician rocks used in the evaluation of the Beekmantown Group, while not as recognizable as the Middle Ordovician rocks, produce petrophysical log patterns that are identifiable over a great extent (Rickard, 1973). Tops used in the evaluation of the Beekmantown Group and surrounding formations in this report were primarily derived from review of Rickard (1973), Flagler (1966) and Bass, Sarwar and Friedman (1996). Figure 45 is a representative log for the tops picked in the evaluation of the Beekmantown Group. Additional visual examples of the Beekmantown Group picks used in this report can be seen in Plates 22 and 23 .

The contact between the Galway and the overlying Little Falls is hard to distinguish and causes considerable confusion among operators. McCann et al. (1968) places the contact between the Galway (the author refers to the formation as the Theresa, see explanation below) and the Little Falls at a relatively consistent "kick" at the top of the major sandstone facies in the upper part of the Galway section. Figure 62, a gamma ray log through the Sauk Sequence from Bass et al (1996), demonstrates this pick and shows that both Bass et al (1996) and McCann et al. (1968) were in agreement as to where the top should be placed.

Cross Sections. Plate 23 is an east-west cross section of the Beekmantown Group from the Mohawk Valley, where cores are available, into south-central New York State where cavern development is possible. The cross sections show the entire Cambro-Ordovician section that comprises the Beekmantown Group, Tribes Hill, Little Falls, Galway (sometimes referred to as the Theresa, see explanation below) and Potsdam Formations as well as the Trenton and Black River Groups and the Precambrian Basement. These are stratigraphic cross sections that are hung on the top of the Trenton Group. Intervals interpreted to have dolomite are highlighted in magenta (see below for an explanation how Dolomite was identified).

Dolomite Identification using Geophysical Logs. Like the carbonates of the Trenton-Black River interval, the limestones of the Beekmantown Group have been hydrothermally altered in some areas. These altered dolomites are localized, but it is possible to locate them using 

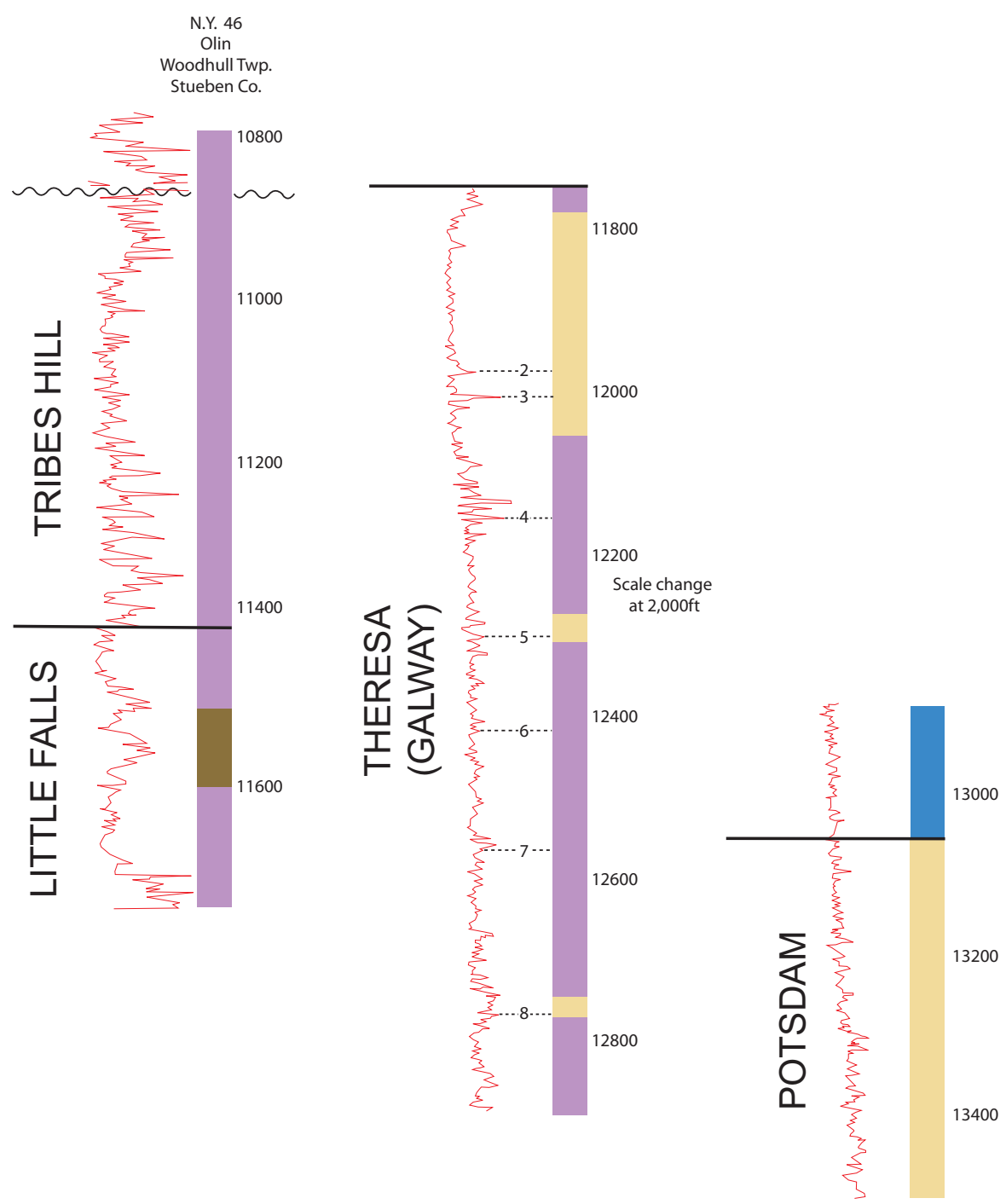

Figure 62 Stratigraphic Profile and Type Log for the Sauk Sequence, Stueben County, New York. (Modified from Bass et al., 1996) 
geophysical well logs. See explanation given above in the Trenton-Black River methods under the same heading for a detailed description of how geophysical well logs can be used to identify intervals of dolomite.

Mohawk Valley Core Description and Correlation Poster. This report contains descriptions of three cores from the Beekmantown Group near the outcrop belt in the Mohawk Valley. The descriptions include: lithology (dolomite, limestone, shale), Dunham rock texture (grainstone, packstone, wackestone, etc), sedimentary structures, fracture intensity, porosity type and more. All of this information is captured in posters. The cores have been correlated to one another, allowing the sequence and cycle boundaries to be picked. We are confident that the sequences and the porosity units within them correlate across the study area.

Rock Mechanics Testing of the Beekmantown Formation Core Samples. Permeability tests were conducted on core samples from the Beekmantown Limestone from the Mohawk Valley of New York State. The core samples were from the Little Falls Formation in the 74NY-1 and 74NY-2 wells (these wells were drilled for mineral exploration and therefore has no API number). The test apparatus is shown in Figure 26. The configuration for the porosity and permeability testing of the Beekmantown samples was the same as that of the Queenston Formation.

Modeling of the Beekmantown Group. Since no major distinction was found between the permeabilities measured in the Queenston sandstone and the Beekmantown limestone, these rock types were not evaluated separately. Instead, rock properties were based on the typical 10.8 percent porosity, which yields a permeability of 0.185 milli-Darcy (same as those used for the Queenston Formation). See methods section for Queenston Formation for a detailed description of the modeling methods used.

\section{Beekmantown Group - Description}

The Cambro-Ordovician Beekmantown group was selected as a potential brine disposal reservoir based on the following generalizations: 
- Reservoir is in porous dolomite and sandstones,

- Porosity may be widespread, as demonstrated by the Beekmantown Study in Ohio and core analysis in the Mohawk Valley of New York State,

- Beekmantown Group is thick within the study area.

The Beekmantown Group represents the Cambro-Ordovician succession of the Sauk Sequence in New York State. As defined by Sloss (1963), the Sauk Sequence encompasses those strata that overlie an interregional unconformity cut on the late Precambrian and older rocks and underlie an interregional unconformity at the base of the succeeding Tippecanoe Sequence (the Black River Group in central New York). In more detail, the succession includes (Figure 63):

Tribes Hill Formation (where present)

Little Falls Formation

Galway Formation (often referred to as the Theresa, explained below)

Potsdam Formation

Together this succession of strata consists of sandstones, sandy dolostone and dolostone. In general the dolostone increases and sandstone decreases from the bottom of the section to the top (Bass et al., 1996, Rickard, 1973). For the purpose of this study the lower three units, the Little Falls, Galway and Potsdam Formations will be considered, as they offer the best disposal potential.

Bass et al. (1996) thought that the Potsdam and Galway (Theresa) Formations offered the best potential for brine disposal. The authors made this comment after reviewing the average porosities of the two formations in the Mitchell \# 1 well at the site of the Avoca Storage Project, Steuben County, New York. In stratigraphic tests of the of the Potsdam Formation in the well, porosities as high as $10 \%$ were recorded along with permeabilities ranging from $200-960 \mathrm{md}$. Bastedo and Van Tyne (1990) commented that the sandstones of both the Galway and Potsdam Formations often have shows of gas and salt water, but that structural closure or fracture systems were necessary to form a trap. 


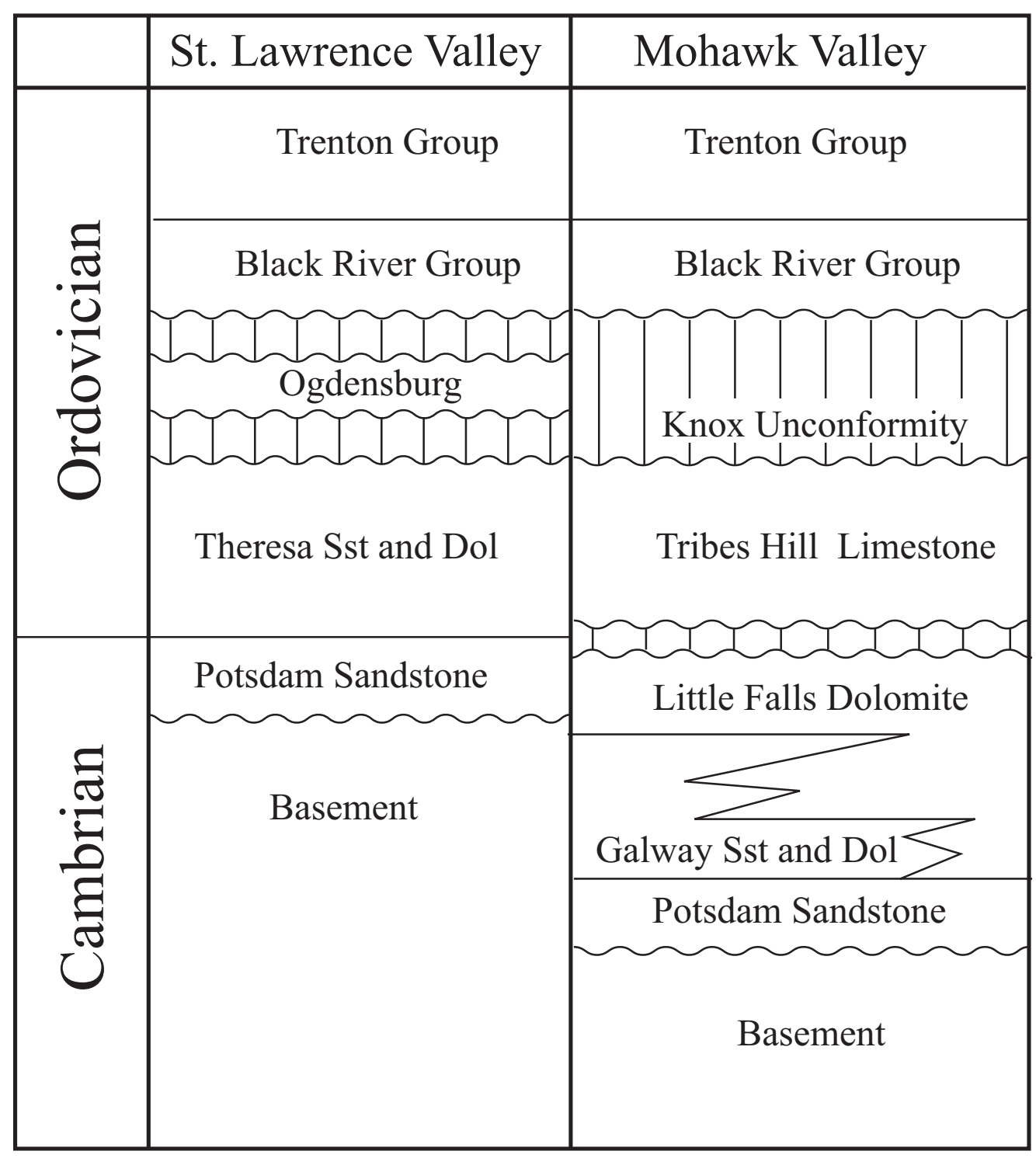

Figure 63 Comparison of the stratigraphy of the Cambro-Ordovician strata in the St. Lawrence Valley and the Mohawk Valley. In the study area of south central New York the stratigraphy most closely resembles that of the Mohawk Valley. 
Potsdam Sandstone. The middle Cambrian Potsdam Sandstone lies unconformably over the eroded surface of the Precambrian Basement (Kreidler, 1975) and is the oldest sedimentary unit recognized in western New York State. Outcrops of the Potsdam sandstone are observed along the northern edge of the Adirondack uplift. In the subsurface of central New York, the Potsdam Formation is very fine- to medium-grained, light brown to gray sandstone with both silica and carbonate cement, frosted sand grains, muscovite and orthoclase feldspar (Saroff, 1987). The top of Potsdam is differentiated from the basal sandstone stringers of the Galway by the coarseness of the sandstone and by the higher feldspar content which is observed as an increase on the gamma ray curve (McCann et al., 1968). Rickard (1973) observed that the contact between the Potsdam sandstone and the Galway was difficult to ascertain in some wells due to the Potsdam sandstone being gradually replaced upwards by the quartzose dolostones and dolostones of the Galway Formation.

The Potsdam strikes generally east-west and regionally dips southward at an average rate of 100 feet/mile $(\sim 19 \mathrm{~m} / \mathrm{km})$. It ranges in depth from 3,000 feet $(915 \mathrm{~m})$ in western New York (near Buffalo) to nearly 13,000 feet (3,962 m) in south central New York (Steuben County near the Pennsylvania Border). On average the thickness of the Potsdam is 100 feet, but thicknesses up to 410 feet (125 m) have been reported in Oneida County (McCann et al., 1968).

According to McCann et al. (1968), the basal portion of the Potsdam is extremely porous and permeable in some places. This zone is believed to have produced natural gas around the turn of the century from several fields in western New York and Ontario. Natural gas was also produced from the basal Potsdam Sandstone in the Memphis area of Onondaga County in 1897 (Robinson , 1983). Where tested in Cattaraugus, Wyoming and Livingston Counties it produced brine (McCann et al., 1968).

Within the study area, no continuous zones of porosity were identified, but the small number of wells that reach this formation limited the sample size. The Mitchell \#1 had some porosity and permeability, but the other injection wells at Avoca had none. This again is now rated as a possible brine injection target, but it has already proven unreliable as a primary target. 
Galway Sandstone and Dolomite - (sometimes called the Theresa). Overlying the Potsdam in central New York is a late Cambrian aged formation that consists of sandstones and dolostones (Rickard, 1973). Researchers working primarily in the oil and gas industry (i.e. Flagler, 1966) have traditionally and erroneously referred to this formation as the Theresa, which has brought about much confusion in later attempts to characterize the formation. The Theresa outcrops mostly along the northern rim of the Adirondack uplift, where in type section it overlies the Little Falls. There the Theresa is an Ordovician in aged sandstone with interbedded dolomite. Rickard (1973) recommended that the name Galway be used because the type Theresa, located north of Watertown New York, is not continuous with what has been called the Theresa in the subsurface of central New York. This distinction was necessary, primarily because of discrepancies between the age and stratigraphic position (Figure 63) of the strata in the type locality and that of the rocks in the subsurface of central New York (Fischer and Hanson, 1951; Rickard 1973; Fisher, 1977; Zenger, 1981).

This study considers the late Cambrian sands and dolostones overlying the Potsdam in central New York to be the Galway Formation. The Theresa sandstone does not occur in the subsurface of western New York. Cambrian aged strata that is referred to as Theresa, is most likely the Galway Formation. This is primarily a nomenclature problem, but is relevant as much of the literature regarding this interval, especially prior to Rickard's work in 1973, refers to the Galway Formation as the Theresa. When citing papers where this is the case, Theresa will appear in parenthesis after Galway so that it will be clear to the reader what was used in the original text.

In the subsurface of central New York, the Galway (Theresa) Formation contains a combination of interbedded dolostones and sandstones, which varies dramatically both vertically and laterally. In many locations the Galway reportedly changes from unconsolidated sandstone to a hard orthoquartzite (Flagler, 1966; Saroff, 1987). East of Cayuga County, the Galway (Theresa) is predominantly a dolostone with few interbedded sandstones. West and southwest of Cayuga and Tompkins Counties, the formation contains considerably more sand and few interbedded carbonate layers (Kreidler, 1975; Saroff, 1987). Saroff noted that in the NYSERDA City of Auburn Well in Cayuga County, central New York, the Galway Sandstone is a light gray, calcitic cemented, subangular to subrounded sandstone with traces of granular hematite. 
The subsurface strike of the Galway is east-west and the regional dip is southward at an average rate of 100 feet/mile. $(\sim 19 \mathrm{~m} / \mathrm{km})$ or slightly more. The average subsurface thickness of the Theresa is 700 feet $(213 \mathrm{~m})$, reaching a max thickness of 1,486 feet $(453 \mathrm{~m})$ in southern Steuben County, New York.

There has recently been production from the Galway sandstones in western New York to the north and west of the study area (Copley, 2004). These new wells may make as much as 0.5 BCF. This sandstone play may occur over a wide area, but its extent is not known at this time. This could be a possible brine disposal target if it can be demonstrated that the porous sandstones extend over a wide area. There was porosity in these sandstones in the Mitchell \#1 at Avoca, but there was very little porosity in this formation in subsequent disposal wells drilled for that project. This is currently rated as a possible disposal reservoir, but at this time it appears that the porous zones are too patchy and small to make it a dependable brine injection target.

Little Falls Formation. The Little Falls in New York State is primarily dolostone with minor amounts of shale, sandstone and siltstone (Kreidler, 1975). The Little Falls outcrops along the southern and eastern edge of the Adirondack Uplift. At its type locality in Little Falls, Herkimer County, New York, the formation is reported to be roughly 200 feet $(61 \mathrm{~m})$ thick (McCann et al., 1968). Several authors have noted that the Little Falls in the subsurface is different from its type section (McCann et al., 1968; Rickard, 1973; Saroff, 1987).

In our study of the Beekmantown Group near the outcrop belt in the Mohawk Valley, there were zones of relatively high intercrystalline porosity in the dolomites of the Little Falls that correlated from well to well (see intervals shaded in green on Plate22). The Beekmantown dolomites have also produced significant quantities of gas in Ohio, which gave us further encouragement.

The subsurface distribution of the Little Falls is limited primarily to the southern extents of western New York. In the subsurface the formation is described as a light tan to brown, finely to medium-crystalline dolostone containing a lot of very fine to coarse quartz sand and in places 
thinly bedded siltstones (McCann et al., 1968; Saroff, 1987). The strike of the Little Falls Dolomite is east-west across the state; regional dip is southward at approximately 100 feet/mile. $(\sim 19 \mathrm{~m} / \mathrm{km})$. The thickness of the formation in the subsurface varies considerably, ranging from 0-300 feet (0-91m) in southeastern New York (Rickard, 1973; Saroff, 1987).

There are numerous porous zones in the upper Little Falls that have yielded salt water in test wells (McCann et al., 1968) in the subsurface. The authors thought that these porous zones were relatively continuous and believed that they could be potential disposal reservoirs. However, after and examination of all wells in the study area for which logs are available, we have not found many continuous porosity zones in the subsurface in that region. There was no porosity in the Little Falls at the site of the Avoca Project and it was not considered to be a good injection candidate there. We have subsequently downgraded the Little Falls as an injection candidate for this reason.

Mohawk Valley Core Description. In cores analyzed from the Mohawk Valley (Plate 21), there are zones of excellent high permeability intercrystalline porosity that appear to be laterally extensive. The correlation in Plate 22 shows that large-scale sequences (on the order of 50-100 feet thick) can be correlated over a distance of several tens of miles. Sequences are generally picked at the tops of high-energy shallow marine grainstones. The strong dolomitization makes it hard to pick sequence boundaries with confidence, but the sequences as picked do appear to correlate pretty well. The best porosity zones occur in sequences LF 4 and LF 5 at both sections, which strongly suggests good lateral extent to reservoir facies. The big "collapse" breccia horizon appears to correlate pretty well and is mostly in sequence LF 7. The tectonic breccia zones do not correlate well. The Galway onlaps the basement to the west rather than interfingering with Little Falls.

Similar laterally extensive porosity zones in the Beekmantown also occur in parts of western New York studied by the Beekmantown Consortium (Smith, 2003). If such a porosity zone could be located in the area where the salt is thick enough, the Beekmantown could easily accept large quantities of brine. Additional work needs to be done to determine the lateral extent of the porosity zones with in the Beekmantown and distribution of the formation within the study area. 
Testing and Modeling Results for the Beekmantown Group. The mean and median permeabilities of the Beekmantown samples were similar to those of the Queenston Formation samples (Table 4). Like those of the Queenston Formation the Beekmantown permeabilities were found to correlate the difference in the confining and pore pressures. A smaller confining and pore pressure resulted in the largest permeabilities, though to a lesser extent in the Beekmantown than in the Queenston Formation (Figure 64 and 35).

Results from testing samples of the Beekmantown Group and the Queenston Formation, were similar enough that only one model was necessary to represent both sets of samples. Rock properties were based on a porosity of 10.8 percent, which yields a permeability of 0.185 milliDarcy. See Testing and Modeling Results section for Queenston Formation for a detail description of model results. Both formations lack porosity and permeability at levels that would make brine disposal possible with out utilizing drilling techniques to increase the amount of formation volume available to the volume of brine to be disposed.

Table 4. Test Matrix

\begin{tabular}{|c|c|c|c|c|c|c|c|}
\hline Formation & $\begin{array}{c}\text { No. of } \\
\text { Samples }\end{array}$ & $\begin{array}{c}\text { No. } \\
\text { of } \\
\text { Tests }\end{array}$ & $\begin{array}{c}\text { Confining } \\
\text { Pressure } \\
\text { (PSI) }\end{array}$ & $\begin{array}{c}\text { Pore } \\
\text { Pressure } \\
\text { (PSI) }\end{array}$ & $\begin{array}{c}\text { Range in } \\
\text { Permeability } \\
\text { (m-D) }\end{array}$ & $\begin{array}{c}\text { Mean } \\
\text { Permeability } \\
\text { (m-D) }\end{array}$ & $\begin{array}{c}\text { Median } \\
\text { permeability } \\
\text { (m-D) }\end{array}$ \\
\hline Queenston & 5 & 86 & $\begin{array}{c}470 \text { to } \\
7000\end{array}$ & $\begin{array}{c}100 \text { to } \\
6700\end{array}$ & $\begin{array}{c}0.000027 \text { to } \\
0.0979\end{array}$ & 0.0162 & 0.0074 \\
\hline $\begin{array}{c}\text { Beekman- } \\
\text { town }\end{array}$ & 5 & 84 & $\begin{array}{c}1000 \text { to } \\
7000\end{array}$ & $\begin{array}{c}320 \text { to } \\
6700\end{array}$ & $\begin{array}{c}0.000091 \text { to } \\
2.90\end{array}$ & 0.132 & 0.00274 \\
\hline
\end{tabular}




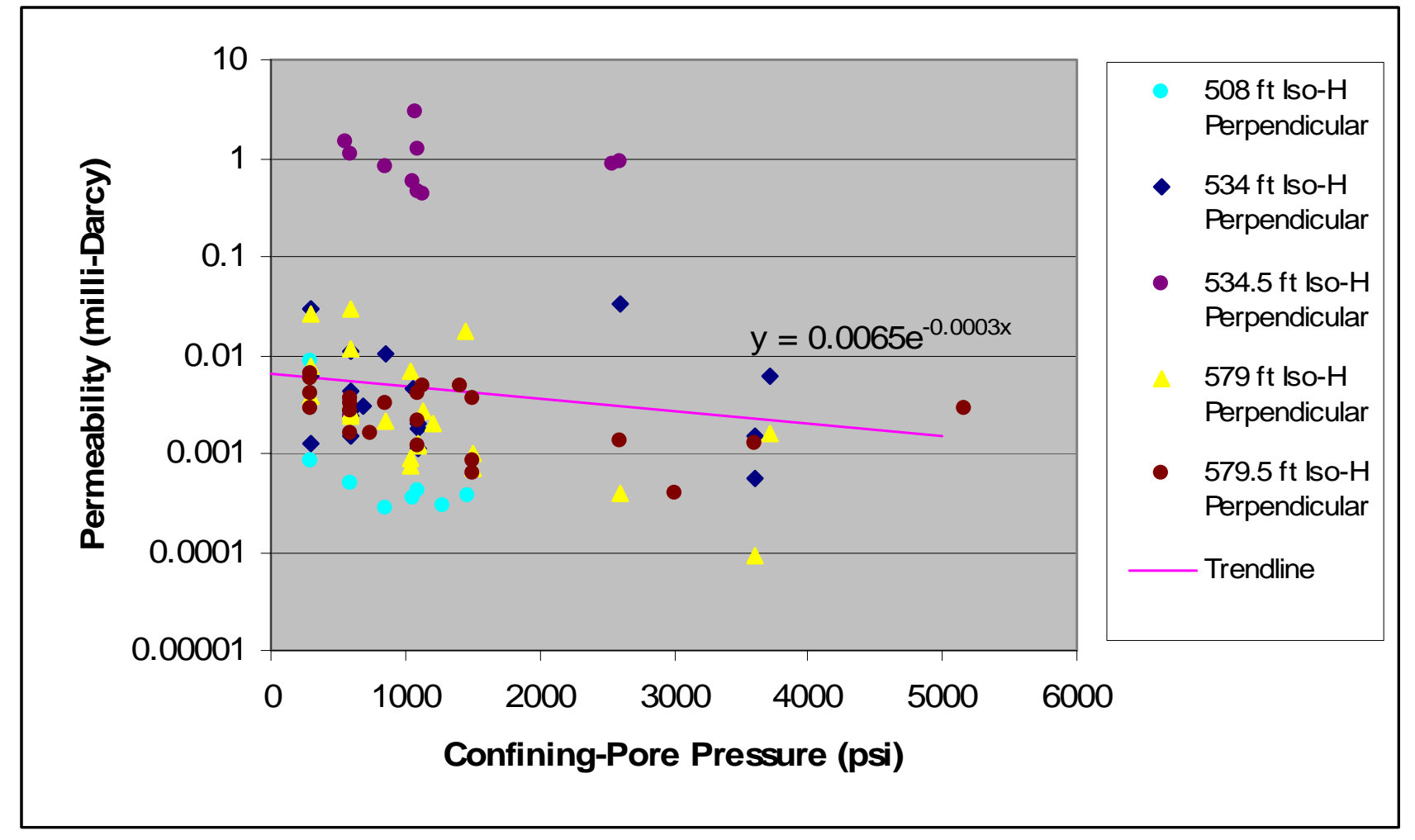

Figure 64. Beekmantown Limestone Permeabilities. 


\section{Section 4 \\ CONCLUSIONS}

Formations that have good porosity and permeability, have history of production, but are not currently being considered for traditional depleted reservoir type storage were considered for their ability to act as brine disposal reservoirs. The Ordovician Queenston Formation, the Early Ordovician Trenton-Black River Group and the Cambrian Beekmantown were initially selected as potential brine disposal reservoirs in the first cut of this selection process.

The sandstone reservoir of the Queenston was promising, because it is widespread and sand rich in the area of usable salt, it has shown to have the capacity to accept brine in current disposal operations and it has produced to the north for over 35 years. Reservoir potential in the Beekmantown Group was initially identified in the porous dolomites intervals and also possibly in the sandstones and hydrothermally altered breccias. Porosity in the Beekmantown is widespread and it is known to be thick in the area of usable salt. Modeling of both the Queenston Formation and the Beekmantown Group limestones showed that neither met Evaluation Criteria 1 and 2 because of the low permeability of each. Neither formation would be able to accept brine at the rates necessary for economic cavern development (10 BPM) without well stimulation or drilling programs that are not practical in New York State.

The Trenton-Black River carbonates have the greatest potential as brine disposal reservoirs. They are the most prolific producers in recent times, the fields are active and located within the area of central New York where salt cavern storage is a possibility; it is possible that the fields will be unattractive for depleted reservoir type storage due to their heterogeneity and unknown lateral extent. Reservoirs in the Trenton-Black River would be found in the vuggy dolomite of the upper Black River section. The Trenton-Black River interval meets and exceeds all three of the Disposal Formation Evaluation Criteria and stands out as the best option for brine disposal. We have been in contact with the companies currently producing gas from these fields and they are interested in either building salt caverns themselves or selling the fields to a gas storage company when they are depleted. 
Drilling and well stimulation techniques will continue to improve along with geophysical techniques. The primary motivation of advances in industrial technology is reservoir development and storage of natural gas, not brine. Never-the-less, the same technology is often applicable to brine disposal. Such advances will better locate potential injection areas and increase well injectivities in the future. At some point, even the marginal brine disposal units discussed above will become economical.

The methodology used in this report could prove effective in other states or regions where brine disposal has negatively affected the progression of salt cavern development. In all areas, it would be important to first identify locations where salt cavern storage would be possible. The criteria governing this evaluation process may differ in other regions or states based on differing state regulation of cavern development or if the material to be stored in the cavern is not natural gas (criteria presented in this report were for natural gas). As in this study, narrowing the area of study will allow future efforts to be focused into areas with cavern development potential. Any evaluation of potential brine disposal reservoirs should first select formations that offer the best potential for successful brine disposal. Beyond selection, modeling informed by parameters from the potential disposal formation can be used quantify the ability of each formation to accept brine at an economic rates and volumes. 


\section{References}

Asquith, G.B., 1982. Methods in Exploration Series: Basic Well Log Analysis For Geologists. The American Association of Petroleum Geologists. Tulsa, Oklahoma.

Bass, J.P., Sarwar, G., Gou, B., and Friedman, G.M., 1996, A preliminary assessment of suitable sites for new high-deliverability salt cavern storage facilities in south-central New York: Northeastern Geology and Environmental Sciences, vol. 18, no. 1/2. p. 36-48.

Bastedo, J.C. and Van Tyne, A.M., 1990. Geology and Oil and Gas Exploration in Western New York. Fieldtrip Guidebook Western New York and Ontario, NYSGA 62nd Annual Meeting.

Beinkafner, K. J., 1983. Deformation of the subsurface Silurian and Devonian rocks of the southernteir of New York State. Unpublished Doctoral Dissertation, Syracuse University, $481 \mathrm{p}$.

Bonnar, R., 2002, Talisman Energy, pers. comm

Briggs, P., 1996. Salt Mining in New York: The Ins and Outs of the Solution Mining industry and Its Significance. Solution Mining Research Institute: Meeting Paper. Fall Meeting, Cleveland, Ohio.

Briggs, P., 2002. Personal communications.

Cadwell, D. H. and Nottis, G. N., 1998. Seismic Hazard Assessment, Onondaga County, New York. Final Report No. 98-001, New York State Emergency Management Office.

Carter, B.J., A.R. Ingraffea, and T. Engelder. Modeling Ithaca's Natural Hydraulic Fractures. 10th IACMAG Conference, Tucson, Arizona, January 7-12, 2001. 
Chenoweth, P. A. and McBride, M.H. (Compiled and edited by), 1984. Formation Correlator for the Appalachians and Eastern Interior States, PennWell Publishing, Tulsa, Ok.

Childs, O. E., 1985. Correlation of stratigraphic units of North America; COSUNA._AAPG: Tulsa, OK.

Code of Federal Regulations, Title 40, Parts 124, 144, 146 and 147.

Cornell, S., 2000. Sequence Stratigraphy and Event Correlation of upper Black River and lower Trenton Carbonates of northern New York State and southern Ontario, Canada. Unpublished Doctoral Dissertation, University of Rochester, 156 p.

Copley, D., 2004. The Theresa Sandstone in New York State: The Next Big Play? IOGA New York Summer Meeting.

Crain, E.R., 1986, The Log Analysis handbook: Volume 1, Quantitative Log Analysis Methods. PenWell Publishing Company, Tulsa, OK.

Ehgartner, B., Lee, M., Bauer, S., Smith, L., Lugert, C. and Nyahay R., 2005. Test analysis of New York Brine Disposal Formations. Solution Mining Research Institute: Technical Papers. Spring Meeting, Syracuse, NY.

EIA, 2005. Energy Information Act website. U.S. Department of Energy. http://www.eia.doe.gov.

Ells, G. D. (1967). Michigan's Silurian oil and gas pools. Michigan geological Survey Report $18,55 \mathrm{pp}$.

Environmental Conservation Law of New York State (ECL)

EPA, 2005. Underground Injection Control (UIC) Program, EPA Website, http://www.epa.gov. 
ESOGIS (Empire State Oil and Gas Information System), 2005. The New York State Museum. www.nysm.gov/esogis.

Federal Energy Regulatory Commission (FERC) Order No. 636

Fisher, D.W., 1977. Correlation of the Hadrynian, Cambrian and Ordovician Rocks in New York State: New York State Museum Map and Chart No. 25.

Fisher, D.W. and Hanson, G.F., 1951, Revisions in the geology of Saratoga Springs, New York and vicinity: American Journal of Science, vol.249, no. 11, pp. 795-814.

Flagler, D.W., 1966, Subsurface Cambrian and Ordovician Stratigraphy of the Trenton GroupPrecambrian Interval in New York State: New York State Museum Map and Chart No. 8

Friedman, G.M., Bass, J.P, Sarwar, G., and Gou, B, 2002, Gas-Storage Assessment for New York State: Principles and Practices. New York State Museum Circular \# 61.

Haddenhorst, Hans-Guenter, 1989. Storage of natural Gas in Salt caverns. IN: Storage of Natural Gas. MR Tek (ed). Kluwer Acedemic Publishers, 177-193.

H.J. Gruy and Associates, Inc., 1979. Core and Log Studies of the Queenston-Medina Sandstones. H.J. Gruy and Associates, Inc.: Dallas, Texas.

Hugout, B. and Roger, C., 1990. The performance of gas storage cavities leached in salt. IN: Underground Storage for Natural gas and LPD. United Nations, Economic Commission for Europe, Energy Series No. 3, New York

Hughes, S.E.A., 1976, The paleogeography and subsurface stratigraphy of the Late Ordovician Queenston Coastal Complex. Unpublished M.S., Cornell University. 
Kearney, W. M., 1983, Subsurface Geology of the Silurian Medina and Clinton Groups, New York State. Unpublished B. S. thesis, Southern Methodist University, 121pp.

Kreidler, W.L., 1975, Underground Disposal of Liquid Wastes in New York. New York State Museum and Science Service, Map and Chart Series, no. 26.

Landes, K.K., (1945). The Salina Bass Island rocks in the Michigan basin. U.S. geological Survey Oil and Gas Inventory (Prelim.) Map 40.

Lindemann, R. and Feldman H., 1987. Paleogeography and brachiopod paleoecology of the Onondaga limestone in eastern New York. New York State Geological Association

Lynch, E. J., 1962. Formation Evaluation. Harper and Row Publishers, New York.

McCann T. P., Privrasky, N. C., Stead, F. L., and Wilson J. E, 1968. Possibilities for disposal of industrial wastes in subsurface rocks on north flank of Appalachian Basin in New York: in Subsurface disposal in Geologic Basins: AAPG Memoir 10, 10pp.

Morrill, D. 1996. Avoca, New York salt cavern gas storage facility: Northeastern Geology and Environmental Sciences. V. 18, no.1-2 p. 59-66.

Matsumoto, M.R., Atkinson, J.F., Bunn, M. D., Hodge, D.S., 1992. Disposal/Recovery Options for Brine Waters From Oil and Gas Production in New York. Final Report: New York State Energy Research and Development Authority (Albany, New York) Agreement No. 1591-ERER-RIER-91.

Muller, E. H. and Cadwell, D. H., 1986. Surficial Geologic Map of New York - Finger Lakes Sheet. Albany: New York State Museum, Map and Chart Series \#40. 
Nicholson C. and R.L. Wesson. Earthquake Hazard Associated with Deep Well Injection- A Report to the U.S. Environmental Protection Agency. U.S. Geologic Survey Bulletin 1951, Denver, CO, 1990.

Rickard L. V., 1969, Stratigraphy of the Upper Silurian Salina Group, New York, Pennsylvania, Ohio, Ontario. New York State Museum Map and Chart Series, no.24, 6p., 4 pls.

Rickard, L.V., 1973, Stratigraphy and structure of the subsurface Cambrian and Ordovician carbonates of New York. New York State Museum and Science Service, Map and Chart Series, no. 18.

Rider, M.H., 1986. The Geological Interpretations of Well Logs. John Wiley and Sons Inc., New York.

Rogers, W. B., Isachsen, Y. W., Mock, T. D., Nyahay, R. E. and Lauber, J., 1990. Geologic Highway map of New York State at 1:1,000,000. New York State geological Survey, Albany New York.

Sanford, K. F., 1996. Development of New York's Solution Salt Mining Regulatory Program. Proceedings of the Ground Water Protection Councils Annual Meeting, St.Paul, Minnesota.

Sanford, K. F., 2000, Recent Trenton-Black River development from a regulatory perspective. AAPG Bulletin, vol. 84, p. 1392.

Saroff, S. T., 1987, Stratigraphy, structure and nature of gas production and entrapment of the Auburn Gas field, Cayuga County, New York. Unpublished B.S. thesis, Syracuse University, $191 \mathrm{p}$.

Saroff, S.T., 1988, Subsurface structures and nature of gas production and entrapment of Upper Ordovician Queenston Formation, Auburn Gas Field, Cayuga County, New York. 
Abstracts with Programs, American Association of Petroleum Geologists Eastern Section Annual Meeting, v.72, p.971.

Schlumberger, 2005. Oil field glossary website. http://www.glossary.oilfield.slb.com.

Sloss, L.L., 1963. Sequences of the Cratonic Interior of North America: Geological Society of America Bulletin, v. 74, p. 93-114.

Stone and Webster Engineering Corporation, 1978. Report of Geological Project Manager-Salina Basin, Phase I, August 1977 - January 1978: Report for the Office of Nuclear Waste Isolation, Battelle Memorial Institute; Columbus, Ohio, v. $1 \&$ v. 2.

Swenson, E. and Potashnik, B., 1994. Evaluation of Benefits and Identification of Sites for a CAES Plant in New York State. Electric Power Research Institute: Palo Alto, California.

Swezey, C., 2002. Regional Stratigraphy and Petroleum Systems of the Appalachian Basin, North America. USGS, Geological Investigation Series Map, I-2768.

Thoms, R.L. and Gehle, R.M. 2000. A brief history of salt cavern use. Solution Mining Research Institute: Meeting Paper.

USGS, 2002. United States Geological Survey Produced Waters Database. http://energy.cr.usgs.gov/prov/prodwat/index.htm

Uteig, J.R., 1964. Upper Niagaran and Cayugan stratigraphy. Ohio Geological survey Report Inv. 51, 48 pp.

Wickstrom , L. H., Gray, J. D. and Stieglitz, R. D., 1992. Stratigraphy, structure, and production of the Trenton Limestone (Ordovician) and adjacent strata in northwestern Ohio. Report of Investigations - Ohio, Division of Geological Survey Report 143, 78 pp., Columbus, $\mathrm{OH}$. 
Zenger, D. H., 1981. Stratigraphy and Petrology of the Little Falls Dolostone (Upper Cambrian), East-Central New York: New York State Museum Map and Chart Series No. 34. 


\section{Appendices}
A - Silurian Data
B - Queenston Formation Data
C- Trenton-Black River Data 


\title{
Appendix A
}

\section{Silurian Data}

\author{
Table 1 General Well Data \\ Table 2 Salina F-Unit Interval Data \\ Table 3 Silurian Formation Tops
}


Apppendix - A - Table 1 - Silurian - General Well Data

\begin{tabular}{|c|c|c|c|c|c|c|c|}
\hline API\# & Hole \# & Name & Lat & Lon & Town & County & Total Depth \\
\hline 31101002160000 & 00216 & Herrington [n593s] & 42.0688 & -77.4108 & Woodhull & STEUBEN & 8625 \\
\hline 31003002460000 & 00246 & Chadwick F 1 & 42.0938 & -78.1709 & Wirt & ALLEGANY & 4850 \\
\hline 31101003290000 & 00329 & Champlin 2 & 42.4032 & -77.21 & Urbana & STEUBEN & 4507 \\
\hline 31015004430000 & 00443 & Kesselring 1 & 42.1986 & -76.5381 & Van Etten & CHEMUNG & 11145 \\
\hline 31011004780000 & 00478 & Mahaney J C & 42.6848 & -76.6443 & Ledyard & CAYUGA & 6166 \\
\hline 31109004810000 & 00481 & Farkas Joe 1 & 42.5292 & -76.5074 & Lansing & TOMPKINS & 6210 \\
\hline 31097005610000 & 00561 & Best 2 [h122] & 42.4805 & -77.0778 & Tyrone & SCHUYLER & 4459 \\
\hline 31011010500000 & 01050 & Aurora 1 & 42.7534 & -76.7047 & Ledyard & CAYUGA & 1068 \\
\hline 31003011590000 & 01159 & King Adelbert 1 & 42.1348 & -77.9712 & Scio & ALLEGANY & 5025 \\
\hline 31017011600000 & 01160 & Lobdell 1 & 42.6933 & -75.3451 & Columbus & CHENANGO & 5701 \\
\hline 31109022860000 & 02286 & Cayuga Rock Salt & 42.5303 & -76.5293 & Lansing & TOMPKINS & 1964 \\
\hline 31023023080000 & 02308 & Overbaugh Philip 1 & 42.4221 & -76.2015 & Harford & CORTLAND & 3218 \\
\hline 31101026790000 & 02679 & Blair 1 & 42.3075 & -77.2567 & Bath & STEUBEN & 3350 \\
\hline 31003029670000 & 02967 & McElroy 1 & 42.5011 & -78.2297 & Centerville & ALLEGANY & 5505 \\
\hline 31111031990000 & 03199 & A Herdman 1 & 42.1004 & -74.3842 & Shandaken & ULSTER & 6400 \\
\hline 31003032640000 & 03264 & Herdman Jos 1 & 42.2849 & -78.0074 & Angelica & ALLEGANY & 5475 \\
\hline 31051032770000 & 03277 & Livonia Salt Shaft 1 & 42.8016 & -77.6786 & Livonia & LIVINGSTON & 1432 \\
\hline 31051033050000 & 03305 & Hunt 1 & 42.6996 & -77.6685 & Conesus & LIVINGSTON & 3411 \\
\hline 31121038650000 & 03865 & Lockwood Harold 1 & 42.5704 & -78.0789 & Genesee Falls & WYOMING & 3583 \\
\hline 31069038660000 & 03866 & Male Merle 1 & 42.6785 & -77.4431 & South Bristol & ONTARIO & 3850 \\
\hline 31121038800000 & 03880 & Fee 14 & 42.6546 & -78.0662 & Castile & WYOMING & 2368 \\
\hline 31101038940000 & 03894 & Hargrave [n588s] & 42.0486 & -77.4264 & Woodhull & STEUBEN & 9790 \\
\hline 31101039240000 & 03924 & Olin [n650s] & 42.063 & -77.4307 & Woodhull & STEUBEN & 13500 \\
\hline 31109039380000 & 03938 & Fee 20 & 42.5482 & -76.5531 & Lansing & TOMPKINS & 2125 \\
\hline 31097039400000 & 03940 & International 29 & 42.4201 & -76.8947 & Reading & SCHUYLER & 2698 \\
\hline 31051039420000 & 03942 & Martuccio 1 & 42.6853 & -77.6618 & Conesus & LIVINGSTON & 3549 \\
\hline 31003039560000 & 03956 & Cook G M 2 & 42.453 & -78.1743 & Hume & ALLEGANY & 7337 \\
\hline 31053039700000 & 03970 & Branangan Donald 1 & 42.8048 & -75.6505 & Lebanon & MADISON & 5703 \\
\hline 31069039710000 & 03971 & Treble 1 & 42.785 & -77.4926 & Richmond & ONTARIO & 2506 \\
\hline 31109039730000 & 03973 & Shepard 1 & 42.3702 & -76.5063 & Danby & TOMPKINS & 10438 \\
\hline 31069039910000 & 03991 & Kage 1 & 42.7847 & -77.4558 & Bristol & ONTARIO & 2902 \\
\hline 31043039930000 & 03993 & Skranko 1 & 42.8807 & -74.9168 & Warren & HERKIMER & 3581 \\
\hline 31069039970000 & 03997 & Clement 1 & 42.7979 & -77.5089 & Richmond & ONTARIO & 2308 \\
\hline 31053040020000 & 04002 & Parteko N-748 & 42.817 & -75.6591 & Lebanon & MADISON & 2794 \\
\hline
\end{tabular}




\begin{tabular}{|c|c|c|c|c|c|c|c|}
\hline API \# & Hole \# & Name & Lat & Lon & Town & County & Total Depth \\
\hline 31069040050000 & 04005 & Allen 1 & 42.8012 & -77.4943 & Richmond & ONTARIO & 2591 \\
\hline 31109040070000 & 04007 & Smiley Jean H 1 & 42.3654 & -76.5033 & Danby & TOMPKINS & 8555 \\
\hline 31121040080000 & 04008 & Cornwell 757 & 42.7965 & -77.9631 & Perry & WYOMING & 2210 \\
\hline 31069040270000 & 04027 & Mills Lewis 1 & 42.7915 & -77.4218 & Bristol & ONTARIO & 3072 \\
\hline 31069040350000 & 04035 & Gladding Phil 1 & 42.8007 & -77.439 & Bristol & ONTARIO & 2986 \\
\hline 31051040530000 & 04053 & Nivers 1 & 42.7649 & -77.6593 & Livonia & LIVINGSTON & 3020 \\
\hline 31077040550000 & 04055 & Lum Paul B et al 1 & 42.6309 & -74.7082 & Worcester & OTSEGO & 5511 \\
\hline 31011040680000 & 04068 & Shoemaker 1 (768-1) & 42.8811 & -76.6398 & Springport & CAYUGA & 1967 \\
\hline 31051040690000 & 04069 & Mc Donald & 42.8716 & -77.9321 & York & LIVINGSTON & 5090 \\
\hline 31025040730000 & 04073 & Hirsch K 1 & 42.3739 & -75.0426 & Franklin & DELAWARE & 5327 \\
\hline 31099040820000 & 04082 & Stein 1 & 42.8759 & -76.84 & Fayette & SENECA & 2286 \\
\hline 31053040850000 & 04085 & Doroshenko 1 & 42.8798 & -75.6867 & Eaton & MADISON & 2988 \\
\hline 31121040920000 & 04092 & Veith D 1 & 42.6173 & -78.0802 & Gainesville & WYOMING & 7182 \\
\hline 31109041300000 & 04130 & Grund GH & 42.4421 & -76.5928 & Enfield & TOMPKINS & 8900 \\
\hline 31051041510000 & 04151 & Smith N834 & 42.8132 & -77.9422 & Leicester & LIVINGSTON & 2079 \\
\hline 31121041620000 & 04162 & Fee 17 & 42.6701 & -78.0826 & Gainesville & WYOMING & 2431 \\
\hline 31051041880000 & 04188 & Austin 1 & 42.7664 & -77.7551 & Geneseo & LIVINGSTON & 2625 \\
\hline 31003042480000 & 04248 & Wolfer Duane A 1 & 42.4704 & -78.1602 & Hume & ALLEGANY & 7560 \\
\hline 31011043650000 & 04365 & Johnson 1 & 42.9705 & -76.5169 & Sennett & CAYUGA & 2000 \\
\hline 31121043850000 & 04385 & Wesley Johns 1 & 42.63 & -78.1538 & Gainesville & WYOMING & 0 \\
\hline 31097044000000 & 04400 & Watkins Storage 1 & 42.3677 & -76.8639 & Dix & SCHUYLER & 2726 \\
\hline 31121044320000 & 04432 & Schuelte Harriett 1 & 42.8359 & -78.3324 & Bennington & WYOMING & 0 \\
\hline 31121044470000 & 04447 & Warren 1 & 42.8026 & -78.1501 & Middlebury & WYOMING & 5820 \\
\hline 31069044500000 & 04450 & Gonenhauser Max 1 & 42.8863 & -77.4817 & West Bloomfield & ONTARIO & 2053 \\
\hline 31109044670000 & 04467 & Fee Richarson 1 & 42.3844 & -76.5407 & Newfield & TOMPKINS & 9390 \\
\hline 31051045310000 & 04531 & Hunn 1 & 42.8319 & -77.9501 & York & LIVINGSTON & 2182 \\
\hline 31121045360000 & 04536 & Page Henry 1 & 42.8267 & -78.1384 & Middlebury & WYOMING & 6233 \\
\hline 31051046300000 & 04630 & Kennedy 1 & 42.6502 & -77.756 & Sparta & LIVINGSTON & 6388 \\
\hline 31023047140000 & 04714 & Clough K \& O 1 & 42.5185 & -76.0009 & Freetown & CORTLAND & 8272 \\
\hline 31123047960000 & 04796 & Fee 1 & 42.6838 & -77.0222 & Benton & YATES & 3061 \\
\hline 31007048540000 & 04854 & Quarella 1 & 42.399 & -75.8804 & Triangle & BROOME & 5831 \\
\hline 31067049020000 & 04902 & Frost Gg Jr 1 & 42.9204 & -76.2904 & Marcellus & ONONDAGA & 2760 \\
\hline 31007050870000 & 05087 & Richards 1 & 42.3235 & -75.9479 & Triangle & BROOME & 9640 \\
\hline 31007066360000 & 06636 & Smith Charles E 1 & 42.4062 & -75.8774 & Triangle & BROOME & 5907 \\
\hline 31007083420000 & 08342 & Gerst 1 & 42.3977 & -75.8906 & Triangle & BROOME & 6420 \\
\hline 31009092350000 & 09235 & Enterprise Transit St 1 & 42.0087 & -78.5687 & Allegany & CATTARAUGUS & 11680 \\
\hline
\end{tabular}




\begin{tabular}{|c|c|c|c|c|c|c|c|}
\hline API \# & Hole \# & Name & Lat & Lon & Town & County & Total Depth \\
\hline 31123098460000 & 09846 & Christenson 1 & 42.7115 & -77.0306 & Benton & YATES & 2971 \\
\hline 31107098480000 & 09848 & Robinson Francis 1 & 42.0759 & -76.4521 & Barton & TIOGA & 5220 \\
\hline 31077101380000 & 10138 & Schwerd Frederick W 1 & 42.6934 & -75.095 & & OTSEGO & 2723 \\
\hline 31109102430000 & 10243 & Place Ruth A 1 & 42.401 & -76.6684 & Enfield & TOMPKINS & 3670 \\
\hline 31015103350000 & 10335 & Matejka 1 & 42.169 & -76.659 & Erin & CHEMUNG & 10614 \\
\hline 31017106090000 & 10609 & Hulbert 1 & 42.3475 & -75.5887 & Oxford & CHENANGO & 6427 \\
\hline 31011121490000 & 12149 & Michael Deptuch 1 & 42.6414 & -76.2933 & Summerhill & CAYUGA & 4542 \\
\hline 31069121950000 & 12195 & Champlin 1 & 42.8685 & -77.5086 & West Bloomfield & ONTARIO & 2122 \\
\hline 31101124020000 & 12402 & Kish 1 & 42.3167 & -77.3894 & BathN & STEUBEN & 5879 \\
\hline 31097128580000 & 12858 & Akzo 57 & 42.4223 & -76.898 & ReadingN & SCHUYLER & 2770 \\
\hline 31097128590000 & 12859 & Akzo 56 & 42.4088 & -76.8976 & ReadingN & SCHUYLER & 2936 \\
\hline 31109131730000 & 13173 & Cargill Core Test & 42.523 & -76.5052 & LansingN & TOMPKINS & 2784 \\
\hline 31121133080000 & 13308 & Shattuck,M 1 & 42.5279 & -78.1413 & PikeN & WYOMING & 3700 \\
\hline 31101136990000 & 13699 & NYS Reforestation 6 & 42.4662 & -77.2654 & Wheeler & STEUBEN & 9794 \\
\hline 31101137360000 & 13736 & Wagner20615-T & 42.4347 & -77.4091 & Wheeler & STEUBEN & 4849 \\
\hline 31003155120000 & 15512 & Barker b-1 & 42.3857 & -78.2452 & Rushford & ALLEGANY & 4205 \\
\hline 31101158340000 & 15834 & Bush Hill 1 & 42.2032 & -77.5924 & Canisteo & STEUBEN & 6595 \\
\hline 31003186510000 & 18651 & Kozoil 1 & 42.4048 & -78.0481 & Allen & ALLEGANY & 4851 \\
\hline 31023194840000 & 19484 & Jones 1 & 42.7028 & -76.2662 & Scott & CORTLAND & 5616 \\
\hline 31101194970000 & 19497 & Evangelos 21436-T & 42.5407 & -77.2162 & Pulteney & STEUBEN & 7961 \\
\hline 31023195400000 & 19540 & Vander Ploeg 1 & 42.5543 & -76.0209 & Freetown & CORTLAND & 7820 \\
\hline 31099196860000 & 19686 & Townsend 1 & 42.5882 & -76.8443 & Lodi & SENECA & 4100 \\
\hline 31097196920000 & 19692 & Perigo 21578 Tpi & 42.4325 & -76.9704 & Reading & SCHUYLER & 8384 \\
\hline 31003200230000 & 20023 & Friendship Dairies 1 & 42.2114 & -78.1173 & Friendship & ALLEGANY & 5236 \\
\hline 31099204460000 & 20446 & Compton 1 (4177) & 42.7086 & -76.8085 & Romulus & SENECA & 6366 \\
\hline 31123205620000 & 20562 & Castner 1-S & 42.6695 & -77.1622 & Potter & YATES & 3674 \\
\hline 31025210050000 & 21005 & Grant, C. 1a & 42.399 & -75.0527 & Franklin & DELAWARE & 5580 \\
\hline 31003211130000 & 21113 & Lucey, J 1 & 42.2354 & -77.9352 & Ward & ALLEGANY & 6057 \\
\hline 31003211150000 & 21115 & Loree, M 1a & 42.3589 & -77.8256 & Almond & ALLEGANY & 5251 \\
\hline 31101214680000 & 21468 & Mitchell 1 & 42.4196 & -77.4535 & Avoca & STEUBEN & 9887 \\
\hline 31097214950000 & 21495 & Bale 1 & 42.2699 & -76.7139 & Cayuta & SCHUYLER & 11823 \\
\hline 31101214960000 & 21496 & Hubbard No. 1 & 42.4053 & -77.4635 & Avoca & STEUBEN & 10051 \\
\hline 31023215000000 & 21500 & NYS REF 6 Well 01 & 42.639 & -75.9136 & Taylor & CORTLAND & 6886 \\
\hline 31101215510000 & 21551 & BPSI 8 & 42.3116 & -77.2567 & Bath & STEUBEN & 6000 \\
\hline 31101215840000 & 21584 & BPSI 10 & 42.3094 & -77.26 & Bath & STEUBEN & 3596 \\
\hline 31101215870000 & 21587 & BPSI 9 & 42.3094 & -77.2591 & Bath & STEUBEN & 3766 \\
\hline
\end{tabular}




\begin{tabular}{|c|c|c|c|c|c|c|c|}
\hline API \# & Hole \# & Name & Lat & Lon & Town & County & Total Depth \\
\hline 31101215880000 & 21588 & BPSI 11 & 42.3111 & -77.2585 & Bath & STEUBEN & 3777 \\
\hline 31101215890000 & 21589 & BPSI 12 & 42.3073 & -77.2596 & Bath & STEUBEN & 3601 \\
\hline 31101217180000 & 21718 & Demun 1 & 42.0956 & -77.5943 & Troupsburg & STEUBEN & 11166 \\
\hline 31009218090000 & 21809 & Hebdon 1 & 42.3954 & -78.6722 & Ashford & CATTARAUGUS & 7502 \\
\hline 31013224980000 & 22498 & Butts 1-B & 42.1438 & -79.4174 & North Harmony & CHAUTAUQUA & 7620 \\
\hline 31123227430000 & 22743 & Sensenig 1 & 42.5073 & -76.9726 & Starkey & YATES & 7241 \\
\hline 31109227530000 & 22753 & Koskinen 623513 & 42.4903 & -76.6733 & Ulysses & TOMPKINS & 7462 \\
\hline 31097227540000 & 22754 & Gunning 1 & 42.4601 & -76.7321 & Hector & SCHUYLER & 7999 \\
\hline 31101227580000 & 22758 & S \& D Farms 623504 & 42.5494 & -77.4542 & Cohocton & STEUBEN & 7416 \\
\hline 31097227930000 & 22793 & Cook 1 & 42.5355 & -76.7359 & Hector & SCHUYLER & 7587 \\
\hline 31123227970000 & 22797 & Bedient 1 (623788) & 42.5834 & -77.1663 & Jerusalem & YATES & 6887 \\
\hline 31101228140000 & 22814 & Howe 1300 & 42.2048 & -77.0545 & Hornby & STEUBEN & 0 \\
\hline 31015228270000 & 22827 & Bennett Family 1 & 42.2841 & -76.775 & Veteran & CHEMUNG & 9442 \\
\hline 31097228300000 & 22830 & Grand Prix 624066 & 42.306 & -77.0808 & Orange & SCHUYLER & 9745 \\
\hline 31015228310000 & 22831 & Lovell 1323 & 42.1867 & -76.9585 & Big Flats & CHEMUNG & 9386 \\
\hline 31015228390000 & 22839 & Whiteman 1 & 42.2852 & -76.9165 & Catlin & CHEMUNG & 9372 \\
\hline 31123228500000 & 22850 & Watson 1 & 42.6179 & -77.317 & Italy & YATES & 7136 \\
\hline 31015228530000 & 22853 & Rhodes 1322 & 42.1953 & -76.9212 & Big Flats & CHEMUNG & 9682 \\
\hline 31101228590000 & 22859 & Huber 1 & 42.5356 & -77.5922 & Wayland & STEUBEN & 7535 \\
\hline 31101228610000 & 22861 & NYS GMA 2 & 42.1575 & -77.1649 & Erwin & STEUBEN & 10524 \\
\hline 31101228710000 & 22871 & Henkel 1359 & 42.1671 & -76.9727 & Corning City & STEUBEN & 0 \\
\hline 31101228840000 & 22884 & Fratarcangelo 1371 & 42.2345 & -76.977 & Hornby & STEUBEN & 9840 \\
\hline 31101228850000 & 22885 & Corning Game Club 624460 & 42.1799 & -77.0665 & Corning & STEUBEN & 10050 \\
\hline 31015228910000 & 22891 & Parker 1401 & 42.2379 & -76.9389 & Catlin & CHEMUNG & 10323 \\
\hline 31015228990000 & 22899 & Trimber 624536 & 42.1603 & -76.6871 & Erin & CHEMUNG & 10530 \\
\hline 31015229010000 & 22901 & Roy 1 & 42.2713 & -76.957 & Catlin & CHEMUNG & 9487 \\
\hline 31015229020000 & 22902 & Lederer 1412 & 42.2525 & -76.8694 & Catlin & CHEMUNG & 9602 \\
\hline 31015229110000 & 22911 & Schmidt 624537 & 42.1467 & -76.6931 & Erin & CHEMUNG & 10366 \\
\hline 31015229180000 & 22918 & Gregory 1446 & 42.2072 & -76.8847 & Catlin & CHEMUNG & 9402 \\
\hline 31015229190000 & 22919 & Hardy 1447 & 42.2374 & -76.9205 & Catlin & CHEMUNG & 9859 \\
\hline 31015229240000 & 22924 & Johnson 1 & 42.2689 & -76.7512 & Veteran & CHEMUNG & 9803 \\
\hline 31015229330000 & 22933 & Usack 624684 & 42.1586 & -76.6625 & Erin & CHEMUNG & 10338 \\
\hline 31107229340000 & 22934 & Manwaring 624470 & 42.0578 & -76.4101 & Tioga & TIOGA & 11552 \\
\hline 31097229350000 & 22935 & Wonderview Farms 1 & 42.3303 & -76.7472 & Catharine & SCHUYLER & 8762 \\
\hline 31123229390000 & 22939 & Button 624469 & 42.7464 & -77.2875 & Middlesex & YATES & 5582 \\
\hline 31097229420000 & 22942 & Bonham 1 & 42.2959 & -76.9894 & Orange & SCHUYLER & 10069 \\
\hline
\end{tabular}




\begin{tabular}{|c|c|c|c|c|c|c|c|}
\hline API \# & $\underline{\text { Hole \# }}$ & $\underline{\text { Name }}$ & $\underline{\text { Lat }}$ & $\underline{\text { Lon }}$ & $\underline{\text { Town }}$ & $\underline{\text { County }}$ & $\underline{\underline{\text { Total Depth }}}$ \\
\hline 31099229500000 & 22950 & Ziefle 1 & 42.5641 & -76.7023 & Covert & SENECA & 7497 \\
\hline 31007229950000 & 22995 & Beagell 2 & 42.1372 & -75.8339 & Kirkwood & BROOME & 10260 \\
\hline 31013232470000 & 23247 & Hayner 2 & 42.2736 & -79.6413 & Westfield & CHAUTAUQUA & 5953 \\
\hline 31009234350000 & 23435 & Geiger Hollow 1 & 42.0284 & -78.5116 & Allegany & CATTARAUGUS & 9346 \\
\hline 31097611920000 & 61192 & Akzo 36 & 42.413 & -76.8954 & Reading & SCHUYLER & 2857 \\
\hline 31097612050000 & 61205 & Akzo 49 & 42.4098 & -76.8979 & Reading & SCHUYLER & 2951 \\
\hline 31097612060000 & 61206 & Akzo 50 & 42.4103 & -76.8947 & Reading & SCHUYLER & 2530 \\
\hline
\end{tabular}


Appendix A - Table 2 - Salina F-unit Interval Data

\begin{tabular}{|c|c|c|c|c|c|c|}
\hline $\begin{array}{c}\text { Study } \\
\text { (see key at bottom } \\
\text { of column) }\end{array}$ & $\begin{array}{c}\text { SAPINO } \\
\text { (short API) }\end{array}$ & $\begin{array}{c}\text { Net } \\
\text { Thickness F- } \\
\text { unit salt (ft.) }\end{array}$ & $\begin{array}{c}\text { Intervals of Salt Suitable for } \\
\text { Cavern Development } \\
\text { (> 100ft of continuous salt with less } \\
\text { than } 10 \mathrm{ft} \text {. of nonsalt layers) }\end{array}$ & 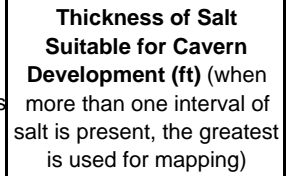 & $\begin{array}{l}\text { Net Thickness of } \\
\text { Salt Suitable for } \\
\text { Cavern } \\
\text { Development (ft.) }\end{array}$ & Comments \\
\hline \multirow[t]{2}{*}{ STW } & 00216-00 & 443 & $4327-4600$ & 273 & 383 & \\
\hline & & & $4770-4880$ & 110 & & \\
\hline \begin{tabular}{|l} 
STWWOR \\
\end{tabular} & $00246-00$ & & & & & \\
\hline \begin{tabular}{|l|} 
STWWOR \\
\end{tabular} & $00329-00$ & & & & & \\
\hline \multirow[t]{3}{*}{\begin{tabular}{|l} 
RKD \\
\end{tabular}} & 00443-00 & 564 & $3833-4003$ & 170 & 653 & \\
\hline & & & $4210-4576$ & 366 & & \\
\hline & & & $4458-4575$ & 117 & & \\
\hline RKD & 00478-00 & 50 & & & & no $100 \mathrm{ft}$ intervals \\
\hline \begin{tabular}{|l|} 
STWWOR \\
\end{tabular} & $00481-00$ & & & & & \\
\hline STW & 00561-00 & & & & & well not deep enough \\
\hline \begin{tabular}{|l|} 
STWWOR \\
\end{tabular} & 01050-00 & & & & & \\
\hline LOC & $01160-00$ & & & & & no f salt \\
\hline \begin{tabular}{|l|} 
STWWOR \\
\end{tabular} & $02286-00$ & & & & & \\
\hline STWWOR & $02308-00$ & & & & & \\
\hline \begin{tabular}{|l|} 
STWWOR \\
\end{tabular} & $02679-00$ & & & & & \\
\hline \begin{tabular}{|l|} 
STWWOR \\
\end{tabular} & $02967-00$ & & & & & \\
\hline \begin{tabular}{|l|} 
RKD \\
\end{tabular} & 03199-00 & 0 & & 0 & & no salt \\
\hline \begin{tabular}{|l|} 
RKD \\
\end{tabular} & $03264-00$ & & & & & no logs \\
\hline \begin{tabular}{|l|} 
STWWOR \\
\end{tabular} & $03277-00$ & & & & & \\
\hline \begin{tabular}{|l|} 
FR \\
\end{tabular} & $03305-00$ & & & & & only caliper log available \\
\hline \begin{tabular}{|l|} 
STWWOR \\
\end{tabular} & $03865-00$ & & & & & \\
\hline \begin{tabular}{|l|} 
STWWOR \\
\end{tabular} & 03866-00 & & & & & \\
\hline \begin{tabular}{|l} 
STW \\
\end{tabular} & 03880-00 & 57 & & 0 & & no $100 \mathrm{ft}$ intervals \\
\hline \multirow[t]{2}{*}{ STW } & 03894-00 & 390 & $4840-4975$ & 135 & 240 & \\
\hline & & & $4500-4605$ & 105 & & \\
\hline RKD & 03904-00 & 0 & & 0 & & no f salt \\
\hline RKD & 03924-00 & 338 & $4545-4660$ & 115 & & \\
\hline \multirow{2}{*}{ RKD } & 03938-00 & 339 & $1706-1846$ & 140 & 272 & \\
\hline & & & $1994-2126$ & 132 & & \\
\hline STWWOR & $03939-00$ & & & & & \\
\hline \multirow[t]{2}{*}{ STW } & $03940-00$ & 348 & $1938-2136$ & 198 & 334 & \\
\hline & & & $2276-2412$ & 136 & & \\
\hline STW & 03942-00 & 5 & & 0 & & no $100 \mathrm{ft}$ intervals \\
\hline STW & 03956-00 & 20 & & 0 & & no $100 \mathrm{ft}$ intervals \\
\hline STW & 03970-00 & 0 & & 0 & & no f salt \\
\hline STW & 03971-00 & 0 & & 0 & & no f salt \\
\hline \multirow[t]{3}{*}{ RKD } & $03973-00$ & 730 & $2927-3111$ & 184 & 656 & \\
\hline & & & $3320-3620$ & 300 & & \\
\hline & & & $3710-3882$ & 172 & & \\
\hline STW & 03991-00 & 36 & & 0 & 0 & \\
\hline RKD & 03993-00 & 0 & & 0 & & no f salt \\
\hline STW & 03997-00 & 47 & & 0 & & no $100 \mathrm{ft}$ intervals \\
\hline \begin{tabular}{|l|} 
STWWOR \\
\end{tabular} & 03999-00 & 0 & & 0 & & no f salt \\
\hline \begin{tabular}{|l} 
STW \\
\end{tabular} & $04002-00$ & 0 & & 0 & & no f salt \\
\hline STW & 04005-00 & 15 & & 0 & & no $100 \mathrm{ft}$ intervals \\
\hline \multirow[t]{3}{*}{ RKD } & \begin{tabular}{|l|}
$04007-00$ \\
\end{tabular} & 772 & $2945-3078$ & 133 & 470 & \\
\hline & & & $3140-3245$ & 105 & & \\
\hline & & & $3700-3825$ & 125 & & \\
\hline
\end{tabular}




\begin{tabular}{|c|c|c|c|c|c|c|}
\hline $\begin{array}{c}\text { Study } \\
\text { (see key at bottom } \\
\text { of column) }\end{array}$ & $\begin{array}{c}\text { SAPINO } \\
\text { (short API) }\end{array}$ & \begin{tabular}{|c|}
\multicolumn{1}{c|}{ Net } \\
Thickness F- \\
unit salt (ft.)
\end{tabular} & $\begin{array}{c}\text { Intervals of Salt Suitable for } \\
\text { Cavern Development } \\
\text { (> 100ft of continuous salt with less } \\
\text { than } 10 \mathrm{ft} \text {. of nonsalt layers) }\end{array}$ & $\begin{array}{c}\text { Thickness of Salt } \\
\text { Suitable for Cavern } \\
\text { Development (ft) (when } \\
\text { more than one interval of } \\
\text { salt is present, the greatest } \\
\text { is used for mapping) }\end{array}$ & $\begin{array}{l}\text { Net Thickness of } \\
\text { Salt Suitable for } \\
\text { Cavern } \\
\text { Development (ft.) }\end{array}$ & Comments \\
\hline & & & $3838-3945$ & 107 & & \\
\hline STW & 04008-00 & 0 & & 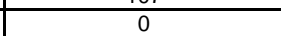 & & 0 no f salt \\
\hline STW & 04027-00 & 62 & & 0 & & no $100 \mathrm{ft}$ intervals \\
\hline STW & $04035-00$ & 0 & & 0 & & no f salt \\
\hline STW & 04053-00 & 39 & & 0 & & no $100 \mathrm{ft}$ intervals \\
\hline RKD & $04055-00$ & 0 & & 0 & & no f salt \\
\hline RKD & $04068-00$ & 0 & & 0 & & ono f salt \\
\hline RKD & $04069-00$ & 0 & & 0 & & o poor logs \\
\hline RKD & $04073-00$ & 0 & & 0 & & no f salt \\
\hline RKD & $04082-00$ & 0 & & 0 & & ono f salt \\
\hline RKD & $04085-00$ & & & & & no logs available for interval \\
\hline RKD & $04092-00$ & 0 & & 0 & & ono f salt \\
\hline \multirow[t]{2}{*}{ RKD } & $04130-00$ & 334 & $3047-3183$ & 136 & 236 & \\
\hline & & & $3415-3515$ & 100 & & \\
\hline STWWOR & 04151-00 & 0 & & 0 & & no $f$ salt-log is bad in this section \\
\hline \begin{tabular}{|l} 
STW \\
\end{tabular} & $04162-00$ & 98 & & 0 & 0 & 0 \\
\hline \begin{tabular}{|l|} 
STWWOR \\
\end{tabular} & \begin{tabular}{|l|}
$04188-00$ \\
\end{tabular} & & & & & \\
\hline RKD & $04248-00$ & 0 & & 0 & & 0 no salt \\
\hline STW & 04447-00 & 0 & & 0 & & 0 no f salt \\
\hline RKD & 04467-00 & 482 & $2846-3140$ & 294 & 294 & \\
\hline STW & 04531-00 & 5 & & 0 & & no $100 \mathrm{ft}$ intervals \\
\hline STW & $04536-00$ & 7 & & 0 & & ono $100 \mathrm{ft}$ intervals \\
\hline STW & $04630-00$ & 89 & & 0 & & no $100 \mathrm{ft}$ intervals \\
\hline STW & 04714-00 & 0 & & 0 & & no usable salt \\
\hline STW & |04796-00 & 53 & & 0 & & no $100 \mathrm{ft}$ intervals \\
\hline RKD & $04902-00$ & 64 & & 0 & & ono $100 f t$ intervals \\
\hline RKD & $05087-00$ & 241 & & 0 & & no $100 \mathrm{ft}$ intervals \\
\hline LOC & $09235-00$ & 25 & & 0 & & no $100 \mathrm{ft}$ intervals \\
\hline STW & 09846-00 & 0 & & 0 & & ono salt \\
\hline LOC & \begin{tabular}{|l|}
$09848-00$ \\
\end{tabular} & 218 & $4600-4773$ & 173 & 173 & \\
\hline LOC & $10138-00$ & 7 & & 0 & & ono $100 \mathrm{ft}$ intervals \\
\hline STW & $10243-00$ & 64 & & 0 & & ono $100 \mathrm{ft}$ intervals \\
\hline \begin{tabular}{|l|l|} 
LOC \\
\end{tabular} & $10609-00$ & 0 & & 0 & & ono f salt \\
\hline \multirow[t]{2}{*}{ FR } & $12149-00$ & 317 & $2550-2660$ & 110 & 228 & \\
\hline & & & $2400-2518$ & 118 & & \\
\hline LOC & $12195-00$ & 43 & & 0 & 0 & no 100ft intervals \\
\hline \multirow[t]{2}{*}{ FR } & $12402-00$ & 370 & $4345-4610$ & 265 & 390 & \\
\hline & & & $4860-4985$ & 125 & & \\
\hline \multirow[t]{2}{*}{ FR } & $12858-00$ & 316 & $2036-2238$ & 202 & 304 & \\
\hline & & & $2398-2500$ & 102 & & \\
\hline \begin{tabular}{|l|l|} 
FR \\
\end{tabular} & $12859-00$ & 251 & $2530-2644$ & 114 & 114 & \\
\hline LOC & $13173-00$ & 369 & $1939-2042$ & 103 & 103 & \\
\hline LOC & $13308-00$ & 0 & & 0 & & no salt in $f$ unit \\
\hline \begin{tabular}{|l|} 
FR \\
\end{tabular} & $13699-00$ & 242 & $3428-3568$ & 140 & 140 & \\
\hline FR & $13736-00$ & 269 & $3236-3371$ & 135 & 135 & \\
\hline FR & 15834-00 & 182 & & 0 & & $\begin{array}{l}0 \text { no usable salt } \\
\end{array}$ \\
\hline LOC & $18651-00$ & 0 & & 0 & & 0 no salt in $\mathrm{f}$ unit \\
\hline \begin{tabular}{|l|l|} 
FR \\
\end{tabular} & 19484-00 & 254 & $2474-2593$ & 119 & 119 & \\
\hline FR & 19497-00 & 134 & $2836-2944$ & 112 & 112 & \\
\hline FR & 19540-00 & 280 & $3150-3275$ & 125 & 125 & \\
\hline
\end{tabular}




\begin{tabular}{|c|c|c|c|c|c|c|}
\hline $\begin{array}{c}\text { Study } \\
\text { (see key at bottom } \\
\text { of column) }\end{array}$ & $\begin{array}{c}\text { SAPINO } \\
\text { (short API) }\end{array}$ & \begin{tabular}{|c|}
\multicolumn{1}{c|}{ Net } \\
Thickness F- \\
unit salt (ft.)
\end{tabular} & $\begin{array}{c}\text { Intervals of Salt Suitable for } \\
\text { Cavern Development } \\
\text { (> 100ft of continuous salt with less } \\
\text { than } 10 \mathrm{ft} \text {. of nonsalt layers) }\end{array}$ & \begin{tabular}{|c} 
Thickness of Salt \\
Suitable for Cavern \\
Development (ft) (when \\
more than one interval of \\
salt is present, the greatest \\
is used for mapping)
\end{tabular} & $\begin{array}{l}\text { Net Thickness of } \\
\text { Salt Suitable for } \\
\text { Cavern } \\
\text { Development (ft.) }\end{array}$ & Comments \\
\hline FR & $19686-00$ & 204 & $2005-2120$ & 115 & 115 & \\
\hline \multirow[t]{2}{*}{ FR } & $19692-00$ & 416 & $2790-3100$ & 310 & 451 & \\
\hline & & & $3149-3290$ & 141 & & \\
\hline \multirow[t]{2}{*}{ LOC } & 20023-00 & 42 & & 0 & \multicolumn{2}{|r|}{0 no usable salt } \\
\hline & 20446-00 & 0 & & 0 & \multicolumn{2}{|r|}{$\begin{array}{l}\text { ? Friedman didn't say there was salt } \\
\text { here }\end{array}$} \\
\hline LOC & 20562-00 & 80 & & 0 & \multicolumn{2}{|r|}{ olno usable salt } \\
\hline LOC & $21005-00$ & 0 & & 0 & \multirow{2}{*}{\multicolumn{2}{|c|}{0 no salt in F-unit, raster not saved }} \\
\hline LOC & 21113-00 & 64 & & 0 & & \\
\hline LOC & 21115-00 & 78 & & 0 & \multicolumn{2}{|r|}{0 no usable salt } \\
\hline FR & 21468-00 & 270 & $3810-3920$ & 110 & 110 & \\
\hline \multirow[t]{2}{*}{ FR } & 21495-00 & 410 & $4425-4587$ & 162 & 422 & \\
\hline & & & $4108-4368$ & 260 & & \\
\hline FR & 21496-00 & 160 & & 0 & \multirow{2}{*}{\multicolumn{2}{|c|}{\begin{tabular}{l|l|}
0 & no $100 \mathrm{ft}$ intervals \\
0
\end{tabular}}} \\
\hline FR & $21500-00$ & 125 & & 0 & \multirow{2}{*}{\multicolumn{2}{|c|}{\begin{tabular}{r|r|}
0 & no $100 \mathrm{ft}$ intervals \\
\end{tabular}}} \\
\hline LOC & $21551-00$ & 271 & $3050-3257$ & 187 & & \\
\hline LOC & 21584-00 & 315 & $3004-3269$ & 265 & 265 & \\
\hline \multirow[t]{2}{*}{ LOC } & $21587-00$ & 457 & $2997-336$ & 363 & 473 & \\
\hline & & & $3410-3520$ & 110 & & \\
\hline LOC & $21588-00$ & 302 & $3109-3350$ & 241 & 241 & \\
\hline LOC & $21589-00$ & 412 & $3008-3310$ & 302 & 302 & \\
\hline LOC & 21718-00 & 86 & & 0 & \multicolumn{2}{|c|}{\begin{tabular}{l|l|}
0 & no usable salt \\
\end{tabular}} \\
\hline LOC & 21809-00 & 0 & & 0 & \multirow{2}{*}{\multicolumn{2}{|c|}{\begin{tabular}{l|l}
0 & no salt in $\mathrm{f}$ unit \\
0 & no salt in $\mathrm{f}$ unit
\end{tabular}}} \\
\hline LOC & 22498-00 & 0 & & 0 & & \\
\hline LOC & $22743-00$ & 184 & $2120-2226$ & 106 & \multicolumn{2}{|c|}{\begin{tabular}{r|r}
0 & no salt in $\mathrm{f}$ unit \\
106 &
\end{tabular}} \\
\hline LOC & $22753-00$ & 100 & $2620-2780$ & 160 & \multicolumn{2}{|c|}{160} \\
\hline LOC & 22754-00 & 294 & $3158-3288$ & 130 & 130 & \\
\hline LOC & $22758-00$ & 110 & & & \multicolumn{2}{|c|}{\begin{tabular}{l|l} 
no usable salt
\end{tabular}} \\
\hline LOC & $22793-00$ & 189 & $2475-2637$ & 162 & \multirow{2}{*}{\multicolumn{2}{|c|}{\begin{tabular}{r|r|}
162 & no $100 \mathrm{ft}$ intervals \\
0 & no $100 \mathrm{ft}$ intervals
\end{tabular}}} \\
\hline LOC & $22797-00$ & 168 & & 0 & & \\
\hline \multirow[t]{2}{*}{ LOC } & 22814-00 & 516 & $4220-4425$ & 205 & \multicolumn{2}{|c|}{\begin{tabular}{r|l}
0 & no $100 \mathrm{ft}$ intervals \\
\end{tabular}} \\
\hline & & & $4438-4620$ & 102 & \multicolumn{2}{|l|}{205} \\
\hline \multirow[t]{2}{*}{ LOC } & $22827-00$ & 430 & $4110-4247$ & 137 & 336 & \\
\hline & & & $3789-3990$ & 199 & & \\
\hline LOC & $22830-00$ & 483 & $3630-3730$ & 100 & 230 & \\
\hline & & & 4104-4234 & 130 & & \\
\hline LOC & 22831-00 & 512 & $4070-4286$ & 216 & 402 & \\
\hline & & & $4314-4500$ & 186 & & \\
\hline LOC & $22839-00$ & 701 & $3453-3776$ & 323 & 543 & \\
\hline & & & $3953-4173$ & 220 & & \\
\hline LOC & $22850-00$ & 89 & & 0 & 0 & no $100 \mathrm{ft}$ intervals \\
\hline LOC & $22853-00$ & 467 & $4017-4365$ & 340 & 340 & \\
\hline LOC & $22859-00$ & 67 & & & & no usable salt \\
\hline LOC & $22861-00$ & 646 & $4320-4550$ & 230 & 710 & \\
\hline & & & $4710-4990$ & 280 & & \\
\hline & & & $5087-5287$ & 200 & & \\
\hline LOC & 22871-00 & 455 & $4062-4290$ & 228 & 370 & \\
\hline & & & $4398-4540$ & 142 & & \\
\hline LOC & 22884-00 & 483 & $3821-4201$ & 380 & 491 & \\
\hline & & & $4254-4365$ & 111 & & \\
\hline
\end{tabular}




\begin{tabular}{|c|c|c|c|c|c|c|}
\hline $\begin{array}{c}\text { Study } \\
\text { (see key at bottom } \\
\text { of column) }\end{array}$ & $\begin{array}{c}\text { SAPINO } \\
\text { (short API) }\end{array}$ & \begin{tabular}{|c|} 
Net \\
Thickness F- \\
unit salt (ft.)
\end{tabular} & $\begin{array}{c}\text { Intervals of Salt Suitable for } \\
\text { Cavern Development } \\
\text { (> 100ft of continuous salt with less } \\
\text { than } 10 \mathrm{ft} \text {. of nonsalt layers) }\end{array}$ & 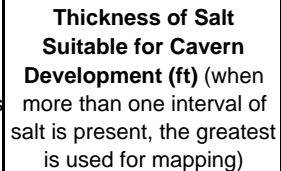 & $\begin{array}{l}\text { Net Thickness of } \\
\text { Salt Suitable for } \\
\text { Cavern } \\
\text { Development (ft.) }\end{array}$ & Comments \\
\hline \multirow[t]{3}{*}{ LOC } & $22885-00$ & 485 & $3777-3972$ & 195 & 432 & \\
\hline & & & $3991-4101$ & 110 & & \\
\hline & & & $4313-4440$ & 127 & & \\
\hline \multirow[t]{2}{*}{ LOC } & 22891-00 & 386 & $4310-4528$ & 218 & 333 & \\
\hline & & & $4680-4795$ & 115 & & \\
\hline \multirow[t]{2}{*}{ LOC } & $22899-00$ & 406 & $4610-4830$ & 220 & 347 & \\
\hline & & & $4953-5080$ & 127 & & \\
\hline \multirow[t]{3}{*}{ LOC } & 22901-00 & 531 & $3290-3554$ & $\frac{121}{264}$ & 490 & \\
\hline & & & $3610-3721$ & 111 & & \\
\hline & & & $3851-3966$ & 115 & & \\
\hline LOC & 22902-00 & 360 & $3960-4227$ & $\frac{115}{267}$ & 267 & \\
\hline \multirow[t]{2}{*}{ LOC } & 22911-00 & 494 & $4233-4672$ & 439 & 569 & \\
\hline & & & $4830-4960$ & 130 & & \\
\hline \multirow[t]{2}{*}{ LOC } & 22918-00 & 523 & $3650-3910$ & 260 & 364 & \\
\hline & & & $3950-4054$ & 104 & & \\
\hline \multirow[t]{2}{*}{ LOC } & 22919-00 & 400 & $4290-4490$ & 200 & 323 & \\
\hline & & & $4657-4780$ & 123 & & \\
\hline \multirow[t]{2}{*}{ LOC } & $22924-00$ & 382 & $3846-4166$ & 320 & 420 & \\
\hline & & & $4190-4290$ & 100 & & \\
\hline \multirow[t]{2}{*}{ LOC } & $22933-00$ & 608 & $4257-4725$ & 468 & 596 & \\
\hline & & & $4880-5008$ & 128 & & \\
\hline LOC & 22934-00 & 176 & $5975-6080$ & 105 & 105 & \\
\hline \multirow[t]{3}{*}{ LOC } & $22935-00$ & 850 & $2566-3008$ & 442 & 645 & \\
\hline & & & $3414-3515$ & 101 & & \\
\hline & & & $3550-3652$ & $\frac{101}{102}$ & & \\
\hline LOC & $22939-00$ & 32 & & 0 & & ono usable salt \\
\hline \multirow[t]{2}{*}{ LOC } & 22942-00 & 556 & 3584-3897 & 313 & 508 & \\
\hline & & & $4135-4330$ & 195 & & \\
\hline LOC & $22950-00$ & 331 & $2426-2690$ & $\frac{105}{246}$ & 246 & \\
\hline LOC & 22995-00 & 127 & $5785-5920$ & 135 & 135 & \\
\hline LOC & $23247-00$ & 0 & & 0 & & nno salt in $\mathrm{f}$ unit \\
\hline LOC & $23435-00$ & 27 & & 0 & & no $100 \mathrm{ft}$ intervals \\
\hline $\begin{array}{ll}\text { FR } \\
\text { PR }\end{array}$ & $\frac{\mid 61192-00}{61190}$ & $\begin{aligned} 148 \\
\end{aligned}$ & $2060-2222$ & 162 & 162 & not complete log of interval \\
\hline \multirow[t]{2}{*}{ FR } & $61205-00$ & 336 & $2530-2642$ & $\frac{104}{112}$ & 214 & \\
\hline & & & $2150-2252$ & 102 & & \\
\hline \multirow[t]{2}{*}{ FR } & 61206-00 & 421 & $2294-2424$ & 130 & 302 & \\
\hline & & & $2434-2606$ & 172 & & \\
\hline
\end{tabular}

LOC $=$ current NYSM study

FR = Friedman et al., 2002

STW $=$ Stone and Webster Eng. Report, 1978

STWOR = Stone and Webster Eng. Report, 1978 (well without raster log)

RKD = Rickard, 1963 
Appendix A - Table 3 - Formation Tops

\begin{tabular}{|c|c|c|c|c|c|c|c|c|c|c|c|c|c|c|c|c|c|c|c|c|c|c|}
\hline \multirow{2}{*}{ API Number } & \multirow[b]{2}{*}{$\begin{array}{l}\text { Well } \\
\text { Label }\end{array}$} & \multirow[b]{2}{*}{ 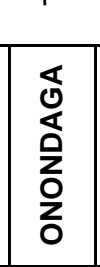 } & \multirow[b]{2}{*}{ 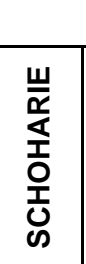 } & \multirow[b]{2}{*}{ 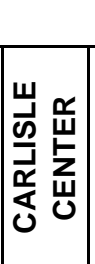 } & \multirow[b]{2}{*}{ 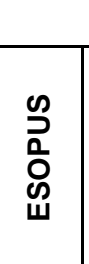 } & \multirow[b]{2}{*}{ 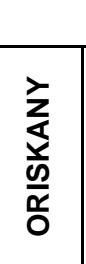 } & \multirow[b]{2}{*}{ 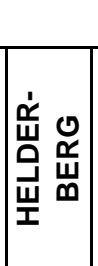 } & \multirow[b]{2}{*}{$\begin{array}{l}\text { 岀 } \\
\text { 范 } \\
\text { 岕 }\end{array}$} & \multirow[b]{2}{*}{ 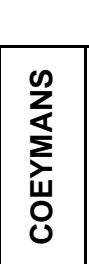 } & \multirow[b]{2}{*}{$\frac{\mathfrak{n}}{\sum}$} & \multirow[b]{2}{*}{ 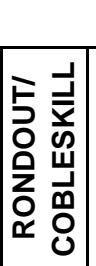 } & \multirow[b]{2}{*}{ 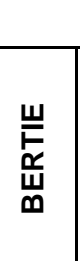 } & \multirow[b]{2}{*}{ 点 } & \multicolumn{3}{|c|}{ Syracuse } & \multicolumn{3}{|c|}{ Vernon } & \multirow[b]{2}{*}{ 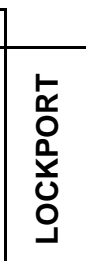 } & \multirow[b]{2}{*}{$\begin{array}{l}z \\
0 \\
\frac{1}{Z} \\
0 \\
0\end{array}$} & \multirow[b]{2}{*}{ 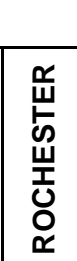 } \\
\hline & & & & & & & & & & & & & & 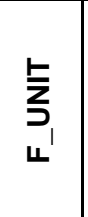 & $\underset{\text { 山' }}{\stackrel{⺊}{\supset}}$ & 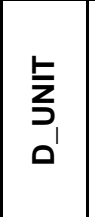 & 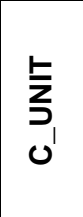 & $\begin{array}{l}\mathfrak{\vdots} \\
\frac{5}{\infty}\end{array}$ & 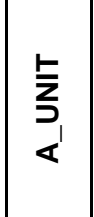 & & & \\
\hline 31101002160000 & 00216 & & & & & & & & & & & & & 5872 & 6631 & & & & & & & \\
\hline 31003002460000 & 00246 & & & & & & & & & & & & & 4620 & \begin{tabular}{|l|}
4812 \\
\end{tabular} & & & & & & & \\
\hline 31101003290000 & 00329 & & & & & & & & & & & & & 3127 & 3587 & & & & & & & \\
\hline 31015004430000 & 00443 & & & & & & & & & & & & & 3700 & 4582 & & & & & & & \\
\hline 31011004780000 & 00478 & & & & & & & & & & & & & 1425 & 1750 & & & & & & & \\
\hline 31109004810000 & 00481 & & & & & & & & & & & & & 3062 & 3432 & & & & & & & \\
\hline 31097005610000 & 00561 & & & & & & & & & & & & & 2156 & 2600 & & & & & & & \\
\hline 31011010500000 & 01050 & & & & & & & & & & & & & 1338 & & & & & & & & \\
\hline 31003011590000 & 01159 & & & & & & & & & & & & & 4197 & 4442 & & & & & & & \\
\hline 31017011600000 & 01160 & & & & & & & & & & & & & 2053 & 2111 & & & & & & & \\
\hline 31109022860000 & 02286 & & & & & & & & & & & & & 1813 & 2494 & & & & & & & \\
\hline 31023023080000 & 02308 & & & & & & & & & & & & & \begin{tabular}{|l|}
4229 \\
\end{tabular} & & & & & & & & \\
\hline 31101026790000 & 02679 & & & & & & & & & & & & & 2951 & & & & & & & & \\
\hline 31003029670000 & 02967 & & & & & & & & & & & & & 5099 & 5194 & & & & & & & \\
\hline 31111031990000 & 03199 & 5195 & 5289 & 5348 & 5450 & 5580 & 5650 & 5700 & 5739 & 5877 & 5932 & 5980 & 6025 & 6045 & 6092 & 6125 & 6135 & & & & & \\
\hline 31003032640000 & 03264 & & & & & & & & & & & & & 4055 & 4244 & & & & & & & \\
\hline 31051032770000 & 03277 & & & & & & & & & & & & & 2265 & 2342 & & & & & & & \\
\hline 31051033050000 & 03305 & & & & & & & & & & & & & 3692 & 3786 & & & & & & & \\
\hline 31121038650000 & 03865 & & & & & & & & & & & & & 4030 & & & & & & & & \\
\hline 31069038660000 & 03866 & & & & & & & & & & & & & 2245 & 2435 & & & & & & & \\
\hline 31121038800000 & 03880 & & & & & & & & & & & & & 3229 & 3319 & & & & & & & \\
\hline 31101038940000 & 03894 & & & & & & & & & & & & & \begin{tabular}{|l|}
4345 \\
\end{tabular} & \begin{tabular}{|l|}
4985 \\
\end{tabular} & & & & & & & \\
\hline 31101039240000 & 03924 & 4045 & & & & 4075 & & & 4135 & 4175 & 4210 & 4280 & 4365 & 4450 & 4970 & 5337 & 5420 & 5922 & 5995 & 6380 & 6669 & 6529 \\
\hline 31109039380000 & 03938 & & & & & & & & & & & & & 1674 & & & & & & & & \\
\hline 31097039400000 & 03940 & & & & & & & & & & & & & 1930 & 2403 & & & & & & & \\
\hline 31051039420000 & 03942 & & & & & & & & & & & & & 2162 & 2252 & & & & & & & \\
\hline 31003039560000 & 03956 & 2700 & & & & & & & & & 2800 & 2810 & 2902 & 2957 & 3052 & 3167 & 3204 & 3375 & 3495 & & 3825 & \\
\hline 31053039700000 & 03970 & \begin{tabular}{|l|}
1250 \\
\end{tabular} & & & & 1320 & 1330 & & & & \begin{tabular}{|l|}
1502 \\
\end{tabular} & 1576 & \begin{tabular}{|l|}
1667 \\
\end{tabular} & 1795 & 1885 & \begin{tabular}{|l|}
1995 \\
\end{tabular} & 2040 & 2200 & 2300 & & 2561 & \\
\hline 31069039710000 & 03971 & & & & & & & & & & & & & 1180 & 1297 & & & & & & & \\
\hline 31109039730000 & 03973 & 2359 & & & & 2420 & 2440 & & 2440 & 2515 & 2615 & 2725 & 2810 & 2873 & 3857 & \begin{tabular}{|l|}
4025 \\
\end{tabular} & 4118 & 4372 & 4490 & 4832 & 5100 & 4970 \\
\hline 31069039910000 & 03991 & & & & & & & & & & & & & 1564 & 1669 & & & & & & & \\
\hline 31043039930000 & 03993 & & & & & & & & & & & & & 647 & 727 & & & & & & & \\
\hline 31069039970000 & 03997 & & & & & & & & & & & & & 967 & 1057 & & & & & & & \\
\hline 31053040020000 & 04002 & 1342 & & & & 1391 & 1398 & & 1577 & & 1577 & 1652 & 1730 & \begin{tabular}{|l|}
1877 \\
\end{tabular} & 1952 & \begin{tabular}{|l|}
2012 \\
\end{tabular} & 2100 & 2265 & 2307 & & 2630 & \\
\hline
\end{tabular}




\begin{tabular}{|c|c|c|c|c|c|c|c|c|c|c|c|c|c|c|c|c|c|c|c|c|c|c|}
\hline \multirow[b]{2}{*}{ API Number } & \multirow[b]{2}{*}{$\begin{array}{l}\text { Well } \\
\text { Label }\end{array}$} & & & & & & & & & & & & & \multicolumn{3}{|c|}{ Syracuse } & \multicolumn{3}{|c|}{ Vernon } & \multirow[b]{2}{*}{ 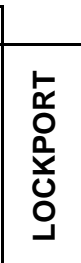 } & \multirow[b]{2}{*}{$\begin{array}{l}z \\
o \\
\underline{J} \\
0\end{array}$} & \multirow[b]{2}{*}{ 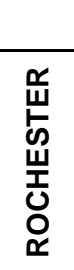 } \\
\hline & & 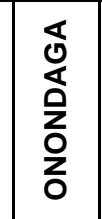 & 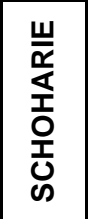 & 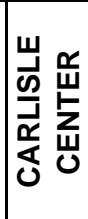 & $\begin{array}{l}\mathscr{N} \\
\stackrel{0}{0} \\
0 \\
\mathscr{W}\end{array}$ & 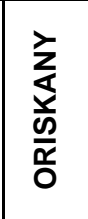 & 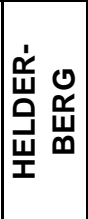 & 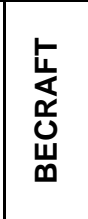 & $\sum_{\substack{\text { D } \\
0}}^{\infty}$ & $\frac{n}{2}$ & 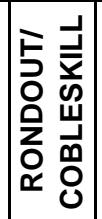 & 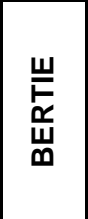 & & $\begin{array}{l}\stackrel{5}{\mathbf{z}} \\
\vec{L} \\
\end{array}$ & $\begin{array}{l}\text { 言 } \\
\text { 工 } \\
\text { w }\end{array}$ & 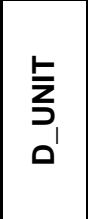 & $\begin{array}{l}\mathbf{E} \\
\mathbf{z} \\
0\end{array}$ & $\begin{array}{l}\stackrel{5}{\mathbf{z}} \\
\mathbf{m}\end{array}$ & 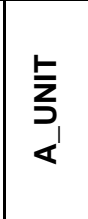 & & & \\
\hline 31069040050000 & 04005 & & & & & & & & & & & & & 1270 & 1358 & & & & & & & \\
\hline 31109040070000 & 04007 & 2327 & & & & 2475 & & & 2487 & 2490 & 2590 & 2687 & 2787 & 2860 & 3930 & 4085 & 4175 & 4442 & 4525 & 4890 & 5170 & 5012 \\
\hline 31121040080000 & 04008 & 900 & & & & & & & & & & 1040 & 1100 & 1169 & 1255 & 1340 & 1350 & 1480 & 1580 & & 1760 & \\
\hline 31069040270000 & 04027 & & & & & & & & & & & & & 1730 & 1854 & & & & & & & \\
\hline 31069040350000 & 04035 & & & & & & & & & & & & & 1666 & 1759 & & & & & & & \\
\hline 31051040530000 & 04053 & & & & & & & & & & & & & 1623 & 1713 & & & & & & & \\
\hline 31077040550000 & 04055 & 1725 & 1830 & 1842 & 1870 & & & & 1895 & 2025 & 2130 & 2175 & & 2250 & 2307 & 2360 & & & & & & \\
\hline 31011040680000 & 04068 & 55 & & & & 155 & & & & 165 & 185 & 230 & 310 & 390 & 513 & 650 & 660 & 885 & 984 & 1225 & 1560 & 1383 \\
\hline 31051040690000 & 04069 & & & & & & & & & & & & & 695 & 780 & & & & & & & \\
\hline 31025040730000 & 04073 & 3946 & 4032 & 408 & 4110 & 4130 & 4132 & 4190 & 4220 & 4374 & 4408 & 4488 & 4556 & 4669 & 4721 & 4816 & 4840 & & & & 5186 & 5188 \\
\hline 31099040820000 & 04082 & 15 & & & & & & & & & 100 & 115 & \begin{tabular}{|l|}
180 \\
\end{tabular} & 265 & 386 & \begin{tabular}{|l|}
511 \\
\end{tabular} & 530 & 745 & 846 & & 1098 & \\
\hline 31053040850000 & 04085 & & & & & & & & & & & & & 1465 & 1568 & & & & & & & \\
\hline 31121040920000 & 04092 & 2010 & & & & & & & & & & 2155 & 2205 & 2255 & 2355 & 2466 & 2478 & 2614 & 2740 & 2910 & 3110 & 3065 \\
\hline 31109041300000 & 04130 & 2500 & & & & 2545 & & & 2570 & 2655 & 2745 & 2825 & 2935 & 3034 & 3502 & 3650 & 3749 & 3975 & 4100 & 4430 & 4675 & 4540 \\
\hline 31051041510000 & 04151 & 700 & & & & & & & & & & 850 & \begin{tabular}{|l|}
920 \\
\end{tabular} & 985 & 1065 & 1130 & 1150 & 1298 & 1480 & & 1585 & \\
\hline 31121041620000 & 04162 & 1712 & & & & 1848 & & & & & & 1856 & 1910 & 1990 & 2150 & & & & & & & \\
\hline 31051041880000 & 04188 & & & & & & & & & & & & & 2510 & 2585 & & & & & & & \\
\hline 31003042480000 & 04248 & 2512 & & & & 2623 & & & & & 2630 & 2643 & 2695 & 2747 & 2863 & 2995 & 3014 & 3175 & 3290 & 3447 & 3650 & 3555 \\
\hline 31011043650000 & 04365 & & & & & & & & & & & & & \begin{tabular}{|l|}
398 \\
\end{tabular} & 500 & & & & & & & \\
\hline 31121043850000 & 04385 & & & & & & & & & & & & & 4063 & & & & & & & & \\
\hline 31097044000000 & 04400 & & & & & & & & & & & & & 1797 & 2417 & & & & & & & \\
\hline 31121044320000 & 04432 & & & & & & & & & & & & & 1345 & 1405 & & & & & & & \\
\hline 31121044470000 & 04447 & 1255 & & & & & & & & & & 1400 & 1450 & 1515 & 1595 & 1690 & 1700 & 1808 & 1911 & & 2070 & \\
\hline 31069044500000 & 04450 & & & & & & & & & & & & & 772 & 875 & & & & & & & \\
\hline 31109044670000 & 04467 & 2260 & & & & 2310 & & & 2342 & 2428 & 2532 & 2620 & 2730 & 2806 & 3456 & 3630 & 3730 & 3979 & 4067 & 4435 & 4695 & 4565 \\
\hline 31051045310000 & 04531 & 810 & & & & & & & & & & \begin{tabular}{|l|}
948 \\
\end{tabular} & 1010 & 2187 & 2267 & 1253 & 1265 & 1390 & 1482 & & 1648 & \\
\hline 31121045360000 & 04536 & 1120 & & & & & & & & & & 1285 & 1320 & 1385 & 1465 & 1565 & 1572 & 21675 & 1775 & & & \\
\hline 31051046300000 & 04630 & 9040 & & & & 1048 & & & & & \begin{tabular}{|l|}
1052 \\
\end{tabular} & 1112 & 1182 & 1257 & 1404 & 1534 & 1584 & 1746 & 1870 & & 2058 & \\
\hline 31023047140000 & 04714 & & & & & & & & & & & & & 4889 & 5274 & & & & & & & \\
\hline 31123047960000 & 04796 & & & & & & & & & & & & & 1356 & 1481 & & & & & & & \\
\hline 31007048540000 & 04854 & 3120 & & & & 3200 & 3218 & & & & 3480 & 3555 & 3694 & 5250 & 5645 & 4320 & 4395 & 54580 & 4660 & 5025 & 5150 & \\
\hline 31067049020000 & 04902 & 617 & & & & 686 & & & & 700 & 751 & 812 & \begin{tabular}{|l|}
906 \\
\end{tabular} & 1020 & 1208 & 1336 & 1362 & 21542 & 1636 & 1890 & 2002 & 1952 \\
\hline 31007050870000 & 05087 & 3100 & & & & 3172 & 3177 & 3227 & 3265 & 3353 & 3440 & 3540 & 3640 & 3812 & 4247 & 4360 & 4400 & 4622 & 4700 & 5090 & 5287 & 5185 \\
\hline 31007066360000 & 06636 & 3095 & & & & & 3217 & & & & 3530 & 3572 & 3853 & 5480 & 5719 & 4370 & 4435 & 4610 & 4687 & 5029 & & 5116 \\
\hline 31007083420000 & 08342 & & & & & & & & & & & & & 5374 & 5760 & & & & & & & \\
\hline
\end{tabular}




\begin{tabular}{|c|c|c|c|c|c|c|c|c|c|c|c|c|c|c|c|c|c|c|c|c|c|c|}
\hline \multirow[b]{2}{*}{ API Number } & \multirow[b]{2}{*}{$\begin{array}{l}\text { Well } \\
\text { Label }\end{array}$} & & & & & & & & & & & & & \multicolumn{3}{|c|}{ Syracuse } & \multicolumn{3}{|c|}{ Vernon } & \multirow[b]{2}{*}{ 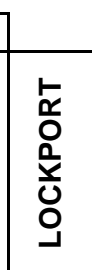 } & \multirow[b]{2}{*}{$\begin{array}{l}z \\
\text { L } \\
\underline{z} \\
u\end{array}$} & \multirow[b]{2}{*}{ 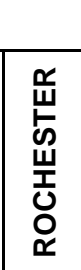 } \\
\hline & & $\begin{array}{l}\mathbb{1} \\
0 \\
\frac{1}{1} \\
\vdots \\
0 \\
\text { ż }\end{array}$ & 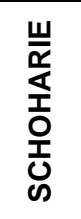 & 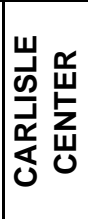 & 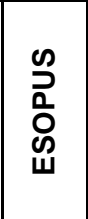 & $\begin{array}{l}\frac{z}{\alpha} \\
\frac{s}{0} \\
\frac{\omega}{\alpha} \\
0\end{array}$ & 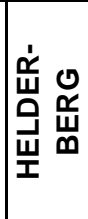 & 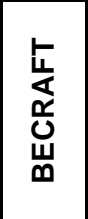 & 点 & $\begin{array}{l}\stackrel{N}{D} \\
\underset{\Sigma}{\Sigma} \\
\Sigma\end{array}$ & 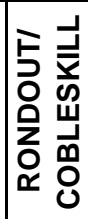 & 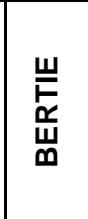 & & $\begin{array}{l}\frac{5}{2} \\
\mathbf{J} \\
\text { L }\end{array}$ & $\begin{array}{l}\text { E } \\
\mathbf{J} \\
\mathbf{w}\end{array}$ & $\begin{array}{l}\frac{\mathbf{z}}{\mathbf{z}} \\
\mathbf{J} \\
\end{array}$ & $\begin{array}{l}\mathbf{E} \\
\mathbf{z} \\
0\end{array}$ & $\begin{array}{l}\mathbf{z} \\
\mathbf{5} \\
\mathbf{\infty}\end{array}$ & 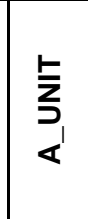 & & & \\
\hline 31009092350000 & 09235 & & & & & & & & & & & & & 7245 & 7380 & & & & & & & \\
\hline 31123098460000 & 09846 & & & & & & & & & & & & & 1328 & 1455 & & & & & & & \\
\hline 31107098480000 & 09848 & 4196 & & & & 4260 & 4290 & & & & & & & 4584 & & & & & & & & \\
\hline 31077101380000 & 10138 & & & & & & & & & & & & & 1927 & 1995 & & & & & & & \\
\hline 31109102430000 & 10243 & & & & & & & & & & & & & 3568 & & & & & & & & \\
\hline 31015103350000 & 10335 & 3398 & & & & 3448 & 3493 & & & & 3770 & 3820 & 3970 & 5458 & 6328 & & 5227 & 5540 & 5690 & 5690 & 6165 & \\
\hline 31017106090000 & 10609 & 3601 & & & & & 3771 & 3754 & 3870 & 4015 & 4125 & 4225 & 4465 & 4778 & 4909 & 4960 & 5035 & 5200 & 5300 & 5690 & 5760 & 5856 \\
\hline 31011121490000 & 12149 & & & & & & & & & & & & & 2338 & 2814 & & & & & & & \\
\hline 31069121950000 & 12195 & & & & & & & & & & & & & \begin{tabular}{|l|}
804 \\
\end{tabular} & 897 & & & & & & & \\
\hline 31101124020000 & 12402 & & & & & & & & & & & & & 3998 & & & & & & & & \\
\hline 31097128580000 & 12858 & & & & & & & & & & & & & 2024 & 2492 & & & & & & & \\
\hline 31097128590000 & 12859 & & & & & & & & & & & & & 2163 & 2639 & & & & & & & \\
\hline 31109131730000 & 13173 & & & & & & & & & & & & & 1930 & 2569 & & & & & & & \\
\hline 31121133080000 & 13308 & & & & & & & & & & & & & 2501 & 2597 & & & & & & & \\
\hline 31101136990000 & 13699 & & & & & & & & & & & & & 3173 & 3543 & & & & & & & \\
\hline 31101137360000 & 13736 & & & & & & & & & & & & & 2999 & 3479 & & & & & & & \\
\hline 31003155120000 & 15512 & 2766 & & & & & 2796 & & & & 2827 & 2876 & 2931 & 3028 & 3130 & 3184 & 3272 & 3423 & 3555 & 3728 & 3919 & 3950 \\
\hline 31101158340000 & 15834 & & & & & & & & & & & & & 4841 & 5238 & & & & & & & \\
\hline 31003186510000 & 18651 & & & & & & & & & & & & & 3179 & 3274 & & & & & & & \\
\hline 31023194840000 & 19484 & & & & & & & & & & & & & 2458 & 2856 & & & & & & & \\
\hline 31101194970000 & 19497 & & & & & & & & & & & & & 2728 & 2902 & & & & & & & \\
\hline 31023195400000 & 19540 & & & & & & & & & & & & 2930 & 3090 & 3472 & 3512 & 3445 & 3805 & 3915 & & 4205 & \\
\hline 31099196860000 & 19686 & 1548 & & & & & 1592 & & & & 1675 & 1735 & 1810 & 1912 & 2225 & 2345 & 2447 & 2710 & 2825 & 3097 & 3235 & \\
\hline 31097196920000 & 19692 & & & & & & 2425 & & & & 2550 & 2600 & 2697 & 2792 & 3298 & 3445 & 3570 & 3660 & 2770 & 4270 & 4440 & \\
\hline 31003200230000 & 20023 & 3619 & & & & & 3690 & & & & 3721 & 3755 & 3813 & 3885 & 4014 & 4133 & 4230 & 4428 & 4500 & 4680 & 4900 & \\
\hline 31099204460000 & 20446 & \begin{tabular}{|l|}
815 \\
\end{tabular} & & & & 870 & 878 & & & & 915 & 980 & 1053 & 1161 & 1301 & 1400 & 1500 & 1704 & 1855 & 2110 & 2232 & 2382 \\
\hline 31123205620000 & 20562 & 1305 & & & & & 1355 & & & & & 1430 & 1468 & 1550 & 1720 & 1838 & 1956 & 2265 & 2340 & 2580 & & 2680 \\
\hline 31025210050000 & 21005 & 3420 & 3510 & 3560 & 3580 & & & 3640 & 3675 & 3844 & 3875 & 3950 & 4050 & 4142 & 4195 & 4270 & 4300 & 4505 & 4582 & 4653 & & 4727 \\
\hline 31003211130000 & 21113 & 4070 & & & & & 4130 & & & & 4195 & 4230 & 4290 & 4352 & 4530 & 4650 & 4745 & 5025 & 5090 & 5303 & & 5420 \\
\hline 31003211150000 & 21115 & 3252 & & & & & 3270 & & & & 3354 & 3394 & 3456 & 3520 & 3695 & 3819 & 3919 & 4170 & 4210 & 4410 & 4410 & 4538 \\
\hline 31101214680000 & 21468 & 3162 & & & & & & & & & 3225 & 3282 & 3358 & 3426 & 3925 & 4126 & 4230 & 4330 & 4380 & 4503 & 4656 & \\
\hline 31097214950000 & 21495 & 3513 & & & & & & & & 3668 & 3795 & 3892 & 3950 & 4065 & 4590 & & & & & 5610 & 5915 & \\
\hline 31101214960000 & 21496 & 3260 & & & & & & & 3276 & 3290 & 3329 & 3386 & 3456 & 3527 & 3800 & 3936 & 4037 & 4228 & 4304 & 4424 & & \\
\hline 31023215000000 & 21500 & 2302 & & & & 2352 & & & 2362 & 2415 & 2525 & 2602 & 2695 & 2870 & 3075 & 3205 & 3265 & 3444 & 3580 & 3870 & & 3980 \\
\hline 31101215510000 & 21551 & 2620 & & & & & 2652 & & & & 2760 & 2855 & 2965 & 3052 & 3450 & 3495 & 3720 & 4050 & 4178 & 4435 & & \\
\hline
\end{tabular}




\begin{tabular}{|c|c|c|c|c|c|c|c|c|c|c|c|c|c|c|c|c|c|c|c|c|c|c|}
\hline \multirow[b]{2}{*}{ API Number } & \multirow[b]{2}{*}{$\begin{array}{l}\text { Well } \\
\text { Label }\end{array}$} & & & & & & & & & & & & & \multicolumn{3}{|c|}{ Syracuse } & \multicolumn{3}{|c|}{ Vernon } & \multirow[b]{2}{*}{ 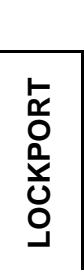 } & \multirow[b]{2}{*}{$\begin{array}{l}z \\
\stackrel{Z}{E} \\
\vdots \\
u\end{array}$} & \multirow[b]{2}{*}{ 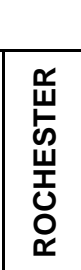 } \\
\hline & & $\begin{array}{l}\mathbb{1} \\
0 \\
\vdots \\
\vdots \\
0 \\
0 \\
0\end{array}$ & 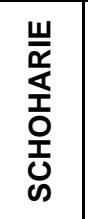 & 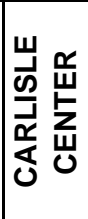 & 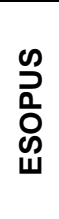 & $\begin{array}{l}\frac{z}{\alpha} \\
\frac{s}{0} \\
\frac{\omega}{\alpha} \\
0\end{array}$ & 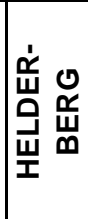 & 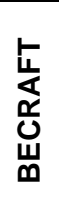 & 离 & 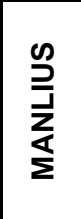 & 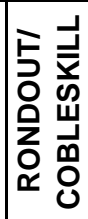 & 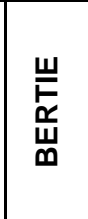 & & $\begin{array}{l}\frac{5}{2} \\
\mathbf{J} \\
\text { L }\end{array}$ & $\begin{array}{l}\text { E } \\
\mathbf{J} \\
\mathbf{w}\end{array}$ & $\begin{array}{l}\frac{\mathbf{z}}{\mathbf{z}} \\
\mathbf{J} \\
\end{array}$ & $\begin{array}{l}\frac{\mathrm{E}}{\mathrm{Z}} \\
\mathrm{J} \\
\mathrm{u}\end{array}$ & $\begin{array}{l}\mathfrak{s} \\
\frac{\mathfrak{z}}{\boldsymbol{\omega}}\end{array}$ & 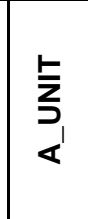 & & & \\
\hline 31101215840000 & 21584 & 2650 & & & & & 2680 & & & & 2778 & 2842 & 2920 & 3005 & 3515 & & & & & & & \\
\hline 31101215870000 & 21587 & 2650 & & & & & 2670 & & & & 2770 & 2834 & 2918 & 2998 & 3500 & 3641 & & & & & & \\
\hline 31101215880000 & 21588 & 2636 & & & & 2658 & 2665 & & & & 2755 & 2818 & 2905 & 3109 & 3495 & 3616 & 3744 & & & & & \\
\hline 31101215890000 & 21589 & 2660 & & & & & 2687 & & & & 2784 & 2845 & 2933 & 3037 & 3537 & & & & & & & \\
\hline 31101217180000 & 21718 & 5095 & & & & & 5131 & & & & 5351 & 5425 & 5566 & 5694 & 5840 & 5944 & 6050 & 6296 & 6434 & 6644 & & \\
\hline 31009218090000 & 21809 & 2545 & & & & & 2581 & & & & 2639 & 2705 & 2750 & 2814 & 2900 & 2950 & 2990 & 3145 & 3170 & 3250 & 3550 & 3519 \\
\hline 31013224980000 & 22498 & 2520 & & & & & & & & & 2550 & 2715 & 2810 & 2870 & 2970 & 3035 & 3098 & 3300 & 3330 & 3425 & 3630 & \\
\hline 31123227430000 & 22743 & 1720 & & & & & & & & & & & 2020 & 2120 & 2450 & 2580 & 2700 & & & & & \\
\hline 31109227530000 & 22753 & 1888 & & & & & 1960 & & & & 2201 & 2325 & 2445 & 2520 & 2780 & 2915 & 3020 & 3265 & 3370 & 3655 & 3810 & \\
\hline 31097227540000 & 22754 & 2390 & & & & & 2470 & & & & 2600 & 2670 & 2770 & 2868 & \begin{tabular}{|l|}
3288 \\
\end{tabular} & 3412 & 3522 & 3775 & 3885 & 4188 & 4458 & 4460 \\
\hline 31101227580000 & 22758 & 2495 & & & & & & & & & & 2578 & 2678 & 2773 & 2950 & 3080 & 3192 & 3426 & 3490 & 3739 & 3890 & \\
\hline 31097227930000 & 22793 & 2055 & & & & & 2098 & & & & 2212 & 2295 & 2390 & 2467 & 2817 & 2945 & 3050 & 3300 & 3402 & 3683 & 3825 & \\
\hline 31123227970000 & 22797 & 1378 & & & & & 1455 & & & & 1504 & 1560 & 1642 & 1725 & 1990 & 2100 & 2220 & 2490 & 2598 & 2870 & & \\
\hline 31101228140000 & 22814 & 3687 & & & & & 3735 & & & & 3965 & 4032 & 4141 & 4220 & 4825 & 4985 & 5140 & 5485 & 5564 & 5935 & & \\
\hline 31015228270000 & 22827 & 3242 & & & & & & & & & 3500 & 3582 & 3680 & 3748 & 4248 & 4332 & 4488 & 4800 & 4935 & 5270 & 5433 & \\
\hline 31097228300000 & 22830 & 3340 & & & & 3391 & 3396 & & 3430 & 3480 & 3468 & 3497 & 3518 & 3560 & 4340 & 4417 & 4602 & 4920 & 4950 & 5367 & & 5665 \\
\hline 31015228310000 & 22831 & 3462 & & & & & 3520 & & & & 3746 & 3860 & 3990 & 4070 & 4705 & 4834 & 4970 & 5320 & 5450 & 5784 & & 5955 \\
\hline 31015228390000 & 22839 & 2912 & & & & & 2952 & & & & 3140 & 3248 & 3330 & 3410 & 4264 & & & & & & & \\
\hline 31123228500000 & 22850 & 2405 & & & & & 2480 & & & & & 2545 & 2613 & 2685 & 2865 & 2898 & 2945 & 3380 & 3470 & 3725 & & \\
\hline 31015228530000 & 22853 & 3360 & & & & & & & 3420 & 3570 & 3670 & 3780 & 3885 & 3944 & 4510 & 4680 & 4822 & 5180 & 5311 & 5625 & 5834 & \\
\hline 31101228590000 & 22859 & \begin{tabular}{|l|}
2325 \\
\end{tabular} & 2380 & & & & & & & & & 2380 & 2460 & 2580 & 2740 & 2860 & 2955 & 3238 & 3300 & 3505 & 3700 & \\
\hline 31101228610000 & 22861 & 3830 & & & & & & & & & 3920 & 4053 & 4132 & 4280 & 5225 & 5467 & 5662 & 6010 & 6260 & 6755 & & \\
\hline 31101228710000 & 22871 & \begin{tabular}{|l|}
3499 \\
\end{tabular} & & & & & 3596 & & & & 3770 & 3895 & 4000 & 4050 & 4722 & 4820 & 5034 & 5378 & 5510 & 5857 & 6020 & \\
\hline 31101228840000 & 22884 & 3260 & & & & & 3310 & & & & 3550 & 3612 & 3710 & 5170 & 5752 & 4505 & 4650 & 5040 & 5138 & 5480 & 5647 & \\
\hline 31101228850000 & 22885 & 3235 & & & & & & & 3295 & 3403 & 3513 & 3600 & 3668 & 3768 & 4441 & 4610 & 4741 & 5050 & 5200 & 5490 & 5695 & \\
\hline 31015228910000 & 22891 & 3755 & & & & & & & 3800 & 3962 & 4062 & 4145 & 4228 & 4310 & \begin{tabular}{|l|}
4793 \\
\end{tabular} & 4948 & 5060 & 5370 & 5532 & 5875 & 6045 & \\
\hline 31015228990000 & 22899 & 3816 & & & & 3887 & 3887 & & 3904 & 4100 & 4201 & 4310 & 4390 & 4500 & 5080 & 5180 & 5358 & 5633 & 5838 & 6205 & & 6480 \\
\hline 31015229010000 & 22901 & 2726 & & & & & 2778 & & & & 2976 & 3084 & 3172 & 3245 & 3966 & 4198 & 4294 & 4626 & 4714 & 5100 & & 5262 \\
\hline 31015229020000 & 22902 & 3365 & & & & & & & 3412 & 3600 & 3648 & 3738 & 3633 & 3908 & 4400 & 4490 & 4630 & 4798 & 5098 & 5460 & & 5742 \\
\hline 31015229110000 & 22911 & 3595 & & & & & & & & & & & & & & & & & & & & \\
\hline 31015229180000 & 22918 & 2950 & & & & & & & 3000 & 3151 & 3250 & 3350 & 3458 & 3528 & 4240 & 4404 & 4530 & 4870 & 5032 & 5395 & 5570 & \\
\hline 31015229190000 & 22919 & 3685 & & & & & & & 3730 & 3774 & 3978 & 4067 & 4140 & 5955 & 6510 & 4892 & 4990 & 5300 & 5460 & 5805 & 5975 & \\
\hline 31015229240000 & 22924 & 3264 & & & & 3292 & 3302 & & 3303 & 3422 & 3520 & 3618 & 3702 & 3800 & 4290 & 4370 & 4535 & 4791 & 4980 & 5330 & & 5628 \\
\hline 31015229330000 & 22933 & & 3610 & & & & 3650 & & & & 3838 & 3973 & 4135 & 4336 & \begin{tabular}{|l|}
4996 \\
\end{tabular} & 5174 & 5270 & 5680 & 5764 & & & \\
\hline 31107229340000 & 22934 & & & & & & & & & & & & & 5384 & 6066 & & & & & & & \\
\hline
\end{tabular}




\begin{tabular}{|c|c|c|c|c|c|c|c|c|c|c|c|c|c|c|c|c|c|c|c|c|c|c|}
\hline \multirow[b]{2}{*}{ API Number } & \multirow[b]{2}{*}{$\begin{array}{l}\text { Well } \\
\text { Label }\end{array}$} & & & & & & & & & & & & & \multicolumn{3}{|c|}{ Syracuse } & \multicolumn{3}{|c|}{ Vernon } & \multirow[b]{2}{*}{ 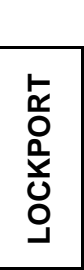 } & \multirow[b]{2}{*}{ 㝋 } & \multirow[b]{2}{*}{ 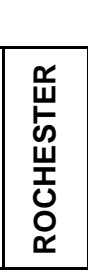 } \\
\hline & & 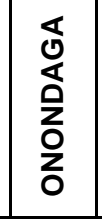 & 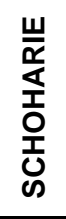 & 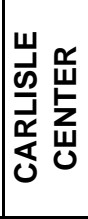 & 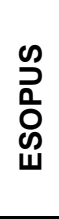 & $\begin{array}{l}\frac{z}{5} \\
\frac{5}{\omega} \\
\frac{\omega}{\alpha} \\
0\end{array}$ & 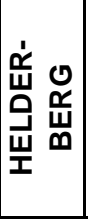 & 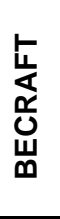 & 足 & $\frac{N}{\stackrel{n}{2}}$ & 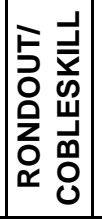 & 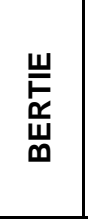 & 岂 & $\begin{array}{l}\mathbf{E} \\
\stackrel{\mathbf{z}}{\mathbf{L}} \\
\mathbf{L}\end{array}$ & $\begin{array}{l}\mathbf{E} \\
\mathbf{z} \\
\mathbf{w}\end{array}$ & $\begin{array}{l}\mathbf{E} \\
\mathbf{z} \\
\mathbf{J}\end{array}$ & 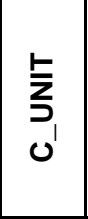 & 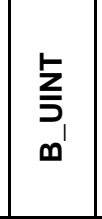 & $\begin{array}{l}\text { E } \\
\text { J } \\
\text { \& }\end{array}$ & & & \\
\hline 31097229350000 & 22935 & \begin{tabular}{|l|}
2062 \\
\end{tabular} & & & & & 2132 & & & & 2290 & \begin{tabular}{|l|}
2367 \\
\end{tabular} & 2480 & 2562 & 3653 & 3755 & 3975 & 4268 & 4390 & \begin{tabular}{|l|}
4725 \\
\end{tabular} & 4892 & 4995 \\
\hline 31123229390000 & 22939 & 1050 & & & & & 1125 & & & & & 1200 & 1238 & 1310 & 1440 & 1800 & 1720 & 1927 & 1978 & & 2180 & \\
\hline 31097229420000 & 22942 & 3118 & & & & & 3160 & & & & \begin{tabular}{|l|}
3306 \\
\end{tabular} & 3400 & 3500 & 3573 & 4330 & 4600 & 4830 & 5170 & 5310 & 5640 & & 5812 \\
\hline 31099229500000 & 22950 & 1902 & & & & & 1940 & & & & 2100 & 2165 & 2212 & 2272 & 2690 & 2815 & 2920 & 3185 & 3298 & 3565 & & 3857 \\
\hline 31007229950000 & 22995 & 4680 & & & & 4825 & & & & & 4830 & 4965 & 5015 & 5146 & 5876 & 6080 & 6170 & 6470 & 6580 & 7008 & 7110 & \\
\hline 31013232470000 & 23247 & 1972 & & & & & & & & & 2016 & 2120 & 2282 & 2344 & 2406 & 2454 & 2496 & 2586 & 2650 & 2855 & & 2946 \\
\hline 31009234350000 & 23435 & 4520 & & & & & & & & & 4590 & 4642 & 4748 & 4805 & \begin{tabular}{|l|}
4951 \\
\end{tabular} & 5078 & 5145 & & & & & \\
\hline 31097611920000 & 61192 & 1558 & & & & & & & & & 1803 & 1885 & 1975 & 2055 & & & & & & & & \\
\hline 31097612050000 & 61205 & & & & & & & & & & & & & 2165 & 2645 & & & & & & & \\
\hline 31097612060000 & 61206 & 1562 & & & & & & & & & 1806 & 1894 & 1988 & 2054 & 2604 & 2744 & & & & & & \\
\hline
\end{tabular}




\section{Appendix B}

\section{Queenston Data}

$\begin{array}{ll}\text { Table } 1 & \text { General Well Data } \\ \text { Table } 2 & \text { Formation Tops } \\ \text { Table } 3 & \text { Delaney Well Thin Section } \\ & \text { Porosity Estimates } \\ \text { Table } 4 & \text { Sample Injection Data From } \\ & \text { Bath Petroleum Inc. }\end{array}$


Appendix B - Table 1 - Queenston Wells General Data

\begin{tabular}{|c|c|c|c|c|c|c|c|c|}
\hline API \# & SAPINO & WELL NAME & OPERATOR & TOWN & COUNTY & $\begin{array}{l}\text { Total } \\
\text { Depth }\end{array}$ & Lat & Lon \\
\hline 31011004780000 & 00478-00-00 & Mahaney J C & Reserve Oil Co. & Ledyard & Cayuga & 6166 & 42.6848 & -76.644 \\
\hline 31121006150000 & $00615-00-00$ & Fee 1 & Wilson K.E. & Arcade & Wyoming & 7144 & 42.5307 & -78.4233 \\
\hline 31017011600000 & $01160-00-00$ & Lobdell 1 & Bradley Producing Corp. & Columbus & Chenango & 5701 & 42.6934 & -75.3447 \\
\hline 31003039560000 & 03956-00-00 & Cook G M 2 & Parsons Bros & Hume & Allegany & 7337 & 42.453 & \begin{tabular}{|l|}
-78.174 \\
\end{tabular} \\
\hline 31109039730000 & 03973-00-00 & Shepard 1 & CNG Transmission Corp. & Danby & Tompkins & 10438 & 42.3703 & -76.506 \\
\hline 31109040070000 & 04007-00-00 & Smiley Jean H 1 & NYS Natural Gas Corp. & Danby & Tompkins & 8555 & 42.3655 & -76.503 \\
\hline 31011040380000 & $04038-00-00$ & Ford 1 (789-1) & Columbia Natural Resources LLC & Aurelius & Cayuga & 1644 & 42.9452 & -76.6413 \\
\hline 31099040640000 & 04064-00-00 & Dewall 1 (796-1) & Columbia Natural Resources LLC & Fayette & Seneca & 2069 & 42.8667 & -76.8571 \\
\hline 31011040680000 & 04068-00-00 & Shoemaker 1 (768-1) & Columbia Natural Resources LLC & Springport & Cayuga & 1967 & 42.8812 & -76.6395 \\
\hline 31099040820000 & 04082-00-00 & Stein 1 & Benedum Paul G. & Fayette & Seneca & 2286 & 42.876 & -76.8396 \\
\hline 31121040920000 & 04092-00-00 & Veith D 1 & NYS Natural Gas Corp. & Gainesville & Wyoming & 7182 & 42.6174 & -78.0799 \\
\hline 31099041110000 & 04111-00-00 & Schaffer 1 (798-1) & Columbia Natural Resources LLC & Fayette & Seneca & 2306 & 42.8578 & -76.8547 \\
\hline 31011041120000 & $04112-00-00$ & Klock 1 (767-1) & Klock Ronald F. \& Carol H. & Springport & Cayuga & 2313 & \begin{tabular}{|l|}
42.8722 \\
\end{tabular} & -76.6364 \\
\hline 31109041300000 & 04130-00-00 & Grund GH & NYS Natural Gas Corp. & Enfield & Tompkins & 8900 & 42.4422 & -76.5925 \\
\hline 31099041580000 & 04158-00-00 & Andrews 1 & Monile Albert & Waterloo & Seneca & 1650 & 42.9177 & -76.8627 \\
\hline 31099042030000 & $04203-00-00$ & Schaffer 2 & United Productions & Fayette & Seneca & 1921 & 42.8763 & -76.8582 \\
\hline 31099042440000 & 04244-00-00 & Robson 1 & NYS Natural Gas Corp. & Fayette & Seneca & 2261 & 42.8252 & -76.8653 \\
\hline 31011043890000 & 04389-00-00 & Patterson 1 (784-1) & Columbia Natural Resources LLC & Aurelius & Cayuga & 1749 & 42.9026 & -76.6633 \\
\hline 31099044080000 & 04408-00-00 & Unger 1 & Murphy-Roberts & Waterloo & Seneca & 1637 & 42.9283 & -76.8865 \\
\hline 31011044480000 & 04448-00-00 & Bacon 1 (785-1) & Columbia Natural Resources LLC & Aurelius & Cayuga & 1768 & 42.9018 & -76.6781 \\
\hline 31109044670000 & 04467-00-00 & Fee Richarson 1 & NYS Natural Gas Corp. & Newfield & Tompkins & 9390 & 42.3844 & -76.5404 \\
\hline 31011044910000 & 04491-00-00 & Juli 1 (788-1) & Juli Donald W. \& Joan S. & Aurelius & Cayuga & 1740 & 42.9493 & -76.6235 \\
\hline 31011044930000 & 04493-00-00 & Burtless 2 (793-1) & Columbia Natural Resources LLC & Aurelius & Cayuga & 1741 & 42.9233 & -76.6609 \\
\hline 31011044970000 & 04497-00-00 & Whitcomb 1 (792-1) & Ford Cregg & Aurelius & Cayuga & 1760 & 42.9352 & -76.6391 \\
\hline 31011045120000 & $04512-00-00$ & Picciano 1 & Ashland Exploration Co. & Throop & Cayuga & 1757 & 42.9616 & -76.6097 \\
\hline 31011045180000 & 04518-00-00 & Janusz 1 (795-1) & Janusz Joseph & Throop & Cayuga & 1777 & 42.954 & -76.6453 \\
\hline 31011045190000 & 04519-00-00 & Smith E 1 & Ashland Exploration Co. & Throop & Cayuga & 1843 & 42.9553 & -76.5922 \\
\hline 31011045210000 & 04521-00-00 & Nugent Patrick J 1 & Midwest Oil Corp. & & Cayuga & 1775 & 42.9622 & -76.6273 \\
\hline 31011045400000 & $04540-00-00$ & Shank 771-1 & Meridian Exploration Corp. & Springport & Cayuga & 1893 & 42.893 & -76.6465 \\
\hline 31099045440000 & 04544-00-00 & Garrett 2 & CNG Transmission Corp. & Fayette & Seneca & 2075 & 42.869 & -76.9264 \\
\hline 31051045670000 & $04567-00-00$ & Johnson 1 & Stein Paul E. \& Sons & Caledonia & Livingston & 4839 & 42.9324 & -77.8838 \\
\hline 31011045710000 & 04571-00-00 & Fabian 1 (773-1) & Columbia Natural Resources LLC & Springport & Cayuga & 1818 & 42.8915 & -76.6624 \\
\hline 31099046000000 & $04600-00-00$ & Christensen 1 & Brown Edward J. and Anne D. & Fayette & Seneca & 2075 & \begin{tabular}{|l|}
42.8749 \\
\end{tabular} & -76.9217 \\
\hline 31011046240000 & 04624-00-00 & Wasielewski 1 & Humble Oil \& Refining Co. & Ira & Cayuga & 3055 & 43.2526 & -76.4907 \\
\hline 31011046280000 & $04628-00-00$ & Jellinghaus 1 (775-1) & Rose State Custom Service Inc & Springport & Cayuga & 1938 & 42.8814 & -76.6544 \\
\hline 31011046520000 & 04652-00-00 & Case E K 1 & Midwest Oil Corp. & Aurelius & Cayuga & 1826 & 42.9466 & -76.7026 \\
\hline 31011047150000 & $04715-00-00$ & Alnutt R 1 & Midwest Oil Corp. & Aurelius & Cayuga & 4853 & \begin{tabular}{|l|}
42.9218 \\
\end{tabular} & -76.6713 \\
\hline 31099047680000 & $04768-00-00$ & Dutton 1 & Dutton Judson J. & Seneca Falls & Seneca & 1905 & 42.8953 & -76.7745 \\
\hline 31123047950000 & 04795-00-00 & Jepsen 1 & Shirk Benjamin Z. Susanna M. & Benton & Yates & 2896 & 42.7181 & -77.0219 \\
\hline
\end{tabular}




\begin{tabular}{|c|c|c|c|c|c|c|c|c|}
\hline API \# & SAPINO & WELL NAME & OPERATOR & TOWN & COUNTY & $\begin{array}{l}\text { Total } \\
\text { Depth }\end{array}$ & Lat & Lon \\
\hline 31123047960000 & $04796-00-00$ & Fee 1 & Borglum Bruce & Benton & Yates & 3061 & 42.6838 & -77.0219 \\
\hline 31123047970000 & $04797-00-00$ & Loree 2 & Loree Ann E. & Benton & Yates & 2757 & 42.7495 & -77.0035 \\
\hline 31099048140000 & 04814-00-00 & Jodiet 1 & Sampson Creek Acres Inc. & Seneca Falls & Seneca & 1850 & 42.8948 & -76.787 \\
\hline 31011049990000 & 04999-00-00 & Parker Robert A 1 & Duchscherer William J. & Brutus & Cayuga & 4260 & 43.0261 & -76.5285 \\
\hline 31011050000000 & $05000-00-00$ & Ripley 1 & Urban Snow Gas Co. Inc. & Cato & Cayuga & 3756 & 43.1051 & -76.5524 \\
\hline 31011050110000 & \begin{tabular}{|l|}
$05011-00-00$ \\
\end{tabular} & O'Neil 1 & Duchscherer William J. & Cato & Cayuga & 3573 & 43.1042 & -76.5531 \\
\hline 31011050310000 & 05031-00-00 & Smith L W 1 & Duchscherer William J. & Victory & Cayuga & 3415 & 43.2016 & -76.6097 \\
\hline 31117050320000 & $05032-00-00$ & Kaiser W 1 & Duchscherer William J. & Galen & Wayne & 3915 & 43.0592 & -76.8958 \\
\hline 31073050690000 & $05069-00-00$ & Nowak 1 & Duchscherer William J. & Kendall & Orleans & 2325 & 43.3191 & -78.0821 \\
\hline 31099050950000 & 05095-00-00 & Reed 1 & Duchscherer William J. & Junius & Seneca & 4149 & 43.0067 & -76.94 \\
\hline 31011054670000 & $05467-00-00$ & House Louis and Mary 1 & Hodges Michael W. & Cato & Cayuga & 3368 & 43.1008 & -76.5124 \\
\hline 31011057940000 & 05794-00-00 & Pethybridge 1 (776-1) & Columbia Natural Resources LLC & Springport & Cayuga & 1850 & 42.8804 & -76.6691 \\
\hline 31011060600000 & $06060-00-00$ & Staehr $1(778-1)$ & Columbia Natural Resources LLC & Springport & Cayuga & 1985 & 42.8688 & -76.6529 \\
\hline 31011067790000 & $06779-00-00$ & Karim 1 & Karim Raja Abdul & Cato & Cayuga & 3128 & 43.1093 & -76.5612 \\
\hline 31011067800000 & $06780-00-00$ & Cole 1 & Urban Snow Gas Co. Inc. & Cato & Cayuga & 3096 & 43.1091 & -76.5466 \\
\hline 31123098460000 & 09846-00-00 & Christenson 1 & Noble Ray A. & Benton & Yates & 2971 & 42.7116 & -77.0303 \\
\hline 31011107010000 & $10701-00-00$ & Rindfleisch Anna 2 & Columbia Natural Resources LLC & Springport & Cayuga & 1801 & 42.8763 & -76.7056 \\
\hline 31011107020000 & $10702-00-00$ & Rindfleisch Anna 1 & Columbia Natural Resources LLC & Springport & Cayuga & 1820 & 42.8766 & -76.6925 \\
\hline 31037107760000 & $10776-00-00$ & Belt 1 & Flint Oil \& Gas Inc. & Bethany & Genesee & 4340 & 42.9205 & -78.1671 \\
\hline 31099108930000 & $10893-00-00$ & Kinney 1 & Hoover Moble C. & Waterloo & Seneca & 4741 & 42.9412 & -76.8764 \\
\hline 31029110020000 & $11002-00-00$ & Brown Ralph H 1 & Great Lakes Energy Partners & Sardinia & Erie & 6293 & 42.5575 & -78.5354 \\
\hline 31029111140000 & $11114-00-00$ & Lietz 2 & Perkins Cooper \& Gondree & Brant & Erie & 4822 & 42.5981 & -78.9841 \\
\hline 31011111290000 & $11129-00-00$ & Joshanski 1 & Urban Snow Gas Co. Inc. & Cato & Cayuga & 3057 & 43.1207 & -76.5477 \\
\hline 31011114320000 & $11432-00-00$ & Rindfleisch 3 & Columbia Natural Resources LLC & Springport & Cayuga & 1901 & 42.872 & -76.6917 \\
\hline 31011114960000 & $11496-00-00$ & Rindfleisch Wn-1386 & Columbia Natural Resources LLC & Springport & Cayuga & 1896 & 42.8719 & -76.7009 \\
\hline 31011115460000 & $11546-00-00$ & Cunningham 6 & Ol Auburn Inc. & Aurelius & Cayuga & 1855 & 42.9135 & -76.6772 \\
\hline 31011115480000 & $11548-00-00$ & Malinowski 1 & Miller Brewing Co. & Throop & Cayuga & 1852 & 42.9738 & -76.6202 \\
\hline 31011115870000 & $11587-00-00$ & Thurston 3 & Ol Auburn Inc. & Throop & Cayuga & 1844 & 42.9639 & -76.6512 \\
\hline 31011116000000 & $11600-00-00$ & Day T101-V1 & Miller Brewing Co. & Throop & Cayuga & 1849 & 42.9856 & -76.6108 \\
\hline 31099116180000 & $11618-00-00$ & Stahl 1 & Columbia Natural Resources LLC & Fayette & Seneca & 2164 & 42.8385 & -76.789 \\
\hline 31011116320000 & $11632-00-00$ & Steimle 9 & Steimle John L \& Shirley L. & Owasco & Cayuga & 2471 & 42.917 & -76.5051 \\
\hline 31011116330000 & $11633-00-00$ & Manrow S100-V5 & Miller Brewing Co. & Sennett & Cayuga & 1902 & 42.9693 & -76.5671 \\
\hline 31011116560000 & $11656-00-00$ & Potter 723-1 & Columbia Natural Resources LLC & Sennett & Cayuga & 1875 & 42.985 & -76.5174 \\
\hline 31099116660000 & $11666-00-00$ & Hoster 1 & Columbia Natural Resources LLC & Fayette & Seneca & 2110 & 42.8452 & -76.787 \\
\hline 31099117080000 & $11708-00-00$ & Reigel 1 & Columbia Natural Resources LLC & Fayette & Seneca & 2171 & 42.8386 & -76.7786 \\
\hline 31099120510000 & $12051-00-00$ & Neal & Columbia Natural Resources LLC & Fayette & Seneca & 2669 & 42.8481 & -76.8076 \\
\hline 31099120520000 & $12052-00-00$ & Olsowske & Columbia Natural Resources LLC & Fayette & Seneca & 2233 & 42.8545 & -76.7943 \\
\hline 31099120530000 & $12053-00-00$ & Partee & Columbia Natural Resources LLC & Fayette & Seneca & 2214 & 42.858 & -76.8015 \\
\hline 31101124020000 & $12402-00-00$ & Kish 1 & Anderson Oil Co. & Bath & Steuben & 5879 & 42.3168 & -77.3892 \\
\hline 31011135530000 & $13553-00-00$ & Pollard A1098 & Ol Auburn Inc. & Aurelius & Cayuga & 2040 & 42.9356 & -76.6561 \\
\hline 31011135540000 & $13554-00-00$ & Edmunds A108-5 & Ol Auburn Inc. & Aurelius & Cayuga & 2065 & 42.9357 & -76.69 \\
\hline
\end{tabular}




\begin{tabular}{|c|c|c|c|c|c|c|c|c|}
\hline API \# & SAPINO & WELL NAME & OPERATOR & TOWN & COUNTY & $\begin{array}{l}\text { Total } \\
\text { Depth }\end{array}$ & Lat & Lon \\
\hline 31011135620000 & $13562-00-00$ & Wormuth S101-3 & Ol Auburn Inc. & Sennett & Cayuga & 2200 & 42.9684 & -76.563 \\
\hline 31011135880000 & $13588-00-00$ & Shank Sp100-2 & Ol Auburn Inc. & Springport & Cayuga & 1955 & 42.8936 & -76.6873 \\
\hline 31011135890000 & $13589-00-00$ & Shank Sp100-1 & Ol Auburn Inc. & Springport & Cayuga & 2100 & 42.8935 & -76.6921 \\
\hline 31011135980000 & $13598-00-00$ & Sosniak T120-8 & Ol Auburn Inc. & Throop & Cayuga & 2120 & 42.9543 & -76.6101 \\
\hline 31011135990000 & $13599-00-00$ & Patterson William A130-2 & Ol Auburn Inc. & Aurelius & Cayuga & 2130 & 42.9085 & -76.6992 \\
\hline 31011136000000 & $13600-00-00$ & Ball C \& W A102-8 & Ol Auburn Inc. & Aurelius & Cayuga & 1954 & 42.9521 & -76.6595 \\
\hline 31011136010000 & $13601-00-00$ & Delaney Tom \& Mary T119-2 & Ol Auburn Inc. & Throop & Cayuga & 2030 & 42.9584 & -76.6363 \\
\hline 31011136060000 & $13606-00-00$ & Delaney Tom \& Mary T120-6 & Ol Auburn Inc. & Throop & Cayuga & 2025 & 42.954 & -76.6182 \\
\hline 31011136370000 & $13637-00-00$ & Cuff Sid \& Oletha A123b-3 & Ol Auburn Inc. & Aurelius & Cayuga & 2180 & 42.9193 & -76.7052 \\
\hline 31011136390000 & $13639-00-00$ & Helenski A-104-6 & Ol Auburn Inc. & Aurelius & Cayuga & 1895 & 42.9442 & -76.669 \\
\hline 31011136440000 & $13644-00-00$ & Ball C \& W T113-11 & Ol Auburn Inc. & Throop & Cayuga & 1985 & 42.9567 & -76.654 \\
\hline 31011136450000 & $13645-00-00$ & Delaney Dave \& Ann A124-5 & Ol Auburn Inc. & Aurelius & Cayuga & 1984 & 42.915 & -76.6899 \\
\hline 31011136460000 & $13646-00-00$ & O'Hara Farms Inc A132-5 & Ol Auburn Inc. & Aurelius & Cayuga & 2010 & 42.9107 & -76.6687 \\
\hline 31011136550000 & $13655-00-00$ & Bench G \& L A-119-6 & Ol Auburn Inc. & Aurelius & Cayuga & 2040 & 42.9251 & -76.6678 \\
\hline 31099136750000 & $13675-00-00$ & Poorman 2503 & Columbia Natural Resources LLC & Fayette & Seneca & 2518 & 42.8646 & -76.8375 \\
\hline 31099136760000 & $13676-00-00$ & Vannostrand 4035 & Columbia Natural Resources LLC & Fayette & Seneca & 2300 & 42.8555 & -76.8371 \\
\hline 31101136990000 & 13699-00-00 & NYS Reforestation 6 & Columbia Gas Trans. Corp. & Wheeler & Steuben & 9794 & 42.4662 & -77.2651 \\
\hline 31101137360000 & $13736-00-00$ & Wagner20615-T & CNG Transmission Corp. & Wheeler & Steuben & 4849 & 42.4347 & -77.4088 \\
\hline 31011137840000 & $13784-00-00$ & Bacon 1 & F \& G Exploration & Springport & Cayuga & 2023 & 42.883 & -76.6867 \\
\hline 31011153770000 & $15377-00-00$ & Staehr 2 (782-1) & Columbia Natural Resources LLC & Springport & Cayuga & 1935 & 42.8622 & -76.6626 \\
\hline 31123154060000 & $15406-00-00$ & Havens Corner 1 & Newman Edgar $\mathrm{F}$ & Benton & Yates & 3000 & 42.7338 & -77.0743 \\
\hline 31101154380000 & 15438-00-00 & Kassow 1 & Minter Lee E. & Pulteney & Steuben & 7956 & 42.5394 & -77.2158 \\
\hline 31011155000000 & $15500-00-00$ & Patterson William 130-1 & Ol Auburn Inc. & Aurelius & Cayuga & 2020 & 42.9089 & -76.6944 \\
\hline 31011155010000 & $15501-00-00$ & Patterson William 123-5 & Ol Auburn Inc. & Aurelius & Cayuga & 2002 & 42.9121 & -76.7024 \\
\hline 31011155020000 & $15502-00-00$ & Delaney Dave \& Ann A124-4 & Ol Auburn Inc. & Aurelius & Cayuga & 2012 & 42.9203 & -76.6906 \\
\hline 31011155290000 & $15529-00-00$ & Wells College 1 & Wells College & Ledyard & Cayuga & 2626 & 42.7414 & -76.6973 \\
\hline 31011156110000 & $15611-00-00$ & Delaney Dave \& Ann A124-6 & Ol Auburn Inc. & Aurelius & Cayuga & 1809 & 42.9174 & -76.6869 \\
\hline 31011156120000 & $15612-00-00$ & O'Hara Farms Inc. A132-4 & Ol Auburn Inc. & Aurelius & Cayuga & 2005 & 42.9132 & -76.668 \\
\hline 31011156430000 & $15643-00-00$ & NYS Electric \& Gas T121-5 & Ol Auburn Inc. & Throop & Cayuga & 2005 & 42.9544 & -76.605 \\
\hline 31011156500000 & $15650-00-00$ & Simmons Theodore A131-2 & Ol Auburn Inc. & Aurelius & Cayuga & 1819 & 42.9107 & -76.6813 \\
\hline 31011156610000 & 15661-00-00 & Emery D \& D A123-B1 & Ol Auburn Inc. & Aurelius & Cayuga & 2009 & 42.9196 & -76.6957 \\
\hline 31011156620000 & $15662-00-00$ & Kirschner H \& J 123-B2 & Ol Auburn Inc. & Aurelius & Cayuga & 2012 & 42.9199 & -76.7005 \\
\hline 31011156630000 & $15663-00-00$ & Kirschner H \& J 123-2 & Ol Auburn Inc. & Aurelius & Cayuga & 1804 & 42.9159 & -76.7004 \\
\hline 31011156640000 & 15664-00-00 & Foster A-119-2 & Ol Auburn Inc. & Aurelius & Cayuga & 1823 & 42.9272 & -76.672 \\
\hline 31011156650000 & $15665-00-00$ & Schwartz A119-4 & Ol Auburn Inc. & Aurelius & Cayuga & 1827 & 42.9247 & -76.6757 \\
\hline 31011157020000 & $15702-00-00$ & Cunningham F \& Aa124-1 & Ol Auburn Inc. & Aurelius & Cayuga & 2001 & 42.921 & -76.6776 \\
\hline 31011157030000 & $15703-00-00$ & Cuff Sid \& Oletha A123-3 & Ol Auburn Inc. & Aurelius & Cayuga & 2004 & 42.9156 & -76.7054 \\
\hline 31011157040000 & $15704-00-00$ & Pattersonn A130-3 & Ol Auburn Inc. & Aurelius & Cayuga & 2000 & 42.9078 & -76.7045 \\
\hline 31011157070000 & $15707-00-00$ & Delaney Dave \& Ann A124-7 & Ol Auburn Inc. & Aurelius & Cayuga & 2000 & 42.9154 & -76.6828 \\
\hline 31011157080000 & $15708-00-00$ & Cunningham F \& Aa124-8 & Ol Auburn Inc. & Aurelius & Cayuga & 1996 & 42.917 & -76.6781 \\
\hline 31011157090000 & $15709-00-00$ & Simmons Theodore A131-5 & Ol Auburn Inc. & Aurelius & Cayuga & 2000 & 42.9063 & -76.6884 \\
\hline
\end{tabular}




\begin{tabular}{|c|c|c|c|c|c|c|c|c|}
\hline API \# & SAPINO & WELL NAME & OPERATOR & TOWN & COUNTY & $\begin{array}{l}\text { Total } \\
\text { Depth }\end{array}$ & Lat & Lon \\
\hline 31011157100000 & $15710-00-00$ & Shank Karl M. A137-4 & Ol Auburn Inc. & Aurelius & Cayuga & 2015 & 42.9022 & -76.6947 \\
\hline 31011157450000 & $15745-00-00$ & Foster A119-3 & Ol Auburn Inc. & Aurelius & Cayuga & 2000 & 42.9281 & -76.6761 \\
\hline 31011157560000 & $15756-00-00$ & Shank Karl M. A137-3 & Ol Auburn Inc. & Aurelius & Cayuga & 2000 & 42.8975 & -76.6921 \\
\hline 31101158340000 & $15834-00-00$ & Bush Hill 1 & Pennzoil Producing Co. & Canisteo & Steuben & 6595 & 42.2032 & -77.5921 \\
\hline 31011158500000 & $15850-00-00$ & Foster A132-3 & Ol Auburn Inc. & Aurelius & Cayuga & 2000 & 42.9151 & -76.6703 \\
\hline 31011159620000 & 15962-00-00 & Staehr 3 (783-2) & Columbia Natural Resources LLC & Springport & Cayuga & 1994 & 42.8604 & -76.6675 \\
\hline 31011159630000 & $15963-00-00$ & Mclntosh Fee 2 & Key Trust Co of Ohio N.A. Trustee & Springport & Cayuga & 2050 & 42.8132 & -76.7085 \\
\hline 31011161200000 & $16120-00-00$ & Venice View Dairy 1-11 & Devonian Energy Corp. & Venice & Cayuga & 7346 & 42.7202 & -76.568 \\
\hline 31011161230000 & $16123-00-00$ & Adams 780-2 & A.D.C.O. Well Services & Springport & Cayuga & 1793 & 42.8876 & -76.6621 \\
\hline 31011161490000 & $16149-00-00$ & Patterson 794-2 & Columbia Natural Resources LLC & Aurelius & Cayuga & 1735 & 42.9057 & -76.6665 \\
\hline 31011161510000 & 16151-00-00 & Fabian Patterson 781-3 & Columbia Natural Resources LLC & Springport & Cayuga & 1752 & 42.8909 & -76.6669 \\
\hline 31011169910000 & 16991-00-00 & Gable 1a & Union Springs School District & Springport & Cayuga & 2150 & 42.8539 & -76.6931 \\
\hline 31011175080000 & $17508-00-00$ & Hunter A\&B 1 & Urban Snow Gas Co. Inc. & Cato & Cayuga & 3658 & 43.1291 & -76.5614 \\
\hline 31011175090000 & $17509-00-00$ & Hunter C 1 & Urban Snow Gas Co. Inc. & Cato & Cayuga & 2866 & 43.1306 & -76.5468 \\
\hline 31011175100000 & $17510-00-00$ & Keysor K 1 & Urban Snow Gas Co. Inc. & Cato & Cayuga & 3649 & 43.1384 & -76.5518 \\
\hline 31011175170000 & $17517-00-00$ & Fuller A118-6 & OI Auburn Inc. & Aurelius & Cayuga & 2011 & 42.9546 & -76.6824 \\
\hline 31011175550000 & $17555-00-00$ & Springler 7241 & Meridian Exploration Corp. & Sennett & Cayuga & 2058 & 42.9956 & -76.4967 \\
\hline 31011175560000 & $17556-00-00$ & Smith 7261 & Smith Alice E. & Owasco & Cayuga & 2539 & 42.9235 & -76.4862 \\
\hline 31011175570000 & $17557-00-00$ & Dickman 7281 & Dickman Richard H. & Fleming & Cayuga & 2684 & 42.8575 & -76.5359 \\
\hline 31011175580000 & $17558-00-00$ & Provo 7271 & Meridian Exploration Corp. & Sennett & Cayuga & 4555 & 43.0112 & -76.5212 \\
\hline 31011175590000 & $17559-00-00$ & Quill 7251 & Columbia Natural Resources LLC & Aurelius & Cayuga & 5038 & 42.9244 & -76.6995 \\
\hline 31099175650000 & $17565-00-00$ & Seneca Co Home 2504 & Columbia Natural Resources LLC & Fayette & Seneca & 2133 & 42.8784 & -76.8179 \\
\hline 31099175670000 & $17567-00-00$ & Macgill 1 (4047) & Equitable Resources Exploraration & Fayette & Seneca & 2164 & 42.8668 & -76.8442 \\
\hline 31099175700000 & $17570-00-00$ & Melcher 1 (4052) & Equitable Resources Exploraration & Fayette & Seneca & 2063 & 42.8737 & -76.8048 \\
\hline 31099175720000 & $17572-00-00$ & D'Amico 2508 & A.D.C.O. Well Services & Fayette & Seneca & 2323 & 42.8344 & -76.8452 \\
\hline 31099175730000 & $17573-00-00$ & Martin 1 (4055) & Equitable Resources Exploraration & Fayette & Seneca & 2218 & 42.8469 & -76.821 \\
\hline 31099175760000 & $17576-00-00$ & Hagadorn 2506 & Columbia Natural Resources LLC & Fayette & Seneca & 2247 & 42.8487 & -76.8539 \\
\hline 31099175780000 & 17578-00-00 & Martin 2505 & A.D.C.O. Well Services & Fayette & Seneca & 2108 & 42.8602 & -76.8287 \\
\hline 31099175790000 & $17579-00-00$ & Dendis $1(4060)$ & Rasmussen Ronnie O. & Fayette & Seneca & 2099 & 42.8845 & -76.8648 \\
\hline 31011175950000 & 17595-00-00 & Wimmer A118-1 & Ol Auburn Inc. & Aurelius & Cayuga & 1878 & 42.9284 & -76.6809 \\
\hline 31011175990000 & 17599-00-00 & Wimmer A118-5 & Ol Auburn Inc. & Aurelius & Cayuga & 1850 & 42.9249 & -76.6807 \\
\hline 31123194030000 & 19403-00-00 & Cook 1 & Ardent Resources Inc. & Barrington & Yates & 4220 & 42.5608 & -77.0307 \\
\hline 31099194590000 & 19459-00-00 & Murray 2512 & Columbia Natural Resources LLC & Fayette & Seneca & 2336 & 42.8154 & -76.7848 \\
\hline 31099194610000 & 19461-00-00 & Karlsen 1 (4088) & Columbia Natural Resources LLC & Varick & Seneca & 2509 & 42.7937 & -76.9044 \\
\hline 31099194620000 & 19462-00-00 & Harris 1 (4079) & Columbia Natural Resources LLC & Fayette & Seneca & 2470 & 42.845 & -76.8741 \\
\hline 31099194630000 & 19463-00-00 & Ritter 1 (4082) & Columbia Natural Resources LLC & Varick & Seneca & 2769 & 42.7963 & -76.8838 \\
\hline 31099194640000 & 19464-00-00 & Larsen 1 (4083) & Columbia Natural Resources LLC & Varick & Seneca & 2662 & 42.8042 & -76.8904 \\
\hline 31099194650000 & 19465-00-00 & Utzman 1 (4076) & Columbia Natural Resources LLC & Fayette & Seneca & 2575 & 42.8382 & -76.8697 \\
\hline 31099194670000 & 19467-00-00 & Tompkins 1 (4075) & Columbia Natural Resources LLC & Fayette & Seneca & 2515 & 42.838 & -76.8838 \\
\hline 31099194700000 & 19470-00-00 & Lerch 1 (4085) & Columbia Natural Resources LLC & Varick & Seneca & 3364 & 42.8051 & -76.8615 \\
\hline 31099194810000 & 19481-00-00 & Robson 3 (4073) & Columbia Natural Resources LLC & Fayette & Seneca & 2316 & 42.8378 & -76.8539 \\
\hline
\end{tabular}




\begin{tabular}{|c|c|c|c|c|c|c|c|c|}
\hline API \# & SAPINO & WELL NAME & OPERATOR & TOWN & COUNTY & $\begin{array}{l}\text { Total } \\
\text { Depth }\end{array}$ & Lat & Lon \\
\hline 31099194820000 & 19482-00-00 & Ritter 3 (4086) & Columbia Natural Resources LLC & Varick & Seneca & 2559 & 42.7917 & -76.8737 \\
\hline 31023194840000 & 19484-00-00 & Jones 1 & F. L. Stead \& Associates Inc. & Scott & Cortland & 5616 & 42.7029 & -76.2659 \\
\hline 31053194850000 & 19485-00-00 & Larkin 1 & F. L. Stead \& Associates Inc. & Brookfield & Madison & 5083 & 42.8088 & -75.4185 \\
\hline 31099194900000 & 19490-00-00 & Ritter 4 (4092) & Columbia Natural Resources LLC & Varick & Seneca & 2552 & 42.7912 & -76.8863 \\
\hline 31099194910000 & 19491-00-00 & Ritter 2 (4084) & Columbia Natural Resources LLC & Varick & Seneca & 2606 & 42.7953 & -76.896 \\
\hline 31101194970000 & 19497-00-00 & Evangelos 21436-T & Columbia Natural Resources LLC & Pulteney & Steuben & 7961 & 42.5408 & -77.2159 \\
\hline 31011194980000 & 19498-00-00 & Quill 762-1 & Columbia Natural Resources LLC & Aurelius & Cayuga & 1800 & 42.929 & -76.7138 \\
\hline 31011195000000 & $19500-00-00$ & Kirshner(Quill)763-2 & Columbia Natural Resources LLC & Aurelius & Cayuga & 1828 & 42.9246 & -76.7051 \\
\hline 31011195010000 & 19501-00-00 & Riford 765-3 & Columbia Natural Resources LLC & Aurelius & Cayuga & 1799 & 42.9302 & -76.6948 \\
\hline 31099195030000 & $19503-00-00$ & Martin/Wise 1 (4103) & Columbia Natural Resources LLC & Varick & Seneca & 2418 & 42.8034 & -76.7845 \\
\hline 31099195040000 & 19504-00-00 & Somerville/Gilbert (4104) & Columbia Natural Resources LLC & Varick & Seneca & 2598 & 42.804 & -76.9055 \\
\hline 31099195050000 & $19505-00-00$ & Somerville 2 (4108) & Columbia Natural Resources LLC & Varick & Seneca & 2623 & 42.7879 & -76.9033 \\
\hline 31099195060000 & 19506-00-00 & St Thomas 1 (4099) & Columbia Natural Resources LLC & Fayette & Seneca & 2557 & 42.805 & -76.9387 \\
\hline 31099195350000 & 19535-00-00 & Johnson $1(4100)$ & Columbia Natural Resources LLC & Fayette & Seneca & 2515 & 42.8231 & -76.896 \\
\hline 31099195410000 & 19541-00-00 & Swartley 2 (4090) & Columbia Natural Resources LLC & Varick & Seneca & 2522 & 42.8023 & -76.8758 \\
\hline 31099195420000 & 19542-00-00 & Swartley 3 (4095) & Columbia Natural Resources LLC & Varick & Seneca & 2523 & 42.7976 & -76.8692 \\
\hline 31099195440000 & 19544-00-00 & Karlsen $3(4106)$ & Columbia Natural Resources LLC & Varick & Seneca & 2493 & 42.7984 & -76.9018 \\
\hline 31099195450000 & 19545-00-00 & Somerville 4 (4110) & Columbia Natural Resources LLC & Varick & Seneca & 2550 & 42.783 & -76.9008 \\
\hline 31099195480000 & 19548-00-00 & Heitmann 1 (4112) & Columbia Natural Resources LLC & Varick & Seneca & 2570 & 42.7895 & -76.8385 \\
\hline 31099195490000 & 19549-00-00 & McCarthy 1 (4116) & Columbia Natural Resources LLC & Fayette & Seneca & 2507 & 42.8669 & -76.8696 \\
\hline 31099195500000 & $19550-00-00$ & Dickenson 1 (4113) & Columbia Natural Resources LLC & Varick & Seneca & 2550 & 42.8066 & -76.8186 \\
\hline 31099195510000 & 19551-00-00 & Swartley 1 (4098) & Columbia Natural Resources LLC & Fayette & Seneca & 2465 & 42.8275 & -76.8933 \\
\hline 31099195530000 & 19553-00-00 & Karlsen 4 (4101) & Columbia Natural Resources LLC & Varick & Seneca & 2585 & 42.7887 & -76.8554 \\
\hline 31099195540000 & 19554-00-00 & Dey 1 (4094) & Columbia Natural Resources LLC & Fayette & Seneca & 2402 & 42.8087 & -76.9292 \\
\hline 31099195550000 & 19555-00-00 & Larsen 1 (4130) & Columbia Natural Resources LLC & Fayette & Seneca & 2484 & 42.833 & -76.8877 \\
\hline 31099195560000 & 19556-00-00 & Larsen 2 (4131) & Columbia Natural Resources LLC & Fayette & Seneca & 2472 & 42.8344 & -76.8776 \\
\hline 31099195570000 & 19557-00-00 & Nielson 1 (4129) & Columbia Natural Resources LLC & Fayette & Seneca & 2495 & 42.818 & -76.9208 \\
\hline 31099195580000 & 19558-00-00 & Kisner 2551 & Columbia Natural Resources LLC & Fayette & Seneca & 2472 & 42.8125 & -76.9201 \\
\hline 31099195620000 & 19562-00-00 & Hamilton 1 (4121) & Columbia Natural Resources LLC & Varick & Seneca & 2430 & 42.8001 & -76.9208 \\
\hline 31099195630000 & 19563-00-00 & Hamilton 2 (4125) & Columbia Natural Resources LLC & Varick & Seneca & 2415 & 42.7985 & -76.93 \\
\hline 31099195740000 & 19574-00-00 & Kime 2550 & Columbia Natural Resources LLC & Fayette & Seneca & 2293 & 42.8536 & -76.9196 \\
\hline 31099195790000 & 19579-00-00 & Nielsen 2544 & Columbia Natural Resources LLC & Fayette & Seneca & 2359 & 42.8243 & -76.9044 \\
\hline 31099195800000 & $19580-00-00$ & Sorensen 1 (4119) & Columbia Natural Resources LLC & Fayette & Seneca & 2385 & 42.8018 & -76.926 \\
\hline 31099195830000 & $19583-00-00$ & Freier 1 & Rasmussen Ronnie $\mathrm{O}$ & Fayette & Seneca & 2151 & 42.8511 & -76.8982 \\
\hline 31099195840000 & 19584-00-00 & Skinner 1 & Rasmussen Ronnie O. & Fayette & Seneca & 2100 & 42.8663 & -76.8833 \\
\hline 31099195850000 & 19585-00-00 & Seitz Farms 1 & Seitz Farms Inc. & Junius & Seneca & 1910 & 42.9846 & -76.9138 \\
\hline 31099195860000 & 19586-00-00 & Deming 1 & Mitchell Exploration Corp. & Seneca Falls & Seneca & 1780 & 42.9406 & -76.798 \\
\hline 31099195870000 & 19587-00-00 & Worden 1 & Mitchell Exploration Corp. & Tyre & Seneca & 1675 & 42.9917 & -76.8475 \\
\hline 31099195880000 & 19588-00-00 & Ritter 6 (4138) & Columbia Natural Resources LLC & Varick & Seneca & 2580 & 42.792 & -76.8801 \\
\hline 31099195890000 & $19589-00-00$ & Covert 1 (4137) & Dunbar Helen A. Covert & Varick & Seneca & 2445 & 42.7582 & -76.7948 \\
\hline 31099195970000 & 19597-00-00 & Guilfoos 1 (4142) & Columbia Natural Resources LLC & Varick & Seneca & 2717 & 42.7832 & -76.8425 \\
\hline
\end{tabular}




\begin{tabular}{|c|c|c|c|c|c|c|c|c|}
\hline API \# & SAPINO & WELL NAME & OPERATOR & TOWN & COUNTY & $\begin{array}{l}\text { Total } \\
\text { Depth }\end{array}$ & Lat & Lon \\
\hline 31099196210000 & 19621-00-00 & Stengle 4158 & Columbia Natural Resources LLC & Varick & Seneca & 2585 & 42.8005 & -76.8546 \\
\hline 31099196230000 & 19623-00-00 & Somerville 5 (4155) & Columbia Natural Resources LLC & Varick & Seneca & 2515 & 42.7907 & -76.8937 \\
\hline 31099196310000 & 19631-00-00 & Lynd (4166) & Columbia Natural Resources LLC & Fayette & Seneca & 2550 & 42.8137 & -76.9098 \\
\hline 31011196340000 & 19634-00-00 & Chappell 1 415-1 & Columbia Natural Resources LLC & Aurelius & Cayuga & 1821 & 42.9442 & -76.7196 \\
\hline 31011196360000 & $19636-00-00$ & Quill (Casler)419-3 & Meridian Exploration Corp. & Aurelius & Cayuga & 1791 & 42.9372 & -76.7091 \\
\hline 31011196370000 & $19637-00-00$ & Quill (Casler)420-4 & Columbia Natural Resources LLC & Aurelius & Cayuga & 1791 & 42.9337 & -76.7101 \\
\hline 31011196380000 & 19638-00-00 & Riford (Case)421-2 & Columbia Natural Resources LLC & Aurelius & Cayuga & 1761 & 42.9387 & -76.6958 \\
\hline 31011196400000 & $19640-00-00$ & Quill (Kirschner) 423-5 & Columbia Natural Resources LLC & Aurelius & Cayuga & 1800 & 42.9288 & -76.7056 \\
\hline 31011196410000 & $19641-00-00$ & Quill Unit 424-6 & Columbia Natural Resources LLC & Aurelius & Cayuga & 1826 & 42.9283 & -76.6998 \\
\hline 31011196420000 & 19642-00-00 & Case Unit 425-1 & Meridian Exploration Corp. & Aurelius & Cayuga & 1800 & 42.9451 & -76.6995 \\
\hline 31011196430000 & $19643-00-00$ & Case Unit 426-2 & Meridian Exploration Corp. & Aurelius & Cayuga & 1800 & 42.9492 & -76.6974 \\
\hline 31011196440000 & $19644-00-00$ & McPherson Unit 427-1 & Columbia Natural Resources LLC & Aurelius & Cayuga & 1800 & 42.9451 & -76.6759 \\
\hline 31011196450000 & $19645-00-00$ & McPherson Unit 428-2 & Columbia Natural Resources LLC & Aurelius & Cayuga & 1800 & 42.9416 & -76.6731 \\
\hline 31011196650000 & 19665-00-00 & Ventafido 1 (434-1) & Columbia Natural Resources LLC & Aurelius & Cayuga & 1825 & 42.9188 & -76.7144 \\
\hline 31011196660000 & $19666-00-00$ & Chappell 431-3 & Meridian Exploration Corp. & Aurelius & Cayuga & 1761 & 42.9389 & -76.7215 \\
\hline 31099196720000 & 19672-00-00 & Martin $1(4160)$ & Columbia Natural Resources LLC & Varick & Seneca & 2500 & 42.8 & -76.8326 \\
\hline 31099196730000 & 19673-00-00 & Boyle 1 (4115) & Columbia Natural Resources LLC & Varick & Seneca & 2570 & 42.7937 & -76.8169 \\
\hline 31011196740000 & $19674-00-00$ & Heintz 432-1 & Meridian Exploration Corp. & Aurelius & Cayuga & 1791 & 42.942 & -76.7082 \\
\hline 31099196750000 & $19675-00-00$ & Draper Farms 2555 & Columbia Natural Resources LLC & Fayette & Seneca & 2173 & 42.8623 & -76.9326 \\
\hline 31099196860000 & $19686-00-00$ & Townsend 1 & Mitchell Exploration Corp. & Lodi & Seneca & 4100 & 42.5882 & -76.844 \\
\hline 31097196920000 & $19692-00-00$ & Perigo 21578 Tpi & Columbia Natural Resources LLC & Reading & Schuyler & 8384 & 42.4326 & -76.9701 \\
\hline 31099204130000 & 20413-00-00 & Leonard 2574 & A.D.C.O. Well Services & Fayette & Seneca & 2355 & 42.8213 & -76.8339 \\
\hline 31099204150000 & 20415-00-00 & Swartley 1 & Pioneer Resources Inc. & Fayette & Seneca & 2495 & 42.8084 & -76.915 \\
\hline 31099204160000 & 20416-00-00 & Stengle-Swartley 1 & Pioneer Resources Inc. & Fayette & Seneca & 2436 & 42.8083 & -76.9083 \\
\hline 31097204170000 & 20417-00-00 & Epstein 21624-Pi & Columbia Natural Resources LLC & Reading & Schuyler & 8520 & 42.4372 & -76.9558 \\
\hline 31011204200000 & $20420-00-00$ & Patterson 212-2 & Columbia Natural Resources LLC & Springport & Cayuga & 1998 & 42.8665 & -76.6615 \\
\hline 31011204210000 & 20421-00-00 & Bacon J 3 & F \& G Exploration & Springport & Cayuga & 1998 & 42.8665 & -76.683 \\
\hline 31011204220000 & 20422-00-00 & Bacon J 2 & F \& G Exploration & Springport & Cayuga & 1998 & 42.8624 & -76.6839 \\
\hline 31099204230000 & 20423-00-00 & Gordner 2575 & Columbia Natural Resources LLC & Fayette & Seneca & 2525 & 42.8124 & -76.8554 \\
\hline 31099204240000 & 20424-00-00 & Karlsen 2 (4172) & Columbia Natural Resources LLC & Varick & Seneca & 2501 & 42.7928 & -76.8561 \\
\hline 31099204290000 & 20429-00-00 & Lerch 2 (4175) & Columbia Natural Resources LLC & Varick & Seneca & 2514 & 42.8 & -76.8638 \\
\hline 31099204300000 & $20430-00-00$ & Adler 2 (4162) & Columbia Natural Resources LLC & Varick & Seneca & 2527 & 42.7867 & -76.8489 \\
\hline 31099204310000 & 20431-00-00 & Clemens 1 (4171) & Columbia Natural Resources LLC & Varick & Seneca & 2511 & 42.7952 & -76.8644 \\
\hline 31099204320000 & 20432-00-00 & Swartley 2571 & Columbia Natural Resources LLC & Fayette & Seneca & 2487 & 42.8133 & -76.8967 \\
\hline 31011204360000 & $20436-00-00$ & Bacon 1 & F \& G Exploration & Aurelius & Cayuga & 1945 & 42.9068 & -76.6722 \\
\hline 31011204370000 & 20437-00-00 & Bacon 2 & F \& G Exploration & Aurelius & Cayuga & 1998 & 42.9094 & -76.6757 \\
\hline 31099204460000 & $20446-00-00$ & Compton 1 (4177) & Equitable Resources Exploraration & Romulus & Seneca & 6366 & 42.7086 & -76.8082 \\
\hline 31099204470000 & 20447-00-00 & Pearce 2577 & Columbia Natural Resources LLC & Fayette & Seneca & 2359 & 42.8437 & -76.9135 \\
\hline 31099204480000 & 20448-00-00 & Deal $1(4180)$ & Columbia Natural Resources LLC & Fayette & Seneca & 2305 & 42.8262 & -76.7863 \\
\hline 31011204510000 & 20451-00-00 & Bacon 1 (521-2) & Columbia Natural Resources LLC & Aurelius & Cayuga & 1825 & 42.9029 & -76.6829 \\
\hline 31011204540000 & 20454-00-00 & Bacon $1(606-5)$ & Columbia Natural Resources LLC & Aurelius & Cayuga & 1838 & 42.8983 & -76.6779 \\
\hline
\end{tabular}




\begin{tabular}{|c|c|c|c|c|c|c|c|c|}
\hline API \# & SAPINO & WELL NAME & OPERATOR & TOWN & COUNTY & $\begin{array}{l}\text { Total } \\
\text { Depth }\end{array}$ & Lat & Lon \\
\hline 31011204550000 & 20455-00-00 & Bacon 1 613-6 & Columbia Natural Resources LLC & Aurelius & Cayuga & 1855 & 42.8995 & -76.6733 \\
\hline 31011204560000 & 20456-00-00 & Patterson E 1 (644-3) & Columbia Natural Resources LLC & Aurelius & Cayuga & 1845 & 42.9 & -76.6678 \\
\hline 31099204590000 & 20459-00-00 & Poorman 1 (2578-1) & Meridian Exploration Corp. & Fayette & Seneca & 2510 & 42.8134 & -76.8397 \\
\hline 31011204600000 & $20460-00-00$ & O'Hara (401-3) & Columbia Natural Resources LLC & Aurelius & Cayuga & 1840 & 42.913 & -76.6578 \\
\hline 31011204610000 & 20461-00-00 & O'Hara (406-4) & Columbia Natural Resources LLC & Aurelius & Cayuga & 1855 & 42.9095 & -76.6568 \\
\hline 31011204640000 & 20464-00-00 & O'Hara (520-7) & Columbia Natural Resources LLC & Aurelius & Cayuga & 1860 & 42.8987 & -76.6581 \\
\hline 31011204670000 & 20467-00-00 & Fabian Unit 685-5 & Columbia Natural Resources LLC & Springport & Cayuga & 1874 & 42.8953 & -76.6622 \\
\hline 31011204880000 & 20488-00-00 & Fee 1 & Union Springs School District & Springport & Cayuga & 2205 & 42.8355 & -76.6879 \\
\hline 31011204990000 & 20499-00-00 & Fabian 347-7 & Columbia Natural Resources LLC & Springport & Cayuga & 1972 & 42.8895 & -76.6574 \\
\hline 31011205010000 & 20501-00-00 & Pethybridge $349-2$ & Columbia Natural Resources LLC & Springport & Cayuga & 1905 & 42.8841 & -76.6706 \\
\hline 31011205030000 & 20503-00-00 & Jellinghaus $708-2$ & Columbia Natural Resources LLC & Springport & Cayuga & 2032 & 42.8845 & -76.6506 \\
\hline 31011205060000 & 20506-00-00 & Staehr 800-2 & Columbia Natural Resources LLC & Springport & Cayuga & 2130 & 42.8717 & -76.6562 \\
\hline 31011205070000 & 20507-00-00 & Staehr 801-3 & Columbia Natural Resources LLC & Springport & Cayuga & 2128 & 42.8737 & -76.6518 \\
\hline 31011205080000 & $20508-00-00$ & Staehr 802-4 & Columbia Natural Resources LLC & Springport & Cayuga & 2102 & 42.8738 & -76.6468 \\
\hline 31011205110000 & 20511-00-00 & Klock 805-2 & Columbia Natural Resources LLC & Springport & Cayuga & 2175 & 42.8742 & -76.6409 \\
\hline 31011205150000 & 20515-00-00 & Downing 809-7 & Columbia Natural Resources LLC & Springport & Cayuga & 1844 & 42.8874 & -76.6764 \\
\hline 31011205160000 & 20516-00-00 & Burtless 810-2 & Columbia Natural Resources LLC & Aurelius & Cayuga & 1833 & 42.9249 & -76.6563 \\
\hline 31011205170000 & $20517-00-00$ & Burtless 811-3 & Columbia Natural Resources LLC & Aurelius & Cayuga & 1817 & 42.9203 & -76.6649 \\
\hline 31099205230000 & 20523-00-00 & Larsen 818-2 & Columbia Natural Resources LLC & Fayette & Seneca & 2266 & 42.8525 & -76.8874 \\
\hline 31011205250000 & $20525-00-00$ & Schenck 820-5 & Columbia Natural Resources LLC & Springport & Cayuga & 2229 & 42.8553 & -76.648 \\
\hline 31099205260000 & 20526-00-00 & Schaffer 821-2 & Columbia Natural Resources LLC & Fayette & Seneca & 2230 & 42.8608 & -76.8582 \\
\hline 31123205370000 & 20537-00-00 & Fulkrod B 1 & Ardent Resources Inc. & Benton & Yates & 3225 & 42.7245 & -77.0094 \\
\hline 31123205390000 & 20539-00-00 & Barden 1 & Ardent Resources Inc. & Benton & Yates & 3034 & 42.6997 & -77.0492 \\
\hline 31123205440000 & 20544-00-00 & Schiek 1a & Ardent Resources Inc. & Benton & Yates & 3100 & 42.7201 & -77.0006 \\
\hline 31123205460000 & 20546-00-00 & Lewis 1 & Ardent Resources Inc. & Benton & Yates & 3005 & 42.7472 & -77.0146 \\
\hline 31011205530000 & $20553-00-00$ & O'Hara Farms 932-8 & Columbia Natural Resources LLC & Aurelius & Cayuga & 1866 & 42.9065 & -76.6539 \\
\hline 31011205540000 & 20554-00-00 & Downing 936-1 & Columbia Natural Resources LLC & Springport & Cayuga & 1820 & 42.8882 & -76.6869 \\
\hline 31011205550000 & $20555-00-00$ & O'Hara Farms 944-9 & Columbia Natural Resources LLC & Aurelius & Cayuga & 1796 & 42.9142 & -76.6634 \\
\hline 31011205560000 & $20556-00-00$ & O'Hara Farms 950-10 & Columbia Natural Resources LLC & Aurelius & Cayuga & 1836 & 42.9132 & -76.6527 \\
\hline 31011205600000 & $20560-00-00$ & Staehr 937-3 & Columbia Natural Resources LLC & Springport & Cayuga & 2044 & 42.8609 & -76.6724 \\
\hline 31011205610000 & 20561-00-00 & Shank 952-4 & Columbia Natural Resources LLC & Springport & Cayuga & 1955 & 42.8952 & -76.6501 \\
\hline 31123205620000 & 20562-00-00 & Castner 1-S & Ardent Resources Inc. & Potter & Yates & 3674 & 42.6696 & -77.1619 \\
\hline 31123205700000 & $20570-00-00$ & Fulkrod A 1 & Ardent Resources Inc. & Benton & Yates & 3208 & 42.7316 & -77.0094 \\
\hline 31123205710000 & 20571-00-00 & Martin 1 & Ardent Resources Inc. & Benton & Yates & 3487 & 42.701 & -77.0619 \\
\hline 31011206090000 & $20609-00-00$ & Klock 1040-3 & Columbia Natural Resources LLC & Springport & Cayuga & 2220 & 42.8749 & -76.6317 \\
\hline 31011206140000 & 20614-00-00 & Staehr 1039-3 & Columbia Natural Resources LLC & Springport & Cayuga & 1970 & 42.8622 & -76.6772 \\
\hline 31011206150000 & 20615-00-00 & Gould 1033-1 & Columbia Natural Resources LLC & Aurelius & Cayuga & 1975 & 42.9101 & -76.6419 \\
\hline 31011206160000 & $20616-00-00$ & Gould 1046-3 & Columbia Natural Resources LLC & Aurelius & Cayuga & 1978 & 42.9135 & -76.6463 \\
\hline 31011206170000 & $20617-00-00$ & Gould 1062-4 & Columbia Natural Resources LLC & Aurelius & Cayuga & 1930 & 42.9093 & -76.6483 \\
\hline 31011206180000 & 20618-00-00 & Shoemaker 1051-3 & Columbia Natural Resources LLC & Springport & Cayuga & 2165 & 42.8783 & -76.6436 \\
\hline 31011206210000 & 20621-00-00 & Patreal Corp 1 (1057-3) & Columbia Natural Resources LLC & Springport & Cayuga & 1860 & 42.8815 & -76.6992 \\
\hline
\end{tabular}




\begin{tabular}{|c|c|c|c|c|c|c|c|c|}
\hline API \# & SAPINO & WELL NAME & OPERATOR & TOWN & COUNTY & $\begin{array}{l}\text { Total } \\
\text { Depth }\end{array}$ & Lat & Lon \\
\hline 31011206240000 & $20624-00-00$ & Lockwood Ray 1 (1047-1) & Columbia Natural Resources LLC & Aurelius & Cayuga & 2074 & 42.911 & -76.6335 \\
\hline 31011206250000 & $20625-00-00$ & Webster Ralph 1 (1064-1) & Columbia Natural Resources LLC & Aurelius & Cayuga & 2213 & 42.9253 & -76.6209 \\
\hline 31011206260000 & $20626-00-00$ & Delaney Wm 1 (1058-1) & Columbia Natural Resources LLC & Fleming & Cayuga & 2221 & 42.8816 & -76.6252 \\
\hline 31099206270000 & $20627-00-00$ & Sigrist 1041-3 & Columbia Natural Resources LLC & Fayette & Seneca & 2249 & 42.8557 & -76.8608 \\
\hline 31099206290000 & $20629-00-00$ & Larsen 1059-3 & A.D.C.O. Well Services & Fayette & Seneca & 2243 & 42.852 & -76.8792 \\
\hline 31011206320000 & 20632-00-00 & Carr Bruce 1038-1 & Columbia Natural Resources LLC & Springport & Cayuga & 2250 & 42.8415 & -76.6591 \\
\hline 31011206380000 & $20638-00-00$ & Patterson W W 1063-1 & Columbia Natural Resources LLC & Aurelius & Cayuga & 2064 & 42.9219 & -76.6156 \\
\hline 31011206390000 & $20639-00-00$ & Patterson W W 1065-1 & Columbia Natural Resources LLC & Springport & Cayuga & 2096 & 42.8563 & -76.6766 \\
\hline 31011206490000 & $20649-00-00$ & O'Hara Farm 1080-3 & Columbia Natural Resources LLC & Aurelius & Cayuga & 2104 & 42.9063 & -76.6339 \\
\hline 31011206500000 & $20650-00-00$ & O'Hara Farm 1081-4 & Columbia Natural Resources LLC & Aurelius & Cayuga & 2121 & 42.9055 & -76.6264 \\
\hline 31011206510000 & $20651-00-00$ & Ward 1067-1 & Columbia Natural Resources LLC & Aurelius & Cayuga & 2339 & 42.9013 & -76.6126 \\
\hline 31011206530000 & 20653-00-00 & Doody $1085-2$ & A.D.C.O. Well Services & Fleming & Cayuga & 2246 & 42.8927 & -76.5983 \\
\hline 31011206560000 & $20656-00-00$ & Patterson 1093-6 & Columbia Natural Resources LLC & Springport & Cayuga & 2080 & 42.8708 & -76.6709 \\
\hline 31011206630000 & $20663-00-00$ & Costello 1068-1 & Columbia Natural Resources LLC & Fleming & Cayuga & 2254 & 42.8907 & -76.6204 \\
\hline 31011206730000 & $20673-00-00$ & Riford 1076-1 & Columbia Natural Resources LLC & Aurelius & Cayuga & 2034 & 42.9214 & -76.6221 \\
\hline 31011206750000 & $20675-00-00$ & Marine Midland 1100-1 & Columbia Natural Resources LLC & Fleming & Cayuga & 2420 & 42.8923 & -76.6055 \\
\hline 31011206810000 & $20681-00-00$ & Bacon 1 & F \& G Exploration & Springport & Cayuga & 1997 & 42.8635 & -76.6921 \\
\hline 31099206830000 & 20683-00-00 & Sigrist 1066-6 & D-J's Farms Inc. & Fayette & Seneca & 2249 & 42.855 & -76.8665 \\
\hline 31099206940000 & 20694-00-00 & Freir 1126-1 & Columbia Natural Resources LLC & Fayette & Seneca & 2243 & 42.8262 & -76.7928 \\
\hline 31011206950000 & $20695-00-00$ & Jordan 1142-1 & Columbia Natural Resources LLC & Springport & Cayuga & 2483 & 42.818 & -76.6884 \\
\hline 31099207000000 & $20700-00-00$ & Keefer 970-1 & Columbia Natural Resources LLC & Varick & Seneca & 2388 & 42.8038 & -76.915 \\
\hline 31099207010000 & $20701-00-00$ & Clemens 984-1 & Meridian Exploration Corp. & Varick & Seneca & 2486 & 42.7741 & -76.9001 \\
\hline 31099207020000 & $20702-00-00$ & Hurst 968-1 & Columbia Natural Resources LLC & Fayette & Seneca & 2179 & 42.8315 & -76.7736 \\
\hline 31099207070000 & $20707-00-00$ & Clemens 991-2 & Columbia Natural Resources LLC & Varick & Seneca & 2475 & 42.7722 & -76.9056 \\
\hline 31099207080000 & $20708-00-00$ & Freir 994-2 & Columbia Natural Resources LLC & Fayette & Seneca & 2190 & 42.8287 & -76.7979 \\
\hline 31099212330000 & $21233-00-00$ & Dewall 1004-3 & Columbia Natural Resources LLC & Fayette & Seneca & 2137 & 42.8679 & -76.8521 \\
\hline 31099212360000 & $21236-00-00$ & Swartley 1131-1 & Columbia Natural Resources LLC & Varick & Seneca & 2468 & 42.8037 & -76.8696 \\
\hline 31011212380000 & $21238-00-00$ & Jellinghause $975-6$ & Columbia Natural Resources LLC & Springport & Cayuga & 2036 & 42.8812 & -76.6595 \\
\hline 31099212480000 & $21248-00-00$ & Hurrin 1001-1 & Columbia Natural Resources LLC & Varick & Seneca & 2456 & 42.7766 & -76.9058 \\
\hline 31099212490000 & $21249-00-00$ & Christensen 1018-1 & Columbia Natural Resources LLC & Fayette & Seneca & 2154 & 42.8619 & -76.9052 \\
\hline 31099212500000 & $21250-00-00$ & Lynd $1128-2$ & Columbia Natural Resources LLC & Fayette & Seneca & 2380 & 42.8224 & -76.9164 \\
\hline 31011212530000 & $21253-00-00$ & Pethybridge 1143-1 & Columbia Natural Resources LLC & Springport & Cayuga & 2400 & 42.8163 & -76.6772 \\
\hline 31099212690000 & $21269-00-00$ & Johnson 1135-1 & Meridian Exploration Corp. & Varick & Seneca & 2500 & 42.7677 & -76.9127 \\
\hline 31099212860000 & $21286-00-00$ & Jensen $1160-1$ & Columbia Natural Resources LLC & Fayette & Seneca & 2125 & 42.8664 & -76.9055 \\
\hline 31099212930000 & $21293-00-00$ & D.J. Farms 1158-1 & Columbia Natural Resources LLC & Fayette & Seneca & 2276 & 42.8415 & -76.8562 \\
\hline 31099212970000 & 21297-00-00 & Christenson $1125-2$ & Columbia Natural Resources LLC & Fayette & Seneca & 2199 & 42.8616 & -76.9118 \\
\hline 31099212980000 & $21298-00-00$ & Jensen $1173-2$ & Columbia Natural Resources LLC & Fayette & Seneca & 2185 & 42.8661 & -76.9114 \\
\hline 31099213150000 & $21315-00-00$ & Larsen 1194-5 & Columbia Natural Resources LLC & Fayette & Seneca & 2180 & 42.8621 & -76.8776 \\
\hline 31099213190000 & $21319-00-00$ & Jensen 1200 & Columbia Natural Resources LLC & Fayette & Seneca & 2048 & 42.874 & -76.8949 \\
\hline 31099213230000 & $21323-00-00$ & Robson 1201 & Columbia Natural Resources LLC & Fayette & Seneca & 2175 & 42.8447 & -76.8517 \\
\hline 31067213350000 & $21335-00-00$ & Halloran 1 & Eastern States Exploration Co. & Camillus & Onondaga & 4044 & 43.0661 & -76.3526 \\
\hline
\end{tabular}




\begin{tabular}{|c|c|c|c|c|c|c|c|c|}
\hline API \# & SAPINO & WELL NAME & OPERATOR & TOWN & COUNTY & $\begin{array}{l}\text { Total } \\
\text { Depth }\end{array}$ & Lat & Lon \\
\hline 31099213540000 & 21354-00-00 & Freir 1210 & Columbia Natural Resources LLC & Fayette & Seneca & 2131 & 42.8357 & -76.8021 \\
\hline 31099213550000 & $21355-00-00$ & Martin 1187 & A.D.C.O. Well Services & Fayette & Seneca & 2218 & 42.8231 & -76.7807 \\
\hline 31099213570000 & $21357-00-00$ & Ch of Jesus Christ 1229 & Columbia Natural Resources LLC & Fayette & Seneca & 2070 & 42.8668 & -76.8755 \\
\hline 31099213580000 & 21358-00-00 & Jensen 1216 & Columbia Natural Resources LLC & Fayette & Seneca & 2089 & 42.8787 & -76.8965 \\
\hline 31099213590000 & $21359-00-00$ & Stein 1214 & Columbia Natural Resources LLC & Fayette & Seneca & 2155 & 42.8565 & -76.8932 \\
\hline 31099213630000 & $21363-00-00$ & Rasmussen 1225 & Columbia Natural Resources LLC & Fayette & Seneca & 2358 & 42.8267 & -76.8678 \\
\hline 31099213720000 & 21372-00-00 & Waelz 1224 & Columbia Natural Resources LLC & Fayette & Seneca & 2061 & 42.8775 & -76.8906 \\
\hline 31099213820000 & 21382-00-00 & Wright 1238 & Meridian Exploration Corp. & Waterloo & Seneca & 1919 & 42.9106 & -76.8934 \\
\hline 31099213840000 & 21384-00-00 & Ch of Jesus Christ 1248 & Columbia Natural Resources LLC & Fayette & Seneca & 2068 & 42.8706 & -76.871 \\
\hline 31099213920000 & 21392-00-00 & Jarman 1204 & Columbia Natural Resources LLC & Fayette & Seneca & 2170 & 42.8528 & -76.8419 \\
\hline 31011213930000 & 21393-00-00 & Bowen 1261 & Columbia Natural Resources LLC & Springport & Cayuga & 2349 & 42.8187 & -76.6823 \\
\hline 31099214070000 & 21407-00-00 & Wagner 1292 & A.D.C.O. Well Services & Fayette & Seneca & 2049 & 42.8749 & -76.9074 \\
\hline 31101214680000 & 21468-00-00 & Mitchell 1 & Semgas Storage L.L.C. & Avoca & Steuben & 9887 & 42.4197 & -77.4532 \\
\hline 31011214690000 & $21469-00-00$ & Asdgt 2 & Auburn Enlarged Central School District & & Cayuga & 5106 & 42.9467 & -76.5413 \\
\hline 31097214950000 & 21495-00-00 & Bale 1 & JMC Cayuta Inc. & Cayuta & Schuyler & 11823 & 42.27 & -76.7136 \\
\hline 31101214960000 & 21496-00-00 & Hubbard No. 1 & Semgas Storage L.L.C. & Avoca & Steuben & 10051 & 42.4053 & -77.4632 \\
\hline 31101215510000 & 21551-00-00 & BPSI 8 & Bath Petroleum Storage Inc. & Bath & Steuben & 6000 & 42.3117 & -77.2564 \\
\hline 31101215920000 & 21592-00-00 & Gray 21625 & Columbia Natural Resources LLC & Pulteney & Steuben & 7176 & 42.5406 & -77.2366 \\
\hline 31101216010000 & 21601-00-00 & Mitchell 2 & Semgas Storage L.L.C. & Avoca & Steuben & 9786 & 42.4334 & -77.4534 \\
\hline 31101216240000 & 21624-00-00 & Avoca 4 & Semgas Storage L.L.C. & Avoca & Steuben & 9202 & 42.4201 & -77.4672 \\
\hline 31101216330000 & 21633-00-00 & Mitchell 3 & Semgas Storage L.L.C. & Avoca & Steuben & 9950 & 42.4279 & -77.4456 \\
\hline 31101216360000 & 21636-00-00 & Fee 6 & Semgas Storage L.L.C. & Avoca & Steuben & 9939 & 42.429 & -77.4657 \\
\hline 31101216880000 & 21688-00-00 & Levandowski 623088 & Columbia Natural Resources LLC & Prattsburg & Steuben & 7313 & 42.5344 & -77.2519 \\
\hline 31101216890000 & 21689-00-00 & Covert 622302 & Columbia Natural Resources LLC & Prattsburg & Steuben & 7499 & 42.5388 & -77.275 \\
\hline 31099216900000 & $21690-00-00$ & Freir 1235-1 & Meridian Exploration Corp. & Fayette & Seneca & 0 & 42.841 & -76.8981 \\
\hline 31101216920000 & 21692-00-00 & Pizura 623143 & Columbia Natural Resources LLC & Pulteney & Steuben & 7091 & 42.5399 & -77.1822 \\
\hline 31101217030000 & 21703-00-00 & Radigan 623267 & Columbia Natural Resources LLC & Pulteney & Steuben & & 42.5435 & -77.1674 \\
\hline 31101217040000 & 21704-00-00 & Fimlaid 1 & Columbia Natural Resources LLC & Wayne & Steuben & 8028 & 42.4394 & -77.1112 \\
\hline 31101217050000 & 21705-00-00 & Smith 1 & Columbia Natural Resources LLC & Pulteney & Steuben & 7110 & 42.5435 & -77.198 \\
\hline 31101217060000 & 21706-00-00 & Fox $1(623217)$ & Columbia Natural Resources LLC & Pulteney & Steuben & 7048 & 42.5387 & -77.2031 \\
\hline 31101217100000 & $21710-00-00$ & Bergstresser 1 & Columbia Natural Resources LLC & Pulteney & Steuben & 6691 & 42.5472 & -77.1723 \\
\hline 31101217150000 & 21715-00-00 & Grace 1 & Columbia Natural Resources LLC & Prattsburg & Steuben & 7879 & 42.5237 & -77.3412 \\
\hline 31109217160000 & $21716-00-00$ & Stairs 1 & Columbia Natural Resources LLC & Dryden & Tompkins & 7468 & 42.5111 & -76.3007 \\
\hline 31101217180000 & 21718-00-00 & Demun 1 & True Oil Co. & Troupsburg & Steuben & 11166 & 42.0956 & -77.594 \\
\hline 31097217250000 & $21725-00-00$ & Forte 1 & Columbia Natural Resources LLC & Tyrone & Schuyler & 8275 & 42.4713 & -77.0039 \\
\hline 31097217260000 & 21726-00-00 & Mast 1 & Columbia Natural Resources LLC & Tyrone & Schuyler & 8174 & 42.4761 & -77.0028 \\
\hline 31101227410000 & 22741-00-00 & Von Rhedey 623519 & Columbia Natural Resources LLC & Pulteney & Steuben & 7500 & 42.4939 & -77.2055 \\
\hline 31101227450000 & $22745-00-00$ & Faber 1 & Columbia Natural Resources LLC & Prattsburg & Steuben & 7371 & 42.5003 & -77.2418 \\
\hline 31123227460000 & $22746-00-00$ & Dewitt 623333 & Columbia Natural Resources LLC & Barrington & Yates & & 42.5173 & -77.0609 \\
\hline 31101227470000 & 22747-00-00 & Smith 1 & Columbia Natural Resources LLC & Pulteney & Steuben & 7442 & 42.5103 & -77.209 \\
\hline 31101227480000 & $22748-00-00$ & McAllister 1 & Columbia Natural Resources LLC & Pulteney & Steuben & 7232 & 42.5107 & -77.1918 \\
\hline
\end{tabular}




\begin{tabular}{|c|c|c|c|c|c|c|c|c|}
\hline API \# & SAPINO & WELL NAME & OPERATOR & TOWN & COUNTY & $\begin{array}{l}\text { Total } \\
\text { Depth }\end{array}$ & Lat & Lon \\
\hline 31123227500000 & $22750-00-00$ & Weitz 1 & Columbia Natural Resources LLC & Barrington & Yates & 7555 & 42.4933 & -77.0873 \\
\hline 31123227520000 & $22752-00-00$ & Knapp 1 & Columbia Natural Resources LLC & Barrington & Yates & 7543 & 42.5285 & -77.0824 \\
\hline 31109227530000 & $22753-00-00$ & Koskinen 623513 & Columbia Natural Resources LLC & Ulysses & Tompkins & 7462 & 42.4904 & -76.673 \\
\hline 31097227540000 & $22754-00-00$ & Gunning 1 & Columbia Natural Resources LLC & Hector & Schuyler & 7999 & 42.4602 & -76.7318 \\
\hline 31101227550000 & $22755-00-00$ & Snyder 1 & Columbia Natural Resources LLC & Pulteney & Steuben & 6816 & 42.5188 & -77.1658 \\
\hline 31101227560000 & 22756-00-00 & Grand View 1 & Columbia Natural Resources LLC & Pulteney & Steuben & 7848 & 42.4823 & -77.2037 \\
\hline 31123227570000 & $22757-00-00$ & NYS Reforestation Area 1 & Belden \& Blake Corporation & Italy & Yates & 7287 & 42.6457 & -77.2463 \\
\hline 31101227580000 & $22758-00-00$ & S \& D Farms 623504 & Columbia Natural Resources LLC & Cohocton & Steuben & 7416 & 42.5494 & -77.4539 \\
\hline 31101227590000 & $22759-00-00$ & S \& D Farms 623144 & Columbia Natural Resources LLC & Cohocton & Steuben & & 42.5334 & -77.4002 \\
\hline 31101227600000 & $22760-00-00$ & Wolcott 623284 & Columbia Natural Resources LLC & Cohocton & Steuben & & 42.5423 & -77.4184 \\
\hline 31099227610000 & $22761-00-00$ & Poorman 2586-01 & Meridian Exploration Corp. & Fayette & Seneca & 5431 & 42.8393 & -76.8367 \\
\hline 31099227620000 & $22762-00-00$ & Schaffer 2584-03 & Columbia Natural Resources LLC & Fayette & Seneca & 5002 & 42.8601 & -76.8517 \\
\hline 31099227630000 & $22763-00-00$ & Murray 2587-01 & Meridian Exploration Corp. & Fayette & Seneca & 5452 & 42.8284 & -76.8375 \\
\hline 31123227640000 & $22764-00-00$ & Costanza 1 & Belden \& Blake Corporation & Italy & Yates & 6473 & 42.632 & -77.2785 \\
\hline 31101227650000 & $22765-00-00$ & Wise 1 (623520) & Columbia Natural Resources LLC & Pulteney & Steuben & & 42.4932 & -77.2345 \\
\hline 31101227660000 & $22766-00-00$ & Peck 1 (623516) & Columbia Natural Resources LLC & Cohocton & Steuben & 7644 & 42.5458 & -77.441 \\
\hline 31109227670000 & $22767-00-00$ & Duddleston 623514 & Columbia Natural Resources LLC & Ulysses & Tompkins & 7454 & 42.512 & -76.6358 \\
\hline 31101227710000 & 22771-00-00 & Jimerson 1240 & Fortuna Energy Inc. & Hornby & Steuben & 9710 & 42.2148 & -77.0145 \\
\hline 31101227720000 & $22772-00-00$ & Egresi 1 & Columbia Natural Resources LLC & Pulteney & Steuben & 7152 & 42.5353 & -77.1718 \\
\hline 31123227730000 & $22773-00-00$ & Knapp 2 & Columbia Natural Resources LLC & Barrington & Yates & 7598 & 42.5241 & -77.0817 \\
\hline 31123227740000 & $22774-00-00$ & Knapp 3 & Columbia Natural Resources LLC & Barrington & Yates & 7101 & 42.5308 & -77.0826 \\
\hline 31123227750000 & $22775-00-00$ & Walters 623641 & Columbia Natural Resources LLC & Jerusalem & Yates & & 42.6141 & -77.1519 \\
\hline 31109227890000 & $22789-00-00$ & Rehebein/Call 1 & Columbia Natural Resources LLC & Dryden & Tompkins & 0 & 42.5429 & -76.2799 \\
\hline 31123227900000 & $22790-00-00$ & Agliata 1 (623780) & Columbia Natural Resources LLC & Milo & Yates & 7417 & 42.582 & -77.0622 \\
\hline 31123227910000 & $22791-00-00$ & Bauer 1 (623781) & Columbia Natural Resources LLC & Barrington & Yates & 7086 & 42.5764 & -77.0579 \\
\hline 31123227950000 & $22795-00-00$ & Martin-Repacki 1 & Columbia Natural Resources LLC & Barrington & Yates & 7333 & 42.5345 & -77.0466 \\
\hline 31123227960000 & $22796-00-00$ & Zimmerman 623825 & Columbia Natural Resources LLC & Barrington & Yates & 7482 & 42.5481 & -77.0398 \\
\hline 31097227990000 & $22799-00-00$ & Rumsey 1 (623838) & Columbia Natural Resources LLC & Tyrone & Schuyler & 8037 & 42.4452 & -77.0582 \\
\hline 31101228140000 & $22814-00-00$ & Howe 1300 & Pennsylvania General Energy & Hornby & Steuben & 10285 & 42.2049 & -77.0542 \\
\hline 31101228250000 & $22825-00-00$ & Rice 1301 & Fortuna Energy Inc. & Hornby & Steuben & 9322 & 42.2127 & -77.0354 \\
\hline 31015228260000 & $22826-00-00$ & Broz Unit 1 & Fortuna Energy Inc. & Veteran & Chemung & 9362 & 42.2728 & -76.7738 \\
\hline 31015228270000 & $22827-00-00$ & Bennett Family 1 & Fortuna Energy Inc. & Veteran & Chemung & 9442 & 42.2841 & -76.7747 \\
\hline 31123228280000 & $22828-00-00$ & Martin 623864 & Columbia Natural Resources LLC & Benton & Yates & 6652 & 42.6724 & -77.1042 \\
\hline 31097228300000 & $22830-00-00$ & Grand Prix 2 (624066) & Fortuna Energy Inc. & Orange & Schuyler & 9745 & 42.3061 & -77.0805 \\
\hline 31015228310000 & $22831-00-00$ & Lovell 1323 & Fortuna Energy Inc. & Big Flats & Chemung & 9386 & 42.1868 & -76.9582 \\
\hline 31015228380000 & $22838-00-00$ & Monahan 624115 & Columbia Natural Resources LLC & Erin & Chemung & 10017 & 42.1754 & -76.6513 \\
\hline 31123228400000 & $22840-00-00$ & Dick 623970 & Columbia Natural Resources LLC & Jerusalem & Yates & 6061 & 42.598 & -77.1677 \\
\hline 31097228410000 & $22841-00-00$ & SRA 21 & Fortuna Energy Inc. & Orange & Schuyler & 8675 & 42.3403 & -77.0204 \\
\hline 31101228450000 & $22845-00-00$ & Medrek 624126 & Columbia Natural Resources LLC & Pulteney & Steuben & & 42.509 & -77.1727 \\
\hline 31123228500000 & $22850-00-00$ & Watson 1 & Belden \& Blake Corporation & Italy & Yates & 7136 & 42.618 & -77.3167 \\
\hline 31101228520000 & $22852-00-00$ & Van Vleet 1355 & Fortuna Energy Inc. & Hornby & Steuben & 10514 & 42.2013 & -77.0863 \\
\hline
\end{tabular}




\begin{tabular}{|c|c|c|c|c|c|c|c|c|}
\hline API \# & SAPINO & WELL NAME & OPERATOR & TOWN & COUNTY & $\begin{array}{l}\text { Total } \\
\text { Depth }\end{array}$ & Lat & Lon \\
\hline 31015228530000 & 22853-00-00 & Rhodes 1322 & Fortuna Energy Inc. & Big Flats & Chemung & 9682 & 42.1953 & -76.9209 \\
\hline 31015228570000 & 22857-00-00 & Kimball 1 & Fortuna Energy Inc. & Veteran & Chemung & 9166 & 42.2727 & -76.7913 \\
\hline 31123228580000 & 22858-00-00 & Mulligan 1 & Belden \& Blake Corporation & Italy & Yates & 6102 & 42.6391 & -77.2771 \\
\hline 31101228590000 & $22859-00-00$ & Huber 1 & Belden \& Blake Corporation & Wayland & Steuben & 7535 & 42.5357 & -77.592 \\
\hline 31101228610000 & 22861-00-00 & NYS GMA 2 & Fairman Drilling Co. & Erwin & Steuben & 10524 & 42.1576 & -77.1646 \\
\hline 31099228640000 & 22864-00-00 & DJ Farms 624312 & Columbia Natural Resources LLC & Fayette & Seneca & 2193 & 42.8562 & -76.8498 \\
\hline 31099228660000 & $22866-00-00$ & DJ Farms 624311 & Columbia Natural Resources LLC & Fayette & Seneca & 2196 & 42.8534 & -76.8536 \\
\hline 31011228790000 & 22879-00-00 & Cuff A123-4 & OI Auburn Inc. & Aurelius & Cayuga & 1896 & 42.9129 & -76.7087 \\
\hline 31097228810000 & 22881-00-00 & Learn 1 & Fortuna Energy Inc. & Montour & Schuyler & 9061 & 42.3083 & -76.8158 \\
\hline 31101228850000 & $22885-00-00$ & Corning Game Club 624460 & Fortuna Energy Inc. & Corning & Steuben & 10050 & 42.1799 & -77.0662 \\
\hline 31097228930000 & 22893-00-00 & Purvis 1 & Fortuna Energy Inc. & Dix & Schuyler & 9095 & 42.2952 & -76.8597 \\
\hline 31015228990000 & 22899-00-00 & Trimber 624536 & Columbia Natural Resources LLC & Erin & Chemung & 10530 & 42.1604 & -76.6868 \\
\hline 31015229020000 & $22902-00-00$ & Lederer 1412 & Pennsylvania General Energy & Catlin & Chemung & 9602 & 42.2525 & -76.8691 \\
\hline 31099229090000 & $22909-00-00$ & Campion 1 & EOG Resources Inc & Lodi & Seneca & 7673 & 42.553 & -76.819 \\
\hline 31015229110000 & 22911-00-00 & Schmidt 624537 & Columbia Natural Resources LLC & Erin & Chemung & 10366 & 42.1468 & -76.6927 \\
\hline 31015229180000 & 22918-00-00 & Gregory 1446 & Pennsylvania General Energy & Catlin & Chemung & 9402 & 42.2073 & -76.8844 \\
\hline 31015229190000 & 22919-00-00 & Hardy 1447 & Pennsylvania General Energy & Catlin & Chemung & 9859 & 42.2374 & -76.9201 \\
\hline 31015229240000 & 22924-00-00 & Johnson 1 & Fairman Drilling Co. & Veteran & Chemung & 9803 & 42.269 & -76.7509 \\
\hline 31107229340000 & 22934-00-00 & Manwaring 624470 & Columbia Natural Resources LLC & Tioga & Tioga & 11552 & 42.0578 & -76.4098 \\
\hline 31097229350000 & $22935-00-00$ & Wonderview Farms 1 & Fortuna Energy Inc. & Catharine & Schuyler & 8762 & 42.3304 & -76.7468 \\
\hline 31123229410000 & 22941-00-00 & Boudinot 623968 & Columbia Natural Resources LLC & Starkey & Yates & 7181 & 42.5239 & -76.9567 \\
\hline 31097229420000 & 22942-00-00 & Bonham 1 & Fortuna Energy Inc. & Orange & Schuyler & 10069 & 42.296 & -76.9891 \\
\hline 31069229430000 & 22943-00-00 & Stoddard 624633 & Columbia Natural Resources LLC & Hopewell & Ontario & 4965 & 42.8889 & -77.1914 \\
\hline 31099229440000 & 22944-00-00 & Lott 624600 & Columbia Natural Resources LLC & Fayette & Seneca & & 42.8797 & -76.8123 \\
\hline 31099229460000 & 22946-00-00 & Nolt 624595 & Columbia Natural Resources LLC & Fayette & Seneca & & 42.863 & -76.8485 \\
\hline 31099229470000 & 22947-00-00 & Hartman 624594 & Columbia Natural Resources LLC & Fayette & Seneca & & 42.8302 & -76.8846 \\
\hline 31099229500000 & $22950-00-00$ & Ziefle 1 & Eastern American Energy Corp. & Covert & Seneca & 7497 & 42.5642 & -76.702 \\
\hline 31007229840000 & 22984-00-00 & Merrill 1 & Belden \& Blake Corporation & Colesville & Broome & 9874 & 42.1782 & -75.6703 \\
\hline 31007229950000 & 22995-00-00 & Beagell 2 & Belden \& Blake Corporation & Kirkwood & Broome & 10260 & 42.1373 & -75.8335 \\
\hline 31101230540000 & 23054-00-00 & Hakes 1 & Fortuna Energy Inc. & Corning & Steuben & 10107 & 42.1786 & -77.0169 \\
\hline 31007230560000 & $23056-00-00$ & Butkowsky 1 & Belden \& Blake Corporation & Kirkwood & Broome & 10105 & 42.1428 & -75.8249 \\
\hline 31101230850000 & $23085-00-00$ & Erwin WMA 1 & Fortuna Energy Inc. & Erwin & Steuben & 9797 & 42.1644 & -77.1496 \\
\hline 31121233890000 & $23389-00-00$ & Krolick 2 & Stedman Energy Inc. & Arcade & Wyoming & 6200 & 42.5648 & -78.4439 \\
\hline 31009234560000 & $23456-00-00$ & Braymiller-Rauch 1454 & Pennsylvania General Energy & Yorkshire & Cattaraugus & 6565 & 42.4976 & -78.5228 \\
\hline
\end{tabular}


Appendix B - Table 2 - Formation Tops

\begin{tabular}{|c|c|c|c|c|c|c|c|c|c|}
\hline API & SAPINO & 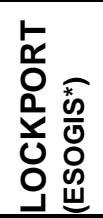 & 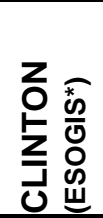 & 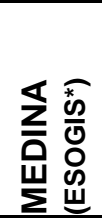 & 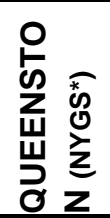 & 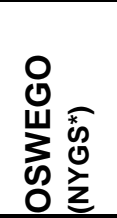 & 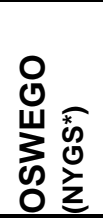 & 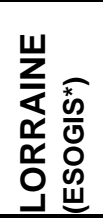 & 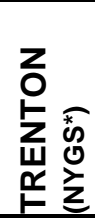 \\
\hline 31011004780000 & $00478-00-00$ & & & & 3099 & 4050 & 4050 & & \\
\hline 31121006150000 & 00615-00-00 & & & & 3358 & & & 4524 & \\
\hline 31017011600000 & $01160-00-00$ & & & & 3075 & & & 3132 & \\
\hline 31003039560000 & $03956-00-00$ & & & & 4110 & & & 5312 & \\
\hline 31109039730000 & 03973-00-00 & & & & 5635 & 6230 & 6230 & 6984 & \\
\hline 31109040070000 & $04007-00-00$ & & & & 5688 & 6390 & 6390 & 7000 & \\
\hline 31011040380000 & $04038-00-00$ & & & & 1465 & & & & \\
\hline 31099040640000 & 04064-00-00 & & & & 1800 & & & & \\
\hline 31011040680000 & $04068-00-00$ & & & & 1810 & & & & \\
\hline 31099040820000 & $04082-00-00$ & & & & 1676 & & & & \\
\hline 31121040920000 & 04092-00-00 & & & & 3366 & & & 4600 & \\
\hline 31099041110000 & 04111-00-00 & & & & 1796 & & & & \\
\hline 31011041120000 & $04112-00-00$ & & & & 1884 & & & & \\
\hline 31109041300000 & $04130-00-00$ & & & & 5185 & 5861 & 5861 & 6555 & \\
\hline 31099041580000 & $04158-00-00$ & & & & 1577 & & & & \\
\hline 31099042030000 & $04203-00-00$ & & & & 1754 & 2790 & 2790 & 3050 & 3479 \\
\hline 31099042440000 & $04244-00-00$ & & & & 2035 & & & & \\
\hline 31011043890000 & $04389-00-00$ & & & & 1542 & & & & \\
\hline 31099044080000 & $04408-00-00$ & & & & 1522 & & & & \\
\hline 31011044480000 & $04448-00-00$ & & & & 1504 & & & & \\
\hline 31109044670000 & $04467-00-00$ & 4425 & 4548 & 5040 & 5199 & 5800 & 5800 & 6555 & 7348 \\
\hline 31011044910000 & $04491-00-00$ & & & & 1510 & & & & \\
\hline 31011044930000 & $04493-00-00$ & & & & 1519 & & & & \\
\hline 31011044970000 & $04497-00-00$ & & & & 1550 & & & & \\
\hline 31011045120000 & $04512-00-00$ & & & & 1556 & & & & \\
\hline 31011045180000 & $04518-00-00$ & & & & 1530 & & & & \\
\hline 31011045190000 & $04519-00-00$ & & & & 1575 & & & & \\
\hline 31011045210000 & $04521-00-00$ & & & & 1550 & & & & \\
\hline 31011045400000 & $04540-00-00$ & & & & 1675 & & & & \\
\hline 31099045440000 & $04544-00-00$ & & & & 1980 & & & & \\
\hline
\end{tabular}




\begin{tabular}{|c|c|c|c|c|c|c|c|c|c|}
\hline API & SAPINO & 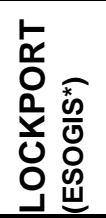 & 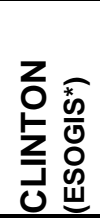 & 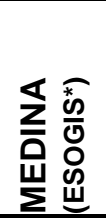 & 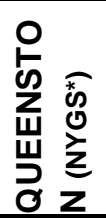 & 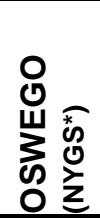 & 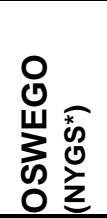 & 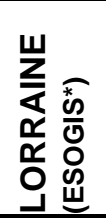 & 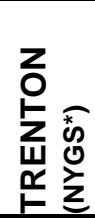 \\
\hline 31051045670000 & 04567-00-00 & & & & 1437 & & & 2548 & \\
\hline 31011045710000 & $04571-00-00$ & & & & 1584 & & & & \\
\hline 31099046000000 & $04600-00-00$ & & & & 1736 & & & & \\
\hline 31011046240000 & $04624-00-00$ & & & & 226 & 1020 & 1020 & 1270 & \\
\hline 31011046280000 & $04628-00-00$ & & & & 1700 & & & & \\
\hline 31011046520000 & $04652-00-00$ & & & & 1520 & & & & \\
\hline 31011047150000 & $04715-00-00$ & & & & 1494 & 2220 & 2220 & 2665 & \\
\hline 31099047680000 & $04768-00-00$ & & & & 1560 & & & & \\
\hline 31123047950000 & $04795-00-00$ & & & & 2685 & & & & \\
\hline 31123047960000 & 04796-00-00 & & & & 2865 & & & & \\
\hline 31123047970000 & $04797-00-00$ & & & & 2520 & & & & \\
\hline 31099048140000 & $04814-00-00$ & & & & 1554 & & & & \\
\hline 31011049990000 & 04999-00-00 & & & & 1409 & & & 2466 & \\
\hline 31011050000000 & $05000-00-00$ & & & & 918 & 1919 & 1919 & 1950 & \\
\hline 31011050110000 & 05011-00-00 & & & & 690 & 1679 & 1679 & 1852 & \\
\hline 31011050310000 & $05031-00-00$ & & & & 606 & & & 1699 & \\
\hline 31117050320000 & $05032-00-00$ & & & & 996 & & & 2080 & \\
\hline 31073050690000 & 05069-00-00 & & & & 100 & & & 730 & \\
\hline 31099050950000 & 05095-00-00 & 568 & 720 & 1028 & 1105 & 1770 & 1770 & 2410 & 2850 \\
\hline 31011054670000 & $05467-00-00$ & & & & 946 & 1950 & 1950 & 2118 & \\
\hline 31011057940000 & 05794-00-00 & & & & 1610 & & & & \\
\hline 31011060600000 & $06060-00-00$ & & & & 1780 & & & & \\
\hline 31011067790000 & $06779-00-00$ & & & & 929 & & & 2004 & \\
\hline 31011067800000 & $06780-00-00$ & & & & 904 & & & 1984 & \\
\hline 31123098460000 & 09846-00-00 & & & & 2751 & & & & \\
\hline 31011107010000 & $10701-00-00$ & & & & 1525 & & & & \\
\hline 31011107020000 & $10702-00-00$ & & & & 1543 & & & & \\
\hline 31037107760000 & $10776-00-00$ & & & & 1588 & & & 2702 & \\
\hline 31099108930000 & $10893-00-00$ & & & & 1434 & 1951 & 1951 & 2755 & 3153 \\
\hline 31029110020000 & $11002-00-00$ & & & & 3308 & & & 4420 & 0 \\
\hline 31029111140000 & $11114-00-00$ & 1547 & 1746 & 1846 & 1969 & 2569 & 2569 & 2988 & 3816 \\
\hline 31011111290000 & $11129-00-00$ & & & & 824 & & & 2000 & \\
\hline
\end{tabular}




\begin{tabular}{|c|c|c|c|c|c|c|c|c|c|}
\hline API & SAPINO & 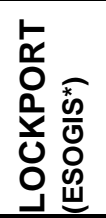 & 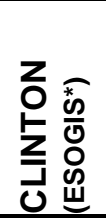 & 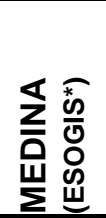 & 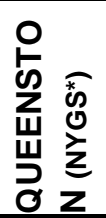 & $\begin{array}{l}0 \\
0 \\
\text { W } \\
\sum_{0}^{*} \\
\text { 心 } \\
0\end{array}$ & 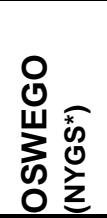 & 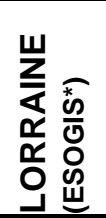 & 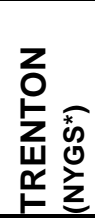 \\
\hline 31011114320000 & $11432-00-00$ & & & & 1550 & & & & \\
\hline 31011114960000 & $11496-00-00$ & & & & 1554 & & & & \\
\hline 31011115460000 & $11546-00-00$ & & & & 1516 & & & & \\
\hline 31011115480000 & $11548-00-00$ & & & & 1505 & & & & \\
\hline 31011115870000 & $11587-00-00$ & & & & 1526 & & & & \\
\hline 31011116000000 & $11600-00-00$ & & & & 1450 & & & & \\
\hline 31099116180000 & $11618-00-00$ & & & & 1854 & & & & \\
\hline 31011116320000 & $11632-00-00$ & & & & & & & & \\
\hline 31011116330000 & $11633-00-00$ & & & & 1630 & & & & \\
\hline 31011116560000 & $11656-00-00$ & & & & 1760 & & & & \\
\hline 31099116660000 & $11666-00-00$ & & & & 1940 & & & & \\
\hline 31099117080000 & $11708-00-00$ & & & & 1860 & & & & \\
\hline 31099120510000 & $12051-00-00$ & & & & 1774 & & & & \\
\hline 31099120520000 & $12052-00-00$ & & & & 1802 & & & & \\
\hline 31099120530000 & $12053-00-00$ & & & & 1780 & & & & \\
\hline 31101124020000 & $12402-00-00$ & & & & 5760 & & & & \\
\hline 31011135530000 & $13553-00-00$ & & & & 1520 & & & & \\
\hline 31011135540000 & $13554-00-00$ & & & & 1500 & & & & \\
\hline 31011135620000 & $13562-00-00$ & & & & 1664 & & & & \\
\hline 31011135880000 & $13588-00-00$ & & & & 1582 & & & & \\
\hline 31011135890000 & $13589-00-00$ & & & & 1525 & & & & \\
\hline 31011135980000 & $13598-00-00$ & & & & 1531 & & & & \\
\hline 31011135990000 & $13599-00-00$ & & & & 1514 & & & & \\
\hline 31011136000000 & $13600-00-00$ & & & & 1568 & & & & \\
\hline 31011136010000 & $13601-00-00$ & & & & 1510 & & & & \\
\hline 31011136060000 & $13606-00-00$ & & & & 1500 & & & & \\
\hline 31011136370000 & $13637-00-00$ & & & & 1500 & & & & \\
\hline 31011136390000 & $13639-00-00$ & & & & 1500 & & & & \\
\hline 31011136440000 & $13644-00-00$ & & & & 1528 & & & & \\
\hline 31011136450000 & $13645-00-00$ & 936 & 1089 & 1449 & 1509 & 2100 & 2100 & 2800 & 3200 \\
\hline 31011136460000 & $13646-00-00$ & & & & 1498 & & & & \\
\hline 31011136550000 & $13655-00-00$ & & & & 1505 & & & & \\
\hline
\end{tabular}




\begin{tabular}{|c|c|c|c|c|c|c|c|c|c|}
\hline API & SAPINO & 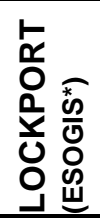 & 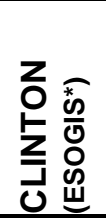 & 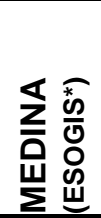 & 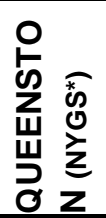 & 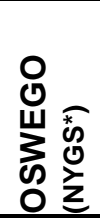 & 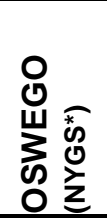 & 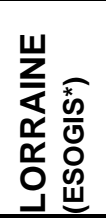 & 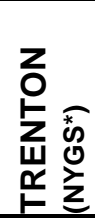 \\
\hline 31099136750000 & $13675-00-00$ & & & & 1805 & & & & \\
\hline 31099136760000 & $13676-00-00$ & & & & 1782 & & & & \\
\hline 31101136990000 & $13699-00-00$ & & & & 5138 & & & 6500 & \\
\hline 31101137360000 & $13736-00-00$ & & & & 4740 & & & & \\
\hline 31011137840000 & $13784-00-00$ & & & & 1543 & & & & \\
\hline 31011153770000 & $15377-00-00$ & & & & 1756 & & & & \\
\hline 31123154060000 & $15406-00-00$ & & & & 2800 & & & & \\
\hline 31101154380000 & $15438-00-00$ & & & & 4445 & & & 5838 & \\
\hline 31011155000000 & $15500-00-00$ & & & & 1533 & & & & \\
\hline 31011155010000 & $15501-00-00$ & & & & 1510 & & & & \\
\hline 31011155020000 & $15502-00-00$ & & & & 1500 & & & & \\
\hline 31011155290000 & $15529-00-00$ & & & & 2400 & & & & \\
\hline 31011156110000 & $15611-00-00$ & & & & 1512 & & & & \\
\hline 31011156120000 & $15612-00-00$ & & & & 1509 & & & & \\
\hline 31011156430000 & $15643-00-00$ & & & & 1566 & & & & \\
\hline 31011156500000 & $15650-00-00$ & & & & 1510 & & & & \\
\hline 31011156610000 & $15661-00-00$ & & & & 1490 & & & & \\
\hline 31011156620000 & $15662-00-00$ & & & & 1500 & & & & \\
\hline 31011156630000 & $15663-00-00$ & & & & 1510 & & & & \\
\hline 31011156640000 & $15664-00-00$ & & & & 1458 & & & & \\
\hline 31011156650000 & $15665-00-00$ & & & & 1492 & & & & \\
\hline 31011157020000 & $15702-00-00$ & & & & 1516 & & & & \\
\hline 31011157030000 & $15703-00-00$ & & & & 1505 & & & & \\
\hline 31011157040000 & $15704-00-00$ & & & & 1518 & & & & \\
\hline 31011157070000 & $15707-00-00$ & & & & 1400 & & & & \\
\hline 31011157080000 & $15708-00-00$ & & & & 1522 & & & & \\
\hline 31011157090000 & $15709-00-00$ & & & & 1502 & & & & \\
\hline 31011157100000 & $15710-00-00$ & & & & 1485 & & & & \\
\hline 31011157450000 & $15745-00-00$ & & & & 1480 & & & & \\
\hline 31011157560000 & $15756-00-00$ & & & & 1515 & & & & \\
\hline 31101158340000 & $15834-00-00$ & & & & 6514 & & & & \\
\hline 31011158500000 & $15850-00-00$ & & & & 1496 & & & & \\
\hline
\end{tabular}




\begin{tabular}{|c|c|c|c|c|c|c|c|c|c|}
\hline API & SAPINO & 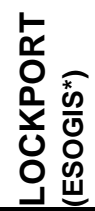 & 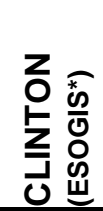 & 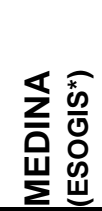 & 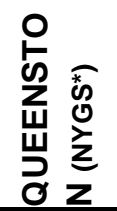 & 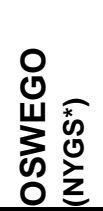 & 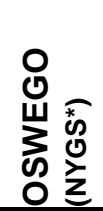 & 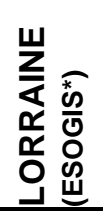 & 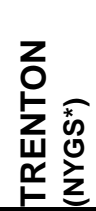 \\
\hline 31011159620000 & $15962-00-00$ & & & & 1768 & & & & \\
\hline 31011159630000 & $15963-00-00$ & & & & 1830 & & & & \\
\hline 31011161200000 & $16120-00-00$ & & & & 3470 & 4157 & 4157 & 4705 & \\
\hline 31011161230000 & $16123-00-00$ & & & & 1586 & & & & \\
\hline 31011161490000 & $16149-00-00$ & & & & 1488 & & & & \\
\hline 31011161510000 & $16151-00-00$ & & & & 1574 & & & & \\
\hline 31011169910000 & 16991-00-00 & & & & 1660 & & & & \\
\hline 31011175080000 & $17508-00-00$ & & & & 780 & & & 1818 & \\
\hline 31011175090000 & $17509-00-00$ & & & & 754 & & & & \\
\hline 31011175100000 & $17510-00-00$ & & & & 696 & & & 1792 & \\
\hline 31011175170000 & $17517-00-00$ & & & & 1510 & & & & \\
\hline 31011175550000 & $17555-00-00$ & & & & 1602 & & & & \\
\hline 31011175560000 & $17556-00-00$ & & & & 2180 & & & & \\
\hline 31011175570000 & $17557-00-00$ & & & & 2340 & & & & \\
\hline 31011175580000 & $17558-00-00$ & & & & 1448 & 2169 & 2169 & 2548 & \\
\hline 31011175590000 & 17559-00-00 & & & & 1400 & 2107 & 2107 & 2612 & \\
\hline 31099175650000 & $17565-00-00$ & & & & 1658 & & & & \\
\hline 31099175670000 & $17567-00-00$ & & & & 1760 & & & & \\
\hline 31099175700000 & $17570-00-00$ & & & & 1688 & & & & \\
\hline 31099175720000 & $17572-00-00$ & & & & 1954 & & & & \\
\hline 31099175730000 & $17573-00-00$ & & & & 1820 & & & & \\
\hline 31099175760000 & $17576-00-00$ & & & & 1854 & & & & \\
\hline 31099175780000 & $17578-00-00$ & & & & 1774 & & & & \\
\hline 31099175790000 & $17579-00-00$ & & & & 1704 & & & & \\
\hline 31011175950000 & 17595-00-00 & & & & 1452 & & & & \\
\hline 31011175990000 & 17599-00-00 & & & & 1467 & & & & \\
\hline 31123194030000 & 19403-00-00 & & & & 3875 & & & & \\
\hline 31099194590000 & $19459-00-00$ & & & & 1934 & & & & \\
\hline 31099194610000 & $19461-00-00$ & & & & 2116 & & & & \\
\hline 31099194620000 & $19462-00-00$ & & & & 1948 & & & & \\
\hline 31099194630000 & $19463-00-00$ & & & & 2187 & & & & \\
\hline 31099194640000 & 19464-00-00 & & & & 2072 & & & & \\
\hline
\end{tabular}




\begin{tabular}{|c|c|c|c|c|c|c|c|c|c|}
\hline API & SAPINO & 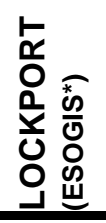 & 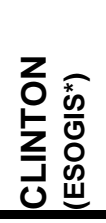 & 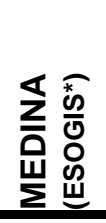 & 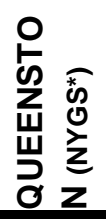 & 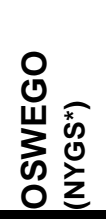 & 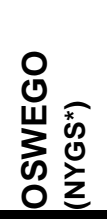 & 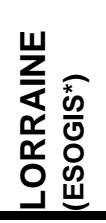 & 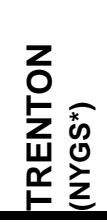 \\
\hline 31099194650000 & $19465-00-00$ & & & & 2000 & & & & \\
\hline 31099194670000 & $19467-00-00$ & & & & 1932 & & & & \\
\hline 31099194700000 & $19470-00-00$ & & & & 2200 & 2874 & 2874 & & \\
\hline 31099194810000 & $19481-00-00$ & & & & 1940 & & & & \\
\hline 31099194820000 & $19482-00-00$ & & & & 2188 & & & & \\
\hline 31023194840000 & $19484-00-00$ & & & & 4260 & & & 5078 & \\
\hline 31053194850000 & $19485-00-00$ & & & & 2840 & & & 3422 & \\
\hline 31099194900000 & $19490-00-00$ & & & & 2146 & & & & \\
\hline 31099194910000 & $19491-00-00$ & & & & 2146 & & & & \\
\hline 31101194970000 & $19497-00-00$ & & & & 4430 & & & 5822 & \\
\hline 31011194980000 & $19498-00-00$ & & & & 1477 & & & & \\
\hline 31011195000000 & $19500-00-00$ & & & & 1504 & & & & \\
\hline 31011195010000 & 19501-00-00 & & & & 1466 & & & & \\
\hline 31099195030000 & $19503-00-00$ & & & & 2030 & & & & \\
\hline 31099195040000 & $19504-00-00$ & & & & 2092 & & & & \\
\hline 31099195050000 & $19505-00-00$ & & & & 2151 & & & & \\
\hline 31099195060000 & $19506-00-00$ & & & & 2004 & & & & \\
\hline 31099195350000 & $19535-00-00$ & & & & 1995 & & & & \\
\hline 31099195410000 & $19541-00-00$ & & & & 2110 & & & & \\
\hline 31099195420000 & $19542-00-00$ & & & & 2155 & & & & \\
\hline 31099195440000 & $19544-00-00$ & & & & 2111 & & & & \\
\hline 31099195450000 & 19545-00-00 & & & & 2125 & & & & \\
\hline 31099195480000 & $19548-00-00$ & & & & 2150 & & & & \\
\hline 31099195490000 & $19549-00-00$ & & & & 1990 & & & & \\
\hline 31099195500000 & $19550-00-00$ & & & & 2150 & & & & \\
\hline 31099195510000 & $19551-00-00$ & & & & 1934 & & & & \\
\hline 31099195530000 & 19553-00-00 & & & & 2155 & & & & \\
\hline 31099195540000 & $19554-00-00$ & & & & 2050 & & & & \\
\hline 31099195550000 & $19555-00-00$ & & & & 1920 & & & & \\
\hline 31099195560000 & $19556-00-00$ & & & & 2022 & & & & \\
\hline 31099195570000 & $19557-00-00$ & & & & 2085 & & & & \\
\hline 31099195580000 & $19558-00-00$ & & & & 2070 & & & & \\
\hline
\end{tabular}




\begin{tabular}{|c|c|c|c|c|c|c|c|c|c|}
\hline API & SAPINO & 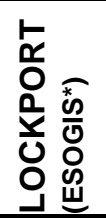 & 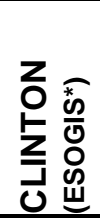 & 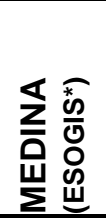 & 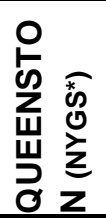 & 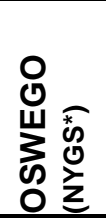 & 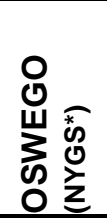 & 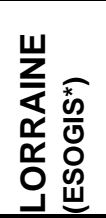 & 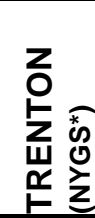 \\
\hline 31099195620000 & $19562-00-00$ & & & & 2050 & & & & \\
\hline 31099195630000 & $19563-00-00$ & & & & 1995 & & & & \\
\hline 31099195740000 & $19574-00-00$ & & & & 1905 & & & & \\
\hline 31099195790000 & $19579-00-00$ & & & & 1972 & & & & \\
\hline 31099195800000 & $19580-00-00$ & & & & 1990 & & & & \\
\hline 31099195830000 & $19583-00-00$ & & & & 1800 & & & & \\
\hline 31099195840000 & $19584-00-00$ & & & & 1825 & & & & \\
\hline 31099195850000 & $19585-00-00$ & & & & 1256 & 1682 & 1682 & & \\
\hline 31099195860000 & $19586-00-00$ & & & & 1490 & & & & \\
\hline 31099195870000 & $19587-00-00$ & & & & 1260 & & & & \\
\hline 31099195880000 & $19588-00-00$ & & & & 2208 & & & & \\
\hline 31099195890000 & $19589-00-00$ & & & & 2362 & & & & \\
\hline 31099195970000 & $19597-00-00$ & & & & 2167 & & & & \\
\hline 31099196210000 & $19621-00-00$ & & & & 2160 & & & & \\
\hline 31099196230000 & $19623-00-00$ & & & & 2139 & & & & \\
\hline 31099196310000 & $19631-00-00$ & & & & 2014 & & & & \\
\hline 31011196340000 & $19634-00-00$ & & & & 1388 & & & & \\
\hline 31011196360000 & $19636-00-00$ & & & & 1502 & & & & \\
\hline 31011196370000 & $19637-00-00$ & & & & 1586 & & & & \\
\hline 31011196380000 & $19638-00-00$ & & & & 1522 & & & & \\
\hline 31011196400000 & $19640-00-00$ & & & & 1473 & & & & \\
\hline 31011196410000 & $19641-00-00$ & & & & 1472 & & & & \\
\hline 31011196420000 & $19642-00-00$ & & & & 1504 & & & & \\
\hline 31011196430000 & $19643-00-00$ & & & & 1490 & & & & \\
\hline 31011196440000 & $19644-00-00$ & & & & 1496 & & & & \\
\hline 31011196450000 & $19645-00-00$ & & & & 1485 & & & & \\
\hline 31011196650000 & $19665-00-00$ & & & & 1466 & & & & \\
\hline 31011196660000 & $19666-00-00$ & & & & 1481 & & & & \\
\hline 31099196720000 & $19672-00-00$ & & & & 2144 & & & & \\
\hline 31099196730000 & $19673-00-00$ & & & & 2180 & & & & \\
\hline 31011196740000 & $19674-00-00$ & & & & 1505 & & & & \\
\hline 31099196750000 & $19675-00-00$ & & & & 1770 & & & & \\
\hline
\end{tabular}




\begin{tabular}{|c|c|c|c|c|c|c|c|c|c|}
\hline API & SAPINO & 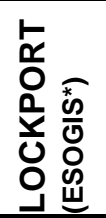 & 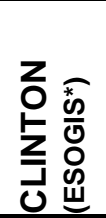 & 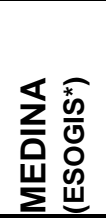 & 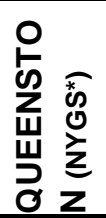 & 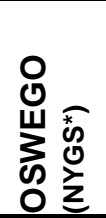 & 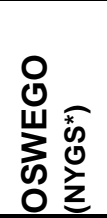 & 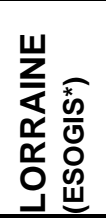 & 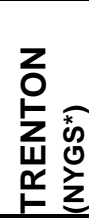 \\
\hline 31099196860000 & $19686-00-00$ & & & & 3762 & & & & \\
\hline 31097196920000 & $19692-00-00$ & & & & 5040 & 6402 & 6402 & 6532 & \\
\hline 31099204130000 & 20413-00-00 & & & & 1980 & & & & \\
\hline 31099204150000 & 20415-00-00 & & & & 2042 & & & & \\
\hline 31099204160000 & 20416-00-00 & & & & 2030 & & & & \\
\hline 31097204170000 & $20417-00-00$ & & & & 5002 & 6290 & 6290 & 6490 & \\
\hline 31011204200000 & $20420-00-00$ & & & & 1746 & & & & \\
\hline 31011204210000 & 20421-00-00 & & & & 1605 & & & & \\
\hline 31011204220000 & $20422-00-00$ & & & & 1630 & & & & \\
\hline 31099204230000 & 20423-00-00 & & & & 2132 & & & & \\
\hline 31099204240000 & $20424-00-00$ & & & & 2122 & & & & \\
\hline 31099204290000 & 20429-00-00 & & & & 2130 & & & & \\
\hline 31099204300000 & $20430-00-00$ & & & & 2137 & & & & \\
\hline 31099204310000 & $20431-00-00$ & & & & 2156 & & & & \\
\hline 31099204320000 & $20432-00-00$ & & & & 2010 & & & & \\
\hline 31011204360000 & 20436-00-00 & & & & 1530 & & & & \\
\hline 31011204370000 & $20437-00-00$ & & & & 1500 & & & & \\
\hline 31099204460000 & 20446-00-00 & 2108 & 2249 & 2625 & 2709 & 3346 & 3346 & 3947 & 4518 \\
\hline 31099204470000 & 20447-00-00 & & & & 1912 & & & & \\
\hline 31099204480000 & $20448-00-00$ & & & & 1890 & & & & \\
\hline 31011204510000 & 20451-00-00 & & & & 1498 & & & & \\
\hline 31011204540000 & 20454-00-00 & & & & 1572 & & & & \\
\hline 31011204550000 & $20455-00-00$ & & & & 1525 & & & & \\
\hline 31011204560000 & 20456-00-00 & & & & 1510 & & & & \\
\hline 31099204590000 & 20459-00-00 & & & & 2135 & & & & \\
\hline 31011204600000 & $20460-00-00$ & & & & 1525 & & & & \\
\hline 31011204610000 & 20461-00-00 & & & & 1532 & & & & \\
\hline 31011204640000 & 20464-00-00 & & & & 1556 & & & & \\
\hline 31011204670000 & 20467-00-00 & & & & 1562 & & & & \\
\hline 31011204880000 & 20488-00-00 & & & & 1860 & & & & \\
\hline 31011204990000 & 20499-00-00 & & & & 1645 & & & & \\
\hline 31011205010000 & 20501-00-00 & & & & 1594 & & & & \\
\hline
\end{tabular}




\begin{tabular}{|c|c|c|c|c|c|c|c|c|c|}
\hline API & SAPINO & 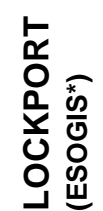 & 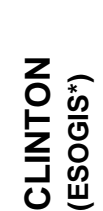 & 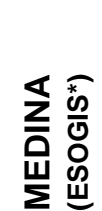 & 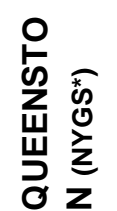 & 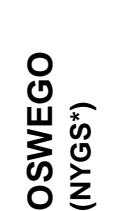 & 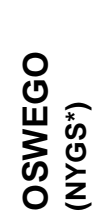 & 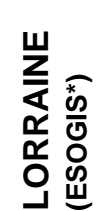 & 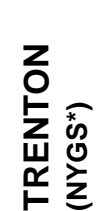 \\
\hline 31011205030000 & $20503-00-00$ & & & & 1714 & & & & \\
\hline 31011205060000 & 20506-00-00 & & & & 1790 & & & & \\
\hline 31011205070000 & $20507-00-00$ & & & & 1805 & & & & \\
\hline 31011205080000 & $20508-00-00$ & & & & 1810 & & & & \\
\hline 31011205110000 & $20511-00-00$ & & & & 1870 & & & & \\
\hline 31011205150000 & $20515-00-00$ & & & & 1568 & & & & \\
\hline 31011205160000 & $20516-00-00$ & & & & 1491 & & & & \\
\hline 31011205170000 & $20517-00-00$ & & & & 1510 & & & & \\
\hline 31099205230000 & 20523-00-00 & & & & 1846 & & & & \\
\hline 31011205250000 & $20525-00-00$ & & & & 1906 & & & & \\
\hline 31099205260000 & $20526-00-00$ & & & & 1820 & & & & \\
\hline 31123205370000 & $20537-00-00$ & & & & 2665 & & & & \\
\hline 31123205390000 & $20539-00-00$ & & & & 2712 & & & & \\
\hline 31123205440000 & 20544-00-00 & & & & 2568 & & & & \\
\hline 31123205460000 & 20546-00-00 & & & & 2508 & & & & \\
\hline 31011205530000 & $20553-00-00$ & & & & 1565 & & & & \\
\hline 31011205540000 & $20554-00-00$ & & & & 1600 & & & & \\
\hline 31011205550000 & $20555-00-00$ & & & & 1502 & & & & \\
\hline 31011205560000 & $20556-00-00$ & & & & 1515 & & & & \\
\hline 31011205600000 & $20560-00-00$ & & & & 1738 & & & & \\
\hline 31011205610000 & $20561-00-00$ & & & & 1662 & & & & \\
\hline 31123205620000 & $20562-00-00$ & & & & 3105 & & & & \\
\hline 31123205700000 & $20570-00-00$ & & & & 2630 & & & & \\
\hline 31123205710000 & $20571-00-00$ & & & & 2970 & & & & \\
\hline 31011206090000 & $20609-00-00$ & & & & 1880 & & & & \\
\hline 31011206140000 & $20614-00-00$ & & & & 1704 & & & & \\
\hline 31011206150000 & $20615-00-00$ & & & & 1616 & & & & \\
\hline 31011206160000 & 20616-00-00 & & & & 1584 & & & & \\
\hline 31011206170000 & $20617-00-00$ & & & & 1578 & & & & \\
\hline 31011206180000 & 20618-00-00 & & & & 1700 & & & & \\
\hline 31011206210000 & $20621-00-00$ & & & & 1495 & & & & \\
\hline 31011206240000 & $20624-00-00$ & & & & 1704 & & & & \\
\hline
\end{tabular}




\begin{tabular}{|c|c|c|c|c|c|c|c|c|c|}
\hline API & SAPINO & 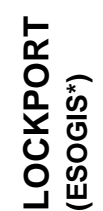 & 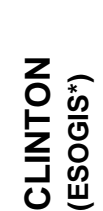 & 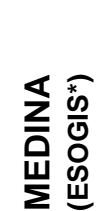 & 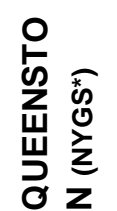 & 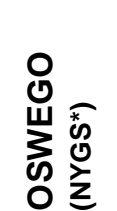 & 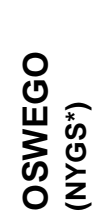 & 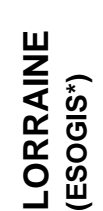 & 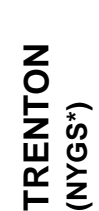 \\
\hline 31011206250000 & $20625-00-00$ & & & & 1676 & & & & \\
\hline 31011206260000 & 20626-00-00 & & & & 1880 & & & & \\
\hline 31099206270000 & $20627-00-00$ & & & & 1840 & & & & \\
\hline 31099206290000 & $20629-00-00$ & & & & 1864 & & & & \\
\hline 31011206320000 & $20632-00-00$ & & & & 1906 & & & & \\
\hline 31011206380000 & $20638-00-00$ & & & & 1680 & & & & \\
\hline 31011206390000 & $20639-00-00$ & & & & 1747 & & & & \\
\hline 31011206490000 & $20649-00-00$ & & & & 1730 & & & & \\
\hline 31011206500000 & $20650-00-00$ & & & & 1546 & & & & \\
\hline 31011206510000 & 20651-00-00 & & & & 1816 & & & & \\
\hline 31011206530000 & $20653-00-00$ & & & & 1921 & & & & \\
\hline 31011206560000 & 20656-00-00 & & & & 1736 & & & & \\
\hline 31011206630000 & $20663-00-00$ & & & & 1870 & & & & \\
\hline 31011206730000 & 20673-00-00 & & & & 1675 & & & & \\
\hline 31011206750000 & $20675-00-00$ & & & & 1936 & & & & \\
\hline 31011206810000 & $20681-00-00$ & & & & 1636 & & & & \\
\hline 31099206830000 & $20683-00-00$ & & & & 1828 & & & & \\
\hline 31099206940000 & $20694-00-00$ & & & & 1875 & & & & \\
\hline 31011206950000 & 20695-00-00 & & & & 1984 & & & & \\
\hline 31099207000000 & $20700-00-00$ & & & & 2030 & & & & \\
\hline 31099207010000 & $20701-00-00$ & & & & 2135 & & & & \\
\hline 31099207020000 & $20702-00-00$ & & & & 1832 & & & & \\
\hline 31099207070000 & $20707-00-00$ & & & & 2119 & & & & \\
\hline 31099207080000 & $20708-00-00$ & & & & 1834 & & & & \\
\hline 31099212330000 & $21233-00-00$ & & & & 1765 & & & & \\
\hline 31099212360000 & $21236-00-00$ & & & & 2105 & & & & \\
\hline 31011212380000 & $21238-00-00$ & & & & 1705 & & & & \\
\hline 31099212480000 & $21248-00-00$ & & & & 2100 & & & & \\
\hline 31099212490000 & $21249-00-00$ & & & & 1940 & & & & \\
\hline 31099212500000 & $21250-00-00$ & & & & 2010 & & & & \\
\hline 31011212530000 & $21253-00-00$ & & & & 2040 & & & & \\
\hline 31099212690000 & $21269-00-00$ & & & & 2100 & & & & \\
\hline
\end{tabular}




\begin{tabular}{|c|c|c|c|c|c|c|c|c|c|}
\hline API & SAPINO & 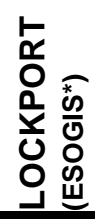 & 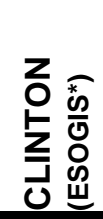 & 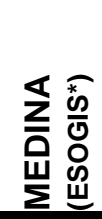 & 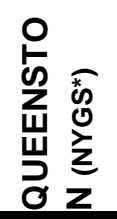 & 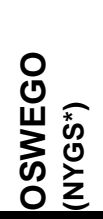 & 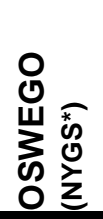 & 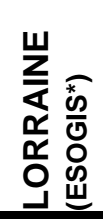 & 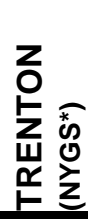 \\
\hline 31099212860000 & 21286-00-00 & & & & 1772 & & & & \\
\hline 31099212930000 & $21293-00-00$ & & & & 1884 & & & & \\
\hline 31099212970000 & $21297-00-00$ & & & & 1815 & & & & \\
\hline 31099212980000 & $21298-00-00$ & & & & 1830 & & & & \\
\hline 31099213150000 & $21315-00-00$ & & & & 1826 & & & & \\
\hline 31099213190000 & $21319-00-00$ & & & & 1725 & & & & \\
\hline 31099213230000 & $21323-00-00$ & & & & 1896 & & & & \\
\hline 31067213350000 & $21335-00-00$ & & & & 1150 & & & 2000 & \\
\hline 31099213540000 & $21354-00-00$ & & & & 1808 & & & & \\
\hline 31099213550000 & $21355-00-00$ & & & & 1910 & & & & \\
\hline 31099213570000 & $21357-00-00$ & & & & 1790 & & & & \\
\hline 31099213580000 & 21358-00-00 & & & & 1690 & & & & \\
\hline 31099213590000 & $21359-00-00$ & & & & 1796 & & & & \\
\hline 31099213630000 & $21363-00-00$ & & & & 2026 & & & & \\
\hline 31099213720000 & 21372-00-00 & & & & 1740 & & & & \\
\hline 31099213820000 & $21382-00-00$ & & & & 1550 & 1790 & 1790 & & \\
\hline 31099213840000 & 21384-00-00 & & & & 1786 & & & & \\
\hline 31099213920000 & 21392-00-00 & & & & 1822 & & & & \\
\hline 31011213930000 & 21393-00-00 & & & & 1992 & & & & \\
\hline 31099214070000 & $21407-00-00$ & & & & 1708 & & & & \\
\hline 31101214680000 & $21468-00-00$ & & & & 5125 & & & 6534 & \\
\hline 31011214690000 & $21469-00-00$ & & & & 1804 & & & 2865 & \\
\hline 31097214950000 & 21495-00-00 & & & & 6500 & 6933 & 6933 & 8080 & \\
\hline 31101214960000 & 21496-00-00 & & & & 5270 & & & 6705 & \\
\hline 31101215510000 & 21551-00-00 & & & & 5170 & & & & \\
\hline 31101215920000 & 21592-00-00 & & & & 4520 & 5376 & 5376 & 5876 & \\
\hline 31101216010000 & 21601-00-00 & & & & 5117 & & & 6528 & \\
\hline 31101216240000 & 21624-00-00 & & & & 5112 & & & 6544 & \\
\hline 31101216330000 & 21633-00-00 & & & & 5105 & & & 6563 & \\
\hline 31101216360000 & $21636-00-00$ & & & & 5127 & 5615 & 5615 & 6586 & \\
\hline 31101216880000 & $21688-00-00$ & & & & 4454 & & & 5858 & \\
\hline 31101216890000 & $21689-00-00$ & & & & 4193 & & & 5575 & \\
\hline
\end{tabular}




\begin{tabular}{|c|c|c|c|c|c|c|c|c|c|}
\hline API & SAPINO & 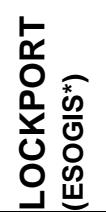 & 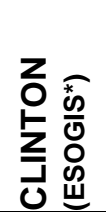 & 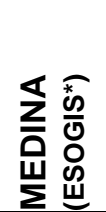 & 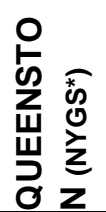 & 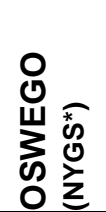 & 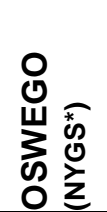 & 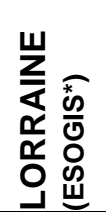 & 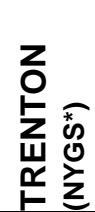 \\
\hline 31099216900000 & $21690-00-00$ & & & & 2420 & & & & \\
\hline 31101216920000 & $21692-00-00$ & & & & 4080 & & & 5489 & \\
\hline 31101217030000 & $21703-00-00$ & & & & 3782 & 4992 & 4992 & 5170 & \\
\hline 31101217040000 & $21704-00-00$ & & & & 4555 & 5872 & 5872 & 6088 & \\
\hline 31101217050000 & $21705-00-00$ & & & & 4172 & 4760 & 4760 & 5566 & \\
\hline 31101217060000 & $21706-00-00$ & & & & 4163 & & & 5688 & \\
\hline 31101217100000 & $21710-00-00$ & & & & 3837 & 5011 & 5011 & 5224 & \\
\hline 31101217150000 & $21715-00-00$ & & & & 4790 & & & 6176 & \\
\hline 31109217160000 & $21716-00-00$ & & & & 4652 & 5300 & 5300 & 5798 & \\
\hline 31101217180000 & $21718-00-00$ & & & & 7340 & 8119 & 8119 & 8902 & \\
\hline 31097217250000 & $21725-00-00$ & & & & 4760 & 6035 & 6035 & 6250 & \\
\hline 31097217260000 & $21726-00-00$ & & & & 4700 & & & 6168 & \\
\hline 31101227410000 & $22741-00-00$ & & & & 4532 & & & 5991 & \\
\hline 31101227450000 & $22745-00-00$ & & & & 4482 & 5305 & 5305 & 5927 & \\
\hline 31123227460000 & $22746-00-00$ & & & & 4476 & 5682 & 5682 & 5884 & \\
\hline 31101227470000 & $22747-00-00$ & & & & 4498 & & & 5968 & \\
\hline 31101227480000 & $22748-00-00$ & & & & 4319 & & & 5782 & \\
\hline 31123227500000 & $22750-00-00$ & & & & 4530 & & & 6004 & \\
\hline 31123227520000 & $22752-00-00$ & & & & 4122 & & & 5554 & \\
\hline 31109227530000 & $22753-00-00$ & & & & 4378 & & & 5772 & \\
\hline 31097227540000 & $22754-00-00$ & 4206 & 4329 & 4803 & 4899 & 5552 & 5552 & 6350 & 6997 \\
\hline 31101227550000 & $22755-00-00$ & & & & 3902 & & & 5292 & \\
\hline 31101227560000 & $22756-00-00$ & & & & 4600 & 5265 & 5265 & 6026 & \\
\hline 31123227570000 & $22757-00-00$ & & & & 3905 & 4510 & 4510 & 5215 & \\
\hline 31101227580000 & $22758-00-00$ & & & & 4302 & & & 5636 & \\
\hline 31101227590000 & $22759-00-00$ & & & & 4862 & & & 6218 & \\
\hline 31101227600000 & $22760-00-00$ & & & & 4802 & 5495 & 5495 & 6163 & \\
\hline 31099227610000 & $22761-00-00$ & & & & 1897 & & & 3104 & \\
\hline 31099227620000 & $22762-00-00$ & & & & 1802 & & & 3000 & \\
\hline 31099227630000 & $22763-00-00$ & 1368 & 1520 & 1870 & 1920 & 2629 & 2629 & 3146 & 3713 \\
\hline 31123227640000 & $22764-00-00$ & & & & 3265 & & & 4600 & \\
\hline 31101227650000 & $22765-00-00$ & & & & 4570 & 5170 & 5170 & 5995 & \\
\hline
\end{tabular}




\begin{tabular}{|c|c|c|c|c|c|c|c|c|c|}
\hline API & SAPINO & 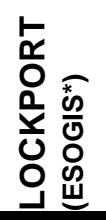 & 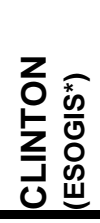 & 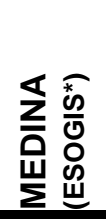 & 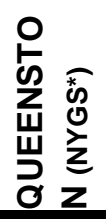 & 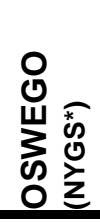 & 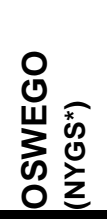 & 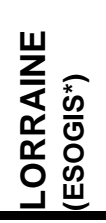 & 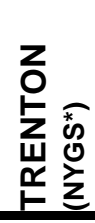 \\
\hline 31101227660000 & 22766-00-00 & & & & 4504 & 5130 & 5130 & 5846 & \\
\hline 31109227670000 & $22767-00-00$ & & & & 4235 & & & 5604 & \\
\hline 31101227710000 & $22771-00-00$ & & & & 6570 & 7140 & 7140 & 8200 & \\
\hline 31101227720000 & $22772-00-00$ & & & & 3947 & & & 5326 & \\
\hline 31123227730000 & $22773-00-00$ & & & & 4098 & & & 5632 & \\
\hline 31123227740000 & $22774-00-00$ & & & & 4085 & & & 5480 & \\
\hline 31123227750000 & $22775-00-00$ & & & & 3088 & & & 4454 & \\
\hline 31109227890000 & $22789-00-00$ & & & & 4500 & & & 5775 & \\
\hline 31123227900000 & $22790-00-00$ & & & & 3580 & 4220 & 4220 & 4892 & \\
\hline 31123227910000 & 22791-00-00 & & & & 3545 & & & 4938 & \\
\hline 31123227950000 & $22795-00-00$ & & & & 4290 & & & 5692 & \\
\hline 31123227960000 & 22796-00-00 & & & & 4108 & & & 5488 & \\
\hline 31097227990000 & $22799-00-00$ & & & & 4508 & 5974 & 5974 & 6006 & \\
\hline 31101228140000 & $22814-00-00$ & & & & 6792 & & & 8460 & \\
\hline 31101228250000 & $22825-00-00$ & & & & 6594 & & & 8226 & \\
\hline 31015228260000 & $22826-00-00$ & & & & 6451 & 7145 & 7145 & 7988 & 8750 \\
\hline 31015228270000 & $22827-00-00$ & & & & 6180 & 6765 & 6765 & 7702 & \\
\hline 31123228280000 & 22828-00-00 & & & & 3268 & 3921 & 3921 & 4670 & \\
\hline 31097228300000 & $22830-00-00$ & & & & 6170 & 6682 & 6682 & 7799 & \\
\hline 31015228310000 & $22831-00-00$ & & & & 6658 & 7390 & 7390 & 8400 & \\
\hline 31015228380000 & $22838-00-00$ & & & & 6979 & 7708 & 7708 & 8624 & \\
\hline 31123228400000 & $22840-00-00$ & & & & 3446 & & & 4810 & \\
\hline 31097228410000 & $22841-00-00$ & & & & 5592 & 6245 & 6245 & 7247 & \\
\hline 31101228450000 & $22845-00-00$ & 3408 & 3547 & 3913 & 4060 & 4696 & 4696 & 5453 & 6058 \\
\hline 31123228500000 & $22850-00-00$ & & & & 4344 & & & 5600 & \\
\hline 31101228520000 & $22852-00-00$ & & & & 6795 & 7372 & 7372 & 8505 & \\
\hline 31015228530000 & 22853-00-00 & & & & 6667 & 7265 & 7265 & 8302 & \\
\hline 31015228570000 & $22857-00-00$ & & & & 6238 & 7068 & 7068 & 7835 & \\
\hline 31123228580000 & $22858-00-00$ & 2618 & 2764 & 3061 & 3209 & 3801 & 3801 & 4510 & 5180 \\
\hline 31101228590000 & $22859-00-00$ & 3508 & 3683 & 3909 & 4054 & 4687 & 4687 & 5394 & 6038 \\
\hline 31101228610000 & $22861-00-00$ & & & & 6790 & 7406 & 7406 & 8472 & \\
\hline 31099228640000 & $22864-00-00$ & & & & 1820 & & & & \\
\hline
\end{tabular}




\begin{tabular}{|c|c|c|c|c|c|c|c|c|c|}
\hline API & SAPINO & 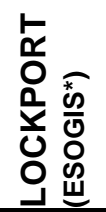 & 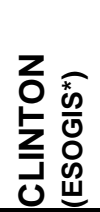 & 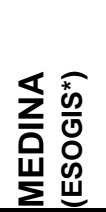 & 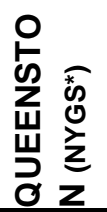 & 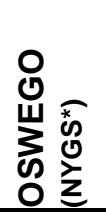 & 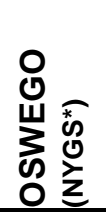 & 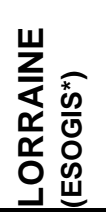 & 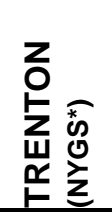 \\
\hline 31099228660000 & $22866-00-00$ & & & & 1822 & & & & \\
\hline 31011228790000 & $22879-00-00$ & & & & 1482 & & & & \\
\hline 31097228810000 & $22881-00-00$ & & & & 5647 & 6408 & 6408 & 7271 & \\
\hline 31101228850000 & $22885-00-00$ & & & & 6393 & 7080 & 7080 & 8121 & \\
\hline 31097228930000 & $22893-00-00$ & & & & 5620 & 6365 & 6365 & 7332 & \\
\hline 31015228990000 & 22899-00-00 & 6206 & 6478 & 6907 & 7132 & 7904 & 7904 & 8769 & 9565 \\
\hline 31015229020000 & $22902-00-00$ & & & & 6301 & 6969 & 6969 & 7961 & \\
\hline 31099229090000 & $22909-00-00$ & & & & 4359 & & & & 6392 \\
\hline 31015229110000 & 22911-00-00 & 6115 & 6377 & 6843 & 7029 & 7805 & 7805 & 8702 & 9565 \\
\hline 31015229180000 & $22918-00-00$ & & & & 6305 & 7048 & 7048 & 8000 & \\
\hline 31015229190000 & 22919-00-00 & & & & 6677 & & & 8395 & \\
\hline 31015229240000 & $22924-00-00$ & & & & 6208 & & & 7802 & \\
\hline 31107229340000 & 22934-00-00 & 7152 & 7400 & 7925 & 8169 & 8854 & 8854 & 9710 & 10597 \\
\hline 31097229350000 & 22935-00-00 & 4718 & 5005 & 5381 & 5563 & 6219 & 6219 & 7105 & 7924 \\
\hline 31123229410000 & $22941-00-00$ & 3288 & 3443 & 3869 & 3995 & 4627 & 4627 & 5433 & 6020 \\
\hline 31097229420000 & $22942-00-00$ & & & & 6488 & 7140 & 7140 & 8152 & \\
\hline 31069229430000 & 22943-00-00 & & & & 2622 & & & 3883 & \\
\hline 31099229440000 & $22944-00-00$ & & & & 1608 & & & & \\
\hline 31099229460000 & 22946-00-00 & & & & 1795 & & & & \\
\hline 31099229470000 & 22947-00-00 & & & & 1914 & & & & \\
\hline 31099229500000 & $22950-00-00$ & 3590 & 3720 & 4157 & 4273 & 4919 & 4919 & 5647 & 6290 \\
\hline 31007229840000 & 22984-00-00 & & & & 7515 & & & 7959 & \\
\hline 31007229950000 & 22995-00-00 & 7010 & 7087 & 7741 & 7958 & 8397 & 8397 & 8729 & 9574 \\
\hline 31101230540000 & $23054-00-00$ & & & & 6935 & & & 8681 & \\
\hline 31007230560000 & $23056-00-00$ & & & & 7226 & & & 8550 & \\
\hline 31101230850000 & $23085-00-00$ & & & & 6714 & & & 8395 & \\
\hline 31121233890000 & $23389-00-00$ & 2925 & 3106 & 3201 & 3316 & 3893 & 3893 & 4372 & 5232 \\
\hline 31009234560000 & $23456-00-00$ & & & & 3620 & & & 4720 & \\
\hline
\end{tabular}

* Source Information

NYGS - Tops picked during the current research initiative

ESOGIS - Tops obtained from NYGS online database ESOGIS, 
Appendix B - Table 3 - Porosity Estimates from the Delaney A-124-5 Well Thinsections

\begin{tabular}{|c|c|}
\hline Depth (ft) & Porosity (\%) \\
\hline 1510.8 & 0 \\
\hline 1513.9 & 0 \\
\hline 1518.1 & $1-5$ \\
\hline 1523.5 & $1-5$ \\
\hline 1525.8 & 1 \\
\hline 1529.0 & $8-10$ \\
\hline 1535.4 & $5-10$ \\
\hline 1541.1 & $\leq 1$ \\
\hline 1542.3 & $4-7$ \\
\hline 1546.4 & $1-5$ \\
\hline 1552.2 & $4-7$ \\
\hline 1553.1 & $8-10$ \\
\hline 1559.9 & 1 \\
\hline 1562.1 & $7-10$ \\
\hline 1571.6 & $\sim 1$ \\
\hline 1577.2 & $>10$ \\
\hline 1578.2 & $7-10$ \\
\hline 1577.4 & $\sim 10$ \\
\hline 1582.2 & $4-7$ \\
\hline 1589.2 & 0 \\
\hline 1592.5 & 0 \\
\hline 1602.7 & $7-12$ \\
\hline 1613.2 & 0 \\
\hline 1617.2 & $7-9$ \\
\hline 1620.8 & $7-9$ \\
\hline 1624.2 & 0 \\
\hline 1625.3 & $\geq 15$ \\
\hline 1634.5 & $\geq 15$ \\
\hline 1638.7 & 1 \\
\hline 1641.1 & $7-10$ \\
\hline 1645.5 & $5-8$ \\
\hline 1647.5 & 0 \\
\hline 1649.0 & $>10$ \\
\hline 1653.8 & $<1$ \\
\hline 1661.5 & 0 \\
\hline 1663.0 & $2-5$ \\
\hline 1670.6 & $<1$ \\
\hline 1672.9 & $2-3$ \\
\hline 1680.5 & $1-2$ \\
\hline 1685.9 & $1-3$ \\
\hline 1692.2 & $<1$ \\
\hline 1699.3 & $<1$ \\
\hline 1705.1 & $<1$ \\
\hline 1711.0 & $5-10$ \\
\hline 1716.5 & $5-10$ \\
\hline 1723.8 & $0-2$ \\
\hline 1725.2 & $1-3$ \\
\hline 1733.2 & $1-3$ \\
\hline & \\
\hline
\end{tabular}

\begin{tabular}{|c|c|}
\hline Depth (ft) & Porosity (\%) \\
\hline 1735.2 & 1 \\
\hline 1737.9 & 0 \\
\hline 1741.5 & $3-5$ \\
\hline 1748.4 & 0 \\
\hline 1749.1 & 0 \\
\hline 1753.6 & $1-3$ \\
\hline 1758.5 & $1-3$ \\
\hline 1764.5 & 0 \\
\hline 1766.3 & 0 \\
\hline 1767.3 & $10-20$ \\
\hline 1776.3 & $5-7$ \\
\hline 1776.7 & $1-7$ \\
\hline 1782.6 & $7-9$ \\
\hline 1785.5 & 0 \\
\hline 1790.8 & $0->10$ \\
\hline 1796.6 & 0 \\
\hline 1805.8 & 0 \\
\hline 1808.8 & $3-7$ \\
\hline 1810.8 & 0 \\
\hline 1810.9 & 0 \\
\hline 1811.0 & $1-3$ \\
\hline 1815.3 & 0 \\
\hline 1816.2 & $3-5$ \\
\hline & \\
\hline
\end{tabular}


Appendix B - Table 4 - Sample Injection Data From Bath Petroleum Inc. (only 2 weeks of multiple month injection)

\begin{tabular}{|c|c|c|c|c|c|c|c|c|c|c|c|}
\hline Date & $\begin{array}{c}\text { Chlorides } \\
\text { (mg/L) }\end{array}$ & $\begin{array}{c}\text { Time } \\
\text { (military) }\end{array}$ & $\begin{array}{l}\text { Annular } \\
\text { Pressure }\end{array}$ & $\begin{array}{l}\text { Injection } \\
\text { Pressure }\end{array}$ & pH & SG & $\begin{array}{l}\text { Brine } \\
\text { Temp. }\end{array}$ & $\begin{array}{c}\text { Meter } \\
\text { Reading } \\
\text { Barrels }\end{array}$ & BPM & GPM & $\begin{array}{l}\text { Name of } \\
\text { Recorder }\end{array}$ \\
\hline $8 / 12 / 2004$ & & 1800 & 200 & 980 & & & & 455309 & & & B Moon \\
\hline & 167000 & 1900 & 200 & 980 & 7.1 & 1.170 & 90 & 455582 & -5 & & B Moon \\
\hline & & 1915 & 200 & 980 & & & & 455750 & & & B Moon \\
\hline & & 1916 & & & & & & & & & B Moon \\
\hline & & 2030 & & & & & & & & & B Moon \\
\hline & & 2050 & 280 & 980 & \multicolumn{2}{|c|}{ off for Repairs } & & 455760 & & & B Moon \\
\hline \multirow[t]{17}{*}{$8 / 13 / 2004$} & & 930 & 190 & & & & & 455760 & & & B Moon \\
\hline & & 950 & \multicolumn{2}{|c|}{ offline - to work on oiler } & & & & & & & B Moon \\
\hline & & 955 & online & & & & & & & & B Moon \\
\hline & & 1040 & 200 & 1040 & & & & 456083 & 5.1 & 214.2 & B Moon \\
\hline & 180000 & 1130 & 300 & 1060 & 7.2 & 1.168 & 95 & 456218 & 5.1 & 214.2 & B Moon \\
\hline & & 1230 & 280 & 1080 & & & & 456617 & 4.9 & 205.8 & B Moon \\
\hline & & 1330 & 290 & 1090 & & & & 456914 & 4.9 & 205.8 & B Moon \\
\hline & & 1430 & 230 & 1095 & & & & 457214 & 5.0 & 210.0 & B Moon \\
\hline & & 1530 & 200 & 1100 & & & & 45716 & 5.0 & 210.0 & B Moon \\
\hline & & 1630 & 200 & 1095 & & & & 457805 & 5.0 & 210.0 & B Moon \\
\hline & & 1730 & 220 & 1090 & & & & 458115 & 5.0 & 210.0 & B Moon \\
\hline & & 1830 & 220 & 1090 & & & & 458428 & 5.0 & 210.0 & B Moon \\
\hline & & 1930 & 220 & 1090 & & & & 458718 & 5.0 & 210.0 & B Moon \\
\hline & & 2030 & 230 & 1090 & & & & 459021 & 5.0 & 210.0 & B Moon \\
\hline & & 2130 & 230 & 1090 & & & & 459332 & 5.0 & 210.0 & B Moon \\
\hline & & 2230 & 220 & 1090 & & & & 459623 & 5.0 & 210.0 & B Moon \\
\hline & & 2330 & 220 & 1090 & & & & 459623 & 5.0 & 210.0 & B Moon \\
\hline $8 / 14 / 2004$ & & 30 & 220 & 1090 & & & & 459942 & 5.0 & 210.0 & B Moon \\
\hline & & 130 & 220 & 1090 & & & & 460236 & 5.0 & 210.0 & B Moon \\
\hline & & 230 & 220 & 1090 & & & & 460556 & 5.0 & 210.0 & B Moon \\
\hline & & 330 & 220 & 1090 & & & & 460860 & 5.0 & 210.0 & B Moon \\
\hline & & 430 & 220 & 1090 & & & & 461173 & 5.0 & 210.0 & B Moon \\
\hline & & 530 & 220 & 1090 & & & & 461485 & 5.0 & 210.0 & B Moon \\
\hline & & 630 & 220 & 1090 & & & & 461790 & 5.0 & 210.0 & B Moon \\
\hline & & 730 & & & & & & 462120 & 5.0 & 210.0 & B Moon \\
\hline & & 830 & & & & & & & & & B Moon \\
\hline
\end{tabular}




\begin{tabular}{|c|c|c|c|c|c|c|c|c|c|c|c|}
\hline Date & $\begin{array}{c}\text { Chlorides } \\
\text { (mg/L) }\end{array}$ & $\begin{array}{c}\text { Time } \\
\text { (military) }\end{array}$ & $\begin{array}{l}\text { Annular } \\
\text { Pressure }\end{array}$ & $\begin{array}{l}\text { Injection } \\
\text { Pressure }\end{array}$ & pH & SG & $\begin{array}{l}\text { Brine } \\
\text { Temp. }\end{array}$ & $\begin{array}{c}\text { Meter } \\
\text { Reading } \\
\text { Barrels }\end{array}$ & BPM & GPM & $\begin{array}{l}\text { Name of } \\
\text { Recorder }\end{array}$ \\
\hline & & 930 & & & & & & & & & B Moon \\
\hline & & 1030 & & & & & & & & & B Moon \\
\hline & & 1110 & & 1000 & & & & 462318 & & & B Moon \\
\hline & & 1150 & \multicolumn{4}{|c|}{ offline for repairs - motor not working } & & 462490 & & & B Moon \\
\hline & & 1230 & & 990 & & & & 462490 & & & B Moon \\
\hline & 17700 & 1345 & & & 13 & 1.172 & 97 & & & & B Moon \\
\hline & & 1337 & 290 & 1045 & & & & 462843 & 5.0 & 210.0 & B Moon \\
\hline & & 1430 & 335 & 1075 & & & & 463111 & 5.0 & 210.0 & B Moon \\
\hline & & 1530 & 250 & 1080 & & & & 463422 & 5.1 & 214.2 & B Moon \\
\hline & & 1630 & 240 & 1080 & & & & 463730 & 5.1 & 214.2 & S Stahl \\
\hline & & 1730 & 225 & 1080 & & & & 464042 & 5.1 & 214.2 & S Stahl \\
\hline & & 1830 & 270 & 1080 & & & & 464347 & 5.1 & 214.2 & S Stahl \\
\hline & & 1930 & 250 & 1080 & & & & 464661 & 5.1 & 214.2 & S Stahl \\
\hline & & 2030 & 240 & 1080 & & & & 464973 & 5.1 & 214.2 & S Stahl \\
\hline & & 2130 & 250 & 1080 & & & & 465276 & 5.0 & 210.0 & S Stahl \\
\hline & & 2230 & 240 & 1070 & & & & 465593 & 5.0 & 210.0 & S Stahl \\
\hline & & 2330 & 240 & 1075 & & & & 465903 & 5.0 & 210.0 & S Stahl \\
\hline $8 / 15 / 2004$ & & 30 & 200 & 1080 & & & & 466212 & 5.0 & 210.0 & J Cardona \\
\hline & & 130 & 220 & 1070 & & & & 466527 & 5.0 & 210.0 & J Cardona \\
\hline & & 230 & 220 & 1090 & & & & 466842 & 5.0 & 210.0 & J Cardona \\
\hline & & 330 & 220 & 1080 & & & & 467160 & 5.1 & 214.2 & J Cardona \\
\hline & & 430 & 220 & 1070 & & & & 467466 & 5.2 & 218.4 & J Cardona \\
\hline & & 530 & 220 & 1080 & & & & 467788 & 5.2 & 218.4 & J Cardona \\
\hline & & 630 & 220 & 1080 & & & & 768094 & 5.2 & 218.4 & J Cardona \\
\hline & & 730 & 220 & 1080 & & & & 768403 & 5.2 & 218.4 & J Cardona \\
\hline & & 830 & 235 & 1085 & & & & 468724 & 5.3 & 222.6 & T Rice \\
\hline & & 930 & 240 & 1080 & & & & 469037 & 5.2 & 218.4 & T Rice \\
\hline & & 1030 & 250 & 1080 & & & & 469350 & 5.2 & 218.4 & T Rice \\
\hline & & 1130 & 280 & 1080 & & & & 469668 & 5.3 & 222.6 & T Rice \\
\hline & 172000 & 1230 & 160 & 1080 & 7.3 & 1.170 & 98 & 469983 & 5.2 & 218.4 & T Rice \\
\hline & & 1330 & 205 & 1080 & & & & 470299 & 5.2 & 218.4 & T Rice \\
\hline & & 1430 & 235 & 1080 & & & & 470614 & 5.2 & 218.4 & T Rice \\
\hline & & 1530 & 240 & 1080 & & & & 470929 & 5.2 & 218.4 & T Rice \\
\hline & & 1630 & 235 & 1080 & & & & 471236 & 5.1 & 214.2 & S Stahl \\
\hline
\end{tabular}




\begin{tabular}{|c|c|c|c|c|c|c|c|c|c|c|c|}
\hline Date & $\begin{array}{c}\text { Chlorides } \\
\text { (mg/L) }\end{array}$ & $\begin{array}{c}\text { Time } \\
\text { (military) }\end{array}$ & $\begin{array}{l}\text { Annular } \\
\text { Pressure }\end{array}$ & $\begin{array}{l}\text { Injection } \\
\text { Pressure }\end{array}$ & $\mathrm{pH}$ & SG & $\begin{array}{l}\text { Brine } \\
\text { Temp. }\end{array}$ & $\begin{array}{c}\text { Meter } \\
\text { Reading } \\
\text { Barrels }\end{array}$ & BPM & GPM & $\begin{array}{l}\text { Name of } \\
\text { Recorder }\end{array}$ \\
\hline & & 1730 & 250 & 1080 & & & & 471562 & 5.1 & 214.2 & S Stahl \\
\hline & & 1830 & 240 & 1080 & & & & 471885 & 5.1 & 214.2 & S Stahl \\
\hline & & 1930 & 250 & 1080 & & & & 472178 & 5.1 & 214.2 & S Stahl \\
\hline & & 2030 & 250 & 1080 & & & & 472498 & 5.1 & 214.2 & S Stahl \\
\hline & & 2130 & 230 & 1075 & & & & 472802 & 5.1 & 214.2 & S Stahl \\
\hline & & 2230 & 240 & 1075 & & & & 473109 & 5.1 & 214.2 & S Stahl \\
\hline & & 2330 & 240 & 1075 & & & & 473436 & 5.1 & 214.2 & S Stahl \\
\hline \multirow[t]{24}{*}{$8 / 16 / 2004$} & & 30 & 220 & 1080 & & & & 473744 & 5.1 & 214.2 & J Cardona \\
\hline & & 130 & 220 & 1080 & & & & 474064 & 5.1 & 214.2 & J Cardona \\
\hline & & 230 & 220 & 1080 & & & & 474380 & 5.1 & 214.2 & J Cardona \\
\hline & & 330 & 210 & 1080 & & & & 474692 & 5.1 & 214.2 & J Cardona \\
\hline & & 430 & 220 & 1080 & & & & 474996 & 5.1 & 214.2 & J Cardona \\
\hline & & 530 & 210 & 1080 & & & & 475305 & 5.1 & 214.2 & J Cardona \\
\hline & & 630 & 210 & 1080 & & & & 475636 & 5.1 & 214.2 & J Cardona \\
\hline & & 730 & 220 & 1080 & & & & 475937 & 5.1 & 214.2 & J Cardona \\
\hline & & 830 & 220 & 1100 & & & & 476254 & 5.2 & 218.4 & T Rice \\
\hline & & 930 & 240 & 1090 & & & & 476563 & 5.1 & 214.2 & T Rice \\
\hline & & 1030 & 250 & 1090 & & & & 476876 & 5.2 & 218.4 & T Rice \\
\hline & & 1130 & 280 & 1080 & & & & 477180 & 5.0 & 210.0 & T Rice \\
\hline & 175000 & 1230 & 285 & 1085 & 7.3 & 1.170 & 97 & 477494 & 5.2 & 218.4 & T Rice \\
\hline & & 1330 & 180 & 1080 & & & & 477805 & 5.1 & 214.2 & T Rice \\
\hline & & 1430 & 195 & 1085 & & & & 478119 & 5.2 & 218.4 & T Rice \\
\hline & & 1530 & 215 & 1085 & & & & 478433 & 5.2 & 218.4 & T Rice \\
\hline & & 1630 & 240 & 1080 & & & & 478752 & 5.1 & 214.2 & S Stahl \\
\hline & & 1730 & 240 & 1080 & & & & 479071 & 5.1 & 214.2 & S Stahl \\
\hline & & 1830 & 220 & 1080 & & & & 479384 & 5.1 & 214.2 & S Stahl \\
\hline & & 1930 & 230 & 1080 & & & & 479688 & 5.0 & 210.0 & S Stahl \\
\hline & & 2030 & 230 & 1080 & & & & 479995 & 5.1 & 214.2 & S Stahl \\
\hline & & 2130 & 240 & 1080 & & & & 480295 & 5.1 & 214.2 & S Stahl \\
\hline & & 2230 & 240 & 1080 & & & & 480612 & 5.1 & 214.2 & S Stahl \\
\hline & & 2330 & 245 & 1080 & & & & 480930 & 5.1 & 214.2 & S Stahl \\
\hline \multirow[t]{3}{*}{$8 / 17 / 2004$} & & 30 & 220 & 1050 & & & & 481256 & 5.1 & 214.2 & J Cardona \\
\hline & & 130 & 210 & 1080 & & & & 481568 & 5.1 & 214.2 & J Cardona \\
\hline & & 230 & 220 & 1080 & & & & 781852 & 5.1 & 214.2 & J Cardona \\
\hline
\end{tabular}




\begin{tabular}{|c|c|c|c|c|c|c|c|c|c|c|c|}
\hline Date & $\begin{array}{c}\text { Chlorides } \\
\text { (mg/L) }\end{array}$ & $\begin{array}{c}\text { Time } \\
\text { (military) }\end{array}$ & $\begin{array}{l}\text { Annular } \\
\text { Pressure }\end{array}$ & $\begin{array}{l}\text { Injection } \\
\text { Pressure }\end{array}$ & $\mathrm{pH}$ & SG & $\begin{array}{l}\text { Brine } \\
\text { Temp. }\end{array}$ & $\begin{array}{c}\text { Meter } \\
\text { Reading } \\
\text { Barrels }\end{array}$ & BPM & GPM & $\begin{array}{l}\text { Name of } \\
\text { Recorder }\end{array}$ \\
\hline & & 330 & 210 & 1080 & & & & 482156 & 5.1 & 214.2 & J Cardona \\
\hline & & 430 & 220 & 1080 & & & & 482478 & 5.1 & 214.2 & J Cardona \\
\hline & & 530 & 210 & 1080 & & & & 482796 & 5.1 & 214.2 & J Cardona \\
\hline & & 630 & 210 & 1080 & & & & 483096 & 5.1 & 214.2 & J Cardona \\
\hline & & 730 & 220 & 1080 & & & & 483399 & 5.1 & 214.2 & J Cardona \\
\hline & & 815 & \multicolumn{2}{|c|}{ for repairs - pump } & & & & 483656 & & & T Rice \\
\hline & & 930 & & & & & & & & & \\
\hline & & 1030 & & & & & & & & & \\
\hline & & 1130 & & & & & & & & & \\
\hline & & 1230 & & & & & & & & & \\
\hline & on & 1350 & 60 & 990 & \multicolumn{3}{|c|}{ Started pump after repairs } & 483656 & & & B Moon \\
\hline & 175000 & 1430 & 250 & 1060 & 7.4 & 1.117 & 98 & 485848 & 5.1 & 214.2 & B Moon \\
\hline & & 1530 & 300 & 1070 & & & & 484140 & 5.1 & 214.2 & S Stahl \\
\hline & & 1630 & 240 & 1075 & & & & 484450 & 5.0 & 210.0 & S Stahl \\
\hline & & 1730 & 270 & 1075 & & & & 484752 & 5.0 & 210.0 & S Stahl \\
\hline & & 1830 & 240 & 1075 & & & & 485064 & 5.1 & 214.2 & S Stahl \\
\hline & & 1930 & 250 & 1075 & & & & 485373 & 5.1 & 214.2 & S Stahl \\
\hline & & 2030 & 250 & 1075 & & & & 485688 & 5.1 & 214.2 & S Stahl \\
\hline & & 2130 & 240 & 1075 & & & & 485997 & 5.1 & 214.2 & S Stahl \\
\hline & & 2230 & 240 & 1075 & & & & 486298 & 5.1 & 214.2 & S Stahl \\
\hline & & 2330 & 245 & 1075 & & & & 486618 & 5.1 & 214.2 & S Stahl \\
\hline $8 / 18 / 2004$ & & 30 & 220 & 1075 & & & & 486942 & 5.1 & 214.2 & J Cardona \\
\hline & & 130 & 220 & 1075 & & & & 487248 & 5.1 & 214.2 & J Cardona \\
\hline & & 230 & 210 & 1080 & & & & 487548 & 5.1 & 214.2 & J Cardona \\
\hline & & 330 & 210 & 1080 & & & & 487860 & 5.1 & 214.2 & J Cardona \\
\hline & & 430 & 210 & 1080 & & & & 488161 & 5.1 & 214.2 & J Cardona \\
\hline & & 530 & 210 & 1080 & & & & 488486 & 5.1 & 214.2 & J Cardona \\
\hline & & 630 & 210 & 1080 & & & & 488796 & 5.1 & 214.2 & J Cardona \\
\hline & & 730 & 210 & 1080 & & & & 487094 & 5.1 & 214.2 & J Cardona \\
\hline & & 830 & 210 & 1120 & & & & 489426 & 5.5 & 231.0 & T Rice \\
\hline & & 930 & 235 & 1120 & & & & 489731 & 5.0 & 210.0 & T Rice \\
\hline & & 1030 & 240 & 1120 & & & & 490030 & 4.9 & 205.8 & T Rice \\
\hline & & 1130 & 250 & 1115 & & & & 490337 & 5.1 & 214.2 & T Rice \\
\hline & 173000 & 1230 & 280 & 1115 & 7.4 & 1.168 & 97 & 490647 & 5.1 & 214.2 & T Rice \\
\hline
\end{tabular}




\begin{tabular}{|c|c|c|c|c|c|c|c|c|c|c|c|}
\hline Date & $\begin{array}{c}\text { Chlorides } \\
\text { (mg/L) }\end{array}$ & $\begin{array}{c}\text { Time } \\
\text { (military) }\end{array}$ & $\begin{array}{l}\text { Annular } \\
\text { Pressure }\end{array}$ & $\begin{array}{l}\text { Injection } \\
\text { Pressure }\end{array}$ & $\mathrm{pH}$ & SG & $\begin{array}{l}\text { Brine } \\
\text { Temp. }\end{array}$ & $\begin{array}{c}\text { Meter } \\
\text { Reading } \\
\text { Barrels }\end{array}$ & BPM & GPM & $\begin{array}{l}\text { Name of } \\
\text { Recorder }\end{array}$ \\
\hline & & 1350 & 300 & 1120 & & & & 490975 & 5.2 & 218.4 & B Moon \\
\hline & & 1430 & 320 & 1120 & & & & 491261 & 4.7 & 197.4 & T Rice \\
\hline & & 1530 & 325 & 1115 & & & & 491549 & 4.8 & 201.6 & T Rice \\
\hline & & 1630 & 310 & 1125 & & & & 491820 & 4.6 & 193.2 & S Stahl \\
\hline & & 1730 & 260 & 1125 & & & & 492125 & 5.1 & 214.2 & S Stahl \\
\hline & & 1830 & 270 & 1125 & & & & 492446 & 5.1 & 214.2 & S Stahl \\
\hline & & 1930 & 250 & 1125 & & & & 492730 & 4.9 & 205.8 & S Stahl \\
\hline & & 2030 & 250 & 1125 & & & & 493041 & 4.7 & 197.4 & S Stahl \\
\hline & & 2130 & 255 & 1125 & & & & 493330 & 4.9 & 205.8 & S Stahl \\
\hline & & 2230 & 260 & 1125 & & & & 493615 & 4.8 & 201.6 & S Stahl \\
\hline & & 2330 & 260 & 1125 & & & & 493908 & 4.8 & 201.6 & S Stahl \\
\hline $8 / 19 / 2004$ & & 30 & 230 & 1125 & & & & 494184 & 4.8 & 201.6 & J Cardona \\
\hline & & 130 & 240 & 1125 & & & & 494509 & 4.8 & 201.6 & J Cardona \\
\hline & & 230 & 240 & 1125 & & & & 494750 & 4.8 & 201.6 & J Cardona \\
\hline & & 330 & 240 & 1125 & & & & 495044 & 4.8 & 201.6 & J Cardona \\
\hline & & 430 & 240 & 1125 & & & & 495338 & 4.8 & 201.6 & J Cardona \\
\hline & & 530 & 240 & 1125 & & & & 495630 & 4.8 & 201.6 & J Cardona \\
\hline & & 630 & 240 & 1125 & & & & 495922 & 4.8 & 201.6 & J Cardona \\
\hline & & 730 & 240 & 1125 & & & & 496215 & 4.8 & 201.6 & J Cardona \\
\hline & & 830 & 245 & 1125 & & & & 496499 & 4.7 & 197.4 & T Rice \\
\hline & & 930 & 250 & 1120 & & & & 496785 & 4.7 & 197.4 & T Rice \\
\hline & & 1030 & 275 & 1120 & & & & 497068 & 4.7 & 197.4 & T Rice \\
\hline & & 1130 & 285 & 1125 & & & & 497371 & 5.0 & 210.0 & T Rice \\
\hline & & 1230 & 315 & 1125 & & & & 497700 & 5.4 & 226.8 & T Rice \\
\hline & 172000 & 1330 & 325 & 1125 & & & & 467984 & 4.7 & 197.4 & T Rice \\
\hline & & 1420 & \multicolumn{2}{|c|}{ line for repairs } & & & & & & & B Moon \\
\hline & & 1430 & 350 & 1125 & & & & 498246 & start & & S Stahl \\
\hline & & 1530 & 280 & 1120 & & & & 498246 & 5.3 & 222.6 & S Stahl \\
\hline & & 1630 & 250 & 1125 & & & & 498551 & 5.2 & 218.4 & S Stahl \\
\hline & & 1730 & 290 & 1125 & & & & 498855 & 5.2 & 218.4 & S Stahl \\
\hline & & 1830 & 250 & 1125 & & & & 449177 & 5.2 & 218.4 & S Stahl \\
\hline & & 1930 & 260 & 1125 & & & & 449482 & 5.2 & 218.4 & S Stahl \\
\hline & & 2030 & 270 & 1135 & & & & 499785 & 5.2 & 218.4 & S Stahl \\
\hline & & 2130 & 230 & 1135 & & & & 500078 & 5.1 & 214.2 & S Stahl \\
\hline
\end{tabular}




\begin{tabular}{|c|c|c|c|c|c|c|c|c|c|c|c|}
\hline Date & $\begin{array}{c}\text { Chlorides } \\
\text { (mg/L) }\end{array}$ & $\begin{array}{c}\text { Time } \\
\text { (military) }\end{array}$ & $\begin{array}{l}\text { Annular } \\
\text { Pressure }\end{array}$ & $\begin{array}{l}\text { Injection } \\
\text { Pressure }\end{array}$ & $\mathrm{pH}$ & SG & $\begin{array}{l}\text { Brine } \\
\text { Temp. }\end{array}$ & $\begin{array}{c}\text { Meter } \\
\text { Reading } \\
\text { Barrels }\end{array}$ & BPM & GPM & $\begin{array}{l}\text { Name of } \\
\text { Recorder }\end{array}$ \\
\hline & & 2230 & 240 & 1135 & & & & 500384 & 5.1 & 214.2 & S Stahl \\
\hline & & 2330 & 250 & 1135 & & & & 500682 & 5.0 & 210.0 & S Stahl \\
\hline \multirow[t]{24}{*}{$8 / 20 / 2004$} & & 30 & 240 & 1135 & & & & 500964 & 5.0 & 210.0 & J Cardona \\
\hline & & 130 & 250 & 1135 & & & & 501258 & 5.0 & 210.0 & J Cardona \\
\hline & & 230 & 250 & 1135 & & & & 501559 & 5.0 & 210.0 & J Cardona \\
\hline & & 330 & 250 & 1135 & & & & 501860 & 5.0 & 210.0 & J Cardona \\
\hline & & 430 & 250 & 1135 & & & & 502144 & 5.0 & 210.0 & J Cardona \\
\hline & & 530 & 250 & 1135 & & & & 502440 & 5.0 & 210.0 & J Cardona \\
\hline & & 630 & 250 & 1135 & & & & 502750 & 5.0 & 210.0 & J Cardona \\
\hline & & 730 & 240 & 1135 & & & & 503056 & 5.0 & 210.0 & J Cardona \\
\hline & & 830 & 250 & 1135 & & & & 503359 & 5.0 & 210.0 & T Rice \\
\hline & & 930 & 260 & 1135 & & & & 503655 & 4.9 & 205.8 & T Rice \\
\hline & & 1030 & 275 & 1140 & & & & 503954 & 4.9 & 205.8 & T Rice \\
\hline & & 1130 & 290 & 1140 & & & & 504253 & 5.0 & 210.0 & B Moon \\
\hline & 178000 & 1230 & 310 & 1140 & 7.4 & 1.167 & 98 & 504558 & 5.0 & 210.0 & T Rice \\
\hline & & 1330 & 320 & 1140 & & & & 504863 & 5.0 & 210.0 & T Rice \\
\hline & & 1430 & 330 & 1140 & & & & 505164 & 5.0 & 210.0 & T Rice \\
\hline & & 1530 & 340 & 1140 & & & & 505467 & 5.0 & 210.0 & T Rice \\
\hline & & 1630 & 340 & 1140 & & & & 505750 & 4.7 & 197.4 & S Stahl \\
\hline & & 1730 & 350 & 1140 & & & & 506060 & 5.0 & 210.0 & S Stahl \\
\hline & & 1830 & 355 & 1140 & & & & 506346 & 5.0 & 210.0 & S Stahl \\
\hline & & 1930 & 360 & 1140 & & & & 506649 & 5.0 & 210.0 & S Stahl \\
\hline & & 2030 & 350 & 1140 & & & & 506950 & 5.0 & 210.0 & S Stahl \\
\hline & & 2130 & 350 & 1140 & & & & 507250 & 5.0 & 210.0 & S Stahl \\
\hline & & 2230 & 330 & 1140 & & & & 507550 & 5.0 & 210.0 & S Stahl \\
\hline & & 2330 & 330 & 1140 & & & & 507850 & 5.0 & 210.0 & S Stahl \\
\hline \multirow[t]{8}{*}{$8 / 21 / 2004$} & & 30 & 330 & 1140 & & & & 508144 & 5.0 & 210.0 & J Cardona \\
\hline & & 130 & 330 & 1140 & & & & 508428 & 5.0 & 210.0 & J Cardona \\
\hline & & 230 & 330 & 1140 & & & & 508756 & 5.0 & 210.0 & J Cardona \\
\hline & & 330 & 330 & 1140 & & & & 509020 & 5.0 & 210.0 & J Cardona \\
\hline & & 430 & 300 & 1140 & & & & 509324 & 5.0 & 210.0 & J Cardona \\
\hline & & 530 & 310 & 1140 & & & & 509618 & 5.0 & 210.0 & J Cardona \\
\hline & & 630 & 320 & 1140 & & & & 509940 & 5.0 & 210.0 & J Cardona \\
\hline & & 730 & 320 & 1140 & & & & 510220 & 5.0 & 210.0 & J Cardona \\
\hline
\end{tabular}




\begin{tabular}{|c|c|c|c|c|c|c|c|c|c|c|c|}
\hline \multirow[t]{17}{*}{ Date } & $\begin{array}{c}\text { Chlorides } \\
\text { (mg/L) }\end{array}$ & $\begin{array}{c}\text { Time } \\
\text { (military) }\end{array}$ & $\begin{array}{l}\text { Annular } \\
\text { Pressure }\end{array}$ & $\begin{array}{l}\text { Injection } \\
\text { Pressure }\end{array}$ & $\mathrm{pH}$ & SG & $\begin{array}{l}\text { Brine } \\
\text { Temp. }\end{array}$ & $\begin{array}{c}\text { Meter } \\
\text { Reading } \\
\text { Barrels }\end{array}$ & BPM & GPM & $\begin{array}{l}\text { Name of } \\
\text { Recorder }\end{array}$ \\
\hline & & 830 & 320 & 1160 & & & & 510524 & 5.0 & 210.0 & T Rice \\
\hline & & 930 & 325 & 1155 & & & & 510822 & 4.9 & 205.8 & T Rice \\
\hline & & 1030 & 345 & 1155 & & & & 511120 & 4.9 & 205.8 & T Rice \\
\hline & & 1130 & 355 & 1155 & & & & 511420 & 5.0 & 210.0 & T Rice \\
\hline & 167000 & 1230 & 360 & 1155 & 7.5 & 1.102 & 94 & 511720 & 5.0 & 210.0 & T Rice \\
\hline & & 1330 & 370 & 1155 & & & & 512022 & 5.0 & 210.0 & T Rice \\
\hline & & 1430 & 375 & 1155 & & & & 512327 & 5.0 & 210.0 & T Rice \\
\hline & & 1530 & 375 & 1155 & & & & 512626 & 4.9 & 205.8 & T Rice \\
\hline & & 1630 & 375 & 1140 & & & & 512912 & 4.7 & 197.4 & S Stahl \\
\hline & & 1730 & 380 & 1140 & & & & 513214 & 5.0 & 210.0 & S Stahl \\
\hline & & 1830 & 380 & 1140 & & & & 513519 & 5.0 & 210.0 & S Stahl \\
\hline & & 1930 & 380 & 1140 & & & & 513823 & 5.0 & 210.0 & S Stahl \\
\hline & & 2030 & 375 & 1140 & & & & 514123 & 5.0 & 210.0 & S Stahl \\
\hline & & 2130 & 370 & 1140 & & & & 514423 & 5.0 & 210.0 & S Stahl \\
\hline & & 2230 & 365 & 1140 & & & & 514723 & 5.0 & 210.0 & S Stahl \\
\hline & & 2330 & 360 & 1140 & & & & 515021 & 5.0 & 210.0 & S Stahl \\
\hline \multirow[t]{18}{*}{$8 / 22 / 2004$} & & 30 & 350 & 1140 & & & & 515320 & 5.0 & 210.0 & J Cardona \\
\hline & & 130 & 350 & 1140 & & & & 515640 & 5.0 & 210.0 & J Cardona \\
\hline & & 230 & 340 & 1140 & & & & 515910 & 5.0 & 210.0 & J Cardona \\
\hline & & 330 & 340 & 1140 & & & & 516215 & 5.0 & 210.0 & J Cardona \\
\hline & & 430 & 340 & 1140 & & & & 516519 & 5.0 & 210.0 & J Cardona \\
\hline & & 530 & 340 & 1140 & & & & 516817 & 5.0 & 210.0 & J Cardona \\
\hline & & 630 & 340 & 1140 & & & & 517118 & 4.9 & 205.8 & J Cardona \\
\hline & & 730 & 320 & 1140 & & & & 517422 & 4.9 & 205.8 & J Cardona \\
\hline & & 830 & 320 & 1200 & & & & 517696 & 4.5 & 189.0 & T Rice \\
\hline & & 930 & 320 & 1200 & & & & 517980 & 4.7 & 197.4 & T Rice \\
\hline & & 1030 & 325 & 1195 & & & & 518262 & 4.7 & 197.4 & T Rice \\
\hline & & 1130 & 355 & 1190 & & & & 518548 & 4.7 & 197.4 & T Rice \\
\hline & 154000 & 1230 & 370 & 1190 & 7.4 & 1.150 & 95 & 518855 & 4.7 & 197.4 & T Rice \\
\hline & & 1330 & 380 & 1200 & & & & 519162 & 5.1 & 214.2 & T Rice \\
\hline & & 1430 & 410 & 1200 & & & & 519470 & 5.1 & 214.2 & T Rice \\
\hline & & 1530 & 240 & 1200 & & & & 519777 & 5.1 & 214.2 & T Rice \\
\hline & & 1630 & 260 & 1200 & & & & 520084 & 5.1 & 214.2 & S Stahl \\
\hline & & 1730 & 270 & 1200 & & & & 520388 & 5.0 & 210.0 & S Stahl \\
\hline
\end{tabular}




\begin{tabular}{|c|c|c|c|c|c|c|c|c|c|c|c|}
\hline Date & $\begin{array}{c}\text { Chlorides } \\
\text { (mg/L) }\end{array}$ & $\begin{array}{c}\text { Time } \\
\text { (military) }\end{array}$ & $\begin{array}{l}\text { Annular } \\
\text { Pressure }\end{array}$ & $\begin{array}{l}\text { Injection } \\
\text { Pressure }\end{array}$ & $\mathrm{pH}$ & SG & $\begin{array}{l}\text { Brine } \\
\text { Temp. }\end{array}$ & $\begin{array}{c}\text { Meter } \\
\text { Reading } \\
\text { Barrels }\end{array}$ & BPM & GPM & $\begin{array}{l}\text { Name of } \\
\text { Recorder }\end{array}$ \\
\hline & & 1830 & 280 & 1200 & & & & 520690 & 5.0 & 210.0 & S Stahl \\
\hline & & 1930 & 280 & 1200 & & & & 520992 & 5.0 & 210.0 & S Stahl \\
\hline & & 2030 & 280 & 1200 & & & & 521290 & 5.0 & 210.0 & S Stahl \\
\hline & & 2130 & 280 & 1200 & & & & 521590 & 5.0 & 210.0 & S Stahl \\
\hline & & 2230 & 290 & 1190 & & & & 521890 & 5.0 & 210.0 & S Stahl \\
\hline & & 2330 & 285 & 1190 & & & & 522190 & 5.0 & 210.0 & S Stahl \\
\hline $8 / 23 / 2004$ & & 30 & 280 & 1190 & & & & 522478 & 5.0 & 210.0 & J Cardona \\
\hline & & 130 & 280 & 1190 & & & & 522784 & 5.0 & 210.0 & J Cardona \\
\hline & & 230 & 280 & 1190 & & & & 522069 & 5.0 & 210.0 & J Cardona \\
\hline & & 330 & 280 & 1190 & & & & 523389 & 5.0 & 210.0 & J Cardona \\
\hline & & 430 & 290 & 1190 & & & & 523675 & 5.0 & 210.0 & J Cardona \\
\hline & & 530 & 280 & 1190 & & & & 523939 & 5.0 & 210.0 & J Cardona \\
\hline & & 630 & 290 & 1190 & & & & 524274 & 4.9 & 205.8 & J Cardona \\
\hline & & 730 & 290 & 1190 & & & & 524568 & 4.9 & 205.8 & J Cardona \\
\hline & & 830 & 285 & 1200 & & & & 524844 & 4.6 & 193.2 & T Rice \\
\hline & & 847 & & & \multicolumn{2}{|c|}{ offline to fix oiler } & & 524929 & & & T Rice \\
\hline & & 930 & & & \multicolumn{2}{|c|}{ oiler repaired } & & & & & T Rice \\
\hline & & 1030 & 260 & 1115 & online & & & 524929 & & & T Rice \\
\hline & & 1130 & 315 & 1200 & & & & 525199 & 4.9 & 205.8 & T Rice \\
\hline & 149000 & 1230 & 365 & 1200 & 7.4 & 1.144 & 96 & 525502 & 5.0 & 210.0 & T Rice \\
\hline & & 1330 & 235 & 1200 & & & & 525806 & 5.0 & 210.0 & T Rice \\
\hline & & 1430 & 205 & 1200 & & & & 526106 & 5.0 & 210.0 & T Rice \\
\hline & & 1530 & 200 & 1200 & & & & 526408 & 5.0 & 210.0 & T Rice \\
\hline & & 1630 & 200 & 1200 & & & & 526710 & 5.0 & 210.0 & S Stahl \\
\hline & & 1730 & 200 & 1200 & & & & 527000 & 4.8 & 201.6 & S Stahl \\
\hline & & 1830 & 220 & 1200 & & & & 527292 & 4.9 & 205.8 & S Stahl \\
\hline & & 1930 & 230 & 1210 & & & & 527596 & 5.0 & 210.0 & S Stahl \\
\hline & & 2030 & 240 & 1210 & & & & 527900 & 5.0 & 210.0 & S Stahl \\
\hline & & 2130 & 240 & 1210 & & & & 528207 & 5.0 & 210.0 & S Stahl \\
\hline & & 2230 & 240 & 1200 & & & & 528514 & 5.1 & 214.2 & S Stahl \\
\hline & & 2330 & 255 & 1200 & & & & 528821 & 5.1 & 214.2 & S Stahl \\
\hline $8 / 24 / 2004$ & & 30 & 260 & 1210 & & & & 529120 & 5.0 & 210.0 & J Cardona \\
\hline & & 130 & 260 & 1210 & & & & 529434 & 5.2 & 218.4 & J Cardona \\
\hline & & 230 & 260 & 1210 & & & & 529741 & 5.1 & 214.2 & J Cardona \\
\hline
\end{tabular}




\begin{tabular}{|c|c|c|c|c|c|c|c|c|c|c|c|}
\hline Date & $\begin{array}{c}\text { Chlorides } \\
\text { (mg/L) }\end{array}$ & $\begin{array}{c}\text { Time } \\
\text { (military) }\end{array}$ & $\begin{array}{l}\text { Annular } \\
\text { Pressure }\end{array}$ & $\begin{array}{l}\text { Injection } \\
\text { Pressure }\end{array}$ & $\mathrm{pH}$ & SG & $\begin{array}{l}\text { Brine } \\
\text { Temp. }\end{array}$ & $\begin{array}{c}\text { Meter } \\
\text { Reading } \\
\text { Barrels }\end{array}$ & BPM & GPM & $\begin{array}{l}\text { Name of } \\
\text { Recorder }\end{array}$ \\
\hline & & 330 & 260 & 1210 & & & & 530050 & 5.2 & 218.4 & J Cardona \\
\hline & & 430 & 270 & 1220 & & & & 530350 & 5.0 & 210.0 & J Cardona \\
\hline & & 530 & 270 & 1220 & & & & 530658 & 5.1 & 214.2 & J Cardona \\
\hline & & 630 & 270 & 1220 & & & & 530960 & 5.0 & 210.0 & J Cardona \\
\hline & & 730 & 270 & 1220 & & & & 531264 & 5.0 & 210.0 & J Cardona \\
\hline & & 830 & 275 & 1235 & & & & 531561 & 4.9 & 205.8 & T Rice \\
\hline & & 930 & 280 & 1235 & & & & 531861 & 5.0 & 210.0 & T Rice \\
\hline & & 1030 & 290 & 1235 & & & & 532161 & 5.0 & 210.0 & T Rice \\
\hline & & 1130 & 315 & 1235 & & & & 532460 & 4.9 & 205.8 & T Rice \\
\hline & 155000 & 1230 & 275 & 1235 & 7.4 & 1.148 & 95 & 532762 & 5.0 & 210.0 & T Rice \\
\hline & & 1330 & 275 & 1235 & & & & 533064 & 5.0 & 210.0 & T Rice \\
\hline & & 1430 & 275 & 1235 & & & & 533358 & 4.9 & 205.8 & T Rice \\
\hline & & 1530 & 280 & 1235 & & & & 533963 & 5.0 & 210.0 & T Rice \\
\hline & & 1630 & 300 & 1240 & & & & 534263 & 5.0 & 210.0 & S Stahl \\
\hline & & 1730 & 310 & 1235 & & & & 534561 & 5.0 & 210.0 & S Stahl \\
\hline & & 1830 & 310 & 1235 & & & & 534561 & 4.9 & 205.8 & S Stahl \\
\hline & & 1930 & 320 & 1230 & & & & 534858 & 4.9 & 205.8 & S Stahl \\
\hline & & 2030 & 320 & 1220 & & & & 535151 & 4.8 & 201.6 & S Stahl \\
\hline & & 2130 & 320 & 1230 & & & & 535454 & 5.0 & 210.0 & S Stahl \\
\hline & & 2230 & 320 & 1230 & & & & 535756 & 5.0 & 210.0 & S Stahl \\
\hline & & 2330 & 320 & 1230 & & & & 536059 & 5.0 & 210.0 & S Stahl \\
\hline $8 / 25 / 2004$ & & 0005 & \multicolumn{4}{|c|}{ off - gas valve on motor not working } & & 536208 & & & J Cardona \\
\hline & & 130 & & & & & & & & & J Cardona \\
\hline & & 300 & 240 & 1220 & On Line & & & 536208 & & & J Cardona \\
\hline & & 330 & 240 & 1220 & & & & 536370 & 5.4 & 226.8 & J Cardona \\
\hline & & 430 & 320 & 1240 & & & & 536667 & 4.9 & 205.8 & J Cardona \\
\hline & & 530 & 250 & 1240 & & & & 536972 & 5.0 & 210.0 & J Cardona \\
\hline & & 630 & 280 & 1240 & & & & 537274 & 5.0 & 210.0 & J Cardona \\
\hline & & 730 & 280 & 1240 & & & & 537578 & 5.0 & 210.0 & J Cardona \\
\hline & & 830 & 300 & 1240 & & & & 537862 & 4.7 & 197.4 & T Rice \\
\hline & & 930 & 315 & 1240 & & & & 538151 & 4.8 & 201.6 & T Rice \\
\hline & & 1030 & 320 & 1240 & & & & 538442 & 4.8 & 201.6 & T Rice \\
\hline & & 1130 & 280 & 1235 & & & & 538733 & 4.8 & 201.6 & T Rice \\
\hline & 155000 & 1230 & 285 & 1235 & 7.4 & 1.146 & 96 & 539025 & 4.8 & 201.6 & T Rice \\
\hline
\end{tabular}




\section{Appendix C}

\section{Trenton-Black River Data}

$\begin{array}{ll}\text { Table } 1 & \text { General Well Data } \\ \text { Table } 2 & \text { Formation Tops } \\ \text { Document } 1 & \text { Calculation of Cavern Gas } \\ & \text { Storage Volume from } \\ & \text { Reserve Volume - Trenton- } \\ & \text { Black River }\end{array}$


Appendix C - Table 1 - Trenton-Black River General Well Data

\begin{tabular}{|c|c|c|c|c|c|c|c|c|}
\hline UWI (APINum) & Well Label & Well Name & Operator & Township & County & TD & Surf Lat & Surf Lon \\
\hline $31-121-00271-00-00$ & $00271-00$ & Bigelow Albert 1 & Wilson K.E. & ARCADEN & WYOMING & 7065 & 42.5732 & -78.4454 \\
\hline $31-015-00443-00-00$ & $00443-00$ & Kesselring 1 & Tremblay Gail R. \& Alan B. & VA ETTENN & CHEMUNG & 11145 & 42.1986 & -76.5381 \\
\hline $31-011-00478-00-00$ & $00478-00$ & Mahaney J C & Reserve Oil Co. & LEDYARDN & CAYUGA & 6166 & 42.6848 & -76.6443 \\
\hline $31-109-00481-00-00$ & 00481-00 & Farkas Joe 1 & Reserve Oil Co. & LA SINGN & TOMPKINS & 6210 & 42.5292 & -76.5074 \\
\hline $31-121-00615-00-00$ & $00615-00$ & Fee 1 & Wilson K.E. & ARCADEN & WYOMING & 7144 & 42.5306 & -78.4235 \\
\hline $31-037-00650-00-00$ & $00650-00$ & Martin 1 & Pavilion Natural Gas Co. & PAVILION & GENESEE & 4082 & 42.8807 & -77.9793 \\
\hline $31-037-00651-00-00$ & $00651-00$ & Gibson & Rice Charles $\mathrm{H}$. & BATAVIAN & GENESEE & 3450 & 43.0412 & -78.2858 \\
\hline 31-055-00671-00-00 & $00671-00$ & Brockport Well & unknown & SWEDEN & MONROE & 2000 & 43.2116 & -77.9411 \\
\hline $31-055-00672-00-00$ & $00672-00$ & Rochester Deep Well & unknown & BRIGHTON & MONROE & 3100 & 43.1702 & -77.6186 \\
\hline $31-065-00680-00-00$ & $00680-00$ & Williams Elmer 1 & Property Shares Inc. & FLORE CEN & ONEIDA & 1451 & 43.3818 & -75.7346 \\
\hline $31-065-00681-00-00$ & $00681-00$ & De LA Roche & Property Shares Inc. & CAMDEN & ONEIDA & 1300 & 43.3575 & -75.7571 \\
\hline $31-065-00682-00-00$ & $00682-00$ & Rinkle Leigh 1 & Cabot G.L. & CAMDEN & ONEIDA & 1793 & 43.3651 & -75.7658 \\
\hline $31-065-00683-00-00$ & $00683-00$ & Owens W T 2 & Property Shares Inc. & CAMDEN & ONEIDA & 1305 & 43.3616 & -75.7707 \\
\hline 31-065-00684-00-00 & $00684-00$ & Owens 1 & Property Shares Inc. & CAMDEN & ONEIDA & 973 & 43.3635 & -75.7767 \\
\hline $31-065-00685-00-00$ & $00685-00$ & Meeker Ezra & Cabot G.L. & CAMDEN & ONEIDA & 1396 & 43.3668 & -75.741 \\
\hline $31-065-00686-00-00$ & $00686-00$ & Macker Estates Meeker & Knese N.R. & CAMDEN & ONEIDA & 1373 & 43.3695 & -75.7413 \\
\hline $31-065-00687-00-00$ & $00687-00$ & Griffin Joseph & Oneida Products & CAMDEN & ONEIDA & 1405 & 43.3772 & -75.762 \\
\hline $31-065-00689-00-00$ & $00689-00$ & Dunn 2 & Oneida Products & CAMDEN & ONEIDA & 1405 & 43.3692 & -75.7481 \\
\hline 31-065-00691-00-00 & $00691-00$ & Donlon Ed & Cabot G.L. & CAMDEN & ONEIDA & 1528 & 43.3588 & -75.7474 \\
\hline $31-065-00692-00-00$ & $00692-00$ & Davies J C 1 & unknown & CAMDEN & ONEIDA & 1880 & 43.3383 & -75.7413 \\
\hline $31-065-00693-00-00$ & $00693-00$ & Homer Dale & Oneida Products & CAMDEN & ONEIDA & 1365 & 43.3605 & -75.7575 \\
\hline 31-065-00694-00-00 & $00694-00$ & Brewster A 2 & Property Shares Inc. & CAMDEN & ONEIDA & 1081 & 43.3687 & -75.7609 \\
\hline $31-065-00695-00-00$ & $00695-00$ & Standard Harvester & Standard Harvester & UTICAN & ONEIDA & 1370 & 43.0977 & -75.2526 \\
\hline $31-065-00696-00-00$ & $00696-00$ & Globe Woolen Works 1 & Globe Woolen Works & UTICAN & ONEIDA & 1720 & 43.1043 & -75.2459 \\
\hline $31-065-00697-00-00$ & $00697-00$ & New York Mills Well 1 & Campbell & WHITESTOWN & ONEIDA & 2250 & 43.108 & -75.2866 \\
\hline 31-065-00698-00-00 & $00698-00$ & Ainsworth Oneida Valley 1 & unknown & VERO AN & ONEIDA & 2795 & 43.1552 & -75.7087 \\
\hline $31-065-00700-00-00$ & $00700-00$ & Ft Stanwick Mfg Co & unknown & ROMEN & ONEIDA & 820 & 43.2158 & -75.4464 \\
\hline 31-065-00701-00-00 & $00701-00$ & Murphy Silas & Ontario Syndicate & ROMEN & ONEIDA & 748 & 43.2365 & -75.4336 \\
\hline $31-065-00704-00-00$ & $00704-00$ & Hathaway $\mathrm{H} \mathrm{H}$ & Natural Gas Property & ROMEN & ONEIDA & 895 & 43.2634 & -75.4656 \\
\hline $31-065-00707-00-00$ & $00707-00$ & Brass \& Copper 1 & unknown & ROMEN & ONEIDA & 1598 & 43.2088 & -75.454 \\
\hline $31-065-00709-00-00$ & $00709-00$ & Fee & unknown & ROMEN & ONEIDA & 1005 & 43.2081 & -75.4546 \\
\hline 31-073-00711-00-00 & $00711-00$ & Emilkamp Henry & Clark Clyde et al & CLARE DONN & ORLEANS & 3030 & 43.1662 & -78.0537 \\
\hline $31-075-00712-00-00$ & $00712-00$ & Stillwater Or Phineas 1 & unknown & ORWELLN & OSWEGO & 1789 & 43.5503 & -75.9201 \\
\hline $31-075-00713-00-00$ & $00713-00$ & Rice Central Sq 1 & unknown & HASTI GSN & OSWEGO & 2450 & 43.2983 & -76.1526 \\
\hline $31-075-00714-00-00$ & $00714-00$ & Wilcox 1 & unknown & PARI HS & OSWEGO & 2080 & 43.4082 & -76.003 \\
\hline $31-075-00715-00-00$ & $00715-00$ & Carley 1 & Eastern Oil Co. of Buffalo & PARI HS & OSWEGO & 2157 & 43.3813 & -76.0932 \\
\hline $31-075-00720-00-00$ & $00720-00$ & Mexico Well/Earl 1 & unknown & MEXICON & OSWEGO & 2000 & 43.4636 & -76.2301 \\
\hline 31-075-00725-00-00 & $00725-00$ & & & VOL EYN & OSWEGO & & 0 & 0 \\
\hline $31-075-00726-00-00$ & $00726-00$ & Vanburen Edward 1 & Lewis \& Case & VOL EYN & OSWEGO & 2050 & 43.3676 & -76.4265 \\
\hline
\end{tabular}




\begin{tabular}{|c|c|c|c|c|c|c|c|c|}
\hline UWI (APINum) & Well Label & Well Name & Operator & Township & County & TD & Surf Lat & Surf Lon \\
\hline $31-075-00727-00-00$ & $00727-00$ & Vogelsang 1 & Lewis \& Case & VOL EYN & OSWEGO & 2500 & 43.3152 & -76.3828 \\
\hline $31-075-00728-00-00$ & $00728-00$ & Oswego City Well 0 & unknown & CRIBAS & OSWEGO & 1196 & 43.468 & -76.4955 \\
\hline $31-067-00804-00-00$ & $00804-00$ & Names 1 & Onondaga Gas Co. & LYSA DERN & ONONDAGA & 2547 & 43.153 & -76.3235 \\
\hline $31-067-00805-00-00$ & $00805-00$ & Monroe 1 & Baldwinsville Light \& Heat & LYSA DERN & ONONDAGA & 2420 & 43.1656 & -76.328 \\
\hline $31-067-00807-00-00$ & $00807-00$ & Binning Hickock Farm 1 & Phoenix Gas Co. & LYSA DERN & ONONDAGA & 0 & 43.1764 & -76.3121 \\
\hline $31-067-00808-00-00$ & $00808-00$ & Yost Yenny 1 & Lupner P.W. \& Kline & O ONDAGAN & ONONDAGA & 4690 & 43.0025 & -76.1875 \\
\hline 31-067-00809-00-00 & $00809-00$ & Spaulding 2 & Onondaga Gas Co. & VA BURENN & ONONDAGA & 0 & 43.1274 & -76.3322 \\
\hline $31-067-00810-00-00$ & $00810-00$ & Waffle 1 & Trenton Rock Oil \& Gas & VA BURENN & ONONDAGA & 2860 & 43.155 & -76.3543 \\
\hline $31-049-00824-00-00$ & $00824-00$ & Steinmaker 1 & Tug Hill Natural Gas & HARRI BURGS & LEWIS & 1156 & 43.7837 & -75.6136 \\
\hline $31-049-00825-00-00$ & $00825-00$ & Nefsey P 2 & Tug Hill Natural Gas & HARRI BURGS & LEWIS & 1186 & 43.7909 & -75.5958 \\
\hline $31-049-00826-00-00$ & $00826-00$ & Nefsey 1 & Tug Hill Natural Gas & HARRI BURGS & LEWIS & 886 & 43.7906 & -75.5909 \\
\hline 31-049-00828-00-00 & $00828-00$ & Finn William 1 & Tug Hill Natural Gas & MARTI SBURGN & LEWIS & 1476 & 43.7744 & -75.614 \\
\hline $31-029-00837-00-00$ & $00837-00$ & Bemus Pierce & $\begin{array}{l}\text { National Fuel Gas Supply } \\
\text { Corp. }\end{array}$ & BRA TN & ERIE & 4560 & 42.5737 & -79.0967 \\
\hline $31-029-00839-00-00$ & $00839-00$ & & & BUFFALON & ERIE & & 0 & 0 \\
\hline $31-029-00840-00-00$ & $00840-00$ & City Hospital Grounds 1 & Buffalo City of & BUFFALON & ERIE & 3420 & 42.9277 & -78.8326 \\
\hline $31-045-00844-00-00$ & $00844-00$ & White 1 & White Rufus & ADAMS & JEFFERSON & 921 & 43.8154 & -76.0434 \\
\hline $31-065-00883-00-00$ & $00883-00$ & Grimm William & Utical Natural Gas Drilling & WESTERN & ONEIDA & 900 & 43.2988 & -75.4498 \\
\hline $31-067-00884-00-00$ & $00884-00$ & Sherwood 1 & Empire Portland Cement & CAMILLUS & ONONDAGA & 3600 & 43.0756 & -76.3483 \\
\hline $31-067-00885-00-00$ & $00885-00$ & Warner Plant Well 1 & Empire Portland Cement & CAMILLUS & ONONDAGA & 3600 & 43.0756 & -76.3279 \\
\hline $31-067-00886-00-00$ & $00886-00$ & Monroe E K 1 & $\begin{array}{c}\text { Cunningham Natural Gas } \\
\text { Corp. }\end{array}$ & CAMILLUS & ONONDAGA & 4427 & 43.0189 & -76.3039 \\
\hline $31-067-00887-00-00$ & $00887-00$ & Ashby H 2 & Meridian Gas Co. & ELBRIDGEN & ONONDAGA & 3631 & 43.0729 & -76.4597 \\
\hline 31-067-00888-00-00 & $00888-00$ & Kendall & Onondaga Gas Co. & LYSA DERN & ONONDAGA & 0 & 43.1708 & -76.3213 \\
\hline $31-073-00911-00-00$ & $00911-00$ & Hobby 1 & unknown & MURRAYN & ORLEANS & 0 & 43.2686 & -78.1937 \\
\hline $31-075-00912-00-00$ & $00912-00$ & Parker F 0 & Shannon L.B. & CO STANTIAN & OSWEGO & 2385 & 43.2807 & -76.0038 \\
\hline $31-075-00913-00-00$ & $00913-00$ & Grey Leo 0 & Underwood & GRA BYN & OSWEGO & 2375 & 43.2879 & -76.4656 \\
\hline $31-075-00914-00-00$ & 00914-00 & Sallie Giaccio 0 & $\begin{array}{l}\text { Hungiville Development } \\
\text { Corp. }\end{array}$ & REDFIELDN & OSWEGO & 1810 & 43.4879 & -75.7583 \\
\hline $31-099-00920-00-00$ & $00920-00$ & Bump 2 & Syracuse Alliance Co. & JU IUSN & SENECA & 3930 & 42.98 & -76.9339 \\
\hline 31-029-00988-00-00 & $00988-00$ & Elma Deep Well & Stearns J.W. & ELMAN & ERIE & 3986 & 42.8496 & -78.6392 \\
\hline 31-029-00989-00-00 & $00989-00$ & Depew Deep Well 2 & Iroquois Gas Corp. & LA CASTERN & ERIE & 3685 & 42.9354 & -78.688 \\
\hline $31-011-01003-00-00$ & $01003-00$ & Slayton $\mathrm{H} 2$ & Duchscherer William J. & CO QUESTN & CAYUGA & 3912 & 43.1211 & -76.5935 \\
\hline $31-043-01005-00-00$ & $01005-00$ & Ilion 1 & $\begin{array}{c}\text { Remington Standard } \\
\text { Typewriter }\end{array}$ & GERMA FLATTSN & HERKIMER & 1135 & 43.0153 & -75.0356 \\
\hline $31-075-01008-00-00$ & $01008-00$ & Beckwith Martin 1 & Lovell Tower et al & SA DY CREEKN & OSWEGO & 2335 & 43.4339 & -76.4653 \\
\hline $31-117-01009-00-00$ & $01009-00$ & Wolcott Well & unknown & WOLCOTTN & WAYNE & 2700 & 43.2228 & -76.8134 \\
\hline 31-067-01010-00-00 & $01010-00$ & Empire Port Cement Co 2 & Empire Portland Cement & VA BURENN & ONONDAGA & 3526 & 43.0884 & -76.3476 \\
\hline $31-073-01013-00-00$ & $01013-00$ & Holley Dr Allen & Stearns J.W. & MURRAYN & ORLEANS & 2025 & 43.2785 & -78.009 \\
\hline $31-013-01017-00-00$ & $01017-00$ & Thomas & Frost Gas & DU KIRK CITYN & CHAUTAUQUA & 4035 & 42.4816 & -79.3088 \\
\hline $31-029-01018-00-00$ & $01018-00$ & Fee 11 & Linde Air Products & TO AWANDAN & \begin{tabular}{|c|} 
ERIE \\
\end{tabular} & 3275 & 42.9738 & -78.8907 \\
\hline $31-029-01019-00-00$ & $01019-00$ & Button George & Reservation Gas & COLLI SN & ERIE & 4602 & 42.5462 & -78.9959 \\
\hline
\end{tabular}




\begin{tabular}{|c|c|c|c|c|c|c|c|c|}
\hline UWI (APINum) & Well Label & Well Name & Operator & Township & County & TD & Surf Lat & Surf Lon \\
\hline $31-029-01020-00-00$ & $01020-00$ & Well In South Park & Buffalo City of & BUFFALON & ERIE & 3288 & 42.8366 & -78.8023 \\
\hline $31-065-01027-00-00$ & $01027-00$ & Rome Brass \& Copper 2 & Rome Brass \& Copper & ROMEN & ONEIDA & 1632 & 43.2067 & -75.4478 \\
\hline $31-065-01028-00-00$ & $01028-00$ & Dean-Garry (Vernon Well) & unknown & VER ONN & ONEIDA & 1968 & 43.0809 & -75.5392 \\
\hline 31-065-01029-00-00 & $01029-00$ & Dodge Or Verona Well & unknown & VERO AN & ONEIDA & 0 & 43.1364 & -75.5632 \\
\hline $31-065-01033-00-00$ & $01033-00$ & Morgan E D 1 & unknown & TRE TONN & ONEIDA & 1000 & 43.2058 & -75.1976 \\
\hline $31-045-01034-00-00$ & $01034-00$ & Unnamed & Black River Gas \& Fuel & WATERTOWN & JEFFERSON & 530 & 43.9781 & -75.9011 \\
\hline 31-073-01047-00-00 & $01047-00$ & Lyman/Eagle Harbor & unknown & ALBION & ORLEANS & 2300 & 43.2445 & -78.2575 \\
\hline 31-001-01071-00-00 & $01071-00$ & & & GUILDERLA DN & \begin{tabular}{|l|} 
ALBANY \\
\end{tabular} & & 0 & 0 \\
\hline $31-013-01157-00-00$ & $01157-00$ & Schafer \#1102 & Heintz Gas \& Oil Co. Inc. & SHERIDAN & CHAUTAUQUA & 0 & 42.51 & -79.2749 \\
\hline $31-017-01160-00-00$ & $01160-00$ & Lobdell 1 & Bradley Producing Corp. & COLUMBUS & CHENANGO & 5701 & 42.6933 & -75.3451 \\
\hline $31-049-01168-00-00$ & $01168-00$ & Aikens G & Cabot G.L. & LEWIS & LEWIS & 1641 & 43.4339 & -75.5907 \\
\hline 31-049-01169-00-00 & $01169-00$ & Goutremont & Tug Hill Natural Gas & HARRI BURGS & LEWIS & 1276 & 43.7894 & -75.615 \\
\hline $31-049-01170-00-00$ & $01170-00$ & Berrus 1 & Tug Hill Natural Gas & HARRI BURGS & LEWIS & 1170 & 43.7855 & -75.6053 \\
\hline 31-053-01173-00-00 & $01173-00$ & Letts 1 & New York Natural Gas Co. & BROOKFIELDN & MADISON & 4170 & 42.8611 & -75.4025 \\
\hline $31-065-01176-00-00$ & $01176-00$ & Roberts M & Cabot G.L. & CAMDEN & ONEIDA & 1933 & 43.3712 & -75.7982 \\
\hline $31-065-01179-00-00$ & $01179-00$ & Comins Laura & Cabot G.L. & FLORE CEN & ONEIDA & 1745 & 43.404 & -75.7737 \\
\hline $31-065-01180-00-00$ & $01180-00$ & Williams E 2 & Property Shares Inc. & FLORE CEN & ONEIDA & 1595 & 43.3845 & -75.7379 \\
\hline $31-065-01181-00-00$ & $01181-00$ & Ringdahl Ivar 1 & Property Shares Inc. & ROMEN & ONEIDA & 900 & 43.2274 & -75.4368 \\
\hline $31-065-01182-00-00$ & $01182-00$ & Ringdahl Ivar 2 & Property Shares Inc. & ROMEN & ONEIDA & 705 & 43.2272 & -75.4339 \\
\hline 31-065-01183-00-00 & $01183-00$ & Ringdahl Ivar 3 & Boyce et al & ROMEN & ONEIDA & 717 & 43.2303 & -75.437 \\
\hline 31-065-01184-00-00 & $01184-00$ & Ringdahl Ivan 4 & Property Shares Inc. & ROMEN & ONEIDA & 760 & 43.2294 & -75.4336 \\
\hline $31-065-01185-00-00$ & $01185-00$ & Youskiewies & Seaton J. & ROMEN & ONEIDA & 1536 & 43.2291 & -75.5143 \\
\hline $31-065-01186-00-00$ & $01186-00$ & Hooper C \& Jones & Property Shares Inc. & ROMEN & ONEIDA & 737 & 43.2407 & -75.4343 \\
\hline 31-065-01188-00-00 & $01188-00$ & Mierek Anton & Utical Natural Gas Drilling & WESTERN & ONEIDA & 746 & 43.3374 & -75.3416 \\
\hline $31-065-01190-00-00$ & $01190-00$ & Skinner R 1 & Property Shares Inc. & WESTMORELA DN & ONEIDA & 1683 & 43.1187 & -75.4798 \\
\hline 31-011-01301-00-00 & $01301-00$ & Old Auburn 1 & Stearns J.W. & THROOPN & CAYUGA & 3600 & 42.9568 & -76.5792 \\
\hline 31-013-01464-00-00 & $01464-00$ & Niehause J.M \#2(Lincoln) & Heintz Gas \& Oil Co. Inc. & SHERIDAN & CHAUTAUQUA & 4517 & 42.5132 & -79.2741 \\
\hline $31-029-01690-00-00$ & $01690-00$ & More E\#1 & Pan Energy Company Inc. & ELMAN & \begin{tabular}{|c|} 
ERIE \\
\end{tabular} & 3100 & 42.8174 & -78.6779 \\
\hline $31-013-01808-00-00$ & $01808-00$ & Niehaus Joseph M 2 & Heintz Gas \& Oil Co. Inc. & SHERIDAN & CHAUTAUQUA & 4510 & 42.5157 & -79.2738 \\
\hline $31-117-01870-00-00$ & $01870-00$ & Welch John 2 & Hadley \& Rogers & GALEN & WAYNE & 2770 & 43.0888 & -76.8566 \\
\hline $31-117-01871-00-00$ & $01871-00$ & Arnold Ethel & Boyce et al & GALEN & WAYNE & 3000 & 43.105 & -76.8344 \\
\hline $31-117-01872-00-00$ & $01872-00$ & Harper R 1 & Boyce et al & GALEN & WAYNE & 3400 & 43.0842 & -76.8569 \\
\hline $31-117-01873-00-00$ & $01873-00$ & Harper R 2 & Boyce et al & GALEN & WAYNE & 2885 & 43.0836 & -76.8592 \\
\hline $31-117-01874-00-00$ & $01874-00$ & Welch J O 1 & Hadley \& Rogers & GALEN & WAYNE & 2740 & 43.0883 & -76.8532 \\
\hline $31-067-01876-00-00$ & $01876-00$ & Bigelow Well 1 & unknown & LYSA DERN & ONONDAGA & 2795 & 43.1759 & -76.3311 \\
\hline $31-067-01877-00-00$ & $01877-00$ & Talmadge & unknown & VA BURENN & ONONDAGA & 0 & 43.14 & -76.3367 \\
\hline $31-117-02287-00-00$ & $02287-00$ & Harper R 3 & Boyce et al & GALEN & WAYNE & 2770 & 43.0869 & -76.8577 \\
\hline $31-045-02289-00-00$ & $02289-00$ & Dexter Village Water 9 & Village of Dexter & BROW VILLEN & JEFFERSON & 701 & 44.0119 & -76.042 \\
\hline $31-067-02366-00-00$ & $02366-00$ & Ashby Harvey 1 & Meridian Gas Co. & ELBRIDGEN & ONONDAGA & 3631 & 43.0721 & -76.4661 \\
\hline $31-067-02403-00-00$ & $02403-00$ & & & & Onondaga & & 43.1963 & -76.3161 \\
\hline $31-067-02404-00-00$ & $02404-00$ & & & & & & 43.2091 & -76.2977 \\
\hline $31-075-02426-00-00$ & $02426-00$ & Baldwin 1 & Lupher & VOL EYN & OSWEGO & 0 & 43.358 & -76.3388 \\
\hline
\end{tabular}




\begin{tabular}{|c|c|c|c|c|c|c|c|c|}
\hline UWI (APINum) & Well Label & Well Name & Operator & Township & County & TD & Surf Lat & Surf Lon \\
\hline $31-075-02432-00-00$ & $02432-00$ & Briggs E 0 & unknown & VOL EYN & OSWEGO & 0 & 43.4014 & -76.4687 \\
\hline $31-075-02433-00-00$ & $02433-00$ & Sanford & Sandy Creek Oil \& Gas & SA DY CREEKN & OSWEGO & 1240 & 43.6459 & -76.0894 \\
\hline $31-075-02446-00-00$ & $02446-00$ & Snyder Ralph Sutton 0 & Sandy Creek Oil \& Gas & SA DY CREEKN & OSWEGO & 900 & 43.6265 & -76.0697 \\
\hline $31-075-02448-00-00$ & $02448-00$ & Nye 0 & Sandy Creek Oil \& Gas & SA DY CREEKN & OSWEGO & 1000 & 43.6311 & -76.0602 \\
\hline $31-075-02449-00-00$ & $02449-00$ & Tuttle Irving Loundb 2 & Sandy Creek Oil \& Gas & SA DY CREEKN & OSWEGO & 0 & 43.6362 & -76.0588 \\
\hline 31-075-02456-00-00 & $02456-00$ & None Specified & Sandy Creek Oil \& Gas & SA DY CREEKN & OSWEGO & 0 & 43.6567 & -76.031 \\
\hline $31-075-02457-00-00$ & $02457-00$ & Grey 0 & Sandy Creek Oil \& Gas & SA DY CREEKN & OSWEGO & 0 & 43.6656 & -76.0321 \\
\hline $31-075-02459-00-00$ & $02459-00$ & Hilton 0 & Sandy Creek Oil \& Gas & SA DY CREEKN & OSWEGO & 0 & 43.6307 & -76.1389 \\
\hline $31-075-02460-00-00$ & $02460-00$ & Woodard 1 & Sandy Creek Oil \& Gas & SA DY CREEKN & OSWEGO & 0 & 43.628 & -76.1327 \\
\hline $31-075-02461-00-00$ & $02461-00$ & Woodard 2 & Sandy Creek Oil \& Gas & SA DY CREEKN & OSWEGO & 0 & 43.6251 & -76.134 \\
\hline $31-075-02463-00-00$ & $02463-00$ & Beldrock 0 & Sandy Creek Oil \& Gas & SA DY CREEKN & OSWEGO & 0 & 43.6343 & -76.0839 \\
\hline $31-075-02489-00-00$ & $02489-00$ & Hollis H Robbins 9 & Sandy Creek Oil \& Gas & SA DY CREEKN & OSWEGO & 0 & 43.653 & -76.0525 \\
\hline $31-075-02494-00-00$ & $02494-00$ & Deshane Baldwin S N 0 & Sandy Creek Oil \& Gas & SA DY CREEKN & OSWEGO & 0 & 43.6604 & -76.0412 \\
\hline $31-075-02495-00-00$ & $02495-00$ & Tollner 1 & Pulaski Gas \& Oil & RICHLA DN & OSWEGO & 1400 & 43.567 & -76.1336 \\
\hline $31-075-02496-00-00$ & $02496-00$ & Tollner 2 & Pulaski Gas \& Oil & RICHLA DN & OSWEGO & 1050 & 43.5685 & -76.122 \\
\hline $31-075-02497-00-00$ & $02497-00$ & Tollner 3 & Pulaski Gas \& Oil & RICHLA DN & OSWEGO & 1175 & 43.5746 & -76.1285 \\
\hline $31-075-02498-00-00$ & $02498-00$ & Betts 2/ Tollner 4 & Pulaski Gas \& Oil & RICHLA DN & OSWEGO & 650 & 43.5725 & -76.1376 \\
\hline $31-075-02499-00-00$ & $02499-00$ & Betts 3 & Pulaski Gas \& Oil & RICHLA DN & OSWEGO & 1200 & 43.5588 & -76.1283 \\
\hline $31-075-02500-00-00$ & $02500-00$ & Tylor 0 & Pulaski Gas \& Oil & RICHLA DN & OSWEGO & 1000 & 43.5822 & -76.1298 \\
\hline $31-075-02501-00-00$ & $02501-00$ & Maltby 0 & Pulaski Gas \& Oil & RICHLA DN & OSWEGO & 1150 & 43.592 & -76.1304 \\
\hline $31-075-02502-00-00$ & $02502-00$ & Heard 8 & Pulaski Gas \& Oil & SA DY CREEKN & OSWEGO & 1200 & 43.6034 & -76.1302 \\
\hline $31-075-02503-00-00$ & $02503-00$ & Clark 0 & Pulaski Gas \& Oil & RICHLA DN & OSWEGO & 1100 & 43.5774 & -76.1211 \\
\hline $31-075-02504-00-00$ & $02504-00$ & Twitchell 0 & Pulaski Gas \& Oil & RICHLA DN & OSWEGO & 1050 & 43.5883 & -76.147 \\
\hline $31-075-02505-00-00$ & $02505-00$ & Lightall Wayne 0 & Pulaski Gas \& Oil & RICHLA DN & OSWEGO & 1000 & 43.5733 & -76.151 \\
\hline $31-075-02506-00-00$ & $02506-00$ & Tollner 0 & Pulaski Gas \& Oil & RICHLA DN & OSWEGO & 1425 & 43.5824 & -76.1166 \\
\hline $31-075-02507-00-00$ & $02507-00$ & Bamburg James 0 & Pulaski Gas \& Oil & RICHLA DN & OSWEGO & 1000 & 43.5695 & -76.1576 \\
\hline $31-075-02508-00-00$ & $02508-00$ & Betts 4 & Pulaski Gas \& Oil & RICHLA DN & OSWEGO & 1200 & 43.5703 & -76.1332 \\
\hline $31-075-02509-00-00$ & $02509-00$ & Smith 0 & Pulaski Gas \& Oil & RICHLA DN & OSWEGO & 1100 & 43.5725 & -76.1434 \\
\hline $31-075-02510-00-00$ & $02510-00$ & Corbett 2 & Pulaski Gas \& Oil & RICHLA DN & OSWEGO & 1175 & 43.577 & -76.1574 \\
\hline $31-075-02511-00-00$ & $02511-00$ & Crocket Howard Stew 0 & Pulaski Gas \& Oil & RICHLA DN & OSWEGO & 1200 & 43.5759 & -76.1665 \\
\hline $31-075-02512-00-00$ & $02512-00$ & Brown 0 & Pulaski Gas \& Oil & RICHLA DN & OSWEGO & 1175 & 43.5754 & -76.177 \\
\hline 31-075-02513-00-00 & $02513-00$ & Hilliker 0 & Pulaski Gas \& Oil & RICHLA DN & OSWEGO & 1150 & 43.5729 & -76.1859 \\
\hline $31-075-02514-00-00$ & $02514-00$ & Nelson 0 & Pulaski Gas \& Oil & RICHLA DN & OSWEGO & 1325 & 43.574 & -76.199 \\
\hline $31-075-02515-00-00$ & $02515-00$ & Gollner 3 & Pulaski Gas \& Oil & RICHLA DN & OSWEGO & 1075 & 43.5695 & -76.1175 \\
\hline $31-075-02516-00-00$ & $02516-00$ & Stewart 2 & Pulaski Gas \& Oil & RICHLA DN & OSWEGO & 780 & 43.5847 & -76.1625 \\
\hline $31-075-02517-00-00$ & $02517-00$ & Stewart 3 & Pulaski Gas \& Oil & RICHLA DN & OSWEGO & 1036 & 43.5702 & -76.1655 \\
\hline $31-075-02518-00-00$ & $02518-00$ & Goodwin S Nelson 0 & Pulaski Gas \& Oil & RICHLA DN & OSWEGO & 1150 & 43.5748 & -76.1935 \\
\hline $31-075-02519-00-00$ & $02519-00$ & Gollner 0 & Pulaski Gas \& Oil & RICHLA DN & OSWEGO & 1140 & 43.5953 & -76.181 \\
\hline $31-075-02520-00-00$ & $02520-00$ & Brown 0 & Pulaski Gas \& Oil & RICHLA DN & OSWEGO & 1075 & 43.5732 & -76.2016 \\
\hline $31-075-02522-00-00$ & $02522-00$ & Russell 0 & Pulaski Gas \& Oil & RICHLA DN & OSWEGO & 1080 & 43.5666 & -76.1895 \\
\hline $31-075-02523-00-00$ & $02523-00$ & Phillips Wallace 0 & Pulaski Gas \& Oil & RICHLA DN & OSWEGO & 890 & 43.5634 & -76.1929 \\
\hline $31-075-02524-00-00$ & $02524-00$ & Letts Fred Price 0 & Central Region & RICHLA DN & OSWEGO & 1150 & 43.5602 & -76.1822 \\
\hline
\end{tabular}




\begin{tabular}{|c|c|c|c|c|c|c|c|c|}
\hline UWI (APINum) & Well Label & Well Name & Operator & Township & County & TD & Surf Lat & Surf Lon \\
\hline $31-075-02525-00-00$ & $02525-00$ & Gollner 0 & Pulaski Gas \& Oil & RICHLA DN & OSWEGO & 1170 & 43.568 & -76.1251 \\
\hline $31-075-02526-00-00$ & $02526-00$ & Banburg 4 & Pulaski Gas \& Oil & RICHLA DN & OSWEGO & 1140 & 43.5857 & -76.1776 \\
\hline $31-075-02527-00-00$ & $02527-00$ & Anderson 0 & Pulaski Gas \& Oil & RICHLA DN & OSWEGO & 1053 & 43.5902 & -76.1703 \\
\hline $31-075-02528-00-00$ & $02528-00$ & Carr 0 & Pulaski Gas \& Oil & RICHLA DN & OSWEGO & 1090 & 43.5932 & -76.1788 \\
\hline $31-075-02529-00-00$ & $02529-00$ & Robinson 0 & Pulaski Gas \& Oil & RICHLA DN & OSWEGO & 1055 & 43.5975 & -76.1599 \\
\hline $31-075-02530-00-00$ & $02530-00$ & Robinson 0 & Pulaski Gas \& Oil & RICHLA DN & OSWEGO & 1060 & 43.6017 & -76.1685 \\
\hline 31-075-02531-00-00 & $02531-00$ & Mitchell 0 & Pulaski Gas \& Oil & RICHLA DN & OSWEGO & 1065 & 43.5603 & -76.1512 \\
\hline $31-075-02532-00-00$ & $02532-00$ & Barclay Hugh Moody 0 & Pulaski Gas \& Oil & RICHLA DN & OSWEGO & 1150 & 43.5619 & -76.1597 \\
\hline $31-075-02533-00-00$ & $02533-00$ & Barclay Hugh Eddy 0 & Pulaski Gas \& Oil & RICHLA DN & OSWEGO & 1125 & 43.5718 & -76.1791 \\
\hline $31-075-02534-00-00$ & $02534-00$ & Barclay H Jamerson40 & Pulaski Gas \& Oil & RICHLA DN & OSWEGO & 1205 & 43.5559 & -76.1459 \\
\hline $31-075-02535-00-00$ & $02535-00$ & Austin 0 & Pulaski Gas \& Oil & RICHLA DN & OSWEGO & 1180 & 43.5596 & -76.1718 \\
\hline $31-075-02536-00-00$ & $02536-00$ & Stewart 0 & Pulaski Gas \& Oil & RICHLA DN & OSWEGO & 1328 & 43.5457 & -76.1274 \\
\hline $31-075-02537-00-00$ & $02537-00$ & Loomis Mrs J B 1 & Pulaski Gas \& Oil & RICHLA DN & OSWEGO & 1240 & 43.5511 & -76.1487 \\
\hline $31-075-02538-00-00$ & $02538-00$ & Richardson D R Hiltn 0 & Pulaski Gas \& Oil & RICHLA DN & OSWEGO & 895 & 43.5544 & -76.1608 \\
\hline 31-075-02539-00-00 & $02539-00$ & Loomis Mrs J B 2 & Pulaski Gas \& Oil & RICHLA DN & OSWEGO & 1238 & 43.549 & -76.1427 \\
\hline $31-075-02540-00-00$ & $02540-00$ & NY Defense Reloc Corp & Pulaski Gas \& Oil & RICHLA DN & OSWEGO & 908 & 43.5406 & -76.1524 \\
\hline $31-075-02541-00-00$ & $02541-00$ & Decater & Pulaski Gas \& Oil & RICHLA DN & OSWEGO & 1230 & 43.5426 & -76.158 \\
\hline $31-075-02542-00-00$ & $02542-00$ & Jamison 0 & Pulaski Gas \& Oil & RICHLA DN & OSWEGO & 1206 & 43.5422 & -76.1629 \\
\hline $31-075-02543-00-00$ & $02543-00$ & Robert Cates 0 & Pulaski Gas \& Oil & RICHLA DN & OSWEGO & 1225 & 43.5508 & -76.1827 \\
\hline $31-075-02544-00-00$ & $02544-00$ & Davis/Perry & Central Region & RICHLA DN & OSWEGO & 1175 & 43.5515 & -76.1946 \\
\hline 31-075-02545-00-00 & $02545-00$ & Manwaring/Givens 51 & Central Region & RICHLA DN & OSWEGO & 1232 & 43.5538 & -76.2046 \\
\hline $31-075-02546-00-00$ & $02546-00$ & Stewart/Mitchell 52 & Central Region & RICHLA DN & OSWEGO & 1165 & 43.5625 & -76.2029 \\
\hline $31-075-02547-00-00$ & $02547-00$ & Hardie 0 & Pulaski Gas \& Oil & RICHLA DN & OSWEGO & 1250 & 43.5453 & -76.1921 \\
\hline $31-075-02548-00-00$ & $02548-00$ & Cole 0 & Pulaski Gas \& Oil & RICHLA DN & OSWEGO & 1250 & 43.5374 & -76.1959 \\
\hline $31-075-02549-00-00$ & $02549-00$ & Patrick Charles D 0 & Pulaski Gas \& Oil & RICHLA DN & OSWEGO & 1218 & 43.5438 & -76.2003 \\
\hline $31-075-02550-00-00$ & $02550-00$ & Calkens 2 & Pulaski Gas \& Oil & RICHLA DN & OSWEGO & 1251 & 43.5448 & -76.2163 \\
\hline 31-075-02554-00-00 & $02554-00$ & Cates Rob Gallagher 0 & Pulaski Gas \& Oil & RICHLA DN & OSWEGO & 1225 & 43.5541 & -76.1776 \\
\hline $31-075-02555-00-00$ & $02555-00$ & Barclay Hugh Sanders 0 & Pulaski Gas \& Oil & RICHLA DN & OSWEGO & 1200 & 43.5547 & -76.172 \\
\hline $31-075-02556-00-00$ & $02556-00$ & Sanders 0 & Pulaski Gas \& Oil & RICHLA DN & OSWEGO & 900 & 43.564 & -76.1465 \\
\hline 31-075-02557-00-00 & $02557-00$ & Calkins 0 & Pulaski Gas \& Oil & RICHLA DN & OSWEGO & 1210 & 43.5377 & -76.1869 \\
\hline 31-075-02558-00-00 & $02558-00$ & Loomis Mrs J B 3 & Pulaski Gas \& Oil & RICHLA DN & OSWEGO & 1240 & 43.5542 & -76.1402 \\
\hline $31-075-02559-00-00$ & $02559-00$ & Letts Fred 0 & Central Region & RICHLA DN & OSWEGO & 1236 & 43.5551 & -76.1835 \\
\hline $31-075-02560-00-00$ & $02560-00$ & Letts 0 & Central Region & RICHLA DN & OSWEGO & 1238 & 43.556 & -76.194 \\
\hline $31-075-02561-00-00$ & $02561-00$ & Baird Curtis Hawlett 1 & Pulaski Gas \& Oil & RICHLA DN & OSWEGO & 1205 & 43.5526 & -76.1553 \\
\hline $31-075-02562-00-00$ & $02562-00$ & Davis 0 & Pulaski Gas \& Oil & RICHLA DN & OSWEGO & 0 & 43.551 & -76.1899 \\
\hline $31-075-02563-00-00$ & $02563-00$ & Baird C K 0 & Pulaski Gas \& Oil & RICHLA DN & OSWEGO & 1255 & 43.5467 & -76.1565 \\
\hline $31-045-02671-00-00$ & $02671-00$ & Smith Dr H L & Springstein & WATERTOWN & JEFFERSON & 870 & 43.9675 & -75.9357 \\
\hline 31-029-02959-00-00 & $02959-00$ & Union Garage 1 & Livingston Mrs (Ira) & CHEEKTOWAGAN & ERIE & 3660 & 42.8848 & -78.756 \\
\hline $31-013-03200-00-00$ & $03200-00$ & Morse Kyle \#1 & Universal Delta Drilling & HARMO YN & CHAUTAUQUA & 7100 & 42.0682 & -79.4156 \\
\hline $31-065-03304-00-00$ & $03304-00$ & Randall 1 & Crandall Oil Company & TRE TONN & ONEIDA & 330 & 43.3029 & -75.2067 \\
\hline 31-009-03868-00-00 & $03868-00$ & Ellis I-1710 & $\begin{array}{c}\text { National Fuel Gas Supply } \\
\text { Corp. }\end{array}$ & PERRY BURGS & FATTARAUGUS & 3925 & 42.4551 & -79.0399 \\
\hline
\end{tabular}




\begin{tabular}{|c|c|c|c|c|c|c|c|c|}
\hline UWI (APINum) & Well Label & Well Name & Operator & Township & County & TD & Surf Lat & Surf Lon \\
\hline $31-055-03879-00-00$ & $03879-00$ & Fee 0 & Sargent \& Greenleaf & IRO DEQUOITN & MONROE & 3362 & 43.1875 & -77.6085 \\
\hline $31-039-03904-00-00$ & $03904-00$ & Maurice Gans 1 & United Productions & WI DHAMN & GREENE & 7185 & 42.3335 & -74.2307 \\
\hline 31-029-03917-00-00 & 03917-00 & Weinheimer J F Fee 22 & $\begin{array}{l}\text { Weinheimer Plumbing } \\
\text { Supply }\end{array}$ & TO AWANDAN & ERIE & 3168 & 43.0044 & -78.8246 \\
\hline 31-101-03924-00-00 & 03924-00 & Olin [n650s] & Dominion Transmission Inc. & WOODHULLN & STEUBEN & 13500 & 42.063 & -77.4307 \\
\hline $31-065-03928-00-00$ & $03928-00$ & Homer A Keith 1 & Keith Homer A. & SA GERFIELDN & ONEIDA & 4366 & 42.868 & -75.4266 \\
\hline 31-009-03934-00-00 & 03934-00 & Conger I-1748 & $\begin{array}{l}\text { National Fuel Gas Supply } \\
\text { Corp. }\end{array}$ & PERRY BURGS & EATTARAUGUS & 5807 & 42.4598 & -79.0391 \\
\hline 31-003-03956-00-00 & 03956-00 & Cook G M 2 & Parsons Bros & HUMEN & ALLEGANY & 7337 & 42.453 & -78.1743 \\
\hline 31-053-03970-00-00 & $03970-00$ & Branangan Donald 1 & New York Natural Gas Co. & LEBA ONN & MADISON & 5703 & 42.8048 & -75.6505 \\
\hline 31-109-03973-00-00 & $03973-00$ & Shepard 1 & CNG Transmission Corp. & DA BYN & TOMPKINS & 10438 & 42.3702 & -76.5063 \\
\hline 31-043-03993-00-00 & 03993-00 & Skranko 1 & New York Natural Gas Co. & WARREN & HERKIMER & 3581 & 42.8807 & -74.9168 \\
\hline $31-109-04007-00-00$ & $04007-00$ & Smiley Jean H 1 & NYS Natural Gas Corp. & DA BYN & TOMPKINS & 8555 & 42.3654 & -76.5033 \\
\hline $31-053-04032-00-00$ & $04032-00$ & Danisevich J 1 & New York Natural Gas Co. & BROOKFIELDN & MADISON & 4889 & 42.7963 & -75.4046 \\
\hline $31-043-04034-00-00$ & $04034-00$ & Puskarenko 1 & Devonian Oil \& Gas & TARKS & HERKIMER & 2717 & 42.9093 & -74.8352 \\
\hline $31-077-04055-00-00$ & $04055-00$ & Lum Paul B et al 1 & NYS Natural Gas Corp. & WORCE TERS & OTSEGO & 5511 & 42.6309 & -74.7082 \\
\hline 31-051-04069-00-00 & $04069-00$ & Mc Donald & New York Natural Gas Co. & YORKN & LIVINGSTON & 5090 & 42.8716 & -77.9321 \\
\hline $31-121-04092-00-00$ & 04092-00 & Veith D 1 & NYS Natural Gas Corp. & GAI ESVILLEN & WYOMING & 7182 & 42.6173 & -78.0802 \\
\hline $31-109-04130-00-00$ & $04130-00$ & Grund GH & NYS Natural Gas Corp. & E FIELDN & TOMPKINS & 8900 & 42.4421 & -76.5928 \\
\hline 31-121-04133-00-00 & 04133-00 & Strathern Bros 1 & $\begin{array}{l}\text { Transamerican Petroleum } \\
\text { Corp. }\end{array}$ & MIDDLEBURYN & WYOMING & 5386 & 42.8306 & -78.1169 \\
\hline $31-049-04150-00-00$ & $04150-00$ & Gould Paper Co & Humble Oil \& Refining Co. & HIGHMARKETN & LEWIS & 1789 & 43.6066 & -75.5992 \\
\hline 31-013-04154-00-00 & $04154-00$ & Shadle S 1 & Humble Oil \& Refining Co. & CHERRY CREEKN & CHAUTAUQUA & 6281 & 42.342 & -79.1319 \\
\hline $31-029-04183-00-00$ & $04183-00$ & Fee & Concrete Delivery & LACKAWA NAN & \begin{tabular}{|c|} 
ERIE \\
\end{tabular} & 3703 & 42.8291 & -78.8497 \\
\hline $31-075-04201-00-00$ & $04201-00$ & Fee 1 & unknown & SA DY CREEKN & OSWEGO & 1393 & 43.6394 & -76.1087 \\
\hline $31-099-04203-00-00$ & $04203-00$ & Schaffer \#2 & United Productions & FAYETTEN & SENECA & 1921 & 42.8762 & -76.8585 \\
\hline $31-075-04208-00-00$ & $04208-00$ & House Edson & Humble Oil \& Refining Co. & HASTI GSN & OSWEGO & 2240 & 43.3262 & -76.1033 \\
\hline $31-075-04209-00-00$ & $04209-00$ & Heaphy & Humble Oil \& Refining Co. & PALERMON & OSWEGO & 2592 & 43.3188 & -76.3476 \\
\hline 31-025-04214-00-00 & $04214-00$ & Campbell $\mathrm{H} \mathrm{A}$ and M W 1 & Gulf Oil Corp. & HAMDEN & DELAWARE & 10992 & 42.1828 & -74.9218 \\
\hline $31-003-04248-00-00$ & $04248-00$ & Wolfer Duane A 1 & NYS Natural Gas Corp. & HUMEN & ALLEGANY & 7560 & 42.4704 & -78.1602 \\
\hline $31-075-04357-00-00$ & $04357-00$ & Kellog & Humble Oil \& Refining Co. & WILLIAMSTOWN & OSWEGO & 1697 & 43.4438 & -75.8769 \\
\hline $31-075-04358-00-00$ & $04358-00$ & Degraff 1 & Davey - Joans & WILLIAMSTOWN & OSWEGO & 1780 & 43.4537 & -75.9196 \\
\hline $31-025-04364-00-00$ & $04364-00$ & Fowler Finch 1 & Gulf Oil Corp. & SID EYN & DELAWARE & 7973 & 42.3168 & -75.2341 \\
\hline $31-025-04379-00-00$ & $04379-00$ & Lanzilotta 1 & Gulf Oil Corp. & ROXBURYN & DELAWARE & 9075 & 42.2735 & -74.6277 \\
\hline $31-121-04392-00-00$ & $04392-00$ & Werner Frank C 1 & NYS Natural Gas Co. & ORA GEVILLEN & WYOMING & 5722 & 42.7477 & -78.1978 \\
\hline 31-121-04436-00-00 & 04436-00 & Wellman L 1 & $\begin{array}{l}\text { Transamerican Petroleum } \\
\text { Corp. }\end{array}$ & MIDDLEBURYN & WYOMING & 5616 & 42.8182 & -78.1386 \\
\hline $31-013-04437-00-00$ & $04437-00$ & Harrington 1 & Pennzoil Products Co. & ELLERYN & CHAUTAUQUA & 7694 & 42.1836 & -79.3378 \\
\hline 31-029-04440-00-00 & 04440-00 & Lascala 1244 (IGC 2075) & Belden \& Blake Corporation & SARDI IAN & ERIE & 5913 & 42.5558 & -78.5063 \\
\hline
\end{tabular}




\begin{tabular}{|c|c|c|c|c|c|c|c|c|}
\hline UWI (APINum) & Well Label & Well Name & Operator & Township & County & TD & Surf Lat & Surf Lon \\
\hline 31-121-04447-00-00 & $04447-00$ & Warren 1 & $\begin{array}{c}\text { Transamerican Petroleum } \\
\text { Corp. }\end{array}$ & MIDDLEBURYN & WYOMING & 5820 & 42.8026 & -78.1501 \\
\hline $31-025-04455-00-00$ & $04455-00$ & C E Leslie Caroline E 1 & \begin{tabular}{|c|} 
Gulf Oil Corp. \\
\end{tabular} & FRA KLINN & DELAWARE & 7952 & 42.3904 & -75.0445 \\
\hline 31-013-04460-00-00 & $04460-00$ & Sommers Tuttle 1 & $\begin{array}{c}\text { Appalachian Basin Oil \& Gas } \\
\text { Inc. }\end{array}$ & SHERIDAN & CHAUTAUQUA & 4460 & 42.5211 & -79.2623 \\
\hline 31-121-04464-00-00 & 04464-00 & Cox George 1 & \begin{tabular}{|c|} 
Transamerican Petroleum \\
Corp.
\end{tabular} & MIDDLEBURYN & WYOMING & 5620 & 42.8383 & -78.0967 \\
\hline 31-109-04467-00-00 & 04467-00 & Fee Richarson 1 & NYS Natural Gas Corp. & EWFIELDN & TOMPKINS & 9390 & 42.3844 & -76.5407 \\
\hline $31-073-04476-00-00$ & $04476-00$ & Brakenbury 1 & Weaver Exploration & CARLTON & ORLEANS & 2234 & 43.3235 & -78.2054 \\
\hline $31-073-04489-00-00$ & $04489-00$ & Foss Harold 1 & Weaver Exploration & YATES & ORLEANS & 2057 & 43.3491 & -78.3788 \\
\hline $31-055-04502-00-00$ & $04502-00$ & Hazen 1 & Colonial Oil \& Gas Corp. & HAMLIN & MONROE & 2187 & 43.331 & -77.9651 \\
\hline $31-075-04520-00-00$ & $04520-00$ & Nicholson & \begin{tabular}{|c|} 
Scully Leon \\
\end{tabular} & RICHLA DN & OSWEGO & 1531 & 43.522 & -76.1738 \\
\hline 31-013-04535-00-00 & $04535-00$ & Martin Alvin 1 & \begin{tabular}{|c|}
$\begin{array}{c}\text { Appalachian Basin Oil \& Gas } \\
\text { Inc. }\end{array}$ \\
\end{tabular} & SHERIDAN & CHAUTAUQUA & 4024 & 42.5114 & -79.2632 \\
\hline 31-121-04536-00-00 & 04536-00 & Page Henry 1 & $\begin{array}{c}\text { Transamerican Petroleum } \\
\text { Corp. }\end{array}$ & MIDDLEBURYN & WYOMING & 6233 & 42.8267 & -78.1384 \\
\hline $31-077-04547-00-00$ & 04547-00 & Burkard Ludwig et al 1 & NYS Natural Gas Co. & MARYLA DN & OTSEGO & 5118 & 42.5305 & -74.8834 \\
\hline 31-051-04552-00-00 & $04552-00$ & McClurg 1 & New York Natural Gas Co. & YORKN & LIVINGSTON & 5648 & 42.8353 & -77.937 \\
\hline 31-013-04561-00-00 & 04561-00 & Gage C T 1 & Belden \& Blake Corporation & ELLERYN & CHAUTAUQUA & 6292 & 42.24 & -79.4142 \\
\hline $31-051-04567-00-00$ & $04567-00$ & Johnson 1 & Stein Paul E. \& Sons & CALEDO IAN & LIVINGSTON & 4839 & 42.9323 & -77.8841 \\
\hline $31-037-04593-00-00$ & $04593-00$ & Tyler 1 & Weaver Oil and Gas Cor. & BYRON & GENESEE & 4000 & 43.0429 & -78.0773 \\
\hline $31-073-04611-00-00$ & $04611-00$ & Kelly F E 1 & Humble Oil \& Refining Co. & BARREN & ORLEANS & 3044 & 43.1909 & -78.2583 \\
\hline 31-011-04624-00-00 & $04624-00$ & Wasielewski 1 & Humble Oil \& Refining Co. & IRAN & CAYUGA & 3055 & 43.2525 & -76.491 \\
\hline $31-051-04630-00-00$ & $04630-00$ & Kennedy 1 & Mt. Morris Drilling Inc. & PARTAS & LIVINGSTON & 6388 & 42.6502 & -77.756 \\
\hline $31-029-04663-00-00$ & $04663-00$ & Victor 1 & JFS Limited Partnership & HAMBURGN & ERIE & 4543 & 42.7232 & -78.9451 \\
\hline 31-023-04714-00-00 & $04714-00$ & Clough K \& O 1 & Delta Drilling Co. & FREETOWN & CORTLAND & 8272 & 42.5185 & -76.0009 \\
\hline $31-011-04715-00-00$ & $04715-00$ & Alnutt R 1 & Midwest Oil Corp. & AURELIUS & CAYUGA & 4853 & 42.9217 & -76.6716 \\
\hline $31-063-04719-00-00$ & $04719-00$ & Wolf Raymond 1 & Duchscherer William J. & OMERSETS & NIAGARA & 2159 & 43.3359 & -78.5128 \\
\hline 31-073-04722-00-00 & $04722-00$ & Cook D R 1 & Duchscherer William J. & HELBYS & ORLEANS & 2989 & 43.1858 & -78.4418 \\
\hline 31-055-04724-00-00 & 04724-00 & Yantz 1 & Duchscherer William J. & SWEDEN & MONROE & 3274 & 43.1509 & -77.9752 \\
\hline 31-073-04730-00-00 & $04730-00$ & Daum Reid L 1 & Duchscherer William J. & BARREN & ORLEANS & 3174 & 43.1803 & -78.1527 \\
\hline $31-073-04752-00-00$ & $04752-00$ & Searles Clayton 1 & Duchscherer William J. & YATES & ORLEANS & 2218 & 43.3067 & -78.4529 \\
\hline $31-073-04753-00-00$ & $04753-00$ & Weil Bernard 1 & Duchscherer William J. & YATES & ORLEANS & 2048 & 43.3485 & -78.4447 \\
\hline $31-117-04754-00-00$ & $04754-00$ & Smith Frank 1 & Duchscherer William J. & MACEDON & WAYNE & 3648 & 43.0824 & -77.2696 \\
\hline $31-069-04760-00-00$ & $04760-00$ & Wyman 1 & Hammerstone Oil & FARMI GTONN & ONTARIO & 4305 & 42.9894 & -77.2798 \\
\hline 31-073-04764-00-00 & $04764-00$ & Morrison Manley 1 & Duchscherer William J. & YATES & ORLEANS & 2750 & 43.3259 & -78.3319 \\
\hline $31-037-04806-00-00$ & $04806-00$ & Naylor 1 & Ashland Oil \& Refining & BYRON & GENESEE & 3410 & 43.1154 & -78.0916 \\
\hline $31-069-04871-00-00$ & 04871-00 & Bowerman Ralph 1 & Duchscherer William J. & FARMI GTONN & ONTARIO & 4353 & 43.0216 & -77.3354 \\
\hline $31-073-04873-00-00$ & $04873-00$ & Green Howard 1 & Duchscherer William J. & CARLTON & ORLEANS & 2025 & 43.3627 & -78.305 \\
\hline 31-073-04912-00-00 & $04912-00$ & Malone 1 & Duchscherer William J. & GAI ESN & ORLEANS & 2556 & 43.2823 & -78.1742 \\
\hline $31-073-04994-00-00$ & 04994-00 & Herman 1 & Duchscherer William J. & KE DALLN & ORLEANS & 2559 & 43.3482 & -78.0387 \\
\hline
\end{tabular}




\begin{tabular}{|c|c|c|c|c|c|c|c|c|}
\hline UWI (APINum) & Well Label & Well Name & Operator & Township & County & TD & Surf Lat & Surf Lon \\
\hline 31-011-04999-00-00 & $04999-00$ & Parker Robert A 1 & Duchscherer William J. & BRUTUS & CAYUGA & 3600 & 43.026 & -76.5288 \\
\hline $31-011-05000-00-00$ & $05000-00$ & Ripley 1 & Urban Snow Gas Co. Inc. & CATON & CAYUGA & 3756 & 43.1051 & -76.5527 \\
\hline $31-073-05007-00-00$ & $05007-00$ & Helfer W G 1 & Duchscherer William J. & CARLTON & ORLEANS & 2218 & 43.3578 & -78.1487 \\
\hline $31-073-05008-00-00$ & $05008-00$ & Thaxter 1 & Duchscherer William J. & RIDGEWAYN & ORLEANS & 2664 & 43.2442 & -78.3292 \\
\hline 31-011-05011-00-00 & $05011-00$ & O'Neil 1 & Duchscherer William J. & CATON & CAYUGA & 3573 & 43.1041 & -76.5535 \\
\hline $31-075-05012-00-00$ & $05012-00$ & Hall 1 & Duchscherer William J. & O WEGOS & OSWEGO & 2559 & 43.3693 & -76.6016 \\
\hline 31-011-05031-00-00 & $05031-00$ & Smith L W 1 & Duchscherer William J. & VICTORYN & CAYUGA & 3415 & 43.2015 & -76.61 \\
\hline $31-117-05032-00-00$ & $05032-00$ & Kaiser W 1 & Duchscherer William J. & GALEN & WAYNE & 3915 & 43.0592 & -76.8961 \\
\hline $31-117-05041-00-00$ & $05041-00$ & Reed 1 & Norris Robert E. III & BUTLERN & WAYNE & 3681 & 43.1458 & -76.7616 \\
\hline $31-073-05069-00-00$ & $05069-00$ & Nowak 1 & Duchscherer William J. & KE DALLN & ORLEANS & 2325 & 43.3191 & -78.0824 \\
\hline $31-073-05086-00-00$ & $05086-00$ & Stevens F 1 & Duchscherer William J. & KE DALLN & ORLEANS & 2445 & 43.308 & -78.0339 \\
\hline $31-007-05087-00-00$ & $05087-00$ & Richards 1 & Joyce Western Corp. & TRIA GLEN & BROOME & 9640 & 42.3235 & -75.9479 \\
\hline $31-073-05091-00-00$ & 05091-00 & Woolston G E 1 & Duchscherer William J. & GAI ESN & ORLEANS & 2345 & 43.306 & -78.2245 \\
\hline 31-099-05095-00-00 & $05095-00$ & Reed 1 & Duchscherer William J. & JU IUSN & SENECA & 4149 & 43.0067 & -76.9403 \\
\hline 31-073-05096-00-00 & 05096-00 & Domoy F 1 & Duchscherer William J. & HELBYS & ORLEANS & 3119 & 43.1621 & -78.3732 \\
\hline $31-117-05114-00-00$ & $05114-00$ & Olson H V 1 & Duchscherer William J. & LYO SN & WAYNE & 3744 & 43.1115 & -77.0206 \\
\hline $31-037-05115-00-00$ & $05115-00$ & Brundage 1 & Duchscherer William J. & ALABAMAN & GENESEE & 3600 & 43.0906 & -78.3135 \\
\hline 31-117-05116-00-00 & $05116-00$ & Hammond F W 1 & Duchscherer William J. & ARCADIAN & WAYNE & 3750 & 43.152 & -77.0698 \\
\hline $31-037-05117-00-00$ & $05117-00$ & Klotzbach \#1 & United States Gypsum Co. & ALABAMAN & GENESEE & 3950 & 43.0403 & -78.3902 \\
\hline $31-029-05402-00-00$ & $05402-00$ & & & TO AWANDAN & ERIE & & 0 & 0 \\
\hline 31-011-05467-00-00 & $05467-00$ & House Louis and Mary 1 & Hodges Michael W. & CATON & CAYUGA & 3368 & 43.1007 & -76.5127 \\
\hline $31-121-06073-00-00$ & $06073-00$ & Fisher Frank et al 1 & Flanigan Brothers & WAR AWS & WYOMING & 5712 & 42.7552 & -78.0976 \\
\hline $31-069-06395-00-00$ & $06395-00$ & Frankish George C 1 & Hoover Moble C. & GORHAMN & ONTARIO & 6012 & 42.8126 & -77.2029 \\
\hline 31-063-06667-00-00 & $06667-00$ & FMC Corp Niag Chem Div 1 & $\begin{array}{c}\text { Niagara Chemical Division } \\
\text { FMC }\end{array}$ & ROYALTON & NIAGARA & 3189 & 43.2076 & -78.4651 \\
\hline $31-029-06668-00-00$ & $06668-00$ & Fee 1 & Bethlehem Steel Corp. & HAMBURGN & ERIE & 4310 & 42.8032 & -78.8444 \\
\hline 31-063-06669-00-00 & 06669-00 & Fee (Hooker Chemical) 1a & $\begin{array}{c}\text { Occidental(Formerly } \\
\text { Hooker) }\end{array}$ & IAGARAN & NIAGARA & 3063 & 43.0799 & -79.0067 \\
\hline 31-117-06719-00-00 & $06719-00$ & Martin 1 & $\begin{array}{l}\text { Union Oil Company of } \\
\text { California }\end{array}$ & GALEN & WAYNE & 4050 & 43.029 & -76.9438 \\
\hline 31-011-06779-00-00 & $06779-00$ & Karim 1 & Karim Raja Abdul & CATON & CAYUGA & 3128 & 43.1093 & -76.5615 \\
\hline 31-011-06780-00-00 & $06780-00$ & Cole 1 & Urban Snow Gas Co. Inc. & CATON & CAYUGA & 3096 & 43.1091 & -76.5469 \\
\hline 31-121-07234-00-00 & 07234-00 & Farrell Robert 1 & $\begin{array}{c}\text { Lenape Resources Corp. } \\
\text { The }\end{array}$ & MIDDLEBURYN & WYOMING & 4944 & 42.7845 & -78.1114 \\
\hline 31-121-07278-00-00 & $07278-00$ & Texas Brine \#18 & Texas Brine Company LLC & MIDDLEBURYN & WYOMING & 4980 & 42.7974 & -78.0912 \\
\hline 31-013-07649-00-00 & 07649-00 & Langworthy \#1 & Cotton Well Drilling Co. Inc. & VILLE OVAN & CHAUTAUQUA & 5940 & 42.4071 & -79.1665 \\
\hline $31-009-08581-00-00$ & $08581-00$ & Thomasett (IGC 2379) 1 & Iroquois Gas Corp. & PERRY BURGS & EATTARAUGUS & 5701 & 42.4563 & -79.033 \\
\hline $31-009-08610-00-00$ & $08610-00$ & Manning (IGC 2380) 1 & Iroquois Gas Corp. & OTTON & EATTARAUGUS & 6762 & 42.3714 & -78.8431 \\
\hline $31-009-09235-00-00$ & $09235-00$ & Enterprise Transit St 1 & Pennzoil Products Co. & ALLEGA YN & EATTARAUGUS & 11680 & 42.0087 & -78.5687 \\
\hline $31-013-09355-00-00$ & $09355-00$ & Newman James 1 & Meridian Exploration Corp. & POMFRETN & CHAUTAUQUA & 4780 & 42.4372 & -79.4071 \\
\hline
\end{tabular}




\begin{tabular}{|c|c|c|c|c|c|c|c|c|}
\hline UWI (APINum) & Well Label & Well Name & Operator & Township & County & TD & Surf Lat & Surf Lon \\
\hline $31-037-09524-00-00$ & $09524-00$ & Buckenmeyer 1 & CNG Transmission Corp. & ALEXA DERN & GENESEE & 4095 & 42.9 & -78.2442 \\
\hline 31-073-09540-00-00 & $09540-00$ & Maxon Roger 1 & $\begin{array}{l}\text { Consolidated Gas Supply } \\
\text { Corp. }\end{array}$ & CLARE DONN & ORLEANS & 2873 & 43.1885 & -78.0376 \\
\hline $31-037-09563-00-00$ & $09563-00$ & Uebelhoer 1 & CNG Transmission Corp. & BYRON & GENESEE & 3379 & 43.0793 & -78.1099 \\
\hline 31-053-09578-00-00 & $09578-00$ & Shepard Helen 1 & CNG Transmission Corp. & FE NERN & MADISON & 4927 & 42.9511 & -75.8078 \\
\hline 31-013-09939-00-00 & 09939-00 & Lesch \#1110 & Lenape Resources Inc. & POMFRETN & CHAUTAUQUA & 5013 & 42.4158 & -79.3787 \\
\hline $31-025-10227-00-00$ & $10227-00$ & Weickert F 1 & Anschutz Corp. & ROXBURYN & \begin{tabular}{|l|} 
DELAWARE \\
\end{tabular} & 6740 & 42.2976 & -74.625 \\
\hline $31-015-10335-00-00$ & $10335-00$ & Matejka 1 & Shell Oil Co. & ERIN & CHEMUNG & 10614 & 42.169 & -76.659 \\
\hline $31-037-10776-00-00$ & $10776-00$ & Belt 1 & Flint Oil \& Gas Inc. & BETHA YN & GENESEE & 4340 & 42.9204 & -78.1673 \\
\hline $31-077-10834-00-00$ & $10834-00$ & Hoose 1 & Amoco Production Co. & LAURE SN & OTSEGO & 5824 & 42.5803 & -75.0481 \\
\hline $31-099-10893-00-00$ & $10893-00$ & Kinney 1 & Hoover Moble C. & WATERLOON & SENECA & 4741 & 42.9411 & -76.8767 \\
\hline $31-055-10921-00-00$ & $10921-00$ & Kerberle 1 & Colonial Oil \& Gas Corp. & HAMLIN & MONROE & 2200 & 43.3334 & -77.9529 \\
\hline 31-121-10936-00-00 & $10936-00$ & Wagenblass Daniel 1 & CNG Transmission Corp. & WAR AWS & WYOMING & 5573 & 42.7442 & -78.1855 \\
\hline 31-121-10939-00-00 & $10939-00$ & Metz 1 & Flint Oil \& Gas Inc. & SHELDON & WYOMING & 5420 & 42.7668 & -78.4179 \\
\hline $31-029-11002-00-00$ & $11002-00$ & Brown Ralph H 1 & Belden \& Blake Corporation & SARDI IAN & ERIE & 6293 & 42.5575 & -78.5357 \\
\hline 31-029-11114-00-00 & $11114-00$ & Lietz 2 & Perkins Cooper \& Gondree & BRA TN & ERIE & 4822 & 42.598 & -78.9844 \\
\hline 31-011-11129-00-00 & $11129-00$ & Joshanski 1 & Urban Snow Gas Co. Inc. & CATON & CAYUGA & 3057 & 43.1206 & -76.548 \\
\hline 31-013-11387-00-00 & $11387-00$ & Emling 373 & Belden \& Blake Corporation & RIPLEYN & CHAUTAUQUA & 6182 & 42.2191 & -79.6635 \\
\hline $31-029-11730-00-00$ & $11730-00$ & Foss 1241 & Lenape Resources Inc. & WALES & ERIE & 5550 & 42.7138 & -78.5173 \\
\hline $31-067-12163-00-00$ & $12163-00$ & Harrison & Pominex Inc. & MARCELLUS & ONONDAGA & 4176 & 42.9369 & -76.3459 \\
\hline $31-121-12178-00-00$ & $12178-00$ & Meeder Wn-1533 & Meeder William H & MIDDLEBURYN & WYOMING & 5325 & 42.7908 & -78.1751 \\
\hline $31-075-12398-00-00$ & $12398-00$ & Nicholson & Kirby Exploration Co. & MEXICON & OSWEGO & 1860 & 43.4868 & -76.1889 \\
\hline $31-075-12399-00-00$ & $12399-00$ & Yager & Yager Eileen R. & RICHLA DN & OSWEGO & 1785 & 43.5087 & -76.1957 \\
\hline $31-075-12406-00-00$ & $12406-00$ & Crane & Kirby Exploration Co. & RICHLA DN & OSWEGO & 1795 & 43.5018 & -76.2001 \\
\hline $31-075-12447-00-00$ & $12447-00$ & Manwaring 1 & Kirby Exploration Co. & RICHLA DN & OSWEGO & 1677 & 43.5188 & -76.1908 \\
\hline $31-029-12745-00-00$ & $12745-00$ & Heary C. N1617 & Ardent Resources Inc. & CO CORDN & ERIE & 5515 & 42.5792 & -78.7203 \\
\hline $31-029-12910-00-00$ & $12910-00$ & Darling \#1 & NYS Natural Gas Co. & COLLI SN & ERIE & 5826 & 42.4664 & -78.8035 \\
\hline 31-121-13278-00-00 & $13278-00$ & Romain George 1 & Stedman Energy Inc. & ARCADEN & WYOMING & 6708 & 42.5346 & -78.3947 \\
\hline $31-037-13672-00-00$ & $13672-00$ & Fee 1 & General Crushed Stone Co. & LE ROYN & GENESEE & 4203 & 42.9935 & -77.9519 \\
\hline 31-101-13699-00-00 & $13699-00$ & NYS Reforestation 6 & Columbia Gas Trans. Corp. & WHEELERN & STEUBEN & 9794 & 42.4662 & -77.2654 \\
\hline $31-051-13700-00-00$ & $13700-00$ & Hilts 20617-T & Columbia Gas Trans. Corp. & MOU T MORRISN & LIVINGSTON & 6403 & 42.6972 & -77.892 \\
\hline $31-101-15438-00-00$ & $15438-00$ & Kassow 1 & Minter Lee E. & PULTE EYN & STEUBEN & 7956 & 42.5393 & -77.2161 \\
\hline $31-053-15467-00-00$ & $15467-00$ & H.J. Becker Et Ux 1 & Elcoex Inc. & DE RUYTERN & MADISON & 4746 & 42.8155 & -75.7866 \\
\hline $31-067-15584-00-00$ & $15584-00$ & Cox R & Cox Family Farm & LYSA DERN & ONONDAGA & 3533 & 43.1548 & -76.4715 \\
\hline $31-075-15613-00-00$ & $15613-00$ & Nicholson & Taber Grover E. Jr. & WEST MO ROEN & OSWEGO & 2240 & 43.3513 & -76.0894 \\
\hline $31-075-15628-00-00$ & $15628-00$ & Marquisee & Marquisee Joseph A. & WILLIAMSTOWN & OSWEGO & 1725 & 43.4884 & -75.9359 \\
\hline $31-011-16120-00-00$ & $16120-00$ & Venice View Dairy 1-11 & Devonian Energy Corp. & VE ICEN & CAYUGA & 7346 & 42.7202 & -76.5683 \\
\hline
\end{tabular}




\begin{tabular}{|c|c|c|c|c|c|c|c|c|}
\hline UWI (APINum) & Well Label & Well Name & Operator & Township & County & TD & Surf Lat & Surf Lon \\
\hline 31-075-16814-00-00 & 16814-00 & Atkinson 1 & $\begin{array}{c}\text { Atkinson James W. \& } \\
\text { Patricia }\end{array}$ & RICHLA DN & OSWEGO & 800 & 43.53 & -76.1708 \\
\hline $31-075-16818-00-00$ & $16818-00$ & Stowell 1 & Kirby Exploration Co. & RICHMO DN & OSWEGO & 865 & 43.5187 & -76.214 \\
\hline 31-011-17508-00-00 & $17508-00$ & Hunter A\&B 1 & Urban Snow Gas Co. Inc. & CATON & CAYUGA & 3658 & 43.129 & -76.5617 \\
\hline 31-011-17509-00-00 & $17509-00$ & Hunter C 1 & Urban Snow Gas Co. Inc. & CATON & CAYUGA & 2866 & 43.1305 & -76.5471 \\
\hline 31-011-17510-00-00 & $17510-00$ & Keysor K 1 & Urban Snow Gas Co. Inc. & CATON & CAYUGA & 3649 & 43.1383 & -76.5522 \\
\hline 31-011-17558-00-00 & $17558-00$ & Provo 7271 & Meridian Exploration Corp. & SE NETTN & CAYUGA & 4555 & 43.0111 & -76.5215 \\
\hline 31-011-17559-00-00 & $17559-00$ & Quill 7251 & \begin{tabular}{|c|}
$\begin{array}{c}\text { Columbia Natural Resources } \\
\text { Inc. }\end{array}$ \\
\end{tabular} & AURELIUS & CAYUGA & 5038 & 42.9243 & -76.6998 \\
\hline 31-053-19485-00-00 & $19485-00$ & Larkin 1 & \begin{tabular}{|c|} 
F. L. Stead \& Associates \\
Inc.
\end{tabular} & BROOKFIELDN & MADISON & 5083 & 42.8088 & -75.4189 \\
\hline 31-101-19497-00-00 & 19497-00 & Evangelos 21436-T & $\begin{array}{c}\text { Columbia Natural Resources } \\
\text { Inc. }\end{array}$ & PULTE EYN & STEUBEN & 7961 & 42.5407 & -77.2162 \\
\hline 31-023-19540-00-00 & $19540-00$ & Vander Ploeg 1 & \begin{tabular}{|l|} 
Berea Oil \& Gas Corp. \\
\end{tabular} & FREETOWN & CORTLAND & 7820 & 42.5543 & -76.0209 \\
\hline 31-097-19692-00-00 & $19692-00$ & Perigo 21578 Tpi & \begin{tabular}{|c|} 
Columbia Natural Resources \\
Inc.
\end{tabular} & READI GN & SCHUYLER & 8384 & 42.4325 & -76.9704 \\
\hline 31-121-19937-00-00 & 19937-00 & Phillips J \#1 & \begin{tabular}{|c|} 
U S Energy Development \\
Corp. \\
\end{tabular} & WAR AWS & WYOMING & 5670 & 42.6977 & -78.1892 \\
\hline 31-053-20411-00-00 & $20411-00$ & Gapski 1 & N. Y. Keelex Corp. & ELSONN & MADISON & 5240 & 42.8574 & -75.7295 \\
\hline 31-097-20417-00-00 & 20417-00 & Epstein 21624-Pi & \begin{tabular}{|c|} 
Columbia Natural Resources \\
Inc.
\end{tabular} & READI GN & SCHUYLER & 8520 & 42.4371 & -76.9561 \\
\hline 31-099-20446-00-00 & $20446-00$ & Compton 1 (4177) & \begin{tabular}{|c|}
$\begin{array}{c}\text { Equitable Resources } \\
\text { Exploraration }\end{array}$ \\
\end{tabular} & ROMULUS & SENECA & 6366 & 42.7086 & -76.8085 \\
\hline $31-037-20687-00-00$ & $20687-00$ & U S Gypsum Co \#2 & United States Gypsum Co. & OAKFIELDN & GENESEE & 4620 & 43.0521 & -78.2373 \\
\hline 31-057-21033-00-00 & 21033-00 & $\begin{array}{c}\text { Montanye Lawrence MNRD } \\
1-A \\
\end{array}$ & $\begin{array}{c}\text { Millennium Natural Resource } \\
\text { Development }\end{array}$ & ROOTN & \multicolumn{2}{|l|}{ MONTGOMERY } & 42.8483 & -74.4576 \\
\hline 31-067-21335-00-00 & $21335-00$ & Halloran 1 & \begin{tabular}{|c|}
$\begin{array}{c}\text { Eastern States Exploration } \\
\text { Co. }\end{array}$ \\
\end{tabular} & CAMILLUS & ONONDAGA & 4159 & 43.066 & -76.3529 \\
\hline 31-067-21336-00-00 & $21336-00$ & Stell 1 & $\begin{array}{c}\text { Eastern States Exploration } \\
\text { Co. }\end{array}$ & VA BURENN & ONONDAGA & 3923 & 43.1228 & -76.4008 \\
\hline 31-101-21468-00-00 & $21468-00$ & Mitchell 1 & $\begin{array}{c}\text { New Avoca Gas Storage } \\
\text { LLC }\end{array}$ & AVOCAN & STEUBEN & 9887 & 42.4196 & -77.4535 \\
\hline 31-011-21469-00-00 & $21469-00$ & Auburn Geothermal Well \#2 & & & & 5122 & 42.9466 & -76.5417 \\
\hline $31-097-21495-00-00$ & $21495-00$ & Bale 1 & JMC Cayuta Inc. & CAYUTAN & SCHUYLER & 11823 & 42.2699 & -76.7139 \\
\hline 31-101-21496-00-00 & $21496-00$ & Hubbard No. 1 & $\begin{array}{c}\text { New Avoca Gas Storage } \\
\text { LLC }\end{array}$ & AVOCAN & STEUBEN & 10051 & 42.4053 & -77.4635 \\
\hline $31-023-21500-00-00$ & $21500-00$ & NYS REF 6 Well 01 & \begin{tabular}{|c|} 
Quaker State Corp. \\
\end{tabular} & TAYLORN & CORTLAND & 6886 & 42.639 & -75.9136 \\
\hline 31-101-21592-00-00 & $21592-00$ & Gray 21625 & \begin{tabular}{|c|}
$\begin{array}{c}\text { Columbia Natural Resources } \\
\text { Inc. }\end{array}$ \\
\end{tabular} & PULTE EYN & STEUBEN & 7493 & 42.5406 & -77.237 \\
\hline 31-101-21601-00-00 & $21601-00$ & Mitchell 2 & $\begin{array}{c}\text { New Avoca Gas Storage } \\
\text { LLC }\end{array}$ & AVOCAN & STEUBEN & 11894 & 42.4333 & -77.4537 \\
\hline
\end{tabular}




\begin{tabular}{|c|c|c|c|c|c|c|c|c|}
\hline UWI (APINum) & Well Label & Well Name & Operator & Township & County & TD & Surf Lat & Surf Lon \\
\hline 31-101-21624-00-00 & $21624-00$ & Avoca 4 & $\begin{array}{c}\text { New Avoca Gas Storage } \\
\text { LLC }\end{array}$ & AVOCAN & STEUBEN & 9224 & 42.42 & -77.4675 \\
\hline 31-101-21633-00-00 & $21633-00$ & Mitchell 3 & $\begin{array}{c}\text { New Avoca Gas Storage } \\
\text { LLC }\end{array}$ & AVOCAN & STEUBEN & 11415 & 42.4278 & -77.4459 \\
\hline 31-101-21636-00-00 & $21636-00$ & Fee 6 & $\begin{array}{c}\text { New Avoca Gas Storage } \\
\text { LLC }\end{array}$ & AVOCAN & STEUBEN & 11030 & 42.429 & -77.466 \\
\hline 31-101-21688-00-00 & $21688-00$ & Levandowski 623088 & \begin{tabular}{|c|}
$\begin{array}{c}\text { Columbia Natural Resources } \\
\text { Inc. }\end{array}$ \\
\end{tabular} & PRATT BURGS & STEUBEN & 7313 & 42.5343 & -77.2522 \\
\hline 31-101-21689-00-00 & $21689-00$ & Covert 622302 & $\begin{array}{c}\text { Columbia Natural Resources } \\
\text { Inc. }\end{array}$ & PRATT BURGS & STEUBEN & 7136 & 42.5387 & -77.2753 \\
\hline 31-101-21689-01-00 & 21689-01 & Covert 622302-A & $\begin{array}{c}\begin{array}{c}\text { Columbia Natural Resources } \\
\text { Inc. }\end{array} \\
\end{array}$ & PRATT BURGS & STEUBEN & 7131 & 42.5387 & -77.2753 \\
\hline 31-101-21692-00-00 & $21692-00$ & Pizura 623143 & $\begin{array}{c}\text { Columbia Natural Resources } \\
\text { Inc. }\end{array}$ & PULTE EYN & STEUBEN & 7091 & 42.5398 & -77.1825 \\
\hline $31-053-21699-00-00$ & $21699-00$ & Beers 1 & \begin{tabular}{|l|} 
Nornew Inc. \\
\end{tabular} & LEBA ONN & MADISON & 4734 & 42.81 & -75.5967 \\
\hline 31-101-21703-00-00 & $21703-00$ & Radigan 623267 & \begin{tabular}{|c|}
$\begin{array}{c}\text { Columbia Natural Resources } \\
\text { Inc. }\end{array}$ \\
\end{tabular} & PULTE EYN & STEUBEN & 7266 & 42.5434 & -77.1677 \\
\hline 31-101-21704-00-00 & $21704-00$ & Fimlaid 1 & \begin{tabular}{|c|}
$\begin{array}{c}\text { Columbia Natural Resources } \\
\text { Inc. }\end{array}$ \\
\end{tabular} & WAY EN & STEUBEN & 8028 & 42.4393 & -77.1115 \\
\hline 31-101-21705-00-00 & $21705-00$ & Smith 1 & \begin{tabular}{|c|}
$\begin{array}{c}\text { Columbia Natural Resources } \\
\text { Inc. }\end{array}$ \\
\end{tabular} & PULTE EYN & STEUBEN & 7110 & 42.5434 & -77.1982 \\
\hline 31-101-21706-00-00 & $21706-00$ & Fox 1 (623217) & $\begin{array}{c}\begin{array}{c}\text { Columbia Natural Resources } \\
\text { Inc. }\end{array} \\
\end{array}$ & PULTE EYN & STEUBEN & 7048 & 42.5386 & -77.2035 \\
\hline 31-101-21707-00-00 & $21707-00$ & Prattsburg Town Farm 1 & \begin{tabular}{|c|}
$\begin{array}{c}\text { Columbia Natural Resources } \\
\text { Inc. }\end{array}$ \\
\end{tabular} & PRATT BURGS & STEUBEN & 7718 & 42.5377 & -77.3033 \\
\hline $31-101-21707-02-00$ & 21707-02 & $\begin{array}{c}\text { Prattsburg Town Farm } \\
623220-B \\
\end{array}$ & \begin{tabular}{|c|}
$\begin{array}{c}\text { Columbia Natural Resources } \\
\text { Inc. }\end{array}$ \\
\end{tabular} & PRATT BURGS & STEUBEN & 7505 & 42.5377 & -77.3033 \\
\hline 31-101-21710-00-00 & $21710-00$ & Bergstresser 1 & $\begin{array}{c}\begin{array}{c}\text { Columbia Natural Resources } \\
\text { Inc. }\end{array} \\
\end{array}$ & PULTE EYN & STEUBEN & 6691 & 42.5472 & -77.1726 \\
\hline 31-101-21712-00-00 & $21712-00$ & Kozak 1 & \begin{tabular}{|c|}
$\begin{array}{c}\text { Columbia Natural Resources } \\
\text { Inc. }\end{array}$ \\
\end{tabular} & PRATT BURGS & STEUBEN & 7690 & 42.5392 & -77.2601 \\
\hline $31-101-21715-00-00$ & $21715-00$ & Grace 1 & \begin{tabular}{|c|}
$\begin{array}{c}\text { Columbia Natural Resources } \\
\text { Inc. }\end{array}$ \\
\end{tabular} & PRATT BURGS & STEUBEN & 7879 & 42.5236 & -77.3415 \\
\hline $31-109-21716-00-00$ & $21716-00$ & Stairs 1 & \begin{tabular}{|c|}
$\begin{array}{c}\text { Columbia Natural Resources } \\
\text { Inc. }\end{array}$ \\
\end{tabular} & DRYDEN & TOMPKINS & 7468 & 42.511 & -76.301 \\
\hline 31-101-21718-00-00 & $21718-00$ & Demun 1 & \begin{tabular}{|c|} 
True Oil Co. \\
\end{tabular} & TROUP BURGS & STEUBEN & 11166 & 42.0956 & -77.5943 \\
\hline $31-097-21725-00-00$ & $21725-00$ & Forte 1 & \begin{tabular}{|c|}
$\begin{array}{c}\text { Columbia Natural Resources } \\
\text { Inc. }\end{array}$ \\
\end{tabular} & TYRO EN & SCHUYLER & 8275 & 42.4713 & -77.0042 \\
\hline $31-097-21726-00-00$ & $21726-00$ & Mast 1 & \begin{tabular}{|c|}
$\begin{array}{c}\text { Columbia Natural Resources } \\
\text { Inc. }\end{array}$ \\
\end{tabular} & TYRO EN & SCHUYLER & 8174 & 42.476 & -77.0032 \\
\hline $31-009-21809-00-00$ & $21809-00$ & Hebdon \#1 & Hebdon Charles \& Cherryl & A HFORDS & CATTARAUGUS & 7502 & 42.3954 & -78.6722 \\
\hline $31-121-21840-00-00$ & $21840-00$ & Howes A \#1 & Miller Gas Corp. & MIDDLEBURYN & WYOMING & 5320 & 42.8172 & -78.1104 \\
\hline
\end{tabular}




\begin{tabular}{|c|c|c|c|c|c|c|c|c|}
\hline UWI (APINum) & Well Label & Well Name & Operator & Township & County & TD & Surf Lat & Surf Lon \\
\hline $31-009-21860-00-00$ & $21860-00$ & Schwerkert-Scharf \#1 & Schweikert William K. & A HFORDS & EATTARAUGUS & 6166 & 42.4905 & -78.6043 \\
\hline 31-009-21869-00-00 & $21869-00$ & Worden \#1 & Thompson Timothy G. & YORK HIRES & EATTARAUGUS & 6166 & 42.5003 & -78.5085 \\
\hline 31-121-21900-00-00 & $21900-00$ & Leaton G \#1 & Miller Gas Corp. & COVI GTONN & WYOMING & 5079 & 42.8307 & -78.0549 \\
\hline $31-121-21907-00-00$ & $21907-00$ & Chamberlain D \#2 & Miller Gas Corp. & MIDDLEBURYN & WYOMING & 5373 & 42.8178 & -78.1167 \\
\hline 31-121-21908-00-00 & $21908-00$ & Howes A\#3 & Miller Gas Corp. & MIDDLEBURYN & WYOMING & 5148 & 42.8199 & -78.1061 \\
\hline 31-121-21909-00-00 & $21909-00$ & Howes A \#2 & Miller Gas Corp. & MIDDLEBURYN & WYOMING & 5350 & 42.8216 & -78.1111 \\
\hline 31-121-21920-00-00 & $21920-00$ & Titus Brothers \#1 & Miller Gas Corp. & MIDDLEBURYN & WYOMING & 5260 & 42.8273 & -78.1012 \\
\hline 31-121-21945-00-00 & $21945-00$ & Howes A\#4 & Miller Gas Corp. & MIDDLEBURYN & WYOMING & 5272 & 42.816 & -78.1048 \\
\hline 31-121-21946-00-00 & $21946-00$ & Chamberlain B \#1 & Miller Gas Corp. & MIDDLEBURYN & WYOMING & 5201 & 42.8128 & -78.1073 \\
\hline 31-121-21962-00-00 & $21962-00$ & Lacey R \#1 & Miller Gas Corp. & COVI GTONN & WYOMING & 5140 & 42.8314 & -78.0488 \\
\hline $31-121-21963-00-00$ & $21963-00$ & Tillotson D \#1 & Miller Gas Corp. & COVI GTONN & WYOMING & 5000 & 42.8271 & -78.0504 \\
\hline 31-121-21964-00-00 & $21964-00$ & Johannes E \#1 & GFS Energy Inc. & COVI GTONN & WYOMING & 5300 & 42.8213 & -78.0685 \\
\hline $31-121-22042-00-00$ & $22042-00$ & Titus Brothers \#4 & Miller Gas Corp. & MIDDLEBURYN & WYOMING & 5211 & 42.8219 & -78.0996 \\
\hline $31-121-22046-00-00$ & $22046-00$ & Titus Brothers \#3 & Miller Gas Corp. & MIDDLEBURYN & WYOMING & 5050 & 42.8177 & -78.099 \\
\hline $31-121-22053-00-00$ & $22053-00$ & Chamberlain $\mathrm{P} \# 2$ & Miller Gas Corp. & MIDDLEBURYN & WYOMING & 5340 & 42.8138 & -78.1134 \\
\hline 31-013-22497-00-00 & $22497-00$ & Kaluza 1 & New York Gas \& Oil Co Inc. & ELLERYN & CHAUTAUQUA & 7288 & 42.2028 & -79.4009 \\
\hline $31-013-22498-00-00$ & $22498-00$ & Butts 1-B & Cei 1992-93 Joint Venture & ORTH HARMONYN & CHAUTAUQUA & 7620 & 42.1438 & -79.4174 \\
\hline $31-121-22520-00-00$ & $22520-00$ & Matusik J \#1 & Belden \& Blake Corporation & ARCADEN & WYOMING & 6321 & 42.5535 & -78.4388 \\
\hline 31-013-22531-00-00 & $22531-00$ & Liddell \#1 & New York Gas \& Oil Co Inc. & ELLERYN & CHAUTAUQUA & 7330 & 42.1979 & -79.3921 \\
\hline 31-013-22588-00-00 & $22588-00$ & Gorczyca \#1 & New York Gas \& Oil Co Inc. & ELLERYN & CHAUTAUQUA & 7136 & 42.2298 & -79.3904 \\
\hline $31-013-22596-00-00$ & $22596-00$ & Schofield S.P. 127 \#1 & Schreiner Oil \& Gas Inc. & WE TFIELDS & CHAUTAUQUA & 5935 & 42.3382 & -79.5319 \\
\hline 31-013-22616-00-00 & $22616-00$ & Crowe \#3 & New York Gas \& Oil Co Inc. & POMFRETN & CHAUTAUQUA & 6174 & 42.3665 & -79.4091 \\
\hline $31-121-22655-00-00$ & $22655-00$ & Stahl \#1 & Belden \& Blake Corporation & ARCADEN & WYOMING & 6021 & 42.577 & -78.4587 \\
\hline 31-101-22741-00-00 & $22741-00$ & Von Rhedey 623519 & \begin{tabular}{|c|}
$\begin{array}{c}\text { Columbia Natural Resources } \\
\text { Inc. }\end{array}$ \\
\end{tabular} & PULTE EYN & STEUBEN & 7494 & 42.4938 & -77.2058 \\
\hline 31-101-22741-01-00 & 22741-01 & Von Rhedey 623519-A & $\begin{array}{c}\begin{array}{c}\text { Columbia Natural Resources } \\
\text { Inc. }\end{array} \\
\end{array}$ & PULTE EYN & STEUBEN & 7783 & 42.4938 & -77.2058 \\
\hline $31-123-22743-00-00$ & $22743-00$ & Sensenig 1 & $\begin{array}{c}\text { Columbia Natural Resources } \\
\text { Inc. }\end{array}$ & TARKEYS & YATES & 7241 & 42.5073 & -76.9726 \\
\hline $31-101-22745-00-00$ & $22745-00$ & Faber 1 & \begin{tabular}{|c|}
$\begin{array}{c}\text { Columbia Natural Resources } \\
\text { Inc. }\end{array}$ \\
\end{tabular} & PRATT BURGS & STEUBEN & 7371 & 42.5002 & -77.2421 \\
\hline $31-123-22746-00-00$ & $22746-00$ & Dewitt 623333 & \begin{tabular}{|c|}
$\begin{array}{c}\text { Columbia Natural Resources } \\
\text { Inc. }\end{array}$ \\
\end{tabular} & BARRI GTONN & YATES & 7925 & 42.5173 & -77.0612 \\
\hline 31-101-22747-00-00 & $22747-00$ & Smith 1 & $\begin{array}{c}\text { Columbia Natural Resources } \\
\text { Inc. }\end{array}$ & PULTE EYN & STEUBEN & 7442 & 42.5102 & -77.2093 \\
\hline
\end{tabular}




\begin{tabular}{|c|c|c|c|c|c|c|c|c|}
\hline UWI (APINum) & Well Label & Well Name & Operator & Township & County & TD & Surf Lat & Surf Lon \\
\hline 31-101-22748-00-00 & $22748-00$ & McAllister 1 & \begin{tabular}{|c|}
$\begin{array}{c}\text { Columbia Natural Resources } \\
\text { Inc. }\end{array}$ \\
\end{tabular} & PULTE EYN & STEUBEN & 7232 & 42.5106 & -77.1921 \\
\hline 31-123-22750-00-00 & $22750-00$ & Weitz 1 & $\begin{array}{c}\text { Columbia Natural Resources } \\
\text { Inc. }\end{array}$ & BARRI GTONN & YATES & 7555 & 42.4933 & -77.0876 \\
\hline 31-123-22752-00-00 & $22752-00$ & Knapp 1 & $\begin{array}{c}\text { Columbia Natural Resources } \\
\text { Inc. }\end{array}$ & BARRI GTONN & YATES & 7543 & 42.5285 & -77.0827 \\
\hline 31-109-22753-00-00 & $22753-00$ & Koskinen 623513 & \begin{tabular}{|c|}
$\begin{array}{c}\text { Columbia Natural Resources } \\
\text { Inc. }\end{array}$ \\
\end{tabular} & ULY SESS & TOMPKINS & 7462 & 42.4903 & -76.6733 \\
\hline 31-097-22754-00-00 & $22754-00$ & Gunning 1 & $\begin{array}{c}\begin{array}{c}\text { Columbia Natural Resources } \\
\text { Inc. }\end{array} \\
\end{array}$ & HECTORN & SCHUYLER & 7999 & 42.4601 & -76.7321 \\
\hline 31-101-22755-00-00 & $22755-00$ & Snyder 1 & $\begin{array}{c}\text { Columbia Natural Resources } \\
\text { Inc. }\end{array}$ & PULTE EYN & STEUBEN & 6816 & 42.5188 & -77.1661 \\
\hline 31-101-22756-00-00 & $22756-00$ & Grand View 1 & \begin{tabular}{|c|}
$\begin{array}{c}\text { Columbia Natural Resources } \\
\text { Inc. }\end{array}$ \\
\end{tabular} & PULTE EYN & STEUBEN & 7848 & 42.4823 & -77.204 \\
\hline 31-123-22757-00-00 & $22757-00$ & NYS Reforestation Area 1 & Belden \& Blake Corporation & ITALYN & YATES & 0 & 42.6456 & -77.2466 \\
\hline 31-123-22757-01-00 & 22757-01 & NYS Reforestation Area 1 & Belden \& Blake Corporation & ITALYN & YATES & 7146 & 42.6456 & -77.2466 \\
\hline 31-101-22758-00-00 & $22758-00$ & S \& D Farms 623504 & $\begin{array}{c}\begin{array}{c}\text { Columbia Natural Resources } \\
\text { Inc. }\end{array} \\
\end{array}$ & COHOCTON & STEUBEN & 7416 & 42.5494 & -77.4542 \\
\hline 31-101-22758-01-00 & $22758-01$ & S \& D Farms 624504-B & \begin{tabular}{|c|}
$\begin{array}{c}\text { Columbia Natural Resources } \\
\text { Inc. }\end{array}$ \\
\end{tabular} & COHOCTON & STEUBEN & 7468 & 42.5494 & -77.4542 \\
\hline $31-101-22759-00-00$ & $22759-00$ & S \& D Farms 623144 & $\begin{array}{c}\text { Columbia Natural Resources } \\
\text { Inc. }\end{array}$ & COHOCTON & STEUBEN & 7892 & 42.5334 & -77.4005 \\
\hline 31-101-22759-01-00 & $22759-01$ & S \& D Farms 623144-A & \begin{tabular}{|c|} 
Columbia Natural Resources \\
Inc.
\end{tabular} & COHOCTON & STEUBEN & 7963 & 42.5334 & -77.4005 \\
\hline $31-101-22759-02-00$ & $22759-02$ & S \& D Farms 623144-B & \begin{tabular}{|c|}
$\begin{array}{c}\text { Columbia Natural Resources } \\
\text { Inc. }\end{array}$ \\
\end{tabular} & COHOCTON & STEUBEN & 8212 & 42.5334 & -77.4005 \\
\hline $31-101-22760-00-00$ & $22760-00$ & Wolcott 623284 & $\begin{array}{c}\text { Columbia Natural Resources } \\
\text { Inc. }\end{array}$ & COHOCTON & STEUBEN & 7832 & 42.5422 & -77.4187 \\
\hline 31-101-22760-01-00 & $22760-01$ & Wolcott 623284-A & \begin{tabular}{|c|}
$\begin{array}{c}\text { Columbia Natural Resources } \\
\text { Inc. }\end{array}$ \\
\end{tabular} & COHOCTON & STEUBEN & 7916 & 42.5422 & -77.4187 \\
\hline $31-099-22761-00-00$ & $22761-00$ & Poorman 2586-01 & \begin{tabular}{|l|} 
Meridian Exploration Corp. \\
\end{tabular} & FAYETTEN & SENECA & 5431 & 42.8393 & -76.837 \\
\hline $31-099-22762-00-00$ & $22762-00$ & Schaffer 2584-03 & $\begin{array}{c}\begin{array}{c}\text { Columbia Natural Resources } \\
\text { Inc. }\end{array} \\
\end{array}$ & FAYETTEN & SENECA & 5002 & 42.86 & -76.852 \\
\hline $31-099-22763-00-00$ & $22763-00$ & Murray 2587-01 & \begin{tabular}{|l|} 
Meridian Exploration Corp. \\
\end{tabular} & FAYETTEN & SENECA & 5452 & 42.8284 & -76.8378 \\
\hline 31-123-22764-00-00 & $22764-00$ & Costanza 1 & Belden \& Blake Corporation & ITALYN & YATES & 6580 & 42.6319 & -77.2788 \\
\hline 31-123-22764-01-00 & $22764-01$ & Costanza 1-A & Belden \& Blake Corporation & ITALYN & YATES & 6188 & 42.6319 & -77.2788 \\
\hline 31-123-22764-02-00 & $22764-02$ & Costanza 1-B & Belden \& Blake Corporation & ITALYN & YATES & 6258 & 42.6319 & -77.2788 \\
\hline
\end{tabular}




\begin{tabular}{|c|c|c|c|c|c|c|c|c|}
\hline UWI (APINum) & Well Label & Well Name & \begin{tabular}{|l|} 
Operator \\
\end{tabular} & Township & County & TD & Surf Lat & Surf Lon \\
\hline 31-101-22765-00-00 & $22765-00$ & Wise 1 (623520) & \begin{tabular}{|c|}
$\begin{array}{c}\text { Columbia Natural Resources } \\
\text { Inc. }\end{array}$ \\
\end{tabular} & PULTE EYN & STEUBEN & 7853 & 42.4931 & -77.2348 \\
\hline 31-101-22765-01-00 & $22765-01$ & Wise 623520-A & \begin{tabular}{|c|}
$\begin{array}{c}\text { Columbia Natural Resources } \\
\text { Inc. }\end{array}$ \\
\end{tabular} & PULTE EYN & STEUBEN & 7641 & 42.4931 & -77.2348 \\
\hline 31-101-22766-00-00 & $22766-00$ & Peck 1 (623516) & $\begin{array}{c}\text { Columbia Natural Resources } \\
\text { Inc. }\end{array}$ & COHOCTON & STEUBEN & 7644 & 42.5457 & -77.4413 \\
\hline 31-109-22767-00-00 & $22767-00$ & Duddleston 623514 & \begin{tabular}{|c|}
$\begin{array}{c}\text { Columbia Natural Resources } \\
\text { Inc. }\end{array}$ \\
\end{tabular} & ULY SESS & TOMPKINS & 7454 & 42.512 & -76.6361 \\
\hline 31-101-22768-00-00 & $22768-00$ & Covert 623222 & $\begin{array}{c}\text { Columbia Natural Resources } \\
\text { Inc. }\end{array}$ & PRATT BURGS & STEUBEN & 7386 & 42.5335 & -77.2719 \\
\hline 31-101-22769-00-00 & $22769-00$ & Ballam-Carter 1 & $\begin{array}{c}\begin{array}{c}\text { Columbia Natural Resources } \\
\text { Inc. }\end{array} \\
\end{array}$ & PULTE EYN & STEUBEN & 7581 & 42.5367 & -77.228 \\
\hline 31-101-22771-00-00 & $22771-00$ & Jimerson 1240 & $\begin{array}{c}\begin{array}{c}\text { Pennsylvania General } \\
\text { Energy }\end{array} \\
\end{array}$ & HOR BYN & STEUBEN & 9710 & 42.2147 & -77.0148 \\
\hline 31-101-22772-00-00 & $22772-00$ & Egresi 1 & \begin{tabular}{|c|}
$\begin{array}{c}\text { Columbia Natural Resources } \\
\text { Inc. }\end{array}$ \\
\end{tabular} & PULTE EYN & STEUBEN & 7152 & 42.5353 & -77.1721 \\
\hline $31-123-22773-00-00$ & $22773-00$ & Knapp 2 & $\begin{array}{c}\text { Columbia Natural Resources } \\
\text { Inc. }\end{array}$ & BARRI GTONN & YATES & 7598 & 42.524 & -77.082 \\
\hline 31-123-22773-01-00 & 22773-01 & Knapp 2 & \begin{tabular}{|c|}
$\begin{array}{c}\text { Columbia Natural Resources } \\
\text { Inc. }\end{array}$ \\
\end{tabular} & BARRI GTONN & YATES & & 42.524 & -77.082 \\
\hline 31-123-22774-00-00 & $22774-00$ & Knapp 3 & \begin{tabular}{|c|}
$\begin{array}{c}\text { Columbia Natural Resources } \\
\text { Inc. }\end{array}$ \\
\end{tabular} & BARRI GTONN & YATES & 7101 & 42.5307 & -77.0829 \\
\hline $31-123-22775-00-00$ & $22775-00$ & Walters 623641 & $\begin{array}{c}\text { Columbia Natural Resources } \\
\text { Inc. }\end{array}$ & JERU ALEMS & YATES & 6849 & 42.6141 & -77.1522 \\
\hline 31-123-22775-01-00 & $22775-01$ & Walters 623641-A & \begin{tabular}{|c|}
$\begin{array}{c}\text { Columbia Natural Resources } \\
\text { Inc. }\end{array}$ \\
\end{tabular} & JERU ALEMS & YATES & & 42.6141 & -77.1522 \\
\hline 31-123-22776-00-00 & $22776-00$ & Silk 1 (623638) & \begin{tabular}{|c|}
$\begin{array}{c}\text { Columbia Natural Resources } \\
\text { Inc. }\end{array}$ \\
\end{tabular} & BARRI GTONN & YATES & 7179 & 42.5513 & -77.0733 \\
\hline $31-109-22789-00-00$ & $22789-00$ & Rehebein/Call 1 & $\begin{array}{c}\text { Columbia Natural Resources } \\
\text { Inc. }\end{array}$ & DRYDEN & TOMPKINS & 7634 & 42.5428 & -76.2803 \\
\hline 31-109-22789-01-00 & 22789-01 & Rehebein/Call 1-A & \begin{tabular}{|c|}
$\begin{array}{c}\text { Columbia Natural Resources } \\
\text { Inc. }\end{array}$ \\
\end{tabular} & DRYDEN & TOMPKINS & & 42.5428 & -76.2803 \\
\hline 31-123-22790-01-00 & $22790-01$ & Agliata $1(623780-A)$ & \begin{tabular}{|c|}
$\begin{array}{c}\text { Columbia Natural Resources } \\
\text { Inc. }\end{array}$ \\
\end{tabular} & MILON & YATES & & 42.582 & -77.0625 \\
\hline 31-123-22791-00-00 & $22791-00$ & Bauer 1 (623781) & \begin{tabular}{|c|}
$\begin{array}{c}\text { Columbia Natural Resources } \\
\text { Inc. }\end{array}$ \\
\end{tabular} & BARRI GTONN & YATES & 7086 & 42.5763 & -77.0582 \\
\hline 31-123-22791-01-00 & 22791-01 & Bauer 623781-A & \begin{tabular}{|c|}
$\begin{array}{c}\text { Columbia Natural Resources } \\
\text { Inc. }\end{array}$ \\
\end{tabular} & BARRI GTONN & YATES & 7132 & 42.5763 & -77.0582 \\
\hline $31-097-22793-00-00$ & $22793-00$ & Cook 1 & \begin{tabular}{|c|}
$\begin{array}{c}\text { Columbia Natural Resources } \\
\text { Inc. }\end{array}$ \\
\end{tabular} & HECTORN & SCHUYLER & 7587 & 42.5355 & -76.7359 \\
\hline 31-097-22794-00-00 & $22794-00$ & Dell-Stilwell 1 (623749) & \begin{tabular}{|c|}
$\begin{array}{c}\text { Columbia Natural Resources } \\
\text { Inc. }\end{array}$ \\
\end{tabular} & HECTORN & SCHUYLER & 7650 & 42.4733 & -76.705 \\
\hline
\end{tabular}




\begin{tabular}{|c|c|c|c|c|c|c|c|c|}
\hline UWI (APINum) & Well Label & Well Name & Operator & Township & County & TD & Surf Lat & Surf Lon \\
\hline 31-097-22794-01-00 & 22794-01 & Dell-Stilwell 1 (623749-A) & $\begin{array}{c}\text { Columbia Natural Resources } \\
\text { Inc. }\end{array}$ & HECTORN & SCHUYLER & & 42.4733 & -76.705 \\
\hline 31-123-22795-00-00 & $22795-00$ & Martin-Repacki 1 & \begin{tabular}{|c|}
$\begin{array}{c}\text { Columbia Natural Resources } \\
\text { Inc. }\end{array}$ \\
\end{tabular} & BARRI GTONN & YATES & 7333 & 42.5345 & -77.0469 \\
\hline 31-123-22795-01-00 & 22795-01 & Martin-Repacki 1 A & \begin{tabular}{|c|}
$\begin{array}{c}\text { Columbia Natural Resources } \\
\text { Inc. }\end{array}$ \\
\end{tabular} & BARRI GTONN & YATES & & 42.5345 & -77.0469 \\
\hline 31-123-22796-00-00 & $22796-00$ & Zimmerman 623825 & $\begin{array}{c}\text { Columbia Natural Resources } \\
\text { Inc. }\end{array}$ & BARRI GTONN & YATES & 7482 & 42.548 & -77.0401 \\
\hline 31-123-22796-01-00 & $22796-01$ & Zimmerman 623825-A & $\begin{array}{c}\text { Columbia Natural Resources } \\
\text { Inc. }\end{array}$ & BARRI GTONN & YATES & 7624 & 42.548 & -77.0401 \\
\hline 31-123-22797-00-00 & $22797-00$ & Bedient 1 (623788) & \begin{tabular}{|c|}
$\begin{array}{c}\text { Columbia Natural Resources } \\
\text { Inc. }\end{array}$ \\
\end{tabular} & JERU ALEMS & YATES & 6887 & 42.5834 & -77.1663 \\
\hline 31-023-22798-00-00 & $22798-00$ & Underwood 1 (623835) & $\begin{array}{c}\text { Columbia Natural Resources } \\
\text { Inc. }\end{array}$ & SOLON & CORTLAND & 7250 & 42.6073 & -76.0419 \\
\hline 31-023-22798-01-00 & 22798-01 & Underwood 1 (623835-A) & \begin{tabular}{|c|}
$\begin{array}{c}\text { Columbia Natural Resources } \\
\text { Inc. }\end{array}$ \\
\end{tabular} & SOLON & CORTLAND & 7076 & 42.6073 & -76.0419 \\
\hline 31-097-22799-00-00 & $22799-00$ & Rumsey 1 (623838) & \begin{tabular}{|c|}
$\begin{array}{c}\text { Columbia Natural Resources } \\
\text { Inc. }\end{array}$ \\
\end{tabular} & TYRO EN & SCHUYLER & 8037 & 42.4451 & -77.0585 \\
\hline 31-097-22799-01-00 & $22799-01$ & Rumsey 1 (623838-A) & \begin{tabular}{|c|}
$\begin{array}{c}\text { Columbia Natural Resources } \\
\text { Inc. }\end{array}$ \\
\end{tabular} & TYRO EN & SCHUYLER & 7926 & 42.4446 & -77.0592 \\
\hline $31-023-22805-00-00$ & $22805-00$ & Bilodeau 1 (623836) & $\begin{array}{c}\begin{array}{c}\text { Columbia Natural Resources } \\
\text { Inc. }\end{array} \\
\end{array}$ & CORTLA DVILLEN & CORTLAND & 7263 & 42.5828 & -76.109 \\
\hline $31-023-22805-01-00$ & $22805-01$ & Bilodeau 1 (623836-A) & \begin{tabular}{|c|}
$\begin{array}{c}\text { Columbia Natural Resources } \\
\text { Inc. }\end{array}$ \\
\end{tabular} & CORTLA DVILLEN & CORTLAND & & 42.5828 & -76.109 \\
\hline $31-067-22809-00-00$ & $22809-00$ & Bartoszewski 1-14 & \begin{tabular}{|l|} 
RSE Partners-I L.P. \\
\end{tabular} & LYSA DERN & ONONDAGA & 3096 & 43.1651 & -76.467 \\
\hline 31-101-22814-00-00 & $22814-00$ & Howe 1300 & $\begin{array}{c}\text { Pennsylvania General } \\
\text { Energy } \\
\end{array}$ & HOR BYN & STEUBEN & 10355 & 42.2048 & -77.0545 \\
\hline 31-101-22814-01-00 & 22814-01 & Howe $1300-A$ & $\begin{array}{c}\text { Pennsylvania General } \\
\text { Energy }\end{array}$ & HOR BYN & STEUBEN & 10125 & 42.2048 & -77.0545 \\
\hline 31-011-22822-00-00 & $22822-00$ & Ziemba 1 & Peninsular Oil \& Gas Co. & CATON & CAYUGA & 3588 & 43.0944 & -76.5083 \\
\hline $31-101-22825-00-00$ & $22825-00$ & Rice 1301 & $\begin{array}{c}\text { Pennsylvania General } \\
\text { Energy }\end{array}$ & HOR BYN & STEUBEN & 9818 & 42.2126 & -77.0357 \\
\hline $31-015-22826-00-00$ & $22826-00$ & Broz Unit 1 & Fortuna Energy Inc. & VETERAN & CHEMUNG & 9362 & 42.2727 & -76.7741 \\
\hline $31-015-22827-00-00$ & $22827-00$ & Bennett Family 1 & \begin{tabular}{|l|} 
Fortuna Energy Inc. \\
\end{tabular} & VETERAN & CHEMUNG & 9455 & 42.2841 & -76.775 \\
\hline $31-123-22828-00-00$ & $22828-00$ & Martin 623864 & $\begin{array}{c}\text { Columbia Natural Resources } \\
\text { Inc. }\end{array}$ & BE TONN & YATES & 6652 & 42.6723 & -77.1046 \\
\hline $31-097-22829-00-00$ & $22829-00$ & Grand Prix 624065 & \begin{tabular}{|c|}
$\begin{array}{c}\text { Columbia Natural Resources } \\
\text { Inc. }\end{array}$ \\
\end{tabular} & ORA GEN & SCHUYLER & 9497 & 42.3236 & -77.0605 \\
\hline $31-097-22830-00-00$ & $22830-00$ & Grand Prix 624066 & $\begin{array}{c}\begin{array}{c}\text { Columbia Natural Resources } \\
\text { Inc. }\end{array} \\
\end{array}$ & ORA GEN & SCHUYLER & 9745 & 42.306 & -77.0808 \\
\hline $31-015-22831-00-00$ & 22831-00 & Lovell 1323 & $\begin{array}{c}\text { Pennsylvania General } \\
\text { Energy }\end{array}$ & BIG FLATS & CHEMUNG & 9824 & 42.1867 & -76.9585 \\
\hline
\end{tabular}




\begin{tabular}{|c|c|c|c|c|c|c|c|c|}
\hline UWI (APINum) & Well Label & Well Name & Operator & Township & County & TD & Surf Lat & Surf Lon \\
\hline $31-015-22838-00-00$ & $22838-00$ & Monahan 624115 & $\begin{array}{c}\begin{array}{c}\text { Columbia Natural Resources } \\
\text { Inc. }\end{array} \\
\end{array}$ & ERIN & CHEMUNG & 10380 & 42.1753 & -76.6516 \\
\hline $31-015-22839-00-00$ & $22839-00$ & Whiteman 1 & \begin{tabular}{|c|} 
Fortuna Energy Inc. \\
\end{tabular} & CATLIN & CHEMUNG & 9511 & 42.2852 & -76.9165 \\
\hline $31-123-22840-00-00$ & $22840-00$ & Dick 623970 & $\begin{array}{c}\text { Columbia Natural Resources } \\
\text { Inc. }\end{array}$ & JERU ALEMS & YATES & 6695 & 42.5979 & -77.168 \\
\hline $31-097-22841-00-00$ & $22841-00$ & SRA 2 \#1 & \begin{tabular}{|c|} 
Fortuna Energy Inc. \\
\end{tabular} & ORA GEN & SCHUYLER & 8770 & 42.3403 & -77.0207 \\
\hline $31-101-22844-00-00$ & $22844-00$ & Doyle 624125 & $\begin{array}{c}\text { Columbia Natural Resources } \\
\text { Inc. }\end{array}$ & PULTE EYN & STEUBEN & 7335 & 42.4959 & -77.1758 \\
\hline 31-101-22844-01-00 & 22844-01 & Doyle 624125-A & $\begin{array}{c}\text { Columbia Natural Resources } \\
\text { Inc. }\end{array}$ & PULTE EYN & STEUBEN & 7195 & 42.4959 & -77.1758 \\
\hline $31-101-22844-02-00$ & 22844-02 & Doyle 624125-B & $\begin{array}{c}\text { Columbia Natural Resources } \\
\text { Inc. }\end{array}$ & PULTE EYN & STEUBEN & 7117 & 42.4959 & -77.1758 \\
\hline $31-101-22845-00-00$ & $22845-00$ & Medrek 624126 & $\begin{array}{c}\text { Columbia Natural Resources } \\
\text { Inc. }\end{array}$ & PULTE EYN & STEUBEN & 7335 & 42.5089 & -77.173 \\
\hline $31-101-22845-01-00$ & 22845-01 & Medrek 624126-A & $\begin{array}{c}\text { Columbia Natural Resources } \\
\text { Inc. }\end{array}$ & PULTE EYN & STEUBEN & 7365 & 42.5089 & -77.173 \\
\hline $31-123-22850-00-00$ & $22850-00$ & Watson 1 & Belden \& Blake Corporation & ITALYN & YATES & 7136 & 42.6179 & -77.317 \\
\hline $31-101-22852-00-00$ & $22852-00$ & Van Vleet 1355 & $\begin{array}{c}\text { Pennsylvania General } \\
\text { Energy }\end{array}$ & HOR BYN & STEUBEN & 10458 & 42.2012 & -77.0867 \\
\hline $31-015-22853-00-00$ & $22853-00$ & Rhodes 1322 & $\begin{array}{c}\text { Pennsylvania General } \\
\text { Energy }\end{array}$ & BIG FLATS & CHEMUNG & 9682 & 42.1953 & -76.9212 \\
\hline $31-015-22857-00-00$ & $22857-00$ & Kimball 1 & Fortuna Energy Inc. & VETERAN & CHEMUNG & 9166 & 42.2727 & -76.7917 \\
\hline $31-123-22858-00-00$ & $22858-00$ & Mulligan 1 & Belden \& Blake Corporation & ITALYN & YATES & 6254 & 42.639 & -77.2774 \\
\hline $31-123-22858-01-00$ & $22858-01$ & Mulligan 1-A & Belden \& Blake Corporation & ITALYN & YATES & 5812 & 42.6378 & -77.2775 \\
\hline $31-101-22859-00-00$ & $22859-00$ & Huber 1 & Belden \& Blake Corporation & WAYLA DN & STEUBEN & 7526 & 42.5356 & -77.5922 \\
\hline 31-101-22861-00-00 & $22861-00$ & NYS GMA 2 & Fairman Drilling Co. & ERWIN & STEUBEN & 10526 & 42.1575 & -77.1649 \\
\hline 31-101-22861-01-00 & $22861-01$ & NYS GMA 2-A & Fairman Drilling Co. & ERWIN & STEUBEN & & 42.1575 & -77.1649 \\
\hline $31-015-22862-00-00$ & $22862-00$ & Lant 1 & Fortuna Energy Inc. & VETERAN & CHEMUNG & 9361 & 42.2682 & -76.8135 \\
\hline $31-101-22871-00-00$ & $22871-00$ & Henkel 1359 & $\begin{array}{c}\text { Pennsylvania General } \\
\text { Energy }\end{array}$ & COR INGN & STEUBEN & 0 & 42.1671 & -76.9727 \\
\hline $31-015-22880-00-00$ & $22880-00$ & Kienzle 1 & Fortuna Energy Inc. & VETERAN & CHEMUNG & 9121 & 42.2789 & -76.8142 \\
\hline $31-015-22880-01-00$ & $22880-01$ & Kienzle 1-A & Fortuna Energy Inc. & VETERAN & CHEMUNG & 9041 & 42.2789 & -76.8142 \\
\hline $31-097-22881-00-00$ & $22881-00$ & Learn 1 & Fortuna Energy Inc. & MO TOURN & SCHUYLER & 9060 & 42.3082 & -76.8161 \\
\hline $31-101-22884-00-00$ & $22884-00$ & Fratarcangelo 1371 & $\begin{array}{c}\text { Pennsylvania General } \\
\text { Energy }\end{array}$ & HOR BYN & STEUBEN & 9830 & 42.2345 & -76.977 \\
\hline 31-101-22884-01-00 & 22884-01 & Fratarcangelo 1371-A & $\begin{array}{c}\text { Pennsylvania General } \\
\text { Energy }\end{array}$ & HOR BYN & STEUBEN & 9818 & 42.2345 & -76.977 \\
\hline
\end{tabular}




\begin{tabular}{|c|c|c|c|c|c|c|c|c|}
\hline UWI (APINum) & Well Label & Well Name & Operator & Township & County & TD & Surf Lat & Surf Lon \\
\hline 31-101-22885-00-00 & $22885-00$ & Corning Game Club 624460 & $\begin{array}{c}\text { Pennsylvania General } \\
\text { Energy }\end{array}$ & COR INGN & STEUBEN & 10183 & 42.1799 & -77.0665 \\
\hline $31-097-22886-00-00$ & $22886-00$ & Ganung 1 & Fortuna Energy Inc. & DIXN & SCHUYLER & 9362 & 42.3091 & -76.8961 \\
\hline 31-097-22886-01-00 & $22886-01$ & Ganung 1-A & Fortuna Energy Inc. & DIXN & SCHUYLER & 8902 & 42.3091 & -76.8961 \\
\hline $31-097-22886-02-00$ & $22886-02$ & Ganung 1-B & Fortuna Energy Inc. & DIXN & SCHUYLER & 8964 & 42.3091 & -76.8961 \\
\hline $31-015-22889-00-00$ & $22889-00$ & Clauss Jr 1 & Fortuna Energy Inc. & VETERAN & CHEMUNG & 9513 & 42.2831 & -76.7941 \\
\hline 31-015-22889-01-00 & $22889-01$ & Clauss Jr 1-A & Fortuna Energy Inc. & VETERAN & CHEMUNG & 9115 & 42.2831 & -76.7941 \\
\hline $31-015-22890-00-00$ & $22890-00$ & Peterson 1 & Fortuna Energy Inc. & CATLIN & CHEMUNG & 9576 & 42.2864 & -76.8923 \\
\hline 31-015-22891-00-00 & 22891-00 & Parker 1401 & $\begin{array}{c}\text { Pennsylvania General } \\
\text { Energy } \\
\end{array}$ & CATLIN & CHEMUNG & 10323 & 42.2379 & -76.9389 \\
\hline 31-101-22892-00-00 & $22892-00$ & Hartman 624546 & $\begin{array}{c}\text { Pennsylvania General } \\
\text { Energy }\end{array}$ & COR INGN & STEUBEN & 10280 & 42.1775 & -77.0002 \\
\hline 31-101-22892-01-00 & 22892-01 & Hartman 624546-A & $\begin{array}{c}\text { Pennsylvania General } \\
\text { Energy }\end{array}$ & COR INGN & STEUBEN & 10214 & 42.1775 & -77.0002 \\
\hline $31-097-22893-00-00$ & $22893-00$ & Purvis 1 & Fortuna Energy Inc. & DIXN & SCHUYLER & 9162 & 42.2951 & -76.8601 \\
\hline 31-015-22899-00-00 & $22899-00$ & Trimber 624536 & \begin{tabular}{|c|}
$\begin{array}{c}\text { Columbia Natural Resources } \\
\text { Inc. }\end{array}$ \\
\end{tabular} & ERIN & CHEMUNG & 10530 & 42.1603 & -76.6871 \\
\hline 31-015-22899-01-00 & 22899-01 & Trimber 624536-A & $\begin{array}{c}\text { Columbia Natural Resources } \\
\text { Inc. }\end{array}$ & ERIN & CHEMUNG & 10364 & 42.1603 & -76.6871 \\
\hline $31-015-22901-00-00$ & $22901-00$ & Roy 1 & \begin{tabular}{|l|} 
Fortuna Energy Inc. \\
\end{tabular} & CATLIN & CHEMUNG & 9487 & 42.2713 & -76.957 \\
\hline 31-015-22902-00-00 & $22902-00$ & Lederer 1412 & $\begin{array}{c}\text { Pennsylvania General } \\
\text { Energy } \\
\end{array}$ & CATLIN & CHEMUNG & 9602 & 42.2525 & -76.8694 \\
\hline 31-015-22902-01-00 & $22902-01$ & Lederer 1412-A & $\begin{array}{c}\text { Pennsylvania General } \\
\text { Energy }\end{array}$ & CATLIN & CHEMUNG & & 42.2525 & -76.8694 \\
\hline 31-123-22903-00-00 & $22903-00$ & Zimmerman 624466 & \begin{tabular}{|c|}
$\begin{array}{c}\text { Columbia Natural Resources } \\
\text { Inc. }\end{array}$ \\
\end{tabular} & POTTERN & YATES & 5812 & 42.705 & -77.1335 \\
\hline 31-123-22903-01-00 & 22903-01 & Zimmerman 624466-A & \begin{tabular}{|c|}
$\begin{array}{c}\text { Columbia Natural Resources } \\
\text { Inc. }\end{array}$ \\
\end{tabular} & POTTERN & YATES & 5831 & 42.705 & -77.1335 \\
\hline 31-101-22908-00-00 & $22908-00$ & Hemly 1445 & $\begin{array}{c}\text { Pennsylvania General } \\
\text { Energy }\end{array}$ & HOR BYN & STEUBEN & 9652 & 42.2541 & -77.0967 \\
\hline $31-099-22909-00-00$ & $22909-00$ & Campion 1 & EOG Resources Inc & LODIN & SENECA & 7973 & 42.5529 & -76.8194 \\
\hline 31-099-22909-01-00 & 22909-01 & Campion 1-A & $\begin{array}{l}\text { Eastern American Energy } \\
\text { Corp. } \\
\end{array}$ & LODIN & SENECA & 7602 & 42.5529 & -76.8194 \\
\hline $31-015-22910-00-00$ & $22910-00$ & Gublo 1 & \begin{tabular}{|l|} 
Fortuna Energy Inc. \\
\end{tabular} & CATLIN & CHEMUNG & 9322 & 42.2785 & -76.8587 \\
\hline 31-015-22911-00-00 & 22911-00 & Schmidt 624537 & \begin{tabular}{|c|}
$\begin{array}{c}\text { Columbia Natural Resources } \\
\text { Inc. }\end{array}$ \\
\end{tabular} & ERIN & CHEMUNG & 10561 & 42.1467 & -76.6931 \\
\hline 31-015-22918-00-00 & 22918-00 & Gregory 1446 & $\begin{array}{c}\text { Pennsylvania General } \\
\text { Energy } \\
\end{array}$ & CATLIN & CHEMUNG & 9404 & 42.2072 & -76.8847 \\
\hline 31-015-22918-01-00 & 22918-01 & Gregory 1446-A & $\begin{array}{c}\text { Pennsylvania General } \\
\text { Energy } \\
\end{array}$ & CATLIN & CHEMUNG & 7602 & 42.2072 & -76.8847 \\
\hline 31-015-22919-00-00 & $22919-00$ & Hardy 1447 & $\begin{array}{c}\text { Pennsylvania General } \\
\text { Energy }\end{array}$ & CATLIN & CHEMUNG & 10039 & 42.2374 & -76.9205 \\
\hline
\end{tabular}




\begin{tabular}{|c|c|c|c|c|c|c|c|c|}
\hline UWI (APINum) & Well Label & Well Name & Operator & Township & County & TD & Surf Lat & Surf Lon \\
\hline 31-015-22919-01-00 & 22919-01 & Hardy 1447-A & $\begin{array}{l}\text { Pennsylvania General } \\
\text { Energy }\end{array}$ & CATLIN & CHEMUNG & 10398 & 42.2374 & -76.9205 \\
\hline $31-015-22924-00-00$ & $22924-00$ & Johnson 1 & Fairman Drilling Co. & VETERAN & CHEMUNG & 9965 & 42.2689 & -76.7512 \\
\hline 31-015-22924-01-00 & 22924-01 & Johnson 1-A & Fairman Drilling Co. & VETERAN & CHEMUNG & 9495 & 42.2689 & -76.7512 \\
\hline 31-015-22933-00-00 & 22933-00 & Usack 624684 & $\begin{array}{c}\text { Columbia Natural Resources } \\
\text { Inc. }\end{array}$ & ERIN & CHEMUNG & 10555 & 42.1586 & -76.6625 \\
\hline 31-107-22934-00-00 & $22934-00$ & Manwaring 624470 & $\begin{array}{c}\text { Columbia Natural Resources } \\
\text { Inc. }\end{array}$ & TIOGAN & TIOGA & 11651 & 42.0578 & -76.4101 \\
\hline 31-107-22934-01-00 & 22934-01 & Manwaring 624470-A & $\begin{array}{c}\begin{array}{c}\text { Columbia Natural Resources } \\
\text { Inc. }\end{array} \\
\end{array}$ & TIOGAN & TIOGA & 11535 & 42.0578 & -76.4101 \\
\hline $31-097-22935-00-00$ & $22935-00$ & Wonderview Farms 1 & \begin{tabular}{|l|} 
Fortuna Energy Inc. \\
\end{tabular} & CATHARI EN & SCHUYLER & 8880 & 42.3303 & -76.7472 \\
\hline $31-097-22935-01-00$ & $22935-01$ & Wonderview Farms 1-A & Fortuna Energy Inc. & CATHARI EN & SCHUYLER & & 42.3303 & -76.7472 \\
\hline 31-123-22939-00-00 & $22939-00$ & Button 624469 & $\begin{array}{c}\text { Columbia Natural Resources } \\
\text { Inc. }\end{array}$ & MIDDLE EXS & YATES & 5581 & 42.7464 & -77.623 \\
\hline 31-123-22939-01-00 & 22939-01 & Button 624469-A & \begin{tabular}{|c|}
$\begin{array}{c}\text { Columbia Natural Resources } \\
\text { Inc. }\end{array}$ \\
\end{tabular} & MIDDLE EXS & YATES & 5520 & 42.7464 & -77.2875 \\
\hline 31-123-22939-02-00 & 22939-02 & Button 624469-B & \begin{tabular}{|c|}
$\begin{array}{c}\text { Columbia Natural Resources } \\
\text { Inc. }\end{array}$ \\
\end{tabular} & MIDDLE EXS & YATES & 5550 & 42.7464 & -77.2875 \\
\hline 31-123-22940-00-00 & $22940-00$ & Folts 624464 & \begin{tabular}{|c|}
$\begin{array}{c}\text { Columbia Natural Resources } \\
\text { Inc. }\end{array}$ \\
\end{tabular} & JERU ALEMS & YATES & 6470 & 42.6275 & -77.1116 \\
\hline 31-123-22941-00-00 & 22941-00 & Boudinot 623968 & $\begin{array}{c}\begin{array}{c}\text { Columbia Natural Resources } \\
\text { Inc. }\end{array} \\
\end{array}$ & TARKEYS & YATES & 7181 & 42.5238 & -76.957 \\
\hline $31-097-22942-00-00$ & $22942-00$ & Bonham 1 & \begin{tabular}{|l|} 
Fortuna Energy Inc. \\
\end{tabular} & ORA GEN & SCHUYLER & 10098 & 42.2959 & -76.9894 \\
\hline 31-069-22943-00-00 & 22943-00 & Stoddard 624633 & $\begin{array}{c}\text { Columbia Natural Resources } \\
\text { Inc. }\end{array}$ & HOPEWELLN & ONTARIO & 4965 & 42.8888 & -77.1917 \\
\hline 31-101-22949-00-00 & $22949-00$ & Gray 624468 & $\begin{array}{c}\begin{array}{c}\text { Columbia Natural Resources } \\
\text { Inc. }\end{array} \\
\end{array}$ & PRATT BURGS & STEUBEN & 0 & 42.4971 & -77.3168 \\
\hline 31-099-22950-00-00 & $22950-00$ & Ziefle 1 & \begin{tabular}{|c|} 
Eastern American Energy \\
Corp.
\end{tabular} & COVERTN & SENECA & 7489 & 42.5641 & -76.7023 \\
\hline 31-099-22950-01-00 & $22950-01$ & Ziefle 1-A & $\begin{array}{l}\text { Eastern American Energy } \\
\text { Corp. }\end{array}$ & COVERTN & SENECA & & 42.5641 & -76.7023 \\
\hline 31-015-22960-00-00 & $22960-00$ & $\begin{array}{c}\text { Chemung SRA } 1 \text { Parcel A } \\
1459 \\
\end{array}$ & $\begin{array}{c}\text { Pennsylvania General } \\
\text { Energy }\end{array}$ & CATLIN & CHEMUNG & & 42.2445 & -76.9068 \\
\hline 31-101-22963-01-00 & $22963-01$ & Maxwell 1-A & East Resources Inc. & CATON & STEUBEN & 11502 & 42.0503 & -77.0369 \\
\hline $31-067-22965-00-00$ & $22965-00$ & Leubner 1 & Triana Energy Inc. & MARCELLUS & ONONDAGA & 5300 & 42.8994 & -76.3421 \\
\hline 31-067-22965-01-00 & 22965-01 & Leubner 1--A & $\begin{array}{c}\text { Columbia Natural Resources } \\
\text { LLC }\end{array}$ & O ONDAGAN & ONONDAGA & 5200 & 42.8994 & -76.3421 \\
\hline 31-067-22971-00-00 & $22971-00$ & Short 1 & \begin{tabular}{|l|} 
Triana Energy Inc. \\
\end{tabular} & MARCELLUS & ONONDAGA & 5139 & 42.9203 & -76.3473 \\
\hline $31-067-22971-01-00$ & $22971-01$ & Short 1-A & Triana Energy Inc. & MARCELLUS & ONONDAGA & 5412 & 42.9203 & -76.3473 \\
\hline $31-015-22975-00-00$ & $22975-00$ & Root 1514 & $\begin{array}{l}\text { Pennsylvania General } \\
\text { Energy }\end{array}$ & CATLIN & CHEMUNG & & 42.2385 & -76.8903 \\
\hline
\end{tabular}




\begin{tabular}{|c|c|c|c|c|c|c|c|c|}
\hline UWI (APINum) & Well Label & Well Name & Operator & Township & County & TD & Surf Lat & Surf Lon \\
\hline 31-101-22976-00-00 & $22976-00$ & Youmans 1511 & $\begin{array}{c}\text { Pennsylvania General } \\
\text { Energy }\end{array}$ & HOR BYN & STEUBEN & & 42.2613 & -76.9964 \\
\hline $31-101-22978-00-00$ & $22978-00$ & Ballymoney 1 & Fortuna (U.S.) Inc. & WEST U IONN & STEUBEN & 10660 & 42.0321 & -77.6776 \\
\hline 31-015-22979-00-00 & 22979-00 & Strope 1516 & $\begin{array}{c}\text { Pennsylvania General } \\
\text { Energy } \\
\end{array}$ & ERIN & CHEMUNG & 9787 & 42.1986 & -76.7242 \\
\hline 31-007-22984-00-00 & 22984-00 & Merrill 1 & Belden \& Blake Corporation & COLE VILLES & BROOME & 9800 & 42.1781 & -75.6707 \\
\hline 31-007-22984-01-00 & $22984-01$ & Merrill 1A & Belden \& Blake & & Broome & & 42.1781 & -75.6707 \\
\hline 31-069-22985-00-00 & $22985-00$ & Bay 1 & Belden \& Blake Corporation & GORHAMN & ONTARIO & 5796 & 42.7908 & -77.2136 \\
\hline 31-069-22985-01-00 & 22985-01 & Bay 1-A & Belden \& Blake Corporation & GORHAMN & ONTARIO & 12764 & 42.7908 & -77.2136 \\
\hline $31-069-22985-02-00$ & $22985-02$ & Bay 1B & Belden \& Blake Corp. & & Ontario & 5480 & 42.7908 & -77.2136 \\
\hline 31-007-22995-00-00 & 22995-00 & Beagell 2 & Belden \& Blake Corporation & KIRKWOODN & BROOME & 11632 & 42.1372 & -75.8339 \\
\hline 31-007-22995-01-00 & 22995-01 & Beagell 2-A & Belden \& Blake Corporation & KIRKWOODN & BROOME & & 42.1372 & -75.8339 \\
\hline $31-109-22997-00-00$ & $22997-00$ & Albanese 1 & Phillips Production Co. & EWFIELDN & TOMPKINS & 8940 & 42.3272 & -76.5504 \\
\hline 31-109-22997-01-00 & 22997-01 & Albanese $1 \mathrm{~A}$ & & & Tompkins & & 42.3272 & -76.5504 \\
\hline 31-109-22998-00-00 & $22998-00$ & Stevenson 1 & Phillips Production Co. & E FIELDN & TOMPKINS & 11965 & 42.4245 & -76.6387 \\
\hline 31-109-22998-01-00 & $22998-01$ & Stevenson 1-A & Phillips Production Co. & E FIELDN & TOMPKINS & 12900 & 42.4245 & -76.6387 \\
\hline $31-051-23003-00-00$ & $23003-00$ & Simpson 3 & Lenape Resources Inc. & YORKN & LIVINGSTON & 10600 & 42.8861 & -77.8818 \\
\hline 31-117-23015-00-00 & 23015-00 & High 1 & $\begin{array}{c}\text { Lenape Resources Corp., } \\
\text { The }\end{array}$ & ButlerN & Wayne & 3960 & 43.1563 & -76.7676 \\
\hline $31-007-23032-00-00$ & $23032-00$ & Pond 1 & Phillips Production Co. & & BROOME & 8990 & 42.2437 & -76.0445 \\
\hline $31-117-23037-00-00$ & $23037-00$ & Harper 1 & Triana Energy, Inc. & GalenN & & 0 & 43.0871 & -76.836 \\
\hline 31-101-23039-00-00 & $23039-00$ & Miller 1 & Triana Energy, Inc. & & & & 42.383 & -77.5452 \\
\hline $31-097-23053-00-00$ & $23053-00$ & WGI 1 & EOG Resources, Inc. & & & & 42.3353 & -76.9472 \\
\hline 31-097-23053-01-00 & $23053-01$ & WGI 1-A & EOG Resources Inc. & & SCHUYLER & 9797 & 42.3353 & -76.9472 \\
\hline 31-101-23054-00-00 & $23054-00$ & Hakes 1 & Fortuna Energy Inc. & & & & 42.1785 & -77.0172 \\
\hline 31-007-23056-00-00 & $23056-00$ & Butkowsky \#1 & Belden \& Blake Corp & & BROOME & & 42.1427 & -75.8253 \\
\hline $31-007-23056-01-00$ & $23056-01$ & & & & BROOME & & 42.1427 & -75.8253 \\
\hline 31-101-23059-00-00 & $23059-00$ & Apenowich 1 & Fortuna Energy Inc. & & Steubrn & 12620 & 42.1977 & -77.1237 \\
\hline $31-075-23070-00-00$ & $23070-00$ & Loomis \#1 & Seneca Resources Corp. & & Oswego & & 43.3648 & -76.274 \\
\hline 31-075-23071-00-00 & $23071-00$ & Huntley \#1 & Seneca Resources Corp. & & & & 43.2939 & -76.2981 \\
\hline $31-101-23085-00-00$ & $23085-00$ & Erwin WMA 1 & & ErwinN & STEUBEN & 0 & 42.1643 & -77.1499 \\
\hline $31-097-23086-00-00$ & $23086-00$ & & & & & 8841 & 42.3034 & -77.045 \\
\hline $31-065-23090-00-00$ & $23090-00$ & Wagner 1 & & VernonN & ONEIDA & 2660 & 43.0362 & -75.538 \\
\hline $31-053-23091-00-00$ & $23091-00$ & Green 1 & Ardent Reources Inc & StockbridgeN & MADISON & 0 & 43.0282 & -75.6428 \\
\hline $31-015-23134-00-00$ & $23134-00$ & Soderblom 1 & & Big FlatsN & CHEMUNG & 0 & 42.1927 & -76.8829 \\
\hline 31-013-23247-00-00 & $23247-00$ & Hayner \#2 & Belden \& Blake Corporation & WE TFIELDS & CHAUTAUQUA & 5953 & 42.2736 & -79.6413 \\
\hline
\end{tabular}




\begin{tabular}{|c|c|c|c|c|c|c|c|c|}
\hline UWI (APINum) & Well Label & Well Name & Operator & Township & County & TD & Surf Lat & Surf Lon \\
\hline 31-121-23389-00-00 & $23389-00$ & Krolick \#2 & Stedman Energy Inc. & ARCADEN & WYOMING & 6200 & 42.5647 & -78.4442 \\
\hline $31-009-23435-00-00$ & $23435-00$ & Geiger Hollow \#1 & Vertical Resources Inc. & ALLEGA YN & EATTARAUGUS & 9346 & 42.0284 & -78.5116 \\
\hline $31-121-23449-00-00$ & $23449-00$ & Jachim \#3 & Stedman Energy Inc. & ARCADEN & WYOMING & 6590 & 42.5568 & -78.3501 \\
\hline 31-009-23456-00-00 & $23456-00$ & Braymiller-Rauch \#1454 & $\begin{array}{c}\text { Pennsylvania General } \\
\text { Energy }\end{array}$ & YORK HIRES & EATTARAUGUS & 6500 & 42.4975 & -78.523 \\
\hline 31-009-23456-01-00 & 23456-01 & Braymiller-Rauch \#1454a & $\begin{array}{c}\text { Pennsylvania General } \\
\text { Energy }\end{array}$ & YORK HIRES & EATTARAUGUS & 9185 & 42.4975 & -78.523 \\
\hline $31-029-23533-00-00$ & $23533-00$ & Bockhahn Wm Unit 1 & Ardent Resources, Inc. & & Erie & 5945 & 42.5978 & -78.5978 \\
\hline 31-011-90001-00-00 & $90001-00$ & Auburn Geothermal & $\begin{array}{c}\text { Auburn Enlarged Central } \\
\text { School District }\end{array}$ & AUBUR CITYN & CAYUGA & 5260 & 42.9447 & -76.5447 \\
\hline
\end{tabular}




\begin{tabular}{|c|c|c|c|c|c|c|c|c|c|c|c|}
\hline Date & $\begin{array}{c}\text { Chlorides } \\
(\mathbf{m g} / \mathbf{L})\end{array}$ & $\begin{array}{c}\text { Time } \\
(\mathbf{m i l i t a r y})\end{array}$ & $\begin{array}{c}\text { Annular } \\
\text { Pressure }\end{array}$ & $\begin{array}{c}\text { Injection } \\
\text { Pressure }\end{array}$ & $\mathbf{p H}$ & SG & $\begin{array}{c}\text { Brine } \\
\text { Temp. }\end{array}$ & $\begin{array}{c}\text { Meter } \\
\text { Reading } \\
\text { Barrels }\end{array}$ & BPM & GPM & $\begin{array}{c}\text { Name of } \\
\text { Recorder }\end{array}$ \\
\hline & & 1330 & 320 & 1235 & & & & 539315 & 4.8 & 201.6 & T Rice \\
\hline & & 1430 & 240 & 1235 & & & & 539606 & 4.8 & 201.6 & T Rice \\
\hline & & 1530 & 230 & 1235 & & & & 539893 & 4.7 & 197.4 & T Rice \\
\hline & & 1600 & off for repairs & & & & 540018 & & & T Rice \\
\hline & & 1630 & 1710 & Restart & & & & & & & S Stahl \\
\hline & & 1730 & 180 & 1235 & & & & 540109 & 5.0 & 210.0 & S Stahl \\
\hline & & 1830 & 250 & 1240 & & & & 540408 & 5.0 & 210.0 & S Stahl \\
\hline & & 1930 & 280 & 1240 & & & & 540704 & 4.9 & 205.8 & S Stahl \\
\hline & & 2030 & 280 & 1240 & & & & 541000 & 4.9 & 205.8 & S Stahl \\
\hline & & 2130 & 290 & 1240 & & & & 541296 & 4.9 & 205.8 & S Stahl \\
\hline & & 2230 & 290 & 1240 & & & & 541591 & 4.9 & 205.8 & S Stahl \\
\hline & & 2330 & 300 & 1240 & & & & 541887 & 4.9 & 205.8 & S Stahl \\
\hline
\end{tabular}


Appendix C - Table 2 - Treton-Black River Formaton Tops

\begin{tabular}{|c|c|c|c|c|c|c|}
\hline API \# & Well Label & LORRAINE & UTICA & TRENTON & $\begin{array}{c}\text { BLACK } \\
\text { RIVER }\end{array}$ & $\begin{array}{c}\text { BLACK } \\
\text { RIVER } \\
\text { BOTTOM }\end{array}$ \\
\hline $31-121-00271-00-00$ & $00271-00$ & & & 5265 & & \\
\hline $31-015-00443-00-00$ & 00443-00 & 8123 & 8668 & 8899 & 9342 & 9810 \\
\hline $31-011-00478-00-00$ & $00478-00$ & & 4897 & 5054 & 5635 & 6045 \\
\hline $31-109-00481-00-00$ & 00481-00 & 5395 & 5700 & 6116 & & \\
\hline $31-121-00615-00-00$ & 00615-00 & 4524 & 5080 & 5340 & 5860 & 6195 \\
\hline $31-037-00650-00-00$ & $00650-00$ & & & 3702 & & \\
\hline $31-037-00651-00-00$ & 00651-00 & & & 2750 & & \\
\hline $31-055-00671-00-00$ & $00671-00$ & & & 600 & & \\
\hline $31-055-00672-00-00$ & $00672-00$ & 1409 & 1850 & 2006 & & \\
\hline $31-065-00680-00-00$ & 00680-00 & & & 956 & & \\
\hline $31-065-00681-00-00$ & 00681-00 & & & 885 & & \\
\hline $31-065-00682-00-00$ & $00682-00$ & & & 928 & & \\
\hline $31-065-00683-00-00$ & 00683-00 & & & 896 & & \\
\hline $31-065-00684-00-00$ & 00684-00 & & & 901 & & \\
\hline $31-065-00685-00-00$ & 00685-00 & & & 965 & & \\
\hline $31-065-00686-00-00$ & 00686-00 & & & 987 & & \\
\hline $31-065-00687-00-00$ & $00687-00$ & & & 994 & & \\
\hline $31-065-00689-00-00$ & 00689-00 & & & 1021 & & \\
\hline $31-065-00691-00-00$ & 00691-00 & & & 935 & & \\
\hline $31-065-00692-00-00$ & $00692-00$ & & & 846 & & \\
\hline $31-065-00693-00-00$ & 00693-00 & & & 980 & & \\
\hline $31-065-00694-00-00$ & 00694-00 & & & 942 & & \\
\hline $31-065-00695-00-00$ & 00695-00 & & 63 & 562 & & \\
\hline $31-065-00696-00-00$ & 00696-00 & & & 570 & & \\
\hline $31-065-00697-00-00$ & 00697-00 & & & 800 & & \\
\hline $31-065-00698-00-00$ & 00698-00 & & & 1507 & 1976 & \\
\hline $31-065-00700-00-00$ & $00700-00$ & & & 612 & & \\
\hline $31-065-00701-00-00$ & 00701-00 & 20 & 150 & 430 & & \\
\hline $31-065-00704-00-00$ & 00704-00 & & 21 & 548 & & \\
\hline $31-065-00707-00-00$ & $00707-00$ & & 505 & 635 & 1080 & \\
\hline $31-065-00709-00-00$ & 00709-00 & & 116 & 630 & & \\
\hline $31-073-00711-00-00$ & $00711-00$ & & & 1972 & 2713 & \\
\hline
\end{tabular}




\begin{tabular}{|c|c|c|c|c|c|c|}
\hline API \# & Well Label & LORRAINE & UTICA & TRENTON & $\begin{array}{c}\text { BLACK } \\
\text { RIVER }\end{array}$ & $\begin{array}{c}\text { BLACK } \\
\text { RIVER } \\
\text { BOTTOM }\end{array}$ \\
\hline $31-075-00712-00-00$ & $00712-00$ & 382 & 912 & 1025 & & \\
\hline $31-075-00713-00-00$ & $00713-00$ & & 1429 & 1624 & & \\
\hline $31-075-00714-00-00$ & 00714-00 & & & 1150 & & \\
\hline $31-075-00715-00-00$ & $00715-00$ & & & 1445 & & \\
\hline $31-075-00720-00-00$ & $00720-00$ & & & 1027 & & \\
\hline $31-075-00725-00-00$ & $00725-00$ & & & 1370 & & \\
\hline $31-075-00726-00-00$ & $00726-00$ & 585 & 1280 & 1370 & & \\
\hline $31-075-00727-00-00$ & $00727-00$ & & & 1645 & & \\
\hline $31-075-00728-00-00$ & $00728-00$ & & & 1197 & & \\
\hline $31-067-00804-00-00$ & $00804-00$ & 1765 & 1878 & 2270 & & \\
\hline $31-067-00805-00-00$ & $00805-00$ & & & 2240 & & \\
\hline $31-067-00807-00-00$ & $00807-00$ & & & 2255 & & \\
\hline $31-067-00808-00-00$ & $00808-00$ & 3000 & 3200 & 3730 & & \\
\hline $31-067-00809-00-00$ & $00809-00$ & & & 2404 & & \\
\hline $31-067-00810-00-00$ & $00810-00$ & & & 2248 & & \\
\hline $31-049-00824-00-00$ & $00824-00$ & & & 690 & & \\
\hline $31-049-00825-00-00$ & $00825-00$ & & & 614 & & \\
\hline $31-049-00826-00-00$ & 00826-00 & & & 602 & & \\
\hline $31-049-00828-00-00$ & $00828-00$ & & & 726 & 1324 & \\
\hline $31-029-00837-00-00$ & $00837-00$ & & & 3750 & & \\
\hline $31-029-00839-00-00$ & $00839-00$ & & & 2665 & & \\
\hline $31-029-00840-00-00$ & $00840-00$ & & & 2600 & & \\
\hline $31-045-00844-00-00$ & 00844-00 & & & 6 & & \\
\hline $31-065-00883-00-00$ & $00883-00$ & & & 515 & & \\
\hline $31-067-00884-00-00$ & 00884-00 & & & 2700 & & \\
\hline $31-067-00885-00-00$ & $00885-00$ & 1960 & & 2696 & 3370 & \\
\hline $31-067-00886-00-00$ & $00886-00$ & & & 3350 & & \\
\hline $31-067-00887-00-00$ & $00887-00$ & & 2160 & 2618 & & \\
\hline $31-067-00888-00-00$ & $00888-00$ & & & 2250 & & \\
\hline $31-073-00911-00-00$ & 00911-00 & & & 1825 & & \\
\hline $31-075-00912-00-00$ & $00912-00$ & & & 1535 & & \\
\hline $31-075-00913-00-00$ & 00913-00 & & & 1700 & & \\
\hline 31-075-00914-00-00 & 00914-00 & & & 1040 & & \\
\hline $31-099-00920-00-00$ & $00920-00$ & & & 3030 & & \\
\hline
\end{tabular}




\begin{tabular}{|c|c|c|c|c|c|c|}
\hline API \# & Well Label & LORRAINE & UTICA & TRENTON & $\begin{array}{c}\text { BLACK } \\
\text { RIVER }\end{array}$ & $\begin{array}{c}\text { BLACK } \\
\text { RIVER } \\
\text { BOTTOM }\end{array}$ \\
\hline $31-029-00988-00-00$ & 00988-00 & & & 3160 & & \\
\hline $31-029-00989-00-00$ & 00989-00 & 2225 & & 2855 & & \\
\hline $31-011-01003-00-00$ & $01003-00$ & & & 2492 & 3220 & 3590 \\
\hline $31-043-01005-00-00$ & $01005-00$ & & 195 & 475 & 580 & \\
\hline $31-075-01008-00-00$ & $01008-00$ & & & 1316 & 1976 & \\
\hline $31-117-01009-00-00$ & 01009-00 & & 1950 & 2700 & & \\
\hline $31-067-01010-00-00$ & $01010-00$ & & & 2700 & & \\
\hline $31-073-01013-00-00$ & 01013-00 & & & 1420 & & \\
\hline $31-013-01017-00-00$ & $01017-00$ & & & 4010 & & \\
\hline $31-029-01018-00-00$ & $01018-00$ & & & 2525 & & \\
\hline $31-029-01019-00-00$ & $01019-00$ & & 3150 & 3835 & & \\
\hline $31-029-01020-00-00$ & $01020-00$ & & & 2960 & & \\
\hline $31-065-01027-00-00$ & $01027-00$ & & 350 & 625 & 1025 & \\
\hline $31-065-01028-00-00$ & $01028-00$ & 510 & & 1165 & & \\
\hline $31-065-01029-00-00$ & $01029-00$ & & & 1400 & & \\
\hline $31-065-01033-00-00$ & 01033-00 & & & 320 & & \\
\hline $31-045-01034-00-00$ & $01034-00$ & & & 275 & & \\
\hline $31-073-01047-00-00$ & 01047-00 & & & 1814 & & \\
\hline $31-001-01071-00-00$ & 01071-00 & & & 2880 & & \\
\hline $31-013-01157-00-00$ & $01157-00$ & 2225 & & 2855 & & \\
\hline $31-017-01160-00-00$ & $01160-00$ & 3132 & 4100 & 4295 & 4500 & 4555 \\
\hline $31-049-01168-00-00$ & $01168-00$ & & & 1082 & & \\
\hline $31-049-01169-00-00$ & 01169-00 & & & 645 & & \\
\hline $31-049-01170-00-00$ & $01170-00$ & & & 660 & & \\
\hline $31-053-01173-00-00$ & $01173-00$ & 2510 & 2881 & 3093 & 3306 & \\
\hline $31-065-01176-00-00$ & $01176-00$ & & & 975 & & \\
\hline $31-065-01179-00-00$ & $01179-00$ & & & 1164 & & \\
\hline $31-065-01180-00-00$ & $01180-00$ & & & 945 & & \\
\hline $31-065-01181-00-00$ & $01181-00$ & & & 525 & & \\
\hline $31-065-01182-00-00$ & $01182-00$ & & & 500 & & \\
\hline $31-065-01183-00-00$ & 01183-00 & & & 464 & & \\
\hline $31-065-01184-00-00$ & 01184-00 & & 150 & 468 & & \\
\hline $31-065-01185-00-00$ & $01185-00$ & & & 728 & & \\
\hline $31-065-01186-00-00$ & 01186-00 & & & 439 & & \\
\hline
\end{tabular}




\begin{tabular}{|c|c|c|c|c|c|c|}
\hline API \# & Well Label & LORRAINE & UTICA & TRENTON & $\begin{array}{c}\text { BLACK } \\
\text { RIVER }\end{array}$ & $\begin{array}{c}\text { BLACK } \\
\text { RIVER } \\
\text { BOTTOM }\end{array}$ \\
\hline $31-065-01188-00-00$ & $01188-00$ & & & 430 & & \\
\hline $31-065-01190-00-00$ & $01190-00$ & & & 1383 & & \\
\hline $31-011-01301-00-00$ & $01301-00$ & & & 3300 & & \\
\hline 31-013-01464-00-00 & $01464-00$ & & & 3714 & 4150 & \\
\hline $31-029-01690-00-00$ & $01690-00$ & & & 3100 & & \\
\hline $31-013-01808-00-00$ & $01808-00$ & & & 3714 & 4144 & \\
\hline $31-117-01870-00-00$ & $01870-00$ & & & 2590 & & \\
\hline $31-117-01871-00-00$ & 01871-00 & & & 2540 & & \\
\hline $31-117-01872-00-00$ & $01872-00$ & & & 2582 & & \\
\hline $31-117-01873-00-00$ & $01873-00$ & & & 2579 & & \\
\hline $31-117-01874-00-00$ & 01874-00 & & & 2590 & & \\
\hline $31-067-01876-00-00$ & 01876-00 & & & 2205 & & \\
\hline $31-067-01877-00-00$ & $01877-00$ & & & 2250 & & \\
\hline $31-117-02287-00-00$ & 02287-00 & & & 2600 & & \\
\hline $31-045-02289-00-00$ & 02289-00 & & & 14 & & \\
\hline $31-067-02366-00-00$ & $02366-00$ & & & 2618 & & \\
\hline $31-067-02403-00-00$ & $02403-00$ & 1340 & & 2040 & & \\
\hline $31-067-02404-00-00$ & 02404-00 & 1404 & 1840 & 2097 & & \\
\hline $31-075-02426-00-00$ & 02426-00 & & & 1819 & & \\
\hline $31-075-02432-00-00$ & 02432-00 & & & 1197 & & \\
\hline $31-075-02433-00-00$ & 02433-00 & & & 450 & & 1170 \\
\hline $31-075-02446-00-00$ & 02446-00 & & & 600 & & \\
\hline $31-075-02448-00-00$ & 02448-00 & & & 400 & & \\
\hline $31-075-02449-00-00$ & $02449-00$ & & & 385 & & \\
\hline $31-075-02456-00-00$ & 02456-00 & & & 650 & & \\
\hline $31-075-02457-00-00$ & 02457-00 & & & 600 & & \\
\hline $31-075-02459-00-00$ & $02459-00$ & & & 380 & & \\
\hline $31-075-02460-00-00$ & $02460-00$ & & & 600 & & \\
\hline $31-075-02461-00-00$ & $02461-00$ & & & 410 & & \\
\hline $31-075-02463-00-00$ & $02463-00$ & & & 520 & & \\
\hline $31-075-02489-00-00$ & 02489-00 & 250 & 418 & 556 & 1142 & \\
\hline $31-075-02494-00-00$ & $02494-00$ & & & 600 & & \\
\hline $31-075-02495-00-00$ & $02495-00$ & & & 500 & & \\
\hline $31-075-02496-00-00$ & 02496-00 & & & 540 & & \\
\hline
\end{tabular}




\begin{tabular}{|c|c|c|c|c|c|c|}
\hline API \# & Well Label & LORRAINE & UTICA & TRENTON & $\begin{array}{c}\text { BLACK } \\
\text { RIVER }\end{array}$ & $\begin{array}{c}\text { BLACK } \\
\text { RIVER } \\
\text { BOTTOM }\end{array}$ \\
\hline $31-075-02497-00-00$ & 02497-00 & & & 555 & & \\
\hline $31-075-02498-00-00$ & 02498-00 & & & 566 & & \\
\hline $31-075-02499-00-00$ & 02499-00 & & & 620 & & \\
\hline $31-075-02500-00-00$ & $02500-00$ & & & 560 & & \\
\hline $31-075-02501-00-00$ & 02501-00 & & & 515 & & \\
\hline $31-075-02502-00-00$ & 02502-00 & & & 500 & & \\
\hline $31-075-02503-00-00$ & $02503-00$ & & & 560 & & \\
\hline $31-075-02504-00-00$ & 02504-00 & & & 484 & & \\
\hline $31-075-02505-00-00$ & 02505-00 & & & 565 & & \\
\hline $31-075-02506-00-00$ & $02506-00$ & & & 525 & & \\
\hline $31-075-02507-00-00$ & $02507-00$ & & & 568 & & \\
\hline $31-075-02508-00-00$ & $02508-00$ & & & 567 & & \\
\hline $31-075-02509-00-00$ & $02509-00$ & & & 580 & & \\
\hline $31-075-02510-00-00$ & $02510-00$ & & & 587 & & \\
\hline $31-075-02511-00-00$ & 02511-00 & & & 585 & & \\
\hline $31-075-02512-00-00$ & $02512-00$ & & & 560 & & \\
\hline $31-075-02513-00-00$ & $02513-00$ & & & 578 & & \\
\hline $31-075-02514-00-00$ & $02514-00$ & & & 551 & & \\
\hline $31-075-02515-00-00$ & 02515-00 & & & 550 & & \\
\hline $31-075-02516-00-00$ & $02516-00$ & & & 490 & & \\
\hline $31-075-02517-00-00$ & $02517-00$ & & & 525 & & \\
\hline $31-075-02518-00-00$ & 02518-00 & & & 542 & & \\
\hline $31-075-02519-00-00$ & 02519-00 & & & 540 & & \\
\hline $31-075-02520-00-00$ & $02520-00$ & & & 510 & & \\
\hline $31-075-02522-00-00$ & $02522-00$ & & & 555 & & \\
\hline $31-075-02523-00-00$ & 02523-00 & & & 560 & & \\
\hline $31-075-02524-00-00$ & 02524-00 & & & 555 & & \\
\hline $31-075-02525-00-00$ & $02525-00$ & & & 555 & & \\
\hline $31-075-02526-00-00$ & 02526-00 & & & 575 & & \\
\hline $31-075-02527-00-00$ & 02527-00 & & & 475 & & \\
\hline $31-075-02528-00-00$ & $02528-00$ & & & 482 & & \\
\hline $31-075-02529-00-00$ & 02529-00 & & & 450 & & \\
\hline $31-075-02530-00-00$ & $02530-00$ & & & 440 & & \\
\hline $31-075-02531-00-00$ & 02531-00 & & & 560 & & \\
\hline
\end{tabular}




\begin{tabular}{|c|c|c|c|c|c|c|}
\hline API \# & Well Label & LORRAINE & UTICA & TRENTON & $\begin{array}{c}\text { BLACK } \\
\text { RIVER }\end{array}$ & $\begin{array}{c}\text { BLACK } \\
\text { RIVER } \\
\text { BOTTOM }\end{array}$ \\
\hline $31-075-02532-00-00$ & 02532-00 & & & 538 & & \\
\hline $31-075-02533-00-00$ & $02533-00$ & & & 519 & & \\
\hline $31-075-02534-00-00$ & 02534-00 & & & 582 & & \\
\hline $31-075-02535-00-00$ & $02535-00$ & & & 543 & & \\
\hline $31-075-02536-00-00$ & $02536-00$ & & & 600 & & \\
\hline $31-075-02537-00-00$ & 02537-00 & & & 603 & & \\
\hline $31-075-02538-00-00$ & $02538-00$ & & & 610 & & \\
\hline $31-075-02539-00-00$ & $02539-00$ & & & 610 & & \\
\hline $31-075-02540-00-00$ & $02540-00$ & & & 606 & & \\
\hline $31-075-02541-00-00$ & 02541-00 & & & 589 & & \\
\hline $31-075-02542-00-00$ & $02542-00$ & & & 606 & & \\
\hline $31-075-02543-00-00$ & 02543-00 & & & 590 & & \\
\hline $31-075-02544-00-00$ & 02544-00 & & & 609 & & \\
\hline $31-075-02545-00-00$ & $02545-00$ & & & 630 & & \\
\hline $31-075-02546-00-00$ & $02546-00$ & & & 575 & & \\
\hline $31-075-02547-00-00$ & $02547-00$ & & & 603 & & \\
\hline $31-075-02548-00-00$ & $02548-00$ & & & 637 & & \\
\hline $31-075-02549-00-00$ & $02549-00$ & & & 616 & & \\
\hline $31-075-02550-00-00$ & $02550-00$ & & & 625 & & \\
\hline $31-075-02554-00-00$ & 02554-00 & & & 583 & & \\
\hline $31-075-02555-00-00$ & $02555-00$ & & & 583 & & \\
\hline $31-075-02556-00-00$ & $02556-00$ & & & 610 & & \\
\hline $31-075-02557-00-00$ & $02557-00$ & & & 592 & & \\
\hline $31-075-02558-00-00$ & $02558-00$ & & & 614 & & \\
\hline $31-075-02559-00-00$ & 02559-00 & & & 600 & & \\
\hline $31-075-02560-00-00$ & $02560-00$ & & & 611 & & \\
\hline $31-075-02561-00-00$ & 02561-00 & & & 605 & & \\
\hline $31-075-02562-00-00$ & $02562-00$ & & & 600 & & \\
\hline $31-075-02563-00-00$ & 02563-00 & & & 630 & & \\
\hline $31-045-02671-00-00$ & $02671-00$ & & & 75 & & \\
\hline $31-029-02959-00-00$ & 02959-00 & & & 2824 & & \\
\hline $31-013-03200-00-00$ & $03200-00$ & & 5823 & 6145 & 6625 & 6945 \\
\hline $31-065-03304-00-00$ & $03304-00$ & & & 199 & & \\
\hline $31-009-03868-00-00$ & $03868-00$ & 4006 & 4540 & 4850 & 5265 & 5621 \\
\hline
\end{tabular}




\begin{tabular}{|c|c|c|c|c|c|c|}
\hline API \# & Well Label & LORRAINE & UTICA & TRENTON & $\begin{array}{c}\text { BLACK } \\
\text { RIVER }\end{array}$ & $\begin{array}{c}\text { BLACK } \\
\text { RIVER } \\
\text { BOTTOM }\end{array}$ \\
\hline $31-055-03879-00-00$ & $03879-00$ & 1387 & & 2410 & & \\
\hline $31-039-03904-00-00$ & 03904-00 & & & 6029 & & \\
\hline $31-029-03917-00-00$ & 03917-00 & & & 2420 & 2875 & 3160 \\
\hline $31-101-03924-00-00$ & 03924-00 & & & 9675 & 10315 & 10870 \\
\hline $31-065-03928-00-00$ & 03928-00 & 2525 & 3000 & 3228 & 3460 & \\
\hline $31-009-03934-00-00$ & 03934-00 & & & 4778 & 5220 & 5540 \\
\hline $31-003-03956-00-00$ & 03956-00 & 5312 & 5960 & 6110 & 6610 & 7103 \\
\hline $31-053-03970-00-00$ & $03970-00$ & & 4130 & 4455 & 4685 & 4847 \\
\hline $31-109-03973-00-00$ & 03973-00 & 6984 & 7697 & 7767 & 8223 & \\
\hline $31-043-03993-00-00$ & 03993-00 & & & 2525 & 3000 & 3105 \\
\hline $31-109-04007-00-00$ & $04007-00$ & 7000 & 7715 & 7785 & 8245 & 8480 \\
\hline $31-053-04032-00-00$ & $04032-00$ & 2675 & 3480 & 3775 & 4126 & \\
\hline $31-043-04034-00-00$ & $04034-00$ & & 986 & 1763 & 2079 & 2166 \\
\hline $31-077-04055-00-00$ & $04055-00$ & 2518 & 3603 & 4264 & 4280 & 4305 \\
\hline $31-051-04069-00-00$ & 04069-00 & 2900 & 3350 & 3569 & 4188 & \\
\hline $31-121-04092-00-00$ & $04092-00$ & 4505 & 4899 & 5305 & 5816 & 6260 \\
\hline $31-109-04130-00-00$ & $04130-00$ & 6555 & 7100 & 7298 & 7750 & 8175 \\
\hline $31-121-04133-00-00$ & $04133-00$ & & & 4258 & 4834 & 5252 \\
\hline $31-049-04150-00-00$ & $04150-00$ & 425 & 690 & 1055 & 1550 & \\
\hline $31-013-04154-00-00$ & 04154-00 & 4555 & 5140 & 5430 & 5875 & 6184 \\
\hline $31-029-04183-00-00$ & $04183-00$ & & & 2900 & & \\
\hline $31-075-04201-00-00$ & 04201-00 & & & 460 & 1052 & 1320 \\
\hline $31-099-04203-00-00$ & $04203-00$ & 2974 & 3360 & 3554 & 4372 & 4760 \\
\hline $31-075-04208-00-00$ & 04208-00 & 700 & 1075 & 1482 & 2008 & 2200 \\
\hline $31-075-04209-00-00$ & 04209-00 & 950 & 1278 & 1615 & 2238 & 2596 \\
\hline $31-025-04214-00-00$ & 04214-00 & 7250 & 7640 & 8230 & 8300 & 8300 \\
\hline $31-003-04248-00-00$ & $04248-00$ & 5186 & 5648 & 5899 & 6450 & 6900 \\
\hline $31-075-04357-00-00$ & $04357-00$ & 408 & 698 & 841 & 1426 & 1657 \\
\hline $31-075-04358-00-00$ & $04358-00$ & & & 975 & 1372 & \\
\hline $31-025-04364-00-00$ & $04364-00$ & & & 7316 & 7398 & 7463 \\
\hline $31-025-04379-00-00$ & $04379-00$ & 5820 & & 6770 & 6790 & 6863 \\
\hline $31-121-04392-00-00$ & $04392-00$ & & & 4724 & 5238 & 5612 \\
\hline $31-121-04436-00-00$ & $04436-00$ & 3615 & 3990 & 4330 & 4904 & 5325 \\
\hline $31-013-04437-00-00$ & $04437-00$ & 5100 & 5944 & 5968 & 6370 & 6750 \\
\hline
\end{tabular}




\begin{tabular}{|c|c|c|c|c|c|c|}
\hline API \# & Well Label & LORRAINE & UTICA & TRENTON & $\begin{array}{c}\text { BLACK } \\
\text { RIVER }\end{array}$ & $\begin{array}{c}\text { BLACK } \\
\text { RIVER } \\
\text { BOTTOM }\end{array}$ \\
\hline $31-029-04440-00-00$ & $04440-00$ & 4078 & & 5004 & 5450 & 5800 \\
\hline $31-121-04447-00-00$ & $04447-00$ & 3620 & 4005 & 4355 & 4955 & 5370 \\
\hline $31-025-04455-00-00$ & 04455-00 & 5190 & & 6054 & 6122 & 6197 \\
\hline $31-013-04460-00-00$ & $04460-00$ & 3150 & 3580 & 3665 & 4082 & 4400 \\
\hline $31-121-04464-00-00$ & 04464-00 & 3145 & 3415 & 3875 & 4434 & 4850 \\
\hline $31-109-04467-00-00$ & 04467-00 & 6555 & 7140 & 7346 & 7820 & \\
\hline $31-073-04476-00-00$ & $04476-00$ & 616 & 1169 & 1331 & 1846 & 2185 \\
\hline $31-073-04489-00-00$ & 04489-00 & 529 & 955 & 1232 & 1740 & 2042 \\
\hline $31-055-04502-00-00$ & $04502-00$ & 515 & 884 & 1152 & 1780 & 2140 \\
\hline $31-075-04520-00-00$ & $04520-00$ & 168 & 410 & 632 & 1248 & 1512 \\
\hline $31-013-04535-00-00$ & $04535-00$ & 2878 & 3578 & 3714 & & \\
\hline $31-121-04536-00-00$ & $04536-00$ & 3480 & 3980 & 4200 & 4770 & 5166 \\
\hline $31-077-04547-00-00$ & $04547-00$ & 3151 & 3700 & 4342 & 4385 & \\
\hline $31-051-04552-00-00$ & $04552-00$ & 3162 & 3625 & 3855 & 4480 & 4880 \\
\hline $31-013-04561-00-00$ & 04561-00 & 4647 & 5277 & 5460 & 5860 & 6222 \\
\hline $31-051-04567-00-00$ & $04567-00$ & 2548 & 3045 & 3200 & 3840 & \\
\hline $31-037-04593-00-00$ & $04593-00$ & 1828 & 2216 & 2460 & 3050 & 3520 \\
\hline $31-073-04611-00-00$ & 04611-00 & 1323 & 1720 & 2007 & 2542 & 2880 \\
\hline $31-011-04624-00-00$ & 04624-00 & 1270 & 1670 & 1922 & 2594 & 2798 \\
\hline $31-051-04630-00-00$ & $04630-00$ & 3820 & 4280 & 4480 & 5065 & 5530 \\
\hline $31-029-04663-00-00$ & 04663-00 & & & 3234 & & \\
\hline $31-023-04714-00-00$ & 04714-00 & 5890 & 6724 & 6895 & 7157 & 7411 \\
\hline $31-011-04715-00-00$ & $04715-00$ & 2665 & & 3252 & 4023 & 4444 \\
\hline $31-063-04719-00-00$ & $04719-00$ & & & 1253 & & \\
\hline $31-073-04722-00-00$ & $04722-00$ & 1305 & 1750 & 2012 & 2510 & 2847 \\
\hline $31-055-04724-00-00$ & 04724-00 & 1456 & 1920 & 2105 & 2692 & 3137 \\
\hline $31-073-04730-00-00$ & $04730-00$ & 1500 & 1892 & 2166 & 2706 & 3060 \\
\hline $31-073-04752-00-00$ & $04752-00$ & 674 & 1198 & 1383 & 1870 & 2177 \\
\hline $31-073-04753-00-00$ & $04753-00$ & 496 & 860 & 1199 & 1692 & 1997 \\
\hline $31-117-04754-00-00$ & $04754-00$ & & & 2500 & 3189 & 3585 \\
\hline $31-069-04760-00-00$ & $04760-00$ & 2348 & 2700 & 2950 & 3526 & 4110 \\
\hline $31-073-04764-00-00$ & 04764-00 & 550 & 1180 & 1310 & 1824 & 2027 \\
\hline $31-037-04806-00-00$ & $04806-00$ & 1495 & 1862 & 2155 & 2788 & 3188 \\
\hline $31-069-04871-00-00$ & $04871-00$ & 2200 & & 2812 & 3500 & \\
\hline
\end{tabular}




\begin{tabular}{|c|c|c|c|c|c|c|}
\hline API \# & Well Label & LORRAINE & UTICA & TRENTON & $\begin{array}{c}\text { BLACK } \\
\text { RIVER }\end{array}$ & $\begin{array}{c}\text { BLACK } \\
\text { RIVER } \\
\text { BOTTOM }\end{array}$ \\
\hline $31-073-04873-00-00$ & 04873-00 & 455 & 868 & 1134 & 1691 & 1985 \\
\hline $31-073-04912-00-00$ & $04912-00$ & 895 & 1290 & 1562 & 2186 & 2435 \\
\hline $31-073-04994-00-00$ & 04994-00 & 618 & 1118 & 1261 & 1830 & 2150 \\
\hline 31-011-04999-00-00 & 04999-00 & 2466 & 2790 & 3110 & 3790 & 4120 \\
\hline $31-011-05000-00-00$ & $05000-00$ & 1950 & 2278 & 2556 & 3247 & 3572 \\
\hline $31-073-05007-00-00$ & $05007-00$ & 360 & 900 & 1216 & 1774 & 2080 \\
\hline $31-073-05008-00-00$ & $05008-00$ & 1053 & 1444 & 1745 & 2250 & 2605 \\
\hline $31-011-05011-00-00$ & 05011-00 & 1852 & 2146 & 2328 & 3012 & 3336 \\
\hline $31-075-05012-00-00$ & $05012-00$ & 970 & 1068 & 1430 & 2108 & 2452 \\
\hline $31-011-05031-00-00$ & 05031-00 & 1699 & 2057 & 2254 & 2926 & 3296 \\
\hline $31-117-05032-00-00$ & $05032-00$ & 2080 & 2290 & 2746 & 3496 & 3905 \\
\hline $31-117-05041-00-00$ & 05041-00 & 1730 & 2194 & 2348 & 3057 & 3442 \\
\hline $31-073-05069-00-00$ & $05069-00$ & 730 & 1102 & 1382 & 1946 & 2264 \\
\hline $31-073-05086-00-00$ & $05086-00$ & 816 & 1230 & 1470 & 2050 & 2380 \\
\hline $31-007-05087-00-00$ & $05087-00$ & 6618 & 7447 & 7537 & 7908 & 8165 \\
\hline $31-073-05091-00-00$ & 05091-00 & 720 & 1190 & 1388 & 1940 & 2260 \\
\hline $31-099-05095-00-00$ & 05095-00 & 2410 & 2608 & 2858 & 3618 & 3978 \\
\hline $31-073-05096-00-00$ & 05096-00 & 1410 & 1830 & 2120 & 2642 & 2965 \\
\hline $31-117-05114-00-00$ & $05114-00$ & 1874 & 2200 & 2485 & 3204 & 3615 \\
\hline $31-037-05115-00-00$ & $05115-00$ & 1742 & 2315 & 2460 & 2960 & 3324 \\
\hline $31-117-05116-00-00$ & $05116-00$ & 1819 & 2245 & 2434 & 3166 & 3564 \\
\hline $31-037-05117-00-00$ & $05117-00$ & 1935 & 2368 & 2713 & 3200 & 3555 \\
\hline $31-029-05402-00-00$ & $05402-00$ & & & 2504 & & \\
\hline $31-011-05467-00-00$ & 05467-00 & 2118 & 2430 & 2622 & 3292 & \\
\hline $31-121-06073-00-00$ & 06073-00 & 3795 & 4315 & 4540 & 5040 & 5525 \\
\hline 31-069-06395-00-00 & 06395-00 & 3736 & 3988 & 4285 & 5040 & \\
\hline $31-063-06667-00-00$ & 06667-00 & 1506 & 1746 & 1844 & 2340 & \\
\hline $31-029-06668-00-00$ & 06668-00 & 2168 & 2552 & 2994 & 3442 & 3792 \\
\hline $31-063-06669-00-00$ & $06669-00$ & 1618 & 1886 & 2105 & 2568 & \\
\hline $31-117-06719-00-00$ & $06719-00$ & 2184 & 2430 & 2786 & 3535 & 3825 \\
\hline $31-011-06779-00-00$ & $06779-00$ & 2004 & 2288 & 2558 & 3066 & \\
\hline $31-011-06780-00-00$ & $06780-00$ & 1984 & 2332 & 2552 & 3034 & \\
\hline $31-121-07234-00-00$ & 07234-00 & 3118 & 3716 & 3888 & 3994 & 4880 \\
\hline $31-121-07278-00-00$ & $07278-00$ & 3190 & 3674 & 3920 & 4423 & 4904 \\
\hline
\end{tabular}




\begin{tabular}{|c|c|c|c|c|c|c|}
\hline API \# & Well Label & LORRAINE & UTICA & TRENTON & $\begin{array}{c}\text { BLACK } \\
\text { RIVER }\end{array}$ & $\begin{array}{c}\text { BLACK } \\
\text { RIVER } \\
\text { BOTTOM }\end{array}$ \\
\hline $31-013-07649-00-00$ & 07649-00 & 4689 & 4946 & 5134 & 5542 & 5892 \\
\hline $31-009-08581-00-00$ & 08581-00 & 4042 & 4630 & 4889 & 5300 & 5655 \\
\hline $31-009-08610-00-00$ & $08610-00$ & 5020 & 5510 & 5818 & 6229 & 6620 \\
\hline $31-009-09235-00-00$ & 09235-00 & 7514 & & 8422 & 8834 & 9326 \\
\hline $31-013-09355-00-00$ & 09355-00 & & 3618 & 3835 & 4240 & 4605 \\
\hline $31-037-09524-00-00$ & 09524-00 & 2562 & 3087 & 3277 & 3732 & \\
\hline $31-073-09540-00-00$ & 09540-00 & 1194 & 1688 & 1852 & 2438 & 2815 \\
\hline $31-037-09563-00-00$ & 09563-00 & 1634 & 2126 & 2300 & 2914 & 3361 \\
\hline $31-053-09578-00-00$ & 09578-00 & 2992 & 3402 & 3776 & 4080 & \\
\hline $31-013-09939-00-00$ & 09939-00 & & 3760 & 4100 & 4512 & 4832 \\
\hline $31-025-10227-00-00$ & $10227-00$ & 5652 & 6389 & 6630 & 6644 & 6690 \\
\hline $31-015-10335-00-00$ & $10335-00$ & 8588 & 9208 & 9330 & 9827 & 10227 \\
\hline $31-037-10776-00-00$ & $10776-00$ & 2702 & 3174 & 3408 & 3962 & 4313 \\
\hline $31-077-10834-00-00$ & $10834-00$ & 3298 & 4012 & 4330 & 4550 & 4610 \\
\hline $31-099-10893-00-00$ & $10893-00$ & 2755 & 2915 & 3184 & 3976 & 4398 \\
\hline $31-055-10921-00-00$ & $10921-00$ & 530 & 890 & 1161 & 1794 & 2155 \\
\hline $31-121-10936-00-00$ & $10936-00$ & 3710 & 4220 & 4605 & 5190 & \\
\hline $31-121-10939-00-00$ & $10939-00$ & 3530 & 3988 & 4342 & 4795 & 5202 \\
\hline $31-029-11002-00-00$ & $11002-00$ & 4420 & 4890 & 5232 & 5680 & 6105 \\
\hline $31-029-11114-00-00$ & $11114-00$ & 2988 & 3402 & 3816 & 4262 & 4606 \\
\hline $31-011-11129-00-00$ & $11129-00$ & 2000 & 2238 & 2482 & 3022 & \\
\hline $31-013-11387-00-00$ & $11387-00$ & 4510 & & 5346 & 5747 & 6120 \\
\hline $31-029-11730-00-00$ & $11730-00$ & 3592 & 4030 & 4354 & 4804 & 5206 \\
\hline $31-067-12163-00-00$ & $12163-00$ & 3290 & 3660 & 3958 & & \\
\hline $31-121-12178-00-00$ & $12178-00$ & & & 4300 & 4840 & \\
\hline $31-075-12398-00-00$ & $12398-00$ & 270 & & 971 & 1581 & 1774 \\
\hline $31-075-12399-00-00$ & $12399-00$ & 132 & 318 & 734 & 1372 & 1682 \\
\hline $31-075-12406-00-00$ & $12406-00$ & & 468 & 758 & 1386 & 1700 \\
\hline $31-075-12447-00-00$ & $12447-00$ & & 400 & 683 & 1300 & 1597 \\
\hline $31-029-12745-00-00$ & $12745-00$ & & & 4722 & 5175 & 5472 \\
\hline $31-029-12910-00-00$ & $12910-00$ & 4060 & 4590 & 4846 & 5280 & 5642 \\
\hline $31-121-13278-00-00$ & $13278-00$ & 4698 & 5304 & 5578 & 6076 & 6458 \\
\hline $31-037-13672-00-00$ & $13672-00$ & 2260 & 2680 & 2919 & 3312 & \\
\hline $31-101-13699-00-00$ & $13699-00$ & 6500 & 6804 & 7091 & 7867 & 8429 \\
\hline
\end{tabular}




\begin{tabular}{|c|c|c|c|c|c|c|}
\hline API \# & Well Label & LORRAINE & UTICA & TRENTON & $\begin{array}{c}\text { BLACK } \\
\text { RIVER }\end{array}$ & $\begin{array}{c}\text { BLACK } \\
\text { RIVER } \\
\text { BOTTOM }\end{array}$ \\
\hline $31-051-13700-00-00$ & $13700-00$ & 3742 & 4228 & 4425 & 5022 & 5430 \\
\hline $31-101-15438-00-00$ & $15438-00$ & 5838 & 6122 & 6444 & 7215 & 7690 \\
\hline $31-053-15467-00-00$ & $15467-00$ & 3632 & 4340 & 4654 & & \\
\hline $31-067-15584-00-00$ & $15584-00$ & 1650 & 2045 & 2320 & 2975 & 3275 \\
\hline $31-075-15613-00-00$ & $15613-00$ & & 1306 & 1510 & 2030 & 2214 \\
\hline $31-075-15628-00-00$ & $15628-00$ & & & 956 & 1492 & 1712 \\
\hline $31-011-16120-00-00$ & $16120-00$ & 4705 & 4945 & 5310 & 5920 & 6455 \\
\hline $31-075-16814-00-00$ & $16814-00$ & & & 625 & & \\
\hline $31-075-16818-00-00$ & $16818-00$ & & & 745 & & \\
\hline $31-011-17508-00-00$ & $17508-00$ & 1818 & 2250 & 2438 & 3126 & 3444 \\
\hline $31-011-17509-00-00$ & $17509-00$ & & & 2414 & & \\
\hline $31-011-17510-00-00$ & $17510-00$ & 1792 & 2176 & 2400 & 3083 & 3402 \\
\hline $31-011-17558-00-00$ & $17558-00$ & 2548 & 2918 & 3142 & 3828 & 4196 \\
\hline $31-011-17559-00-00$ & $17559-00$ & 2612 & 3018 & 3202 & 3988 & 4424 \\
\hline $31-053-19485-00-00$ & $19485-00$ & 3422 & 3792 & 4004 & 4250 & \\
\hline $31-101-19497-00-00$ & $19497-00$ & 5822 & 6102 & 6424 & 7188 & 7690 \\
\hline $31-023-19540-00-00$ & $19540-00$ & 5758 & 6410 & 6645 & 7023 & 7313 \\
\hline $31-097-19692-00-00$ & $19692-00$ & 6532 & 6830 & 7162 & 7944 & \\
\hline $31-121-19937-00-00$ & $19937-00$ & 4166 & 4756 & 4972 & 5412 & \\
\hline $31-053-20411-00-00$ & 20411-00 & 3608 & 4462 & 4629 & 4876 & \\
\hline $31-097-20417-00-00$ & $20417-00$ & & & 7132 & 7916 & 8414 \\
\hline $31-099-20446-00-00$ & $20446-00$ & 3947 & 4264 & 4535 & 5367 & 5865 \\
\hline $31-037-20687-00-00$ & $20687-00$ & 1962 & 2302 & 2665 & 3186 & 3550 \\
\hline $31-057-21033-00-00$ & $21033-00$ & & & 165 & 279 & \\
\hline $31-067-21335-00-00$ & $21335-00$ & 2000 & 2365 & 2751 & 3420 & \\
\hline $31-067-21336-00-00$ & $21336-00$ & 2000 & 2250 & 2680 & 3404 & \\
\hline $31-101-21468-00-00$ & $21468-00$ & 6534 & 6876 & 7164 & 7819 & 8314 \\
\hline $31-011-21469-00-00$ & $21469-00$ & 2865 & & 3478 & 4175 & \\
\hline $31-097-21495-00-00$ & $21495-00$ & 8080 & 8405 & 8847 & 9320 & \\
\hline $31-101-21496-00-00$ & $21496-00$ & 6705 & 7208 & 7330 & 7986 & 8528 \\
\hline $31-023-21500-00-00$ & $21500-00$ & 5100 & 6028 & 6179 & 6487 & 6670 \\
\hline $31-101-21592-00-00$ & $21592-00$ & 5876 & 6197 & 6472 & 7245 & \\
\hline $31-101-21601-00-00$ & $21601-00$ & 7127 & 7678 & 7987 & 8381 & \\
\hline $31-101-21624-00-00$ & 21624-00 & 6544 & 6892 & 7174 & 7820 & 8345 \\
\hline
\end{tabular}




\begin{tabular}{|c|c|c|c|c|c|c|}
\hline API \# & Well Label & LORRAINE & UTICA & TRENTON & $\begin{array}{c}\text { BLACK } \\
\text { RIVER }\end{array}$ & $\begin{array}{c}\text { BLACK } \\
\text { RIVER } \\
\text { BOTTOM }\end{array}$ \\
\hline $31-101-21633-00-00$ & $21633-00$ & 6563 & 6939 & 7279 & 8147 & 8946 \\
\hline $31-101-21636-00-00$ & $21636-00$ & 6586 & 6985 & 7296 & 8109 & 8775 \\
\hline $31-101-21688-00-00$ & $21688-00$ & 5858 & 6193 & 6453 & 7211 & \\
\hline $31-101-21689-00-00$ & $21689-00$ & 5575 & 5978 & 6178 & 6948 & 7452 \\
\hline $31-101-21689-01-00$ & 21689-01 & 5588 & 5953 & 6191 & 6981 & \\
\hline $31-101-21692-00-00$ & $21692-00$ & 5489 & 5797 & 6089 & 6882 & \\
\hline $31-053-21699-00-00$ & $21699-00$ & 3400 & 4023 & 4247 & 4558 & \\
\hline $31-101-21703-00-00$ & $21703-00$ & 5170 & 5518 & 5772 & 6570 & \\
\hline $31-101-21704-00-00$ & 21704-00 & 6088 & 6435 & 6695 & 7556 & \\
\hline $31-101-21705-00-00$ & $21705-00$ & 5566 & 5887 & 6156 & 6945 & \\
\hline $31-101-21706-00-00$ & $21706-00$ & 5688 & 6018 & 6292 & 6675 & \\
\hline $31-101-21707-00-00$ & $21707-00$ & 5978 & 6578 & 6575 & 7342 & \\
\hline $31-101-21707-02-00$ & 21707-02 & 6003 & 6345 & 6574 & 7332 & \\
\hline $31-101-21710-00-00$ & $21710-00$ & 5224 & 5616 & 5826 & 6634 & \\
\hline $31-101-21712-00-00$ & 21712-00 & 5880 & 6208 & 6484 & 7255 & \\
\hline $31-101-21715-00-00$ & $21715-00$ & 6176 & 6740 & 6783 & 7525 & \\
\hline $31-109-21716-00-00$ & $21716-00$ & 5798 & 6295 & 6622 & 6998 & 7342 \\
\hline $31-101-21718-00-00$ & 21718-00 & 8902 & 9775 & 9785 & 10422 & \\
\hline $31-097-21725-00-00$ & $21725-00$ & 6056 & 6546 & 6828 & 7652 & \\
\hline $31-097-21726-00-00$ & $21726-00$ & 6168 & 6596 & 6748 & 7565 & \\
\hline $31-009-21809-00-00$ & $21809-00$ & 4875 & 5532 & 5712 & 6163 & 6523 \\
\hline $31-121-21840-00-00$ & $21840-00$ & 3200 & 3740 & 4070 & 4640 & 5056 \\
\hline $31-009-21860-00-00$ & $21860-00$ & 4258 & & 5077 & 5540 & 5877 \\
\hline $31-009-21869-00-00$ & $21869-00$ & 4522 & 5141 & 5366 & 5844 & 6194 \\
\hline $31-121-21900-00-00$ & $21900-00$ & 3140 & 3505 & 3834 & 4410 & \\
\hline $31-121-21907-00-00$ & 21907-00 & 3330 & 3726 & 4189 & 4755 & 5182 \\
\hline $31-121-21908-00-00$ & $21908-00$ & 3300 & 3780 & 4017 & 4586 & 5015 \\
\hline $31-121-21909-00-00$ & 21909-00 & 3400 & 3800 & 4120 & 4628 & 5115 \\
\hline $31-121-21920-00-00$ & $21920-00$ & 3234 & 3608 & 3958 & 4518 & 4918 \\
\hline $31-121-21945-00-00$ & 21945-00 & 3534 & 3820 & 4000 & 4576 & 4990 \\
\hline $31-121-21946-00-00$ & 21946-00 & 3120 & 3760 & 3994 & 4568 & 4994 \\
\hline $31-121-21962-00-00$ & 21962-00 & 3100 & 3448 & 3818 & 4402 & 4816 \\
\hline $31-121-21963-00-00$ & $21963-00$ & 3188 & 3589 & 3884 & 4458 & 4875 \\
\hline $31-121-21964-00-00$ & 21964-00 & 3390 & 3590 & 3856 & 4422 & 4838 \\
\hline
\end{tabular}




\begin{tabular}{|c|c|c|c|c|c|c|}
\hline API \# & Well Label & LORRAINE & UTICA & TRENTON & $\begin{array}{c}\text { BLACK } \\
\text { RIVER }\end{array}$ & $\begin{array}{c}\text { BLACK } \\
\text { RIVER } \\
\text { BOTTOM }\end{array}$ \\
\hline $31-121-22042-00-00$ & 22042-00 & 3230 & 3642 & 3942 & 4512 & 4930 \\
\hline $31-121-22046-00-00$ & $22046-00$ & & 3606 & 3810 & 4378 & 4796 \\
\hline $31-121-22053-00-00$ & 22053-00 & 3380 & 3977 & 4158 & 4660 & 5150 \\
\hline $31-013-22497-00-00$ & $22497-00$ & 4670 & 5362 & 5541 & 5948 & \\
\hline $31-013-22498-00-00$ & $22498-00$ & 4945 & 5490 & 5818 & 6206 & 6600 \\
\hline $31-121-22520-00-00$ & $22520-00$ & 4402 & 5030 & 5264 & 5690 & 6088 \\
\hline $31-013-22531-00-00$ & 22531-00 & 4768 & & 5639 & 6054 & 6462 \\
\hline $31-013-22588-00-00$ & $22588-00$ & 4797 & 5448 & 5668 & 6106 & 6379 \\
\hline $31-013-22596-00-00$ & $22596-00$ & 3448 & 3998 & 4250 & 4668 & 4990 \\
\hline $31-013-22616-00-00$ & $22616-00$ & & 4348 & 4698 & 5116 & 5538 \\
\hline $31-121-22655-00-00$ & $22655-00$ & 4220 & 4880 & 5115 & 5600 & 5932 \\
\hline $31-101-22741-00-00$ & 22741-00 & 5991 & 6310 & 6543 & 7371 & \\
\hline $31-101-22741-01-00$ & 22741-01 & 5987 & 6327 & 6540 & 7350 & \\
\hline $31-123-22743-00-00$ & $22743-00$ & 5507 & 5972 & 6108 & 6943 & \\
\hline $31-101-22745-00-00$ & $22745-00$ & 5927 & 6506 & 6496 & 7272 & \\
\hline $31-123-22746-00-00$ & $22746-00$ & 5884 & 6388 & 6478 & 7358 & \\
\hline $31-101-22747-00-00$ & $22747-00$ & 5968 & 6256 & 6524 & 7312 & \\
\hline $31-101-22748-00-00$ & $22748-00$ & 5782 & 6139 & 6336 & 7126 & \\
\hline $31-123-22750-00-00$ & $22750-00$ & 6004 & 6346 & 6603 & 7386 & \\
\hline $31-123-22752-00-00$ & $22752-00$ & 5554 & 5844 & 6143 & 7082 & \\
\hline $31-109-22753-00-00$ & $22753-00$ & 5772 & 6122 & 6410 & 7063 & \\
\hline $31-097-22754-00-00$ & 22754-00 & 6350 & 6769 & 7018 & 7624 & \\
\hline $31-101-22755-00-00$ & $22755-00$ & 5292 & 5824 & 5894 & 6684 & \\
\hline $31-101-22756-00-00$ & 22756-00 & 6026 & 6408 & 6609 & 7396 & \\
\hline $31-123-22757-00-00$ & 22757-00 & 5215 & 5569 & 5830 & 6582 & \\
\hline $31-123-22757-01-00$ & 22757-01 & 5215 & 5569 & 5821 & 6605 & \\
\hline $31-101-22758-00-00$ & $22758-00$ & 5636 & 6163 & 6263 & 6977 & \\
\hline $31-101-22758-01-00$ & 22758-01 & 5670 & 6040 & 6302 & 7022 & \\
\hline $31-101-22759-00-00$ & $22759-00$ & 6218 & 6625 & 6816 & 7505 & \\
\hline $31-101-22759-01-00$ & $22759-01$ & 6217 & 6615 & 6834 & 7506 & \\
\hline $31-101-22759-02-00$ & $22759-02$ & 6228 & 6578 & 6893 & 7620 & 8100 \\
\hline $31-101-22760-00-00$ & $22760-00$ & 6163 & 6597 & 6777 & 7445 & \\
\hline $31-101-22760-01-00$ & $22760-01$ & 6165 & 6518 & 6778 & 7488 & \\
\hline $31-099-22761-00-00$ & 22761-00 & 3104 & 3478 & 3680 & 4518 & 4910 \\
\hline
\end{tabular}




\begin{tabular}{|c|c|c|c|c|c|c|}
\hline API \# & Well Label & LORRAINE & UTICA & TRENTON & $\begin{array}{c}\text { BLACK } \\
\text { RIVER }\end{array}$ & $\begin{array}{c}\text { BLACK } \\
\text { RIVER } \\
\text { BOTTOM }\end{array}$ \\
\hline $31-099-22762-00-00$ & $22762-00$ & 3000 & 3300 & 3578 & 4400 & \\
\hline $31-099-22763-00-00$ & $22763-00$ & 3146 & 3520 & 3736 & 4588 & 5023 \\
\hline $31-123-22764-00-00$ & 22764-00 & 4600 & 4993 & 5238 & 5996 & \\
\hline $31-123-22764-01-00$ & 22764-01 & 4600 & 5050 & 5522 & 6005 & \\
\hline $31-123-22764-02-00$ & 22764-02 & 4600 & 5050 & 5221 & 5972 & \\
\hline $31-101-22765-00-00$ & $22765-00$ & 5995 & 6388 & 6602 & 7387 & \\
\hline $31-101-22765-01-00$ & 22765-01 & 5989 & 6352 & 6603 & 7414 & \\
\hline $31-101-22766-00-00$ & $22766-00$ & 5846 & 6216 & 6467 & 7205 & \\
\hline $31-109-22767-00-00$ & $22767-00$ & 5604 & 6117 & 6296 & 6939 & 7328 \\
\hline $31-101-22768-00-00$ & $22768-00$ & 5568 & 5872 & 6175 & 6946 & \\
\hline $31-101-22769-00-00$ & $22769-00$ & 5860 & 6240 & 6464 & 7244 & \\
\hline $31-101-22771-00-00$ & 22771-00 & 8200 & 8625 & 8994 & 9638 & \\
\hline $31-101-22772-00-00$ & $22772-00$ & 5326 & 5621 & 5930 & 6725 & \\
\hline $31-123-22773-00-00$ & $22773-00$ & 5632 & 5941 & 6214 & 7132 & \\
\hline $31-123-22773-01-00$ & 22773-01 & 5632 & 5952 & 6217 & 7144 & \\
\hline $31-123-22774-00-00$ & $22774-00$ & 5480 & 5780 & 6058 & 6980 & \\
\hline $31-123-22775-00-00$ & $22775-00$ & 4454 & 4956 & 5044 & 5846 & \\
\hline $31-123-22775-01-00$ & 22775-01 & 4455 & 4787 & 5060 & 5930 & \\
\hline $31-123-22776-00-00$ & $22776-00$ & 5196 & 5454 & 5754 & 6676 & \\
\hline $31-109-22789-00-00$ & $22789-00$ & 5886 & 6445 & 6692 & 7121 & 7475 \\
\hline $31-109-22789-01-00$ & 22789-01 & 5745 & 6520 & 6352 & 6756 & \\
\hline $31-123-22790-01-00$ & $22790-01$ & 4885 & 5245 & 5473 & 6640 & \\
\hline $31-123-22791-00-00$ & 22791-00 & 4938 & 5390 & 5580 & 6500 & \\
\hline $31-123-22791-01-00$ & 22791-01 & 5095 & 5403 & 5728 & 6704 & \\
\hline $31-097-22793-00-00$ & 22793-00 & 5792 & 6007 & 6376 & 7062 & \\
\hline $31-097-22794-00-00$ & 22794-00 & 5910 & 6336 & 6583 & 7189 & \\
\hline $31-097-22794-01-00$ & 22794-01 & 5925 & 6290 & 6615 & 7263 & \\
\hline $31-123-22795-00-00$ & 22795-00 & 5692 & 5958 & 6264 & 7143 & \\
\hline $31-123-22795-01-00$ & 22795-01 & 5675 & 5982 & 6270 & 7234 & \\
\hline $31-123-22796-00-00$ & $22796-00$ & 5488 & 5806 & 6057 & 6950 & \\
\hline $31-123-22796-01-00$ & 22796-01 & 5490 & 5718 & 6115 & 7088 & \\
\hline $31-123-22797-00-00$ & 22797-00 & 4868 & 5215 & 5463 & 6260 & \\
\hline $31-023-22798-00-00$ & 22798-00 & 5490 & 6340 & 6455 & 6807 & 7118 \\
\hline $31-023-22798-01-00$ & 22798-01 & 5487 & 6223 & 6461 & 6822 & \\
\hline
\end{tabular}




\begin{tabular}{|c|c|c|c|c|c|c|}
\hline API \# & Well Label & LORRAINE & UTICA & TRENTON & $\begin{array}{c}\text { BLACK } \\
\text { RIVER }\end{array}$ & $\begin{array}{c}\text { BLACK } \\
\text { RIVER } \\
\text { BOTTOM }\end{array}$ \\
\hline $31-097-22799-00-00$ & $22799-00$ & 6006 & 6350 & 6602 & 7452 & \\
\hline $31-097-22799-01-00$ & 22799-01 & 6006 & 6399 & 6618 & 7510 & \\
\hline $31-023-22805-00-00$ & $22805-00$ & 5590 & 6282 & 6524 & 6872 & \\
\hline $31-023-22805-01-00$ & 22805-01 & 5655 & 6300 & 6620 & 6985 & 7210 \\
\hline $31-067-22809-00-00$ & $22809-00$ & 1650 & 2000 & 2300 & 2941 & \\
\hline $31-101-22814-00-00$ & 22814-00 & 8460 & 8877 & 9234 & 9880 & \\
\hline $31-101-22814-01-00$ & 22814-01 & 8465 & 8878 & 9274 & 9962 & \\
\hline $31-011-22822-00-00$ & $22822-00$ & 1980 & 2318 & 2564 & 3242 & 3542 \\
\hline $31-101-22825-00-00$ & $22825-00$ & 8226 & 8650 & 9044 & 9726 & \\
\hline $31-015-22826-00-00$ & $22826-00$ & 7988 & 8501 & 8755 & 9308 & \\
\hline $31-015-22827-00-00$ & $22827-00$ & 7702 & 8153 & 8445 & 8978 & \\
\hline $31-123-22828-00-00$ & $22828-00$ & 4670 & 5015 & 5242 & 6035 & \\
\hline $31-097-22829-00-00$ & $22829-00$ & & & 7906 & 8416 & \\
\hline $31-097-22830-00-00$ & $22830-00$ & 7799 & 8309 & 8479 & 9178 & \\
\hline $31-015-22831-00-00$ & 22831-00 & 8400 & 8680 & 9155 & 9785 & \\
\hline $31-015-22838-00-00$ & 22838-00 & 8624 & 9228 & 9354 & 9910 & 10335 \\
\hline $31-015-22839-00-00$ & $22839-00$ & 7777 & 8307 & 8699 & 9430 & \\
\hline $31-123-22840-00-00$ & $22840-00$ & 4810 & 5098 & 5404 & 6208 & \\
\hline $31-097-22841-00-00$ & 22841-00 & 7257 & 7627 & 7902 & 8632 & \\
\hline $31-101-22844-00-00$ & $22844-00$ & 5610 & 5811 & 6196 & 6985 & \\
\hline $31-101-22844-01-00$ & 22844-01 & 5828 & 5945 & 6194 & 6986 & \\
\hline $31-101-22844-02-00$ & 22844-02 & 5610 & 5894 & 6202 & 7002 & \\
\hline $31-101-22845-00-00$ & $22845-00$ & 5453 & 5820 & 6056 & 6846 & \\
\hline $31-101-22845-01-00$ & 22845-01 & 5455 & 5890 & 6060 & 6890 & \\
\hline $31-123-22850-00-00$ & $22850-00$ & 5600 & 6000 & 6202 & 6953 & \\
\hline $31-101-22852-00-00$ & $22852-00$ & 8505 & 8890 & 9248 & 9926 & 10378 \\
\hline $31-015-22853-00-00$ & $22853-00$ & 8302 & 8600 & 9048 & 9594 & \\
\hline $31-015-22857-00-00$ & $22857-00$ & 7835 & 8240 & 8592 & 9114 & \\
\hline $31-123-22858-00-00$ & 22858-00 & 4510 & 4884 & 5114 & 5875 & \\
\hline $31-123-22858-01-00$ & 22858-01 & 4512 & 4886 & 5119 & 5886 & \\
\hline $31-101-22859-00-00$ & $22859-00$ & 5394 & 5931 & 6039 & 6665 & 7144 \\
\hline $31-101-22861-00-00$ & 22861-00 & 8472 & 9078 & 9220 & 9916 & \\
\hline $31-101-22861-01-00$ & 22861-01 & 8482 & 8975 & 9220 & 9927 & \\
\hline $31-015-22862-00-00$ & $22862-00$ & 7502 & 7881 & 8237 & 8767 & 9157 \\
\hline
\end{tabular}




\begin{tabular}{|c|c|c|c|c|c|c|}
\hline API \# & Well Label & LORRAINE & UTICA & TRENTON & $\begin{array}{c}\text { BLACK } \\
\text { RIVER }\end{array}$ & $\begin{array}{c}\text { BLACK } \\
\text { RIVER } \\
\text { BOTTOM }\end{array}$ \\
\hline $31-101-22871-00-00$ & 22871-00 & 8500 & 8867 & 9237 & 9795 & \\
\hline $31-015-22880-00-00$ & $22880-00$ & 7537 & 7997 & 8276 & 8822 & \\
\hline $31-015-22880-01-00$ & $22880-01$ & & 8038 & 8265 & 8790 & \\
\hline $31-097-22881-00-00$ & 22881-00 & 7271 & 7861 & 7989 & 8562 & \\
\hline $31-101-22884-00-00$ & $22884-00$ & 8100 & 8658 & 8916 & 9656 & \\
\hline $31-101-22884-01-00$ & 22884-01 & 8078 & 8610 & 8906 & 9668 & \\
\hline $31-101-22885-00-00$ & $22885-00$ & 8121 & 8429 & 8865 & 9496 & \\
\hline $31-097-22886-00-00$ & $22886-00$ & 7231 & 7819 & 7970 & 8746 & \\
\hline $31-097-22886-01-00$ & 22886-01 & 7196 & 7686 & 7913 & 8579 & \\
\hline $31-097-22886-02-00$ & 22886-02 & 7243 & 7778 & 8237 & 8758 & \\
\hline $31-015-22889-00-00$ & $22889-00$ & 7702 & 8168 & 8456 & 9002 & 9415 \\
\hline $31-015-22889-01-00$ & 22889-01 & 7700 & 8328 & 8439 & 8964 & \\
\hline $31-015-22890-00-00$ & $22890-00$ & 7448 & 7776 & 8219 & 8875 & 9308 \\
\hline $31-015-22891-00-00$ & 22891-00 & 8462 & 8850 & 9206 & 9886 & \\
\hline $31-101-22892-00-00$ & 22892-00 & 8435 & 9008 & 9182 & 9870 & \\
\hline $31-101-22892-01-00$ & 22892-01 & 8450 & 8822 & 9198 & 9886 & \\
\hline $31-097-22893-00-00$ & $22893-00$ & 7332 & 7763 & 8043 & 8616 & \\
\hline $31-015-22899-00-00$ & 22899-00 & 8769 & 9135 & 9497 & 9992 & \\
\hline $31-015-22899-01-00$ & 22899-01 & 8773 & 9381 & 9496 & 9989 & \\
\hline $31-015-22901-00-00$ & 22901-00 & 7612 & 7900 & 8359 & 9026 & \\
\hline $31-015-22902-00-00$ & $22902-00$ & 7961 & 8288 & 8695 & 9266 & \\
\hline $31-015-22902-01-00$ & 22902-01 & 7968 & 8425 & 8709 & 9316 & \\
\hline $31-123-22903-00-00$ & $22903-00$ & 4335 & 4720 & 4921 & 5700 & \\
\hline $31-123-22903-01-00$ & 22903-01 & 4335 & 4732 & 4930 & & \\
\hline $31-101-22908-00-00$ & 22908-00 & 7866 & & 8572 & 9412 & \\
\hline $31-099-22909-00-00$ & $22909-00$ & 5772 & 6230 & 6391 & 7082 & 7502 \\
\hline $31-099-22909-01-00$ & 22909-01 & 5772 & 6115 & 6388 & 7267 & \\
\hline $31-015-22910-00-00$ & $22910-00$ & 7870 & 8166 & 8587 & 9139 & \\
\hline $31-015-22911-00-00$ & 22911-00 & 8702 & 9318 & 9435 & 9940 & \\
\hline $31-015-22918-00-00$ & 22918-00 & 8076 & 8418 & 8788 & 9343 & \\
\hline $31-015-22918-01-00$ & 22918-01 & 8053 & 8420 & 8800 & 9389 & \\
\hline $31-015-22919-00-00$ & 22919-00 & 8395 & 8807 & 9172 & 9856 & \\
\hline $31-015-22919-01-00$ & 22919-01 & 8388 & 8870 & 9175 & 9950 & \\
\hline $31-015-22924-00-00$ & 22924-00 & 7802 & 8118 & 8594 & 9394 & 9863 \\
\hline
\end{tabular}




\begin{tabular}{|c|c|c|c|c|c|c|}
\hline API \# & Well Label & LORRAINE & UTICA & TRENTON & $\begin{array}{c}\text { BLACK } \\
\text { RIVER }\end{array}$ & $\begin{array}{c}\text { BLACK } \\
\text { RIVER } \\
\text { BOTTOM }\end{array}$ \\
\hline $31-015-22924-01-00$ & 22924-01 & 7802 & 8438 & 8598 & 9306 & \\
\hline $31-015-22933-00-00$ & 22933-00 & 8695 & 9339 & 9477 & 10081 & \\
\hline $31-107-22934-00-00$ & 22934-00 & 9710 & 10471 & 10626 & 11098 & 11390 \\
\hline $31-107-22934-01-00$ & 22934-01 & & 10150 & 10575 & 11034 & 11400 \\
\hline $31-097-22935-00-00$ & $22935-00$ & 7105 & 7717 & 7818 & 8361 & \\
\hline $31-097-22935-01-00$ & 22935-01 & 7114 & 7509 & 7844 & 8400 & \\
\hline $31-123-22939-00-00$ & $22939-00$ & 4008 & 4380 & 4577 & 5292 & \\
\hline $31-123-22939-01-00$ & 22939-01 & & 4342 & 4577 & 5281 & \\
\hline $31-123-22939-02-00$ & 22939-02 & & & 4658 & 5400 & \\
\hline $31-123-22940-00-00$ & $22940-00$ & 4830 & 5156 & 5418 & 6215 & \\
\hline $31-123-22941-00-00$ & 22941-00 & 5435 & 5891 & 6020 & 6837 & \\
\hline $31-097-22942-00-00$ & $22942-00$ & 8194 & & 8857 & 9580 & \\
\hline $31-069-22943-00-00$ & 22943-00 & 3045 & 3521 & 3727 & 4462 & 4895 \\
\hline $31-101-22949-00-00$ & $22949-00$ & 6440 & 6830 & 7053 & 7800 & \\
\hline $31-099-22950-00-00$ & $22950-00$ & 5650 & 6159 & 6291 & 7010 & 7382 \\
\hline $31-099-22950-01-00$ & 22950-01 & 5634 & 5963 & 6280 & 6999 & 7345 \\
\hline $31-015-22960-00-00$ & $22960-00$ & 8145 & 8630 & 8887 & 9498 & \\
\hline $31-101-22963-01-00$ & 22963-01 & 9904 & 10517 & 10642 & 11158 & 11408 \\
\hline $31-067-22965-00-00$ & 22965-00 & 3439 & & 4365 & 4924 & \\
\hline $31-067-22965-01-00$ & $22965-01$ & 3668 & 4147 & 4365 & 4591 & \\
\hline $31-067-22971-00-00$ & 22971-00 & 3520 & 3995 & 4210 & 4772 & \\
\hline $31-067-22971-01-00$ & 22971-01 & 3533 & 3980 & 4285 & 4866 & \\
\hline $31-015-22975-00-00$ & $22975-00$ & 7950 & 8623 & 8722 & 9339 & \\
\hline $31-101-22976-00-00$ & 22976-00 & 8508 & 8830 & 9240 & 9953 & \\
\hline $31-101-22978-00-00$ & 22978-00 & 9197 & 9943 & 10000 & 10470 & \\
\hline $31-015-22979-00-00$ & $22979-00$ & 6570 & 8645 & 8887 & 9420 & \\
\hline $31-007-22984-00-00$ & 22984-00 & 7959 & 9178 & 9351 & 9583 & 9744 \\
\hline $31-007-22984-01-00$ & 22984-01 & 7959 & 9179 & 9489 & 9698 & \\
\hline $31-069-22985-00-00$ & 22985-00 & 3883 & 4300 & 4435 & 5192 & 5592 \\
\hline $31-069-22985-01-00$ & 22985-01 & & 4235 & 4435 & 5221 & \\
\hline $31-069-22985-02-00$ & 22985-02 & 4019 & & 4442 & 4893 & \\
\hline $31-007-22995-00-00$ & 22995-00 & 8529 & 9527 & 9694 & 9934 & 10126 \\
\hline 31-007-22995-01-00 & 22995-01 & 8546 & & 9668 & 9914 & \\
\hline $31-109-22997-00-00$ & 22997-00 & 7453 & 8144 & 8234 & 8728 & \\
\hline
\end{tabular}




\begin{tabular}{|c|c|c|c|c|c|c|}
\hline API \# & Well Label & LORRAINE & UTICA & TRENTON & $\begin{array}{c}\text { BLACK } \\
\text { RIVER }\end{array}$ & $\begin{array}{c}\text { BLACK } \\
\text { RIVER } \\
\text { BOTTOM }\end{array}$ \\
\hline $31-109-22997-01-00$ & 22997-01 & & 8026 & 8259 & 8754 & \\
\hline 31-109-22998-00-00 & 22998-00 & 6474 & 6940 & 7210 & & \\
\hline $31-109-22998-01-00$ & 22998-01 & 6498 & 7052 & 7216 & 7647 & \\
\hline $31-051-23003-00-00$ & $23003-00$ & & 3240 & 3439 & 4064 & \\
\hline $31-117-23015-00-00$ & $23015-00$ & 1700 & & 2391 & 3110 & \\
\hline $31-007-23032-00-00$ & $23032-00$ & 7552 & 8334 & 8402 & 8766 & \\
\hline $31-117-23037-00-00$ & $23037-00$ & & & 2600 & & \\
\hline $31-101-23039-00-00$ & $23039-00$ & 6815 & 7370 & 7465 & 8091 & 8560 \\
\hline $31-097-23053-00-00$ & $23053-00$ & 7349 & & 8015 & 8707 & \\
\hline $31-097-23053-01-00$ & 23053-01 & 7332 & & 8020 & 8754 & \\
\hline $31-101-23054-00-00$ & $23054-00$ & 8681 & 9250 & 9412 & 10989 & \\
\hline $31-007-23056-00-00$ & $23056-00$ & 8550 & & 9695 & 9933 & \\
\hline $31-007-23056-01-00$ & $23056-01$ & & & 9676 & 9984 & \\
\hline $31-101-23059-00-00$ & $23059-00$ & 8124 & & 8854 & & \\
\hline $31-075-23070-00-00$ & $23070-00$ & 774 & 1334 & 1490 & 2100 & 2400 \\
\hline $31-075-23071-00-00$ & 23071-00 & 1057 & & 1747 & 2353 & \\
\hline $31-101-23085-00-00$ & $23085-00$ & 8395 & & 9104 & 9524 & \\
\hline $31-097-23086-00-00$ & $23086-00$ & 7290 & & 7988 & 8518 & \\
\hline $31-065-23090-00-00$ & $23090-00$ & & & 2144 & 2366 & \\
\hline $31-053-23091-00-00$ & 23091-00 & 1770 & & 2932 & 3182 & \\
\hline $31-015-23134-00-00$ & $23134-00$ & & 8810 & 9007 & 9482 & \\
\hline $31-013-23247-00-00$ & $23247-00$ & 4322 & 4733 & 4895 & 5296 & 5636 \\
\hline $31-121-23389-00-00$ & $23389-00$ & 4372 & 4972 & 5232 & 5684 & 6102 \\
\hline $31-009-23435-00-00$ & $23435-00$ & 7400 & 8107 & 8340 & 8765 & 9240 \\
\hline $31-121-23449-00-00$ & $23449-00$ & 4630 & 5248 & 5552 & 6050 & 6406 \\
\hline $31-009-23456-00-00$ & $23456-00$ & 4720 & 5411 & 5589 & 6060 & 6460 \\
\hline $31-009-23456-01-00$ & 23456-01 & 5175 & 5370 & 5604 & 6065 & 6480 \\
\hline $31-029-23533-00-00$ & 23533-00 & & & 5035 & 5604 & \\
\hline $31-011-90001-00-00$ & 90001-00 & 2860 & 3235 & 3460 & 4160 & 4500 \\
\hline
\end{tabular}




\section{Appendix C- Document 1}

\section{Calculation of Cavern Gas Storage Volume from Reserve Volume Trenton- Black River}

\section{Method 1}

1) $\frac{P_{R}}{P_{S}}=B_{G P}$

2) $\quad \frac{V_{R}\left(1-S_{w}\right)}{B_{P_{G}}}=V_{F}$

3) $\quad V_{G R} \cdot S G_{S} \cdot \rho_{W}=m_{B}$

4) $m_{B} \cdot\left(S_{S}\right)=m_{S}$

5) $\frac{m_{S}}{\rho_{S}}=V_{C}$

6) $\frac{P_{C}}{P_{S}}=B_{G S}$

7) $V_{C} \cdot B_{G S}=V_{C S}$

Where:

$P_{R} \quad=$ Pressure of gas in reservoir (psi)

$S_{S}=$ Saturation of salt in brine

$P_{S}=$ Surface or atmospheric pressure (Fraction) (psi)

$m_{S} \quad=$ Mass of salt that could be removed

$B_{G P}=$ Gas-Fluid Volume Factor of the potential disposal reservoir (unitless) based on the $\mathrm{mB}$ that is disposed (pounds)

$V_{F} \quad=$ Formation Volume $\left(\mathrm{ft}^{3}\right)$

$\rho_{S} \quad=$ Density of salt $\left(\right.$ pounds $/ \mathrm{ft}^{3}$ )

$V_{R} \quad=$ Volume of gas that was produced

$P_{C} \quad=$ Cavern Operating Pressure (psi) from $\mathrm{V}_{\mathrm{F}}(\mathrm{BCF})$

$V_{C} \quad=$ Potential cavern volume $\left(\mathrm{ft}^{3}\right)$

$\mathrm{S}_{\mathrm{W}}=$ Water saturation of gas produced

$B_{G S}=$ Gas-Fluid Volume Factor of the from potential disposal reservoir Cavern Development formation (Fraction) (unitless)

$S G_{S}=$ Specific Gravity of Salt (Fraction)

$\rho_{W} \quad=$ Density of water $\left(\right.$ pounds $/ \mathrm{ft}^{3}$ )

$m_{B}=$ Mass of brine with volume $V_{\mathrm{GR}}$ (pounds) 


\section{Sample Calculations for Method 1}

1) $\frac{P_{R}}{P_{S}}=B_{G P} \approx 250$ (Estimated for TBR at $9000 \mathrm{ft}$.)

2) $\quad \frac{V_{R}\left(1-S_{w}\right)}{B_{P G}}=V_{F}=\frac{10 B C F \cdot(1-0.7)}{250}=28 \mathrm{e}^{6} \mathrm{ft}^{3}$

3) $\quad V_{G R} \cdot S G_{S} \cdot \rho_{W}=m_{B}=\left(28 \mathrm{e}^{6} \mathrm{ft}^{3}\right) \cdot(1.18) \cdot\left(62.6 \mathrm{lb} / \mathrm{ft}^{3}\right)=2.06 e^{9} \mathrm{lb}$

4) $\quad m_{B} \cdot\left(S_{S}\right)=m_{S}=\left(2.06 e^{9} \mathrm{lb}\right) \cdot(0.25)=515 e^{6} \mathrm{lb}$

5) $\frac{m_{S}}{\rho_{S}}=V_{C}=\frac{515 e^{6} \mathrm{lb}}{134.8 \mathrm{lb} / \mathrm{ft}^{3}}=3.8 e^{6} \mathrm{ft}^{3}$

6) $\frac{P_{C}}{P_{S}}=B_{G S} \approx 235$ (Estimated for Salina at $4000 \mathrm{ft}$.)

(7) $\quad V_{C} \cdot B_{G S}=V_{C S}=\left(3.8 e^{6} \mathrm{ft}^{3}\right) \cdot 245=0.90 \mathrm{BCF}$ 


\section{Method 2}

1) $\frac{P_{R}}{P_{S}}=B_{G P}$

2) $\quad \frac{V_{R}\left(1-S_{w}\right)}{B_{P_{G}}}=V_{F}$

3) $\frac{V_{F}}{B_{B}}=V_{C}$

5) $\frac{P_{C}}{P_{S}}=B_{G S}$

4) $\quad V_{C} \cdot B_{G S}=V_{C S}$

Where:

$P_{R} \quad=$ Pressure of gas in reservoir $(\mathrm{psi})$

$B_{B} \quad=$ Brine Volume Factor (unitless)

$P_{S} \quad=$ Surface or atmospheric pressure

$\mathrm{S}_{\mathrm{w}}=$ Water saturation of gas produced (psi)

$B_{G P}=$ Gas-Fluid Volume Factor of the from potential disposal reservoir (Fraction) potential disposal reservoir (unitless)

$V_{C} \quad=$ Potential cavern volume $\left(\mathrm{ft}^{3}\right)$

$V_{F} \quad=$ Formation Volume $\left(\mathrm{ft}^{3}\right)$

$V_{R} \quad=$ Volume of gas that was produced from $\mathrm{V}_{\mathrm{F}}(\mathrm{BCF})$

$P_{C} \quad=$ Cavern Operating Pressure (psi)

$B_{G S}=$ Gas-Fluid Volume Factor of the Cavern Development formation (unitless)

\section{Sample Calculations for Method 2}

1) $\frac{P_{R}}{P_{S}}=B_{G P} \approx 250$ (Estimated for TBR at $9000 \mathrm{ft}$.)

2) $\quad \frac{V_{R}\left(1-S_{w}\right)}{B_{P G}}=V_{F}=\frac{10 B C F \cdot(1-0.7)}{250}=28 \mathrm{e}^{6} \mathrm{ft}^{3}$

3) $\frac{V_{F}}{B_{B}}=V_{C}=\frac{28 e^{6} \mathrm{ft}^{3}}{7}=4 e^{6} \mathrm{ft}^{3}$

4) $\frac{P_{C}}{P_{S}}=B_{G S} \approx 240$ (Estimated for Salina at $4000 \mathrm{ft}$.)

5) $\quad V_{C} \cdot B_{G S}=V_{C S}=\left(4 e^{6} f^{3}\right) \cdot(245)=0.98 B C F$ 


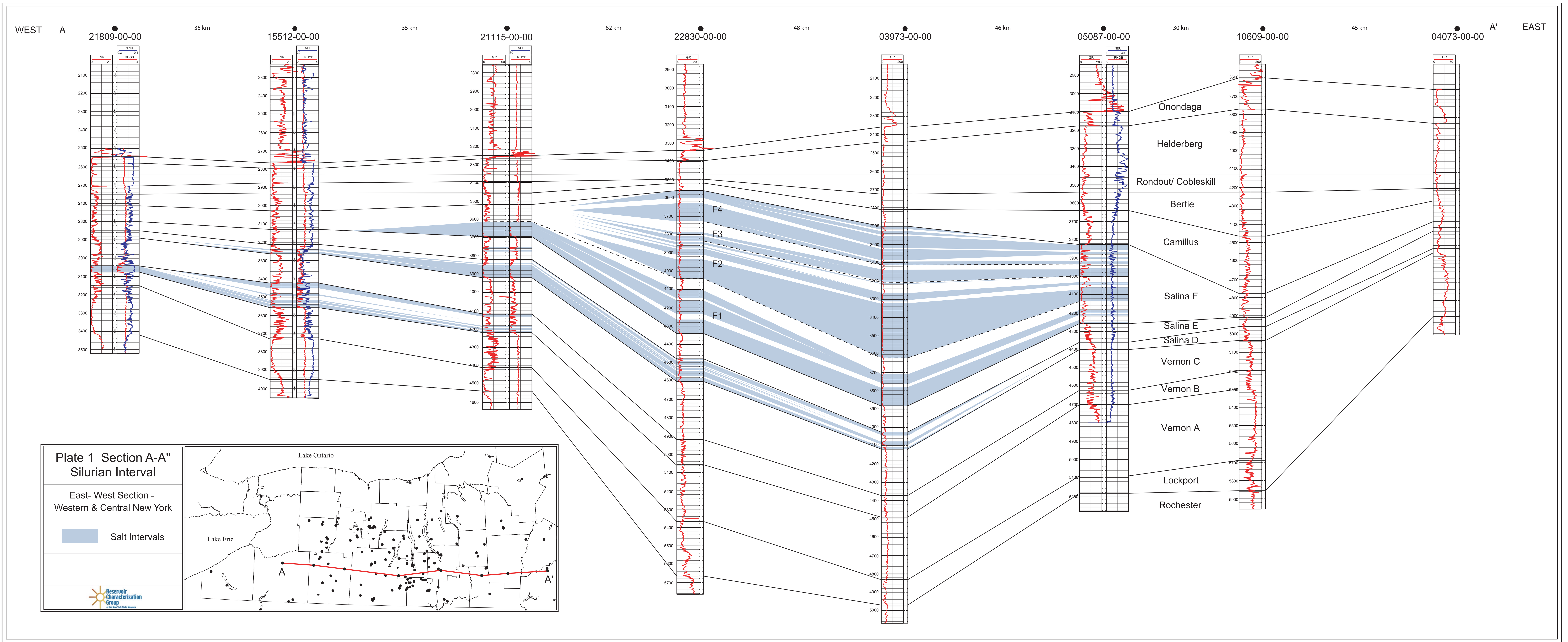




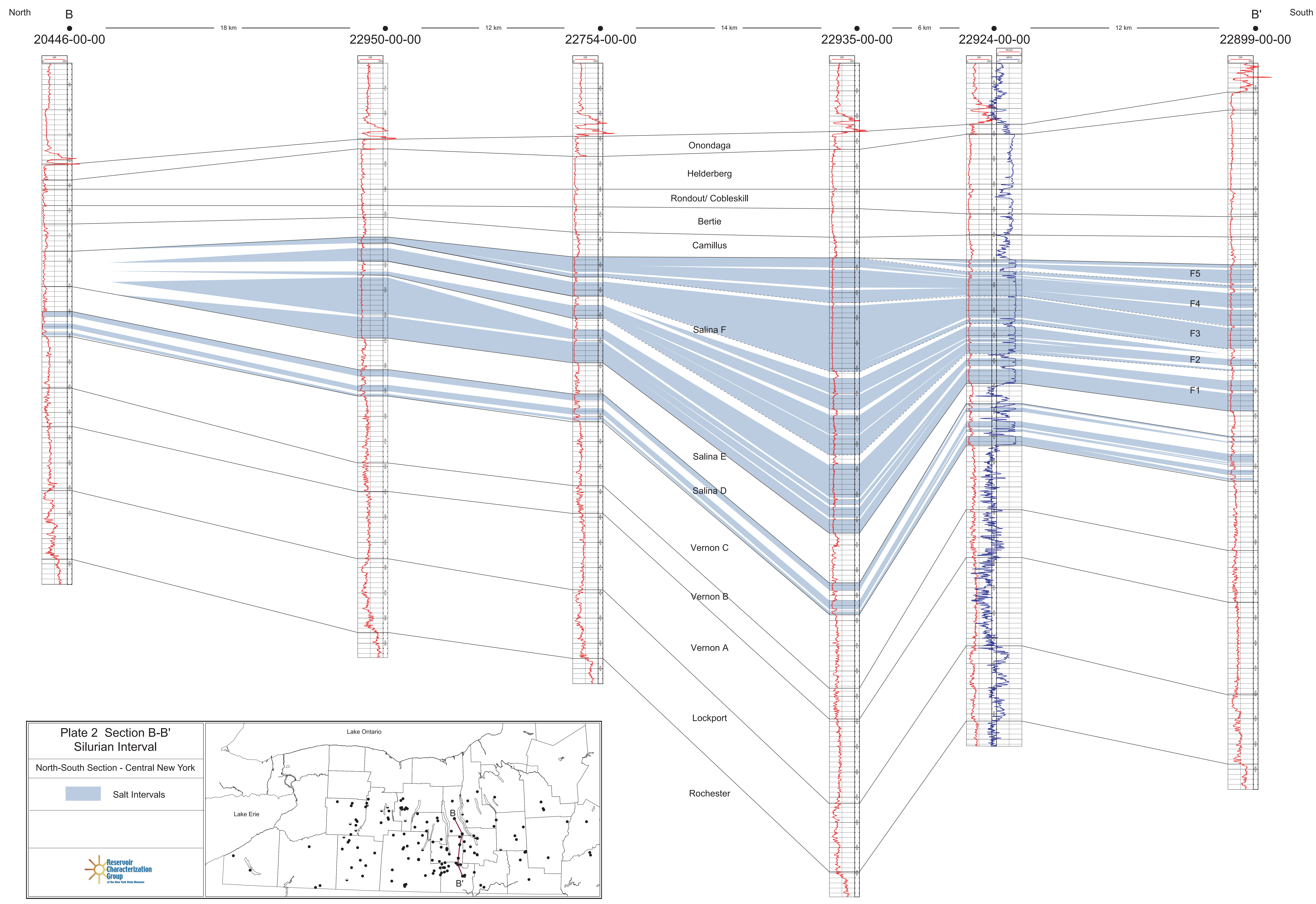




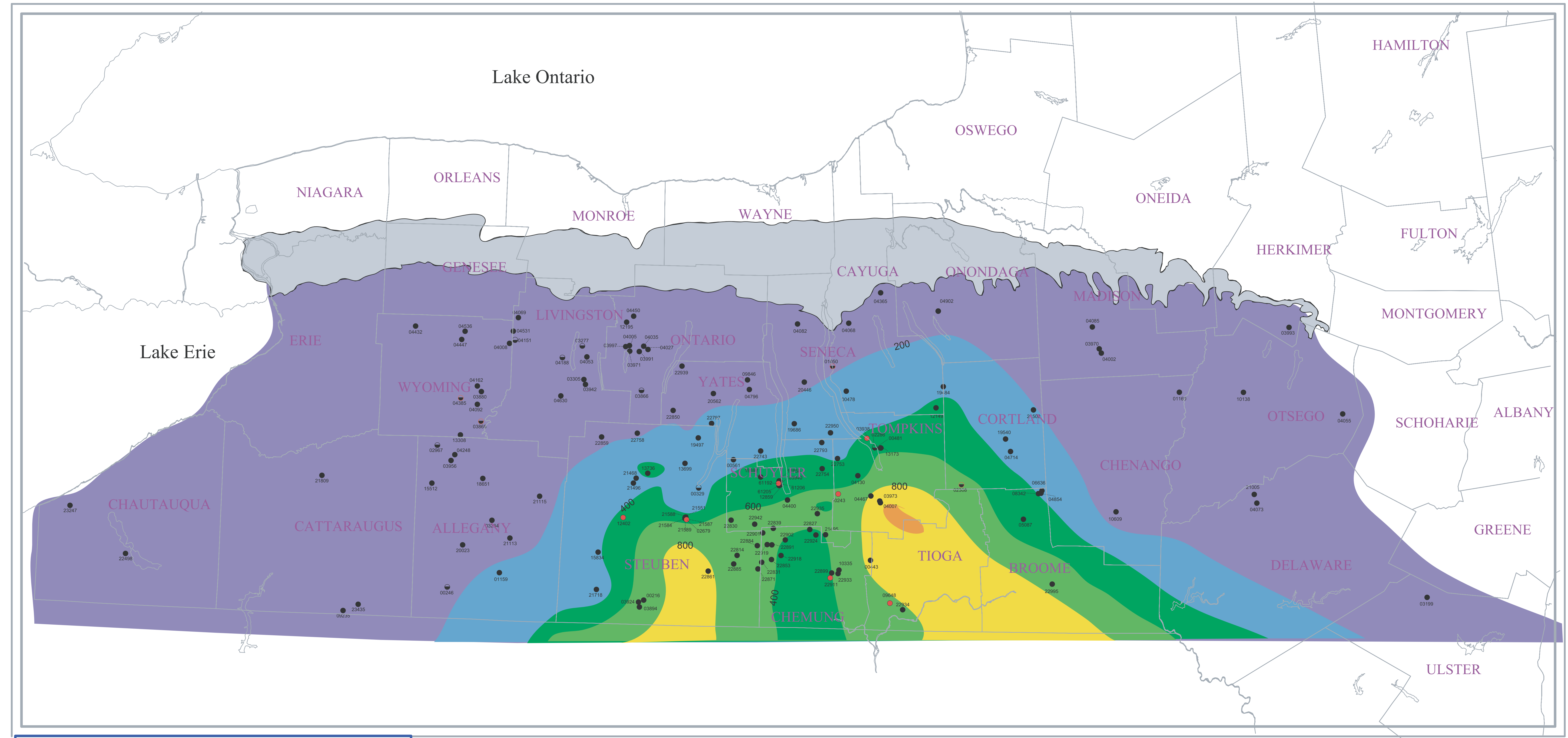

\begin{tabular}{|c|c|}
\hline \multicolumn{2}{|c|}{ Salina F-unit Isopachous Map } \\
\hline \multicolumn{2}{|c|}{ Scale } \\
Well Symbols \\
- Wells with Raster logs \\
- Wells without Raster logs
\end{tabular}

Plate 3 Isopachous map of the entire (aggregate) thickness of the Salina F-unit. This includes both salt and nonsalt beds. South central New York has the greatest thicknesses in the F-unit. The thickening of the F-unit is primarily due to the addition of many thick salt beds, making this area desirable for salt cavern development. 


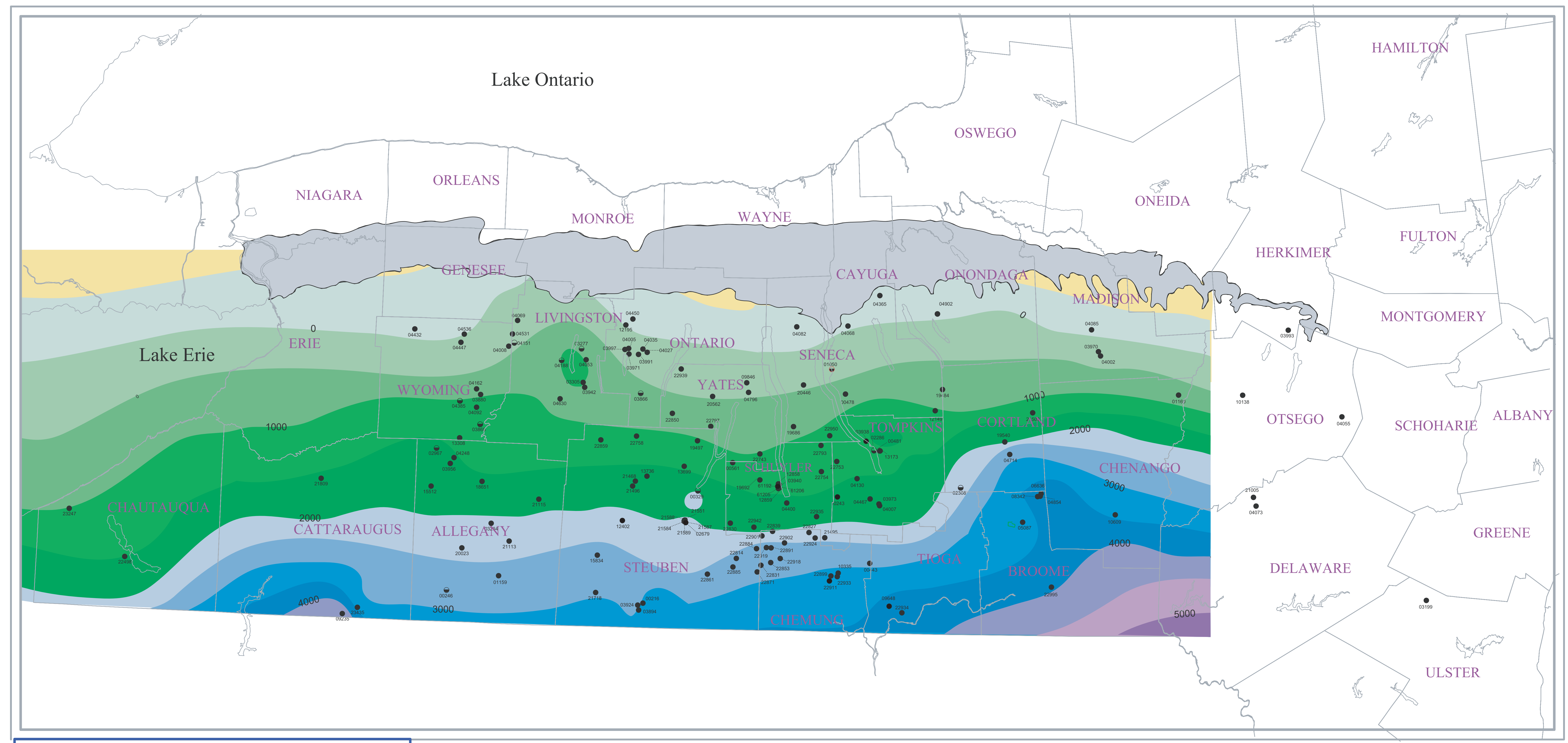

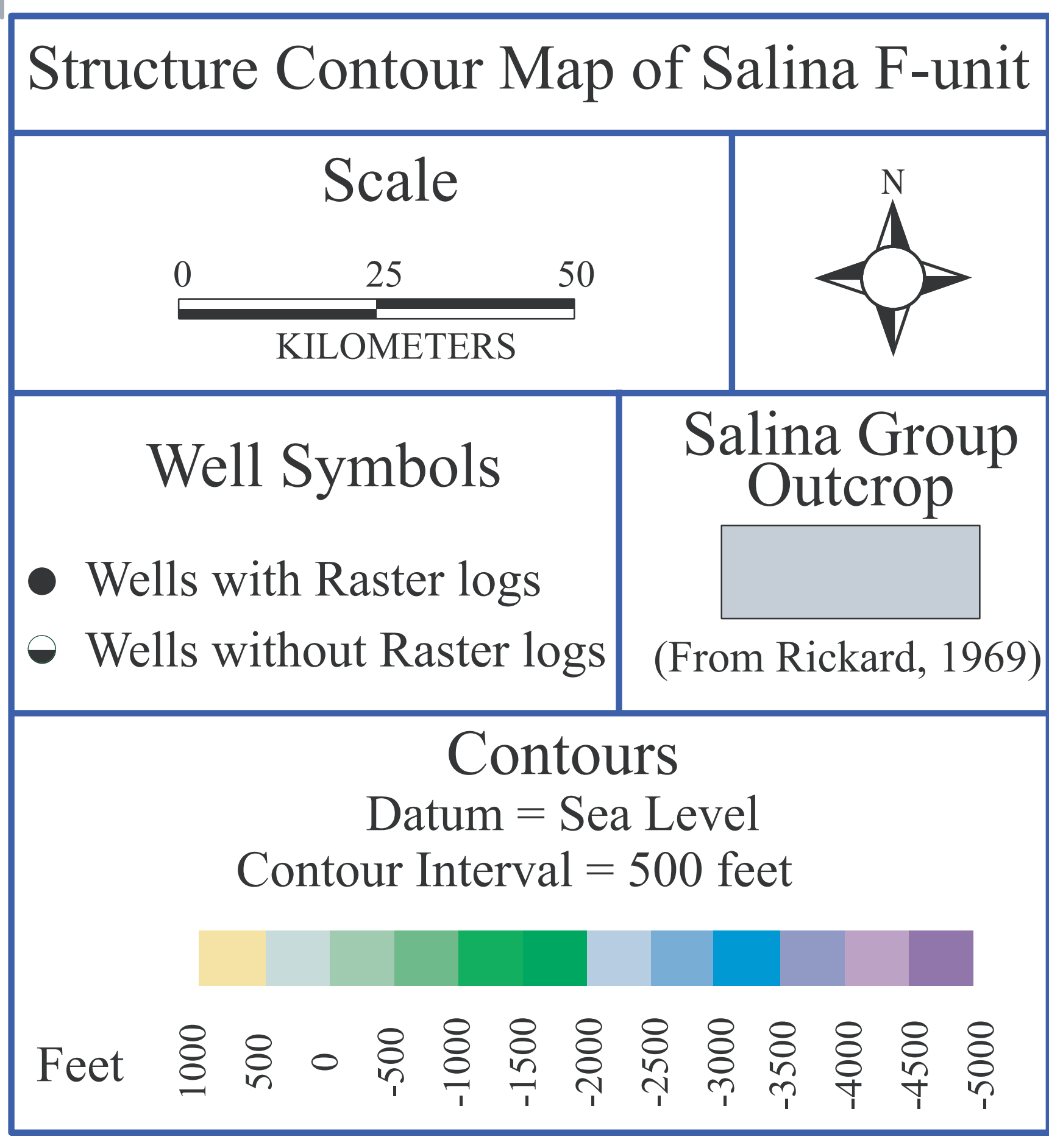

Plate 4 Structure Contour Map of the Salina F-unit. Datum is sea level and the undulations are believed to be variations in the surface of the F-unit. In south-central New York the F-unit reaches depths of 1000- 4000 feet below sea level 


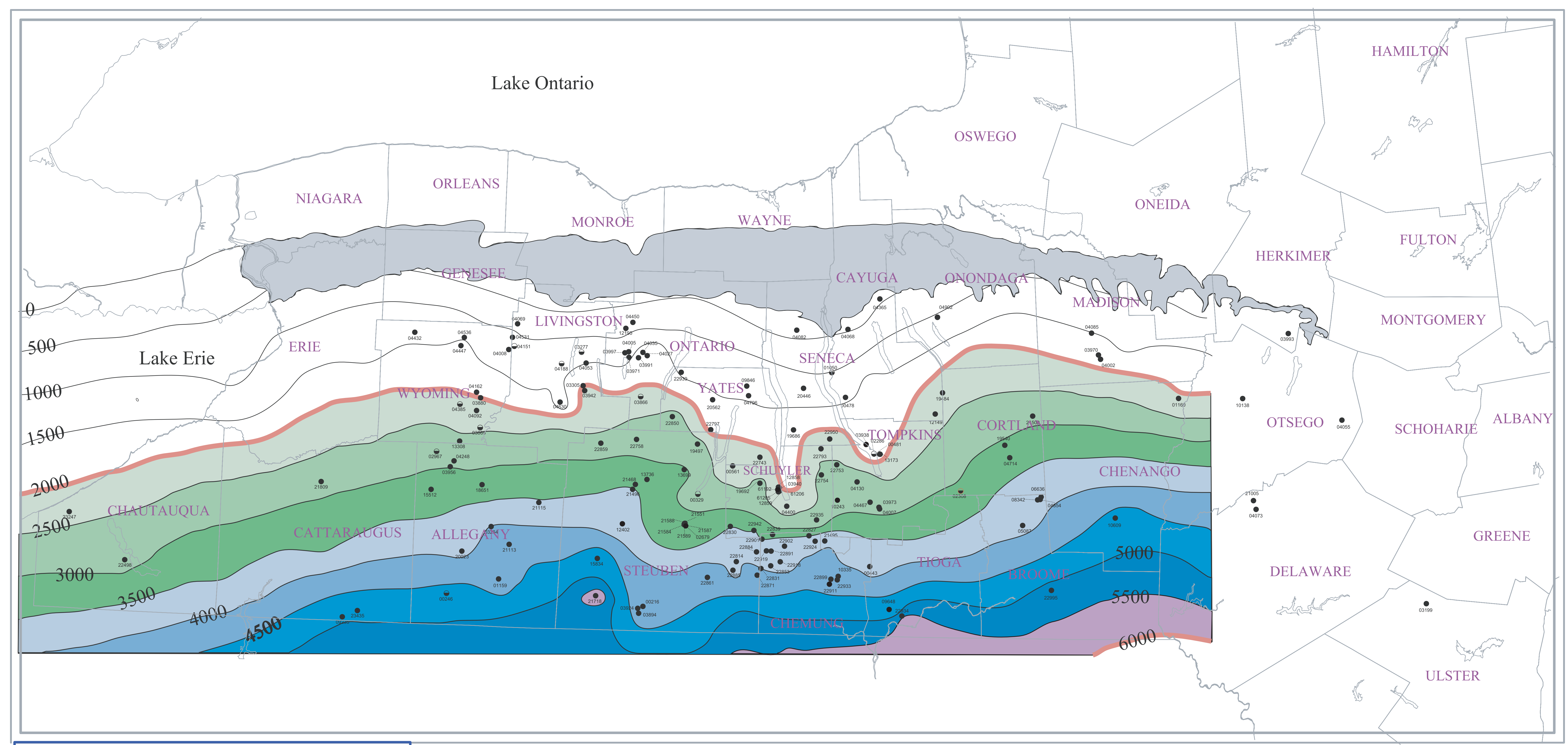

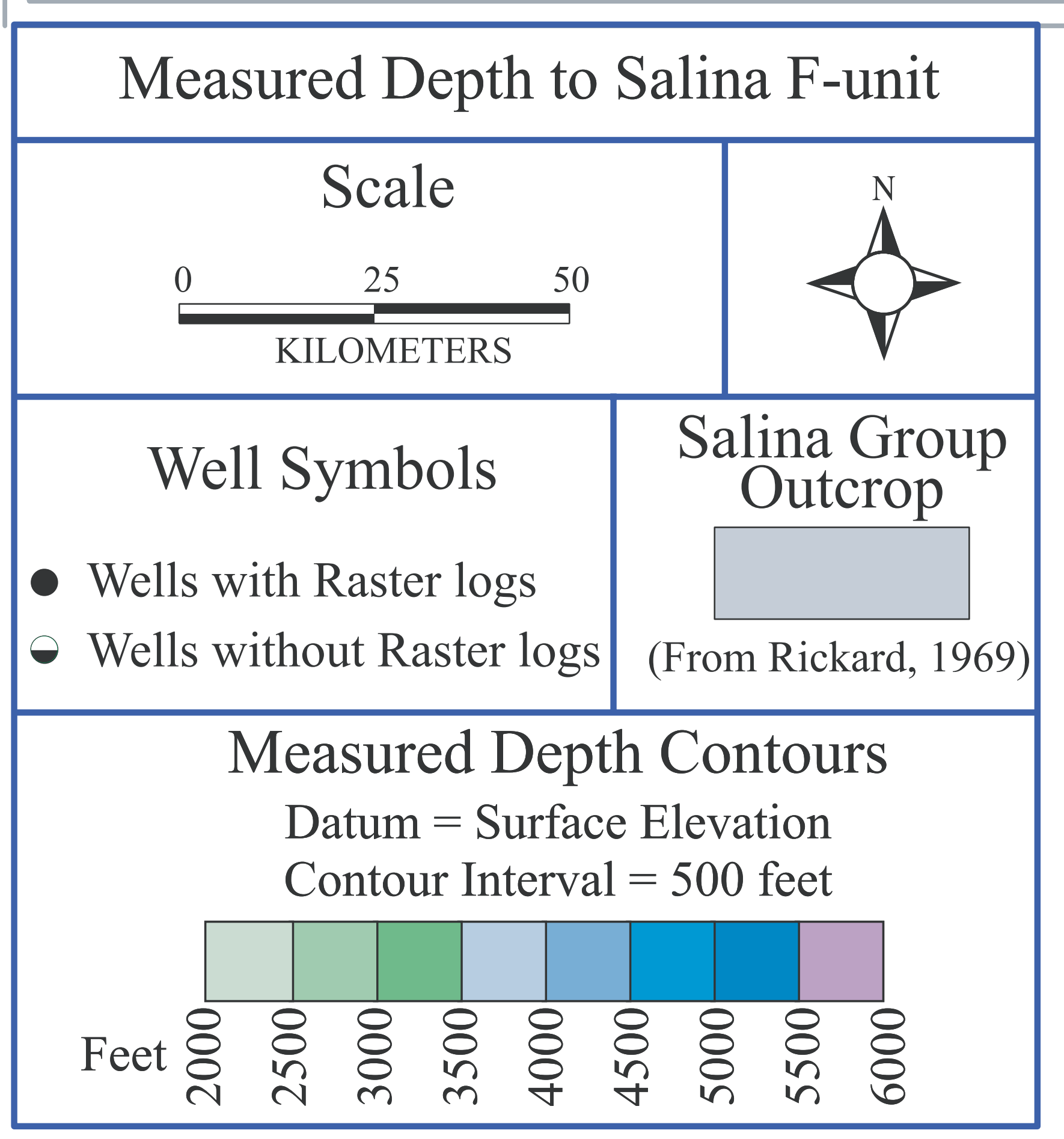

Plate 5 Measured depth to the top of the Salina F-unit in western and central New York State. Contours indicate depth measured from the surface elevation. Measured depth was used to take into account the hilly topography of the region covered by the map. The shaded contours highlight the portion of New York where the Salina F-unit lies at the appropriate depth for cavern development. Cavern development is considered in salt at depths between 2000 and 6000 feet (red). 


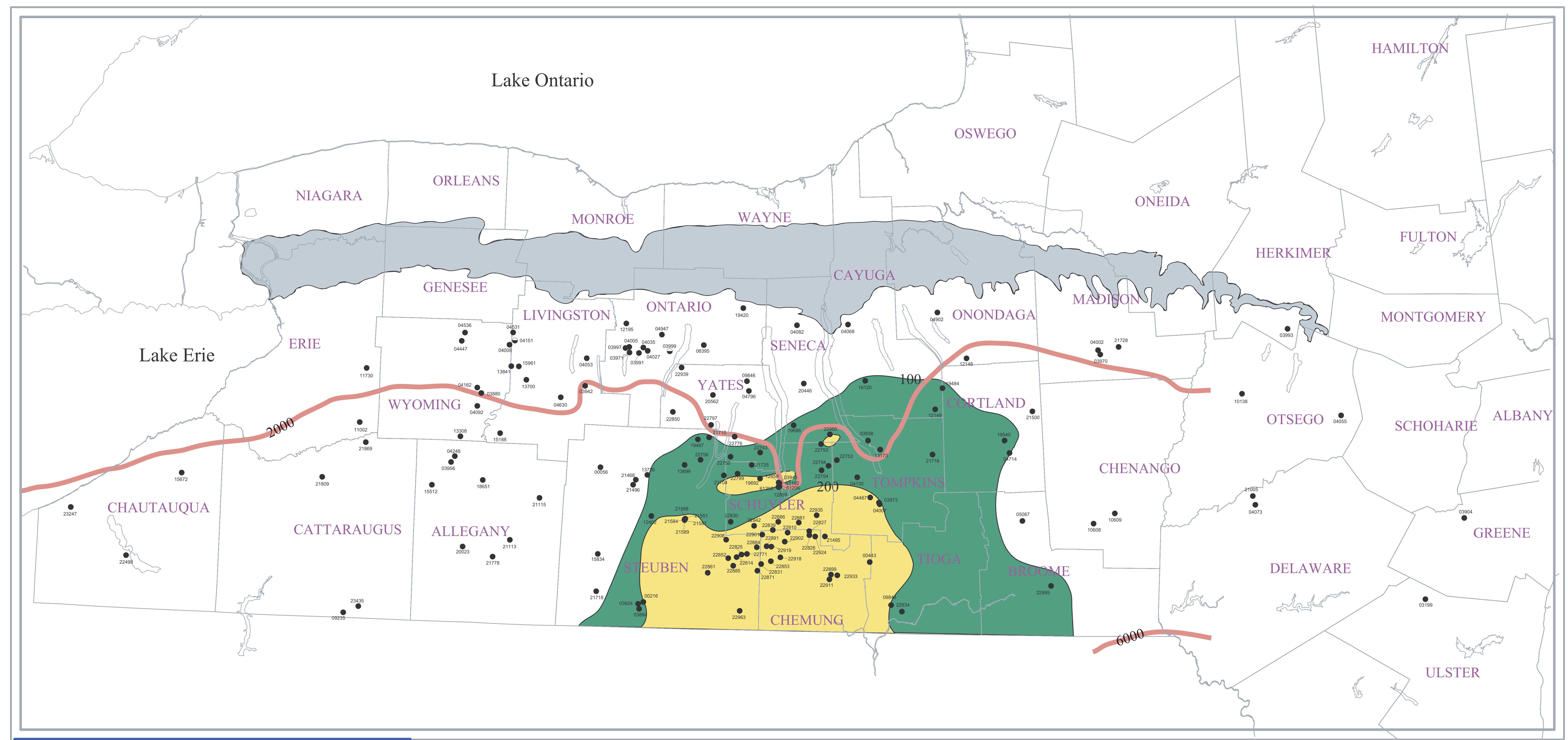

Salt Suitable for Cavern Development

\begin{tabular}{|c|c|}
\hline \multicolumn{2}{|c|}{ Scale } \\
Well Symbols \\
- Wells with Raster logs \\
- Wells without Raster logs \\
Isopachs \\
$\begin{array}{c}\text { The thickness the greatest interval of salt that is both greater than } \\
\text { (Fo ft thick and has no non-salt breaks greater than 10 ft thick. } \\
\text { Outcrop } \\
\text { Feet } 100 \quad \text { 200 } \\
\text { (optimal) }\end{array}$ \\
\hline
\end{tabular}

Plate 6 Map of Salt Suitable for Cavern Development. Map of the area underlain by salt that meets Phase I Criteria II, aggregate salt thickness of 100 feet or more with less than 10 feet of non salt breaks. In several wells there was more than one interval of salt in the F-unit that met these criteria, only the interval with the greatest thickness was used to generated the contours display in this map. The red contours are the 2000 and 6000 foot contours. The area between these contours is underlain by F-unit salt that also meets Phase I Criterion I (appropriate depth for cavern development), as shown on Plate 6. 


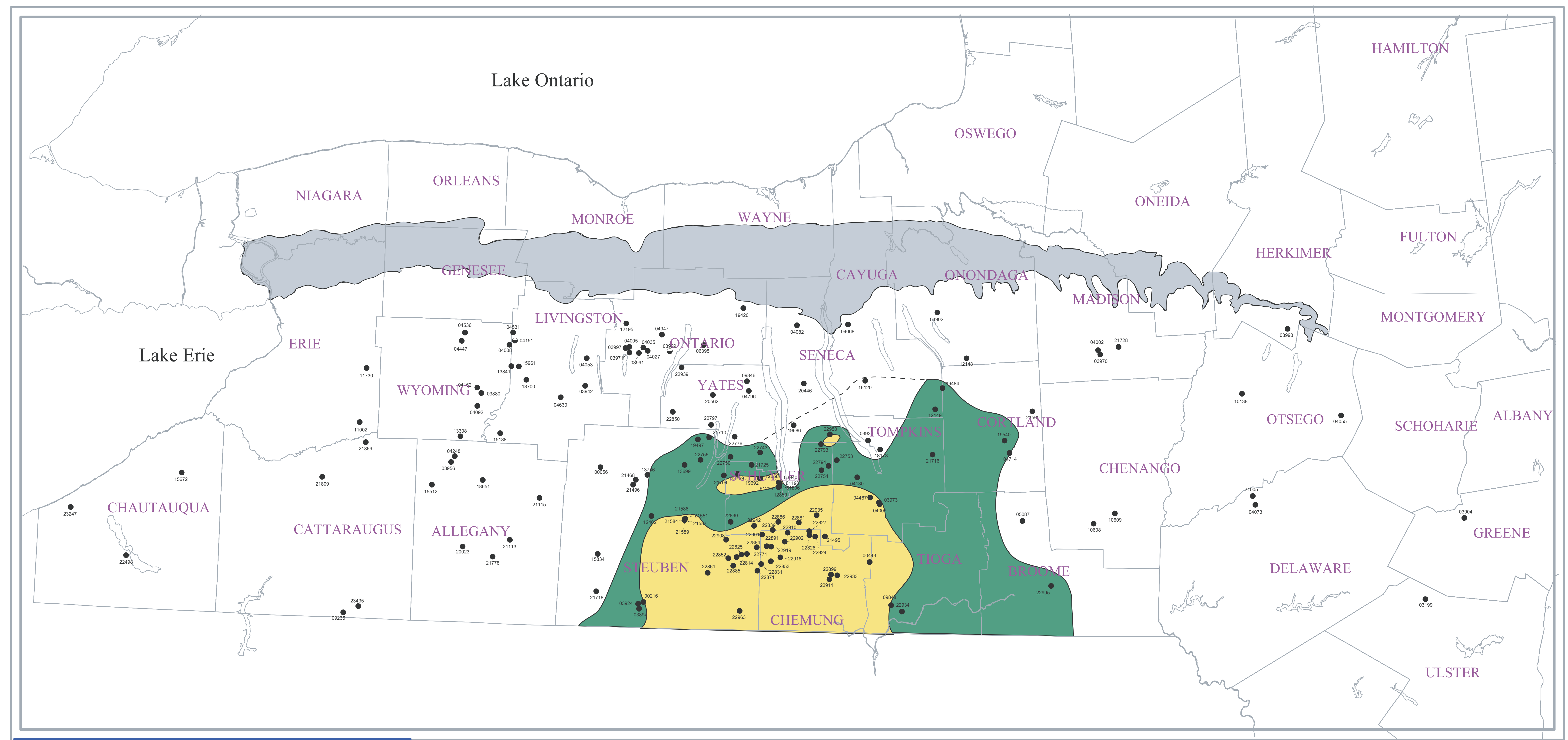

\begin{tabular}{|c|c|c|}
\hline \multicolumn{3}{|c|}{ Project Study Area } \\
\hline \multicolumn{2}{|r|}{ Scale } & \\
\hline \multirow[t]{2}{*}{0} & 50 & \\
\hline & ILOMETERS & \\
\hline \multicolumn{2}{|c|}{ Well Symbols } & $\begin{array}{c}\text { Salina Group } \\
\text { Outcrop }\end{array}$ \\
\hline \multirow{2}{*}{\multicolumn{2}{|c|}{$\begin{array}{l}\text { - Wells with Raster logs } \\
\text { Wells without Raster logs }\end{array}$}} & \\
\hline & & (From Rickard, 1969) \\
\hline \multicolumn{3}{|c|}{ Isopachs } \\
\hline Feet & $\begin{array}{c}>200 \\
\text { (optimal) }\end{array}$ & Feet \\
\hline & $\begin{array}{l}\text { Region of salt that } \\
\text { quality criteria, bu }\end{array}$ & $\begin{array}{l}\text { meets the thickness and } \\
\text { not the depth criteria }\end{array}$ \\
\hline
\end{tabular}

Plate 7 Study area defined in Phase I. The shaded portion of this map represents that area underlain by F-unit salt the meets both criteria for Phase one of this research. The green dashed line represents the area rejected based on Phase I Criterion I. Salt in the rejected portion, while thick enough, is not deep enough for cavern development based on industry standards. A review of the engineering and economics of developing a cavern in the rejected portion may prove that it is viable. Large portions of Stueben, Chemung, Tioga, Broome Cortland, Tompkins, Allegany and Schuyler Counties are underlain by F-unit salt in which a salt cavern storage facility could potentially be created 


\section{NEW YORK STATE POTENTIAL DISPOSAL RESERVOIR}

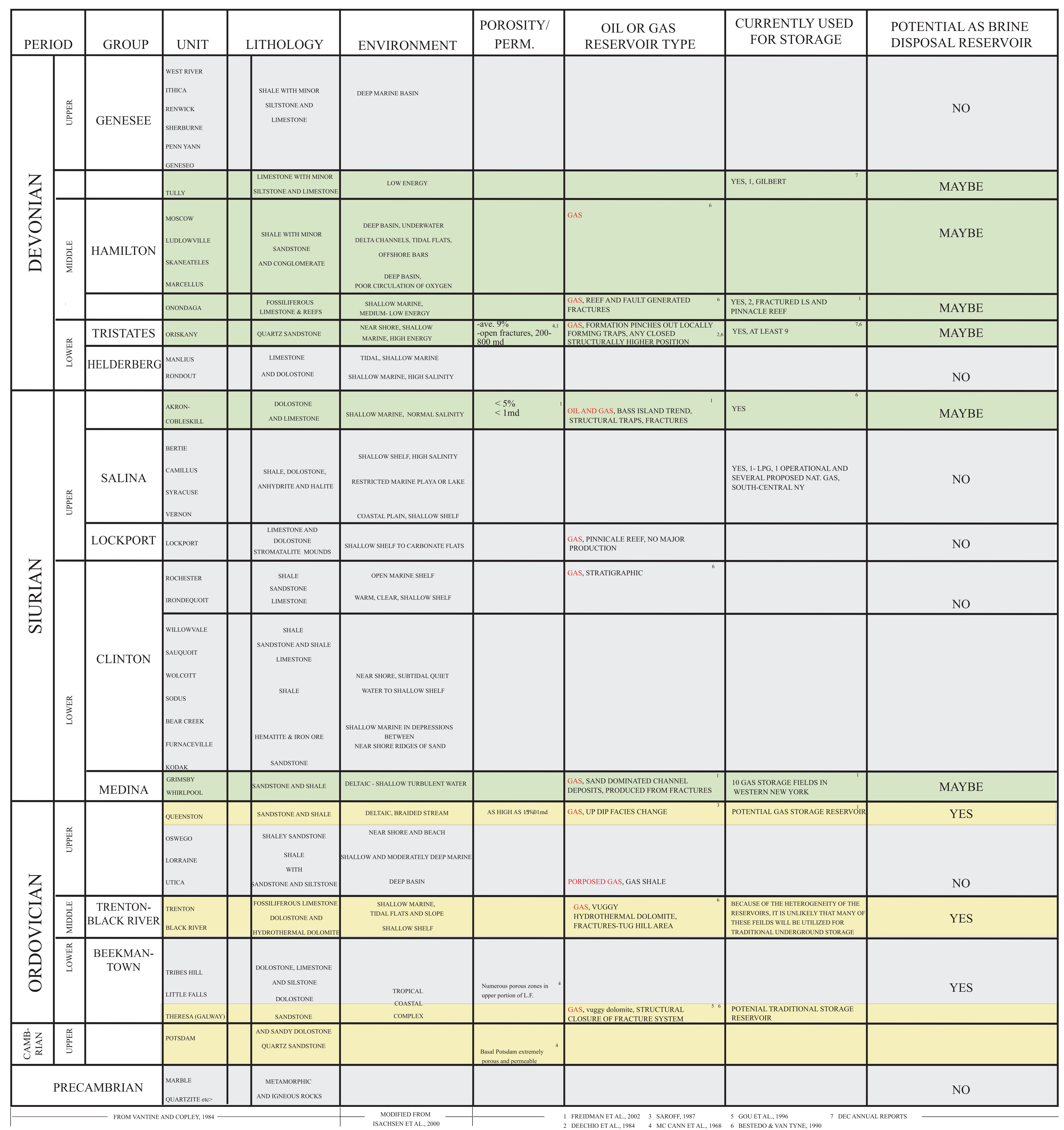

Plate 8 The table above is a compilation of information from several sources. By bringing this information together we were able to identify formations with potential as brine disposal reservoirs. Potential brine disposal reservoirs were chosen based on Lithology, coverage in south central New York and production and storage potential and history. Formations with potential to act as brine disposal reservoirs were designated as YES or MAYBE. Formations that have produced oil or gas were designated YES based on the similar characteristics necessary for both production and disposal. The MAYBE designation was used when a formation is commonly used for storage. This becomes necessary because economically, an operator would probably profit more form getting online quickly with a storage facility that will continually operate rather than the possible slow, one-time disposal that would occur with the brine disposal use. 


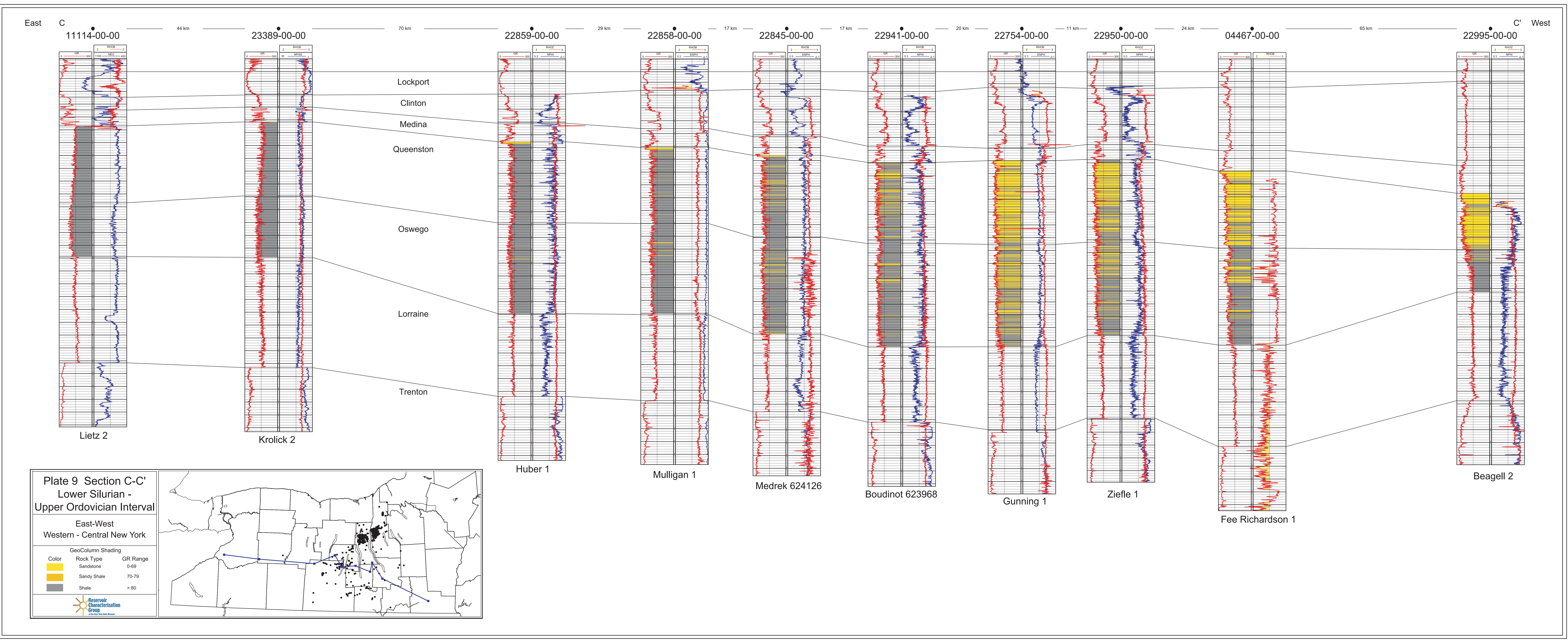




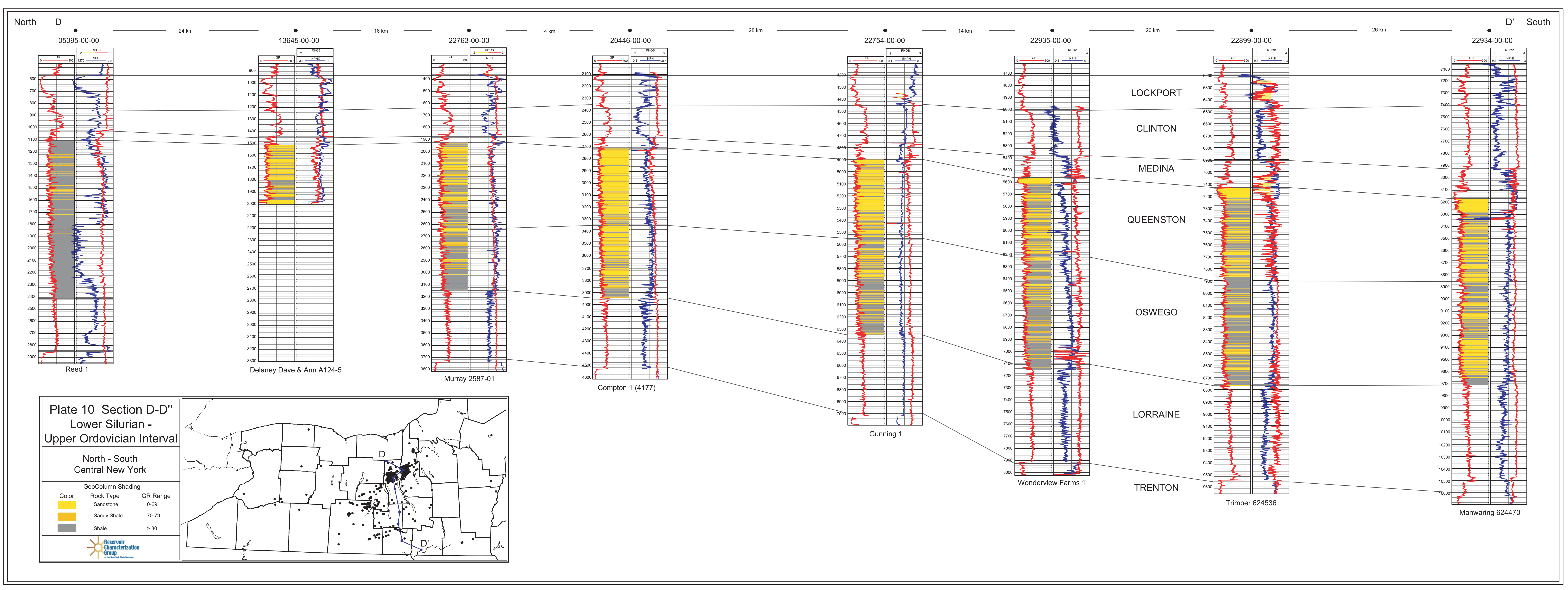




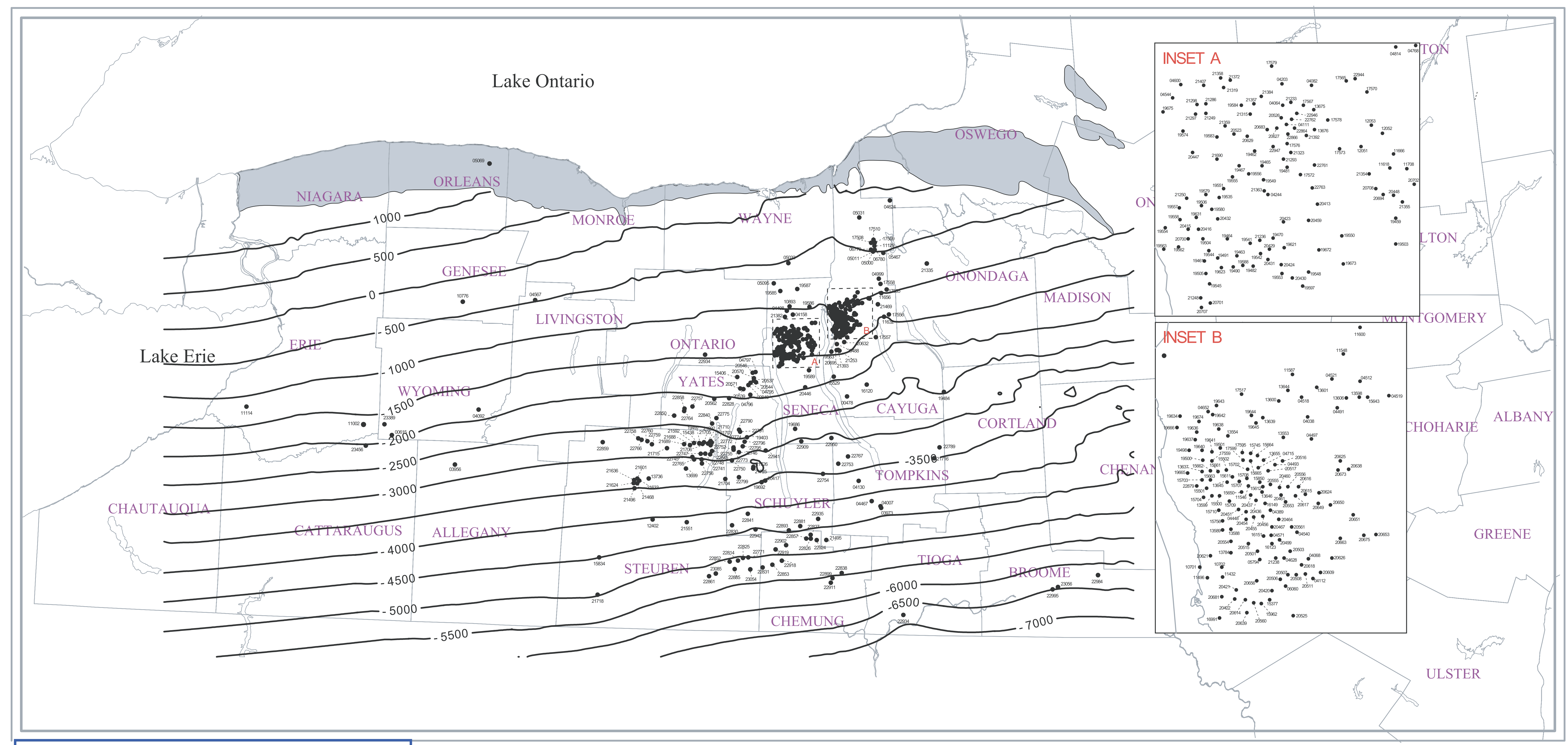

\begin{tabular}{|c|c|}
\hline \multicolumn{2}{|c|}{ Queenston Structure Contour Map } \\
\hline \multicolumn{2}{|c|}{ Scale } \\
\hline Well Symbols & $\begin{array}{c}\text { Queenston Fm. } \\
\text { Outcrop }\end{array}$ \\
\hline (From Rogers et al., 1990) \\
\hline Conterval = 500 feet \\
\hline
\end{tabular}

Plate 11 Queenston Formation structure contour map. The top of the Queenston Formation is roughly 1000 to $1800 \mathrm{ft}$ below sea level in the producing area in north-central New York. From the Producing area the formation dips to the south roughly $50 \mathrm{ft} /$ mile, reaching depths of $6000 \mathrm{ft}$ or more below sea level at the New York - Pennsylvania Border. Within the study area the Queenston is between 2500 and $6500 \mathrm{ft}$ below sea level. 


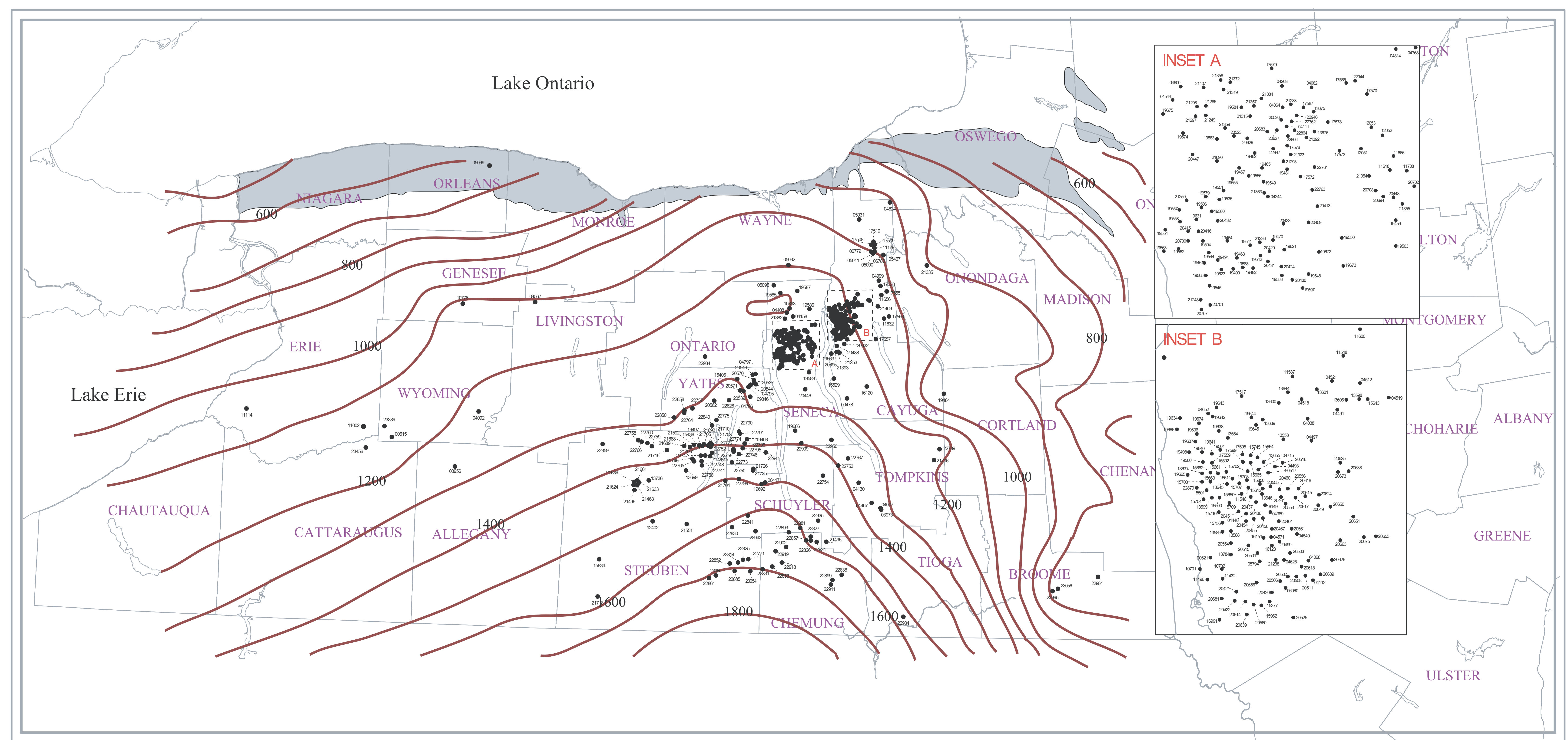

\begin{tabular}{|c|c|}
\hline \multicolumn{2}{|c|}{ Queenston - Oswego Isopachous Map } \\
\hline \multicolumn{2}{|c|}{ Scale } \\
\hline Well Symbols & \begin{tabular}{c} 
Queenston Fm. \\
Outcrop \\
\hline KILOMETERS
\end{tabular} \\
\hline (From Rogers et al., 1990) \\
\hline Interval = 100 feet \\
\hline
\end{tabular}

Plate 12 Isopachous map of the Queenston-Oswego interval. This interval is thickest in south-central New York in areas where salt cavern development is a possibility. 


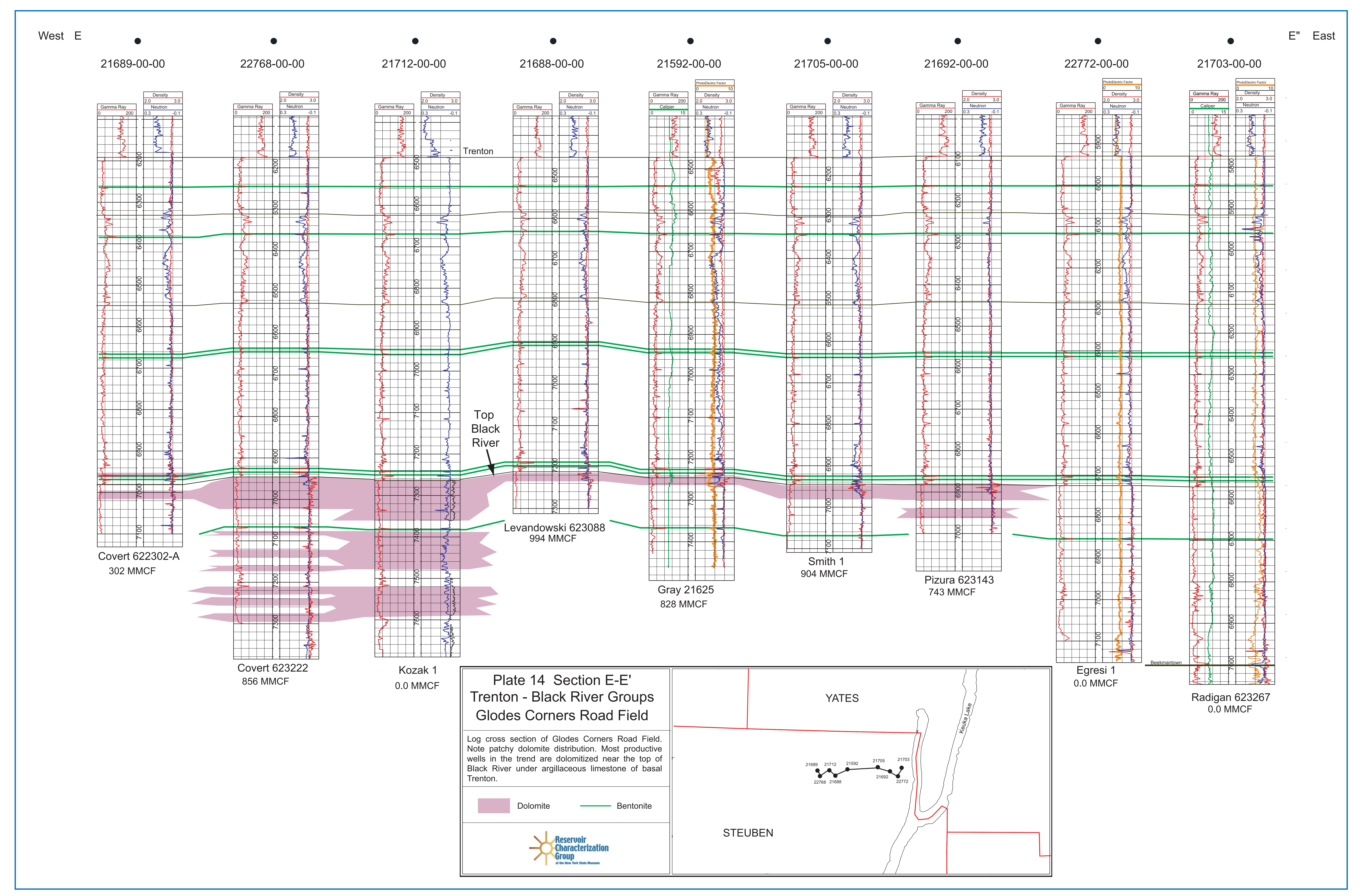




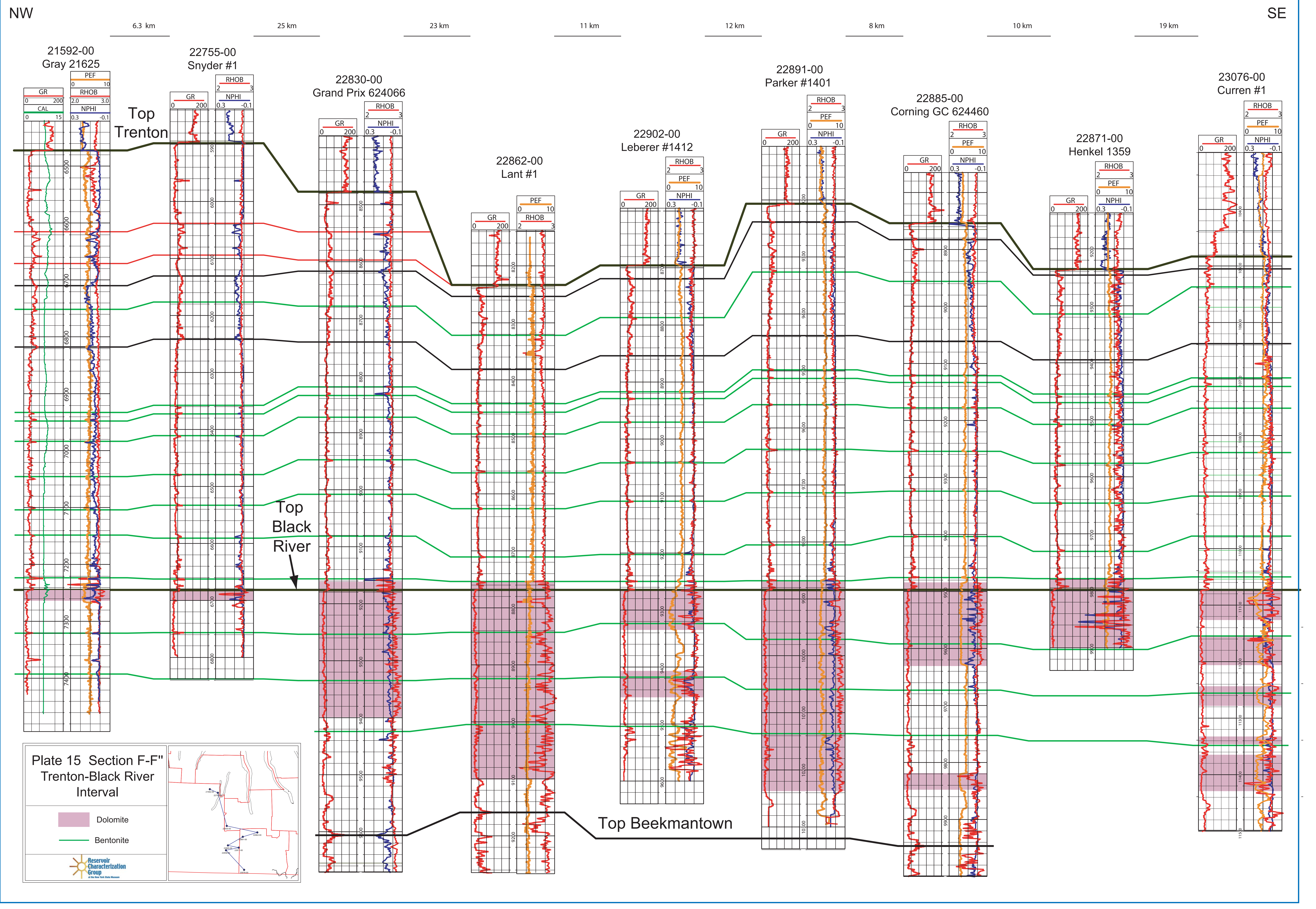



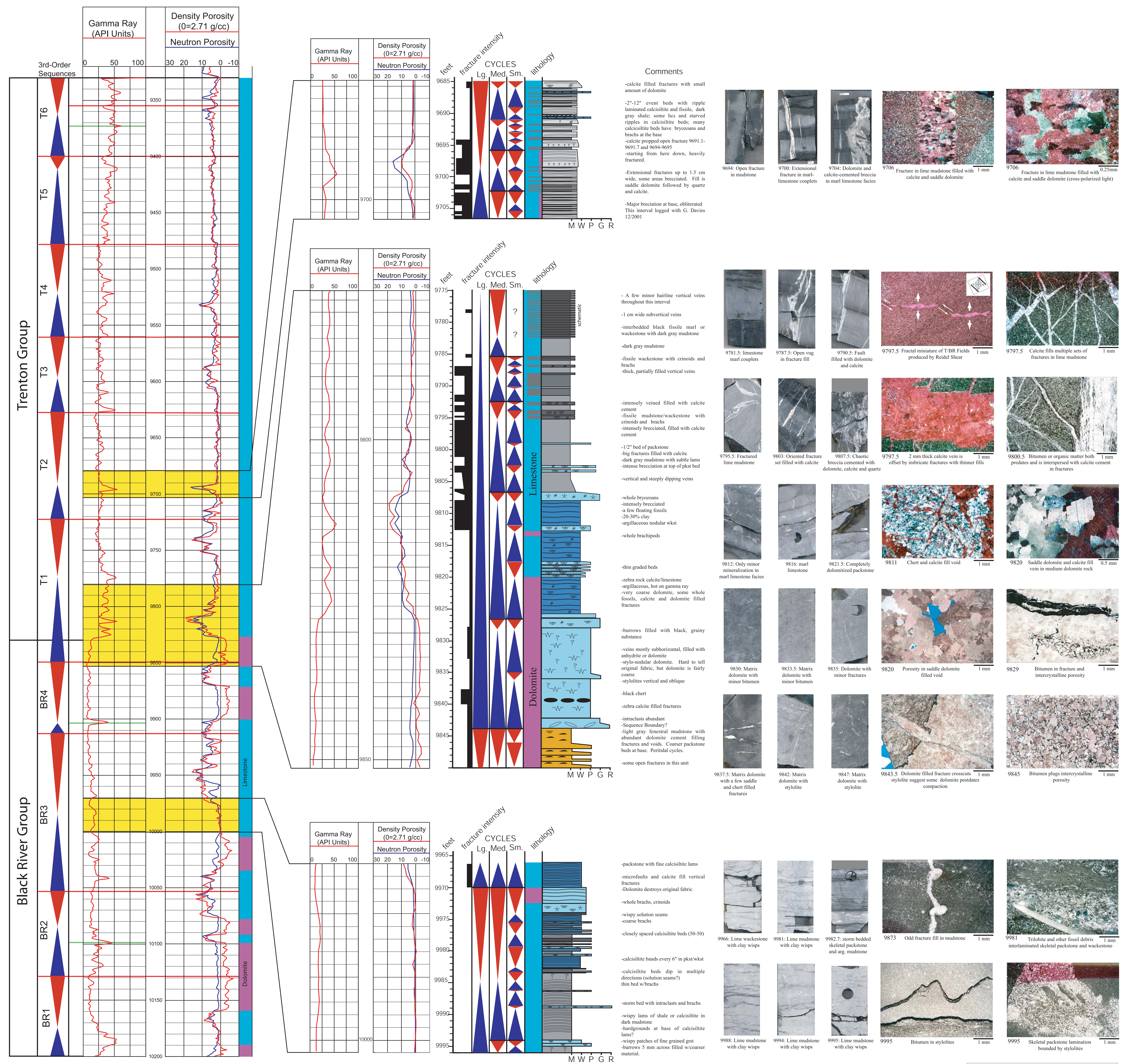

Sequence and cycle picks are tentative, based only on one core. Further work is necessary before fully establishing a sequence stratigraphic hierarchy.

Sequences boundary just below Trenton/Black River boundary occurs at base of transgressive lag conglomerate. Progressive deepening occurs and host rock changes from dolomitized grainstone to packstone, to wackestone to interbedded shale and dark mudstone in maximum flooding interval.

Based on this one core, dolomitized zones occur where the neutron porosity log reads more porosity than the density log. Zones where the density porosity $=$ the neutron porosity are dominantly limestone. The biggest porosity kicks are in

hosts with calcite and less commonly saddle dolomite and quartz cement filling

hosts with
voids.

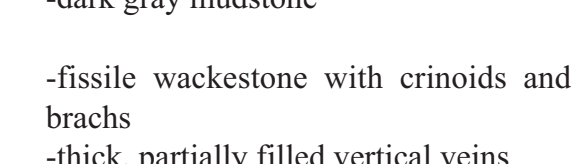

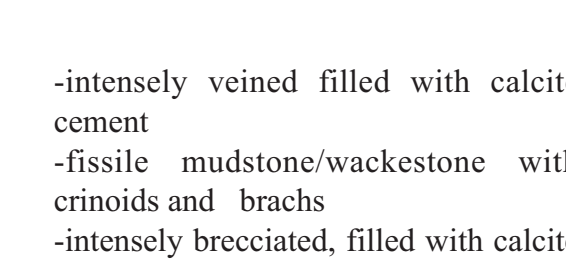
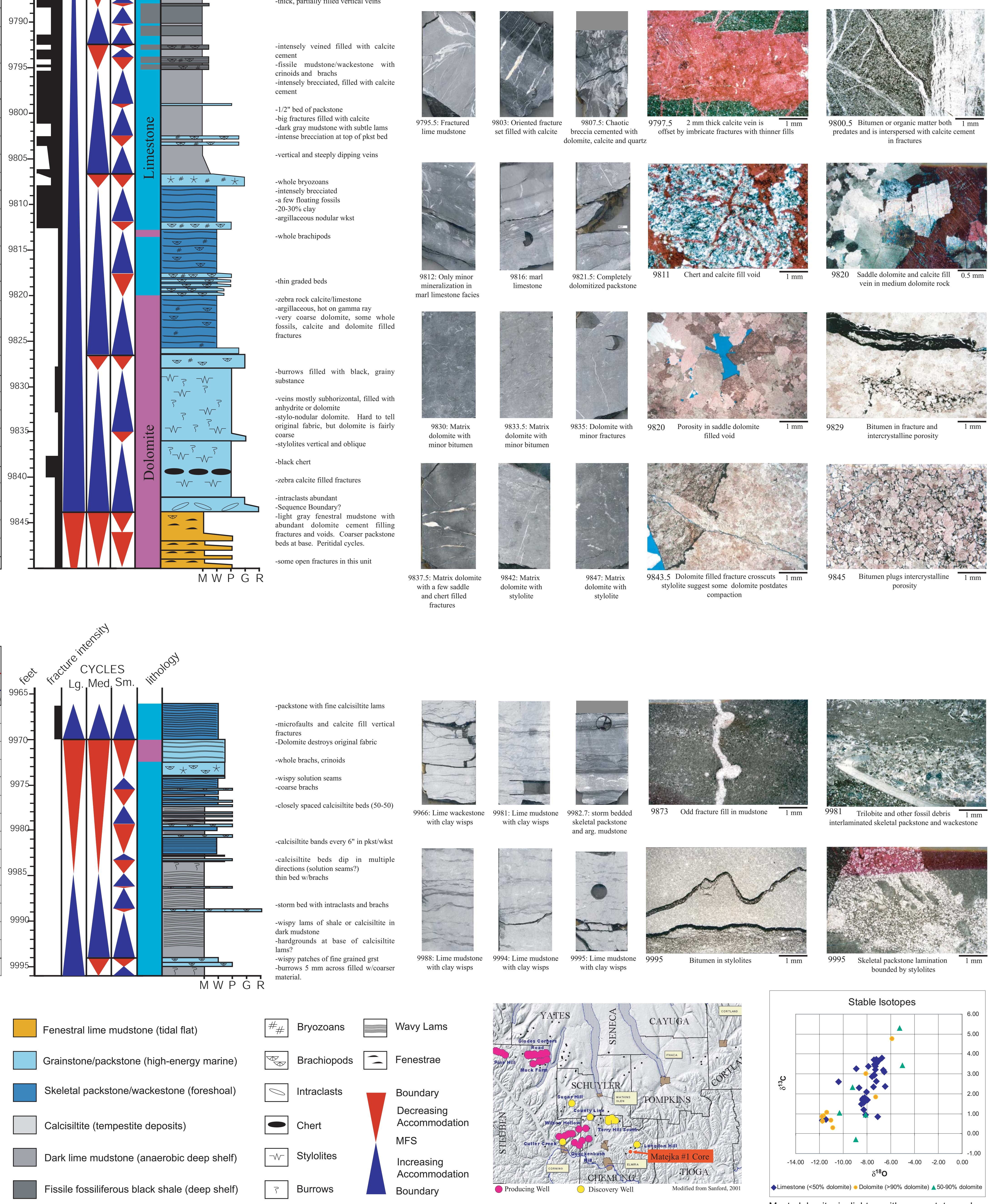

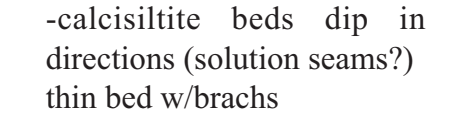

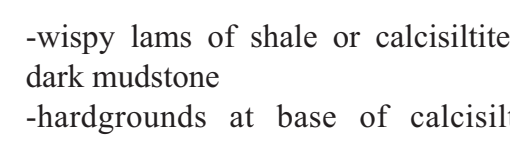
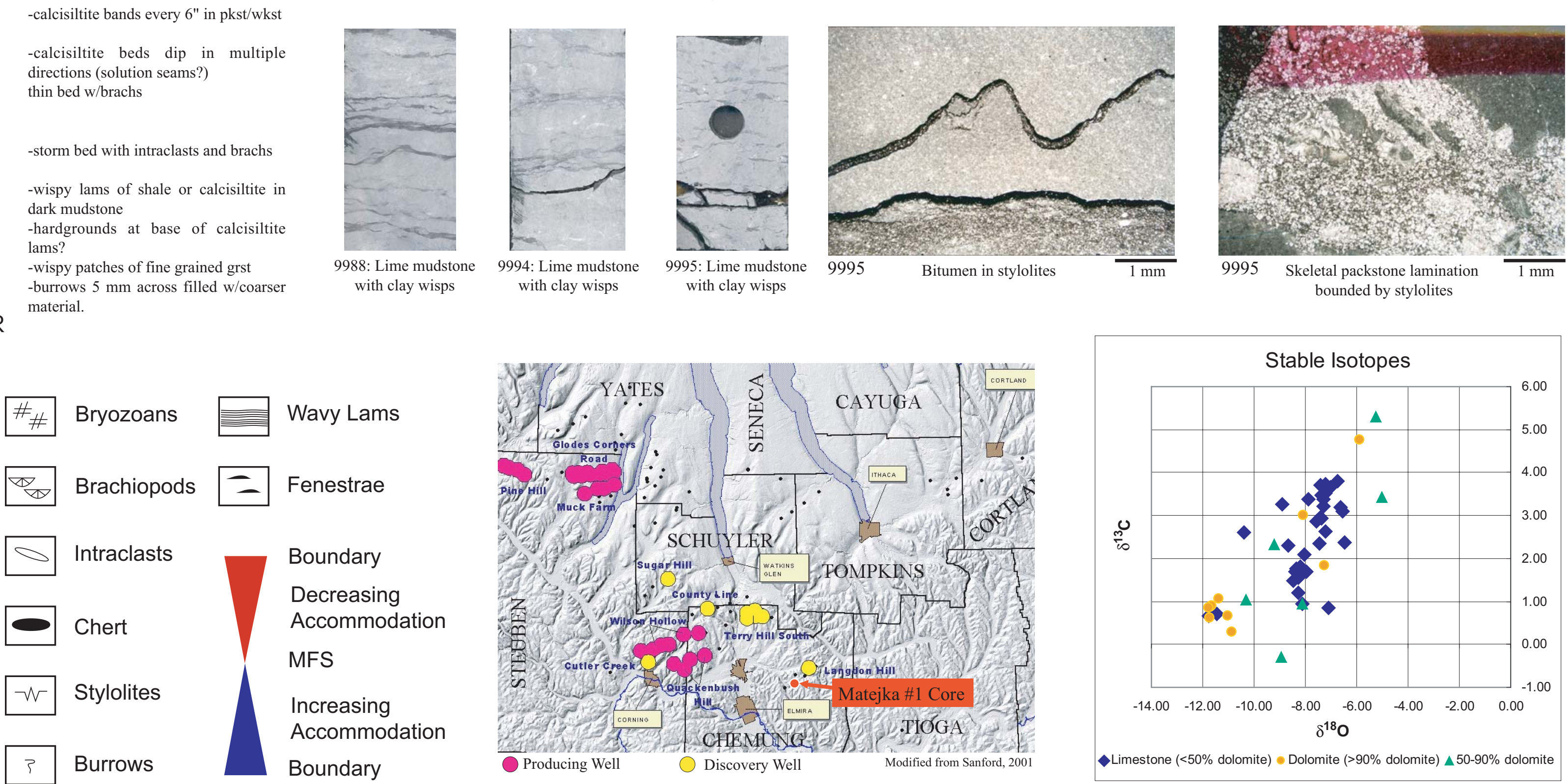

?

. Smith, 2002, Reservoir Characterization Group, New York State Museum, Room 3140 CEC, Albany, NY 12230 Phone: 518-486-2161 Email: Lsmith@mail.nysed.gov 
Reservoir
Characterization

Group

at the New von
Plate 17 - Gray \# 624468

Steuben County, New York
Columbia

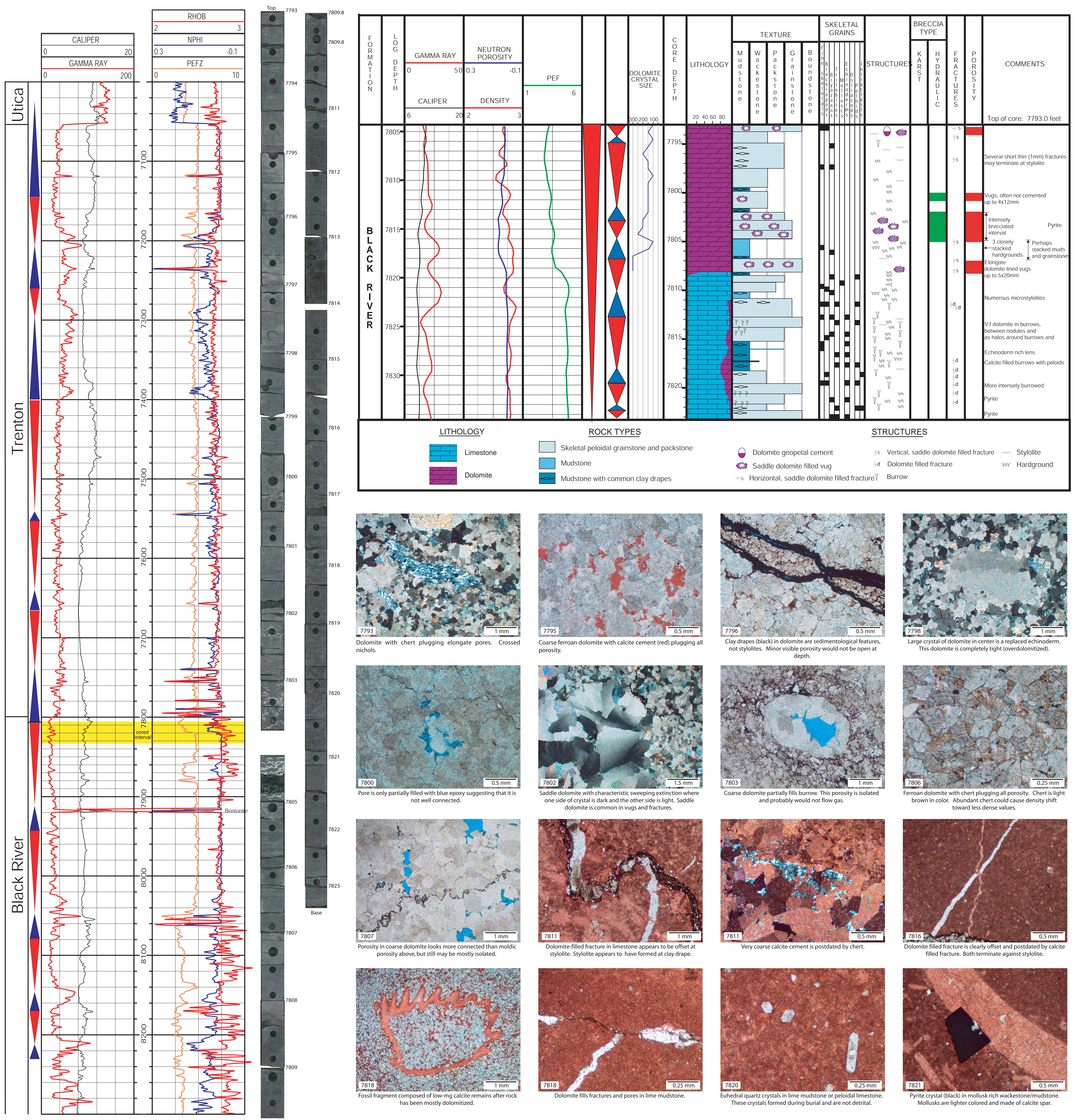




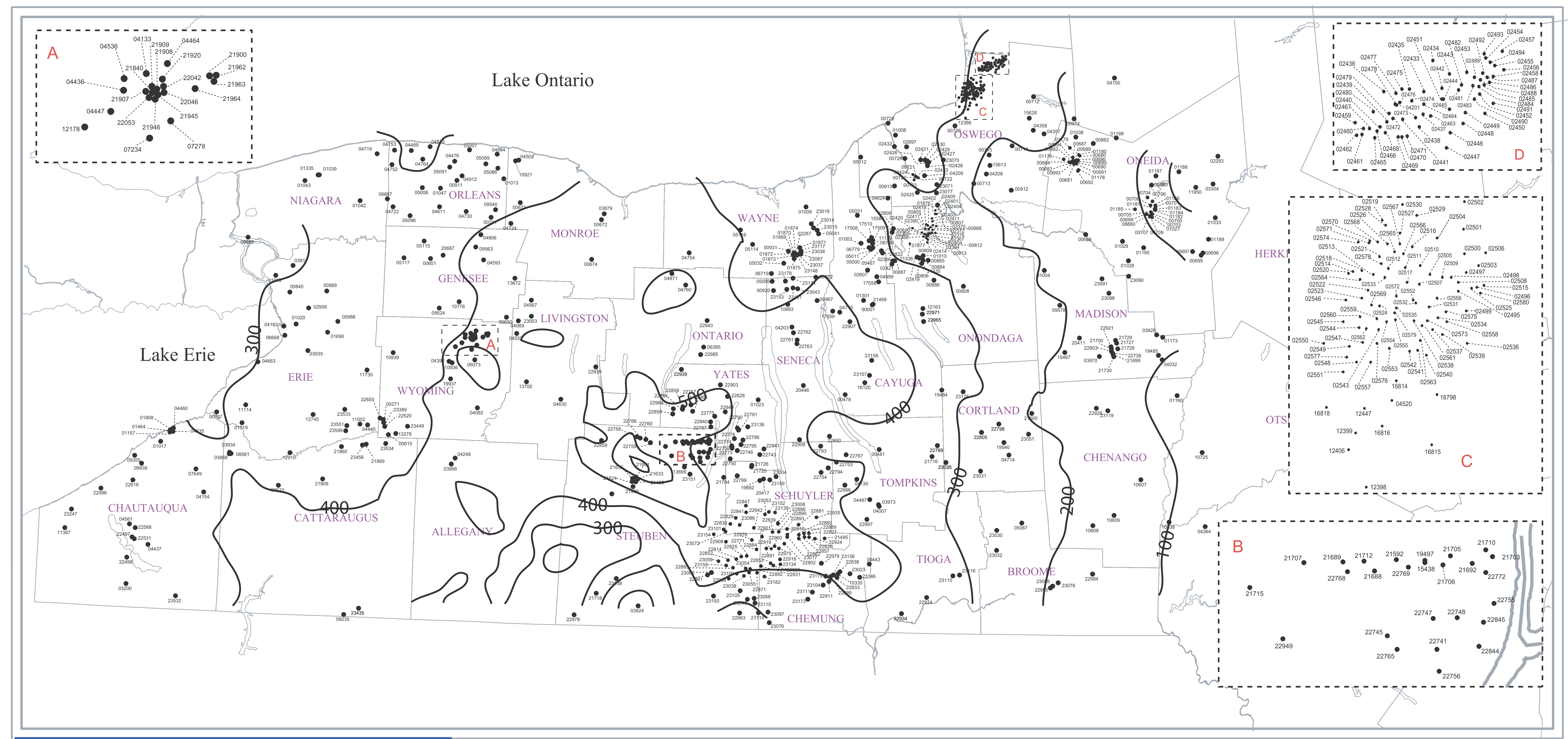

Black River Isopachous Map

\begin{tabular}{|c|c|}
\hline \multicolumn{2}{|c|}{ Scale } \\
\hline WILOMETERS
\end{tabular}

Plate 18 Black River Isopachous Map. 


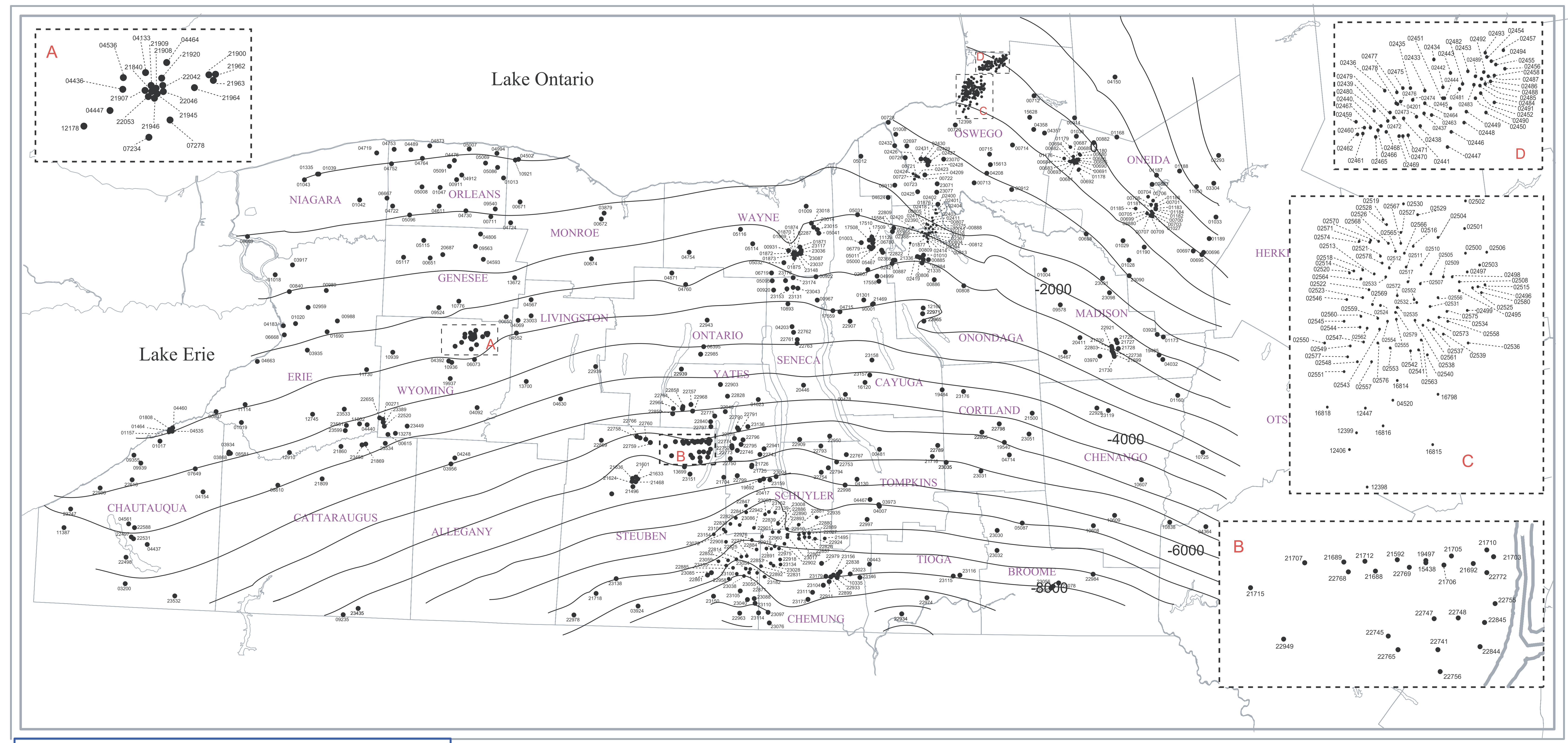

Black River Structure Contour Map

\begin{tabular}{|l|l|}
\hline \multicolumn{2}{|c|}{ Scale } \\
\hline WiLOMETERS \\
\hline $\begin{array}{l}\text { Well Symbols } \\
\text { Wells with TBR } \\
\text { tops }\end{array}$ & Contours \\
Interval = 100 feet \\
\hline
\end{tabular}

Plate 19 Black River Structure Countour Map. 


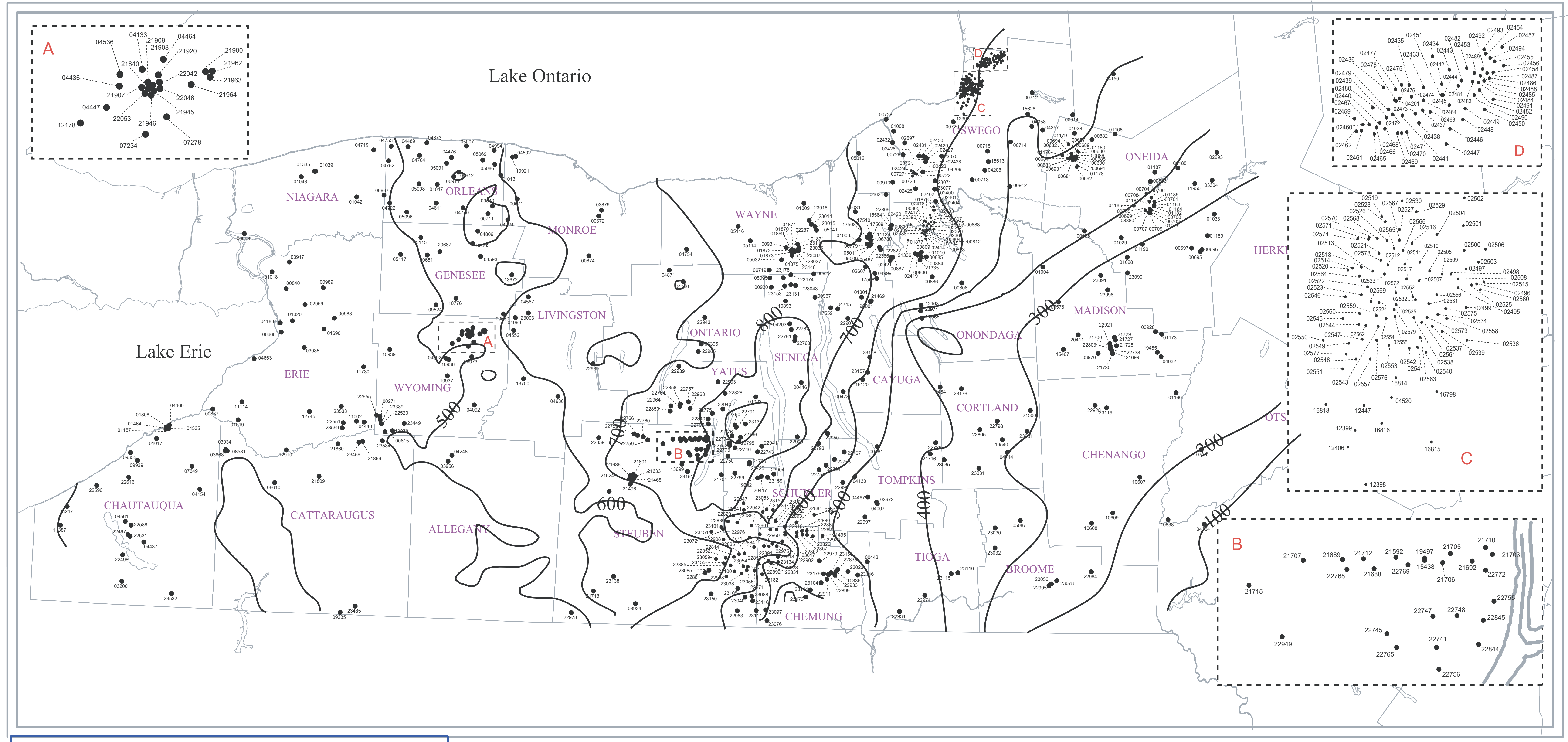

\section{Trenton Isopachous Map}

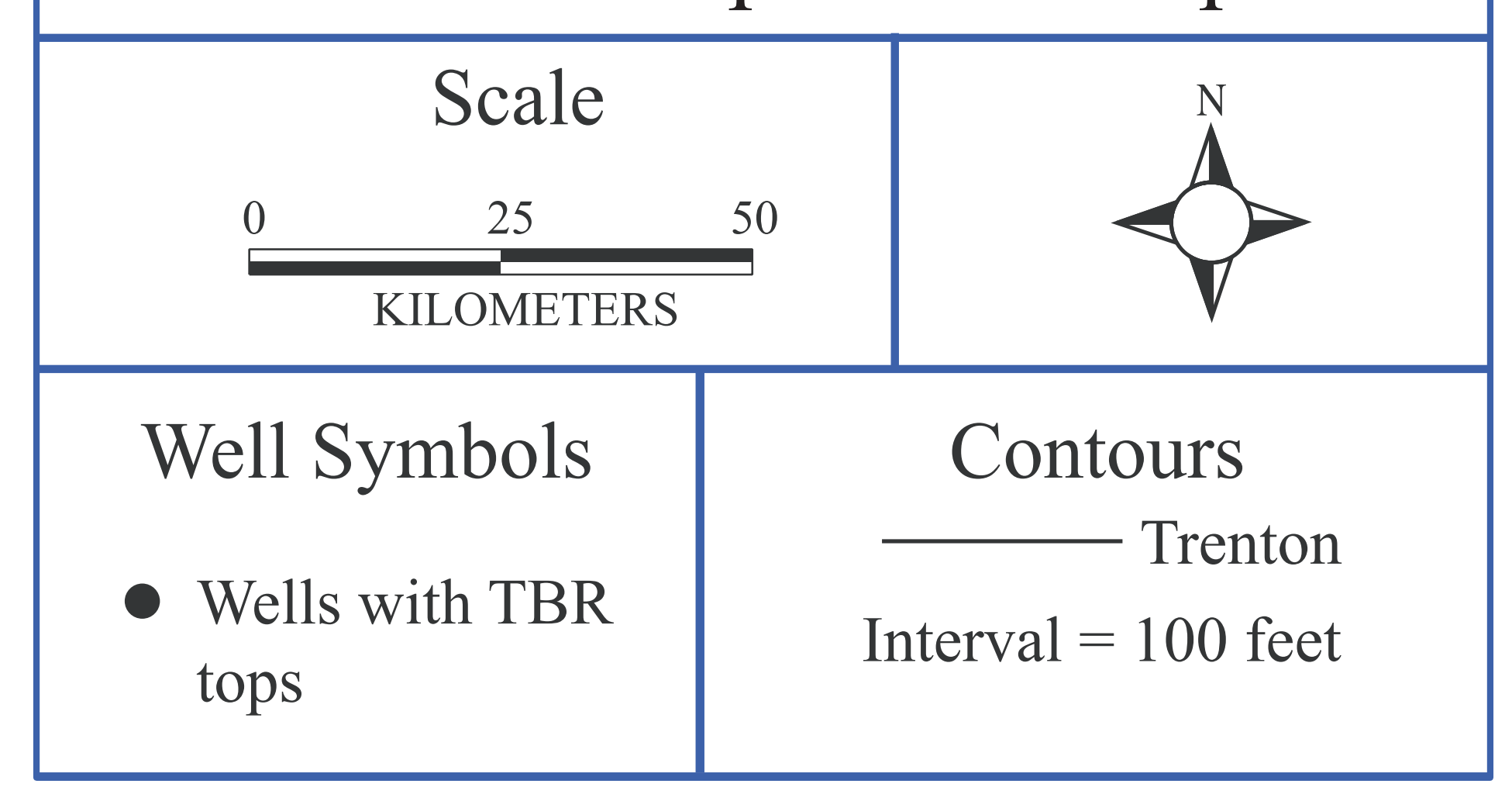

Plate 20 Trenton Isopachous Map. 


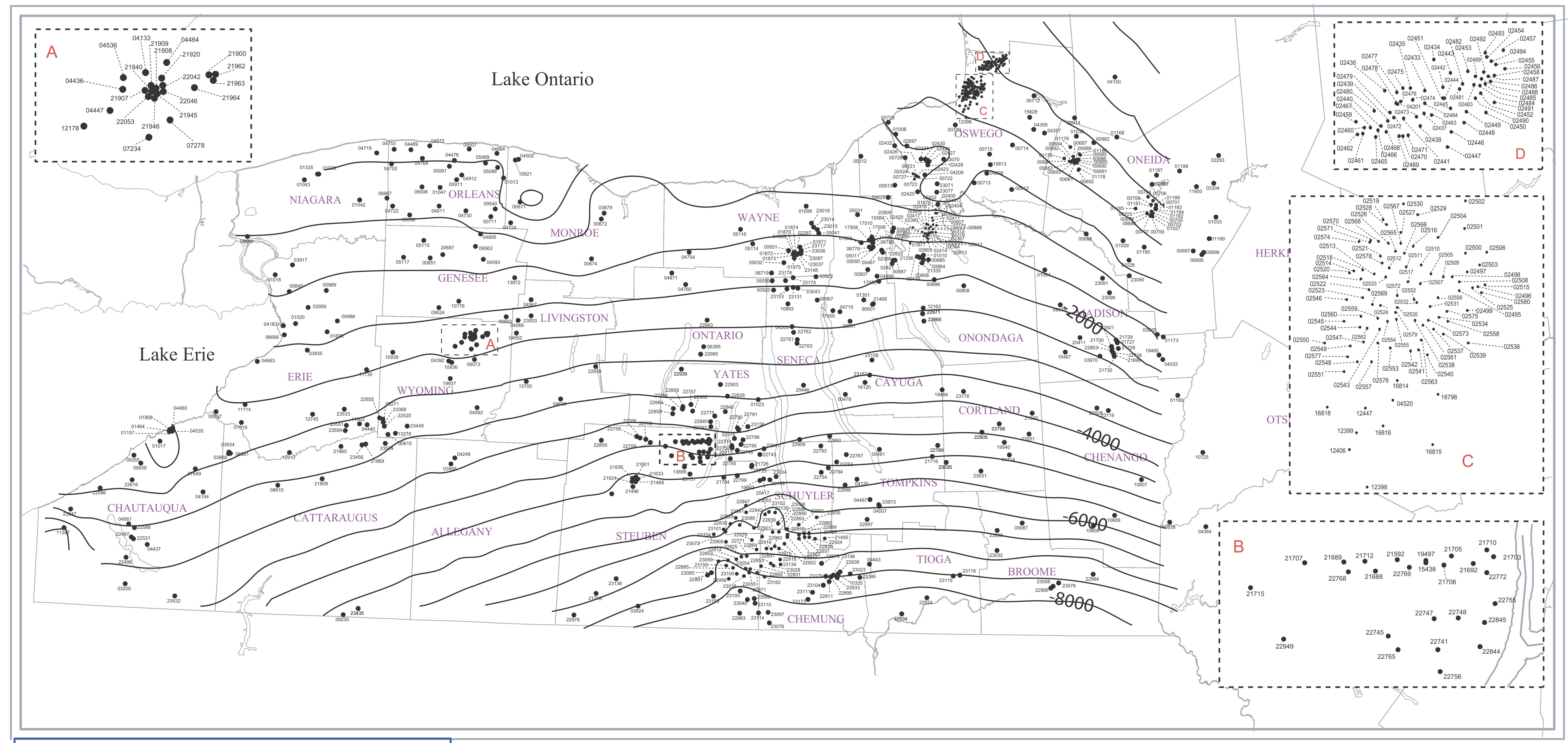

Trenton Structure Contour Map

\begin{tabular}{|l|c|}
\hline \multicolumn{2}{|c|}{\begin{tabular}{|c|}
\hline \multicolumn{2}{|c|}{ Scale } \\
KILOMETERS
\end{tabular}} \\
\hline $\begin{array}{l}\text { Well Symbols } \\
\text { Wells with TBR } \\
\text { tops }\end{array}$ & Contours \\
Interval $=500$ feet \\
\hline
\end{tabular}

Plate 21 Trenton Structure Countour Map. 


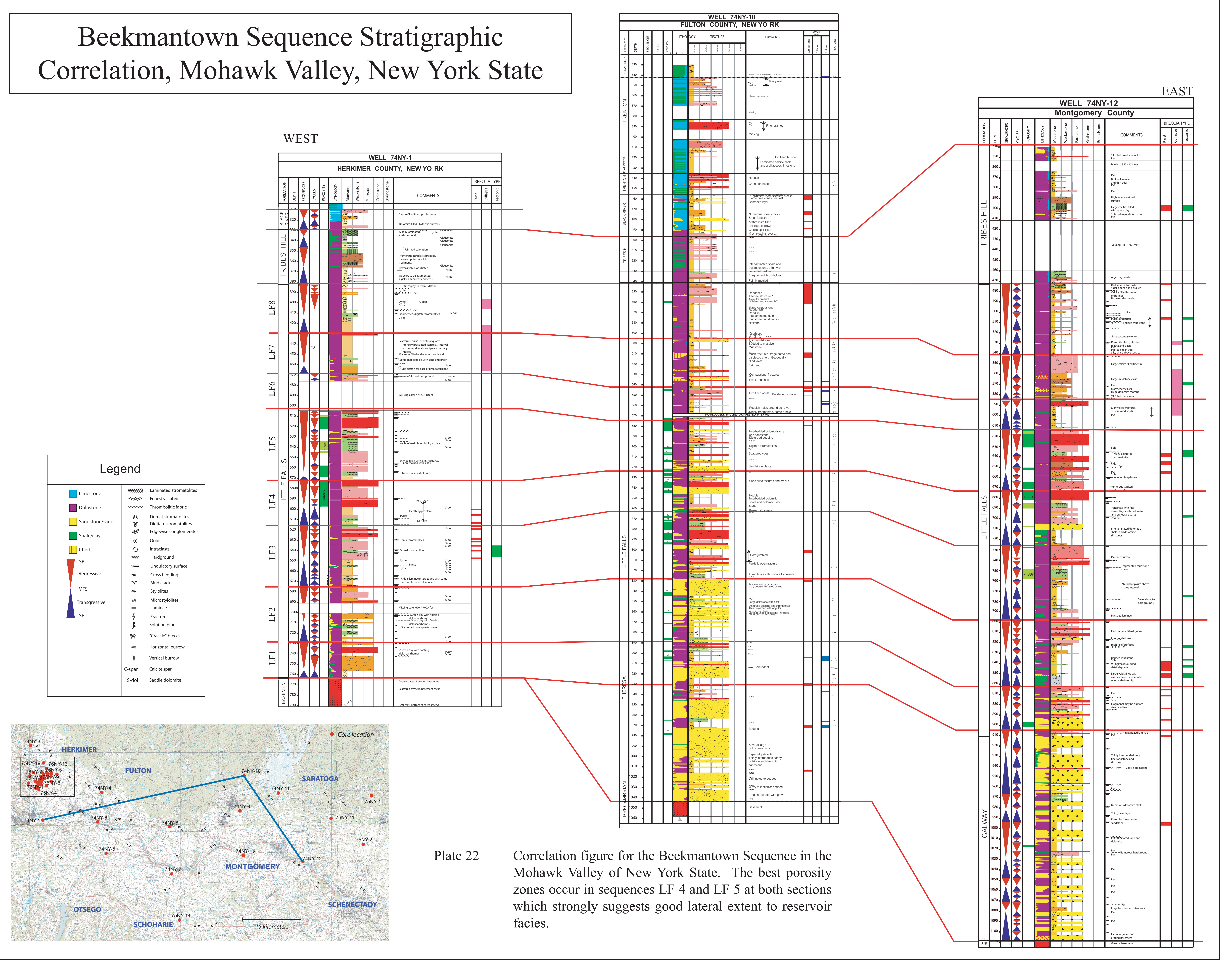




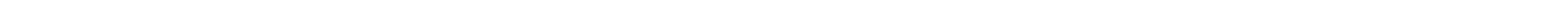

